Reinhard Johler, Christian Marchetti, Monique Scheer (eds.) Doing Anthropology in Wartime and War Zones 

Reinhard Johler, Christian Marchetti, Monique Scheer (eds.) Doing Anthropology in Wartime and War Zones. World War I and the Cultural Sciences in Europe 

to the support of libraries working with Knowledge Unlatched. KU is a collaborative initiative designed to make high quality books Open Access for the public good. The Open Access ISBN for this book is 978-3-8394-1422-4. More information about the initiative and links to the Open Access version can be found at www. knowledgeunlatched.org.

\section{(c) $(1)(9)$}

This work is licensed under the Creative Commons Attribution-NonCommercial-NoDerivatives 4.0 (BY-NC-ND) which means that the text may be used for non-commercial purposes, provided credit is given to the author. For details go to

http://creativecommons.org/licenses/by-nc-nd/4.0/

To create an adaptation, translation, or derivative of the original work and for commercial use, further permission is required and can be obtained by contacting rights@transcript-verlag.de

Creative Commons license terms for re-use do not apply to any content (such as graphs, figures, photos, excerpts, etc.) not original to the Open Access publication and further permission may be required from the rights holder. The obligation to research and clear permission lies solely with the party re-using the material.

\section{(C) 2010 transcript Verlag, Bielefeld}

\section{Bibliographic information published by the Deutsche Nationalbibliothek}

The Deutsche Nationalbibliothek lists this publication in the Deutsche Nationalbibliografie; detailed bibliographic data are available in the Internet at http://dnb.d-nb.de

Cover layout: Kordula Röckenhaus, Bielefeld

Cover illustration: The Hamburg anthropologist Paul Hambruch with soldiers from (French) Madagascar imprisoned in the camp in Wünsdorf, Germany, in 1918. Source: Wilhelm Doegen (ed.): Unter Fremden Völkern. Eine neue Völkerkunde. Berlin: Stollberg, 1925, p. 65.

Proofread and Typeset by Christel Fraser and Renate Hoffmann

Printed by Majuskel Medienproduktion $\mathrm{GmbH}$, Wetzlar

Print-ISBN 978-3-8376-1422-0

PDF-ISBN 978-3-8394-1422-4 


\section{Acknowledgments}

Financial support for the publication of this volume was provided by the Collaborative Research Centre 437: War Experiences - War and Society in Modern Times, University of Tübingen, Germany. Technical support was provided by the Max Planck Institute for Human Development, Berlin. The editors thank the Institute's directors, especially Ute Frevert, for the use of the technical facilities and Christel Fraser and Renate Hoffmann for their support with the preparation of the layout and index. Thanks are also due to Jim Batteridge for his translation of the chapter by Paolo de Simonis and Fabio Dei. The editors are especially grateful to Nell Zink for her patient and careful language polishing of many of the chapters and for her superb translation of Reinhard Johler's chapter. 

Financial support for the publication of this volume was provided by the Collaborative Research Centre 437: War Experiences-War and Society in Modern Times, University of Tübingen, Germany. Technical support was provided by the Max Planck Institute for Human Development, Berlin. The editors thank the Institute's directors, especially Ute Frevert, for the use of the technical facilities and Christel Fraser and Renate Hoffmann for their support with the preparation of the layout and index. Thanks are also due to Jim Batteridge for his translation of the chapter by Paolo de Simonis and Fabio Dei. The editors are especially grateful to Nell Zink for her patient and careful language polishing of many of the chapters and for her superb translation of Reinhard Johler's chapter. 



\section{Contents}

"A Time Like No Other": The Impact of the Great War on

European Anthropology

Monique Scheer, Christian Marchetti, and Reinhard Johler

\section{Adapting to Wartime: The Anthropological Sciences in Europe}

Continuity and Change in British Anthropology, 1914-1919

HenRika KuKLick

Doing Anthropology in Russian Military Uniform

MARINA MOgILner

Wartime Folklore: Italian Anthropology and the First World War

Paolo De Simonis and Fabio Dei

Science behind the Lines: The Effects of World War I on

Anthropology in Germany

ANDREW D. Evans

Laboratory Conditions: German-Speaking Volkskunde and

the Great War

REINHARD JOHLER

"Betwixt and Between": Physical Anthropology in Bulgaria and

Serbia until the End of the First World War

Christian Promitzer

\section{Constructing a War Zone: Austrian Ethnography in the Balkans}

Swords into Souvenirs: Bosnian Arts and Crafts under

Habsburg Administration

Diana Reynolds Cordileone 
Ursula Reber

Austro-Hungarian Volkskunde at War: Scientists on

Ethnographic Mission in World War I

Christian Marchetti

\section{Studying the Enemy: Anthropological Research in Prisoner-of-War Camps}

Large-Scale Anthropological Surveys in Austria-Hungary, 1871-1918

Margit Berner

Jews among the Peoples: Visual Archives in German Prison Camps

during the Great War

Margaret Olin

Captive Voices: Phonographic Recordings in the German and Austrian Prisoner-of-War Camps of World War I

Monique SCHeER

AfterMath: Anthropological Data from Prisoner-of-War Camps

BritTA LANGE

Ethnographic Films from Prisoner-of-War Camps and the

Aesthetics of Early Cinema

Wolfgang FumRmann

\section{Afterword}

After the Great War: National Reconfigurations of Anthropology in Late Colonial Times

AndRE GINGRICH

List of Contributors

Name Index 


\title{
"A Time Like No Other": The Impact of the Great War on European Anthropology
}

\author{
Monique Scheer, Christian Marchetti, and Reinhard Johler
}

Disciplinary histories of anthropology in Europe generally recognize World War I as an important caesura. Most attempts at periodization locate the beginnings of the discipline among Enlightenment philosophers, travelers, and missionaries, and then proceed to a phase in the nineteenth century characterized by the paradigm of natural history, moving toward evolutionary theory. It is also the phase of anthropology's increasing institutionalization, primarily in learned societies and museums. This continues up to 1914-and there the narrative tends to break off, picking up again in the interwar period. Very little has been said about what exactly was happening in the field of anthropology from 1914 to 1919. It is as if historians have assumed that the entire field had taken a break during that time, for one of several reasons: Some of its practitioners were forced to remain outside Europe for a time, as in the case of many who were at the meeting of the British Association for the Advancement of Science in Melbourne in August of 1914, when World War I broke out. Some served on the battlefield-and some of them perished there. The rest, it is assumed, simply "lay low," lecturing to the diminished numbers of students at the universities and managing their museums with ever-decreasing funds. Indeed, to a certain extent, this was the scenario in much of Europe during these years. More importantly, the beginning of the interwar period has also seemed an opportune place for historians to define a new phase in anthropology, because of the enormous influence of Bronislaw Malinowski's publication of Argonauts of the Western Pacific in 1922. His work, together with A. R. Radcliffe-Brown's The Andaman Islanders published in the same year, are viewed as marking the decisive turn away from the paradigms of the nineteenth century, a turn away from speculative histories of humankind and toward a functionalist analysis of present-day 
societies. World War I, as an event, provides a clear break to this narrative in intellectual history revolving around the (arguably dominant) British tradition because before 1914 anthropology was an armchair discipline; after the war, it never would be again.

Of course, this is a very general and perhaps somewhat unfair characterization of the historiography of anthropology, which has also been at great pains to explode the myths and to complicate the overly simple narratives which the field has cultivated over the last century and to present more nuanced accounts. ${ }^{1}$ The present collection represents another contribution to this effort, one that seeks to address the rupture created by World War I by asking if it was, in fact, such a clear break outside the sphere dominated by British anthropology and, if so, whether it was the same kind of break everywhere in Europe. The contributions to this volume all take a close look at what anthropologists did during the years 1914-1919 in a broad range of European countries, from Great Britain to Czarist Russia. The book's most intensive focus is on the area in which the (arguably) second-most dominant tradition of anthropology was at home: the German and Austro-Hungarian Empires. In these countries, it will be shown, there was indeed quite a bit of anthropological work taking place, not only in spite of the privations of wartime, but often within a framework the war itself had made possible.

Armed interventions that were connected with Europe's military and economic domination of the non-European world is one arena in which to measure the impact of military conflict on the scientific practice of anthropology. This relationship between colonialism and the cultural sciences is a topic which has received much scholarly attention in recent years, ${ }^{2}$ with civil administrative

1 See Henrika Kuklick, ed., A New History of Anthropology (Oxford: Blackwell, 2008); Fredrik Barth, Andre Gingrich, Robert Parkin, and Sydel Silverman, One Discipline, Four Ways: British, German, French, and American Anthropology; The Halle Lectures (Chicago, IL: University of Chicago Press, 2005).

2 The pathbreaking collection on this topic: Talal Asad, ed., Anthropology and the Colonial Encounter (New York: Humanities Press, 1973). An adequate overview of the relevant literature cannot be given here, but as it has been dominated by treatments of the Anglo-American schools, a few titles dealing with intersections of colonial knowledge and the cultural sciences in Continental Europe should be mentioned: Claude Blanckaert, ed., Les politiques de l'anthropologie, discours et pratiques en France (1860-1940) (Paris: L'Harmattan, 2001); Andrew Zimmerman, Anthropology and Antihumanism in Imperial Germany (Chicago, IL: University of Chicago Press, 2001); Emmanuelle Sibeud, Une science impériale pour l'Afrique? La construction des savoirs africanistes en France, 1878-1930 (Paris: Éditions de l'École des Hautes Études en Sciences Sociales, 2002); H. Glenn Penny and Matti Bunzl, eds., Worldly Provincialism: German Anthropology in the Age of Empire (Ann Arbor, MI: University of Michigan Press, 2003). 
power structures receiving as much, or more, attention than anthropologists working in, or for, the military per se. A focus on collaborations between anthropologists and the military during World War II has also been pronounced: The cooperation between German anthropologists and the National Socialist state, for some time a subject of research within Germany, ${ }^{3}$ has also received recent attention from Anglophone scholars. ${ }^{4}$ Anthropologists were extensively involved in resettlement projects in eastern Europe and in consulting the regime on issues of determining the racial status of populations in occupied areas of Europe. ${ }^{5}$ Activities of US anthropologists during this time have also been quite thoroughly examined, most recently and systematically by David $\mathrm{H}$. Price. ${ }^{6}$ They either lent their particular expertise to the government or used opportunities created by the war to do research from which the government ultimately benefited. ${ }^{7}$ Margaret Mead was a leading force behind the application of anthropology to build American morale, devise effective propaganda, and help

3 For example: Thomas Hauschild, ed., Lebenslust und Fremdenfurcht: Ethnologie im Dritten Reich (Frankfurt a.M.: Suhrkamp, 1995); Wolfgang Jacobeit, Hannjost Lixfeld, and Olaf Bockhorn, eds., Völkische Wissenschaft: Gestalten und Tendenzen der deutschen und österreichischen Volkskunde in der ersten Hälfte des 20. Jahrhunderts (Vienna: Böhlau, 1994).

4 Gretchen E. Schafft, From Racism to Genocide: Anthropology in the Third Reich (Urbana, IL: University of Illinois Press, 2004).

5 See the series Geschichte der Kaiser-Wilhelm-Gesellschaft im Nationalsozialismus, edited by Reinhard Rürup and Wolfgang Schieder for the Presidential Commission of the Max Planck Society, in particular the following volumes: Doris Kaufmann, ed., Geschichte der Kaiser-Wilhelm-Gesellschaft im Nationalsozialismus: Bestandsaufnahme und Perspektiven der Forschung (Göttingen: Wallstein Verlag, 2000); Hans-Walter Schmuhl, ed., Rassenforschung an Kaiser-Wilhelm-Instituten vor und nach 1933 (Göttingen: Wallstein Verlag, 2003); idem, Grenzüberschreitungen: Das Kaiser-Wilhelm-Institut für Anthropologie, menschliche Erblehre und Eugenik, 1927-1945 (Göttingen: Wallstein Verlag, 2005).

6 David H. Price, Anthropological Intelligence: The Deployment and Neglect of American Anthropology in the Second World War (Durham, NC: Duke University Press, 2008).

7 Price cites a report by American Anthropological Association (AAA) secretary Fred Eggan written in 1943 stating that "Over one half of the professional anthropologists in this country are directly concerned in the war effort, and most of the rest are doing part-time war work. The comprehensive knowledge of the peoples and cultures of the world which anthropologists have gathered through field research has proved of great value to both the Army and the Navy, and to the various war agencies." (Quoted in David H. Price, "Lessons from Second World War Anthropology: Peripheral, Persuasive and Ignored Contributions," Anthropology Today 18 [2002]: 14-20). 
plan efficient food rationing practices. ${ }^{8}$ Her husband, Gregory Bateson, was one of many anthropologists who worked for US intelligence during World War II, ${ }^{9}$ and her associate Ruth Benedict gathered data on the Japanese "national character" in American internment camps during the same war. Anthropologists were also involved in the administration of these camps. ${ }^{10}$ Benedict's popular study, The Chrysanthemum and the Sword, was commissioned by the government as a sort of manual for the occupying forces of Japan after $1945 .{ }^{11}$ Clearly, the ethical issues surrounding the Allies' involvement in war work from 1939 to 1945 are overshadowed by the perception of this conflict as a "good war" and a cause worth fighting for. ${ }^{12}$ The minority dissent among anthropologists against this kind of work grew considerably after 1945, but members of the field in the US continued to do war-related work throughout the Cold War era. ${ }^{13}$ In contrast, in Europe, during the postwar period, further collaboration between anthropologists and the state seems to have been at a fairly low ebb, as anthropologists all over Europe, but certainly far more forcefully in the German-speaking countries, had learned from the murderous collaborations of World War II that such cooperation should be avoided at all costs.

8 See Carleton Mabee, "Margaret Mead and Behavioral Scientists in World War II: Problems in Responsibility, Truth, and Effectiveness," Journal of the History of the Behavioral Sciences 23 (1987): 3-13.

9 See David H. Price, "Gregory Bateson and the OSS," Human Organization 57 (1998): 379-384.

10 See Orin Starn, "Engineering Internment: Anthropologists and the War Relocation Authority," American Ethnologist 13 (1986): 700-720.

11 Ruth Benedict, The Chrysanthemum and the Sword: Patterns of Japanese Culture (Boston, MA: Houghton Mifflin, 1946). On Benedict's wartime work, see Judith Schachter Modell, Ruth Benedict: Patterns of a Life (Philadelphia, PA: University of Philadelphia Press, 1983), 267-271. David H. Price has done extensive work on the involvement of American anthropologists with military intelligence organizations. See, for example, his "Anthropologists as Spies," The Nation 271, no. 16 (November 20, 2000): 24-27.

12 Cf. Price, "Lessons from Second World War Anthropology," 15.

13 The role of anthropologists during the Cold War was less unambiguous, however: They did not always know that they were being funded by the CIA, and some were harrassed by the US government for their dissenting views. See David H. Price, "Cold War Anthropology: Collaborators and Victims of the National Security State," Identities 4, nos. 3-4 (1998): 389-430; idem, "Anthropology Sub Rosa: The AAA, the CIA and the Ethical Problems Inherent in Secret Research," in Ethics and the Profession of Anthropology: Dialogue for Ethically Conscious Practice, ed. Carolyn Fluehr-Lobban, 2nd ed. (Walnut Creek, CA: AltaMira Press, 2003), 29-49. An important study on the involvement of anthropologists in Southeast Asia during the Vietnam War is Eric Wakin, Anthropology Goes to War: Professional Ethics and Counterinsurgency in Thailand (Madison, WI: University of Wisconsin Press, 1992). 
Comparably extensive research is not available for World War I. In some cases, this may be because there simply was no extensive cooperation between anthropologists and the military during this time. In the US, for example, many of those anthropologists who were deployed will have turned their trained eyes to the cultural idiosyncrasies of the military, as Ralph Linton did during his two years of service during World War I, ${ }^{14}$ though not all of them published their observations. But these would have been strictly personal efforts, reflected upon after the war. It appears that only a few anthropologists took part in bona fide "war work" or used their expertise to publicly support the war effort. ${ }^{15}$ In Europe, this practice seems to have been more firmly anchored during World War I, where intellectuals and scholars on both sides of the front lines engaged in a guerre des plumes beginning in the fall of $1914 .{ }^{16}$ Émile Durkheim, for example, was among the prominent members of the Parisian "Committee for Studies and Documents on the War" founded to distribute "objective analyses"

14 See Ralph Linton, "Totemism and the A. E. F.," American Anthropologist 26 (1924): 296-300; in which he discusses the identity-building functions of symbols among the divisions of the American Expeditionary Force on the frontlines in France and the "superstitious" beliefs soldiers had in regard to these symbols. As Clyde Kluckhohn relates in a biographical sketch, it was said that "Linton angered [Franz] Boas by returning to Boas's classes at Columbia in uniform, and that Boas excluded Linton from the courses" for that reason (Biographical Memoirs, vol. 31 [Washington, DC: National Academy of Sciences, 1958], available online at http://www.nasonline.org under "Publications").

15 Franz Boas publicly criticized four American anthropologists for using their professional status as fieldworkers in Central America as a cover for espionage. Their activities were defended by the AAA, which issued Boas a censure also implying that, as a native-born German, his loyalty to the American war effort was questionable. See George W. Stocking, "The Scientific Reaction against Cultural Anthropology, 1917-1920," in Race, Culture, and Evolution: Essays in the History of Anthropology, ed. George W. Stocking (Chicago, IL: University of Chicago Press, 1968), 270-307; David H. Price, "'The Shameful Business': Leslie Spier on the Censure of Franz Boas," History of Anthropology Newsletter 28, no. 2 (2001): 9-12.

16 See Stuart Wallace, War and the Image of Germany: British Academics 1914-1918 (Edinburgh, UK: Donald, 1988); Martha Hanna, The Mobilization of Intellect: French Scholars and Writers during the Great War (Cambridge, MA: Harvard University Press, 1996); Jürgen von Ungern-Sternberg and Wolfgang von Ungern-Sternberg, Der Aufruf "An die Kulturwelt!": Das Manifest der 93 und die Anfänge der Kriegspropaganda im Ersten Weltkrieg, Historische Mitteilungen: Beiheft 18 (Stuttgart: Steiner Verlag, 1996); Jeffrey Verhey, The Spirit of 1914: Militarism, Myth, and Mobilization in Germany, Studies in the Social and Cultural History of Modern Warfare 10 (Cambridge, UK: Cambridge University Press, 2000). 
of the character and origins of the war against the German Empire. ${ }^{17}$ German and Austrian anthropologists, too, were not beneath writing propaganda pamphlets, giving public lectures on the racial composition of the enemy soldiers or contributing to wartime exhibitions of images of the enemy, in photographs or plaster casts of the heads of prisoners-of-war (POWs).$^{18}$ This activity, in addition to the extensive use of POW camps as a site for anthropological research, ${ }^{19}$ came at a decisive moment for the institutionalization of this scientific field as an academic discipline in most European countries. Thus, to what extent the First World War might be seen as an important part of the political history of the establishment of this science is a question that this volume wishes to explore.

World War I had some unexpected effects. Its length more or less mandated the length of Malinowski's stay in the Trobriand Islands. The fieldwork standards resulting from his extended presence there, which were to become paradigmatic, can therefore be viewed as a fruit of wartime. However, it is not such accidental or serendipitous influences of the war which are examined in this volume, but rather those which emerged from a conscious decision to utilize the war situation for research purposes, whether with or without a scientific aim that was thought to somehow aid one's own side in battle.

17 Hanna, The Mobilization of Intellect, 75.

18 See the contribution by Andrew D. Evans in this volume as well as Monique Scheer, "'Völkerschau' im Gefangenenlager: Anthropologische 'Feind'-Bilder zwischen popularisierter Wissenschaft und Kriegspropaganda 1914-1918," in Zwischen Krieg und Frieden: Die Konstruktion des Feindes; Eine deutschfranzösische Tagung, eds. Reinhard Johler, Freddy Raphaël, Claudia Schlager, and Patrick Schmoll (Tübingen: Tübinger Vereinigung für Volkskunde, 2009), 69-109. On the contributions of anthropologists to the war exhibitions of 1916/17 in Germany and Austria, see Christine Beil, Der ausgestellte Krieg: Präsentationen des Ersten Weltkriegs 1914-1939 (Tübingen: Tübinger Vereinigung für Volkskunde, 2004), 193-207; Britta Lange, Einen Krieg ausstellen: Die Deutsche Kriegsausstellung 1916 in Berlin (Berlin: Verbrecher-Verlag, 2003), 40-63. On the war exhibitions in Vienna generally, see Maureen Healy, "Exhibiting a War in Progress: Entertainment and Propaganda in Vienna 19141918," Austrian History Yearbook 31 (2000): 57-85.

19 Andrew D. Evans, "Anthropology at War: Racial Studies of POWs during World War I," in Worldly Provincialism: German Anthropology in the Age of Empire, eds. H. Glenn Penny and Matti Bunzl (Ann Arbor, Ml: University of Michigan Press, 2003), 198-229; idem, “Capturing Race: Anthropology and Photography in German and Austrian Prisoner-of-War Camps during World War I," in Colonialist Photography: Imag(in)ing Race and Place, eds. Eleanor M. Hight and Gary D. Sampson (London: Routledge, 2002), 226-256; Margit Berner, “Die 'rassenkundlichen' Untersuchungen der Wiener Anthropologen in Kriegsgefangenenlagern 1915-1918," Zeitgeschichte 30 (2003): 124-136. 
During World War I, German and Austrian anthropologists, aside from taking part in domestic morale-building war exhibitions and giving learned lectures on the physical and cultural characteristics of the enemy, did not apply their expertise to psychological warfare on the front lines or engage in espionage. ${ }^{20}$ One could say, perhaps, that, from 1914 to 1918 , anthropologists supported the war effort as much as they were permitted, but that the state had not yet fully recognized what kinds of roles they could play. Instead, as a result of their constant struggle to secure research funding, anthropologists sought to use the war effort primarily to help support themselves. In order to access opportunities and spaces created by the war for their own research purposes, they implied a usefulness of their field for the greater good of the nation or empire, though it cannot necessarily be said that their work directly aided the war effort. The ethical questions which are at the center of research on the application of anthropological knowledge to warfare become strongly pronounced from the Second World War onward. In the First World War they are no more-but also no less - than potential issues. Here, we are looking at a development in its infancy, the initial establishment of the links between cultural scientists and the warfaring state, on which later cooperation would build. Thus, while ethical questions are not completely excluded from the discussion in this volume, they are not the focus of inquiry. The contributions to this volume seek to explore a broader territory in which such ethical questions are embedded. How did the experiences of wartime influence individual researchers' thinking and help to frame the questions of their research? Which anthropological practices were dictated by, or cultivated in, wartime? In what ways did such influences impact the field as a whole? What trajectories were set or adjusted due to the outbreak of the war? In other words, this volume seeks to address Eric Wolf's call for "a more layered understanding of the forces-both external and internal-that formed [anthropology]" at this most crucial juncture of the field's development. ${ }^{21}$

As stated above, by focusing on World War I, this volume concentrates on the European anthropological traditions, not only because the US entered the war later, but also because American anthropologists apparently did not involve

20 One exception to this rule was Leo Frobenius's plan to travel secretly to his former fieldwork areas in the Sudan and use his influence there to incite a rebellion against the British. This plan was never carried out, however, as his impolitic behavior on his way there sabotaged the effort. See Peter Heine, "Leo Frobenius als politischer Agent: Ein Beitrag zu seiner Biographie," Paideuma 26 (1980): 1-5.

21 Eric Wolf, "Anthropology among the Powers" Social Anthropology 7, no. 2 (1999): 121-134, quote from p. 121. This was the key address to the Fifth Biennial Conference of the European Association of Social Anthropologists in Frankfurt in 1998. 
themselves in their professional capacity. Within Europe, too, there were differences in the intensity with which anthropologists chose to use the war situation to further their research. It appears, for example, that in France, the war years were indeed ones in which anthropologists pursued little active research. The "study of man" in France had been characterized since the mid-nineteenth century by deep rifts dividing the work of the ethnographers in Africa (who were often part of the colonial administration) from that of the theoreticians in Paris, most especially the physical anthropological school around Paul Broca and somewhat later the Durkheimian school, which, in turn, were also deeply divided from one another. There was no university chair for physical or cultural anthropology in France, only museums, learned societies, and teaching schools which could not confer university degrees. By 1913, Marcel Mauss was still lamenting the stagnation of ethnography due to a lack of sufficient institutions and drew up a proposal for the creation of a Bureau of Ethnography attached to the university. ${ }^{22}$ Nothing came of it, as war had been declared and many French ethnographers and anthropologists were called to the front lines. The effect of the war on French anthropology, therefore, was of a more indirect nature. As Emmanuelle Sibeud has recently argued, the academicians who had been loathe to cooperate with "colonial ethnographer/administrators," viewing them as theoretically uninformed amateurs, reconsidered this stance after 1918. Durkheim and Mauss in particular had avoided contact, as they were politically critical of France's colonial engagement and feared ethnology could become a handmaiden to it. However, "World War I and its aftermath changed ethnologists' relationship to colonial regimes," writes Sibeud, because the "engagement of intellectuals in the war effort had fostered an expansion of the possible relationships between scientific networks and political authorities." ${ }^{23}$ Furthermore, the war had taken the lives of many of Mauss's students; Durkheim lost his own son in 1917 and died shortly thereafter himself. Mauss concentrated in the interwar years, therefore, on salvaging what was left of his school and chose to put aside prewar rivalries with the colonial ethnographers, viewing them now as a useful network for the production of ethnological data. The establishment of the Institut d'ethnologie at the Sorbonne in 1925, granting anthropology full academic status in France, was the direct result of this "alliance struck [...] between academic ethnology and colonial domination" 24 and-one might

22 Marcel Mauss, "L'ethnographie en France et à l'étranger," Revue de Paris (1913), 549, 820-821; cited in Alice L. Conklin, "The New 'Ethnology' and 'La Situation Coloniale' in Interwar France," French Politics, Culture \& Society 20, no. 2 (2002): 29-46, quote on pp. 32-33.

23 Emmanuelle Sibeud, "The Metamorphosis of Ethnology in France, 18391930," in Kuklick, A New History of Anthropology, 96-110, quote on p. 107.

24 Ibid., 107-108. 
add-a direct result of changes in thinking brought about by World War I. Whereas in other European countries the war caused a stronger differentiation between the subdisciplines, leading physical and social anthropology to drift further apart, in France it appears the war had a major role in bringing these disparate fields together. Since, however, the practice of anthropology in spaces created by the war did not play a significant role, French anthropology lies outside the purview of this volume.

Accounting for ideological shifts in German anthropology has enlivened the discussion of this particular country's history of cultural science. Studies, such as those by Robert Proctor and Benoit Massin, ${ }^{25}$ have considerably substantiated the argument that German-speaking anthropology was governed by a politically liberal paradigm before World War I. Contrary to the notion that racial theory had developed in a more or less straight line of völkisch thinking from Johann Gottfried Herder's Volksgeist to National Socialist science, recent studies have emphasized that, in the second half of the nineteenth century, German anthropologists were committed to a rather fluid, hybridist theorization of race which was not tightly bound to concepts of nation or Volk. ${ }^{26}$ The leading figures in the burgeoning academic field of anthropology, Adolf Bastian (1826-1905) and Rudolf Virchow (1821-1902), were united in their skepticism of the Darwinian model. Bastian taught his own brand of evolutionary theory,

25 Robert Proctor, "From Anthropologie to Rassenkunde in the German Anthropological Tradition," in Bones, Bodies, Behavior: Essays on Biological Anthropology, History of Anthropology 5, ed. George W. Stocking, Jr. (Madison, WI: University of Wisconsin Press, 1988), 138-179; Benoit Massin, "From Virchow to Fischer: Physical Anthropology and 'Modern Race Theories' in Wilhelmine Germany," in Volksgeist as Method and Ethic: Essays on Boasian Ethnography and the German Anthropological Tradition, History of Anthropology 8, ed. George W. Stocking, Jr. (Madison, WI: University of Wisconsin Press, 1996), 79-154.

26 See most recently Andre Gingrich, "Liberalism in Imperial Anthropology: Notes on an Implicit Paradigm in Continental European Anthropology before World War I," Ab Imperio 8, no. 1 (2007): 224-239; Andrew D. Evans, "A Liberal Paradigm? Race and Ideology in Late-Nineteenth-Century German Physical Anthropology," Ab Imperio 8, no. 1 (2007): 113-138. See also Matti Bunzl and H. Glenn Penny, "Introduction: Rethinking German Anthropology, Colonialism, and Race," in Penny and Bunzl, Worldly Provincialism, 1-30. The discussion on the connections between political liberalism and anthropological theory originated with Woodruff D. Smith, Politics and the Sciences of Culture in Germany 1840-1920 (New York: Oxford University Press, 1991). On the roots of German Volkskunde [folklore studies] in cultural anthropology and its liberal orientation, see Bernd Jürgen Warneken, "'Völkisch nicht beschränkte Volkskunde': Eine Erinnerung an die Gründungsphase des Fachs vor 100 Jahren," Zeitschrift für Volkskunde 95 (1999): 169-196. 
based on the assumption of a "psychic unity of mankind" manifest in universal Elementargedanken [elementary thoughts] which found their expression among different peoples in their particular Völkergedanken. Bastian placed great emphasis on the influence of geographical and climatic factors on cultural progress and did not discount the impact of contact between different peoples on their developmental trajectories, but his name became associated with the idea that, left to their own devices, any human group would develop along the same evolutionary scheme dictated not by the "struggle for existence," but by the very fact of their being human. ${ }^{27}$ Virchow's progressive liberalism was evinced in his political work as a member of the German Reichstag, where he was a vocal opponent of Otto von Bismarck's policies as well as of rising anti-Semitism. Like Bastian, Virchow held fast to the monogenetic view of human diversity and conceived "race" as a purely physical category which had no bearing on the ways that humans construed their political and cultural units as nations or ethnicities. ${ }^{28}$ The influence of these two men on the field of anthropology in German-speaking science can hardly be overestimated: The first open attack against the evolutionary paradigm they represented-the "diffusionist revolt" of $1904^{29}$-was not launched until after Virchow's death and Bastian's final departure from Europe. ${ }^{30}$ Moreover, as Massin has shown, full acceptance of Charles Darwin's theory in anthropological circles in the German-speaking world was delayed out of respect for Virchow's opposition to it. ${ }^{31}$ Its implementation in connection with the recently rediscovered Mendelian laws of genetics heralded the decline of the liberal paradigm in the field during the first decade of the twentieth century.

27 Cf. Klaus Peter Köpping, "Enlightenment and Romanticism in the Work of Adolf Bastian: The Historical Roots of Anthropology in the Nineteenth Century," in Fieldwork and Footnotes: Studies in the History of Anthropology, eds. Hans Vermeulen and Arturo Alvarez Roldán (London: Routledge, 1995), 75-91.

28 For a balanced treatment of Virchow's anthropological engagement, see Constantin Goschler, Rudolf Virchow: Mediziner, Anthropologe, Politiker (Cologne: Böhlau, 2002), 179-185, 318-350.

29 This term was coined by Woodruff D. Smith; see his "The Social and Political Origins of German Diffusionist Ethnology," Journal of the History of the Behavioral Sciences 14 (1978): 103-112; idem, "Friedrich Ratzel and the Origins of Lebensraum," German Studies Review 3 (1980): 51-68. On diffusionism as a theory particularly endemic to German-speaking ethnology, see Werner Petermann, Die Geschichte der Ethnologie (Wuppertal: Hammer, 2004), 579642.

30 Bastian saw Europe for the last time when he departed for the Caribbean in 1903 at the age of 78. He died in February 1905 in Port of Spain, Trinidad.

31 Massin, "From Virchow to Fischer," 114-120. 
The shift to an illiberal brand of German anthropology which aligned race with nation and fundamentally questioned the basic sameness of all humans was not fully completed, however, until after the cataclysm of World War I. This argument has been presented most forcefully by Andrew Evans, who has traced this process in the biographies of individual researchers working in the POW camps of the German and Austrian Empires. ${ }^{32}$ In this volume, Evans looks at the broader effects the war had on the mindset of German anthropologists as well as the impact of international academic isolation on the field as a whole. Subscription to a "catastrophic narrative" of the impact of the war on German anthropology was not a prerequisite, however, for all the contributions to this volume. An equally strong argument has been made for continuities in German anthropology that emphasize the affinity of the liberal worldview with the colonial project: Both the assertion of the essential unity of the human species as well as the organization of diversity into civilizational hierarchies provided ideological support for imperial endeavors. From this perspective, the fundamental shift in German anthropology takes place much earlier and in close connection with the Reich's accumulation of colonized territories in the late nineteenth century. The historian Andrew Zimmerman sees anthropologists defining themselves primarily over and against the hegemonic discourse of humanism, valorizing the methods of the natural sciences, objectifying their objects of study, and expanding the domain of culture and history beyond the confines of Europe ${ }^{33}$ From the perspective of their common "antihumanism," the divide between liberals and illiberals would be viewed as secondary.

The contributions to this volume, while not necessarily conceived of as direct interventions in this debate, were certainly written with it in mind. German anthropology's liberal heritage had a far-reaching impact, not only to the US, where Adolph Bastian's student, Franz Boas, established a cultural anthropology founded on many of his teacher's philosophical and methodological principles, ${ }^{34}$ but also in eastern Europe, from where many anthropologists came to German cities for their training. The fate of the liberal paradigm in other continental European countries is a question that could deserve more attention. ${ }^{35}$ Furthermore, the insight into a more nuanced account of German

32 Andrew D. Evans, Anthropology at War: World War I and the Science of Race in Germany (Chicago, IL: University of Chicago Press, 2010).

33 Andrew Zimmerman, Anthropology and Antihumanism in Imperial Germany (Chicago, IL: University of Chicago Press, 2001).

34 See Matti Bunzl, "Franz Boas and the Humboldtian Tradition: From Volksgeist and Nationalcharakter to an Anthropological Concept of Culture," in Stocking Jr., Volksgeist as Method and Ethic, 17-78.

35 For an account of the affinities between political orientations and anthropological theories in Great Britain, see Henrika Kuklick, "Tribal Exemplars: 
anthropology's development "help us," as Andre Gingrich has pointed out, "to remain cautious about assumptions that anthropology was programmed from the beginning to become a tool of nationalism in countries like Hungary or Romania, or, for that matter, that it represented a necessary precondition for a Marxist paradigm in Bolshevist Russia after 1917."36 Marina Mogilner's contribution to this volume on Russian anthropology engages the question of the status of liberalism in the field as she looks at the role of the military in this regard. At the same time, her account, as well as several other contributions to this volume, does not neglect the decades leading up to the war, allowing a clearer perception of continuities as well as ruptures during the "long turn of the century" to emerge. Finally, German anthropology itself is subjected to an analysis which differentiates between its German and Austrian brands. The role of liberalism in the anthropology of the German Reich with its overseas colonies cannot be transferred in whole piece to the Austrian case with its proximate Empire. As the war approached and ensued, the pressures of increased patriotism on the liberal paradigm worked themselves out in different ways in Germany than in an Austro-Hungarian Empire struggling to maintain its cohesion in the face of nationalist sentiments.

In the contributions to this volume, anthropological work carried out during the war years can be seen to have been concentrated in three major arenas: in the trenches among the soldiers, in search of what was quickly termed "war folklore"; in occupied territories among the local populations; and in the POW camps. The first of these sought to collect and document soldiers' songs, "trench art," and what it perceived as a dramatic rise in "superstitious" practices. As Reinhard Johler shows in his contribution, these topics were primarily the domain of Volkskunde, folklore studies, and études de folklore, disciplines interested in establishing themselves at universities. They implemented their "folklore studies of war" to achieve this end, with varying rates of success. Nations at war with each other nevertheless shared the same sets of questions in these research projects with deep historical roots in the ethnography of Europe. The first publication of this kind-a collection of soldiers' letters and journal entries from the Danish-Prussian war assembled by the Danish poet Karl Larsen published in German in $1907^{37}$ - was met with great enthusiasm by German-speaking Volkskunde and provided a model for the collection of

Images of Political Authority in British Anthropology, 1885-1945," in Functionalism Historicized: Essays on British Social Anthropology, History of Anthropology 2, ed. George Stocking (Madison, WI: University of Wisconsin Press, 1984), 59-82.

36 Gingrich, "Liberalism in Imperial Anthropology," 225.

37 Rudolph von Fischer-Benzon and Karl Larsen, Ein modernes Volk im Kriege: In Auszügen aus dänischen Briefen und Tagebüchern der Jahre 1863/64 (Kiel: Lipsius \& Tischer, 1907). 
"soldier language" initiated by the Swiss Society for Volkskunde shortly after the outbreak of World War I. ${ }^{38}$ The Swiss initiative motivated German and Austrian folklorists to start their own large collections of Kriegsvolkskunde as well as French and Italian reesearchers. "Folklore de la guerre" and "folklore de guerra" became distinct research fields of considerable importance and with links to cultural anthropology, as the contribution by Paolo De Simonis and Fabio Dei discusses.

Despite the ongoing war, there was intensive and extensive scientific exchange between these countries. Not only were the collection themes similar, the collectors also employed virtually the same methods and questionnaires. They also used similar reasoning for the justification of these large research projects: Congruent with the notion that the Great War was going to be the last, it was widely viewed as providing a singular, "once-in-a-lifetime opportunity" for ethnographic studies. Commentators on both sides of the front lines expressed their conviction that this modern war had robbed the simple soldiers of their thin veneer of civilization and could offer, through the study of their language, songs, and superstitions, a deep insight into the "Seelenleben des Volkes," the heart and soul of the common people. Documenting and analyzing it-as German, Austrian, Italian, and French scholars agreed-served not only the cause of ethnology, but also the causes of their respective armies. The folksongs and soldiers' ditties collected during the war were deliberately used as war propaganda, and the ethnological interest in "soldier superstitions" was fueled by increasing reports of the moral degradation in the trenches. This particular issue, however, was assessed quite differently among the European nations: German-speaking folklorists regarded the resurgence of what they considered archaic, magical practices under wartime conditions as almost perfectly natural, while French folklorists and anthropologists were taken aback. They had been convinced that superstition was virtually extinct in civilized and enlightened France and suspected at first that only French colonial troops and the German enemy would fall prey to it. But as they soon realized, French soldiers were in no way immune to the phenomenon, engaging in a variety of "superstitious" practices. ${ }^{39}$

This example shows that, at certain points, German Kriegsvolkskunde, French folklore de la guerre, and Italian folklore de guerra could also diverge from one another. To a certain extent, they were, in fact, competitors, and they could base

38 Though Switzerland remained neutral throughout World War I, it did mobilize its own armed forces and provided camps for the internment of POWs from both sides of the conflict.

39 Cf. Ralph Winkle, "'Connaître à fond l'âme du soldat': Französische Aberglaubensforschung während des Ersten Weltkriegs," in Alliierte im Himmel: Populare Religiosität und Kriegserfahrung, ed. Gottfried Korff (Tübingen: Tübinger Vereinigung für Volkskunde, 2006), 349-370. 
their research on quite different theoretical premises. Folklorists influenced by Germanic philology assumed a "Germanic continuity" of the primitive elements of "folk life," while French folklorists were more strongly influenced by cultural anthropology and spoke of an "âme collective" whose origins were based in "prelogical" thought. There were also considerable differences between German and Austrian Volkskunde. Whereas, in Germany, the study of soldiers' language was a major point of interest, Austrian folklorists placed little importance on this subject with good reason: In the dual monarchy's multinational army, emphasizing the importance of German soldiers' language would have been viewed as counterproductive, undermining patriotic objectives. Instead, Austrian Volkskunde concentrated on multinational collections of linguistic and musical data and developed their own, explicitly multinational Kriegsvolkskunde.

The roots of this different style of folklore studies, more closely linked with anthropology than with philology, had much to do with the specific subtradition of cultural science that was located in the Habsburg monarchy, especially its Cisleithanian portion with Vienna as its center, and its particular interest in the cultures of the Balkan Peninsula. The Austrian academy had always been an integral part of the German-speaking scientific world. Mutual exchanges of scientific and scholarly personnel between German and Austrian institutions was frequent, and Austrian scholars played influential roles in German anthropology, just as Germans did in Austria. ${ }^{40}$ As in Germany, a division between Völkerkunde (ethnology of non-European populations) and Volkskunde (folklore studies, or ethnology of European populations) evolved in Austria in the course of disciplinary institutionalization. However, simplified historiographic equations of Völkerkunde with colonialism and Volkskunde with ethnic nationalism do not work as easily in the Austro-Hungarian context.

The Habsburg realm was a multinational empire and a Great Power, but it held no colonies outside Europe. Naval explorations of the entire globe were conducted from Vienna with an air of universalist scientific neutrality. ${ }^{41}$ Austrian explorers roamed the world, but the study of other cultures and their concrete political interests did not intertwine in faraway lands. In the late

40 Pater Wilhelm Schmidt, founder of the "Viennese school" of ethnology, was born in Dortmund, Germany. Felix von Luschan and Richard Thurnwald are just two examples of Austrian-born anthropologists who made their careers in Germany. See Marion Melk-Koch, "Zwei Österreicher nehmen Einfluß auf die Ethnologie in Deutschland: Felix von Luschan und Richard Thurnwald," in Kulturwissenschaft im Vielvölkerstaat: Zur Geschichte der Ethnologie und verwandter Gebiete in Österreich ca. 1780 bis 1918, ed. Britta Rupp-Eisenreich (Vienna: Böhlau, 1995), 132-140.

41 Verena Stagl, "Die Weltumseglung der Fregatte Novara (1857-1859) im Spiegel zoologischer Sammlungen," Mitteilungen der Anthropologischen Gesellschaft in Wien 136/137 (2006/2007): 1-14. 
nineteenth century, the house of Habsburg projected its imperial expansionist energies into the post-Ottoman territories in southeastern Europe, rather than overseas. This activity was closely tied to Austria's long history of proximity to the Ottoman Empire, seen as a confrontation of equals. Austrian elites cultivated a certain solidarity with the Ottoman ruling classes, while Austrian ethnologists working in the Asian parts of the Ottoman Empire produced ethnographies based on long and close contact with the local population. This gave them insight that went beyond the stereotypes and blind spots of Orientalism, ${ }^{42}$ and it meant that Austrian Völkerkunde developed in a context quite different from that of Germany. By the same token, the link between Volkskunde and ethnic nationalism, so typical for the rise of folklore studies in Germany, was not possible for a scientific community aspiring to public acceptance and advancement in a multiethnic metropole. While national folklorist movements evolved toward the end of the nineteenth century in subcenters of the monarchy such as Prague or Agram (Zagreb), Vienna launched a Volkskunde of all the peoples of the monarchy. As a field of research, the Empire was conceptualized as a diversity of national and ethnic cultures on the surface, but with an underlying universal, primitive substrate. The eastern Slavic parts of the Empire, with their lower degree of industrialization, provided a rich field for folklorist research, much of which was carried out by Slavic scholars who were not only educated in traditions of German thought, but were also actors in the Viennese scientific community. ${ }^{43}$ Thus, the evolution of Volkskunde as a discipline in Austria was much more closely related to colonial expansion than its Völkerkunde counterpart, as the particular Habsburg brand of imperialism was one of short distances. ${ }^{44}$ Its premier "colonial situation" was located in the former Ottoman provinces of Bosnia and Herzegovina. Occupied in 1878 and annexed in 1908, they may be labeled the Habsburgs' "proximate colony." ${ }^{45}$

42 Andre Gingrich, "Kulturgeschichte, Wissenschaft und Orientalismus: Zur Diskussion des 'frontier orientalism' in der Spätzeit der k.u.k. Monarchie," in Schauplatz Kultur-Zentraleuropa, Transdisziplinäre Annäherungen: Moritz Csàky zum 70. Geburtstag gewidmet, ed. Johannes Feichtinger (Innsbruck: Studien Verlag, 2006), 279-288.

43 Reinhard Johler, "Das ethnische als Forschungskonzept: Die österreichische Volkskunde im europäischen Vergleich," in Ethnologia Europaea: 5. internationaler Kongreß der Societé International d'Ethnologie et de Folklore Wien, 12.-16.9.1994, ed. Klaus Beitl (Vienna: Veröffentlichungen des Instituts für Volkskunde der Universität Wien, 1995), 69-101.

44 Günther Kronenbitter, Krieg im Frieden: Die Führung der k.u.k. Armee und die Großmachtpolitik Österreich-Ungarns 1906-1914 (Munich: Oldenburg, 2003), 131-133.

45 Robert Donia, "The Proximate Colony: Bosnia-Herzegovina under AustroHungarian Rule" (2007), available online at http://www.kakanien.ac.at/beitr/ fallstudie/RDonia1.pdf (accessed January 13, 2010). 
For the late Habsburg Empire, the Balkans were borderlands laden with significance on many levels: Slavic nationalist movements inside the monarchy could exploit their ethnic ties with the post-Ottoman nation-states, such as Serbia and Bulgaria; metropolitan circles in Vienna, irritated by Hungarian obstinacy, favored a remodeling of the power structure of the dual monarchy by including a third entity of Slavic origin.

It was during the occupation of Bosnia and Herzegovina in 1878 that the Habsburg army experienced its last major military engagement prior to World War I. The annexation of 1908 and the wars of 1912/13 waged between the Ottoman Empire and the Balkan states, as well as amongst themselves, precipitated a crisis in the southeastern reaches of the Austro-Hungarian Empire. With the independence of Albania as an outcome of the Balkan Wars, a potential, but contested, satellite emerged for Austria-Hungary. Apart from the assassination in Sarajevo which sparked the war, the Balkans played a relatively minor role in the war as a whole. But for the Habsburg Empire, it was a significant region among its few territorial conquests before the war finally brought the dual monarchy to an end.

This belligerent expansion into the Balkans provided the framework for ethnographic and anthropological practices emanating from the metropole into the region. Ethnographic knowledge and practices of representation were thus not confined to academic circles. Diana Reynolds Cordileone outlines the involvement of an exhibitionary complex in symbolically pacifying "warlike" Bosnia and Herzegovina and integrating it into Austria's multiethnic realm. Knowledge and preservation practices by folklorists and anthropologists played a central role in this process. The small, mountainous principality of Montenegro was another Balkan region in which the "belligerence" of its population was a central feature in popular and ethnographic representations. Ursula Reber probes into this complex of anthropological practices in the public, political, and military spheres surrounding a contested border region. For Austrian Volkskunde as a nascent discipline, the occupied territories in World War I became an important region for gathering fieldwork experience. By taking part in their scientific exploration, Volkskunde demonstrated its usefulness to the occupying forces and could garner official attention from the state, as Christian Marchetti's contribution shows.

Among the spaces which the war created and which were used for anthropological research were the POW camps. In Great Britain, anthropologists entered POW camps for the purpose of examining Germans (see Henrika Kuklick's contribution in this volume), as did some French anthropologists. ${ }^{46}$

46 See, for example, Annette Becker, Oubliés de la Grande Guerre: Humanitaire et Culture de Guerre 1914-1918; Population Occupés, Déportés Civils, Prisonniers de Guerre (Paris: Éditions Noêsis, 1998), 329. 
However, the numbers of soldiers held prisoner in these countries was considerably lower than in Germany and Austria. In both of these countries, research of unprecedented magnitude was conducted in POW camps. Tens of thousands of captive soldiers from Europe, Asia, and Africa came into contact with German scholars and journalists allowed into the camps by the military authorities. Prisoners were asked to stand as models for artists and photographers; they were brought to the physical anthropologist to be measured and photographed; they were asked to perform for the film camera and the phonograph: speaking, singing, playing instruments, dancing, and demonstrating their knowledge of handicrafts. For such "services" rendered by the POWs, they generally received some sort of recompense, be it cigarettes or simply a reprieve from their usual forced labor shifts. What is at issue here is less a question of the ethics of such "exchanges"-which in any case would have to be discussed within the broader context of anthropological practices of the colonial period-than how the power relations created by the space of the camp affected scientists' attitudes and practices. The use of this wartime space as a venue for scientific data-gathering is illuminated from different angles in several chapters of this volume, each determined by the scientific or scholarly discipline involved as well as the data-gathering technology employed by each. The POWcamp research initiative originated in Austria, and Margit Berner sets up its historical context by explaining Austrian anthropologists' rationale for requiring large amounts of data and by looking at the ways in which the state had facilitated and hindered large-scale anthropological surveys in the past. Her contribution illuminates the ways in which the POW-camp studies were part of a longer tradition in imperial Austrian anthropology. This chapter is followed by four contributions each highlighting different kinds of media technology used in the camps. Margaret Olin begins with a discussion of the forays of the artist Hermann Struck and art historian Adolph Goldschmidt, both of them Jewish Germans, into the POW camps. Using visual images-drawings and photographs-Olin examines the ways in which these men positioned themselves among the Jews in the camps and how Jews were positioned among the nations interred in German POW camps during World War I. Britta Lange also discusses the use of photographs among German and Austrian anthropologists, highlighting the different roles visual "data" played in anthropological research. One scientist's lack of confidence in the visual image led him to place a higher value on another medium of representation of race: graphs and curves depicting statistical distributions of specific physical features among the prisoners he measured. Monique Scheer discusses the differences between different audio recording technologies and their impact on the ethnomusicological and linguistic studies conducted among POWs. The space of the camp made the use of gramophone technology more feasible for field research, leading to the creation of an "archive of sounds" in Berlin that continued to be built up after 
the war. Finally, the burgeoning technology of moving pictures was present in the Austrian POW camps. Wolfgang Fuhrmann situates the film recordings made there in the broader context of early ethnographic and commercial filmmaking, illuminating the aesthetic templates to which they adhere.

In the closing contribution to this volume, Andre Gingrich considers the impact of the war in the years that followed. In Italy, as the chapter from Simonis und Dei shows, there was little influence of the folklore de guerra on the development of demologia. In Central Europe, however, direct consequences can be seen: After Germany and Austria lost the war, Kriegsvolkskunde with its large collections quickly became obsolete. However, its underlying motive, the necessity to turn the gaze inward, toward one's own ethnicity as well as toward one's own national tradition of anthropology, was dramatically facilitated by defeat, in Germany and Austria as well as in the successor states of the Habsburg monarchy. This provided a new framework for the institutionalization of the cultural sciences at the universities, one of the main outcomes of World War I for this discipline. 
Adapting to Wartime:

The Anthropological Sciences

in Europe 



\title{
Continuity and Change in British Anthropology, 1914-1919
}

\author{
HeNRIKa KuKLICK
}

In large part, the activities that British anthropologists undertook during World War I and the conclusions they reached then sustained disciplinary trends that had begun at the turn of the century. The journals produced by the Royal Anthropological Institute (RAI) of Great Britain and Ireland (the geographical terms together equaled the United Kingdom) published very little with direct relevance to the war, and had content practically indistinguishable from prewar or postwar publications; the articles I cite in this chapter constitute the sum total of war-related contributions to RAI journals. ${ }^{1}$ In the meetings of Section $\mathrm{H}$, the anthropological section of the British Association for the Advancement of Science (BAAS), the war may have received somewhat more attention than was expressed in RAI publications, but the societies were not discrete entities - and papers delivered to the BAAS often became printed articles in RAI periodicals. Regardless, there were limited wartime opportunities for BAAS deliberations, since its 1917 and 1918 meetings were cancelled. ${ }^{2}$

1 These journals were Man, published from 1901-1994, which was the vehicle for publication of the "Miscellanea and Reviews" that had previously been a section of the Society's main journal, The Journal of the Royal Anthropological Institute of Great Britain and Ireland (usually referenced as the Journal of the Royal Anthropological Institute, first published in 1872 and titled the Journal of the Anthropological Institute until 1907), which would incorporate Man-and, for a time, take its name.

2 For example, we know that Arthur Keith delivered an address at the 1916 meeting in which he discussed the possibility that the British population was changing in physical terms, but we have no idea what he said, since his paper, like many delivered at the Association's meetings, was not printed; only presidential addresses were invariably published. See Report of the 86th Meeting of the British Association for the Advancement of Science, 1916 (London: John Murray, 1916), 468. 
Consider, for example, the physician-turned-ethnologist C. G. Seligman's 1916 presidential address to Section H. It began by bemoaning "the heavy losses which the Teutonic lust of power has inflicted upon our science, no less than any other department of humane and beneficent activity," and named six persons important in anthropological circles who had died in the war. But thereafter it turned to exposition of the early history of the Anglo-Egyptian Sudan. Similarly, though the physical anthropologist Arthur Keith began his 1917 presidential address at an RAI meeting by saying that in the recent past "our best endeavours, and our best thoughts, have been concerned with the affairs of a great and terrible war," he then told the history of the development of anthropology in Britain as an inspirational tale, which would motivate his listeners to resume their anthropological inquiries after the war's end. Although Keith was among the anthropologists who offered advice to the government during the war, and expressed some frustration that his like-minded colleagues' learned expertise was insufficiently recognized, he also suggested that those contributions which anthropologists made to the war effort did not serve disciplinary ends. ${ }^{3}$ Last, but hardly least, in his 1920 presidential address to Section H, the biometrician Karl Pearson, to whom anthropology was a justifiable enterprise largely because it had practical uses, effectively denounced practitioners of the discipline because their wartime service had no relation to their specialized expertise, notwithstanding their involvement in war-related activities. $^{4}$

Thus, perhaps the most significant feature of organized anthropology during the war was how little notice practitioners seemed to take of it in their scholarly capacities. Nevertheless, wartime experience provided significant confirmation of generalizations that had originated in nonmilitary contexts, and new evidence conduced to redesign of the discipline. In this chapter, I will discuss three major issues that anthropologists addressed during the war. First: What were the physical characteristics of British soldiers? What bearing did assessments of soldiers' characteristics have on questions about the present and future of the British race? Second: Was there some sort of racial basis for the military conflict? Third: How should anthropology's understanding of the basic characteristics of humankind be affected by observations of the behavior of men who suffered mental breakdown on the battlefield? Within the general category of mental distress, called "war neurosis," was an extreme condi-

3 Arthur Keith, "Presidential Address: How Can the Institute Best Serve the Needs of Anthropology?" Journal of the Royal Anthropological Institute 47 (1917): 12.

4 Karl Pearson, "Presidential Address," Report of the 88th Meeting of the British Association for the Advancement of Science, 1920 (London: John Murray, 1920), 36-151. 
tion named "shell-shock" by Charles S. Myers, whose early career spanned the boundary between anthropology and psychology. Myers restricted himself to psychology after the war, probably not least in consequence of his service during the war, which included serving as a consulting psychologist to the British army in France.

\section{The First Issue: The Condition of the British Race}

Late nineteenth-century British anthropologists, like their counterparts in other countries, were concerned about the possibility that the physical stock of their nation was degenerating in quality. In 1883, for example, anthropologists serving on a BAAS Anthropometric Committee warned that the human species would grow extinct if the position of women continued to improve. Recall that this was a period in which Lamarckian ideas were still widespread among scientists. (Indeed, there were trace elements of Lamarckism in Charles Darwin's work, which has long been understood as a definitive repudiation of it.) Lamarckian notions informed the Anthropometric Committee's judgment that inheritance of the qualities that women acquired through education was making successive generations' pelvises increasingly inadequate for delivering babies; making matters worse, babies gestated under civilized conditions had increasingly larger heads. Little more than a decade after the Committee rendered this judgment, wartime experiences made the question of racial degeneration especially urgent.

That is, during the South African War of 1899-1901 (also known as the Boer War), 40 percent of those who presented themselves as candidates for military service were rejected on health grounds-and the British forces in South Africa were hard-pressed to defeat their Afrikaner opponents in the territory that would become the Union of South Africa. After the Boer War, the government convened the Inter-Departmental Committee on Physical Deterioration to consider the physical condition of the British race, and the Committee called persons who were prominent in anthropological circles to testify as expert witnesses. Of great significance to the Committee were the opinions of the professor of anatomy at the University of Edinburgh, D. J. Cunningham, whose anthropological activities had included joint ventures with the biologist-turned-ethnologist A. C. Haddon (of whom much more in time). Cunningham asserted that what appeared to be signs of decline of the race in terms of its collective hereditary potential were merely transient, circumstantial phenomena-functions of deficient diets, housing, and exercise; Britons' physical defects did not prove, say, that the best of the nation's specimens were failing to reproduce in substantial numbers while the population 
of the lower orders exploded. Indeed, he was especially concerned to deny that the changing role of women was harmful to the race, arguing that enlarged opportunities for women improved their health, freeing them from restrictive corsets and encouraging them to exercise. Cunningham's views were incorporated in the Committee's 1904 Report, which recommended implementation of social welfare measures. ${ }^{5}$

Anthropologists' efforts during World War I were directly inspired by the 1904 report. Anthropologists figured in the Conjoint Board of Scientific Societies, established, in 1916, a private, nonprofit body dedicated to offering advice to the government and the public. The Board's Subcommittee on Anthropology counted among its members such notables as Arthur Keith, Karl Pearson, and the anatomist/paleoanthropologist Grafton Elliot Smith. The subcommittee recommended that all military recruits be examined by the newly established Medical Boards. ${ }^{6}$ Information accumulated during World

5 For a lengthy analysis of the debates about the status of the British race, the Boer War, and the Inter-Departmental Committee, see Henrika Kuklick, The Savage Within (New York: Cambridge University Press, 1991), esp. 133, 152153, 172.

6 Arthur Keith, "Anthropological Activities in Connection with the War in England," American Journal of Physical Anthropology 1 (1918): 91-96. In the journal, it is noted that the article was based on information Keith supplied, rather than written by him. Keith's discussion of the measurement of military recruits was evidently intended to inspire a postwar anthropometric survey of the British Isles-which was not realized; see also idem, "Presidential Address," 27. See also Keith's note on French anthropological leaders' active concern to influence military decisions, describing "Une Application Anthropologique à I'Art Militaire," written before World War I by the secretary of the Anthropological Society of Paris, which had "passed without notice in this country"; idem, Report of the 85th Meeting of the British Association for the Advancement of Science, 1915 (London: John Murray, 1916), 671. While in pedagogic and professional contexts the differentiation of British anthropology's subspecialties-physical anthropology, social anthropology, and archaeology - was not effected until the end of the interwar period (and never effected in the publications of the RAI), it was beginning at this time. The nonevent of the anthropometric survey is one indicator of the changes that were taking place in the discipline and, in particular, of the decline in prestige of physical anthropology. Social anthropology became the largest and most prestigious of the discipline's subfields, not least because it was advertised as useful to colonial administrators. (That professional social anthropologists were usually disdained by colonial governments, and their largest source of financial support was the American Rockefeller Foundation, is another matter. Anthropological developments during the interwar period are discussed at various subsequent points in this chapter.) Pearson, "Presidential Address," 36-151. 
War I corroborated the 1904 Committee's conclusions. That is, during the course of their military training, British soldiers showed dramatic personal improvement in every particular, and especially in their physical conditions, owing to their existence in "ideal open-air conditions, and ample and excellent food." Here was compelling evidence that the state of the British race was considerably affected by environmental factors.

Nevertheless, there was fear that military casualties could remove the finest specimens of British manhood from the breeding stock of the next generation-a fear that was often expressed. ${ }^{8}$ But it was countered by two different arguments. One was that soldiers fighting in battlefields relatively close to Britain were given leaves of sufficient length to permit them to visit their wives at home and procreate, even though they might be killed after they returned to battle. The other was that soldiers who became casualties were the least fit of the fighting forces; those best suited to reproduce would survive and return to civilian life. Indeed, to some, the most disturbing prospect was that the best specimens of British womanhood would withdraw from the breeding pool because of the war. As men left the British workforce to fight, women gained unprecedented opportunities to make occupational advances. Perhaps the most successful of unmarried self-supporting women might decide to remain unmarried, or would defer marrying until they could do so under particularly attractive terms; thus, the best suited might reproduce in smaller numbers than they could have done had they married at younger ages. ${ }^{9}$

What were the implications of wartime findings for postwar efforts to improve the quality of the population? In short, what policies might be adopted in the name of eugenics, the project conceived and named by Charles Darwin's cousin and anthropological luminary Francis Galton? Consider the research of Pearson, who, in 1911, became the first occupant of the chair in eugenics established with funds bequeathed by Galton at University College, London. Pearson is best remembered for his position that biological laws governed not only the intergenerational transmission of physical characteristics, but also such traits as temperament and aptitude, and that heredity was far more important in determining individuals' characteristics than environmental factors. He took this position in 1903, when he delivered the address in memory of Thomas Huxley that was an annual event of the RAI, then the Anthropological Institute. (The Institute was given a Royal charter in 1907, which may be taken as an index to the respect that the discipline had then earned as a truly scientific enterprise.) The Inter-Departmental Committee on Physical Deterioration

7 Sir Hercules Read, "Presidential Address: Anthropology and War," Journal of the Royal Anthropological Institute 49 (1919): 14.

8 For one illustration, see Pearson, "Presidential Address," 144.

9 Ibid., 17-19. 
was considering Pearson's ideas at the time of his Huxley lecture, speculating that the British population as a whole was deteriorating because its inferior specimens were reproducing out of proportion to their numbers, but, as I have already observed, made no recommendations suggested by his ideas.

Just as significant, Pearson and members of his professional circle did not restrict their research to documenting laws of inheritance. For purposes of suggesting possible policy interventions, they investigated the importance of environmental factors in individuals' growth-factors that were more amenable to deliberate intervention than biological relationships. Pearson and his colleagues undertook a congeries of studies, including his own On the Relationship of Health to the Psychical and Physical Characters in School Children, published in 1923. Indeed, no environmental factor was too trivial to investigate. Consider the work Pearson produced in collaboration with Mary Noel Kan, Study of the Data Provided by a Baby-Clinic in a Large Manufacturing Town, published in $1922 .{ }^{10}$ Controlling for variation that might be a function of class, this study found that babies were healthiest if dressed in wool garments, slightly less healthy if dressed in cotton, and least healthy if clothed in cotton-wool mixtures. Although Pearson never abandoned the position that nature was far more important than nurture in determining individuals' characteristics, it is notable that he devoted considerable time to research into the effects on individuals' life chances that environmental changes might make. Britain may have been the birthplace of the eugenics movement, but its response to the fears that provoked this was movement toward the development of a welfare state. It enacted little legislation that constituted either "positive" or "negative" eugenics - that is, respectively, measures designed to encourage the putatively inherently superior members of its population to have more children, as opposed to actions that eliminated the supposedly unfit from the breeding population through involuntary sterilization or outright murder. In notable contrast, the United States passed eugenics legislation, with the state of California leading the nation in enthusiasm and practice; American laws sanctioned involuntary sterilization as the application of scientific knowledge to policy making-and served the National Socialists who implemented the "final solution" as an example that justified their more radical eugenics program. ${ }^{11}$

10 See Henrika Kuklick, "The British Tradition," in A New History of Anthropology, ed. idem (Oxford: Blackwell, 2008), 59.

11 The definitive work on the eugenics movement, which makes the distinction between "positive" eugenics (broadly defined, this category includes public health measures) and "negative" eugenics is Daniel J. Kevles, In the Name of Eugenics: Genetics and the Uses of Human Heredity (New York: Knopf, 1985). 


\section{The Second Issue: Was There a Racial Basis for World War I?}

No later than 1903, Myers had asserted that it was a "familiar modern dictum" among anthropologists that there were no "pure" races in existence; within any given population, there was considerable variation in biological (as well as social) traits, although populations might differ both in their degree of variability and in the relative frequency of specific traits among them. ${ }^{12}$ In his 1920 presidential address to Section $\mathrm{H}$, Pearson reiterated this dictum. ${ }^{13}$ Did the war provide an occasion for some British anthropologists to modify their views of race? Andrew Evans has recently argued that the anthropometric studies of prisoners-of-war (POWs) in Germany that physical anthropologists conducted during the war contributed to decisive changes in the development of German anthropology as a discipline. Examining captives of diverse points of origin and focusing on those thought to be quite different from themselves, German anthropologists established correlations between race and nationality and laid some of the foundations for the German scientific racism that developed in the 1920s and 1930s. Moreover, to have studied POWs proved to have been a good career move in postwar German anthropology. ${ }^{14}$ The apparently analogous inquiries of British physical anthropologists were simply surveys of German POWs and led to rather different conclusions.

Significantly, such figures as the now-forgotten F. G. Parsons and the wellremembered, distinguished W. E. Le Gros Clark (who achieved the rank of Captain during the war) reported their findings tentatively after examining POWs in British hands. Above all, they worried about the effect of the socalled "personal equation"-differences in individuals' perceptions-on the measurements they took. Inconsistent judgments of such physical characteristics as head form and facial features were to be expected. Indeed, the war itself presented occasions for revelation of the unreliability of anthropometric evaluations, since initial assessments of the characteristics of individual prisoners, taken when they were captured, differed from the results of subsequent measurements of the same individuals. Furthermore, particular traits defied precise specification, since their classifications were affected both by the situations in which they were studied and by scientists' idiosyncrasies when they

12 Charles S. Myers, "The Future of Anthropometry," Journal of the Anthropological Institute 33 (1903): 37.

13 Pearson, "Presidential Address."

14 They paid virtually no attention to the British POWs, for example. See Andrew D. Evans, "Anthropology at War: Racial Studies of POWs during World War I," in Worldly Provincialism: German Anthropology in the Age of Empire, eds. H. Glenn Penny and Matti Bunzl (Ann Arbor, MI: University of Michigan Press, 2003), 198-229. 
used supposedly fixed typologies. That is, anthropologists doubted that they could make consistent observations of skin and eye color as well as of hair characteristics. There had been efforts to create standard color swatches for classifications of skin and eye color, such as those that were printed in the successive editions of Notes and Queries on Anthropology, jointly produced at irregular intervals by the RAI and the BAAS. But using these swatches was problematic: Comparisons could be affected by whether observations were taken indoors or outdoors and by qualities of light under any circumstances. Classifications of individuals' eye colors varied, depending, say, on whether an anthropometrist attached special significance to the color of the rim of the iris. Consistent measurements of hair color and texture were impossible, depending as they did on such factors as whether any given head of hair had been washed recently and how it was dressed. It was hard to judge a man's height when he was lying down, as wounded POWs often were. Finally, when physical anthropologists were not worrying about how results could be affected either by the personal equation or the conditions under which measurements were taken, they debated the very possibility of standardizing anthropometric techniques. ${ }^{15}$

Regardless, perhaps the most important question that concerned physical anthropologists was whether in fighting the Germans the British were fighting their close relatives. There was a well-established tradition of historical analysis that a significant proportion of the peoples who colonized Ancient England were of German stock. The migrants' habits of "Teutonic liberty" had made "England the purest type of the free Germanic polity," in which individuals' freedom was considerable because local government was exceptionally strong. ${ }^{16}$ Teutonic ideals and institutions spread throughout Great Britain and were perpetuated from generation to generation as well as transmitted to the migrants who came to Britain from time immemorial to the present day. Parsons and Le Gros Clark, like their German counterparts, found racial differences between British and German soldiers, although the ancient colonists of England had been Germanic. Paradoxically, then-contemporary Britons were in racial characteristics closer to the ancient inhabitants of the territory that became Germany than present-day Germans. Measuring such traits as head form, British physical anthropologists concluded that the population of

15 See, for example, F. G. Parsons, "A Reply to Mr. Pyecraft's Plea for a Substitute for the Frankfort Base-Line," Man 16 (1916): 71-73; W. P. Pyecraft, "A Plea for a Substitute for the Frankfort Base-Line: With an Account of a New Method of Drawing Skull Contours," Man 15 (1915): 101-106; A. J. N. Tremearne, "A New Head-Measurer," Man 15 (1915): 87-88; F. G. Parsons, "The Colour Index of the British Isles," Journal of the Royal Anthropological Institute 50 (1920): 159-182. The late nineteenth-century British historian William Stubbs, quoted in Stefan Collini, Donald Winch, and John Burrow, That Noble Science of Politics (Cambridge, UK: Cambridge University Press, 1983), 204. 
Germany had changed considerably over time; through successive waves of migration, persons of Alpine and Slavic stock had constituted increasingly larger proportions of Germany's inhabitants. ${ }^{17}$

Nevertheless, British physical anthropologists did not use their analyses of German POWs to equate the German population with a distinctive race. They plotted racial variation within Germany using an updated version of the so-called "index of nigrescence" developed by John Beddoe to describe racial variation throughout the British Isles. Although improved knowledge and techniques suggested modifications in Beddoe's approach, it was still fundamentally sound-and superior in conceptualization and application to the work of contemporary German physical anthropologists. Beddoe's research indicated a range of racial types distributed throughout Britain. ${ }^{18}$ His analysis was consistent with the dominant view among late nineteenth-century British anthropologists: The population as a whole represented variously blended mixtures of three basic stocks. That is, in such isolated geographical areas as the small islands near the mainlands of Scotland and Ireland, there were populations that had idiosyncratic characteristics. But there were not gross distinctions among the peoples of England, Ireland, Scotland, and Wales that would justify classifying them as separate racial types; in each of these areas, the population was of mixed ancestry. As the BAAS Anthropometric Committee reported, the most marked physical variations among the nation's population were associated with class, not race: The poor, and particularly the urban poor, were notably shorter and thinner. (This finding was consistent with the inquiries into the possibility of racial degeneration that I have already discussed.)

For British anthropologists, then, the absence of a clear association between geography and race meant that there was no justification for the late nineteenth-century argument that the Irish were a qualitatively different race, inherently incapable of the behavior necessary for full citizenship in the United Kingdom. From a contemporary perspective, endorsement of Irish Home Rule seems a liberal political position, but it was a complicated issue when it became controversial-and about which persons of generally liberal inclinations were

17 F. G. Parsons, "Anthropological Observations on German Prisoners of War," Journal of the Royal Anthropological Institute 49 (1919): 20-35. Also see Arthur Keith, "Presidential Address: The Bronze Age Invaders of Britain," Journal of the Royal Anthropological Institute 45 (1915): 12-22. It is worth noting that the subject of human migrations was of considerable interest to late nineteenthand early twentieth-century anthropologists, although the particulars of their narratives varied considerably. That they were interested in migrations is hardly surprising, given that they were living in an era in which there was much population movement.

18 On Beddoe, see, for example, George W. Stocking, Jr., Victorian Anthropology (New York: Free Press, 1987), 66-67. 
sharply divided; it figured prominently in the decline of the Liberal party. (For the Fabian socialists Beatrice and Sidney Webb, for example, Irish Home Rule was essential to separate Great Britain from a people they called "this detestable race." ${ }^{\text {"19 }}$ But late nineteenth-century British anthropologists did not judge the Irish to be a separate, inferior race, and the leading lights of the field were vehemently opposed to Home Rule for Ireland. ${ }^{20}$ By analyzing the German population as a mixture of various stocks, just as the British population was, anthropologists suggested that the German soldiers who fought in World War I were not drawn from a distinctive race that was suited to a way of life utterly alien to British norms.

In sum, British anthropologists of the World War I era did not conflate race, culture, and nation. Early in the war, Elliot Smith argued that there were "legitimate national aspirations" which could only be realized through implementation of "the art of tolerance and the spirit of compromise"; rhetorical appeals to "due recognition of the claims of race and nationality" were predicated on ignoring "a multitude of other factors." ${ }^{21}$ Subsequent history did not provoke dissent from such views. Consider the statement published in the Journal of the Royal Anthropological Institute in 1919 by Harold Peake, a devoted amateur anthropologist (he was independently wealthy):

It is always unwise to use an ethnic term as a designation for a race, and a linguistic term usually serves no better. There is no country whose population is racially uniform, no language which is spoken by one race alone, or by all members of a race. Therefore, we have given up talking of the English race, and have left the term British race to journalists [...]. ${ }^{22}$

This is hardly to say that anthropological arguments linking ethnicity and nation were not invoked when the victors of World War I redrew the map of Europe. Ethic issues figured prominently in the deliberations of the parties to the Paris Peace Conference of 1919. The official participant in the Conference

19 Quoted in Kuklick, The Savage Within, 116. Italics in the original.

20 Ibid., 114-116. It is of parenthetical interest that contemporary geneticists have used DNA testing to confirm nineteenth-century anthropologists' judgment that the populations of all parts of the British Isles were essentially a single people, though they differ considerably in their identifications of the origins of the components of this people. See Nicholas Wade, "A United Kingdom? Maybe," New York Times, March 6, 2007, F1, F4.

21 G. Elliot Smith, "Opening Statement" to a joint session of Section H and Section E (Geography) of the BAAS. Report of the 85th Meeting of the British Association for the Advancement of Science, 1915 (London: John Murray, 1916), 672.

22 Harold Peake, "The Finnic Question and Some Baltic Problems," Journal of the Royal Anthropological Institute 49 (1919): 186. 
who was most committed to the idea that national boundaries should be determined by ethnic affinities was Arthur Balfour, most famous for the 1917 official declaration known by his name, which pronounced that Palestine would become a homeland for the Jewish people. Balfour was hardly naïve, and he consistently promoted the application of scientific knowledge to public policy; he was personally connected to many members of the intellectual aristocracy, not least of these his younger brother Francis, the outstanding physiologist of his generation (and Haddon's original scientific role model). Balfour had been Britain's Prime Minister before the war, and became Foreign Secretary during it. At the Paris Peace Conference itself, he was at the height of his influence during the period when both Britain's Prime Minister, Lloyd George, and America's President, Woodrow Wilson, were absent. He argued effectively for the re-creation of Poland, a nonexistent entity since 1795, its diverse parts having been annexed by Germany, Russia, and the Austro-Hungarian Empire. For Balfour, ethnic characteristics could be ignored only if the national boundaries drawn on strictly ethnic lines entirely would lead to nonviable economic polities. $^{23}$

Was the war followed by major changes in British physical anthropology? No. It remained, as it had been-an enterprise with diverse factions, some more influential than others. Its practitioners had common meeting grounds in such settings as the RAI and the Section H of the BAAS, but their intellectual diversity was a function of their employment in a range of institutional settings, from anatomy departments to agricultural experiment stations. For example, in the World War I era, they debated the merits of Franz Boas's study of the characteristics of the American-born children of immigrants. Some, such as Haddon, writing in 1910, found Boas's findings compelling, because they showed intergenerational variation in head form; to Haddon, Boas's finding was especially significant, because head form had been thought among the most stable of intergenerational characteristics. Recall that head form figured prominently among the variables that physical anthropologists in both Britain and Germany considered in judging what racial variation obtained among the nations that were parties to World War I. At this time, Haddon had enormous influence in organized anthropology, and his opinion carried considerable weight. ${ }^{24}$ But there were other prominent figures in the anthropological com-

23 On Balfour, see, for example, Margaret Macmillan, Paris 1919 (New York: Random House, 2001).

24 A. C. Haddon, "Environment versus Heredity," Nature 2140 (1910): 11-12. Haddon (1855-1940), was at this time Reader in Ethnology at Cambridge University, and retired as such in 1926 (there was no professor of anthropology at Cambridge until 1932). This was not to say that findings about changes in head form could not be interpreted differently. For example, though Pearson had nothing specific to say about Boas's study, he dismissed head- 
munity, such as H. J. Fleure, who differed with him, writing in 1914 that Boas's conclusions were merely indications of flawed methodology. ${ }^{25}$ Along with Fleure, many who were impressed by the recently rediscovered Mendelian laws of heredity argued for the sustained durability of different race types in the British population-while also endorsing the conclusion that the population as a whole was mixed. ${ }^{26}$

If Haddon's approach represented conventional wisdom, it was not accepted by everyone. Moreover, the deliberations of the postwar years did not yield consensus. Perhaps the best illustration of British physical anthropologists' intellectual disarray was their difficulty in reaching collective agreement about how to counter National Socialist scientific racism. A Race and Culture Committee was formed in 1934 under the auspices of the RAI, with the support of the Institute of Sociology. (Interestingly, it included no Jews, since they were deemed insufficiently objective to assess National Socialist propagandaalthough there were Jews active behind the scenes in the Committee.) But the Committee failed in its task; its 1936 report was inconclusive. The race question had to be resolved somehow, however. In 1936, the BAAS zoology and anthropology sections held a joint meeting that addressed the question, concluding that the word "race" should be eliminated from scientific and public discourse, because it had been thoroughly politicized-echoing the argument of We Europeans (1935), coauthored for a popular audience by A. C. Haddon and the biologist Julian Huxley-Thomas Huxley's grandson. ${ }^{27}$ Under such circumstances, the minority of anthropologists who were scientific racists could be overwhelmed. In sum, unlike in Germany, in which wartime experience

form measurements as of no disciplinary value, saying that they, along with all manner of anthropometric measurements, had no correlation whatsoever with hereditary traits; Pearson, "Presidential Address," 186-187.

$25 \mathrm{H}$. J. Fleure, review of Descendants of Immigrants, Changes in Bodily Form of by Franz Boas, Man 14 (1914): 206-208. Fleure (1877-1969) was, in 1914, professor of zoology and lecturer in geography at the University of Wales, Aberystwyth, where he later became professor of geography and anthropology in 1917; he then became professor of geography at Manchester University in 1930, retiring in 1944. Although he held high offices in both the RAI and Section $\mathrm{H}$ throughout his career, the variation in his professional identity over time suggests that his sort of physical anthropology was growing less fashionable after the war.

26 Idem, review of Anthropology and History by William McDougall (Robert Boyle Lecture, Oxford 1920), Man 20 (1920): 190-191; idem and L. Winstanley, "Correspondence on 'Anthropology and Our Older Histories,'" Man 19 (1919): 129-132.

27 See Elazar A. Barkan, The Retreat of Scientific Racism (New York: Cambridge University Press, 1992), 286-296. 
seemed to clarify the relationship between race and nation for anthropologists, in postwar Britain, there was still variation in opinion.

\section{The Third Issue: War Neurosis-Its Origins and Implications}

This is the feature of my narrative with the most significant anthropological pedigree-and which represents the most important legacy that wartime experience left to British anthropology. The reader may initially wonder why this is the case, but the origin point of this narrative was the 1898 Cambridge Anthropological Expedition to Torres Straits, which took a seven-man team to do fieldwork on a cluster of islands located between Australia and New Guinea from late April to mid-November; Myers, who would coin the term shellshock, was one member of the team. The team's organizer was Haddon, who assumed the first position established in ethnology at Cambridge University shortly after the expedition concluded. The expedition's leading intellectual light was W. H. R. Rivers, who was, in 1898, Cambridge's lecturer in experimental psychology and the physiology of the senses (in which capacity he had taught Myers). The overarching conceptual scheme that informed the expedition's inquiries was Darwinian biogeography. ${ }^{28}$ In this chapter, there is no reason to summarize the various ways in which the expedition's findings corroborated this scheme, nor is there need to explain why Rivers would shortly pronounce that fieldwork must be done by individuals, rather than teams, and that adequate research required at least a year spent in the field. What matters is the model of individual action consistent with Darwinian biogeography that Rivers expounded in the expedition's reports. This was his explanation of human action as adaptive behavior.

Rivers addressed the question of the relationship between biological and cultural evolution. It had long been argued that in biological terms so-called primitives were closer to the lower animals than evolved Europeans: Primitives supposedly had acute eyesight and hearing and were relatively insensible to pain. When Rivers employed methods developed in European psychological laboratories to test islanders' sensory responses, he demonstrated that the islanders did not have innately superior sensibilities; indeed, their hearing was not as good as that of members of the expedition team. Of necessity, however, the islanders had cultivated their observational skills in order to survive in unimproved nature. For example, they were highly alert to signs of impeding

28 For a general account of the expedition, see Henrika Kuklick, "Islands in the Pacific: Darwinian Biogeography and British Anthropology," American Ethnologist 23 (1996): 611-638. 
danger as well as able to recognize edible animals looming in the distance. But Europeans placed in circumstances similar to primitives were fully capable of developing equivalent sensory skills. There was the specific issue of the islanders' relative indifference to the color blue: Perhaps it showed that, in at least this instance, they were at a lower level of biological evolution than Europeans-in a state of arrested development-since, like European children, they preferred red. Moreover, the dark pigmentation of the macula in their eyes created a slight insensitivity to blue. Still, psychological tests showed that the islanders could recognize the color. They were not, however, as appreciative of blue as were advanced Europeans-since admiration of the color was an element in the aesthetic contemplation of nature for which they had no time. Indeed, Europeans who had lived among primitive peoples and followed their ways of life provided important anecdotal evidence; their experience indicated that, when Europeans were in positions in which they had to focus on basic survival, they lost interest in the high intellectual activities that had once engaged them.

The general principle that explained cultural variation was the law of the conservation of energy, underpinning an energetic model that informed disciplines from physics to physiological psychology. That is, Rivers understood the human body as a closed energy system: The way that individuals expended their fixed portion of energy determined the quality of their lives. Primitives' lives did not afford opportunities for philosophical speculation or aesthetic appreciation, because they were entirely devoted to sheer survival. The physiological psychological tests Rivers administered in the field confirmed that body economies of energy expenditure and not limited biological evolution explained primitives' habits.

Subsequently, Rivers served as a military psychiatrist during World War I, treating victims of shell-shock and achieving the rank of Captain. His therapeutic approach was not predominant. British psychiatrists used a range of therapeutic techniques (some quite punitive) to deal with victims of shellshock, and, in fact, their practices were similar to those used by psychiatrists in military employment in other forces fighting the war. ${ }^{29}$ What was distinctive about Rivers's approach was that it was informed by his experiences of ethnographic fieldwork. Rivers analogized his patients' behavior to primitives' behavior. Soldiers collapsed on the battlefront, because they could not cope with pressures to act heroically while their lives were constantly threatened. Soldiers were engaged in a literal struggle for existence; indeed, their struggle was far fiercer than that of meeting the requirements of sustaining life in unimproved nature-such as the struggle of the most primitive of peoples. Moreover, no soldier was immune to shell-shock, however heroic he had previously

29 See, for example, Paul Lerner, Hysterical Men (Ithaca, NY: Cornell University Press, 2003), 1-11. 
been in battle, nor did it matter whether his family had a history of mental illness. Any soldier could succumb to shell-shock if his situation became sufficiently threatening. Victims could become infantilized, losing their powers of speech or movement. Soldiers could also lose the capacity for abstract thought. For example, a soldier could become unable to name colors, only capable of seeing that one given object was the same color as another object. As Rivers said, soldiers were "reduced by neural injury to the state of the many peoples who denote colours by their resemblance to natural objects." ${ }^{30}$

Rivers's analysis represented a means to discredit the unilinear evolutionist scheme that had prevailed among nineteenth-century British anthropologists. Its exponents included such luminaries as E. B. Tylor and J. G. Frazer. Tylor, born in 1832, was the most eminent anthropologist of his generation and the occupant of the first university position established in Britain for the subjectthe readership in anthropology created for him in 1884. Frazer, born in 1854, a fellow of Trinity College, Cambridge, was the last notable anthropologist to use the nineteenth-century model. To document the unilinear evolutionist scheme was to demonstrate that all peoples, everywhere, developed along an invariant route of progress from humankind's most primitive condition to its highest form-European civilization; peoples differed in the pace of their evolution, but not the direction it took, the pace being determined by such factors as geographical conditions.

Rivers did not doubt that there were higher and lower forms of behavior. He insisted, however, that each individual had the potential to exhibit the full range of behavioral possibilities. It was also significant that the symptoms of shell-shock belied previous sexual stereotypes. The psychological disturbance designated "hysteria" had previously been assumed peculiar to women, as its very name indicates, but the behavior of soldiers during war demonstrated that men were fully capable of becoming hysterical. Not surprisingly, given his identity as a psychologist, Rivers had challenged the unilinear evolutionary scheme by translating historical processes that shaped societies (however much they depended on the cognitive skills of individuals) into a structure of personality dynamics that allowed any given individual to advance and regress (possibly repeatedly) during the course of a lifetime.

Rivers's theoretical alternative to unilinear evolutionism was diffusionism-a historical, rather than a historicist, model. Anthropological diffusionism came in a variety of forms, including those developed in the Germanspeaking world as well as transported (and translated) into terms that North Americans found congenial before World War I. British diffusionism had some very peculiar features, and Rivers did not expound upon the most improbable

30 For a general discussion of the interpretation of shell-shock made by Rivers and his like-minded associates, see Kuklick, The Savage Within, 171. 
elements of its narrative. He announced his enthusiasm for diffusionism in his 1911 presidential address to Section H. Rivers clearly found the diffusionist approach attractive, because it relied on psychological explanations, and it is notable that British diffusionism was articulated by another medically trained figure who became active in British anthropological circles. This was Grafton Elliot Smith, who, during World War I, served as a psychiatrist in the military hospital where Rivers was also stationed and wrote, along with T. H. Pear, what was considered a definitive study of shell-shock.

The most significant feature of Rivers's conceptualization of personality dynamics, however, was that it had no necessary connection to a historically oriented anthropology. Furthermore, the evidence gathered from treatment of shell-shock victims was exceptionally compelling-more compelling than observations made during the Torres Straits Expedition. That is, the unintended experiments that created shell-shock victims yielded exceptionally persuasive evidence, because they were performed on European bodies-and those bodies were vast in number; persons who never fully recovered from shell-shock formed the largest category of military pensioners in Britain after the war. If Rivers's interpretation of shell-shock was by no means the only one available to the military during World War I, it was the only one that affected the direction of British anthropology. (In the military mind, cowardice was a far more acceptable explanation of shell-shocked soldiers' behavior. $)^{31}$

That is, Rivers's energetic model of the body served two anthropological purposes. It explained how the anthropologist as fieldworker could become a scientific instrument by immersing himself in the lifestyle of the people among whom he was working. It is notable that Bronislaw Malinowski described himself in the terms of a fixed energy system in the diaries he kept during the fieldwork he did in the World War I era. (I am not claiming that Malinowski was familiar with Rivers's wartime psychiatric work; but he read Rivers's programmatic injunctions while in the field and acknowledged Rivers's influence on his methodology.) Rivers's scheme allowed anthropologists to repudiate historical analysis-to argue that only synchronic analysis provided significant explanations of variations in human behavior; the shell-shock victim had a personal history, a medical case history, but this had no necessary relationship to collective historical experience. Moreover, since all human beings were capable of degeneration, there was no relationship between biological and cultural variation. Thus, along with W. H. R. Rivers's student A. R. RadcliffeBrown, Bronislaw Malinowski founded the functionalist school of anthropol-

31 This judgment has recently been restored to public consciousness. In August, 2006, the British Parliament issued a group pardon to 306 British and British Empire soldiers who had been executed for such offenses as cowardice and desertion, despite presenting symptoms of shell-shock. 
ogy, which was purely social anthropology, thoroughly differentiated from the disciplines' other subfields. ${ }^{32}$ Functionalists dominated British anthropology from roughly 1930 to 1970 . Clearly, Rivers's wartime observations enabled him to develop his theoretical scheme to its apogee, and its influence was considerable, albeit in some ways that Rivers could not affect (not least because he died in 1922).

There is a certain irony in the conclusion of my narrative. Malinowski might not have put into practice the research method that Rivers preached had he not been interned in Australia during World War I, because he was a citizen of the Austro-Hungarian Empire and thus classified as an enemy alien. He was then Seligman's protégé at the London School of Economics, and he had come to Australia before the outbreak of the war in order to attend the 1914 meetings of the BAAS, held in Sydney and Melbourne. He was as an internee unable to leave the territory under Australia's jurisdiction until after the war ended. He had intended to do fieldwork in the area, but it might not have been so protracted as it was (although it was not quite as lengthy as he intimated) had he not been in Australia when the war began. Arguably, Malinowski's ascent in British anthropology was the single most important disciplinary phenomenon following the war-but its connection to the war was indirect. ${ }^{33}$

32 Shortly before his death, Rivers lamented the fragmentation of anthropology into discrete subfields. See his "Presidential Address: The Unity of Anthropology," Journal of the Royal Anthropological Institute 52 (1922): 12-25. On the young Malinowski's personal saga, early career, and misrepresentation of his fieldwork experience, see Michael W. Young, Malinowski: Odyssey of an Anthropologist, 1884-1920 (New Haven, CT: Yale University Press, 2004). For Malinowski's ascent in postwar British anthropology, see Kuklick, The Savage Within, esp. 208-214. His eminence depended, in large measure, on his ability to secure financing for his students' field research, which he did with the monies provided by the Rockefeller Foundation. During the negotiations that led to the Foundation's support of British anthropology, eminent British scientists observed that Rivers would be the most creative mind in British anthropology, were he not dead; standard Rockefeller policy was to consult leading figures worldwide in whatever research areas they supported, in order to guarantee that Foundation money would be well spent. Interwar British anthropology might have been rather different had Rivers been alive to assume the professional power that Malinowski secured. 



\title{
Doing Anthropology in Russian Military Uniform ${ }^{1}$
}

\author{
Marina MogILner
}

The interplay between two of the most significant categories in post-Hegelian European modernity-total war and race-has not been subject to analysis within the narrative of Russian history. "Race" was seen as the natural, historically conditioned human collective, a synthesis between a discrete human subspecies and the unique artefact of its "spirit." "Total war" was regarded in certain circles as an ideal mechanism for the selection of peoples of superior vitality, able collectively to sustain long-term military, economic, cultural and political competition. Total war would pit nation against nation, each combatant's resolve cemented by "national" values and interests, "natural" virtues, and "organic" racial traits. The reasons for this abstinence have been several: Russian involvement in World War I has been overshadowed by the nearly concurrent traumata of the 1917 revolutions and the civil war that followed. The war's role as both the climax of Russian prerevolutionary development and the cradle of many Soviet discourses and practices is gaining appreciation, only now, in the history writing of the past decade. ${ }^{2}$

1 Research for this article was supported by the Gerda Henkel Stiftung (AZ 09/ $\mathrm{SR} / 02$ ) and the Volkswagen Stiftung (grant in support of the collaborative project "Languages of self-description and representation of the Russian Empire," 2006). I am grateful to all the participants of the conference "Doing Anthropology in Wartime and War Zones" for their stimulating comments and questions.

2 Dietrich Beyrau, Militär und Gesellschaft im vorrevolutionären Russland (Cologne: Böhlau, 1984); N. N. Smirnov et al., eds., Rossiia i Pervaia mirovaia voina, Materialy mezhdunarodnogo nauchnogo kollokviuma (St. Petersburg: Dmitrii Bulanin, 1999); Peter Gatrell, A Whole Empire Walking: Refugees in Russia during World War I (Bloomington, IN: Indiana University Press, 1999); Josh Sanborn, "The Mobilization of 1914 and the Question of the Russian Nation: A Reexamination," Slavic Review 59, no. 2 (2000): 267-289; Peter Holquist, 
As for race, scholars' indifference toward its role in Russian culture and politics can be traced to a dominant Sonderweg perception of Russian modernity as underdeveloped and derivative, incapable of generating modern liberal, national, colonial, or gender discourses, institutions, or practices. ${ }^{3}$ Tacit recog-

Making War, Forging Revolution: Russia's Continuum of Crisis, 1914-1921 (Cambridge, MA: Harvard University Press, 2002); Joshua Sanborn, Drafting the Russian Nation: Military Conscription, Total War, and Mass Politics, 1905-1925 (Dekalb, IL: Northern Illinois Press, 2003); Eric Lohr, Nationalizing the Russian Empire: The Campaign against Enemy Aliens during World War I (Cambridge, MA: Harvard University Press, 2003); Melissa K. Stockdale, "United in Gratitude: Honoring Soldiers and Defining the Nation in Russia's Great War," Kritika: Explorations in Russian and Eurasian History 7, no. 3 (2006): 459-486.

3 See the discussion of the implications of the Sonderweg paradigm for Russian history in Ab Imperio 3, no. 1 (2002): 15-101 (contributions by Carl E. Schorske, Hans van der Loo, Gunilla-Friederike Budde, Jürgen Kocka, and Manfred Hildermeier). Race was, and remains, an important issue for historians studying Russian politics toward Jews. This is the result of their "socialization" in general Jewish historiography rather than in Russian history. See Hans Rogger, Jewish Policies and Right-Wing Politics in Imperial Russia (Berkeley, CA: University of California Press, 1986); Eli Weinerman, "Racism, Racial Prejudice and Jews in Late Imperial Russia," Ethnic and Racial Studies 17, no. 3 (1994): 442-495; the most recent example: Eugene Avrutin, "The Power of Documentation: Vital Statistics and Jewish Accommodation in Tsarist Russia," Ab Imperio 4, no. 4 (2003): 271-300; idem, "The Politics of Jewish Legibility: Documentation Practices and Reform during the Reign of Nicholas I," Jewish Social Studies 11, no. 2 (2005): 136-169; idem, "Racial Categories and the Politics of (Jewish) Difference in Late Imperial Russia," Kritika: Explorations in Russian and Eurasian History 8, no. 1 (2007): 13-40; Marina Mogilner, "Evreiskaia antropologia v Rossii v kontekste evropeiskikh rasovykh issledovanii," in Istoriia i Kul'tura Rossiiskogo i Vostochnoevropeiskogo Evreistva: Novye istochniki, novye podkhody, eds. Oleg Budnitskii et al. (Moscow: Dom evreiskoi knigi, 2004), 116-137. Students of Soviet history also had additional incentives to consider race as a part (or not a part) of Russian modernity. See Eric Weitz, "Racial Politics without the Concept of Race: Reevaluating Soviet Ethnic and National Purges," Slavic Review 61, no. 1 (2002): 1-29; Paul Weindling, "German-Soviet Medical Co-operation and the Institute for Racial Research," German History 10, no. 2 (1992): 177-206. As an example of a new emerging interest in race in the post-Soviet countries, see Vladimir B. Avdeev and A. N. Savel'ev, eds., Rasovyi smysl Russkoi idei: Sbornik Statei (Moscow: Belye Al'vy, 2000); Vladimir B. Avdeev, ed., Russkaia rasovaia teoriia do 1917 goda: Sbornik original'nykh rabot russkikh klassikov (Moscow: Feri-V, 2002); Vladimir Menzhulin, Drugoi Sikorskii: Neudobnye stranitsy istorii psikhiatrii (Kyiv: Sfera, 2004). On Russian modernity and its resistance to biological determinism, see Laura Engelstein, Keys to Happiness: Sex and the Search for Modernity in Fin-de-Siècle Russia (Ithaca, NY: Cornell University Press, 1992); 
nition of the atypical character of Russia's contiguous Empire contributed to the production of colonial and anticolonial discourses that avoided recourse to standard European imperial categories such as race. ${ }^{4}$ As a result, the story of Russian "race studies" has to be written virtually from scratch. But even initial steps reveal a substantial and highly differentiated tradition of physical anthropology in the Russian Empire. ${ }^{5}$ Despite the differing modes of anthropology's institutionalization and the fluidity of major anthropological paradigms, the fact remains that anthropology established itself as a legitimate academic field in Russia in the 1870s.

The first Russian chair in anthropology was established at Moscow University in $1879^{6}$ - the same year the first German professorship was bestowed on Johannes Ranke in Munich. ${ }^{7}$ Remarkably, this first and major Russian professorship subsisted on private donations, as did the Anthropological Division of the Moscow-based Society of the Lovers of the Natural Sciences, Anthropology and Ethnography (1863) that had raised the money to fund it. ${ }^{8}$ The Anthropological Division was the real center of Russian anthropology, connected with other academic societies and individuals engaged in anthropological research across the Empire. Again, this was not a uniquely Russian form of institutionalization; ${ }^{9}$ what made Russia unusual was the clear linking of partic-

James Allen Rogers, "Charles Darwin and Russian Scientists," Russian Review 19, no. 4 (1960): 371-383.

4 The classical work in this regard remains the dissertation by Nathaniel Knight, "Constructing the Science of Nationality: Ethnography in Mid-Nineteenth Century Russia" (PhD thesis, Columbia University, 1995); see also his "Ethnicity, Nationality, and the Masses: Narodnost' and Modernity in Imperial Russia," in Russian Modernity: Politics, Knowledge, Practices, eds. David L. Hoffmann and Yanni Katsonis (New York: St. Martin's Press, 2000), 41-66.

5 See Marina Mogilner, Homo Imperii: Istoriia fizicheskoi antropologii v Rossiiskoi imperii (konets XIX-nachalo XX vv.) [Homo imperii: A history of physical anthropology in the Russian Empire, late 19th to early 20th centuries] (Moscow: Novoe Literaturnoe Obozrenie, 2008).

6 The detailed history of the chair is reconstructed on the basis of archival materials from the Moscow Central Historical Archive (TsIAM. F. 418. Op. 48. D. 422; F. 428. Op. 46. D. 339.) in Mogilner, Homo Imperii. See also N. G. Zalkind, Moskovskaia shkola antropologii v razvitii otechestvennoi nauki o cheloveke (Moscow: Nauka, 1974).

7 Paul Weindling, Health, Race and German Politics between National Unification and Nazism, 1870-1945 (Cambridge, UK: Cambridge University Press, 1989), 54.

8 The Society received the donation from the industrialist K. F. von Mekk. See TsIAM. F. 428. Op. 46. D. 339. L. 2-10; L. 67-67 rev.

9 On the German pattern of anthropological institutionalization, see Andrew Zimmerman, Anthropology and Antihumanism in Imperial Germany (Chicago, IL: University of Chicago Press, 2001). 
ular varieties of political and anthropological discourse to particular anthropological societies - all equally alienated from, and ignored by, officialdom.

\section{Three Competing Schools and a Pluralistic Army}

The Moscow Anthropological Division became the stronghold of the liberal anthropology of imperial diversity, heavily influenced by the German tradition of Rudolf Virchow. The Moscow scholars embraced a very broadly defined liberal, universalistic, and optimistic political outlook based on ideas of human unity, monogenism, and evolutionism. ${ }^{10}$ The school studied not "races" but "physical types." Its project of a comprehensive anthropological survey of the population of the Russian Empire aimed at establishing "degrees of kinship" and types of interaction, rather than hierarchies. It adhered to the existing official prenational nomenclature of peoples, abstaining from the construction of larger national entities; refused to equate race and nation or to support any racial hierarchies, whether inside or outside Europe or Russia proper; and studied both the Russian and non-Russian peoples of the Empire, viewing the imperial borders as the natural limits of a not yet "anthropologically rationalized" Russian Empire, a coming anthropological utopia. ${ }^{11}$ Many members of this immensely influential school were liberal opponents of the regime, while its leader, Professor Dmitrii Nikolaevitch Anuchin, ${ }^{12}$ could be called the

10 For a detailed treatment of Virchow's "liberal anthropology," see Andrew D. Evans, "A Liberal Paradigm? Race and Ideology in Late-Nineteenth-Century German Physical Anthropology," Ab Imperio 8, no. 1 (2007): 113-138.

11 An influential Moscow anthropologist, Alexander A. Ivanovkii, proposed a kind of synthesis of these approaches in his racial "classification" of the Russian Empire: Idem, "Ob antropologicheskom sostave naseleniia Rossii," Izvestia Imperatorskogo Obshchestva Liubitelei estestvoznaniia, antropologii i etnografii: Trudy Antropologicheskogo otdela XXII (1904): 1-287, 4 maps.

12 V. V. Bogdanov, Dmitrii Nikolaevitch Anuchin: Sbornik v chest' semidesiatiletiia Dmitriia Nikolaevitcha Anuchina (Moscow: IOLEAE, 1913), VII-XL; about Anuchin's career as the Moscow university anthropology professor, see TsIAM. F. 418. Op. 86. D. 547. LI. 9-20; V. V. Bunak, "Deiatel'nost' D. N. Anuchina v oblasti antropologii," Russkii Antropologicheskii Zhurnal 13, nos. 3-4 (1924): 1-18; L. S. Berg, "Dmitrii Nikolaevitch Anuchin (1843-1923)," in Ocherki po istorii russkikh geograficheskikh otrkytii, ed. L. S. Berg (Moscow-Leningrad: SSSR's Academy of Science, 1946), 282-318. The list of Anuchin's scholarly works published before 1913, see Bogdanov, Dmitrii Nikolaevitch Anuchin, xxiv-xxvii; works published between 1913 and 1923 were catalogued by N. A. Sinel'nikov and published by B. B. Bunak in Russkii Antropologicheskii Zhurnal 13, nos. 3-4 (1924): 17-18. 
Russian Virchow both for his scientific views and for his ability to keep the anthropological community within the bounds of the liberal paradigm. ${ }^{13}$

The Russian Anthropological Society at St. Petersburg University (1884/88) chose colonial anthropology as its model and promoted an expert ethos. Its traditional orientation was toward French physical anthropology. The school expressed loyalty to the regime and a desire to become the official science of the modern Empire. Although its membership and ideology evolved with time, its elitist, expert-oriented discourse and contempt for public opinion, with its focus on the anthropology of imperial minorities, persisted until the eve of the Great War. ${ }^{14}$ The state, for its part, proved uninterested in the expertise offered by the St. Petersburg anthropologists and unwilling to support their initiatives to modernize imperial rule. The Imperial Ministry of Education modestly funded the Moscow Anthropological Division's Russian Anthropological Journal as a matter of course, because it was a well-established journal. As it was the major mouthpiece of liberal anthropologists, the Ministry therefore unintentionally helped to spread their political influence across the Empire, ${ }^{15}$ while the St. Petersburg Russian Anthropological Society was denied even

13 See Anuchin's interpretation of Virchow's anthropology in Dmitrii Nikolaevitch Anuchin, "R. Virkhov kak antropolog," Russkii Antropologicheskii Zhurnal VII-VIII, nos. 3-4 (1901): X-XXXII. For more on Anuchin and Virchow in the Russian context, see Marina Mogilner, "Russian Physical Anthropology in Search for 'Imperial Race': Liberalism and Modern Scientific Imagination in the Imperial Situation," Ab Imperio 8, no. 1 (2007): 191-223.

14 On the Russian Anthropological Society, see the Central State Historical Archive of St. Petersburg (TsGIASPb), F. 14. Op. 1. D. 8591; Op. 1. Vol. 4. D. 9045; "Ustav Russkogo Antropologicheskogo Obshchestva [RAO] pri S.-Peterburgskom Universitete," in Protokoly zasedanii RAO pri IPU za 1895/6 god, ed. V. Ol'derogge (St. Petersburg: RAO, 1898), 3-6; L. P. Nikol'skii, "Pamiati Professora Eduarda Jul'evicha Petri," Trudy Antropologicheskogo Obshchestva pri Voenno-Meditsinskoi academii (1899-1900 academic year) VI (1900): 3-8; "Russkoe Antropologicheskoe Obshchestvo pri Peterburgskom universitete," Russkii Antropologicheskii Zhurnal VII-VIII, nos. 1-2 (1904): 233; I. L. Tikhonov, Arkheologia $v$ Sankt-Peterburgskom universitete: Istoriograficheskie ocherki (St. Petersburg: Izdatel'stvo SPb. universiteta, 2003), appendix. For an extensive treatment, see Mogilner, Homo Imperii.

15 The first issue of Russkii Antropologicheskii Zhurnal was published in 1900. Its predecessor was "The Diary of the Anthropological Division" [Dnevnik Antropologicheskogo otdela] published in 1890-1893 in three volumes (20 issues). Russkii Antropologicheskii Zhurnal remained a regular publication until 1906 when a fire in the printing shop and financial problems hampered its regular production. The journal was not published between 1908 and 1911 or between 1914 and 1915. It reemerged in 1916, was interrupted by the revolutions of 1917 and did not appear again regularly until 1924. 
small subsidies for its publications since they were regarded by the Ministry as redundant. ${ }^{16}$

Kiev University became the major locus of Russian nationalist anthropology. Ivan Alekseevich Sikorskii, a professor of psychiatry, was its leading proponent of ethnic Russian racial nationalism. ${ }^{17}$

Other local versions of Russian imperial anthropology can be found in conjunction with one of these three major centers. ${ }^{18}$ Yet, their continuing dialogue and overt or implicit references to major paradigms permit us to speak of Russian imperial anthropology as a cohesive phenomenon. It was characterized not only by a shared focus on the peoples of the Russian Empire, but also by its self-organization. The anthropological movement was largely left to its own devices by an indifferent and generally incurious state apparatus, with the result that anthropology and the state were alienated from one another. The state's hands-off attitude failed to encourage the establishment of a single dominant paradigm of race science conceived as an instrument of imperial politics.

It is against this background that one should approach Russian military anthropology. Among the many currents within the heterogeneous space of Russian imperial anthropology, it was the only one acknowledged and in active use by the state itself. As an applied science, it collapsed with the disintegration of the army after 1917, along with the War Ministry that had determined how,

16 Russian State Historical Archive, F. 733. Op. 144. D. 3 "O naznachenii posobii uchenym Obshchestvam, uchrezhdeniam i litsam," 1904; Russian State Historical Archive, F. 733. Op. 145. D. 3 "O naznachenii posobii uchenym Obshchestvam, uchrezhdeniam i litsam". LI. 1-92, etc.

17 On the history of Sikorskii's anthropological initiatives in Kiev, see Kiev City Archive (GAK). F. 16. Op. 465. D. 255. LI. 25-28; Central State Historical Archive of Ukraine (TsGIAU). F. 707. Op. 262. D. 8. 8 II.; Marina Mogilner, “Entsiklopedia russkogo natsionalisticheskogo proekta," Ab Imperio 4, no. 3 (2003): 225-240; Menzhulin, Drugoi Sikorskii. All of Sikorskii's major works have been recently reprinted by today's supporters of Russian racial nationalism in Avdeev, Russkaia rasovaia teoriia do 1917 goda.

18 About different centers of Russian physical anthropology, see Mogilner, Homo Imperii. For more or less general contemporary accounts, see Fedor Volkov, "Antropologia i ee universitetskoe prepodavanie (K peresmotru universitetskogo ustava)" in Ezhegodnik RAO pri Imperatorskom Petrogradskom universitete, ed. S. I. Rudenko (Petrograd: RAO, 1915), 99-107; Idem, "K voprosu o prepodavanii antropologii v Kazanskom universitete," Zhurnal Kazanskogo Mediko-Antropologicheskogo Obshchestva 1 (1921): 272; E. G. Landau, Kratkoe rukovodstvo k izucheniu antropologii (Jur'ev: University Press, 1912); R. L. Veinberg, "Glavneishie priiemy sovremennoi antropologicheskoi tekhniki (Iz antropologicheskoi laboratorii Jur'evskogo anatomicheskogo instituta)," Russkii Antropologicheskii Zhurnal XVII-XVIII, nos. 1-2 (1904): 79-120 and all issues of Russkii Antropologicheskii Zhurnal. 
where, and to whom its science would be "applied." However, many campaigns fought by European anthropologists during and after the war had been waged by Russian military anthropologists before the war began. They had confronted the supposed "impractical" nature of liberal anthropology; worked both for and against "European" Others within the Empire; fought the temptation to exploit ready-made European blueprints in structurally colonial situations marked by the presence of Others within the imperial borders; and advocated for a hygienic alliance with the state.

As elsewhere, the Great War compromised a liberal tradition. Russian anthropology's central figures abandoned the project of a self-mobilizing anthropological community to join state-sanctioned committees for the study of population as a "productive force," 19 and many ordinary practitioners turned toward more radical nationalist or socialist ideologies. But in contrast to some European nations, the war did not provide incentives for Russian military anthropologists to expand their scope. To get a good look at the Other, scientists hardly needed prisoner-of-war (POW) camps; they had been traveling the Empire for years. Accordingly, they did not share the excitement of German ${ }^{20}$ and Austrian colleagues who gained access to POWs. Likewise, they were not particularly attracted to the prospect of constructing the Other within Europe itself. In the eyes of Russians who had looked to the West for reformist inspiration since the mid-nineteenth century, German or Austrian POWs were unlikely to become Others overnight. Furthermore, since Russian imperial territory was viewed simultaneously as Europe and Asia, Empire and nationstate, military anthropologists dealt simultaneously with "European" and "non-European" peoples of Russia, some of whom were termed "inorodtsy" ("aliens")-an official category for the non-Russian peoples often constructed by definition as inferior to the Russian population. ${ }^{21}$

19 The Commission for the Study of the Natural Productive Forces of Russia (KEPS) was established in May 1915 with the funding from the War and Naval Ministries; the committee to study the population of Russia (KIPS) was established in February 1916 within the Academy of Sciences of the USSR. See Dmitrii Nikolaevitch Anuchin, "Izuchenie proizvoditel'nykh sil Rossii," Zemlevedenie 23, nos. 1-2 (1916): 97-103.

20 For more, see Andrew D. Evans, "Anthropology at War: Racial Studies of POWs during World War I" in Wordly Provincialism: German Anthropology in the Age of Empire, eds. H. Glenn Penny and Matti Bunzl (Ann Arbor, MI: University of Michigan Press, 2003), 198-229.

21 This specific character of the Russian Empire, compared to Western colonial empires, received its most general treatment in Dominic Lieven, Empire: The Russian Empire and its Rivals (New Haven, CT: Yale University Press, 2000). On inorodtsy, see the classic study from John W. Slocum, "Who, and When, Were the Inorodtsy? The Evolution of the Category of 'Aliens' in Imperial Russia," Russian Review 57, no. 2 (1998): 173-190. 
The war became the moment of truth for Russian military anthropology in one sense only: It exposed its limits as the only state-sanctioned anthropological paradigm in Russia. To understand what happened, we need to look more thoroughly at how anthropology in uniform functioned in the decades immediately preceding the war.

\section{The Military-Medical Academy}

Russian military anthropology arose with reforms of the 1860s and 1870s that aimed at modernizing the Russian army. The military code of 1874 established the principle of universal all-soslovie [social estates] conscription. ${ }^{22}$ The War Minister Dmitrii Miliutin (1816-1912) figured as a reformer. Unlike the majority of civilian ministers, he saw the army as a modern institution fostering integration, including integration (with all de facto limitations) of the inorodtsy. ${ }^{23}$ To achieve this goal, Miliutin and the postreform general staff needed up-to-date population statistics and data on the "fitness" of the population. ${ }^{24}$ While the Interior Ministry continued to use religious confession as the main marker of difference, the War Ministry actively pursued geography, ethnography, and demographics. The reformist military became the conduit for the introduction of modern population policies and colonial discourses.

22 Ustav o voinskoi povinnosti, so vsemi dopolneniiami i raziasneniiami, posledovavshimi so vremen obnarodovaniia ego (St. Petersburg: Gogenfel'den, 1875).

23 On Muliutin's reforms in the army, see Petr Zaionchkovskii, Voennye reformy 1860-1870 godov v Rossii (Moscow: Moscow State University, 1952); Forrestt A. Miller, Dmitrii Miliutin and the Reform Era in Russia (Nashville, TN: Vanderbilt University Press, 1968); Beyrau, Militär und Gesellschaft; John L. Keep, Soldiers of the Tsar: Army and Society in Russia, 1562-1874 (Oxford: Clarendon Press, 1985); Bruce W. Lincoln, Nikolai Miliutin, and Enlightened Russian Bureaucrat (Newtonville, NJ: Oriental Research Partners, 1977).

On Miliutin's and the general staff officers' role in the development of Russian military statistics, see Carl Van Dyke, Russian Imperial Military Doctrine and Education (New York: Greenwood, 1990); David Rich, The Tsar's Colonels: Professionalism, Strategy, and Subversion in Late Imperial Russia (Cambridge, MA: Harvard University Press, 1998); idem, "Imperialism, Reform, and Strategy: Russian Military Statistics, 1840-1880," Slavonic and East European Review 74, no. 4 (1996): 621-639; Nikolai A. Mashkin, Vysshaia voennaia shkola v Rossiiskoi imperii (Moscow: Academia, 1997); Peter Holquist, "To Count, to Extract and to Exterminate: Population Statistics and Population Politics in Late Imperial and Soviet Russia," in A State of Nations: Empire and Nation-Making in the Age of Lenin and Stalin, eds. Ronald Grigor Suny and Terry Martin (Oxford: Oxford University Press, 2001), 110-143. 
The underlying logic of modernist reforms was once summarized by Peter Holquist in a memorable formula: "to count, to extract and to exterminate." 25 The phrase implies a colonial knowledge-power relation and is intended to explain pre-World War I and wartime deportations and manipulations of groups viewed by military scholars and officers as unreliable or "unfit." But in the case of Russian military anthropology, the teleological explanation is inadequate. As an autonomous client of military population statistics, it explicitly resisted colonial approaches in whose internal dynamic a census leads inevitably to mass murder. Though inspired by Western notions of the homogeneous national army as the core of a healthy national organism, Russian military anthropology was also strongly influenced by Moscow liberal anthropology's preoccupation with imperial diversity. General Staff Academy graduates and cadets had been exposed to colonial (i.e., western European) ideologies and techniques, but the military anthropologists, graduates of the St. Petersburg Military-Medical Academy (MMA), thought in terms of constructive social policy and the improvement of medical and sanitary conditions. They did not shrink from the task of redefining the imperial population in terms of relative "fitness." But their aim, rather than to "conquer" the Empire, was to bring the army into agreement with it-that is, to suggest a model that would rationally utilize the Empire's existing supply of "physical types."

In March of 1893, a group of MMA professors applied for permission to found an anthropological society, the first scholarly association in the academy's history. They were joined by high-ranking military officials including Chief Military-Medical Inspector Adolf Remmert, Chief Navy Medical Inspector Vladimir Kudrin, MMA Chancellor Viktor Pashutin, and a group of nonacademic anthropologists including criminal anthropologists such as Praskov'ia Tarnovskaia and the director of the St. Petersburg Anthropometric Station, Colonel Nikolay Kozlov. The application included standardized by-laws modeled on the statutes of the Moscow and St. Petersburg Anthropological Societies, ${ }^{26}$ and a rather informal letter explaining how anthropology was understood by the founders of the Society. The letter described aspirations to join the ranks of the anthropological movement in "civilized countries" at a stage when anthropology was ceasing to be an abstract science and becoming an empirical field to which physicians, linguists, and archaeologists, lawmakers and attorneys could turn for practical knowledge and

25 Ibid.

26 "Ustav Antropologicheskogo Obshchestva pri Imperatorskoi Voenno-Meditsinskoi academii," Trudy Antropologicheskogo Obshchestva pri IVMA za 1893 god 1, no. 1 (1894): 5-10. As a separate edition, see Ustav Antropologicheskogo Obshchestva pri Imperatorskoi Voenno-Meditsinskoi academii (St. Petersburg: Tipografia V. S. Ettingera, 1893). 
advice. ${ }^{27}$ It framed the goals of Russian anthropology in the language of the Moscow school, seeing its advantage in access to a uniquely diverse population on contiguous territory within a single polity.

Inspired by the example of the Moscow Anthropological Division, the founders of the MMA Anthropological Society wanted it to become a national centre for practical medical anthropology. The specific tasks of military anthropology were inscribed into this general agenda: Anthropology belonged in the tool kit of every physician. Doctors should gather objective knowledge about different groups within the imperial population and work on issues of special interest to the War and Naval Ministries. For the signatories, the connection between the study of "physical characteristics" of different peoples and the "interests" of military reformers was self-evident. ${ }^{28}$ While emphasizing the tradition of military professionals' participation in overseas expeditions and in the studies of inorodtsy in remote imperial borderlands, the MMA initiative would not carry forward the tradition of "exotic studies." Its aim was to normalize physical anthropology by making it a required topic in medical military training and the basis for a rational reorganization of the army. The charter received prompt approval from the War Ministry, and, by April 25, 1893, the MMA Anthropological Society was officially registered. The Academy held an opening ceremony in its assembly hall, broadly publicizing the event to demonstrate support for the new endeavor, ${ }^{29}$ and its leading professor of anatomy and later chancellor, Alexander Ivanovitch Tarenetskii (1845-1905), was elected chairman. ${ }^{30}$

27 "Vvedenie," Trudy Antropologicheskogo Obshchestva pri IVMA za 1893 god 1, no. 1 (1894): 1-4.

28 Ibid., 3-4.

29 "Otkrytie," Trudy Antropologicheskogo Obshchestva pri IVMA za 1893 god 1, no. 1 (1894): 13-14.

30 His anthropological works included Alexander Ivanovitch Tarenetskii, "Beiträge zur Craniologie der Ainos auf Sachalin," Mémoires de l'Académie Impériale des Sciences de Saint-Pétersbourg: VII-e sér XXXVII, no. 13 (1890): 1-55; idem, "Weitere Beiträge zur Craniologie der Bewohner von Sachalin-Aino, Giljaken und Oroken," Mémoires de l'Académie Impériale des Sciences de Saint-Pétersbourg: VII-e sér XLI, no. 5 (1893): 1-45; idem, "Beiträge zur Skelett- und Schädelkunde der Aleuten, Konaegen, Kenai und Koljuschen mit vergleichend anthropologischen Bemerkungen," Mémoires de l'Académie Impériale des Sciences de Saint-Pétersbourg: VII-e sér IX, no. 4 (1900): 1-73, etc. For a full bibliography of Tarenetskii's work, see in "Pamiati A. I. Tarenetskogo," Voenno-Meditsinskii zhurnal 3 (1905):899-904. About his life, see A. Ivanovskii, "A. I. Tarenetskii: Nekrolog," Russkii Antropologicheskii Zhurnal XXIII-XXIV, nos. 3-4 (1905): 214-217; [D. Anuchin?], "A. I. Tarenetskii (Nekrolog)," Russkie Vedomosti, November 6, 1905, 3; Professora voenno-meditsinskoi (medikokhiryrgicheskoi) academii 1798-1998 (St. Petersburg: Nauka, 1998). 
Anthropology, especially applied anthropology, had never enjoyed such prominent recognition and support from any Russian academic institution, military or civilian. It became a widely accepted, quasi-mandatory method of assessing conscripts, who were viewed as bearers of national-racial characteristics. Tarenetskii's own method-armchair craniology $y^{31}$ - proved a poor model, but he should be credited with fostering an atmosphere that encouraged enthusiasts of anthropology to devise research projects and develop them into dissertations. In his obituary in the Russian Anthropological Journal, Tarenetskii's image as a scholar and anthropologist is clearly overshadowed by his reputation as a supervisor of numerous dissertations defended at the MMA. $^{32}$

The real ideologist of the MMA Anthropological Society was Dmitrii Petrovitch Nikol'skii, himself a graduate of the Academy, a sanitary doctor and anthropologist who studied both ethnic (inorodtsy) and social (workers, women) subaltern groups. He was also a popular activist of socialist convictions. ${ }^{33}$ It was Nikol'skii, not Tarenetskii, who gave the first programmatic presentation in the Society on November 22, 1893. His characterization of the field of anthropology was unusually broad: A study of imperial diversity

31 Tarenetskii studied skulls of the inorodtsy since they were present in the museum collections accessible to him, and due to his personal interest in the genesis of the "Indian" type. However, when he had a chance, he studied the "Great Russian" skulls with a similar zeal. See, for example: Alexander Ivanovitch Tarenetskii, "Beiträge zur Craniologie der grossrussischen Bevölkerung der nördlichen und mittleren Couvernes des Europäischen Russlands," Mémoires de l'Académie Impériale des Sciences de SaintPétersbourg: VII-e sér XXXII, no. 13 (1884). He did not personally participate in the expeditions that involved the study of a living population, however, for his students and the MMA Anthropological Society's members, he developed and published instructions on how to take measurements on live subjects. See idem, Neskol'ko zamechanii po povodu antropologicheskikh issledovanii na zhivykh (St. Petersburg: Military-Medical Academy, 1889); idem, $K$ voprosu ob izmereniiakh cherepa i mozga (St. Petersburg: Military-Medical Academy, 1884).

32 His program was included in the text of the article, idem, "Neskol'ko zamechanii po povodu antropologicheskikh issledovanii na zhivykh," Vrach 3 (1989): 45-46.

33 On his life and work, see "O sluzhbe privat-dotsenta D. P. Nikol'skogo," TsGIA SPb. F. 436. D. 14480. Op. 1, Vol. 2. (1913). 22 LI., esp. 9-11; "Doklad komissii po razboru trudov d-ra med. D. P. Nikol'skogo, ischuschego zvaniia privat Dotsenta gigieny pri SPb. Zhenskom Meditsinskom institute," TsGIA SPb. F. 436. D. 14480. Op. 1, Vol. 2. LI. 2-8 rev.; "Obzor rabot po antropologii v sviazi s meditsinoi, predstavlennykh Dr. Nikol'skim k soiskaniiu zvaniia privatdotsenta SPb. Zhenskogo Meditsinskogo institua po kafedre gigieny," TsGIA SPb. F. 436. Op. 1. D. 14480, Vol. 2. LI. 4-6 rev. 
on the Moscow liberal model, ${ }^{34}$ it included "anthropological-ethnographical, craniological, medical-anthropological (with demography), and anthropometrical" research. ${ }^{35}$ The practical orientation of MMA faculty was evident in their respectful treatment of Russian physicians, lawyers, and intellectuals who were followers of the Italian founder of criminal anthropology Cesare Lombroso, ${ }^{36}$ whereas other learned societies were critical of criminal anthropology. Nikol'skii, however, established a synthesis of traditional academic anthropology and its applied forms, medical-sanitary anthropology. ${ }^{37}$

Prewar Russian society had only limited concern for social hygiene. MMA scholarship primed the eventual wartime and postwar mobilization of state and society around the problem of the healthy individual and national body, ${ }^{38}$ although its wartime role was limited. Unlike the Moscow Anthropological Division, a think tank with its own financial and institutional resources and research agenda, the MMA Anthropological Society was an association of individuals, unable to function without military physicians, who attended the Academy for three years and wrote dissertations under the tutelage of MMA professors. It was these practitioners of applied military anthropology, and not the Society's Petersburg-based founders, who collectively shaped its agenda in accordance with directives and ideological messages coming from the War Ministry and its main Military-Sanitary Administration. The structural constraints became apparent during the Russian-Japanese War (1904-1905). When the army doctors- "major presenters at our meetings," as the Society's

34 Nikol'skii chose to open his presentation with a detailed overview of the publications of the Moscow Anthropological Division.

35 D. P. Nikol'skii, "Obzor russkikh rabot po antropologii za posledniie tri goda," Trudy Antropologicheskogo Obshchestva pri IVMA za 1893 god I, no. 1 (1894): 107. Ibid., 123-131.

37 Ibid., 138.

38 In accordance with such a broad understanding of anthropology, presentations given at the Society's meetings ranged from the "classical" anthropology of imperial diversity, for example, Ju. D. Tal'ko-Hryntsevitch, "On anthropology of the peoples of Lithvenia and Belorussia (Protokol zasedania 20 dekabria 1893 g.)," Trudy Antropologicheskogo Obshchestva pri IVMA za 1893 god I, no. 1 (1894): 155-187; to ethnographic studies, Vladimir Bogoraz, "O chukchakh kolymskogo okruga (Protokol zasedaniia 24 janvaria 1900 g.)," Trudy Antropologicheskogo Obshchestva pri IVMA za 1899-1900 uchebn. goda VI (1903): 31-47; from craniology, Alexander Ivanovitch Tarenetskii, "Posmertnye povrezhdeniia cherepa (Protokol zasedaniia 27 sentiabria 1893.)," Trudy Antropologicheskogo Obshchestva pri IVMA za 1893 god I, no. 1 (1894): 19-24; to criminal anthropology, A. L. Marshand, "Nekotorye nabliudeniia nad det'mi prestupnikov (Protokol zasedania 24 fevralia 1897 g.)," Trudy Antropologicheskogo Obshchestva pri IVMA za 1896-97 god IV, no. 1 (1899): 122-152. 
secretary K. Yatsuta put it ${ }^{39}$-left for the front, the Society suspended its activities. ${ }^{40}$ The same happened during the Great War.

\section{The Army as Empire}

The MMA library holds a collection of dissertations defended in the Academy. They represent only the tip of the military-medical-anthropological iceberg, but they suggest the scale of the anthropological work conducted in the Russian army in the prewar years. ${ }^{41}$ Although anthropological theses never exceeded seven percent of all MMA dissertations (the percentage varies from year to year), given the absence of a tradition of academic anthropological scholarship and the modest number of anthropological dissertations defended in Russian universities, this can be regarded as an impressive percentage.

A review of anthropological dissertations defended at the MMA from 1882 to $1913^{42}$ testifies to the limited appeal of colonial-style anthropology. Only a few projects feature the uniformed scientist armed with his own civilization's superiority passing judgment on a non-Russian population in terms of their inherent inferiority. Yet, even the few theses taking an explicit "colonialist" approach were heavily influenced by the liberal discourse of imperial diversity. A case in point is the dissertation by Nikolai Vasil'evitch Gil'chenko, M.D., who, after leaving the MMA, served in the Caucasus at the Vladikavkaz military hospital. ${ }^{43} \mathrm{He}$ had total control over soldiers' cadavers as well as the organs of deceased local residents as it was the region's only medical facility. Gil'chenko exploited the advantages of his position in the hospital to study human difference, if only post mortem. His situation allowed him to practice the most technologically complex type of anthropology, which had developed mostly outside Europe in remote colonies and on a limited scale: the study of the brains of "living people" (i. e., not centuries old), or, as was said at the time, "fresh brains." The discipline required immediate and unrestricted access.

39 K. Yatsuta, "Ot redaktora," Trudy Antropologicheskogo Obshchestva pri IVMA za 1901-1904 uch. goda VII (1912): 3.

40 Because of the revolutionary events, the pause lasted until the end of 1906.

41 Spisok dissertatsii, izdannykh Voenno-Meditsinskoi Akademiei (a typewritten copy). Fundamental library of the MMA named after S. M. Kirov; E. S. Viaz'menskii, Dissertatsii VMOLA (half typewritten and half handwritten copy). Fundamental library of the MMA named after S. M. Kirov. I am indebted to the librarians for letting me work with these archival catalogues.

42 See Mogilner, Homo Imperii.

43 For his biography see Curriculum vitae attached to the dissertation Nikolai Vasil'evitch Gil'chenko, "Materialy dlia antropologii Kavkaza. I. Osetiny" (PhD thesis, Imperial Military-Medical Academy, 1890), 216-217. 
With industrial efficiency, Gil'chenko extracted, prepared, and weighed the brains of peoples including Great Russians, Little Russians, other Slavic soldiers as well as the mountain-dwelling inorodtsy of the Caucasus. ${ }^{44}$ Although formally a doctoral student of Tarenetskii, Gil'chenko turned to the Moscow Anthropological Division for methodological guidance; by including the Caucasian brains, his unprecedented (in terms of actual number of brains weighed) research extended beyond those brains customarily included in the contested construct of the "big Russian nation."

He also calculated the median and average "brain of the Empire." ${ }^{45}$ Gil'chenko took issue with devotees of Lombroso by defending his right to include the brains of Chechen "criminals." He insisted that they were criminals only from the Russian point of view, while, in the context of their own culture, they were its best representatives, embodying native notions of dignity, brotherhood, and justice. ${ }^{46}$ They were neither atavisms nor deviants who had to be isolated from a civilized, normative, and healthy social body, but "normal" or even high-quality physical elements of the imperial organism. He openly rejected correlations between brain weight and intellectual faculty. He did so the more easily, the less his findings confirmed racist stereotypes; the brains of Russians in his collection proved to be the lightest, while the brains of the inorodtsy were heaviest. ${ }^{47}$ Women's brains were disregarded as a priori lighter, with 40 measurements produced in support.

44 Idem, "Ves golovnogo mozga i nekotorykh ego chastei u razlichnykh plemen naseliauschikh Rossiiu," Izvestiia IOLEAE (Trudy Antropologicheskogo otdela XIX) XC (1899): 167-219. For similar examples of military anthropological research, see I. Bukhshtab, "Materily k voprosu o vese, ob'eme i udel'nom vese golovnogo mozga u sub'ektov oboego pola i raznogo vozrasta: Takzhe o razmerakh cherepa i naruzhnoi poverkhnosti dolei mozga" (PhD thesis, Imperial Military-Medical Academy, 1884); see also a published version of the presentation by the military doctor F. A. Birulia-Belynitskii at the meeting of the MMA Anthropological Society containing the results of his study of 336 brain samples. F. A. Birulia-Belynitskii, "K voprosu o vese mozga: Materialy dlia antropologii slavianskikh narodnostei Rossii; Doklad na zasedanii 9 janvaria 1895 g.," Vrach 3 (1895): 14-32.

45 The median "imperial brain" combined data for 221 Great Russian brains, 133 Little Russian brains, 90 brains of the undetermined "Russians" from the Caucasus, Don region, and western borderlands of the Empire; 102 Polish brains, 7 Lithuanian, 16 German, 23 Jewish, 3 Estonian, 8 Votiak, 1 Permiak, 16 Zyriane, 2 Mordva, 7 Cheremis, 9 Chuvash, 9 Tatar, 11 Bashkir, 11 Osetian, 17 Chechen, 1 Cirkassian, 3 Dagestani, 11 Georgian, and 12 Armenian brains.

46 Gil'chenko, "Ves golovnogo mozga i nekotorykh ego chaste," 107.

47 The Russian brain was the lightest in the Empire (1,367.9 gr.), while the Russian average height index corresponded to the general height calculated for the 
Studies in "military-sanitary anthropology" generally focused on discussions of a new kind of army, reassessing national-ethnic strata and reassigning ideological semantics to physical characteristics. In the 1910s, there was concern that the army was in need of optimization before it could handle the new style of warfare that military leadership now anticipated. Working on a project conceivable only within the structural framework of military anthropology, but thinking in terms of the liberal anthropology of imperial diversity, Gil'chenko was prepared to find arguments in favor of noncoercive, objectively justified integration of imperial subjects, rather than colonial hierarchies. With such a pragmatic focus-a modern army - the female becomes an Other of sorts, somewhat in defiance of the reformist feminism of the MMA Anthropological Society's founders. ${ }^{48}$

\section{Ethnic Fitness}

While religion remained a prevailing official category of difference, in the MMA's military-sanitary anthropological dissertations, ethnically neutral categories, such as "recruit" and "healthy soldier," ${ }^{49}$ were forced out by notions of the soldier as a bearer of national or racial characteristics.

whole imperial population. To imagine the scale of a problem, consider the weight of the "Ossetian brain" which was calculated as 1,465.5 gr.

The feminist trend in Russian anthropology stressed the importance of the study of female bodies, posited woman as a more "pure" bearer of a racial type, and rejected female racial inferiority. This trend coexisted with an "orientalizing" trend that assumed females were racially inferior. As examples of the latter, see V. V. Vorob'ev, "Neskol'ko dannykh po antropologii velikorusskoi zhenschiny," Russkii Antropologicheskii Zhurnal 3-4 (1903): 9-16; E. Chepurkovskii, "K antropologii Russkikh zhenschin," Russkii Antropologicheskii Zhurnal 2 (1903): 13-23. As the example of the former approach, see the criminal-anthropological research by Praskov'ia Tarnovskaia, who constructed both Russian national "deviation" and Russian national "norm" on the basis of female anthropometrical data, P. N. Tarnovskaia, Zhenschinyubiitsy: Antropologicheskoe issledovanie s 163 risunkami i 8 antropometricheskimi tablit-sami (St. Petersburg: Tovarischestvo Khudozhestvennoi pechati, 1902). About discourse on race as a possible code of gender differences, see Nancy Leys Stepan, "Race and Gender: The Role of Analogy in Science," Isis 77 (1986): 261-277.

49 As an example of the usage of this category, see V. Baulin, "Materialy k izmereniam u zdorovykh soldat rosta, vesa, ob'ema grudi, zhiznennoi sily legkikh, sily ruchnykh kistei vmeste i sily pod'ema" (PhD thesis, Imperial MilitaryMedical Academy, 1889). While using the notion of a "healthy soldier", Baulin does not indicate his nationality or confession and provides only very insufficient data on the region from where each "healthy soldier" was drafted. 
As an emerging academic and public concept predicated on language and customs, ethnicity stood in the way of the blending of distinct groups in a single national body. For example, it distinguished Great Russians from Little Russians and White Russians (roughly corresponding to today's Russians, Ukrainians and Belorussians) instead of labeling them, cumulatively, "Russians." The trend to nationality and race was a radical novelty that had begun with the introduction in 1887 of a mandatory "medical form" [meditsinskii listok] on file for each recruit. It recorded confession, social origin, occupation, and physical characteristics such as height, weight, chest circumference, and leg length, but not nationality. ${ }^{50}$ Previously, as of 1869 , body weight and chest circumference had been the major criteria of fitness for military service. The latter indicator roused many debates in the military-medical community and was not considered universal. The same could be said for weight, which ceased to be a crucial indicator of fitness in $1875 .^{51}$

The new medical form drew on the experience of physical anthropology, which operated not in absolute terms but on a relational system. Beginning in 1887, it was no longer body weight, chest circumference, or height that determined "fitness," but such proportions as the ratio of chest circumference to the half-height index. ${ }^{52}$ Obviously, a physician filling in such a form was expected to know the basics of anthropometry, sensitizing him to anthropological thinking in general. The forms constructed each soldier as a "physical element" representing larger social (confessional, social estate) and physical (racial) collectives. Medical forms became a font of anthropometric data, with no analogue in nonmilitary anthropology. The medical form accompanied the soldier through his years of army service, documenting his medical history within a multinational collective.

The medical forms of soldiers recognized as "unfit" were appended to the monthly reports of garrison physicians and forwarded to the main Military-

50 The form is reproduced in P. G. Avramov, "Materialy po voenno-meditsinskoi statistike: Opyt razrabotki 'meditsinskikh listov'"' (PhD thesis, Imperial Military-Medical Academy, 1895), 5-6.

51 For more on the problems of using weight as a criteria of "fitness," see N. I. Oranskii, "K voprosu o znachenii vesa tela, kak dopolnitel'nogo kriteriia k tsifram grudi i rosta u novobrantsev (po dannym meditsinskikh listov): Po materialam Glavnogo Voenno-Sanitarnogo upravleniia" (PhD thesis, Imperial Military-Medical Academy, 1911).

52 See, for example, in Avramov's dissertation the discussion pertaining to the determining of degree of physical development on the basis of ratio of chest circumference to a half-height index. See idem, "Materialy po voenno-meditsinskoi statistike," 73-74; see also a systemic approach as expressed in the very title of the dissertation by Oranskii "K voprosu o znachenii vesa tela" and many other examples. 
Sanitary Administration in St. Petersburg to be filed in its archives. Thus, information about the Empire's physically "unfit" population accumulated centrally. Due to the form's format, physical and medical data were automatically associated with confession, name, and place of birth. Given the persistence of "premodern," mostly religious, categories of ethnic and social difference in official Russian statistics, ${ }^{53}$ only the combination of those data permitted the extraction, or rather construction, of "nationality."

Anthropologists were disturbed by the absence of the category of "nationality" in military documents. As Ivan Mikhnevich, a junior physician in the 79th Infantry Kurinsky Regiment, wrote in his dissertation:

In the medical forms, there are entries for the province [gubernia] and district [uezd], but there is no entry for nationality. For those cases where religion coincides with nationality, we can easily solve the problem of nationality of each new recruit. Yet in the majority of cases we have to base our conclusions about nationality on a combination of the province of origin [gubernia] with religion, risking a greater margin of error. ${ }^{54}$

On April 20, 1898, the MMA Anthropological Society gathered to discuss Dr. Nikol'skii's presentation on a minority of the Volga region, the Teptiars, regarded by both scholars and the state as a distinct ethnic group. Originally a social estate that included ethnic Tatars, Mari, and other peoples of the Volga, they had, in the course of their existence, developed a distinctive cultural identity. Nikol'skii based his conclusions on a very limited number of anthropometric measurements, but, nonetheless, Society members resolved to propose a revision of the religious-ethnic nomenclature used in the "medical forms" in which all Muslim inorodtsy were identified as ethnic Tatars. Thus Nikol'skii's somewhat dubious attempt to establish a Teptiar "type" was greeted by his fellow anthropologists as proof of Teptiar "nationality." By hook or by crook, nationality came to play a role in military statistics. ${ }^{55}$

53 On the categories of social difference, see Gregory Freeze, "The Soslovie [Social Estate] Paradigm and Russian Social History," The American Historical Review 91, no. 1 (1986): 11-36.

54 Ivan I. Mikhnevitch, "Uvolennye po protestu novobrantsy prizyvov 18951898 gg." (PhD thesis, Imperial Military-Medical Academy, 1900), 14-15. See also his "Meditsinskie listy v kachestve statisticheskogo materiala. Opyt statisticheskoi razrabotki meditsinskikh listov pekhotnoi divizii za tri sroka sluzhby," Voenno-Meditsinskii zhurnal IV (1899): 13-21.

55 "Protokol zasedaniia 20 aprelia 1898 g.," Trudy Antropologicheskogo Obshchestva pri IVMA za 1897-1899 uchebn. goda V (1901): 96. Nikol'skii's colleagues argued that, since "the number of the examined persons exceeded 11," his conclusions were quite precise. 
Why did military anthropologists decry the absence of "nationality"? At the end of the 1880s, even as they obsessively synthesized nationalities from surnames, confessions, and regions, official imperial statistics made do with religion and occasionally ethnicity, both understood as cultural categories. ${ }^{56}$ It is a remarkable fact that the state-run Herald of Popular Hygiene, Forensic and Practical Medicine published military statistics purged of religious-not to mention ethnic-categories. ${ }^{57}$ In such a presentation, the Russian Empire appears as an a-national state. This bothered Russian imperial military anthropologists. In their quest for a modern, efficient army, they looked to European nation-states whose armies were formed on the principle of universal conscription. The trend dated back to Miliutin's reforms and was reinforced by his military statistician followers through their continually escalating criticism of the Empire's poor population management. Holquist very appropriately quotes a textbook for students of the General Staff Academy by A. M. Zolotariev (1885), who contrasted the loyal and homogenous populations of the Moscow military district and the Île-de-France with the heterogeneous, ethnically diverse, unreliable populations of the Caucasus and British India. ${ }^{58}$ Naturally, in this context, it was the category of nation, and not religion, that would permit comparison of Russian and Western realities.

The MMA Anthropological Society's reaction to Nikol'skii's presentation reveals an aspect of "nationality" that was even more important to Russian military anthropologists. While both "religion" and "ethnicity" were seen as outdated, irrational cultural categories, "nation" and "race" represented modern, verifiable categories of scientific discourse - an attitude that strongly suggested race as a basis for sorting out nationality. In other words, a nation might be constructed from a unitary and congenital physical type, traceable to each individual member of a given collective. This represented a major deviation

56 On the religious category of difference in Imperial Russia, see Robert Crews, "Empire and the Confessional State: Islam and Religious Politics in Nineteenth-Century Russia," The American Historical Review 108, no. 1 (2003): $50-83$.

57 See "Otchet Glavnogo Voenno-Meditsinskogo Upravleniia za 1897 god", adapted for publication under the title "Boleznennost', smertnost'i uvol'neniie v nesposobnye v Russkoi armii za 1897 god," Vestnik Obshchestvennoi gigieny, sudebnoi i prakticheskoi meditsiny 9 (1899): 93-96. Here, the neutral term "lower-rank personnel" is used, while statistics are organized according to the arm of the service and the type of illness.

58 This example quotes Peter Holquist in "Total'naia mobilizatsia i politika naseleniia: Rosi-iskaia katastrofa (1914-1921) v evropeiskom kontekste," in Rossiia i Pervaia mirovaiia voina, Materialy mezhdunarodnogo nauchnogo kollokviuma, eds. N. N. Smirnov, Z. Galili, R. Zelnik et al. (St. Petersburg: Dmitrii Bulanin, 1999), 85. 
from the Moscow liberal paradigm that insisted on a fundamental differentiation between race and nation, stressing the unscientific nature of speculations connecting "physical type" to abilities and physical and intellectual "fitness."

To further complicate the peculiarity of the military-anthropological discourse, its "nation-race" was not a purely biological category. Whatever "nation" supplied its "contingent" to the army was treated as a collective imperial subject and an object of social, economic, cultural, and political influence. Thus, the discourse often appeared to be quite sensitive to the immediate social, historical, and cultural circumstances of a group's existence in a particular territory. ${ }^{59}$ This difference was especially evident in the case of Jews. Official military statistics constructed them as poor citizens who would do anything to evade conscription. ${ }^{60}$ Military anthropologists performing measurements and calculations and working with the new medical forms were more willing to recognize such factors as the high mobility of the Jewish population and its predominantly urban makeup. Cities everywhere in the Empire, including highly urbanized regions such as Poland with its substantial Jewish population, consistently produced the greatest numbers of physically weak recruits as well as those who did not wish to serve. ${ }^{61}$ Attentive to the local environment and conditions, the anthropologists tended to regard ethnic and confessional groups-whether "Russian" or inorodtsy-as "nations," modernizing the representation and elevating the status of groups whose men were eligible for military service. Yet, such outcomes had nothing to do with liberal ideology or a desire on the part of the War Ministry to introduce universal conscription. Military anthropologists appeared to be vanguard "nationalists," because they embraced the race-nation dogma and because their practical goal was to lay the foundation for rational implementation of intrinsic national differences in one supranational military body.

59 This distinguished Russian military anthropology from the "a-social" approach of many works by leading Russian military statisticians, such as Alexander M. Zolotariev. See idem, "Materily po voennoi statistike Rossii: Boleznennost', smertnost' i ubyl' armii za period 1869-1884 gg.," Voennyi sbornik 2 (1888): 323-341; ibid., 3 (1888): 177-193; ibid., 4 (1888): 351-365; ibid., 11 (1888): 157-176; idem, "Materily po voennoi statistike Rossii: Naseleniie Rossii kak istochnik komplektovaniia ee armii," Voennyi sbornik 5 (1889): 98-141; ibid., 6 (1889): 334-359.

60 For an exhausting analysis of the military statistics on Jews, see Yohanan Petrovkii-Shtern, Evrei v Russkoi armii: 1827-1914 (Moscow: Novoe Literaturnoe Obozrenie, 2003), Ch. IV.

61 Moscow, for example, persistently supplied a high percentage of weak soldiers, many of whom were recognized as "unfit" for military service. In 1882, their number made up to 69 percent of all recruits. See I. V. Gessen, Voina $i$ evrei (St. Petersburg: Tipografia Stasulevicha, 1912), 97-100. 
In military anthropology, dissertations defended roughly before the period of normalization and reaction that followed the Revolution of 1905-1907 perceived the dynamic coexistence of biologically, psychologically, and socially different collectives within the Empire rather positively. However, this changed with the postrevolutionary political demobilization. On the eve of the Great War, the metaphor of the army as a modernized Empire acquired more negative connotations. A close reading of two dissertations typical for their time should elucidate this dramatic rupture in the history of Russian military anthropology.

\section{Extracting Nationality}

Mikhnevich, who defended his dissertation in 1900, proceeded from the assumption that foreign armies were radically unlike the Russian army. Foreign armies were biologically homogeneous, drawing contingents from comparatively small territories. The district of conscription tended to coincide with the area of service, with soldiers typically serving in familiar surroundings among people who shared their religion, language, and customs. ${ }^{62}$ One-fourth of the Russian army, on the contrary, was composed of inorodtsy; soldiers of different nationalities represented "contingents differing in a physical sense." They served in far-flung corners of a huge empire with an "absolutely new climate and population [for them]." ${ }^{63}$ The food regimen in the army was not "adapted" to existing national diversity: The standard menu could satisfy neither a northerner accustomed to rich food nor a native of the Caucasus unused to sour bread. The requirements of Jews posed problems, yet they were comparable to those of soldiers from the mountains of the Caucasus (Imeretins and Mingrels). ${ }^{64}$ The issue of "adaptation," which in European pre-World War I anthropology usually meant the acclimatization of a European to a tropical environment, was reformulated by Mikhnevich as a domestic problem of central importance to the Russian army. The argument's colonial connotations faded. In the army, everyone, everywhere, had to "adapt."

62 Ivan I. Mikhnevich, "Uvolennye po protestu novobrantsy prizyvov 1895-1898 gg." (PhD thesis, Imperial Military-Medical Academy, 1900), 1-2. Quotations are given according to the published version of the analytical (as opposed to numbers and calculations) part of the dissertation: Idem, "Uvolennye po protestu novobrantsy 1895-1898 gg.," Voenno-Meditsinskii zhurnal 3 (1900): 848. Ibid.

64 Ibid., 890. Mingrels and Imeretins are subgroups of the Georgians who until the 1930s had their own census groupings (including the pre-1917 censuses). Their dietary habits included many herbs, spicy meals, and only unleavened bread. 
Each nationality drafted into the army was assigned certain innate physical traits, allowing Mikhnevich to rank the "fitness" of various race-nations. None were categorized as "harmful" or "organically unfit"; Mikhnevich never forgot his central goal of easing cooperation among unequal nations. Study of their physical peculiarities would allow him to explain (with racial, environmental, or other factors) and manipulate them. His approach questioned the universal applicability of the physical criteria of "fitness." It differed, in principle, from the exceptions introduced by the Interior Ministry for Jews, who could be drafted even when they failed to meet fitness standards. ${ }^{65}$ As Mikhnevich explained in his dissertation, since the nation-races of the Empire were anthropologically different, criteria could not be universal: They must incorporate the entire spectrum of extant differences. He specifically addresses the issue of height, considered by turn-of-the-century anthropology to be a marker of race- a view endorsed by Russia's most prominent anthropologist, Anuchin, who authored a classic study of the height index's distribution among the male population of Russia. ${ }^{66}$ Mikhnevich proposed that norms be revised to reflect the Empire's diversity.

The farther north a province lies, the greater the percentage of short people among its population; the highest percentage of short people are provided by Kazan, Ufa and Viatka provinces [gubernii]-more than $20 \%$ of all drafted to the army. ${ }^{67}$

According to Mikhnevich, race had to be taken seriously, both as a basis for flexible "fitness" criteria and as a governing principle for appropriate deployment of soldiers to produce a strong, resilient, and competitive modern army.

To prove the validity of his analysis, Mikhnevich turned to the medical forms in search of "nation-race." He easily found this in Jews whose ethnicity and religion coincided and in Armenian Orthodox and CatholicsMikhnevich combined them into a single Armenian nation. ${ }^{68}$ But that was the

65 Between 1880 and 1881, the Ministry of Internal Affairs introduced the whole range of police measures aimed at preventing "Jewish evasion" of military service. The Minister of Interior, Dmitrii Tolstoi, among other things, ordered to draft Jews whose chest circumference was smaller than the officially accepted measurement. In general, military medical commissions could legally violate established standards of fitness when they examined Jewish recruits. Petrovkii-Shtern, "Evrei v russkoi armii," 189.

Dmitrii Nikolaevitch Anuchin, "O geograficheskom raspredelenii rosta muzhskogo naseleniia Rossii (po dannym o vseobschei voinskoi povinnosti v Imperii za 1874-1883 gg.) sravnitel'no s raspredeleniem rosta v drugih stranakh," Zapiski Imperatorskogo Russkogo Geograficheskogo Obshchestva po otdeleniiu statistiki VII, no. 1 (1889).

67 Mikhnevich, "Uvolennye po protestu novobrantsy 1895-1898 gg.," 899.

68 Ibid., 851. 
end of the easy cases, where nationality followed from religion. Mikhnevich considered Orthodox Christians "predominantly Russian," a nation that integrated Great Russians, Little Russians, and White Russians with Old Believers and Dissenters. Military and civil statistics treated the latter two groups as distinct from "Russians," ${ }^{\prime}$ but the logic of assembling a nation from archaic categories that fragmented the organic national whole necessitated the return of religious dissidents into the national body. The nationalization of "Orthodox Christians" on the medical forms was further complicated by the fact that "Russians" made up only 76.4 percent of that group, with the rest composed of Moldavians, Georgians, Greeks, South Slavs, and Finnish peoples of the Volga and Ural regions. Complications were common. Splitting Roman Catholics into two large national groups, Poles and Lithuanians, left the German Catholics of Saratov and Samara unaccounted for. Protestants could be "nationalized" as Germans, Estonians, or Latvians.

To solve such problems, Mikhnevich introduced an additional variable: territory. Ignoring the existing system of provinces and districts, including military districts, he introduced sixteen regions with more or less ethnically and religiously homogeneous populations. ${ }^{70}$ Great Russians, Moldavians, Germans, Lithuanians and other collectives studied by Mikhnevich were assigned national territories along with their national status. To eyes schooled in nationalism, such a remapping is highly suggestive, but Mikhnevich apparently did not see the political implications of his approach. He was merely doing his best to extract nationality from the medical forms in hope of establishing morbidity rates for nations supplying recruits to the army.

He concluded that there were no "sick" or "healthy" nations. Pagans, Jews, and Muslims were most frequently judged "unfit" due to eye problems; Armenians, Muslims, Protestants and Catholics produced the majority of recruits with neurological disorders. Very few neurological diseases were registered among Jews; yet they, together with Muslims, took the lead in chronic skin conditions. Mikhnevich's dissertation contains anti-Jewish and antiMuslim statements, in some cases as citations from the work of military statisticians, but they remain peripheral to the narrative, as they explicitly contradict his method and goal.

69 Irina Paert, "Two or Twenty Million?," Ab Imperio 7, no. 3 (2006): 75-98.

70 Mikhnevich, "Uvolennye po protestu novobrantsy 1895-1898 gg.," 852-853. This type of "cartography" that helped to tie down a population to a particular territory was practiced by almost all military anthropologists unsatisfied with the categories of official military statistics. Dr. Avramov, whose dissertation, like many others, was based on the medical forms, divided all of European Russia into seventeen climate zones and tied each to a particular group of the population. Idem, "Materily po voenno-meditsinskoi statistike," 61-62. 
To generate his taxonomy, Mikhnevich had to operate with the categories on the medical forms. However, he missed no opportunity to transpose them into the language of nationality that he had invented. The marginalization of actual soldiers diagnosed with particular diseases was a side effect of such manipulations. Their afflictions, no longer individual if not necessarily innate, became typical of race-nations that were populating the Russian army with deficient recruits, ${ }^{71}$ provoking scrutiny of the common causes of "degeneration"-not just of weaker elements, but of a population as a whole. Mikhnevich wrote:

All European Russian territories, excluding only the far north, gave a rather substantial percentage of unfit recruits. As we can see, the fact that these unfit recruits keep coming to the army depends on some general causes and is not characteristic to some particular territories. This is a very broad, common phenomenon. ${ }^{72}$

\section{Unequal Nations}

Racial traits, hereditary deficiencies, and the merits of potential "contingents" were the building blocks used by military anthropologists to construct their model of an ideal imperial army. Their construction work was guided by a rational logic of integration, rather than segregation and racial discrimination. Such an approach characterizes the majority of anthropological dissertations written under the tutelage of MMA professors before about 1907. Moreover, the integrationist agenda can be spotted even in military-medical works produced on the eve of World War I, under new political circumstances and in the context of the imperial elite's reorientation toward state-sponsored ethnic Russian nationalism.

Yet, despite the persistence of some liberal tropes and research methods, the 1910s saw a shift toward a more radical discourse of physical "unfitness" in Russian military anthropology. The shift was heavily influenced by the experiences of the Russian-Japanese War and the First Russian Revolution, as well as Duma debates that drew popular attention to the "national question" and its potentially dire political implications. The war of 1904-1905 unleashed anxieties over the "yellow peril," leading to the introduction of anti-Chinese and anti-Korean legislation. ${ }^{73}$ The mass revolutionary movement used national

71 Mikhnevich, "Uvolennye po protestu novobrantsy 1895-1898 gg.," 861-877.

72 lbid., 879.

73 See more in Lewis H. Siegelbaum, "Another 'Yellow Peril': Chinese Migrants in the Russian Far East and the Russian Reaction before 1917," Modern Asian Studies 12, no. 2 (1978): 307-330; regarding the "yellow peril" discourse on 
rhetoric, while increased press freedom led to a wide distribution of racist and ethnic images and stereotypes ${ }^{74}$ as well as nationalist programs. The April 1905 law on religious freedom legalized conversions, further exacerbating the existing fluidity of social, confessional, and ethnic boundaries. Politicians, government officials, and military and civil professionals became aware of the mobilizing power and dangers of nationalism.

As an applied technical science loyal to the state, military-medical anthropology experimented with categories of race and nation while remaining on the margins of the dominant political discourses. The situation changed when the army was officially reevaluated as an institution of the Russian national state. Non-Russian nationalism had begun to be seen as threatening the very survival of the Russian Empire. This was the time of the birth of a "new army anti-Semitism," in the words of Dietrich Beyrau. ${ }^{75}$ Military anthropology acquired a new scientific mission: to justify the cleansing of the Russian national military organism from elements that made it liable to "degeneration."

Finally, in October of 1909, the main Medical Corps administration issued directive No. 21221, authorizing "nationality" as a category on the medical forms. The military anthropological community had long awaited the canonization of nationality in military statistical discourse, but it came at a moment when the concept, with its racial implications, had already become a widespread-and semantically overloaded-category in Russian politics. When the MMA PhD candidate Mikhail Ivanovitch Gusev, a physician of the Eighth Military Corps, wrote his dissertation in 1910 ("An Experiment in the Study of Comparative Fitness for Military Service of Different Nationalities Composing the Russian Army"76), he was well aware of the implications of the new political situation. He drew on a previous tradition of military anthropological scholarship, citing Mikhnevich and other supporters of integration. He repeatedly complained about the absence of "nationality" in the pre-1909 medical forms and even reproduced some of the liberal tropes from earlier

the eve of the Russian-Japanese war, see David Schimmelpenninck van der Oye, toward the Rising Sun: Russian Ideologies of Empire and the Path to War with Japan (Dekalb, III: Northern Illinois Press, 2001).

74 This was especially true of anti-Semitic images and stereotypes. See HeinzDietrich Löwe, "Political Symbols and Rituals of the Russian Radical Right, 1900-1914," Slavonic and East European Review 76, no. 3 (1998): 441-466. See also D. A. Kotsubinskii, Russkii natsionalizm v nachale XX stoletiia: Rozhdenie i gibel' ideologii Vse-rosiiskogo natsional'nogo soiuza (Moscow: ROSSPEN, 2001).

75 Beyrau, Militär und Gesellschaft, 423-429.

76 M. I. Gusev, "Opyt razrabotki voprosa o sravnitel'noi godnosti k otbyvaniiu voisnkoi povinnosti razlichnykh natsional'nostei, komlektuiuschikh russkuiu armiu," Voenno-Meditsinskii zhurnal 6 (1910): 309-344. 
works. Yet the starting point of his research undermined all the efforts of his predecessors: In Gusev's view, Miliutin's reforms and the introduction of allsoslovie conscription in 1874 had been mistakes from both the political and biological perspectives.

General conscription, as it is known, aimed at equal distribution of the burdens of service among a population of different ethnographic groups; this is, indeed, a fair approach. Yet its practical realization was possible only under the condition of equal physical abilities of all recruits. The material that we studied shows that this is not the case and that different national groups differ radically in their fitness for military service $\left[\ldots .{ }^{77}\right.$

Gusev's materials were the medical files of the Odessa military hospital dealing with soldiers "rejected" [oprotestovannye] by the garrison physicians. Since the files dated from 1907-1908, and thus did not include "nationality," Gusev replicated familiar manipulations based on religion, ethnicity, and place of birth. Like his predecessors, he faced the necessity of constructing Russians from the various Orthodox Christians, but, unlike them, he was irritated by the fact that Orthodox Georgians and Moldavians could join the constructed Russian national collective. Accepting the inevitability of such "mistakes," Gusev justified them (and his method) by stressing that their inclusion would lower Russian scores and subject Russian "fitness" to an especially stringent test. $^{78}$ The inferiority of non-Russians, even those of the Orthodox faith, was for Gusev axiomatic.

Gusev added a new category to the earlier organization of data by frequency of disease or racial traits. He collected all inorodtsy in one group, directly opposing them to Russians and concluding that inorodtsy were rejected twice as often as Russians. ${ }^{79}$ Such an approach split the imperial army into two distinct organisms. "Great," "Little," and "White," as components of the racially superior "Russian" organism, lost the national status and territories granted them by Gusev's predecessors. In his conclusions, Gusev saw incontestable proof of his own opening statement: The burden of military service was distributed unevenly because some non-Russian nations were organically "unfit" to serve in the army. The new army would have to be composed of "the crèmede-la-crème physical element" represented by "Russians."

The latter assertion aimed at the heart of the imperial army as an instrument of integration. The military-anthropological tradition had routinely connected the study of the military body with a larger discussion of the social and national collectives that supplied recruits. The ideas advanced by Gusev

77 lbid., 343.

78 lbid., 318.

79 Ibid., 327-328. 
suggested a different model of society itself: a Russian core surrounded by a racially inferior, unreliable, non-Russian periphery whose political and social rights were justifiably limited.

\section{Russian Military Anthropology's Last Stand}

The Great War interrupted the systematic anthropological study of the imperial army's "contingents." The war required total mobilization of the combatants' economic, political, and human resources. In Russia, this lent support to the ideal of a strong and motivated national army that would represent the best elements of the Russian imperial state and society and be capable of fighting alongside modern European nations for a new world order based on national principles and rational governance. Those who did not represent the interests of "the best elements," or were deemed unlikely to share collective Russian interests, would be put aside to make way for the emerging nation. The war decisively transformed Jews, formally a potentially "unreliable" contingent, into an internal enemy that had to be resettled from the front line to the interior. Germans, Lithuanians, Latvians, Poles, and Armenians shared in their fate. ${ }^{80}$

Yet, the mass mobilization of civilians in the course of the war made ethnic cleansing and Russification of the army de facto impossible. Against a background of social polarization and ideological radicalization, crises of authority, and the growing disintegration and demoralization of the army, military anthropology's professional reformism came to be seen as a limited and inadequate solution and lost its credibility. As the conflict progressed, the language of nationality gained in importance. Governments of the countries at war, as well as those who intended to sponsor the postwar system (the Wilson administration), along with political opponents of the regime inside Russia, championed the principle of "national rights." For the Russian Empire, this principle was a death knell. ${ }^{81}$ As Steven A. Smith writes, World War I revealed the inability of both old and new imperial political elites and military professionals in

80 On population deportations in the Russian Empire during World War I, see Gatrell, A Whole Empire Walking; Lohr, Nationalizing the Russian Empire; S. G. Nelipovich, "Repressii protiv podannykh 'tsentral'nykh derzhav': Deportatsii v Rossii," Vorenno-istoricheskii zhurnal 6 (1996): 42-52. See an especially interesting analysis of racial treatment of baptized Jews in the war years by Eugene Avrutin, "Kreschenye evrei, etnicheskii konflikt, i politika povsednevnoi zhizni v Rossii vo vremia mirovoi voiny," in Mirovoi Krizis 1914-1920 godovi sud'by vostochnoevropeiskogo evre-istva, ed. Oleg Budnitskii (Moscow: ROSSPEN, 2005), 99-123.

81 See Aviel Roshwald, Ethnic Nationalism and the Fall of Empires: Central Europe, Russia and the Middle East, 1914-1923 (New York: Routledge, 2001). 
Russia to carry out either of the major models for modernization that were advanced during the prewar decades: Russification of the Empire and the army, or the incorporation of non-Russian elements under the slogan of egalitarian patriotism. ${ }^{82}$ The Russian army could not stand up to the demands of modern warfare, but its physical "unfitness" was no longer an issue. The issue was now political "fitness," in both the army and society in general.

In late 1916, the well-known academician Sergey F. Ol'denburg, chairman of the Imperial Russian Geographical Society's Ethnographic Division, learned of the German ethnographic project to study the ethnic makeup of outlying Russian imperial territory recently occupied by Germany. The study aimed to justify the establishment of nationally based administrative units (Lithuanian, Belorussian). ${ }^{83}$ Ol'denburg was outraged by the Russian government's ignorance of these territories and its reliance on descriptive reports of provincial governors-general and "scientific" data provided by military statisticians whom he characterized as inept. A new committee composed of civilian scholars not compromised by service to the old regime-anthropologists, ethnographers, linguists, and geographers-was needed to support Russian war efforts and provide a basis for postwar political and territorial arrangements. The subsequent establishment of the Commission for the Study of the Tribal Composition of the Population of the Borderlands of Russia (KIPS) was, in part, an answer to the failure of the military's applied science to produce the modern army and the modern "empire of knowledge." ${ }^{84}$ Emerging in early February 1917, under the auspices of the Academy of Sciences, KIPS received genuine official recognition only under the Bolshevik government. ${ }^{85}$

The state-sponsored Russian military anthropology that had empowered researchers by providing live subjects for large-scale studies displayed certain parallels and continuity with the anthropological projects of the Soviet epoch of mass civilian mobilization. But the comparison is superficial; Soviet initiatives no longer aimed at integration or Russification. In Soviet Russia,

82 Steven A. Smith, "Citizenship and the Russian Nation during World War I: A Comment," Slavic Review 59, no. 2 (2000): 316-329, esp. 322.

83 On German activities on the Russian western borderlands, see Wiktor Sukiennicki, East Central Europe during World War I: From Foreign Domination to National Independence, 2 vols., ed. Maciej Siekierski (Boulder, CO: East European Monographs; New York: Columbia University Press, 1984): Vol. 1, 159-166.

84 I borrowed this metaphor from Alexander Vucinich, Empire of Knowledge: The Academy of Sciences of the USSR (1917-1970) (Berkeley, CA: University of California Press, 1984).

85 The best analysis of KIPS activities can be found in Francine Hirsch, Empire of Nations: Ethnographic Knowledge and the Making of the Soviet Union (Ithaca, NY: Cornell University Press, 2005). 
traditional ethnography pushed physical anthropology to the margins, ${ }^{86}$ which then found a home in the eugenics movement of the 1920s. ${ }^{87}$ In the words of Mark Adams,

Eugenics fit ideally the new emphasis on science as a way of undermining religion and improving the human condition; it entailed a scientistic, materialist, biosocial concept of human condition; it sought to apply the results of genetics to benefit society; and it emphasized the human power to shape the future. ${ }^{88}$

The eugenicist agenda's presence among the pre-1917 military anthropologists had been very limited; their orientation had been thoroughly pragmatic, and their social engineering ambitions were limited by the ideology of the War Ministry. The anthropological projects born of the Great War were studies of a displaced and starving population, but such studies became possible on a large scale only after the civil war, during the early Soviet state-building of the 1920s. Generally, they were carried out by civilian anthropologists, traditionally interested in imperial diversity, who had never before enjoyed state support. With the reconfiguration of the former imperial space and the disruption of funding for expeditions to distant corners of the former empire, they found their sole sponsor in the Soviet state and its consolidated medical commands or social assistance groups, investigating the impact of war on human "resources." The new military and eugenic concerns allowed them to survive professionally under the new regime.

Thus, however tempting it may be to reject 1917 as a major dividing line in Russian historical narrative, the old chronological orthodoxy should remain unchanged in the case of military anthropology. Its story as part of the ideological context of the ancien régime ended with the Great War and the Revolution. As an embodiment of the ideal of the "nation in arms," the Red Army faced the same challenges of ethnic and regional diversity as the old Imperial Army. However, for ideological reasons, there was no place for military anthropologists and their recommendations on optimum strategies for the integration of minorities; with ethnic and confessional variations reformulated in terms of social and class differences, their place had been usurped by the commissars.

86 For a superb analysis of the ethnographers' role in defining the language of Soviet nationality politics, see Hirsch, Empire of Nations.

87 On eugenics in Russia, see Mark B. Adams, "Eugenics in Russia, 1900-1940" in The Wellborn Science: Eugenics in Germany, France, Brazil, and Russia, ed. idem (Oxford: Oxford University Press, 1990), 153-216. 


\title{
Wartime Folklore: Italian Anthropology and the First World War'
}

\author{
Paolo De Simonis and Fabio Dei
}

\section{Introduction}

The First World War ended a rather lively era in Italian anthropology. It had brought forth an abundance of studies of regional folklore, along with vastly heightened ethnological ambitions. But wartime scientific mobilization was practically nonexistent, and the years that followed saw little attention given to any anthropological questions the conflict might have raised. The 1920s and 1930 s in Italy witnessed an overall weakening of the social sciences tout court, both because fascist policy prevented international debate ${ }^{2}$ and because of the influence of the idealism of Benedetto Croce, with its rejection of the very notion of a "science" of man. Nevertheless, a small body of studies and collections of "war folklore"-the customs, beliefs, symbolic systems, and cultural practices that developed among soldiers at the front-offer a prism through which the relationship between Italian anthropology and the Great War can be discerned. Various scholars regarded the trenches as laboratories where processes of cultural creation, transmission, and change could be observed in real time. They classified and described discrete phenomena including songs, superstitions, forms of religious devotion, and linguistic habits, sometimes making them the objects of quite interesting interpretative ideas. The following pages analyze this literature and identify internal tensions that were not to find full expression until after the Second World War-a much more decisive juncture for anthropology in Italy than the First.

1 This chapter was cowritten by Paolo De Simonis (first three sections) and Fabio Dei (last three sections).

2 The notable exceptions were Raffaele Pettazzoni and Giuseppe Cocchiara. 
Our first section presents a synthesis of conditions affecting the anthropological disciplines in Italy before World War I and during the fascist regime. The second section examines the work of the physician, psychologist, and theologian Fr. Agostino Gemelli, a singular figure destined to become highly influential in Italian Catholicism, and the first to make systematic observations of war folklore. The third section reviews contributions on the favorite theme of popular wartime songs. Studies of religious beliefs, practices, and superstitions are discussed in the fourth and fifth sections, with emphasis on the critique of Fr. Agostino Gemelli by the folklorist Raffaele Corso. Their disagreement, touching on crucial interpretative questions, exemplifies the theoretical backwardness that remained problematic throughout the fascist era. The final section looks in more general terms at the problem of the relation between war and anthropological knowledge. By presenting the contrasting approach of the ethnologist and historian of religion, Ernesto De Martino, we will show that World War II brought about a real and radical epistemological rupture for the "human sciences" in Italy.

\section{Italian Cultural Anthropology}

The discipline of anthropology gained a foothold in Italy in 1869 with Paolo Mantegazza's university chair and was soon joined by the Italian Society of Anthropology and Ethnology, the periodical Archivio per l'Antropologia e l'Etnologia, and the National Museum of Anthropology. Mantegazza's anthropology was essentially physical, with cultural phenomena assigned to the domain of biology and subjected to naturalistic methods.

Giovenale Vegezzi Ruscalla ${ }^{3}$ had introduced the term "ethnology" in Italy ten years earlier, including in it the study of peoples "of culture" as well as "of nature." When attention within the discipline turned to the latter almost exclusively, Italian contributions were not lacking. Absent, however, was a framework for the elaboration of investigative findings, which often resulted in isolation. Italy's late and limited colonial adventures had failed to inspire an ethnology determined by the remorse of a "colonial conscience" or the "revolt of the ethnological object," as had happened elsewhere. Instead, it was civil institutions and their origins that aroused the strongest interest, a development favored by the strong tradition of classical studies of the Greco-Roman world. As the century progressed, scholars' attention increasingly became focused on regional popular traditions, especially songs and folktales-a practice that began in the Romantic era and was consolidated under the banner of positivist philology and

3 Giovenale Vegezzi Ruscalla, "Della convenienza di un corso di Etnologia," Rivista Contemporanea XVI (1859): 81-88. 
large-scale, comparative historical methods. But its position remained marginal; Italian identity did not center on a "popular national soul," but rather on the nation's medieval and renaissance literary and artistic heritage. Scholars, such as Constantino Nigra, Alessandro D’Ancona, and Angelo De Gubernatis, had gained their reputations in fields other than ethnology, perhaps another reason why their studies of songs and folktales were selective and compartmentalized. The "National Society for Italian Popular Traditions," with its publication Rivista delle Tradizioni Popolari, founded in 1893 by De Gubernatis, aspired to a more compact "cultural" conception, but was short-lived.

The beginnings of the twentieth century saw strategically convergent proposals beginning to take form, not least the investigative options cited above, along with the realization that physical-naturalistic methods could not extend to cover phenomena from human life. Race no longer determined culture, and cultural data had detached themselves from somatic data. In 1902, Aldobrandino Mochi expressed the need to take a closer look at "the people of our countryside, of the mountains, [...] of all those backward corners where civilization has not yet arrived." ${ }^{4}$ In 1905, Lamberto Loria asked,

Why do we go so far away to study the customs and habits of peoples, when we still do not know those of our own countrymen, politically united under the same government, but with a thousand different inheritances blended, or simply mixed, in their blood? ${ }^{5}$

A doctor from Palermo, Giuseppe Pitré, coined the term demopsicologia for "the psychology of the masses" and was appointed to its first chair at his hometown university in 1911.

The "First Congress of Italian Ethnography" was held in Rome in October of the same year. Accompanied by a major "Exhibition of Italian Ethnography," it was part of the "Universal Exposition" staged to celebrate fifty years of Italian unification. The $A c t s^{6}$ of the Congress indicate tendencies then current in the demo-ethno-anthropological sciences and suggest that different generations and disciplines engaged in animated discussions marked by a desire for openness, innovation, and research of greater scope and ambition. Calls to the anthropology of the Anglo-Saxon world-Edward B. Tylor, James G. Frazer, Robert R. Marett, and Edwin S. Hartland-can be clearly heard, chiefly from younger scholars, but also to the German school of P. Wilhelm Schmidt and

4 Aldobrandino Mochi, "Per l'Etnografia italiana," Archivio per l'Antropologia e I'Etnologia XXXII (1902): 645.

5 Lamberto Loria, "Del modo di promuovere gli studi di Etnografia italiana," Rassegna Contemporanea III, 7 (1905): 4.

6 Atti del Primo Congresso di Etnografia Italiana, Roma 19-24 Oct. 1911 (Perugia: Unione Tip. Coop., 1912). 
Rudolf Otto, particularly from Raffaele Pettazzoni. Hugo Schuchardt presented Wörter und Sachen, while Raffaele Corso invoked, despite opposition, Arnold Van Gennep. ${ }^{7}$ To conventional themes were added new ones-jargons, gypsies, and migration. In research on songs, it was considered vital that music be recorded using technologies then newly available. The ethnography presented-as the nonspecialist press noted and appreciated-"radiates outward into philosophy, art, music, history, anthropology, sociology, medicine, religion, geology, archaeology, and linguistics." Italiana came out a few months later, with an editorial by Loria promoting the discipline's usefulness for colonial administration and national policy.

Facts do not always follow intentions, however. Symbolic of this is the fate of the exhibition that should have rapidly been installed in the National Museum of Ethnography: In fact, it remained in storage until 1956, when it finally went on permanent display at the National Museum of Popular Arts and Traditions. During these decades, Italian anthropology suffered a period of stagnation-easy to verify, but more difficult to explain. Several leading figures, particularly on the cultural side, were lost in rapid succession. Lamberto Loria died in 1913, followed in 1915 by Francesco Novati, his successor as president of the Italian Society of Ethnography, and in 1916 by Giuseppe Pitré. But we can identify two more specific causes for the stagnation in folklore studiesone at the level of ideas and the other political.

First, the idealistic historicism of Croce negated philology and the new social sciences by rejecting causalism and generalization, considering them useful only as ancillary practices for purposes of ordering and classification. The only valid human science for Croce was history. His ideas had considerable influence from the turn of the century onward, and when under fascism they became hegemonic, folklore studies (according to the reading of Pietro Clemente ${ }^{9}$ ) tried to elude them either with syncretistic solutions (see below for the particular position of Vittorio Santoli) or by claiming to produce not science, but merely useful material for it. In other words, folklorists continued to live positivist practices and adhered only extrinsically to historicism. They survived like heretics converted only superficially to orthodoxy, condemned to an extreme marginalization.

Second, the fascist preference for peasant traditions over industrial modernity shrewdly parried early twentieth-century anxieties. Practices that had been dying out or changing (feast days and festivals, customs, and dances)

7 Alba Rosa Leone, "La Chiesa, i cattolici e le scienze dell'uomo: 1860-1960," in L'antropologia italiana: Un secolo di storia, ed. Pietro Clemente (Bari: Laterza, 1985), 133-134.

8 Vittorio Podrecca, "La storia dei poveri," Avanti!, October 20, 1911, 3.

9 Cf. Pietro Clemente, "Alcuni momenti della demologia storicistica in Italia," in idem, L'antropologia italiana, 3-49. 
were reconstructed as leisure activities, primarily for the benefit of tourists. Within the discipline, reactionary elements took center stage, placing nationalism, ruralism, localism, sexism, and so forth in the service of ideology and propaganda, with predictable results. In 1932, it was decided to "locate and discipline" the various initiatives connected with folklore "in the ranks of a decidedly fascist institution," ${ }^{10}$ the Italian National Committee for the Popular Arts. To reduce the foreign taint, the discipline was renamed "popolaresca." Raffaele Corso, the founder of Il Folklore Italiano (renamed Archivio per la raccolta e lo studio delle tradizioni popolari italiane), was among the signers of the Manifesto degli scienziati razzisti in $1938,{ }^{11}$ along with Giuseppe Cocchiara, who wrote various articles on the "Difesa della razza" and a controversial 1939 essay for the Zeitschrift für Volkskunde. Even exhibitions on the recently conquered Ethiopians and Eritreans celebrated Italian virtues. ${ }^{12}$ The fourth ethnological congress, held in Venice in 1940, was devoted to formulating arguments for Italian dominion over the Mediterranean. ${ }^{13}$ Emma Bona, editor of Lares, held it incumbent on researchers to gather evidence for the "irrepressible force and iron temperament"14 of the Italian people.

\section{War as Laboratory: The Contribution of Gemelli}

“The war," Giuseppe Vidossi would note in 1931,

with its psychology and mass movements, created extraordinary conditions that allowed-in folklore as in so many other fields-developments normally requiring long elaborative cycles to mature in a brief period of years. The wartime climate was, in this sense, similar to the artificial climate of a laboratory, where one attempts to reproduce natural phenomena in order to study them. ${ }^{15}$

10 Lares 3-4 (1932): 157.

11 Published in July, the Manifesto constitutes "scientific" support for the "Measures for the Defense of Italian Race"-a law approved in November of the same year by the fascist government which opened the way for the Jews' persecutions.

12 Historical and juridical surveys were conducted by Carlo Conti-Rossini and Enrico Cerulli.

13 Atti del IV Congresso Nazionale di arti e tradizioni popolari (Venice: Opera Nazionale Dopolavoro, 1940), 606.

14 In a letter dated March 5, 1941, cited in Stefano Cavazza, Piccole patrie: Feste popolari tra regione e nazione durante il fascismo (Bologna: II Mulino, 1997), 145.

15 Giuseppe Vidossi, "Folklore di guerra: Ex voto italiani," II Folklore Italiano, no. 6 (1931); later published in Saggi e scritti minori di folklore (Torino: Bottega d'Erasmo, 1960), 79. 
It was not folklorists, however, who performed the bulk of wartime fieldwork. The chaplain and medical officer Gemelli was perhaps the first to realize folklore's significance for the human sciences, writing that "this study, this collection of material, must be carried out from this moment on." ${ }^{16}$ But although he shared folklorists' sense of anguished urgency regarding ephemeral data, he did not share their training. Born in Milan in 1878 to a bourgeois family of radical Masonic inclinations, Gemelli frequented republican and socialist circles, enrolling in the medical school in Pavia and collaborating with the socialist weekly La plebe. In 1898, he organized meetings in Milan and took part in demonstrations, against the high cost of living, that were bloodily suppressed by General Bava Beccaris. He became acquainted with Roberto Ardigò in Pavia and became passionately interested in laboratory research. His military service after graduation was as a medical officer in a hospital, and it was there that his swift conversion to Catholicism took place. In defiance of his parents, he entered the Franciscan order. He studied biology and specialized in neuropsychiatry in Berlin, frequently staying in Bonn and Frankfurt to attend lectures in physiology and neurology. Ordained in 1908, he founded the Rivista di Filosofia Neoscolastica in 1909 and, in 1914, the cultural journal Vita e Pensiero, which upheld a return to theocentric positions. In the meantime, he pursued research in histology and experimental psychology and sought to establish a scientific basis for the miracles of Lourdes.

On Italy's entry into the war, his faith, abilities, and patriotism became one. Already nationally known, he entered into a variety of relationships with the Army General Staff, directing the high command's experimental psychophysiology laboratory and undertaking various tasks for the ethico-social section of the historiographic office. He suffered no hesitations as to the duty of Catholics to fight in the war, which he described in May of 1915 as "a terrible and severe eliminator of those peoples who have betrayed their mission, and an instrument in the hands of Providence." ${ }^{17} \mathrm{He}$ wrote prolifically on current affairs, publishing on topics running from lice in the trenches to war games played by children, from the effect of wind in spreading the sound of artillery to medical methods of selecting flight crews- "placing myself next to the subject to be examined during the flight, [...] I studied his pulse, breathing, and blood pressure and the changes to them during the flight itself." 18

16 Agostino Gemelli, Il nostro soldato: Saggi di psicologia militare (Milan: Treves, 1917), 6.

17 Idem, "Contrasti e paradossi della guerra: Le conseguenze benefiche della guerra," Vita e Pensiero I, p. 9, May 10, 1915, 529.

18 Idem, Sull'applicazione dei metodi psico-fisici dei candidati all'aviazione militare-Relazione di ricerche sperimentali compiute per incarico del Ministero della Guerra presentata al Congresso della Società per il progresso delle Scienze (Milan: Vita e Pensiero, 1917), 7-8. 
His central concern, however, was the mind and soul of the common soldier, which he believed would decide the outcome of the war. He was against the modern overvaluation of technical equipment, against the man-machine, almost consonant with the criticisms leveled at Fordist industrial production. "Man, above all the soul of man - that, and I would say that alone, constitutes today, as yesterday, as always, as it shall be tomorrow, the soul of the battle, the true factor in victory." ${ }^{19}$ Not confined to values, the "soul" of the Italian soldier included a hereditary knack for improvisation: "You see him erect kitchens, build shelters, make machinery work! With a piece of wood, a little cable, he knows how to rig up delicate instruments and in a short space he creates the modest comforts of his life." ${ }^{20}$ At the front, each soldier's native soul mixes with those of his comrades from other localities:

In songs, superstitions, etc., we have material that reflects in its freshest reality the simple soul of our soldier. This material also allows a comparative study among the regions where the soldiers were recruited, among the localities they are from [...]. The study of war folklore is thus a contribution to Italian folklore. ${ }^{21}$

Gemelli followed the emotional metamorphosis of the Italian soldier in situations proceeding step by step from the excitement of departure and the formative depersonalization of the barracks, to the battlefield sublimation into the collective "I" of the group. His method was unabashedly positivistic, employing direct observation and questionnaires. "I managed to pass the nerve-jangling hours of waiting and the epic ones of the trials, next to him in the front lines; I jotted down in my notebook even the simplest phrases that fell from his lips."22 Such fieldwork vaunted its stripping away of the armchair rhetoric of writers and journalists who were guilty of "a conventionality of the moment, for which a typical soldier is painted, one that in reality you will never meet." ${ }^{23}$ Gemelli aspired to show things as they were, not as they should have been:

I wanted to shine a light even on the base things, the pusillanimity, the deplorable tendencies that our soldier shows, and that are the effect of his earlier life [...]. The soldier is worth the same as the people from whom he comes, and so he brings to the battlefield the defects he had at home. ${ }^{24}$

Such explicit use of the transgressive reach of positivism found acknowledgement of very different kinds. Antonio Gramsci praised Agostino Gemelli's

19 Idem, "I fattori della vittoria," Vita e Pensiero I, p. 1, July 20, 1915, 19.

20 Idem, II nostro soldato, 21.

21 Ibid., 182-183.

22 Ibid., 8.

23 Ibid., 10.

24 Ibid., 12. 
resolve to reduce "the hero to a man who cries, is afraid, even while carrying out acts that-seen from afar and removed from hackneyed, day to day affairs-take on an epic greatness, something superhuman." ${ }^{25}$ For Gemelli, the dialectic of courage and fear was managed by a sort of alienation or disavowal that shielded actors from the agony of choice. "The soldier ceases to be 'he'; his 'I' is another; the life that he leads as a soldier is a parenthesis in his life; it is not 'his' life but another life to which he attaches little importance, and so he lives outside himself." ${ }^{26}$ Submission to hierarchies clearly formed part of the picture, but precluded heroism. Particularly in military spheres, the demythologization of the soldier-hero met with censure or even outrage: "Almost blasphemous" was the judgment passed on Gemelli by Lieutenant Colonel Francesco Lavagna. ${ }^{27}$

Gemelli was more than an impartial observer. When it seemed to him that the war, contrary to initial information, was not inspiring large numbers of soldiers to "return" to religion, he planned and directed a mass revival. On the first Friday of 1917, "having confessed and taken communion, over two million soldiers and sailors, with numerous officers of all ranks, consecrated themselves to the Sacred Heart of Jesus, wherever they were; in the trenches, in hospitals, in Italy, Albania, Macedonia, Libya." ${ }^{28}$ A triangular piece of material with the motto In hoc signo vinces and the words protezione del soldato was placed on the chest of each soldier, in part to counteract the use of amulets.

Gemelli's enthusiasm for folklore represented a mere phase in his varied career as a scholar, researcher, and man of the cloth-a rather short phase, but one of typical intensity, and his observations emerged as the most organic and least banal that the war would produce. After demobilization, his scientific and organizational activities continued unabated. In 1921, he inaugurated Milan's Catholic University, where he founded a modern psychology department. Of his commitment to the dictatorship, there can be no doubt.

No one can deny that fascism, both by recognizing that the Catholic religion is the religion of the Italian people and, with the full exercise of its powers, getting rid of Masonic sects and anticlerical parties, has brought about the conditions for the implementation of the Lateran Treaty. ${ }^{29}$

25 Antonio Gramsci, "La predica di frate Agostino Gemelli," Avanti!, Pag. Piemontese, April 29, 1916, 119.

26 Gemelli, Il nostro soldato, 103.

27 Vito Labita, "La psicologia militare italiana (1915-18)," in La Grande Guerra: Esperienza, memoria, immagini, eds. D. Leoni and C. Zadra (Bologna: II Mulino, 1986), 242.

28 Memoria di Padre Agostino Gemelli dei Frati Minori (Milan: Curia dei Frati Minori Lombardi, 1960), 45.

29 Agostino Gemelli, Introduzione a Chiesa e Stato (Milan: Vita e Pensiero, 1939), xi. 
After World War II, he was nominated to the higher council on public education, dedicating himself to the development of the university, where he became life rector in 1953. He died in 1959, ending his career with a tenacious campaign against the laicism that had marked its beginnings:

against the depravity of contemporary thought, whether it be called Croce or Marx, whether it be clothed as scientific thought, proclaiming itself as the affirmation of new conquests; we will do this, because we know we are defending our young people in the name of our parents. ${ }^{30}$

\section{Collecting War Folklore: Soldiers' Songs}

At first glance, the Italian bibliography relating to the musical folklore of the Great War appears decidedly full. But most of the items are collections in the Romantic tradition of preserving popular lyrics as storehouses of national values and even the studies by folklorists fail to notate tunes. The more contemporary philological, historicizing approach, with its interest in identifying origins and regional dynamics (or on Nigra's scheme, songs' position on a continuum from Celtic narrative songs in the north to the lyrical love songs of the Italic south), neglected wartime folklore. As Ermolao Rubieri noted in 1877, "an aversion to military life is predominant amongst the general moral characteristics of Italian popular poetry." ${ }^{31}$ Folklorists similarly did their best to ignore the war, and leading scholars of popular song, such as Michele Barbi and Vittorio Santoli, succeeded. Wartime conditions obviated the "distance" from which folklorists preferred to observe their subjects. Modern warfare was too dynamic, too contemporary and, above all, too destructive of "traditional" ways of life. It thus fell to others to collect, conserve or refigure, and (on occasion) study soldiers' songs-primarily official bodies, such as the Military History Office of the Army General Staff. On the frontispiece of the 1922 publication I canti del fante by Mario Griffini, ${ }^{32}$ for example, we read "Istituto storiografico della mobilitazione: Serie etico-sociale (folklore). ${ }^{{ }^{33}}$

Gemelli published I canti del nostro soldato: Documenti per la psicologia militare $^{34}$ in 1917. Consistent with his medical interests, he saw the songs as a diagnostic tool "to determine the contents of the psychic life of the soldier," ${ }^{35}$

30 Memoria di Padre Agostino Gemelli, 101.

31 Ermolao Rubieri, Storia della poesia popolare italiana (Florence: Barbera, 1877), 93.

32 Mario Griffini, I canti del fante (Rome: Alfieri e Lacroix, 1922).

33 Historiographical Institute of Mobilization. Ethical-social series (folklore).

34 Agostino Gemelli, I canti del nostro soldato: Documenti per la psicologia militare (Milan: Vita e Pensiero, 1917).

35 Ibid., 375. 
but held their primary function to be "psychophysiological." "Musical rhythm makes muscular effort easier, or at least prolongs it, as a well-known psychological law affirms, according to which muscular movements carried out rhythmically use up less energy." ${ }^{36}$ Gemelli had likely never examined popular songs in any detail, as indicated by his amazement at texts which "seem in the beginning tales of events, but then as the song goes on refer to the most various and odd things without any connection between them.." ${ }^{37}$ On the other hand, his naïve approach may have picked up on noncanonic elements that would have gone unnoticed by specialists, as, for example, when he suggests that certain couplets were composed by an Austrian agent. ${ }^{38}$

Canti di soldati raccolti da Barba Piero-Zona di fuoco, estate 1918, by Piero Jahier, a poet and literary man stationed as an officer at the front, was published in the trench newspaper L'Astico to broad acclaim. ${ }^{39} \mathrm{He}$ had observed his alpine troops attentively as they sang, noting that they wrote lyrics down and passed them around "like a letter from the beloved." But his aims were not merely descriptive. He saw a need to "discipline and direct this very evident love with a bit of schooling," teaching soldiers "the songs of free peoples, which give this war conscience." Another nonfolklorist, Arturo Marpicati, published La proletaria: Saggi sulla psicologia delle masse combattent $i^{40}$ in 1920. A writer who held political posts in the regime, Marpicati confessed to an ambition:

to produce work that is in a certain sense almost scientific: not-God help me-the science of pompous titles, sociology, demo-psychology and so on, but something humbler and perhaps truer, happy simply to collect, order and interpret the fruits of direct experience. ${ }^{41}$

One result was the decision-not entirely trivial-to present songs in order of the "formative" stages of the soldier: departure, barracks, trenches, and combat.

The work of the young ethnologist Giuseppe Cocchiara was still more detached from the events of the war, ${ }^{42}$ as was that of the ethnomusicologist

36 Ibid., 374.

37 Ibid., 376.

38 Ibid., 392.

39 Released the following year in book form as Vittorio Gui and Piero Jahier, Canti di soldati, raccolti da Piero Jahier tenente degli Alpini, armonizzati da Vittorio Gui, tenente del Genio (Milan: Sonzogno, 1919).

40 Arturo Marpicati, La proletaria: Saggi sulla psicologia delle masse combattenti (Florence: Bemporad, 1920).

41 Ibid., 5-6.

42 Giuseppe Cocchiara, L'anima musicale del popolo italiano nei suoi canti (Milan: Hoepli, 1929). 
Cesare Caravaglios. ${ }^{43}$ Neither study displays particular originality or profundity, instead they work through cases with standard inquiries on the nature, origins, and diffusion of popular songs. The brief succession of "studies" is concluded in 1937, with Guerra e folklore by Giulio Mele, ${ }^{44}$ a quasi-journalistic work lacking a disciplinary standpoint.

All the collections and studies betray an amateurish enthusiasm for labeling and sorting. With their typical "outsider" logic, the criteria throw more light on the observer than the observed, proposing distinctions between marching songs and songs of the barracks, the prison, or particular units; songs satirical, popular, original, amorous or "contaminated" in nature; and of warlike exaltation, of evasion or resignation, of rage. Griffini's "songs of the corps" were sung "during marches when different divisions met, or at the inn-a sure route to fistfights and jail." ${ }^{35}$ Improper songs are represented by their titles, if at all. ${ }^{46}$ Collectors emphasized the diverse regional origins of "the people," occasionally used to denote an ethnic substratum. The southern soldier "sings alone, out of melancholy, and then his song, by its nature, is not choral. The true choral artist is from the north." ${ }^{37}$ Interregional contacts affected traditional songs, sometimes with official encouragement. Griffini noted that "Jahier has the great merit of having spread the Friulian villotte folk songs to the divisions from other lands. This is very difficult with dialect songs-the beautiful Sardinian songs have not gone beyond the Sassari brigade." ${ }^{48}$ The soldiers preferred more familiar fare: "Common songs come with satirical stanzas, almost all modeled on one of three originals: Sor Capanna, Petrolini, Bombacè (in order of time)." ${ }^{39}$ Interestingly, Petrolini was an art song linked to Futurism, the theater and the Café-chantant-perhaps all the more amenable to general acceptance. The exchange of songs had important consequences for analyses focused on diffusion and regional types. Gemelli had noted how the propagation of songs along the front followed the movement of divisions, and Santoli observed in 1930 that:

rather than the adaptation of parts of traditional songs to the circumstances of the time, the Great War had the effect of spreading the songs of different regions into areas where before there had been no trace of them, because it forced large numbers of people from various parts of Italy into contact with one another. ${ }^{50}$

43 Cesare Caravaglios, I canti delle trincee: Contributo al folklore di guerra, Introduction by Raffaele Corso (Rome: Leonardo da Vinci, 1930).

44 Giulio Mele, Guerra e folklore (Naples: Pironti, 1937).

45 Griffini, I canti del fante, 59.

46 Ibid., 4.

47 lbid., 3.

48 Ibid., 4.

49 Ibid., 3.

50 Vittorio Santoli, "Nuove questioni di poesia popolare (a proposito di una raccolta di canti toscani)," Pallante: Studi di filologia e folklore 5 (1930); also in 
More precise considerations of songs' origins were delayed and dismissive. "Who composed them? Nobody knows. The artist is the people taken together." 51

Folklorists applied late Romantic aesthetics to "the divine ingenuity of the war song, the unadorned elegance of epic singing," 52 but even militarist authors had to admit that "in such a war, there could not have been popular songs in which courageous colored flags waved, shaking with loyal disdain, in which shone a winged desire for adamantine glory." ${ }^{33}$ They soon "discovered" that heroism need not be expressed literally. In the anguish that preceded a decisive assault, Griffini writes:

a small infantryman softly sang "Quanto è bello far l'amore." It was an appeal to life; doubt and tiredness disappeared; we were all hate and anger-it was our love that we were defending — and we sprang out, injured, cut up, famished as we were. And we won. ${ }^{54}$

In sum, Italy's folklorists disregarded the war, missed every opportunity to verify observations or calibrate methods, and shared the task of producing simplified, ideologically rectified readings with outsiders to the field. War songs were "imagined" as being what they should have been-jingoistic material. Wartime propaganda had primed the pump by advocating musical continuity with the Risorgimento. In September, 1915, for example, a competition was announced in Florence for new songs in the local style that could be "compared, for sincerity and freshness, with many of those that our fathers sang as they moved impetuously from homes all over Italy in the wars of independence." 55 Three years later, the command of the Third Army publicly requested a hymn that would "have a very simple form and structure, as is proper for a popular song to be sung chorally." "It is necessary"-Marpicati held-"that the recruits know the hymns of the country by heart. The officers from the 94 th Infantry have had the good idea of having an hour's daily patriotic singing with their men," 57 although Griffini noted the "strange phenomenon that the infantryman is absolutely ignorant of what we might call official songs." 58 "All

idem, I canti popolari italian: Ricerche e questioni (Florence: Sansoni, 1968), 39.

51 Marpicati, La proletaria, 44.

52 Vincenzo M. Fontana, I canti delle trincee (Novara: E. Cattaneo, 1936), 3.

53 Marpicati, La proletaria, 46.

54 Griffini, I canti del fante, 2.

55 Rispetti e Stornelli Patriottici Toscani (Florence: Casa editrice La Nazione, 1916), 3.

56 Caravaglios, I canti delle trincee, 269.

57 Marpicati, La proletaria, 50.

58 Griffini, I canti del fante, 3. 
the songs compiled by officers," Cocchiara maintained, "never attained much popularity with the infantryman, and so they died before they were born, so to speak," ${ }^{29}$ while satires were presumed to originate in the officer's mess and spread to the ranks through the kitchens. Another apparent mode of vertical transmission was the songbook: Already in 1915, Il canzoniere del soldato offered sixty-four pages of "close print [...] at the tiny price of a simple postcard," to be mailed "in an open envelope with a two cent stamp." At home, "mothers, wives, fiancées, and sisters [...] marked with a pencil the poems they held most dear, as if to say 'they speak for you [...] we wish we had composed them for you.'"'60

After the war, as commemorations devoted to the construction of national memory declined in number and frequency, singing was relinked to leisure and socializing, with skiing and hiking clubs borrowing repertoires from the canzonieri. The songs regained their bellicose function for the 1936 conquest of Ethiopia. Mele described how "old, nostalgic war songs have been dug up, witty and defiant themes of memorable alpine songs" diffusion in the popular press. "You saw these songs hung like multicolored bunting on Neapolitan stands and stalls [...]. Some became very popular [...]. Now, the war having finished, the patriotic muse falls silent again." ${ }^{62}$ After World War II-and less than ten years later-Mele returned to publishing war songs, in this case those of the partisan resistance. With blatant trasformismo, he pays his homage in familiar terms: "The songs of the soldiers have a special function, moral and ideological, which using a scientific term we could better call psychophysiological. The song, with marching rhythm, gives impetus to the body and wings to the soul." ${ }^{3}$

\section{Wartime Superstitions: The Corso-Gemelli Debate}

Reflection on wartime folklore peaked with the debate on superstition between Gemelli and the folklorist Corso. Gemelli had collected material on superstition, which he defined as "the complex of beliefs and practices belonging to ancient religions, primitive and inferior, [that] had not totally disap-

59 Cocchiara, L'anima musicale, 293.

60 S. G. Girola, Il canzoniere del soldato: Rime d'amore e canti guerreschi (Como: Ist. Tip. A. Volta di Caccia e Corti, 1915), 2.

61 Mele, Guerra e folklore, 137.

62 Ibid., 138.

63 Raffaele Corso, "Introduzione," in Caravaglios, I canti delle trincee, cited in Giulio Mele, "Canti partigiani," Folklore 1 (1946): 39. 
peared but persisted." ${ }^{4}$ This evolutionist definition is curious and perhaps contradictory, given that Gemelli assumed the birth or resurgence of superstition in war. Superstitions could well be drawn from an ancient, fragmentary repertoire of survivals, but for Gemelli they were activated by current psychological motives. The trenches were particularly "favorable for the study, I would say almost in an experimental way, of the growth and propagation of superstitious practices," for at least two reasons. First, they imposed isolation on groups of soldiers constrained to live incommunicado and in mortal danger for long periods. Second, "the mixing of soldiers from different regions allowed for the transmission of traditions, beliefs, and customs from different regions." 65 The first factor was prominent in international literature; Marc Bloch, to name only the best-known example, saw isolation as the key factor in the birth of "false news" about the war. ${ }^{66}$ The second factor is specific to the situation of the Italian army, where regional linguistic and cultural differences were very marked. Gemelli describes mixing here as a sort of mythopoietic multiplier, using the suggestive image of "contagion." ${ }^{67}$

Gemelli's empirical material is laid out in typically positivist classificatory fashion. He began by distinguishing collective from individual superstitions as well as practices from beliefs, such as legends, prophecies, and omens. We see themes not far from Bloch's "false memories," with examples emphasizing the rapidity and scale on which the content of the legend spread. Practices were divided into remedies of magical-religious character, protective or therapeutic magical formulae, amulets, and prayers (in chain letters, scapulars, and the like). Gemelli gives short examples for each category, along with a comparative case history, including references to folklore studies, particularly French ones (the classics of British anthropology, such as Tylor and Frazer, are cited in French translation). For example, the habit of driving a nail with a protective function occasions an ample comparative digression, evolutionist in style, proceeding from the ancient world to ethnological cases in European folklore. Gemelli here appears attracted by the ethnographic and comparative approach, but feels the need to maintain distance. His interest focuses not on the diffusion or remote origin of popular beliefs and practices, but on the conditions of their resurgence in the context of war, and he insists on the specific nature of the psychological approach.

What, then, is his psychological interpretation? Here, Gemelli looks to a theoretical framework outside the Italian positivist tradition, based on the

64 Gemelli, II nostro soldato, 142.

65 Ibid., 141.

66 Marc Bloch, Réflexions d'un histoiren sur les fausses nouvelles de la guerre, 1st ed. (1921; repr. Paris: Allia, 1999).

67 Gemelli, Il nostro soldato, 148. 
vitalism of Henri Bergson and the phenomenological psychology of Pierre Janet and Théodule Ribot. Recourse to superstition, he argues, is a cultural technique that relieves the individual of responsibility for making decisions in difficult or dangerous situations-in the language of Janet, a technique for the maintenance of "the reality function" through mechanical behavior (heterodirected, with tradition overriding individual choice) that avoids excessive expenditure of psychic energy. Thus, "superstition subtracts the soldier from the necessity of taking a decision that he would be incapable of taking because of an insufficiency or inadequacy of psychic energy." 68 The soldier in wartime is analogous to the "many squeamish, apathetic, psychasthenic sick people, who with their manias and habits have recourse to objects and votives, simply to avoid being obliged to decide in the various circumstances of their lives." 69

The argument suffers from a fundamental weakness: Gemelli is well aware that new recruits arrive at basic training in possession of a stable and articulated folkloric repertoire. The claim that superstitions are "born" or "reborn" in wartime clashes with the notion that they are permanent and long-lasting dimensions of "popular mentality." Gemelli reacts by introducing, alongside the thesis of the protection of the reality function, an intellectualist theoretical framework that bases superstitious beliefs and practices on primitive thought of a magical or participative type, that survives in modern times only in the most backward social strata. Primitive thought provides "collective" beliefs with a foundation, while psychological-existential functionality explains individual religious devotion. Clearly, the two theories cannot comfortably live side by side, since they presuppose very different models of human rationality.

Corso's critique targeted exactly that point. A follower of Van Gennep at the time of the Rome Congress, he would become one of the folklorists most openly allied to the fascist regime and its ideology. ${ }^{70} \mathrm{He}$ dedicated the introductory lecture of his course in ethnography at the University of Rome in December of 1919 to a critique of Gemelli, published in 1920 in the religious studies journal Bylichnis. ${ }^{71} \mathrm{He}$ seems primarily concerned with defending the discipline from psychological approaches, addressing as well the theses of the French scholar Albert Dauzat, author of a monograph on war folklore. ${ }^{72}$ For Corso, such inter-

$68 \mathrm{lbid}, 174$.

69 Ibid.

70 Cavazza, Piccole patrie, 105-106.

71 Raffaele Corso, "La rinascita della superstizione nell'ultima guerra," Bylichnis 9 (1929): 81-98.

72 Albert Dauzat, Legendes, prophéties et superstition de la guerre (Paris: Le Renaissance du Livre, 1919). Corso referred to Gemelli and Dauzat as "the two psychologists." In reality, Dauzat was a linguist, although he claimed to consider the problem of war folklore from the perspective of "social psychology." Corso shows no evidence of having appreciated the strongest and 
pretations are nothing but variants of nineteenth-century theories that rooted religion in man's dread and awe at the power of natural phenomena. For "modern" psychology, magical thought and behavior in wartime are pathological.

The fighting man, faced with the danger, anxiety, and trepidation of the moment, would be constrained to substitute mechanical for voluntary action, and so his thought would take refuge in the ravines of antiquated tradition, making involuntary use of them. ${ }^{73}$

Against this thesis, Corso proposed the classical model of evolutionist intellectualism in which "superstition, considered ethnographically, is not the fruit of that sad tree of terror [...] but rather of thought in constant evolution." ${ }^{74}$ In other words, superstition is a manifestation of magical thought in a Frazerian sense-not anomalous thought or behavior in response to extraordinary situations, but a "normal" attempt (however fallacious or illusory) to understand and influence the world.

In consequence, Corso thought it misleading to isolate the phenomenon of wartime superstition from superstition in general. To assume that superstitions arise with particular force in wartime means to ignore their prior and ordinary diffusion, violating the spirit of a genealogical investigation. The latter can easily show that wartime superstitions do nothing more than reprise beliefs and practices already widespread in popular mentality. "Although observed at the edge of the trenches and battlefields, superstition is not a product sui generis, a fact deriving from the mentality of the moment, in this case warlike, but rather the exponent of the many and varied common popular traditions." 75 War brings no rebirth of superstition, but merely reflects its permanence.

The man who carries a weapon in his hand and fights on the borders of his fatherland does not forget, does not leave behind him [...] the traditions of his lands and his lares. His prejudices are those that populated the mind and the home of his ancestors. ${ }^{76}$

To sum up, for Corso, a cultural particularity of the wartime context, one that could make it into a special anthropological laboratory, did not exist. The diffusion of superstition amongst the soldiers could be simply explained by their origins in the "people," specifically the peasantry-"the countless pollen of plebeian superstition, transported by the wartime air, spread from life in the

most original element in Dauzat's position, the attribution of legends and superstitions to a collective dimension of cultural creation.

73 Corso, "La rinascita della superstizione," 84.

74 Ibid., 85.

75 Ibid., 86.

76 Ibid. 
fields to that in the battlefields, where it seemed to seed and flower, almost as a rebirth." But that "birth" is only an optical illusion, Corso believed: In fact, all superstition derives from the unmoving substratum of magical thought, primitive and prelogical (he cites James G. Frazer as well as Lucien LévyBruhl), that has never ceased to dominate the cultural life of the lower classes. On the one hand, Corso reasserts the crucial role of the anthropological conception of culture against what we might call the psychological reductionism of Gemelli. On the other hand, his anthropological comprehension does not go beyond an evolutionist model of primitive thought. His essay continually revolves around the metaphors of the "evil plant" and of the "disastrous illusion" of magic, crudely representing the popular world as immersed in prejudice and error.

Paradoxically, the psychologist Gemelli presented a more promising anthropological theory, extracting the relationship between culture and what today we would call human agency from evolutionist metaphysics. Influenced by Janet and Ribot, Gemelli reached an intuitive understanding of ritual's functional role in domesticating the world. Although in a fragmentary and sometimes contradictory way, he lays the foundations for overcoming the positivistic idea of "superstition" that had been developed to classify folk errors and prejudices and sketches a connection between cultural rites and symbols and individual identity, the construction or protection of Self as an active decision-making center. What Gemelli attempted to talk about-without finding suitable terms - was the modern anthropological category of symbolic efficacy. Reflections on the war led him to articulate a vitalist psychology and cultural theory, a road that would be much followed internationally in succeeding decades.

That road, however, remained off limits to Italian culture. After the publication of Il nostro soldato, Gemelli devoted himself to quite different intellectual projects, concerned less with linking anthropology and psychology than with linking Catholicism and fascism. With regard to anthropological and folklore studies, Corso's eloquent critique terminated the discussion.

\section{Gathering, Classifying, and Creating Collections}

The fascist era continued to produce reflections on war folklore, but they employed a philological, classificatory approach far from the sweeping theories of the "science of man." In what follows, we consider two examples: Giuseppe Bellucci on amulets and Cesare Caravaglios on "the religious soul of war."

The chemist Bellucci was an avid collector of paleologic and ethnographic remains. His collection of fetishes and amulets today forms an impor- 
tant museum in Perugia. He dedicated two books in the early 1920s to war folklore, ${ }^{77}$ making superstition and attendant objects, like fetishes and amulets, his dominant theme. His chief interpretive category is "mysticism," defined as a "primitive philosophical form, well-adapted to infantile or abnormal minds, incapable of reflection or obedience to the principles of reason." Wartime conditions provoke the primitive mindset to reappear-creating, for the author, a sudden atavism.

Faced with social disturbance on such a large scale and so profound, mysticism necessarily appeared in the most varied forms, becoming utterly evident in the different collective units of the warring peoples [...]. The superstitious mentality, which is that of prehistoric peoples and which remains more or less manifest in all peoples, reawakened as in all turbid epochs, and produced an ample mass of phenomena analogous to those which came about in antiquity, when civil progress was less accentuated and demonstrations of barbarism easier. ${ }^{78}$

More than the continuity between beanfields and battlefields, Bellucci was interested in the historical or evolutionary permanence of superstition and its reemergence in wartime. Substantially unalterable, superstition lies buried in "civilized" times, raising its head as conditions of barbarism permit. "Legends, prophecies, prejudices, collective means of protection; individual means of protection or defense; means to guarantee the attack on the enemy; amulets; songs; war cries; ironic expressions"-such elements did not spring from the current circumstances, but "were recalled from previous periods of warfare, returning to flower again when the conditions of social life corresponded to those of the past"79 with minor adjustments for technological progress. In the folklore of the Great War, "reminiscences of a past, one whose primordial beginnings arose in a very ancient time" coexist with "beliefs formulated in the present." Amulets made of prehistoric stone can coexist with others "formed of the copper rings from poison gas grenades." ${ }^{0}$

But evolution and syncretism take second place to the immobile unity of the primitive mind. Talking of the protective use made of projectiles taken from the bodies of the wounded and of parts of dead bodies-a custom also documented in previous wars-Bellucci remarks "that the human brain, finding itself in the same condition, even though distant in time, felt exactly those vibrations that had resonated before, manifested itself with the same thoughts,

77 Guiseppe Bellucci, Folklore di guerra (Perugia: Unione Tipografica Cooperativa, 1920); idem, I vivi ed i morti d'Italia nell'ultima guerra (Perugia: Unione Tipografica Cooperativa, 1920).

78 Idem, Folklore di guerra, 8.

79 Ibid., 9, 13.

80 Ibid., 14. 
and showed the same faith in corresponding objects." ${ }^{11}$ Here, an idea of polygenesis starts to intrude, allowing beliefs and practices from diverse times and places to be juxtaposed without regard to their cultures of origin. Italian or German, Catholic or Protestant, urban or rural: All soldiers belong to the subaltern classes, and all are alike immersed in vast, motionless reservoirs of magical-mystical thought.

Having laid down these premises, Bellucci sets about describing his examples, classified by type of belief or object according to function, material, and morphology. He relies on personal observations and his own collection as well as a small European bibliography. Several chapters cover the folklore of soldiers from other European countries, including Austria-Hungary, France, England, and even neutral Switzerland. As often happens with authors of the period, sensitive descriptions contrast with the poverty and ingenuousness of his interpretative categories. A genuine affection for amulets leads him to detail their profound human significance, in implicit denial of their "barbaric" character, so that his account retains some usefulness for studies of culture or "mentality."

While Bellucci died in 1921, Caravaglios lived to embody all the ambiguities of the compromise between folklore studies and the regime. His major 1935 work on religious war folklore ${ }^{82}$ is a singular admixture of interesting documentary and philological material and nationalist and prowar rhetoric, of sensitivity toward forms of popular devotion, and utilitarian reflections on how to place faith in the service of victory. The material is organized under headings, such as "cult practice at the front," "amulets and relics of war," "wartime ex-votos," and so on. A concluding section analyzes letters from troops at the front. Each category of cultural practice is then subclassified using sundry criteria. Votive offerings, for example, are divided by morphology: (a) those that reproduce parts of the ailing, injured, or frozen body that were cured; (b) weapons, one's own or the enemy's, offered to the divine protector, generally the Madonna; (c) clothing worn by the soldier at the moment of danger; (d) written messages, such as letters or dedications on photographs; (e) paintings; and (f) collective offerings, such as the erection of shrines. These religious forms "of the most humble" draw on the resources of primitive mentality. While admitting their superstitious character, Caravaglios does his utmost to demonstrate their compatibility with the authentic religious spirit and a "healthy faith" linked to patriotic self-sacrifice.

While highly respectful of Gemelli, he repeats Corso's criticisms, but misunderstands them, trying to mold them into an antirationalist fideism. Ritual protective practices are due "more than as a substitution of the involuntary for the voluntary, or a more or less greater abdication of individual will, to

81 Ibid., 106.

82 Cesare Caravaglios, L'anima religiosa della guerra (Milan: Mondadori, 1935). 
the need to link oneself, in the moment of danger, to the Supreme Being." ${ }^{33}$ Admittedly, the soldier hopes to survive unharmed, but the religious sentiment is authentic even when unaccompanied by an adequate education-for Cesare Caravaglios (citing Joseph De Maistre), one that unites the religious with the military spirit, locating the supreme value and spiritual objective in self-immolation for the Fatherland. ${ }^{84}$

With Caravaglios, we take a retrograde step that Corso and Bellucci had only hinted at. Hoarding and classification go hand in hand with the abandonment of any pretensions to "scientific" analysis of cultural processes, now replaced by nationalist rhetoric, or rather with the ideology of the regime.

\section{Reestablishing Presence: De Martino}

Theories of power after Michel Foucault have favored sexuality, deviance, illness, and punishment over military topics as subjects of analysis. Yet "total war" was surely the culmination of the dream of making the human body and soul into a wholly malleable instrument, its mass armies at one with the machine-body of the nation. The human sciences eagerly joined the fray, which required redefining the relationships between individual and collective conscience, pragmatic rationalism and political emotion, and the collective unconscious and motivation. But the human sciences were not merely enforcers of the state's cultural dominion, nor were they a simple ideological reflection of power. They consciously attempted to enable "self-discipline" that would relieve state power of the need to impose itself by force, but, at the same time, their disassembly of mechanisms of cultural and moral conditioning also laid the foundations for a critique of that power.

In the years following the Great War, this critique took the form of a "culture of crisis" which, while primarily literary and artistic in its manifestations, had its foundation in the human sciences. Anthropology and psychoanalysis (The Golden Bough and Totem und Taboo were widely read) had an enormous influence on modernist culture and on its efforts to reestablish the sense of history and humanity the war had so radically questioned. Referring to the poetics of the "mythic method," understood as "a way of controlling, of ordering, of giving shape and a significance to the immense panorama of futility and anarchy which is contemporary history," T. S. Eliot wrote in 1932 that "psychology [...], ethnology and The Golden Bough have concurred to make possible what was impossible even a few years ago." ${ }^{85}$ Between the wars, it was the social

83 lbid., 157.

84 Ibid., 158, 160.

85 T. S. Eliot, "'Ulysses,' Order and Myth," The Dial (November, 1923); also in Selected Prose of T. S. Eliot, ed. Frank Kermode (London: Faber \& Faber, 1975), 175. 
sciences that sustained a profound reconsideration of notions of progress and the relationship between the individual and society as well as reflection on the roots of violence and its connection to civilization.

In Italy, however, that potential remained unrealized. Corso and other folklorists turned to The Golden Bough, on the contrary to Eliot, as a dogmatic and antimodernist weapon. Harking back to the unmoving substratum of magical thought that dominated the lives of the lower classes (including soldiers), they placed them outside history, making them instead participants in natural evolution. The scholars were aware that soldiers in the trenches were engaged in the destruction of a world and that they lived with the unbearable, inescapable presence of death, but where Gemelli saw their resistance as a subjective creation of meaning, the folklorists regarded soldiers as an inert mass, passively reproducing a timeless mythical matrix. There is no drama of subjectivity, no process involving cultural dynamics to be understood, but simply cases to collect, conserve, and classify. No specific problem arises regarding the culture of soldiers, Corso tells us; they are merely displaced peasants. He reasserts the purely philological nature of his discipline, which can only proceed horizontally, collecting instances of the eternal, primitive mentality in which the people are submersed. One effect was to reify the gap between the "people" and the upper or intellectual classes. The latter go to war; the "people" are their tool.

The environment of fascism served to exacerbate the interpretive closure still further, carrying the folklorist and philological discourse toward an evermore striking superficiality and prowar rhetoric. The mating of research and ideology spawned curious and disturbing hybrids. As noted above, in L'anima religiosa della guerra, Caravaglios melds meticulous documentation with nationalist zeal in a truly singular way. The book begins with a sensitive evocation of a wartime existence dominated by looming death and chaos, seeming to cast doubt on the rhetoric of heroism. But we soon discover that he simply wishes to play up the role that folklore beliefs can play in calming and controlling the terrorized masses. In particular, it is beliefs about the soul, briefly summed up à la Frazer, that counteract the fear of death and reconcile soldiers to a war of mutual assured destruction.

Peoples of every time, every place and every civilization have at the foundation of their moral life the idea of the immortality of the soul. This gives us to suppose that if we could develop this healthy idea amongst our people, we would have a spiritual improvement amongst our masses and, more importantly, we would resolve, in the case of war, the so-called problem of fear, which could more properly be called that of attachment to life. ${ }^{86}$

86 Caravaglios, L'anima religiosa della guerra, 34. 
Again,

if we manage to implant in the soul of the fighting man the idea that life is not only physical, vegetative, that it does not finish with the dissolution of our body, but that we could live it in a better way, we will succeed in convincing him that should he die for the Fatherland, his death would be the safest way to ascend to the immortal heavens. $^{87}$

Here, the practical task for an anthropology of war is outlined: to create soldiers free from that fastidious nuisance of an attachment to life, ideal servants without the fear of death. The figure of the model soldier-or rather of the suicide bomber duped by cynical handlers-emerges forcefully from this explosive pastiche of militarist nationalism, fideism, and anthropological research, disguised as a dispassionate and erudite documentary collection.

To arrive at a new attitude, anthropology in Italy would require World War II-although it must be said that philological positivism sat out some of its bleakest moments unfazed. Vidossi entrusted to Lares his remarks on the "new traditions" and processes of folklore creation in wartime, his protagonists this time were not soldiers, but civilian evacuees from cities menaced by shelling or air raids. In Turin, he observed the practice of attaching sacred images to the facades of houses and bomb shelters. The variations among families by regional origin fascinated him. He describes his system of index cards, lists superstitions linked to comets, and cites stories of visions foretelling the end of the war in no particular order. ${ }^{88}$ The incongruity between the drama of the situation and the collector's zeal is almost grotesque. He seems unperturbed by the apocalypse unfolding before his very eyes-as if the self-destruction of Europe, the collapse of the very "civilization" that defined him as an "intellectual," had nothing to do with him.

With the recognition of this irony, a quite different mode of anthropological reflection began, epitomized by the work of De Martino, perhaps the most important figure in the reestablishment of the Italian social sciences after World War II. "Our civilization is in crisis-one world seems ready to fall to pieces while another is waiting to take its place," he wrote in his first book, published in $1941 .{ }^{89}$ A pupil of Croce, he pursued a historicist critique of ethnology's naturalist tradition. His first book was a critical examination of canonic authors and ideas from Émile Durkheim to Lucien Lévy-Bruhl, from

87 Ibid., 37.

88 Giuseppe Vidossi, "Appunti di demopsicologia di guerra," Lares XIV (n.s.) (1943); idem, in Saggi e scritti minori di folklore (Turin: Bottega d'Erasmo, 1969), 413-415.

89 Ernesto De Martino, Naturalismo e storicismo nell'etnologia (Bari: Laterza, 1941), 12. 
P. Wilhelm Schmidt to American anthropology; all were found guilty of naturalizing cultural facts and thus removing them from the comprehension of historical intelligence.

De Martino spent the war years developing a historicist approach to a classic anthropological theme, that of magic. Il mondo magico (1948) argues against theories grounded in a dogmatic, ethnocentric notion of "reality" that see the essence of magical thought in its illusory character. Rather, magic creates its own reality on the basis of a "historic drama" peculiar to itself-the crisis and cultural redemption of "presence." "Presence" for De Martino is the unity of the self and the active autonomy of the individual vis-à-vis the world and others. A fundamental good that our culture takes for granted, presence is a historical formation. There was an epoch - that of magic - in which presence was not guaranteed. It had to be defended and reaffirmed by the community time after time, whenever it faced pressure from the "negative." Even now, when the "negative" becomes menacing, presence can enter into crisis and require redemption by ritual and symbolic actions.

The categories used by De Martino have their roots more in phenomenology than in classical historicism, and Croce himself reproved him on that point. In particular, Janet's "reality function" is a principal source for De Martino, as it had been for Gemelli. De Martino never wrote explicitly of the rites or symbols of war, nor of the existential condition of the soldier. But it is difficult to avoid the impression that the drama of presence lost and regained, recounted in his book, relates to the tragedy of the war, with its dissolution and reconstitution of the Western subject. The world of magic is an archaic one, but it can manifest itself in the present: "In a situation of particular suffering and privation, during a war, a famine, or the like, being may not be able to resist the exceptional strain and so open itself again to the existential magic drama." ${ }^{90}$

One commentator has noted that the cultural crisis and redemption of the presence is the peculiar way in which De Martino talks about the "contemporary crisis" linked to the war.

What is happening is a type of transfert: the unexpressed emotional load is projected onto the object, the lability and precariousness experienced in the present become the essential constants of the magical world [...]. This transfert acts in such a way that il mondo magico constitutes, in a sense, a "redemption of presence" in the western world. ${ }^{11}$

90 Idem, Il mondo magico: Prolegomeni a una storia del magismo (Turin: Einaudi, 1948), 156.

91 Cesare Cases, "Introduzione," in Ernesto De Martino, II mondo magico, 2nd ed. (Turin: Boringhieri, 1973), p. xxv. 
We are a long way from the idea of war as a laboratory. The positivist distinction between subject and object defines the laboratory, and the folklorists' contributions gaze across a chasm that divides intellectuals guided by reason and faith in progress from a "people" dominated by an archaic and irrational culture. The former think, the latter live-or die, if the Fatherland so desires. For De Martino, on the other hand, war is the destruction of any possible laboratory. Faith in progress cannot survive unaltered where the world lies in ruins. It is with this reflection that anthropology reasserts its presence at the end of "the European civil war"-a historiographic category recently proposed by Enzo Traverso that, while open to debate, reflects the coherence of the period 1914-1945 also on a cultural level..$^{92}$ Anthropological reflections on the Great War remained closed in the dogmatism, ideological compromises, or nationalist enthusiasms of the period. Instead, it was World War II that finally permitted a radical epistemological break which went well beyond the contraposition of naturalism and historicism. Also apparent elsewhere, the radical rupture was particularly emphatic in Italy and Germany, where totalitarian ideology, after its military defeat, rang especially hollow.

92 Enzo Traverso, A ferro e fuoco: La guerra civile europea 1914-45 (Bologna: II Mulino, 2007). 


\title{
Science behind the Lines: The Effects of World War I on Anthropology in Germany ${ }^{1}$
}

\author{
ANDREW D. Evans
}

Just days after the outbreak of war in August 1914, the anthropologist Felix von Luschan arrived in Australia, a country that had become Germany's enemy during his steamship journey from Europe. As a prominent professor of anthropology at the University of Berlin, Luschan planned to attend the international conference of the British Association for the Advancement of Sciences as an honored guest, along with several of his German colleagues. His stay in Australia was to be the first stop on a larger anthropological research trip to New Zealand, India, and Indonesia. ${ }^{2}$ For an anthropologist like Luschan, the conference was a major event; leading figures in the British field, such as W. H. R. Rivers, were scheduled to present papers. ${ }^{3}$ The meeting of the British Association proceeded normally at first, and the attitude toward the German participants was open and friendly. The various speakers, including the president of the British Association, emphasized the international character of all science, even during wartime, and praised German contributions

1 I would like to thank Monique Scheer, Reinhard Johler, and Christian Marchetti for their insightful comments and useful suggestions during the preparation of this chapter. I am also grateful to the University of Chicago Press for giving permission to use material from my book, Anthropology at War: World War I and the Science of Race in Germany, in this chapter. ( 2010 by the University of Chicago. All rights reserved.

2 Felix von Luschan to the Rektor of the Handelshochschule in Berlin, May 22, 1914, Archiv der Humboldt-Universität zu Berlin [HU], F. v. Luschan PersonalAkten, UK-L252, Bd. 1, BI. 5.

3 "Proceedings of Societies: Anthropology at the British Association for the Advancement of Science, 1914," Man 14 (1914): 171-175. 
to learning. ${ }^{4}$ In Adelaide, Luschan was even awarded an honorary doctorate, after which he "was cheered as never before in my life."

This friendly mood did not last for long, however. Luschan complained of having to stand and remove his hat for the national anthems of England, France, Russia, and Belgium several times a day during the conference. ${ }^{6}$ "If those people had had the Serbian and Montenegrin anthems, they would have served those four or five times daily too."7 Official friendliness also abruptly ceased. Luschan was not allowed to travel to New Zealand, and an initial offer for him to conduct scientific work in Australian museums was rescinded. Eventually, the authorities became more interested in the scientists. One of the German academics, Fritz Gräbner, was arrested and imprisoned on the charge of smuggling documents. ${ }^{8}$ Another scientist, Albrecht Penck, was taken into custody and shipped to London, where he spent the first several months of the war under a loose form of house arrest. ${ }^{9}$ Three weeks after his arrival in Australia, Luschan and his wife managed to escape on an American steamer bound for Honolulu, where they spent several weeks before finally traveling to San Francisco and then to New York. Over the next ten months, Luschan struggled unsuccessfully to find passage back to Germany.

Under the influence of war, the initially open and international tone of the British conference in Australia rapidly deteriorated. The experiences of Luschan, Penck, and Gräbner in Australia illustrate the direct and immediate impact of World War I on the wider scientific community, and, more specifically, on the discipline of anthropology in Germany. In Luschan's case, the outbreak of war disrupted his plans for anthropological research abroad, poisoned the atmosphere of national cooperation at an international conference, and put him under suspicion as a spy. ${ }^{10}$ Perhaps more importantly, the

4 Felix von Luschan, "In Australien und Amerika," Berlin Vossische Zeitung, January 31, 1915.

5 Ibid.

6 Felix von Luschan to "Herr Rechnungsrat," "Am Sedantag" [September 2], 1914, Archiv des Museum für Völkerkunde, Berlin [MfVB], I/MfV 193, Illc, Band 21. It is significant that Luschan dated his letter "Sedan day." That date, which marked the anniversary of the Prussian victory over France in 1870, was one of the most patriotic Prussian holidays.

7 Idem, "In Australien und Amerika."

8 "Verhandlungen der Berliner Gesellschaft für Anthropologie, Ethnologie und Urgeschichte," Zeitschrift für Ethnologie 47 (1915): 242-270.

9 Albrecht Penck to Felix von Luschan, Feb. 8, 1915, File Penck, Nachlaß Felix Luschans, Handschriftenabteilung, Staatsbibliothek zu Berlin-Preußischer Kulturbesitz [NL Luschan].

10 German-speaking anthropologists were not alone in this regard. Bronislav Malinowski, a Polish subject of the Austrian Empire who had lived for four years in Great Britain, remained in Australia as an "enemy alien" after the 
atmosphere of extreme nationalism that Luschan noted in Australia was also peaking in European countries in the fall of 1914, as a surge of national feeling swept across nations like Germany. As Luschan fled Australia, German academics back home were rallying to the German flag with an intense fervor, mobilizing themselves and their disciplines for the war effort. ${ }^{11}$ Beginning in the fall of 1914, German science, including Luschan's discipline of anthropology, now operated in a new environment, defined by the realities of war and framed by nationalistic mentalities.

The goal of this chapter is to examine how this new wartime context affected the institutional circumstances and ideological orientation of physical anthropology in Germany. As one might expect, any examination of anthropology during World War I plunges the scholar into larger debates about continuity and discontinuity in the history of the discipline. A central disagreement in recent scholarship is whether or not anthropology in Germany changed fundamentally between the late nineteenth and early twentieth century. Andrew Zimmerman has argued that clear lines of continuity connect the German anthropology of the late nineteenth century with the race science of the 1920s and 1930s. As anthropology in Germany institutionalized during the late nineteenth century, he maintains, it offered an "anti-humanist" alternative to the humanist and historicist paradigms that dominated the German academy. In the process, it also approached colonial subjects with a basic inhumanity that laid the foundations for National Socialist race science. ${ }^{12}$ Robert Proctor, Benoit Massin, and Woodruff Smith, however, have argued that a major shift occurred in German-speaking anthropology and ethnology sometime in the late nineteenth and early twentieth century. In these narratives of discontinuity, the discipline abandoned a pluralistic and liberal brand of anthropology championed by the renowned pathologist Rudolf Virchow and the ethnologist Adolf Bastian sometime around the turn of the century, replacing it with a racist and narrowly nationalist racial science (or Rassenkunde) designed to serve

British Association Conference. Despite this status, he managed to conduct his groundbreaking fieldwork in Papua and the Trobriand Islands. In 1915, Malinowski was briefly arrested by the Australian authorities when he failed to report to the local authorities in Melbourne. See Michael W. Young, Malinowski: Odyssey of an Anthropologist, 1884-1920 (New Haven, CT: Yale University Press, 2004), 289-307, 364-366.

11 Wolfgang Mommsen, "German Artists, Writers, and Intellectuals and the Meaning of War," in State, Society, and Mobilization in Europe during the First World War, ed. John Horne (Cambridge, UK: Cambridge University Press, 1997), 21-38.

12 Andrew Zimmerman, Anthropology and Anti-Humanism in Imperial Germany (Chicago, IL: University of Chicago Press, 2001). 
the interests of the state and nation. ${ }^{13}$ One problem with many of these analyses, however, is that they fail to connect the history of the discipline in the late nineteenth century with developments in the field in the 1920s. As H. Glenn Penny and Matti Bunzl have remarked, "we continue to know very little about what clearly was the contested road from liberal to Nazi anthropology." 14

This chapter contends that World War I facilitated a final break with the liberal anthropology that had dominated the late nineteenth century. In the atmosphere of total war, German anthropologists sought to make their science more relevant to the nation and the state by mobilizing their disciplinary authority as experts on the world's peoples and applying their disciplinary tools to the war effort. ${ }^{15}$ The result was a more politically instrumentalized and narrowly nationalistic anthropology that broke with the liberal tradition and paved the way for postwar forays into Rassenkunde. The war marked a decisive move away from critical elements that characterized anthropology under Virchow: internationalism within the discipline, prohibitions on engaging anthropology in politics, and liberal distinctions between the key concepts of race, nation, and Volk (or people). These currents were strengthened by the extreme institutional distress experienced by the anthropological community after the war. In the aftermath of the conflict in the early 1920s, anthropologists fashioned their discipline into a nationalist race science designed to counter Germany's postwar weakness. Deeply nationalist and desperate to attract the attention of the state, a growing number of younger anthropologists, many

13 Robert Proctor was among the first to identify a shift in German anthropology from Virchow's medical and physicalist Anthropologie, which held that race was a purely physical concept, to the racist and eugenicist Rassenkunde of the 1920s. Woodruff Smith and Benoit Massin see the central change as a shift from a liberal to an illiberal anthropology. See Robert Proctor, "From Anthropologie to Rassenkunde in the German Anthropological Tradition," in Bones, Bodies, Behavior: Essays on Biological Anthropology, ed. George W. Stocking (Madison, Wl: University of Wisconsin Press, 1988), 138-179. Also see Benoit Massin, "From Virchow to Fischer: Physical Anthropology and Modern Race Theories in Wilhelmine Germany," in Volksgeist as Method and Ethic: Essays on Boasian Ethnography and the German Anthropological Tradition, ed. George W. Stocking, Jr. (Madison, WI: University of Wisconsin Press, 1996), 79-154; Woodruff Smith, Politics and the Sciences of Culture in Germany, 18401920 (New York: Oxford University Press, 1991). For a description of the growing consensus on the shift, see Matti Bunzl and H. Glenn Penny, "Introduction: Rethinking German Anthropology, Colonialism, and Race," in Worldly Provincialism: German Anthropology in the Age of Empire, eds. H. Glenn Penny and Matti Bunzl (Ann Arbor, MI: University of Michigan Press, 2003), 17-22.

14 Idem, "Introduction," 29.

15 Throughout this chapter, I use the term "anthropologist" to refer to physical anthropologists and "ethnologist" to refer to cultural anthropologists. 
of whom had the war experience in common, focused on conducting racial surveys of Germans and pursuing eugenics as a means of building a stronger nation. These disciplinary interests and directions grew, in large part, out of the wartime and postwar experience.

\section{The Liberal Tradition in German Anthropology before World War I}

In the late nineteenth century, German-speaking anthropology encompassed multiple traditions and directions, but the most dominant strand was a selfconsciously liberal and resolutely empirical science associated with the leading figures of the discipline: Rudolf Virchow, professor of pathology at the University of Berlin, Reichstag deputy, and prominent member of the left-liberal Progressive Party [Deutsche Fortschrittspartei]; Johannes Ranke, professor of anthropology at the University of Munich; Adolf Bastian, head of the Berlin Museum für Völkerkunde; Julius Kollman, anatomist and anthropologist at the University of Basel; Rudolf Martin, professor of anthropology in Zurich and later Munich; and Felix von Luschan, professor of anthropology in Berlin after 1908. From their positions of influence at universities and anthropological societies, these men enforced a methodological and ideological framework for how anthropological research was to be conducted.

What made the anthropology of these men "liberal," however, was not a strict adherence to a progressive political program, but an approach to humanity that drew on liberal concepts of universalism. ${ }^{16}$ Adopting a monogenist perspective on the origins of humankind, they consistently argued for the "unity of the human species," maintaining that physical and cultural differences among peoples were merely variations on the common of theme of humanity, and that dissimilarities were of minimal importance next to the elements that bound humanity together. All people, in other words, were united on a fundamental level by their similarities and had the capacity for intellectual improvement. ${ }^{17}$ Virchow wrote, "I have a certain tendency [...] to be enthusiastic for the idea of the unity of the human species. I admit that behind it lies a traditional, even sentimental idea [...] that we really are brothers and

16 Andrew D. Evans, "A Liberal Paradigm? Race and Ideology in Late Nineteenth Century German Physical Anthropology," Ab Imperio 8, no. 1 (2007): 113-138; Andre Gingrich, "Liberalism in Imperial Anthropology: Notes on an Implicit Paradigm in Continental European Anthropology before World War I," $A b$ Imperio 8, no. 1 (2007): 224-239. Also see Smith, Politics and the Sciences of Culture, 100-114.

17 Ibid., 103. 
sisters."18 Ranke, like Virchow, considered the differences separating mankind to be minimal compared to what united them. At meetings of the German Anthropological Society, Ranke emphasized the "equality of feelings and mental life of all humanity." 19

The liberal perspective adopted by Virchow and his colleagues influenced their views on race. They championed a brand of anthropology that depended upon a distinction between the categories of race, nation, and Volk. Imbued with liberal ideals of progress, leading anthropologists readily accepted the idea that some societies were more advanced than others (an assumption embodied by the division between "natural peoples" [Naturvölker] and "cultured peoples" [Kulturvölker] in German-speaking anthropology), but they refused to connect race to mental faculty or cultural ability. As liberals, they were reluctant to argue that one's capacity for improvement was constrained by biology. Indeed, a critical assumption of the anthropometric anthropology practiced by Virchow and his colleagues was that races were little more than physical variations unconnected to culture or mental characteristics. Virchow argued that physical anthropology had "nothing to do with culture" and called races "nothing more than hereditary variations." ${ }^{20}$ Following these principles, race could not be connected to mental ability or levels of cultural achievement. In Virchow's view, race did not indicate superiority or inferiority. ${ }^{21}$ Furthermore, groups that shared a common language or set of customs did not necessarily share a common physical type, and, therefore, race, language, and culture did not coincide. It followed that racial classifications were in no way linked to ethnic groups [Völker] or nations, which were determined by language, customs, geography, and politics, rather than physical characteristics. In his influential anthropological textbook of 1914, Martin made this very point:

The ethnological word "Volk" is to be sharply distinguished from the zoological and anthropological term "variety" or "race." Whole units of smaller or larger

18 Cited in Johannes Ranke, Der Mensch, vol. 2 (Leipzig: Verlag des Bibliographischen Institutes, 1887), 233. Also quoted in Massin, "From Virchow to Fischer," 87.

19 Quoted in ibid., 87.

20 Statement about culture quoted in ibid., 82. On race, see Rudolf Virchow, "Rassenbildung und Erblichkeit," in Festschrift für Adolf Bastian zu seinem 70. Geburtstag, 26 June 1896 (Berlin: Reimer, 1896), 43.

21 George W. Stocking, Jr., Race, Culture, and Evolution: Essays in the History of Anthropology (Madison, WI: University of Wisconsin Press, 1968), 166-167. Also see Paul Weindling, Health, Race, and German Politics between National Unification and Nazism, 1870-1945 (Cambridge: Cambridge University Press, 1989), 55; Smith, Politics and the Sciences of Culture, 103; Erwin Ackerknecht, Rudolf Virchow: Doctor, Statesman, Anthropologist (Madison, WI: University of Wisconsin Press, 1953), 215. 
groupings (tribe, clan, Volk, nation) are racial aggregates or racial pluralities that have fused into ethnic unions. The deciding factor [in these cases] is not, as with race, morphological agreement, blood relationship, or common ancestry. Rather, what binds the members of a Volk [people] together is a common language and culture, a national feeling developed over time, a common government, political boundaries, etc. In anthropology, the term Volk has no place. ${ }^{22}$

In no uncertain terms, liberal anthropologists argued against investing categories like nation and Volk with racial meaning.

Virchow's brand of anthropology was also defined by a positivist commitment to inductive empiricism, which favored careful data collection and forbade any direct engagement with politics in scientific pursuits. Drawing on a scientific model stretching back to Sir Francis Bacon, empiricists rejected deduction and arguments by analogy, instead upholding specific facts as the foundation on which to build larger conclusions. The drive in the anthropological disciplines was to accumulate as much objective data as possible, to move very slowly from the specific to the general, rather than to propose unsupported theories. In German anthropological circles, the adherence to the inductive method enshrined the pursuit of the empirically verifiable fact as the central goal. Colleagues described how Virchow remained "cool, even ironic, toward every rash conclusion. For him [anthropology] was primarily about the researching and securing of facts." ${ }^{23}$ It was on the basis of empirical induction that Virchow, Bastian, and Ranke, and others in the German anthropological establishment objected to Darwin's theory of evolution as unproven. ${ }^{24}$ The positivist commitment to empirical induction also meant that anthropologists sought to avoid the influence of political considerations and events in the practice of their science. Their devotion to inductive method was bound up with a claim of conducting a science above politics. Ranke directly linked the two ideas on the very first page of his influential anthropological textbook. Following inductive principles, he argued, "hypotheses belong only in the laboratory of the researcher," and, furthermore, "the tradition of exact anthropology in Germany" necessitated the "avoidance of all overlap with politics, philosophy, and religion." ${ }^{25}$ In his view, the "dignity of science" did not allow "piquant side glances into [such] foreign areas." ${ }^{26}$ After Ranke's death in 1916, his obituary emphasized his "position against tugging anthropological research into the realm of politics until his death, despite many

22 Rudolf Martin, Lehrbuch der Anthropologie in systematischer Darstellung (Jena: Fischer, 1914), 9.

23 "Gedächtniss-Feier für Rudolf Virchow," Zeitschrift für Ethnologie 34 (1902): 327.

24 Zimmerman, Anthropology and Anti-Humanism, 116-117; Massin, "From Virchow to Fischer," 114-118.

25 Johannes Ranke, Der Mensch, vol. 1 (Leipzig: Verlag des Bibliographischen Institutes, 1887), v.

26 Ibid., (1887), vi. 
attacks." ${ }^{27}$ Claims to be practicing a "political anthropology" were met with scorn and derision by the leaders of the anthropological community.

Anthropologists with a liberal perspective also emphasized the international character of their science. The Berlin anatomist and anthropologist Wilhelm von Waldeyer spoke for many within the discipline in 1909 when he called anthropology "an international brotherhood" and claimed: "A science, like anthropology, that wants to be of use to humanity, must be international by necessity." 28 Martin likewise continued to maintain in 1915 that "the question, 'national or international science' is superfluous. All science is by nature international." 29 Shared methodologies and theoretical approaches helped forge connections between anthropologists in Germany and abroad. Members of the anthropological community expressed their internationalism by studying and working in foreign countries (Luschan studied under Paul Broca in Paris; Martin also worked in France) and cultivating close ties with foreign colleagues, as demonstrated by the large numbers of international "corresponding members" on the membership rolls of the Berlin Anthropological Society. Nationalism was a presence in liberal anthropology, but it was usually expressed in terms of scientific competition between national communities, rather than in the content of the science itself.

After Virchow's death in 1902, the liberal consensus in German anthropology began to erode. New fossil discoveries weakened the resistance to Darwinism within the anthropological community and, as a result, the disciplinary commitment to empirical induction waned. Greater acceptance of Darwinism in anthropological circles also undermined liberal notions about the fundamental similarities of humankind. Because the mechanism of natural selection was based on struggle and the creation of biological inequality, it seemed to justify the assumption of inequality among peoples as well. ${ }^{30}$ The rediscovery of Gregor Mendel's laws of inheritance by the scientific community around the turn of the century also had an impact on the discipline. Younger anthropologists, such as Eugen Fischer, then a relatively unknown scientist working at the Anatomical Institute in Freiburg, set out to apply genetic principles to anthropology, thus allowing researchers to conceive of race as more than simply a physical category. ${ }^{31}$ After Virchow's death, Fischer, the

27 F. Birkner, "Johannes Ranke," Correspondenz-Blatt der Deutschen Anthropologischen Gesellschaft 47 (1916): 39.

28 "40. Allgemeine Versammlung der Deutschen Anthropologischen Gesellschaft," Posener Tageblatt, August 3, 1909.

29 Rudolf Martin, "Nationale oder internationale Wissenschaft," Die Umschau 14 (1915): 306.

30 Massin, "From Virchow to Fischer," 114-120.

31 Proctor, "From Anthropologie to Rassenkunde," 145-148; Massin, "From Virchow to Fischer," 120-126. 
Strasbourg anatomist Gustav Schwalbe, and the young anthropologist Otto Reche also indicated their support for völkisch racial typologies that emphasized a superior northern European or "Nordic" race that possessed a specific psychology in contrast to others. ${ }^{32}$ Such classificatory systems violated the liberal prohibition against combining questions of race and with judgments on culture and ability. Eugenics, or "racial hygiene," also gained popularity in anthropological circles as a means of combating a wide variety of social ills through the "rational" administration of reproduction. In the years leading up to World War I, however, these departures were still relatively new, and liberal ideas continued to be championed by the leaders of the discipline, especially Ranke, Martin, and, despite his growing acceptance of Darwinism, Luschan. Despite the retreat from the principles associated with Virchow in the first decade of the twentieth century, liberal elements still had a prominent place within the field when the war broke out in 1914.

\section{Institutional Hardships in Wartime}

The realities of war quickly changed the financial and practical landscape in which the institutions of German anthropology operated. From the outset, the European conflict imposed hardships on the main sites where anthropological work took place, particularly anthropological societies, ethnographic museums, and German universities. The chief problems involved shortages of money and personnel, the very resources necessary to keep these institutions in operation. Moreover, the worldwide nature of the conflict severed international contacts and disrupted the ability to travel. In the years following the declaration of war, opportunities for anthropological work both at home and abroad were severely limited by wartime realities, causing some anthropologists to seek new avenues of activity.

Anthropological societies and institutions did not shut down as war broke out, but they recognized from the outset that the conflict would severely affect their normal operations. After the declaration of hostilities in August, the Berlin Anthropological Society did not meet until October, and, when it did, its president Eduard Seler frankly admitted that the war was already having a negative effect on the institution: "The dreadful war that rages around us and

32 Gustav Schwalbe, "Ueber eine umfassende Untersuchung der physischanthropologischen Beschaffenheit der jetzigen Bevölkerung des Deutschen Reiches," Correspondenz-Blatt der Deutschen Anthropologischen Gesellschaft 34 (1903): 73-74; Otto Reche, "Längen-Breitenindex und Schädellänge," Archiv für Anthropologie 38 (1911): 90; on Fischer, see Niels C. Lösch, Rasse als Konstrukt: Leben und Werk Eugen Fischers (Frankfurt a. M: Lang, 1997), 101. 
reaches deep into all relationships has of course also affected our Society." ${ }^{33}$ Younger members of the societies left for the front, while others canceled their memberships, because they could no longer pay their dues under the financial pressure of war. Beginning in 1915, the number of members in the Berlin Society steadily decreased until the end of the conflict. ${ }^{34}$ Still more serious was that many members still listed as active were not able to pay their dues. This was especially true of foreign members of the Society, with whom contact was now largely impossible. ${ }^{35}$

Perhaps even more significant was the lack of funding for anthropological research and disruption of travel abroad. A chief source of backing before the war had been the Rudolf Virchow Foundation, an endowment connected to the Berlin Society that was designed to support research, especially involving travel, in all the subfields of anthropology. ${ }^{36}$ During the war, the activities of the foundation nearly came to a complete stop; it only provided small sums for limited research, usually for archeological digs in Germany and other accessible parts of Europe. ${ }^{37}$ Like Luschan in Australia, other anthropologists who were already in the field also did not escape the influence of the war. Martin, who was conducting research in Paris when the war broke out, was forced to flee the city as quickly as possible, abandoning his personal library in his haste to leave. ${ }^{38} \mathrm{In}$

33 "Verhandlungen der Berliner Gesellschaft für Anthropologie, Ethnologie und Urgeschichte," Zeitschrift für Ethnologie 46 (1914): 746.

34 Christian Andree, "Geschichte der Berliner Gesellschaft für Anthropologie, Ethnologie und Urgeschichte, 1869-1969," in Festschrift zum Hundertjährigen Bestehen der Berliner Gesellschaft für Anthropologie, Ethnologie und Urgeschichte, eds. Hermann Pohle and Gustav Mahr (Berlin: Verlag Bruno Hessling, 1969), 113.

35 Seler summarized these problems in 1915: "In this new year the number of members has fallen off dramatically because of deaths, departures (as a result of diminished ability to work), and the small number of new applications. And above all, the war has interrupted our connections to our foreign members, especially those overseas, so that a good third of our membership dues were not collected. The society finds itself in serious financial distress." Vorsitzende der Berliner Gesellschaft to Minister der geistlichen, Unterrichtsund Medizinal-Angelegenheiten, September 23, 1915, Geheimes Staatsarchiv Preußischer Kulturbesitz, Berlin [GStA PK], I HA, Rep 76 Vc, Sekt. 1, Tit. 11, Teil I, Nr 4 Band 4, BI. 105.

36 Hans Virchow to Polizei-Präsidenten von Berlin, Herr von Borries, June 20, 1903, GStA PK, I HA, Rep 76 Vc, Sekt. 1, Tit. 8, Nr. 5.

37 Andree, "Geschichte der Berliner Gesellschaft," 113. See also "Verhandlungen der Berliner Gesellschaft für Anthropologie, Ethnologie und Urgeschichte," Zeitschrift für Ethnologie 50 (1918): 258-259.

38 Ferdinand Birkner, Nachruf für Rudolf Martin, July 7, 1925, Ludwig-Maximilian Universitätsarchiv München [LMU], E-II-N, Personalakte Rudolf Martin, BI. 4. 
1914, Richard Thurnwald, an Austrian ethnologist who had been conducting fieldwork in New Guinea before the outbreak of hostilities, found his research disrupted by Australian troops, who plundered his camp. ${ }^{39}$ The hardships that the discipline faced during the war could not be ignored, and the limitations of wartime academic life affected the activities of individual anthropologists and anthropological institutions. From 1914 onward, the war was a palpable presence within German anthropology.

\section{Anthropology in Wartime}

The conflict did more than simply disrupt the work of anthropologists; it also stoked nationalist feelings within the discipline. Internationalism within the anthropological community quickly receded from view as German anthropologists eagerly asserted their patriotism. As younger members of the discipline left for the front, older anthropologists propagandized for the war effort, giving talks on war-related topics, defending Germany's honor in public venues, and commenting favorably on wartime activities through their popular scientific writings. Despite his prewar rhetoric about "international brotherhood," Waldeyer joined ninety-three other prominent German professors and intellectuals in signing the patriotic manifesto, "Aufruf 'An die Kulturwelt'," which denied that the German army had committed atrocities in Belgium and asserted that Germany had not been responsible for the outbreak of war. ${ }^{40}$ Although many of the original signers distanced themselves from the document once the truth about Belgium emerged, including Waldeyer, the "Aufruf" represented a fateful step away from internationalism in the German academy and created a rift between German academics and their foreign colleagues. ${ }^{41}$ Less surprising was

39 "Verhandlungen der Berliner Gesellschaft für Anthropologie, Ethnologie und Urgeschichte," Zeitschrift für Ethnologie 48 (1916): 94.

40 Jürgen von Ungern-Sternberg and Wolfgang von Ungern-Sternberg, DerAufruf "An die Kulturwelt": Das Manifest der 93 und die Anfänge der Kriegspropaganda im Ersten Weltkrieg (Stuttgart: Franz Steiner Verlag, 1996): 156-164.

41 Bernhard von Brocke, "Wissenschaft und Militarismus: Der Aufruf der 93 'An die Kulturwelt!' und der Zusammenbruch der internationalen Gelehrtenrepublik im Ersten Weltkrieg," in Wilamowitz nach 50 Jahren, eds. William M. Calder III, Hellmut Flashar, and Theodor Lindken (Darmstadt: Wissenschaftliche Buchgesellschaft, 1985) 649-719, esp. 664-678. Waldeyer remained decidedly nationalistic throughout the war and served as president of the ad hoc propagandistic organization that grew out of the "manifesto," the "Cultural Association of German Artists and Professors" [Kulturbund deutscher Künstler und Gelehrter], which sought to "combat the systematic lies and incitements spread by our enemies." See ibid., 664. 
that the increasingly völkisch anthropologist Schwalbe signed a similar document and formally renounced the English academic honors that he had received during his lifetime.$^{42}$ Echoing such manifestos, other anthropologists joined the chorus of voices condemning the supposed greed and duplicity of Germany's enemies. At the first wartime meeting of the Berlin Anthropological Society, Seler expressed hopes for peace and the reestablishment of healthy international relationships, but he also maintained that the war had been "forced on us in a dastardly manner through the hatred and jealousy of our enemies [...]."43

Nationalist fervor ran so high in anthropological circles that when Luschan did not immediately return from the United States during the initial months of the war, members of the Berlin Anthropological Society questioned his patriotism. ${ }^{44}$ Luschan was originally from Austria, and his background may have raised questions about his attachment to the German Empire. August Brauer, a professor of zoology in Berlin, starting a whispering campaign against Luschan and the scientists who had attended the conference in Australia, charging that they had maintained relations with their hosts even after the war had started. Gestures of internationalism at the Australian conference in the first weeks of the war were now enough to bring the patriotism of the men into question. Upon his return in 1915, Luschan loudly and publicly defended German militarism and the Hollenzollern monarchy. ${ }^{45}$ In a further rejection of internationalism, he mocked his colleagues in England by relating a story about how one of them, while on a trip to Berlin before the war, had supposedly exclaimed, "Yes, [...] your Kaiser! If we only had a Kaiser. We would gladly trade you for our king." ${ }^{\prime 6}$ Great pressure to display nationalist sentiment clearly existed in anthropological circles.

Wartime nationalism soon crept into the content of anthropological science itself, as prominent anthropologists used their position as experts on the "world's peoples" to engage political questions and to present a racialized view of Germany's enemies and allies. In the process, they broke with liberal principles by overtly politicizing their science and mixing the categories of

42 Hermann Kellermann, ed., Der Krieg der Geister: Eine Auslese deutscher und ausländischer Stimmen zum Weltkriege 1914 (Weimar: Alexander Duncker Verlag, 1915), 28-29.

"Verhandlungen der Berliner Gesellschaft für Anthropologie, Ethnologie und Urgeschichte," Zeitschrift für Ethnologie 46 (1914): 747.

44 Albrecht Penck to Felix von Luschan, Feb. 8, 1915, NL Luschan.

45 Felix von Luschan, "Rassen und Völker," in Deutsche Reden in schwerer Zeit: Gehalten von den Professoren an der Universität Berlin, vol. 3, eds. Ulrich von Wilamowitz-Moellendorff et al. and Zentralstelle für Volkswohlfahrt und dem Verein für volkstümliche Kurse von Berliner Hochschullehrern (Berlin: Heymann, 1914), 349-381, quote from p. 366.

lbid. 
race, nation, and Volk. For anthropologists who had already converted to a Nordic or völkisch perspective, such as Fischer, this was not a great leap. In 1914, Fischer wrote an article for a popular science magazine about the ancestry of the South African Boers, arguing that the events of the war made it "worthwhile to examine how close the Boers stand to us in their ancestry." He concluded that the Boers were much more German than Dutch in their descent, and this connection had relevance in the current conflict: "So we want to consider, that when our magnificent 'Southwestern' [settlers] fight shoulder to shoulder with the Boers, that 'German' blood stands against 'English'-and hopefully soon German victory against English defeat!"48 The clear distinction between the blood of the Germans and the English portrayed them as two separate groups with two separate racial ancestries. Such references to "blood" confused the category of race and skirted the boundaries of völkisch ideology, which underscored the mystical blood bond between members of the same national community as a central theme.

Luschan, who remained generally liberal in his anthropology, also argued for "blood" connections between Germany and its allies upon his return from the United States. In this case, the ally in question was the Ottoman Empire. In 1916, Luschan gave a public lecture in which he claimed that the Germans and the Turks were related "not only by the brotherhood of arms, but also by a blood relationship." ${ }^{49}$ The venue-the Württemberg Anthropological Society-made the comment even more significant, because it was aimed at individuals with working knowledge of anthropology. In addition, Luschan asserted that blond northern Europeans had migrated east and south in the prehistorical period and that, as a result, blond and blue-eyed Kurds could still be found in areas where they had remained "pure and unmixed." (The Kurds were a minority in the Ottoman Empire, but well represented in the Ottoman military during the war. $)^{51}$ Luschan also claimed that evidence of blond and blue-eyed peoples had been found during excavations of medieval

47 Eugen Fischer, “Die Herkunft der Buren," Die Umschau 18 (1914): 1053.

48 Ibid., 1053-1054.

49 "Württembergischer Anthropologischer Verein: Bericht über 1914 (zweite Hälfte) bis 1916," Correspondenz-Blatt der Deutschen Anthropologischen Gesellschaft 47 (1916/17): 6-8.

50 Felix von Luschan, untitled handwritten manuscript, in file "Allgemeine Phys. Anthropologie," NL Luschan. There is a great likelihood that this manuscript is the text of the talk that Luschan gave at the Württemberg Anthropological Society. It contains some of the same phrasing as the report on the talk in the Correspondenz-Blatt, and Luschan's mention of the Turks as allies of Germany in the text indicates that it was written during the war.

51 Jwaideh, Wadie, The Kurdish National Movement: Its Origins and Development (Syracuse, NY: Syracuse University Press, 2006), 125-126. 
sites in Asia Minor. In short, he was anxious to show a biological relationship between Germany and the peoples of the Ottoman Empire, and, in the process, he evoked several physical characteristics that were considered the hallmarks of race, such as eye and hair color. Luschan did not directly mention a racial relationship between Germans and Turks or Kurds, but his mention of blood and his discussion of physical characteristics certainly implied it. In the highly nationalistic context of war, even Luschan was willing to blur liberal distinctions between race, nation, and Volk.

Waldeyer provided perhaps the most conspicuous example of such rhetoric in 1915 when he spoke on "The Peoples of the World War in Anthropological Perspective" for a popular patriotic lecture series in Berlin. The talk represented an instance in which an anthropologist used the tools of his discipline to present a racialized portrait of the enemy. Noting that Germany was "at war with half the inhabited planet" and that "from all parts of the world, from all races and peoples, enemies are intruding on us," Waldeyer portrayed anthropology as a practical instrument that could shed light on the current conflict. Throughout his talk, he was careful on the topic of race and initially drew a sharp distinction between race and Volk. The content of his lecture, however, often contradicted this stance. He claimed, for example, that the purpose of anthropology was to investigate the "classification of humanity into races, peoples, and states [Rassen, Völker und Staaten]," thereby implying that the makeup of both "peoples" and "states" was a focus of anthropological inquiry. This was a far cry from Martin's admonition that "in anthropology, the term Volk has no place," or Virchow's statement that "anthropology really cannot address the question of nationality that is continually raised." 52

Moreover, Waldeyer's portrayals of warring peoples described each as if it were distinct in its racial and bodily constitution, thereby creating the impression that each group did indeed possess a distinct racial character in comparison to others. His comments on each group combined physical and racial descriptions with stereotypes of character and psychological qualities. He noted the "outstanding physical development of the English, Scots, and Irish" and the "tiny, dainty bodies and physical agility" of the Italians and French, which "reminds one of the Japanese." ${ }^{53}$ His description of the Serbs was typical of his mixture of essentialized racial descriptions with stereotypes of character and links to wartime politics:

52 Martin, Lehrbuch, 9; Rudolf Virchow, "Meinungen und Thatsachen in der Anthropologie," Correspondenz-Blatt der Deutschen Anthropologischen Gesellschaft 30 (1899): 82.

53 Wilhelm von Waldeyer, "Die im Weltkriege stehenden Völker in anthropologischer Betrachtung," in Wilamowitz-Moellendorff et al. Deutsche Reden in schwerer Zeit, 339-340, quote from p. 330. 
By race, they belong to the European-Westasian, are light-skinned but mostly dark-haired, very short-skulled, high in growth, a powerful lineage. Mentally they are on average well equipped [...]. Long and in part bitter wars with the Goths, Huns, and Turks [...] steeled this people, but also awoke the frequent violence and unscrupulousness that gave rise to the current World War. ${ }^{54}$

Here, Waldeyer not only described the Serbs as a distinct physical type, but also used the opportunity to blame their national character for the war. At the conclusion of the talk, Waldeyer praised the peoples arrayed against Germany as its "equal in physical ability, bravery, courage," but there remained little doubt that the nations arrayed against Germany were racially and even psychologically "other." In its political engagement and purposeful overlap of race and nation, his talk violated the principles of the liberal tradition in German anthropology.

At the other end of the spectrum, the war saw a number of efforts to mobilize anthropology and ethnology that did not directly employ race, but still represented instances in which science was utilized to rally support for the nation and to emphasize the themes of wartime propaganda. One example was Leo Frobenius, a freelance explorer and ethnographer known for his privately funded journeys to Africa. Frobenius was a controversial figure in the German anthropological community who did not possess a professional position in the field, but who was one of the founders of Kulturkreis theory ${ }^{55}$ During the war, Frobenius used his position as an ethnologist to condemn the use of colonial troops by the Allied Powers and to refute negative images of Africans, even while he suggested that Germany might make a superior imperial master for the colonized peoples of the world. He visited African soldiers in various POW camps throughout Germany and gave public lectures denouncing the colonial policies of the Entente Powers. At a public lecture about African POWs in Berlin in 1917, he condemned popular stereotypes of Africans as "black dogs" and denounced those European powers who would use colonials as cannon fodder, while also providing an alternative (and equally paternalistic) imperial vision that focused on "cultivating" and aiding colonials. ${ }^{56}$ Germany was the nation to take up this task, since it was clearly the "most able" to solve the problems of middle Africa. ${ }^{57}$ Frobenius's voice was shriller still in a 1916 popular publication on the use of colonial troops in the war, provocatively entitled

54 Ibid., 326.

55 On Frobenius, see Dewitt Clinton Durham, "Leo Frobenius and the Reorientation of German Ethnology, 1890-1930" (PhD thesis, Stanford University, 1985); Suzanne Marchand, "Leo Frobenius and the Revolt against the West," Journal of Contemporary History 32, no. 2 (1997): 153-170.

56 "Unsere farbigen Gefangenen, Vortrag von Leo Frobenius," Berlin Vossische Zeitung, May 2, 1917.

57 Ibid. 
Our Enemies' Circus of Peoples [Der Völkerzirkus unserer Feinde]. The book, which included photographs of colonial troops, amounted to a blistering denunciation of the British, whom he accused of acting like veritable circus trainers and treating Africans and other colonials as wild animals. Germany, he argued, had always been the last line of defense against the imperial abuses of the British. ${ }^{58}$ Frobenius unabashedly wielded his authority as a scientist as a weapon in the propaganda wars against the Entente Powers.

The influence of the war on the work of Martin was even more direct, drawing him away from the tradition of a nonpolitical and "value free" science that Ranke and Virchow had championed. After Ranke's death in 1916, Martin was offered the chair in anthropology at the University of Munich, the premier position in the field. Once there, Martin launched a major anthropological study of nutritional levels and physical development among Munich schoolchildren. The project was explicitly designed to determine the effects of the Allied blockade on the German school-age population. According to his assistant at the institute, Ferdinand Birkner, the initial motivation for the studies was to "supply exact proof of in what measure the health of German children had been harmed by the hunger blockade of the enemy powers" in order to qualify for charitable relief from outside the country. ${ }^{59}$ After years of work, Martin found that German children were significantly smaller than their counterparts in other countries like the United States. ${ }^{60} \mathrm{He}$ concluded that poor nutrition resulting from the Allied blockade was to blame. Race, in his view, played no role, since all the groups in the study were of "Anglo-Saxon descent." The political message of Martin's study, however, was clear: The wartime policies of the Entente Powers had warped the bodies of German children. Martin's methods during the studies remained empirical, but the project represented a foray into a brand of anthropology designed to serve political and patriotic purposes.

The most prominent anthropological project launched during the war was the study of POWs in German and Austrian POW camps. ${ }^{61}$ As the camps

58 Leo Frobenius, Der Völkerzirkus unserer Feinde (Berlin: Eckhart-Verlag, 1916), 13.

59 Ferdinand Birkner, "Nachruf für Rudolf Martin," July 7, 1925, LMU, E-II-N, Personalakte Rudolf Martin.

60 Rudolf Martin, "Die Körperentwicklung Münchener Volksschulkinder in den Jahren 1921, 1922, und 1923," Sonderdruck aus dem Anthropologischen Anzeiger I (1924): 85.

61 See Andrew D. Evans, "Anthropology at War: Racial Studies of POWs during World War I," in Penny and Bunzl, Worldly Provincialism, 198-229. See also Margit Berner, "Forschungs-'Material' Kriegsgefangene: Die Massenuntersuchungen der Wiener Anthropologen an gefangenen Soldaten, 1915-1918," in Vorreiter der Vernichtung? Eugenik, Rassenhygiene, und Euthanasie in der 
filled with colonial soldiers from Africa, India, and East Asia, anthropologists and ethnologists alike became more and more excited about the rare chance of studying colonial subjects on European soil. With the aid of government and military officials, scientists in Germany and Austria launched a series of expeditions to investigate the language, culture, and physical makeup of the prisoners. Once there, however, physical anthropologists focused increasingly on the peoples of Central and eastern Europe. The setting of the camp served to collapse the distinction between African and Asian colonial troops and European soldiers, replacing it with a dynamic that underscored the divide between captors and prisoners, enemies and allies. The physical circumstances and lopsided power relationships drastically altered the subject positions of the European prisoners, highlighting their difference from Germans. Before the war, by contrast, anthropologists commonly claimed that there was little physical difference between Germanic, Slavic, and Celtic groups. ${ }^{62}$ During the war, anthropologists enjoyed an unprecedented degree of power over their subjects, measuring Russian, French, British, Serb, and other European groups alongside Senegalese, Algerian, and Indian.

Fueled by wartime nationalism, younger researchers, such as Egon von Eickstedt and Otto Reche, began selecting subjects and organizing their data on the basis of national and political affiliation. Following the advice of Luschan, Eickstedt initially set out to investigate the physical characteristics "of an anthropologically interesting group: Indians, Turks, or inner Asians," eventually settling on the racial characteristics of the Sikhs as the topic for his dissertation. ${ }^{63}$ As time wore on in the camps, however, he became increasingly interested in measuring select European POWs and organized his lists of subjects according to national citizenship, thereby suggesting that he implicitly sought to investigate the racial makeup of nations. He conducted studies on groups from eastern Europe, Russia, and southern France, but avoided the investigation of peoples who were in any way associated, however tangentially, with "Germanness," such as those considered to be descended from Germanic tribes, particularly the English and peoples from northern France. ${ }^{64}$ The term "Germanic" had no place in the liberal tradition, because it described a language group, but Eickstedt's selection of subjects demonstrated that a

österreichischen Diskussion vor 1938, eds. Heinz Eberhard Gabriel and Wolfgang Neugebauer (Vienna: Böhlau, 2005), 167-198.

62 Felix von Luschan, "Zur Anthropologie der Preußen," Berliner Tageblatt, June 7, 1914. See also Rudolf Martin, "Germanen, Kelten, und Slaven," Die Umschau 20 (1916): 201.

63 Luschan to Eickstedt, July 30, 1915, NL Luschan, File Eickstedt. For Eickstedt's dissertation, see Egon von Eickstedt, "Rassenelemente der Sikh," Zeitschrift für Ethnologie 52 (1920/21): 317-394.

64 Eickstedt to Luschan, Dec. 6, 1916, NL Luschan, File Eickstedt. 
connection to "Germanic" background functioned as the standard against which racial otherness was judged. Reche, meanwhile, had already begun to move decisively toward völkisch and Nordic racial theories before 1914, but the war encouraged him to fashion his science into an explicitly nationalist and political instrument. In the POW camps, he focused on peoples who lived in areas already occupied by German forces, arguing that those who "as a result of the war may come into tighter political connection with us" deserved "special attention." ${ }^{65} \mathrm{He}$ purposely sought to determine the racial makeup of the peoples who would come under the control of the German Empire after the war was over in order to determine their relationship to Germans and the Nordic racial group. The overall result of the POW studies was a politically motivated anthropology that investigated national enemies as "racial others" and blurred the boundaries between nation, Volk, and race. By the time the war ended in 1918, the pattern of mobilizing anthropology as both a scientific and political tool in the service of the nation had been firmly established.

\section{Anthropology in the Aftermath}

The effects of World War I did not end with the armistice in 1918. The political and economic crisis that followed severely limited the ability of anthropological institutions to function. Anthropological societies like the Berlin organization continued to meet, but overall activity remained at a minimum, new journal issues were radically reduced in size, and members conducted scientific work only with great difficulty. ${ }^{66}$ Shortages of state and private funds also combined to bring work at Germany's university institutes to a standstill. In 1919, Martin expressed fears that the anthropological institute in Munich would not survive, because of minimal funding from the state. ${ }^{67}$ The hyperinflation of the early 1920s wiped out the remaining assets of the Rudolf Virchow Foundation, so that it essentially existed in name only by $1924 .{ }^{68}$ Moreover, the economic and political dislocation of the immediate postwar period also meant that paying positions for scientists were extremely rare. Writing to Franz Boas in the hopes of securing a job in the United States, Egon von Eickstedt described the situation this way:

65 Reche to Hamburg Oberschulbehörde, March 13, 1918, Staatsarchiv der Freien und Hansestadt Hamburg [HAS] 361-5 II Hochschulwesen II W a 8, BI. 31-32.

66 Andree, "Geschichte der Berliner Gesellschaft," 114.

67 Rudolf Martin to Franz Boas, November 28, 1919, Franz Boas Collections [FBC], American Philosophical Society.

68 Andree, "Geschichte der Berliner Gesellschaft," 121. 
Modern Germany does not want at all men of science. More or less it is a socialistic state, where culture is considered to be perhaps agreeable, but at any rate a very superfluous thing: men of culture are in a certain degree outcasts, are economically uprooted and, as the greater part of the middle classes, left to their fate. ${ }^{69}$

Postwar disruption reinforced the wartime trend of making anthropological science relevant to state and society, this time in order to secure its survival.

The wartime erosion of internationalism within the discipline also continued after the defeat, despite the desire of some liberal anthropologists to rebuild relationships with academics abroad. German scientists tended to place the blame for poor relations on their foreign colleagues, rather than on their own rhetoric or actions during the war, even when they desired renewed contact. In 1919, Luschan remarked in correspondence with the American anthropologist Boas that the "future connections between German academics and colleagues in enemy lands" remained "uncertain." "The great majority of Frenchmen will naturally remain crazy for a very long time, and I fear that the English will remain unfriendly for a long period as well." ${ }^{70}$ Martin maintained that German science could only be revived when the "academic circles abroad move away from their unjustified and unfounded tone of hatred toward German science [...]."71 Boas organized emergency funds to aid in the continued publication of German anthropological journals, but, in general, German-speaking anthropologists felt increasingly cut off from the their colleagues abroad. The 1920 creation of an International Union of Academics in Paris that excluded members of the Central Powers highlighted this feeling. ${ }^{72}$

Increasingly isolated, desperate for support from the new Weimar government and nursing wounded national pride, anthropologists began to turn their scientific energies inward, toward Germany and its problems. The ruinous human cost of the conflict fanned fears of population decline, and the economic and political dislocations after 1918 fostered the sense that German society was in crisis. In eugenics, anthropologists found a means of addressing what they saw as a broken and ailing society while also demonstrating the practical uses of their discipline to the state. Eugenics-also called Sozialanthropologie-had been a serious object of interest before 1914, but, after the war, it moved to the absolute center of the anthropological project as a means of healing a nation enervated and damaged by war. Luschan, who had been a proponent of eugenics before the war, considered it his patriotic duty as an anthropologist to promote racial hygiene as a means of supporting the country's "physical, mental, and

69 Egon von Eickstedt to Franz Boas, May 7, 1920, FBC.

70 Luschan to Boas, January 18, 1920, FBC.

71 Rudolf Martin to Boas, November 28, 1919, FBC.

72 Rudolf Martin to Boas, February 10, 1920, FBC. 
moral recovery" after the "deepest humiliation of our fatherland." ${ }^{73}$ Members of the discipline consistently emphasized the usefulness of eugenics to the state. In 1919, Fischer argued that the "youngest branch of anthropology, Sozialanthropologie" had "won eminent meaning for the state in recent times," because it had "placed itself next to national economics, sociology, and others." "74 Eickstedt claimed that racial hygiene could address economic problems by improving the quality of the population and therefore increasing national efficiency. ${ }^{75}$ In the postwar context, anthropologists eagerly cast aside earlier prohibitions against engaging anthropology in politics and crafted a eugenicist racial science designed to attract the attention of the state.

For Martin, the postwar period saw a growing interest in the health of the German nation that eventually shaded into an engagement with eugenics. He continued his studies of German schoolchildren, arguing that they represented "an overview of the bodily development of our youth for the entire Reich" and could be used to encourage health on a national scale. In the early 1920 s, he also began to take measurements of German athletes and gymnasts. He maintained that physical training and exercise were a means of improving the "toughness" of the German people, who had been weakened by years of war and malnutrition. Moreover, in 1923, Martin's anthropological institute in Munich opened a "consultation station for biological and family research," designed to provide information about one's genetic inheritance, ostensibly for use in decisions about marriage and thus reproduction. This was a clear foray into the realm of eugenics. All of these measures were designed to strengthen the nation and attract the attention of the state. Martin maintained that the Reich Public Health Office might be interested in the data from the studies on schoolchildren, for example, arguing that the research possessed meaning "not only for the individual but for the state."76

Another avenue of displaying anthropology's worth was to focus on anthropological studies of Germans. After 1918, anthropologists increasingly sought to make distinctions between the racial makeup of the German Volk and the rest of Europe. Germanicized and Nordic racial concepts, which had achieved growing acceptance in the prewar period, now became the norm within German anthropological circles. Moreover, in a marked shift in the

73 Felix von Luschan, "Einige Aufgaben der Sozial-Anthropologie," Die Schwester 4 (Jan. 1921): 1.

74 Eugen Fischer, "Die Notwendigkeit anthropologischer Lehrstühle an den Universitäten," Correspondenz-Blatt der Deutschen Anthropologischen Gesellschaft 50 (1919): 38.

75 Egon von Eickstedt, "Menschenkundliche Zeitforderungen," Die Deutsche Politik VI (1921): 576.

76 Rudolf Martin to Rektorat der Universität München, Feb. 22, 1924 and Nov. 28, 1921, Bayerische Hauptstadtsarchiv, MK 11820. 
focus of inquiry from the prewar period, postwar anthropology took the racial classification of Europeans, and especially Germans, as a central task. Anthropologists and anthropological institutions alike called for government-funded racial surveys, arguing that such studies would not only have military application, but would also aid in preserving "German" qualities. In 1919, Fischer called for more chairs in anthropology, heralding the discipline as a tool that could not only solve the "problem of the racial makeup of our Volk," but also answer questions about "the military capabilities of our Volk." In 1919, the German Anthropological Society also requested more professorships in anthropology on the grounds that a wide-ranging anthropological study of Germany was necessary for the country. Without such a survey, it argued, "[...] we will never learn in the face of increasing internationalism which races make up the German Volk [...]."78 After World War I, the anthropological community feared the dilution of "Germanness," arguing that the races within the German population would soon be mixed to the point where they could not be determined. Such proposals not only blurred the distinctions between race, nation, and Volk, but also demonstrated the desire of anthropologists to make their discipline more relevant to state and nation.

These trends were aided by the completion of a generational shift within anthropological circles during and after the war. Virchow died in 1902 and Bastian in 1905. The other major representatives of the liberal tradition began to pass from the scene during and after the war. Ranke died in 1916, Kollman in 1918, Luschan in 1924, and Martin in 1925. In their place rose a younger generation of anthropologists who consistently worked toward a nationalist and völkisch brand of anthropology that took an increasingly racialized version of eugenics as its central direction and the anthropological investigation of Germans as a major goal. Many of these men had been shaped by experiences in the German colonies or during the Great War, sometimes both.

The leader of this new group was of course Fischer, who had made his name with a study of race mixing between Dutch settlers and native Hottentots in German Southwest Africa, which he published in 1913. ${ }^{79}$ Fischer succeeded Luschan at the University of Berlin in 1924. In Munich, Martin was replaced by Theodor Mollison, who embraced Rassenkunde as the future of anthropology, and joined the National Socialist party in $1937 .{ }^{80}$ When he occupied the Munich chair in 1926, he argued for the continuation of Martin's studies

77 Fischer, "Die Notwendigkeit anthropologischer Lehrstühle," 38.

78 "An die deutschen Universitäten," Correspondenz-Blatt der Deutschen Anthropologischen Gesellschaft 50 (1919): 37.

79 Eugen Fischer, Die Rehobother Bastards und das Bastardierungsproblem beim Menschen (Jena: Fischer, 1913).

80 Proctor, "From Anthropologie to Rassenkunde," 158. 
of schoolchildren on the grounds that they served "social-anthropological" (i.e., eugenic) purposes and later launched a series of racial studies of Bavarians. ${ }^{81}$ Reche, who had participated in the German South Sea expedition of 1908-1910, served as an infantry officer at the front during World War I and participated in the wartime studies of foreign POWs, succeeded Rudolf Pöch to the prestigious chair of anthropology at the University of Vienna in 1924 and became professor of anthropology in Leipzig in 1927. Throughout the 1920s, he championed a völkisch brand of anthropological science, arguing that race and language actually coincided with one another and pursuing research into blood groups as a means of determining the distribution and value of different racial classifications. ${ }^{82}$ Walter Scheidt, a former student of Rudolf Martin in Munich, replaced Reche as the resident physical anthropologist at the Hamburg Museum für Völkerkunde. Having served on the eastern front during the war, he brought a nationalist perspective to Rassenkunde, which he saw as a eugenic means of countering postwar German weakness and encouraging "Germany's renewal." 83 In his view, race and nationality were linked, and once in Hamburg, he set out to explore the racial makeup of Germans in surveys of local populations. ${ }^{84}$ Eickstedt, who had served on the western front as a doctor in a mobile X-ray unit and taken part in the POW studies, argued for more racial studies of Germans in the early 1920s, as well as greater support for racial hygiene as a means to solve Germany's problems. ${ }^{85} \mathrm{He}$ became a full professor of anthropology at Breslau in 1933 and achieved success during the

81 On continuing Martin's studies of schoolchildren, see Mollison to Bayerisches Staatsministerium für Unterricht und Kultus and Staatsrat Dr. Hauptmann, Jan. 28, 1926, Bayerische Hauptstadtsarchiv, Munich [Bay. HSTA], MK/V 1366. "Universität München, Philosophische Fakultät, Ordentliche Professor für Anthropologie, 1925-1971" [no folio numbers]. On racial studies of the Bavarian populations, see Mollison to Bayerisches Staatsministierum für Unterricht und Kultus. Oct. 2, 1928. Bay. HSTA. MK 11723. "Anthropologie und Archäologie in genere" [no folio numbers].

82 For Reche's views on race and language, see Otto Reche, "Rasse und Sprache," Archiv für Anthropologie 46 (1921): 218. On his work with blood groups, see Pauline M. H. Mazumdar, "Blood and Soil: The Serology of the Aryan Racial State," Bulletin of the History of Medicine 64 (1990): 187-219, esp. 191-198.

83 Walter Scheidt, "Rassenbiologie und Familienanthropologie," Deutschlands Erneuerung 7 (1923): 47.

84 On race and nation, see idem, "Rasse, Volkstum, und Landesgrenzen," Der Auslandsdeutsche 6 (1923): 485. On racial surveys around Hamburg, see idem, Die Elbinsel Finkenwärder: Veröffentlichung des Werkbundes für Deutsche Volkstums- und Rassenforschung (Munich: J. F. Lehmann Verlag, 1927).

85 Egon von Eickstedt, "Menschenkundliche Zeitforderungen," Die Deutsche Politik VI (1921): 572-576. 
1930 s as the editor of premier anthropological journal of the National Socialist period, the Zeitschrift für Rassenkunde und ihre Nachbargebiete. ${ }^{86}$

The culmination of wartime and postwar trends in German anthropology arrived in 1927 with the foundation of the Kaiser Wilhelm Institute for Anthropology, a government-funded institution headed by Fischer. From the outset, the institute was dedicated to a racist form of eugenics in the service of the state and nation. In his 1926 proposal for the institute, Fischer argued that the state and the German people in general had an overwhelming self-interest in eugenic questions.

The state has the utmost interest, the whole Volk the truly vital interest, in gaining flawless information about the inheritance of healthy and sick, physical and mental structures, about the de- or regeneration of parts of the population with possible racial differences, the meaning of inbreeding, mixture, increase and decrease in children and all the other questions of social anthropology. ${ }^{87}$

This passage implied that eugenics or social anthropology was crucial to the future of Germany, but it also incorporated race into the eugenic equation. The country that solved these problems, Fischer claimed, would "have the future." ${ }^{88}$ It is not surprising that the first project launched by the Institute was a comprehensive racial survey of the German population. The foundation of the Institute not only represented resolution of the institutional insecurity of the immediate postwar period, but also signaled the victory of a highly politicized and nationalist anthropology that repudiated liberal concepts.

\section{Conclusion}

Historians of anthropology have long been aware of the need to examine how anthropologists functioned within multiple and often overlapping contexts-political, cultural, institutional, and colonial-in order to understand how disciplinary change occurred over time. One critical context that has largely been ignored in the history of discipline, however, is war. World War I was the central event of the early twentieth century, an all-consuming conflict that fundamentally altered the circumstances in which anthropolo-

86 Proctor, "From Anthropologie to Rassenkunde," 161-162.

87 Eugen Fischer, "Ein Forschungsinstitut für Anthropologie und menschliche Erblichkeitslehre," May 15, 1926, GStA PK, I HA, Rep 76 Vc Sekt. 2, Tit. 23A, Nr. 144, Bd. 1, BI. 22.

88 Idem, "Zweck und Aufgaben eines Forschungsinstituts für Anthropologie, menschliche Erblichkeitslehre und Eugenik," GStA PK, I HA, Rep 76 Vc Sekt. 2, Tit. 23A, Nr. 144, Bd. 1, BI. 57. 
gists operated, not only between 1914 and 1918, but also in the years that followed. In its most obvious manifestation, the war changed the ideological context of anthropological work in Germany by encouraging a wave of nationalism within anthropological circles. Although nationalism had been on the rise in the discipline before 1914, the conflict encouraged anthropologists to define their own roles and the aims of their scientific work in strictly nationalist terms. Members of the discipline fully mobilized their science for war, putting their science at the service of the nation and the state, thereby breaking from a long disciplinary tradition of remaining aloof from expressly political topics. The mobilization of anthropology was also partly motivated by the persistent feeling of institutional uncertainty that gripped the field during and after the war. Hoping for more government support, and in the thrall of surging nationalism, anthropologists quickly utilized their science to swing support behind the state. Members of the discipline provided anthropological profiles of the enemy, investigated nutritional levels among German schoolchildren, and increasingly turned their attention to eugenics as a means of aiding a nation in crisis.

In order to chart the "contested road from liberal to Nazi anthropology," scholars must incorporate the story of wartime anthropology. The wider shift in German anthropology from the anthropology of the late nineteenth century to the racial science of the 1920s and 1930s clearly had multiple causes, both internal and external, but studies of the field that end in 1914 miss a critical part of the picture. The war had a profound impact on the discipline. From the lecture hall to the POW camp, changes in the direction of German anthropology were at least partially contingent on the wider wartime political and ideological contexts in which anthropologists did their work. The war led to the increasing international isolation of German anthropology, the turn to a narrowly nationalistic and highly politicized science, and the abandonment of the concepts at the heart of the liberal tradition. It is evident that no history of anthropology in Germany-or in Europe, for that matter-can be complete without attention to the Great War, which had a profound impact on the world of science, just as it did on the realms of politics, society, and culture. 


\title{
Laboratory Conditions: German-Speaking Volkskunde and the Great War
}

\author{
ReINHARD JOHLER
}

Leo Spitzer was born in 1887 into a prosperous Viennese Jewish family. He took a doctorate in Romance languages at the University of Vienna with a thesis on "Word Coinage as a Stylistic Means on the Example of Rabelais," attaining the status of Privatdozent (just short of professor) at the age of 26. In 1920, he followed his teacher Wilhelm Meyer-Lübke to Bonn. In 1925, he accepted a chair in Romance languages in Marburg and, in 1930 in Cologne. National Socialist persecution drove him first to Istanbul in 1933 and then to Johns Hopkins University in Baltimore. Spitzer died in 1960 in Forte dei Marmi, Italy. The two volumes of Style Studies ${ }^{1}$ are regarded as his magnum opus.

By all accounts, Spitzer made significant contributions to the study of Romance languages. The lasting value of his work is still being debated. One can dismiss him, as Hans Ulrich Gumbrecht does in a biographical essay, as a fashionable but methodologically aimless "high flyer," as the Romance languages scholar Bernhard Hurch of Graz has been doing for years and with ample justification, the founder of discourse analysis. ${ }^{3}$ This is not the place to elaborate on the evidence in favor of the latter, but it includes the translations of Spitzer's works into Italian ${ }^{4}$ and-by no less than Michel Foucault himself-into French, translations which have attained remarkable scholarly

1 Leo Spitzer, Stilstudien (Munich: Hueber, 1928).

2 Hans Ulrich Gumbrecht, "'Methode als Erlebnis': Leo Spitzers Stil," in Vom Leben und Sterben der großen Romanisten:Karl Vossler, Ernst Robert Curtius, Leo Spitzer, Erich Auerbach, Werner Krauss (Munich: Hanser, 2002), 72-152.

3 Bernhard Hurch, "[(Die Suche nach dem Stil) als Text]: Diskursanalytisches zu Gumbrechts Spitzer Buch," Romanische Forschungen 118 (2006): 341-355.

4 Leo Spitzer, Saggi di critica stilistica (Florence: Sansoni, 1985). 
renown. ${ }^{5}$ More directly relevant to the present argument is that Spitzer, just after the First World War, published three monographs in brief succession whose approach can more or less be described as discourse analysis. All three would have been inconceivable without the war. Circumlocutions for Hunger in Italian: Stylistic-Onomasiological Study on the Basis of Unpublished Censorship Materials ${ }^{6}$ was published in Halle, Germany, in 1920; in 1921, a work on Letters of Italian Prisoners of War: Materials for a Characterization of Italian Folk Correspondence ${ }^{7}$ was published in Bonn. In 1922, a unifying synthesis covering much of the same ground, Italian Vernacular Speech, ${ }^{8}$ was published in Bonn and Leipzig.

How might wartime conditions have prompted the "invention" of discourse analysis? As the books' titles imply, Spitzer had access to vast amounts of source material that he, beginning in September 1915-without direct orders, but clearly as an element of his military service-had systematically copied as director of the censorship department of the central registration office [Gemeinsames Nachweisebureau] for Italian prisoners of war (POWs) in Vienna. He subjected the euphemisms that the prisoners used to elicit shipments of food from home without attracting the attention of censors ${ }^{9}$ to meticulous philological analysis, and his researches persuaded him of the "patternedness" of "folk correspondence" and inspired the first scholarly account of Italian vernacular language as a whole. ${ }^{10}$

5 Jean Starobinski, "Leo Spitzer et la lecture stylistique," in Les études de style, ed. Leo Spitzer (Paris: Gallimard, 1970), 7-42.

6 Leo Spitzer, Die Umschreibungen des Begriffes "Hunger" im Italienischen: Stilistisch-onomasiologische Studie auf Grund von unveröffentlichtem Zensurmaterial (Halle a.S.: Niemeyer, 1920).

7 Idem, Italienische Kriegsgefangenenbriefe: Materialien zu einer Charakteristik der volkstümlichen italienischen Korrespondenz (Bonn: Hanstein, 1921).

8 Idem, Italienische Umgangssprache (Bonn: Schroeder, 1922).

9 Italian POWs' complaints of hunger-and their veiled requests for food in letters home-had a specific background: Despite the miserable conditions in the camps, the Italian government-in contrast to its allies-refused to forward supplies, so that prisoners were exclusively reliant on help from their families. Hunger became a central concern for the six hundred thousand Italian POWs, and their mortality rate was correspondingly high. See Giovanna Procacci, "'Fahnenflüchtige jenseits der Alpen': Die italienischen Kriegsgefangenen in Österreich-Ungarn und Deutschland," in Kriegsgefangene im Europa des Ersten Weltkriegs, ed. Jochen Oltmer (Paderborn: Schöningh, 2006), 194-215. The policy background is examined in detail in the informative introduction to the Italian translation of Spitzer's Kriegsgefangenenbriefe: Lorenzo Renzi, "Presentazione," in Lettere di prigionieri di guerra italiani: 1915-1918, by Leo Spitzer (Turin: Boringhieri, 1976), vii-xxxiii.

10 On life and work, see also Bernhard Hurch, "Der Kontext," in Leo Spitzers Briefe an Hugo Schuchardt, ed. idem (Berlin: de Gruyter, 2006), VII-LV. 
Spitzer's office was generally notable for its original scholarship and intellectual productivity. In both his data-gathering and his thinking, he enjoyed the company of a friend, the biologist Paul Kammerer, who was to become famous in the 1920s for a series of experiments eventually exposed as fakescharges that were never entirely disproved. Kammerer's wartime assignments included the systematic iconographic analysis of a "postcard collection"11 assembled by the Italian side for propaganda purposes. His study "Sociological Questions of Captivity as a Prisoner of War"12 included methodologically innovative and theoretically ambitious deliberations on the nature of war that ultimately led him-based on analogies suggested by modern warfare's oftnoted mechanical repetitiveness and regularity-to publish an interesting if perhaps too daring book, The Law of the Series: A Doctrine of the Recurrences in Life and World Events. ${ }^{13}$

For Spitzer and Kammerer, the First World War opened previously unsuspected avenues for systematic collection and analysis. Almost before the first shots were fired, it had begun to appear to both researchers as a tremendous "experiment" that would permit research under "laboratory" conditions more commonly associated with the natural sciences. It is therefore hardly a coincidence that recourse to new methods-perhaps indeed the "invention" of discourse analysis - and the adoption of the serial paradigm of the natural sciences occurred under the unique and novel conditions prevailing in the war.

Kammerer and Spitzer were not the only researchers on whom mass archiving and its potential to facilitate innovative evaluative techniques left a deep impression. Soldiers' letters were collected in large quantities by the "German Folk Song Archive" in Freiburg beginning in $1915^{14}$ and were parsed on both sides of the front by renowned folklorists at their desks in Paris ${ }^{15}$ and German philologists at the POW camp in Chemnitz. ${ }^{16}$ To date, the role of

11 Paul Kammerer, "Meine Ansichtskarten," in Menschheitswende: Wanderungen im Grenzgebiet von Politik und Wissenschaft (Vienna: Der Friede, 1919), 86-97.

12 Idem, "Soziologische Fragen der Kriegsgefangenenschaft," in Menschheitswende, 74-85.

13 Idem, Das Gesetz der Serie: Eine Lehre von den Wiederholungen im Lebens- und Weltgeschehen (Stuttgart: Deutsche Verlags-Anstalt, 1919).

14 John Meier, "Sammlungen deutscher Kriegsbriefe und deutscher Tagebuchaufzeichnungen aus dem Kriege," Mitteilungen des Verbandes deutscher Vereine für Volkskunde 21 (1915): 43-44.

15 Cf. Albert Dauzat, L'Argot de la guerre: D'après une enquête auprès des officiers et soldats (Paris: Colin, 1918); L[azare] Sainéan, L'Argot des tranchées: D'après les lettres des Poilus et les journaux du front (Paris: Boccard, 1915).

16 Willy Hunger, Argot: Soldaten-Ausdrücke und volkstümliche Redensarten der französischen Sprache (Leipzig: Fock, 1917). 
the censor-researcher in the Great War has been as little illuminated as the importance of censorship bureaus as loci of research and collecting. ${ }^{17}$ It is nonetheless apparent that the war was regarded by researchers across Europe as a unique laboratory and an unprecedented opportunity. ${ }^{18}$ The war was seen not only as an original research topic-often charged with patriotic pathosbut also as an ideal opportunity to build careers and refine disciplines. From philology to physics, many sciences absorbed lasting modulations with regard to theory, methods, or source materials, while others were from their inception so intertwined with the war that they can fairly be described as its by-products.

As obvious as the link between scientific progress and a concerted war effort may be ${ }^{19}$ the First World War's generation and transformation of scientific research has been made the subject only of a few rudimentary studies, mostly of disciplines that were firmly entrenched at the outset. ${ }^{20}$ German and

17 Hanns Bächtold-Stäubli, one of the initiators of Kriegsvolkskunde in Switzerland, was employed during the First World War as a military censor. He used his work to gather material for the Handwörterbuch des deutschen Aberglaubens-one of the major postwar projects of German-language Volkskunde. Cf. Christoph Daxelmüller, "Vorwort," in Handwörterbuch des deutschen Aberglaubens, vol. 1 (Berlin: de Gruyter, 1987), v-xxxiv.

18 The ethical questions raised by this particular type of investigation in POW camps have virtually never been addressed. One exception is Romance languages scholar Cesar Foligno of Oxford, who expressed the following judgment in a review: "The mass of material he has collected must have been enormous, judging from the 300 pages of quotations he prints, and if ever a mother was kept waiting a day longer than necessary for news of her son in order that this book could be written, that was a crime for which this book or ten such books, however interesting and learned, would fail to be extenuating circumstances."-Cesare Foligno, review of "Die Umschreibungen des Begriffes 'Hunger' im Italienischen: Stilistisch-onomasiologische Studie," The Modern Language Review 17 (1922): 197-201.

19 Mitchell G. Ash, "Wissenschaft—Krieg-Modernität: Einführende Bemerkungen," Berichte zur Wissenschaftsgeschichte 19 (1996): 69-75. For the anthropological disciplines, cf. David H. Price, Anthropological Intelligence: The Deployment and Neglect of American Anthropology in the Second World War (Durham, NC: Duke University Press, 2008).

20 A selection of works on Germany and France: Annette Becker, Maurice Halbwachs: Intellectuel en guerres mondiales 1914-1945 (Paris: Viénot, 2003); Kurt Flasch, Die geistige Mobilmachung: Die deutschen Intellektuellen und der Erste Weltkrieg (Berlin: Fest, 2000); Martha Hanna, The Mobilization of Intellect: French Scholars and Writers during the Great War (Cambridge, MA: Harvard University Press, 1996); Peter Hoeres, Krieg der Philosophen: Die deutsche und britische Philosophie im Ersten Weltkrieg (Paderborn: Schöningh, 2004); Wolfgang Mommsen and Elisabeth Müller-Luckner, eds., Kultur und 
Austrian Volkskunde, on the other hand, was a discipline that had arisen late in the nineteenth century, not in universities but in anthropological societies and clubs, and which was establishing itself one step at a time. The young discipline saw itself as poised to handle whatever the war might bring. Kammerer, in his preliminary evaluations of letters from Italian POWs, spoke of "hidden treasures" and "all kinds of trivialities" that it would be the task of a "future science of culture" to appreciate. ${ }^{21}$ With its nimble creative minds and insatiable collecting, the fresh and innovative discipline of Volkskunde seemed to him-as it seemed to Spitzer and a great many other scholars ${ }^{22}$ - uniquely well positioned to take advantage of the war. Indeed, Spitzer's publications were received with eager curiosity by journals of Volkskunde and regarded by Volkskunde scholars as highly relevant to their work. ${ }^{23}$

\section{Kriegsvolkskunde(n)—War Folklore(s)}

The First World War brought renewed public attention to cultural expressions that had been regarded as premodern or long forgotten-wartime superstitions, prophecies of war and peace, protective amulets, "soldierly" humor on the battlefield, and primitive folk art in the trenches. ${ }^{24}$ Across Europe, Volkskunde sought to profit from the unexpected boom in interest and the surfeit of source materials. Scholars jockeyed for intellectual leadership in the organization of events and collecting and publishing activities that had-for reasons propagandistic, patriotic, and scientific-been initiated by stakeholders ranging from the General Staff to the mass media to individual hobbyists. A niche product originally developed in neutral Switzerland, "Soldatische Volkskunde" quickly became a model for German and Austro-Hungarian "Kriegsvolks-

Krieg: Die Rolle der Intellektuellen, Künstler und Schriftsteller im Ersten Weltkrieg (Munich: Oldenbourg, 1996); Klaus Schwabe, Wissenschaft und Kriegsmoral: Die deutschen Hochschullehrer und die politischen Grundfragen des Ersten Weltkrieges (Göttingen: Musterschmidt, 1969).

21 Kammerer, "Meine Ansichtskarten," 97.

22 The Hamburg art historian Aby Warburg was also particularly intrigued by the collecting of wartime folklore and related themes, see Gottfried Korff, ed., Kasten 117: Aby Warburg und der Aberglaube im Ersten Weltkrieg (Tübingen: Tübinger Vereinigung für Volkskunde, 2008).

23 [Theodor] Siebs, review of "Spitzer, Prof. Dr. Leo, Italienische Umgangssprache," Mitteilungen der Schlesischen Gesellschaft für Volkskunde 25 (1924): 262.

24 Cf. Gottfried Korff, ed., Kleines aus dem Großen Krieg: Metamorphosen militärischen Mülls (Tübingen: Tübinger Vereinigung für Volkskunde, 2002). 
kunde," French "folklore de guerre," Italian "folklore di guerra," and a comparatively weak British "folklore of the war."25

In the following, Kriegsvolkskunde will be introduced in some detail and then, using a comparative approach-without neglecting its nineteenth century parent, anthropology ${ }^{26}$ - situated within the developmental process that eventually produced the various European Volkskunden, ethnologies, and anthropologies. The chief aims are to explore how, on the one hand, anthropological/ethnological/Volkskunde studies germinating in the late nineteenth century ${ }^{27}$ were mobilized for and altered by the war effort, and, on the other hand, how wartime mobilization-with results that varied slightly in different parts of Europe-brought about the eventual institutionalization of the subdisciplines physical anthropology, prehistory and ancient history, Volkskunde, and Völkerkunde/non-European ethnology.

Gottfried Korff recently prepared an admirably hesitant and cautious survey of Kriegsvolkskunde, concentrating on Germany. He argues that the relationship between the wars of the nineteenth and twentieth centuries and the origins of Volkskunde as a science have not yet been adequately explored. He suggests that it cannot be ruled out that the First World War-and the ad hoc discipline of Kriegsvolkskunde with its large-scale collecting projects-served to boost the autonomy of university Volkskunde departments. But although the war, and in particular its outcome, had palpable repercussions for the field of Volkskunde (not the least of which was the publication of the Handbook of

25 On British folklore studies in particular, see R. R. Marett, "Presidental Address: War and Savagery," Folklore 26 (1915): 10-27.

German and especially Austrian Volkskunde developed in the late nineteenth and early twentieth century from anthropological societies that had been founded only a few decades earlier. On the "Berliner Gesellschaft für Anthropologie, Ethnologie und Urgeschichte," see Annette Lewerentz, "Rudolf Virchow als Anthropologe und seine Bedeutung für die Berliner Gesellschaft für Anthropologie, Ethnologie und Urgeschichte," in Zwischen Charité und Reichstag: Rudolf Virchow; Mediziner, Sammler, Politiker, ed. Geraldine Saherwala, Thomas Schnalke, Konrad Vanja, and Hans-Joachim Vogel (Berlin: Museumspädagogischer Dienst, 2002), 123-137; on "Anthropologischen Gesellschaft in Wien," see Karl Pusman, Die "Wissenschaften vom Menschen" auf Wiener Boden (1870-1959): Die Anthropologische Gesellschaft in Wien und die anthropologischen Disziplinen im Fokus von Wissenschaftsgeschichte, Wissenschafts- und Verdrängungspolitik (Münster: LIT, 2008).

27 On the divergent development of Volkskunde in Europe, see Tamás Hofer, "National Schools of European Ethnology and the Question of 'Latent Ethnicity,'" Ethnologia Europaea 26 (1996): 89-96; Thomas Schippers, "A History of Paradoxes: Anthropologies of Europe," in Fieldwork and Footnotes: Studies in the History of European Anthropology, eds. Han V. Vermeulen and Arturo A. Roldán (London: Routledge, 1995), 234-246. 
German Superstition as a follow-up to the questionnaires that had been administered to soldiers during the war), one should use caution in positing sustained effects or even middle-term survival for Kriegsvolkskunde:

Volkskunde during the First World War pounced on these source materials, but admittedly without benefiting in terms of either productivity or argumentation. The diversity of collecting and archiving endeavors led only in the most infrequent cases to the development of typologies amenable to continued use, analyses of objects, or methodological reflections. The diffuse nature of the discipline's selfunderstanding, the reality of industrialized trench warfare that had been transformed during the war, but first and foremost the outcome of the war had a disillusioning effect on the investigative and collecting enterprises that had begun with such élan and enthusiasm. The political and societal transformations of the years 1918-1919 "molded, repressed, channeled, and in short altered" (R. Koselleck) the new scientific field of activity that had arisen during the war. ${ }^{28}$

One can, on the whole, share this appraisal while agreeing that it deserves additional elaboration. Both the outward structure and the internal differentiations in the total European disciplinary map of anthropology/ethnology/ Volkskunde are incomprehensible without a precise look at the First World War, which was, after all, for a long time an intra-European conflict. But first it will be necessary to let some light into the neglected era's "black box" and sort through its contents, which remained largely unexamined by historians of the discipline.

That such an accounting has not yet taken place in Germany has much to do with a competing interest: In Tübingen, to take one prominent example, unstinting scrutiny was given to Volkskunde's complicity in National Socialism, while the First World War was accorded virtually no essential significance whatever. Thus Hermann Bausinger raised, in the early 1960s, the question of whether National Socialism had not been able to harness "central ideas of this scientific discipline" for its own ends. In the years that followed, the discussion of Volkskunde's National Socialist past ${ }^{29}$ called for by Bausinger produced numerous studies of the ideology of the "folk" as well as investigations of Volkskunde and National Socialism per se. The view that "Volkskunde in the twentieth century" 30 had always been a nationalistic "folkish science" gained increasing currency. Scholars exposed its contributions to the genocides of the

28 Gottfried Korff, "Vorwort," in KriegsVolksKunde: Zur Erfahrungsbindung durch Symbolbildung, ed. idem (Tübingen: Tübinger Vereinigung für Volkskunde, 2005), 9-28.

29 Hermann Bausinger, "Volksideologie und Volksforschung: Zur nationalsozialistischen Volkskunde," Zeitschrift für Volkskunde 61 (1965): 177-204.

30 Utz Jeggle, "Volkskunde im 20. Jahrhundert," in Grundriss der Volkskunde: Einführung in die Forschungsfelder der Europäischen Ethnologie, ed. Rolf W. Brednich (Berlin: Reimers, 2001), 53-75. 
1940s in minute detail, ${ }^{31}$ treating the First World War and the years before and after as an ill-starred ideological "prehistory" of little significance for the history of science.

In fact, it is a worthwhile exercise to consider a considerably more significant role for the First World War in the European-and German-development of Volkskunde. This suggestion will be substantiated in six separate remarks that correspond roughly to six major influences released by the war that drove the discipline's development and modification, particularly in the cases in which it achieved institutionalization as a university department. Volkskunde, in summary, chose an independent and, above all, empirically dense path, with aspirations that recall Eduard Spranger's 1914 declaration that the mission of the university was "to interpret the new time, to-as one used to say-'set' it in thoughts." ${ }^{2}$

This conceptual setting - that is: the division of scientific labor that arose during the war-becomes apparent in a report prepared by Otto Mausser, director of the Bavarian dictionary archive in the Royal Bavarian Academy of Sciences and chairman of the "Commission for the Collection of German Soldiers' Language." Mausser $^{33}$ had developed two questionnaires on soldiers' slang and had them distributed in the trenches and behind the lines in large numbers. The resulting material would enable the publication of a "Dictionary of Soldiers' Language":

No world war yet in history has, from its inception, preoccupied public opinion and every kind of science to such a degree as the current one. The literature of justification is growing both here and over there into the incalculable, and the literature describing the war has attained a scope that in no wise always stands in proper proportion to its inherent quality. The sciences are no less stimulated in the most diverse ways by the unsettling experience of war that threatens to dislodge all the foundations of life and life-orientation. There will hardly be found a time in the history of German science in which technology, practically and experimentally, worked with such liveliness as in the period of the war from 1914 to 1917. At the same time, the technical literature also grew to a correspondingly high degree. What is true of the technical sciences is also true of the humanities. The war also assigned them a series of tasks that were already being tackled during the time of the field campaigns. Among all the humanities, however, the task of personally observing and collecting the manifold manifestations of the war falls to Volkskunde. ${ }^{34}$

31 Wolfgang Jacobeit, Hannjost Lixfeld, and Olaf Bockhorn, eds., Völkische Wissenschaft: Gestalten und Tendenzen der deutschen und österreichischen Volkskunde in der ersten Hälfte des 20. Jahrhunderts (Vienna: Böhlau, 1994).

32 Eduard Spranger, "Welchen Sinn hat es, jetzt zu studieren?," Akademische Rundschau 3 (1914/15): 142-146.

33 Cf. Otto Mausser, Deutsche Soldatensprache: Ihr Aufbau und ihre Probleme (Strasbourg: Trübner, 1917).

34 Idem, "Der Liederbestand bairischer Truppen im Weltkrieg (1916)," Bayerische Hefte für Volkskunde 4 (1917): 57-136. 
Numerous claims for the discipline can be read between the lines of Mausser's assessment-for instance, the inspiringly novel quality of a world war as Volkskrieg; the high level of propagandistic and scientific interest and the unabashed attempt to exploit the war to consolidate the discipline's status and establish professional reputations. European Kriegsvolkskunde, folklore della guerra or folklore militaire was a confluence of highly divergent interests. Some participants acted alone, some as elements in vast systematized collective endeavors. Some were educated in Volkskunde, others in theology, psychology, literary criticism, anthropology, or musicology. What they all had in common-and this is the first remark-was that they saw Kriegsvolkskunde, because of its direct relation to the war, as for the time being the equal of any other science, including the most recondite technical specializations. On occasion, it was even perceived as such by outsiders.

Its self-styled contemporaneity and equality with various other scientific disciplines has abundant implications. Kriegsvolkskunde may well have arisen to meet substantive needs, but it also originated-and here, already, is the second remark-in a particular kind of war experience. The First World War was understood by countless scholars in virtually every country party to the war as an utterly novel "laboratory" and possibly "unique" scientific opportunity that was "never to return." The war had not merely, as the Swiss scholar of folk tradition Hanns Bächtold had surmised, pushed aside the curtain of civilization and allowed deep "insight into the psychic life of the people as we only seldom experience it so unveiled"35; it had also revealed itself, as the Viennese sociologist and historian Friedrich Hertz pointed out in his 1915 book Rasse und Kultur, to be "the great mixer of races and cultures"36 - and that in a twofold sense: With its territorial conquests and its millions of POWs, the war brought different cultures into contact and created the conditions for ethnographic and anthropological investigation of unfamiliar and culturally "alien" people, while, at the same time, soldiers with the same national allegiances but differing geographical or social origins were thrown together in the trenches and field hospitals. The potential of their nascent "soldierly" culture to become a new object of scientific examination was likewise regarded as "unique."

The third remark: Scientists who took an active part in Kriegsvolkskunde were able to see themselves as contributing to the war effort because the knowledge and advice they could offer might be of use to those wishing a better un-

35 Hanns Bächtold, Deutscher Soldatenbrauch und Soldatenglaube (Strasbourg: Trübner, 1917), 2.

36 Friedrich Hertz, Rasse und Kultur: Eine kritische Untersuchung der Rassentheorien, 2nd rev. ext. ed. (Leipzig: Kröner, 1915), 91.

37 Theodor Imme, Die deutsche Soldatensprache in der Gegenwart und ihr Humor (Dortmund: Ruhfus, 1917). 
derstanding of the troops' behaviors. For example, to condemn the conspicuous rise in superstition both on the battlefield and at home as either a product of scams devised by profiteers or as obsolete or antiquated behavior would have been to beg the question; superstition needed to be understood for a variety of practical reasons, and scholars of Kriegsvolkskunde gave it-depending on their respective concrete disciplinary or national points of departure-a variety of interpretations. What those interpretations had in common was that the researcher's gaze was generally directed right past the amulet, song, or slang term straight into the Volksseele (a "people's soul" conceived as essentially German) or âme populaire ${ }^{38}$ (an orientation toward prelogical thinking). Each phenomenon was viewed as a "survival" or revival of the distant past. At the same time, their interest was focused on the significance of these phenomena for the present day.

For while the war's destructive power was acknowledged-with increasing openness as the war went on, and especially after it had been lost-its creative potential was seen with equal clarity. The Kriegsvolkskunde scholar John Meier, for example, stated that he could hear soldiers' songs becoming "amalgamated" into a "new unity" as "creations of the war." ${ }^{39}$ The war not only revived premodern aspects of culture, it also created new cultural forms, although-Meier added-the "ease with which it arose" would be matched at war's end by the "ease of its disappearance." ${ }^{40}$

Meier's faith in the ease with which wartime cultural phenomena vanish was based on experience of the Franco-Prussian War of 1870-71. It had not been documented by Volkskundler, and accordingly its traces in popular culture had been almost entirely lost. Thus, it was Meier who formulated the central goal of Kriegsvolkskunde: The job of collecting was not primarily to document what the war was destroying, but rather to preserve the new cultural creations arising during the war for future use-whether by the grandchildren of the combatants as a memorial or as an irreplaceable resource for scholarly activity in the postwar world. ${ }^{41}$

Indeed, as the war began, the collecting-and here is the fourth remark-of anything and everything that had to do with soldiers became a regular mania. ${ }^{42}$

38 Cf. Ralph Winkle, "'Connaître à fond l'âme du soldat': Französische Aberglaubensforschung während des Ersten Weltkriegs," in Alliierte im Himmel: Populare Religiosität und Kriegserfahrung, ed. Gottfried Korff (Tübingen: Tübinger Vereinigung für Volkskunde, 2006), 349-370.

39 John Meier, Das deutsche Soldatenlied im Felde (Strasbourg: Trübner, 1916), 5.

40 Idem, Deutsche Soldatensprache (Karlsruhe: Braun, 1917), 12.

41 Karl Wehrhan, "Fragebogen zur Kriegsvolkskunde," Zeitschrift für rheinische und westfälische Volkskunde 13 (1916): 94-96.

42 Susanne Brandt, "Kriegssammlungen im Ersten Weltkrieg: Denkmäler oder Laboratoires d'historie," in "Keiner fühlt sich hier mehr als Mensch...": Erlebnis 
Its pursuit occupied, in addition to the military, the mass media (i.e., with the "Fliegende Blätter"), a great many individuals acting alone, and numerous scientific clubs and associations located primarily in Germany and AustriaHungary, many of them freshly established in the name of Volkskunde. ${ }^{43}$ The structure and the course of those collecting activities cannot be described in detail here; it must suffice to indicate that an impetus of signal importance came in early 1915 from the Swiss Society for Volkskunde. With support from the Swiss military, it distributed a detailed questionnaire to its soldiers-and later to French and German POWs as well-that became the first comprehensive collection of "soldierly Volkskunde." ${ }^{44}$ Thanks to the questionnaire's translation into Italian and French, the collecting initiative was taken up in both Italy and France within months, if only by individual researchers such as Albert Dauzat and Agostino Gemelli.

A 1915 questionnaire on "The Folk Song in War"45 - systematically organized by the Association of German Volkskunde Clubs and then also by the regional Volkskunde associations ${ }^{46}$ - was the first of the German Empire's major collecting efforts that culminated in the compendium of soldier's songs, the aforementioned "soldiers' language," and ultimately in the "Collection of German Soldiers' Traditions and Beliefs." ${ }^{\text {" } 7}$

In Austria-Hungary, by contrast, the collecting of "soldiers' language" remained on the sidelines; an overly strong emphasis on German in the multinational Austro-Hungarian military could have generated substantial friction. Instead, in line with the Empire's multinational character, Austrian Volkskunde collected phenomena in various languages and therefore developed a unique, because multinational, Kriegsvolkskunde. The initiative to collect "Soldier's Songs of the Imperial and Royal Army" began in November of 1915 and led in 1916 to the founding of the "Music-Historical Archive of the Imperial and

und Wirkung des Ersten Weltkriegs, eds. Gerhard Hirschfeld, Gerd Krumeich, and Irina Renz (Frankfurt a. M.: Klartext, 1996), 283-302.

On Austrian Volkskunde, see Herbert Nikitsch, Auf der Bühne früher Wissenschaft: Aus der Geschichte des Vereins für Volkskunde (Vienna: Selbstverlag des Vereins für Volkskunde, 2006), 129-149.

44 Hanns Bächtold, "Volkskundliche Mitteilungen aus dem schweizerischen Soldatenleben: Proben aus den Einsendungen schweizerischer Wehrmänner," Schweizerisches Archiv für Volkskunde 19 (1915): 201-264.

"Das Volkslied im jetzigen Kriege (Fragebogen des Verbandes deutscher Vereine für Volkskunde)," Zeitschrift für österreichische Volkskunde 25 (1915): 392.

46 A typical example: Adolf Spamer, "Der Krieg, unser Archiv und unsere Freunde: Ein Aufruf des Volkskundearchivs des Bayerischen Vereins für Volkskunst und Volkskunde in München," Bayerische Hefte für Volkskunde 2 (1915): 1-72.

47 See summary, Bericht über die Sammlung soldatischer Volkskunde, erstattet vom Verband deutscher Vereine für Volkskunde (Freiburg im Breisgau: C. A. Wagner, 1918). 
Royal War Ministry" and thus to large-scale collecting of soldiers' songs; the staff of the "music-historical headquarters" included Béla Bartok and Zoltán Kodály. ${ }^{48}$ Also deserving of mention are the "Volkskunde of the occupied Balkan territories" ${ }^{\prime 99}$ pursued by Austrian Volkskunde during the war with its own "Balkan expeditions" and the major anthropological and music-historical studies and recording projects carried out in POW camps in 1915 at the initiative of the "Anthropological Society in Vienna," with the support of the Imperial Academy of Sciences. In contrast to their counterparts in Germany, the Austro-Hungarian studies did not focus on the colonial troops of the Allied Powers, but rather on the "peripheral" peoples of the Russian Empire. ${ }^{50}$

The list presented here, however incomplete, testifies to the tremendous rush of collecting activity under the banners of both Volkskunde and anthropology that was generated by the First World War across Europe. It was marked by clear national peculiarities; the organization of collecting activities varied from country to country, and the academic disciplines involved were not the same. Nonetheless-and this will lead to the fifth remark-collecting during the war was a European project ${ }^{51}$ and not, as was often later claimed, the manifestation of a "German Sonderweg." ${ }^{2}$ Across borders-or rather on both sides of the front-researchers used virtually identical questionnaires. They exchanged and compared their findings. They pursued similar lines of inquiry owed by and large to evolutionism, whether with respect to soldiers' physical characteristics or their jargon, songs, superstitions, and prophecies.

48 Cf. Eva Maria Hois, "Völkerverbindend oder national? Die Funktionalisierung des Volksliedes in der Habsburgermonarchie," Jahrbuch des Österreichischen Volksliedwerkes 48 (1999): 130-148.

49 Cf. the chapter by Christian Marchetti in this volume and his "Scientists with Guns: On the Ethnographic Exploration of the Balkans by Austria-Hungarian Scientists before and during World War I," Ab Imperio 8, no. 1 (2007): 165-190.

50 See the chapter by Monique Scheer in this volume.

51 "Abroad, the importance of a collection of soldiers' language has already been acknowledged: L. Sainéan and A. Dauzat in France, Raffaele Corso in Italy, and other researchers in England are more or less officially active. In neutral Switzerland, the language used by Swiss soldiers is being collected with the direct support and at the orders of the high command, and collecting is being conducted at the same time among prisoners of various nationalities. In Austria the Imperial Academy of Sciences is occupied with the task, and in Germany the Association of German Volkskunde Societies has taken the thing in hand and is being supported by various academies and scientific associations." Meier, Deutsche Soldatensprache, 12.

52 This was suggested by Ake Hultkrantz in the early 1960s, cf. Ake Hultkrantz, General Ethnological Concepts (Copenhagen: Rosenkilde and Bagger, 1960). The German collections typically differed only in their higher degree of organization. 
In a similar fashion, the design of methods and procedures also spanned the front, limited only by the specific kind of materials being collected. They ranged from the highly original discourse-analytic methods devised in Vienna to questionnaires - the war's trademark data-gathering technique-distributed and administered by a great variety of organizations, scientific "expeditions," individual observations conducted in military hospitals, and, in the case of the Italian, Gemelli, even field research on the front lines. ${ }^{53}$ The anthropologicalmusicological investigations in the POW camps were also technically more elaborate and possibly more innovative, combining the moving image, still photography, and phonographic recordings. Whether the "camp studies" constituted a form of early field research in some limited sense is debatable, but, in any case, the POW-camp setting, as Monique Scheer has shown, became known as a space that permitted the application of serialized methods and the latest technologies. ${ }^{54}$

The scope of the data and materials collected was enormous, as were response rates for the various questionnaires, so that, while the war lasted, publication of findings was almost exclusively limited to interim reports and initial summary outlines. ${ }^{55}$ Soldiers' songs that had been submitted were returned to the front in booklet form in hopes both of improving morale and of eliciting additional material. With the armistice-and this leads to the sixth and final remark-monographs on topics within Kriegsvolkskunde and studies conducted in POW camps began appearing in Italy, ${ }^{56}$ France, ${ }^{57}$ and in Germanlanguage publications. ${ }^{58} \mathrm{~A}$ series of doctoral theses exploited the large collections that had been amassed and with no shortage of theoretical ambition. But generally speaking, interest swiftly waned, and by the end of the 1920s at the very latest, it was gone-if only (this is added as a kind of subordinate clause) to reawaken with a start at the National Socialist takeover and come into its

53 Agostino Gemelli, Il nostro soldato: Saggi di psicologia militare (Milan: Fratelli Treves, 1917).

54 Monique Scheer, "'Völkerschau' im Gefangenenlager: Anthropologische 'Feind'-Bilder zwischen popularisierter Wissenschaft und Kriegspropaganda 1914-1918," in Zwischen Krieg und Frieden: Die Konstruktion des Feindes; eine deutsch-französische Tagung, eds. Reinhard Johler, Freddy Raphaël, Patrick Schmoll, and Claudia Schlager (Tübingen: Tübinger Vereinigung für Volkskunde, 2009), 69-109.

55 Bächtold, Deutscher Soldatenbrauch; Mausser, Deutsche Soldatensprache; Meier, Das deutsche Soldatenlied; idem, Deutsche Soldatensprache.

56 For example: Giuseppe Bellucci, Folklore di guerra (Perugia: Unione Tipografica Cooperativa, 1920).

57 Dauzat, L'Argot de la guerre.

58 Wilhelm Doegen, ed., Unter fremden Völkern: Eine neue Völkerkunde (Berlin: Stollberg, 1925); Arthur Byhan, Arthur Haberlandt, and Michael Haberlandt, eds., Europa und seine Randgebiete (Stuttgart: Strecker und Schröder, 1926). 
own with the Second World War, when it was conducted in the same countries, and in many cases by the same researchers, but under circumstances that had changed radically. ${ }^{59}$

\section{Consequences of War}

Why then, the question becomes, did the war era's vast collections of materials and data cease to interest German-speaking scholars so very quickly and, with only a few exceptions, experience no more scientific interpretation? The answer is threefold. One reason was in a sense practical: Defeat had not only made the original goal of collection-documentation of the new soldierly culture-obsolete; it had also, in some cases, put the collections themselves at risk. Otto Mausser, for example, complained that a considerable portion of the Bavarian "collections [of soldiers' language] had been irretrievably lost through the incomprehension of northern German revolutionaries in the year 1918." ${ }^{60}$ More importantly, to continue the multinational collecting activities as they had been conducted, for instance in Austria-Hungary, no longer made sense in the new postimperial regime of diminished nation-states; they were therefore put aside or divided between the participating disciplines. Secondly, scientists increasingly became disillusioned with the Kriegsvolkskunde collections. It seemed to many in retrospect that central basic assumptions of their collecting endeavors had been wrong. For example, it was soon generally accepted that the war-which had proved not to be a Volkskrieg after all-had not given birth to a folk poetry of the war ("volksläufige Soldatendichtung"). The soldiers' lack of productivity, scholars now claimed, should have come as no surprise, since urban proletarians had dominated the ranks. ${ }^{61}$ Thirdly, while a lack of theoretical skills had hardly hindered collecting-and probably even facilitated it - analysis of the resulting flood of material presented tremendous difficulties. It was thus not subjected to renewed attempts. ${ }^{62}$

But, in spite of those caveats with regard to findings, it would be shortsighted to see, in the diverse activities that were carried on in the name of Kriegsvolkskunde, merely a mania for collecting and storage with few tangible

59 Bernhard Schwertfeger and Erich Otto Volkmann, eds., Die deutsche Soldatenkunde, vol. 1 (Leipzig: Bibliographisches Institut, 1933).

60 Otto Mausser, "Die deutsche Soldatensprache," in Schwertfeger and Volkmann, Deutsche Soldatenkunde, 400-425.

61 Wilhelm Hansen, "Das Soldatenlied," in Schwertfeger and Volkmann, Deutsche Soldatenkunde, 426-472.

62 For a detailed account, see Reinhard Olt, Krieg und Sprache: Untersuchungen zu deutschen Soldatenliedern des Ersten Weltkriegs, 2 vols. (Giessen: Schmitz, 1981/82). 
results. Instead, one should support the view of Christine Beil, whose investigation of the "exhibited world war" discovered innovative forms of presentation that are still in use today. ${ }^{63}$ One must also agree with Gottfried Korff, ${ }^{64}$ who places several major international (the Volkskundliche Bibliographie, the Handbook of German Superstition, the First International Folk Art Congress in 1928 in Prague initiated by the League of Nations) as well as national (above all the Atlas of German Volkskunde ${ }^{65}$ ) forms of cooperation that appeared in the immediate postwar era in the context of Kriegsvolkskunde. Leopold Schmidt surely did not err in seeing in Kriegsvolkskunde a tentative but important contribution to a developing Volkskunde of contemporary life ("Gegenwartsvolkskunde") and a precursor to the study of occupational and regional subcultures that created a more precisely differentiated understanding of the term Volk. ${ }^{66}$ Furthermore, the heated theoretical debates of the 1920s can only be understood in the context of the war. Whether one saw, as Karl Reuschel did in 1920, the existence of an ennobling national Volksseele as having been confirmed by the war ${ }^{67}$ or dismissed plebeian ways as a "primitive Gemeinschaftskultur,"68 as did Hans Naumann, was not merely a bone of contention between Romantics and ethnologists within the field, as Viktor von Geramb claimed in an influential article in 1937; such positions were ultimately traceable to researchers' war experiences and their level of personal involvement in Kriegsvolkskunde.

One more point: The air of the serial and technical that had been noted and pursued with such alacrity by Kriegsvolkskunde-which, to paraphrase Viktor von Geramb, reflected its hopes of becoming a hard science ${ }^{69}$ - had, in combination with the sheer volume of data, led to a multiplication and expansion of methods that favored quasi-experimental and natural-scientific interpretive approaches. One result was that, even before the war had ended, it had gone so

63 Christine Beil, Der ausgestellte Krieg: Präsentationen des Ersten Weltkriegs 19141939 (Tübingen: Tübinger Vereinigung für Volkskunde, 2004).

64 Korff, "Vorwort," in KriegsVolksKunde.

65 Cf. Friedemann Schmoll, Die Vermessung der Kultur: Der "Atlas der deutschen Volkskunde" und die Deutsche Forschungsgemeinschaft 1928-1980 (Stuttgart: Steiner, 2009).

66 Leopold Schmidt, Gegenwartsvolkskunde: Eine bibliographische Einführung (Vienna: Verlag der Österreichischen Akademie der Wissenschaften, 1976), 11.

67 Karl Reuschel, Deutsche Volkskunde im Grundriß, vol. 1 (Leipzig: Teubner, 1920), 12.

68 Hans Naumann, "Bauernhaus und Kornkammer in Litauen: Ein Beitrag zum nördlichen Herd- und Vorhallenhaus," in Primitive Gemeinschaftskultur: Beiträge zur Volkskunde und Mythologie (Jena: Diederichs, 1921), 148-167. It is often forgotten that Naumann, beginning in 1916, was the editor-in-chief of two frontline newspapers in Lithuania.

69 Viktor von Geramb, "Urverbundenheit," Hessische Blätter für Volkskunde 36 (1937): 1-31. 
far as to foreground the category of "race" as an interpretive possibility. By the time the war was over, "race" and its cultural counterpart "Volkstum" appeared to many of the German and Austrian scholars discussed here as the only remaining "reliable basic orientation in the great questions of humanity."70

\section{A New European Disciplinary Map}

Reinhart Koselleck once remarked that the vanquished generally develop more far-reaching historical insights than the victors. Friedrich Lenger, recalling Koselleck's dictum, identifies Germany's defeat in the First World War as the deciding factor in an important innovation in the study of history-Volksgeschichte $^{71}$-and (rightly) draws parallels with its disciplinary neighbor Volkskunde. ${ }^{72}$ Both underwent a rapid "inward turn," setting national limits to both their subject matter and their channels of communication. That this occurred in Germany can be seen as the continuation of a "völkisch" trend that had been gaining strength since the turn of the century. ${ }^{73}$ In Austria, despite its territorial losses, the multinational tradition of imperial-and-royal Volkskunde ${ }^{74}$ remained in effect, if in a weakened form. ${ }^{75}$

70 Phrased approximately thus by the doyen of Austrian Volkskunde Michael Haberlandt in his eulogy for the initiator of the POW studies, Rudolf Pöch: Michael Haberlandt, "Nachruf auf Prof. Dr. Rudolf Pöch," Mitteilungen der Anthropologischen Gesellschaft in Wien 51 (1921): 12-13.

71 Willi Oberkrome, Volksgeschichte: Methodische Innovation und völkische Ideologisierung in der deutschen Geschichtswissenschaft 1918-1945 (Göttingen: Vandenhoek und Ruprecht, 1993); Lutz Raphael, ed., Von der Volksgeschichte zur Strukturgeschichte: Die Anfänge der westdeutschen Sozialgeschichte 19451968 (Leipzig: Leipziger Universitätsverlag, 2002).

72 Friedrich Lenger, "Eine Wurzel fachlicher Innovation? Die Niederlage im Ersten Weltkrieg und die 'Volksgeschichte' in Deutschland-Anmerkungen zu einer aktuellen Debatte," in Kriegsniederlagen: Erfahrungen und Erinnerungen, eds. Horst Carl, Hans-Henning Kortüm, Dieter Langewiesche, and Friedrich Lenger (Berlin: Akademie-Verlag, 2004), 41-55.

73 Bernd Jürgen Warneken, "'Völkisch nicht beschränkte Volkskunde': Eine Erinnerung an die Gründungsphase des Fachs vor 100 Jahren," Zeitschrift für Volkskunde 95 (1999): 169-196.

74 Jurij Fikfak and Reinhard Johler, eds., Ethnographie in Serie: Zu Produktion und Rezeption der "österreichisch-ungarischen Monarchie in Wort und Bild (Vienna: Verlag des Instituts für Europäische Ethnologie, 2008).

75 Reinhard Johler, "Das Ethnische als Forschungskonzept: Die österreichische Volkskunde im europäischen Vergleich," Ethnologia Europaea, eds. Klaus Beitl and Olaf Bockhorn (Vienna: University of Vienna, 1995): 69-101. 
Volkskunde in Germany and Austria did not meet with rapid success in its efforts to achieve institutionalization at the university level, despite having intensified them during the war. A central "Imperial Institute for German Volkskunde" had been called for as early as 1917, but remained unrealized for the duration of the Weimar Republic. ${ }^{76}$ Postwar Volkskunde in both countries narrowed its focus to Volkstum and Heimat-folk traditions and the "homeland" were regarded, on the one hand, as having been devastated by the war, but, on the other, as panaceas for current ills-and attempted to gain a foothold in the universities through the back door via teacher education and instruction in Heimatkunde. ${ }^{77}$ Success came in slow stages, but, by the 1930s, a number of universities employed professors of Volkskunde (e.g., Hamburg, Graz, and Innsbruck) and the autonomy of the field was no longer in doubt.

When both Europe and the overarching discipline are taken as a whole, a pattern emerges: The war had routed the German Empire and done away with the Habsburg monarchy; in what remained of Germany and Austria, as well as the mostly quite small states that succeeded Austria-Hungary, specifically national versions of Volkskunde soon succeeded in establishing a university presence while non-European ethnology languished. In the victorious nations of England, France, and Italy, on the other hand, where wartime collecting had not been pursued with the same dogged intensity, non-European ethnology and social anthropology soon eclipsed Volkskunde. Almost universally, however, in terms of academic sinecures, it was another subdiscipline-physical anthropology - that reaped the spoils of war.

Anthropology, ethnology, Volkskunde: The disciplinary map that the war left behind ${ }^{78}$ was clearly in the making before the turn of the century. But the war did more than confirm existing trends. It put an end to Europe's common scientific culture, effectively killing off the evolutionism that had been popular until then, leaving the academic landscape fractured along national lines. ${ }^{79}$ It

76 Hannjost Lixfeld, "John Meier und sein 'Reichsinstitut für deutsche Volkskunde': Zur volkskundlichen Fachgeschichte zwischen Monarchie und Faschismus," Beiträge zur Volkskunde in Baden-Württemberg 3 (1989): 102-144.

77 The Prussian minister of culture and later first president of the "Emergency Association of German Science" Friedrich Schmidt-Ott was central to the restructuring of the educational system; see Fritz Boehm, "Volkskunde und Schule," in Deutsche Forschung: Aus der Arbeit der Notgemeinschaft der Deutschen Wissenschaft (Deutsche Forschungsgemeinschaft) (Berlin: Verlag der Notgemeinschaft der Deutschen Wissenschaft, 1922), 74-85.

78 A more detailed account: Reinhard Johler, "La guerre, I'ennemi et la Volkskunde," Revue des Sciences Sociales 43 (2010): 116-129.

79 Andre Gingrich, "Liberalism in Imperial Anthropology: Notes on Implicit Paradigm in Continental European Anthropology before World War I," Ab Imperio 8, no. 1 (2007): 224-239. 
helped bring about the dissolution of both the methods and the subject matter that had made up the "old" German liberal anthropology of the nineteenth century. ${ }^{80}$ In 1915, Adolf Spamer had written that the "young" science of Volkskunde was "a science of innumerable questions," a "future science." ${ }^{11}$ Its habit of methodological innovation, in combination with its ethical shortcomings, would eventually pave the way for a different "future science": cultural anthropology imported from the United States.

80 Cf. H. Glenn Penny and Matti Bunzl, eds., Worldly Provincialism: German Anthropology in the Age of Empire (Ann Arbor, MI: University of Michigan Press, 2003); Andrew Zimmerman, Anthropology and Antihumanism in Imperial Germany (Chicago, IL: University of Chicago Press, 2001).

81 Spamer, "Der Krieg, unser Archiv und unsere Freunde," 3. 


\title{
"Betwixt and Between": Physical Anthropology in Bulgaria and Serbia until the End of the First World War
}

\author{
Christian Promitzer
}

Bulgaria entered the First World War on the side of the Central Powers in September 1915. At the time, few in the German Reich had profound knowledge of its new ally. The German majority cultivated vague impressions of a possibly wild and romantic, but definitely backward, petty kingdom somewhere on the eastern fringes of Europe. The better informed also knew that the monarch was of German descent, and that the First Balkan War of 1912-1913, in which the Bulgarian army was a decisive party, had been a rehearsal to the ongoing European war with respect to conduct and weapons. Experts on Bulgaria-among them anthropologists and ethnologists-quickly perceived an opportunity to gain publicity by servicing the demand for information.

In 1917, Johann Baptist Loritz (1891-1965) published a short book, Unser Verbündeter Bulgarien [Our Ally Bulgaria], dedicating several pages of its lengthy chapter on the Bulgarian people to anthropological origins. Like the Serbs and Croats, Bulgarians were linguistically South Slavs, but Loritz stressed their divergent racial makeup-especially opportune now that Serbia was an enemy of the Reich. Bulgarians, he claimed, differed somatically from other South Slavs. Serbs were taller, with lighter hair and eyes, while Bulgarians were more compact, but with a reduced incidence of brachycephaly (round heads). The Balkan Peninsula's pre-Slavic Illyrian population had left only minor traces among the Bulgarians, compared to other South Slavs. Instead, the Bulgarian's ancestors were non-Slavic "proto-Bulgarians" from the Volga basin who had settled the country in the sixth and seventh centuries. Loritz contended that his own anthropological investigations had shown that the Bulgarians were not of Finnish origin, as was commonly held by scholars in Bulgaria, but were descendants of the ancient population of 
Asia Minor and nomadic peoples of North Africa. ${ }^{1}$ How did Loritz acquire this sophistication about the Bulgarian people? And what was the relevance of their appearance to the war?

Loritz was the deputy secretary of Munich's German-Bulgarian Society, founded to strengthen bonds between the allies. ${ }^{2} \mathrm{He}$ owed his expertise to an excursion in the summer of 1913, where he undertook anthropological examinations of about fifty skulls; his findings were published in his doctoral dissertation in 1915. ${ }^{3}$ While in Bulgaria, he also examined Macedonian refugees from the Balkan wars. In the winter term of 1914, he examined circa one hundred Bulgarian students at the University of Munich, ${ }^{4}$ where he was a student of Johannes Ranke (1836-1916) and Ferdinand Birkner (1868-1944). ${ }^{5}$ The firstever professor of anthropology in Germany and author of Der Mensch, an influential work of the 1880 s, Ranke had become something of a monument. The considerably younger Birkner served as associate professor of anthropology and custodian of the Bavarian State Prehistoric Collection as well as founder and chairman of the German-Bulgarian Society.

Obviously, Loritz's tendentious depiction of the origins and bodily particularities of the Bulgarian people was not a product of his thirst for knowledge alone. Its aim was also to provide fodder for anthropological propaganda: Serbian-Bulgarian affinities-be they somatic, linguistic, or ethnographic-had become inappropriate after Bulgaria took part in the conquest of Serbia by the Central Powers in 1915. But animosities between Serbian and Bulgarian national elites dated from the late nineteenth century, revolving around the ethnic affiliation of the Slavic population of Macedonia, then an Ottoman province. In the First Balkan War, Bulgaria had joined Serbia and Greece in attacking the Ottoman Empire in order to seize its Balkan provinces, but soon thereafter felt cheated of its share of the Macedonian spoils.

1 Johann Baptist Loritz, Unser Verbündeter Bulgarien (Regensburg: Friedrich Pustet, 1917), 61-66.

2 Цветана Тодорова [Cvetana Todorova] and Елена Стателова [Elena Statelova], “Към началната история на Германско-българското дуржество (1916-1918)" [On the first years of the German-Bulgarian Society (1916-1918)], in Българско-германски отношения и вързки: Изследвания и материали [Bulgarian-German relations and connections: Studies and materials], vol. 2, ed. Българска Академия на науките, Институт за история [Bulgarian Academy of Sciences, Institute for History] (Sofia: БАН [Bulgarian Academy of Sciences], 1979), 165.

3 Johann Baptist Loritz, Anthropologische Untersuchungen an bulgarischen Schädeln aus alter und neuer Zeit (Munich: J. Fuller, 1915).

4 Idem, "Über die Herkunft des südbulgarischen Dolichocephalus," Korrespondenz-Blatt der Deutschen Gesellschaft für Anthropologie, Ethnologie und Urgeschichte 46, nos. 5-8 (1915): 21.

5 Idem, Anthropologische Untersuchungen, 8, 157. 
In 1913, Bulgaria declared war on Serbia and Greece, losing its Second Balkan War in a matter of weeks. This defeat prompted Bulgaria to enter World War I as an ally of the Central Powers two years later.

Birkner delivered a lecture on "Bulgaria in Prehistoric Times" at the German-Bulgarian Society in late 1916. ${ }^{6}$ In May 1917, he published his views on the anthropological properties of the Bulgarians in the Deutsche Balkanzeitung, a Sofia-based paper responsible for spreading propaganda for the Central Powers in southeastern Europe. ${ }^{7}$ Due to the manifold waves of migration that had rolled over Bulgaria throughout history, Birkner wrote, its inhabitants' "somatic peculiarities do not show too much homogeneity." However, he found the data sufficient to justify according the prehistoric Balkan population a greater role in shaping the modern Bulgarian than had Loritz. $^{8}$

Georg Buschan's (1862-1943) 1917 booklet is also worthy of mention: He awarded the Bulgarians first prize among the peoples of the Balkans for their "bravery, patriotism, intelligence, and aspiration to higher things." Buschan conceded that cohabitation with Slavic peoples since their arrival in the seventh century had tainted Bulgarian purity, but "by the power of heredity, an array of characteristics distinct from the Slavic type have preserved themselves now and then among the population." ${ }^{10}$ In his view, Finns, Hungarians, and Turks-allies or potential allies of the Reich-were the closest relatives of the original Bulgarians. ${ }^{11}$ Like Loritz, Buschan stressed that Bulgarians differed somatically from Serbs, Romanians, and Greeks. ${ }^{12}$ He noted the frequent occurrence of central Asian traits (which he considered to be such phenomena as brachycephaly and the epicanthal fold) among the population of northern Bulgaria, whereas, in southern Bulgaria, dolichocephaly (long-headedness) was more common. Whereas Loritz had derived southern Bulgarians' long heads from ancient Mediterranean peoples and North African nomads,

6 Helmut W. Schaller, "Wissenschaftliche Sammelbände zu Bulgarien in Deutschland im 20. Jahrhundert," Bulgarian Historical Review 34, nos. 1-2 (2006): 43; Ferdinand Birkner, "Die Vorgeschichte Bulgariens," Korrespondenz-Blatt der Deutschen Gesellschaft für Anthropologie, Ethnologie und Urgeschichte 47, nos. 7-9 (1916): 41-47.

7 Todorova and Statelova, "On the First Years of the German-Bulgarian Society," 190-191.

8 Ferdinand Birkner, "Die anthropologische Erforschung Bulgariens," Deutsche Balkanzeitung, May 15, 1917.

9 Georg Buschan, Die Bulgaren: Herkunft und Geschichte, Eigenschaften, Volksglauben, Sitten und Gebräuche (Stuttgart: Strecker und Schröder, 1917), 1.

10 lbid., 4.

11 Ibid., 5, 10.

12 Ibid., 19. 
Buschan saw a connection to northern Europe, as he believed the Balkan mountain range had saved southern Bulgaria from being overrun by Asian Fremdvölker [foreign peoples]. ${ }^{13}$

As a leading figure in the popularization of ethnology in Germany, Buschan could rely on a rich literature on contemporary Bulgaria, much of it by Bulgarian authors. Birkner remarked that "in Bulgaria, anthropological research has been conducted in an exemplary fashion and to an extent which has been hardly equalled, and never surpassed anywhere." ${ }^{14}$ Did anthropological research in Bulgaria really justify such an assessment? One thing can be said with certainty: German interest in the tradition of physical anthropology in Bulgaria had been rather slight up to then. It is therefore conspicuous that the increased attention came just as the new allies were compelled to close ranks. But to do justice to Bulgarian anthropology, we should not confine our attention to the well-meaning, but condescending, opinions of German contemporaries, but rather examine its origins and ideological ramifications. To do this, it would serve us well to compare them with parallel developments in Bulgaria's rival Serbia. ${ }^{15}$

There were abundant similarities between the two countries. The establishment of a national language as well as the collection of "folk poetry" and ethnographic objects and their ensuing canonization as "folk culture," played an important role in constructing national borders and a national "soul." Around the turn of the twentieth century, political geography, archaeology, prehistory, and physical anthropology joined philological and ethnographic endeavors. The national elites of Serbia and Bulgaria both felt that their countries, stuck in a post-Ottoman setting and bound by the regulations of the Congress of Berlin of 1878, were in a subaltern position vis-à-vis the European powers. Borders drawn in Berlin left nationalists grumbling. The two countries' national elites employed a variety of academic disciplines to legitimize their territorial aspirations-a process that eventually led to their becoming enemies in the Second Balkan War. This chapter will concentrate on the specific role physical anthropology played in that process.

13 Ibid., 22-23; Loritz, "Über die Herkunft des südbulgarischen Dolichocephalus," 25-26.

14 Birkner, "Die anthropologische Erforschung Bulgariens."

15 A short assessment of Greek anthropology until the end of the First World War can be found in Sevasti Trubeta, "Anthropological Discourse and Eugenics in Interwar Greece," in Blood and Homeland: Eugenics and Racial Nationalism in Central and Southeast Europe 1900-1940, eds. Marius Turda and Paul J. Weindling (Budapest: Central European University Press, 2007), 124-125. 


\section{“... Killing Something": The Hierarchical Setting of Anthropology in the Balkans}

Physical anthropology in the Balkans began with the reproduction and application of knowledge acquired by students in the German Reich and the Habsburg monarchy. The Balkan scholars' position was not an easy one: Their methods would be measured by the standards of contemporary European anthropology, and they had to decide whether they should also adopt its models or if they should develop their own models, which might push their research in new directions. In either case, their own nations were the focus of interest, generating parallel efforts to render the discipline relevant within the local academic communities and to demonstrate on the international level that their findings were more than just appendices to existing studies.

The pivotal question, however, was how to deal with the verdicts of western and central European predecessors. The anatomists Sámuel Henriket Scheiber (1834-1906) and Isydor Kopernicki (1825-1891) had been the first to examine the crania of several Bulgarians who had died in a hospital in Bucharest, ${ }^{16}$ but it was others, under the influence of the "Eastern Question" that had flared up again in 1875, who interpreted their results. Thus, the French armchair anthropologist Alexandre Abel Hovelacque (1843-1896) declared: “The Bulgarian appears to be a Tartar who has traded his own language for a Slavic one." ${ }^{17}$ Rudolf Virchow (1821-1902) was inclined to believe that Bulgarians were of Finnish or Turkish origin, agreeing with Hovelacque that, if they were Slavs, they were so by virtue of their language alone. ${ }^{18}$ He turned his attention to the Bulgarians in 1877, calling them "the tribe who, at the moment, is in the foreground of political interest and whom, we must say, the fight is about." 19 The earliest exhaustive anthropological examinations of the western South Slavs (Serbs, Croats, Bosnians, and Slovenes) were conducted by the Austrian anatomist Augustin

16 Sámuel Henriket Scheiber, "Tabelle mit den Maassen von 5 Bulgarenschädeln," Verhandlungen der Berliner Gesellschaft für Anthropologie, Ethnologie und Urgeschichte [Sitzung vom 10. Mai 1873] (1873): 94-97; Jsidore Kopernicki, "Sur la conformation des cranes bulgares," Revue d'Anthropologie 4 (1875): 68-96.

17 Alexandre Abel Hovelacque, "Sur deux crânes bulgares," Bulletins de la Société d'anthropologie, 2nd ser., 10 (1875): 429.

18 Rudolf Virchow, "Die nationale Stellung der Bulgaren," Verhandlungen der Berliner Gesellschaft für Anthropologie, Ethnologie und Urgeschichte [Sitzung vom 11. Februar 1877] (1877): 74-75; D. Kadanoff and St. Mutafov, "Rudolf Virchows Beobachtungen an Schädeln von Bulgaren im Lichte neuer anthropologischer Untersuchungen," Zeitschrift für die gesamte Hygiene und ihre Grenzgebiete 18, no. 6 (1972): 458-461.

19 Virchow, “Die nationale Stellung der Bulgaren," 70-71. 
Weisbach (1837-1914) from the late 1860s through the turn of the century. ${ }^{20}$ His interminable anthropometric tables do little to convey the glamor the Balkans possessed for Western amateurs in search of thrills and prestige. The British physician and ethnologist John Beddoe (1826-1911) promoted scientific pursuits in Ottoman Macedonia to the leisured classes:

Here are fine opportunities for any enterprising Englishmen with money and a taste for travel and adventure, and with sufficient brains to be able to pick up a language. But alas! Such men usually seem to care for nothing but 'killing something., ${ }^{21}$

When they published their findings, Western anthropologists only rarely provoked negative reactions from native intellectuals. One of the few criticisms on record comes from the Serbian ethnographer Tihomir R. Đorđević (18681944), angered by the Swiss anthropologist Eugène Pittard's (1867-1962) hasty assessment of the racial makeup of the Serbs. He complained about the arrogance of Western researchers whose statements were considered valid even when they had no foundation in reality. ${ }^{22}$

The earliest representatives of Bulgarian anthropology apparently took no offence at their country's subaltern position in European anthropology, nor to the fact that they were trained on colonial "material" before attending to their compatriots. The preeminent Bulgarian anthropologist, the physician Stefan Vatev (1866-1946), began his career as a student of Felix von Luschan (18541924). He helped the renowned anthropologist measure some one hundred Africans on display at the German Colonial Exhibition of 1896 in Berlin. ${ }^{23}$ The second most important Bulgarian anthropologist, Krum Drončilov (1889-

20 On Weisbach, see Brigitte Fuchs, "Rasse," "Volk," Geschlecht: Anthropologische Diskurse in Österreich 1850-1960 (Frankfurt a.M.: Campus, 2003), 139-145; idem, "'Kultur' und 'Hybridität': Diskurse über 'Rasse,' Sexualität und 'Mischung' in Österreich 1867 bis 1914." Austrian Studies in Social Anthropology 1 (2005), http://www.univie.ac.at/alumni.ethnologie/journal/ volltxt/Artikel\%201\%20_Fuchs.pdf; Christian Promitzer, "The Body of the Other: 'Racial Science' and Ethnic Minorities in the Balkans," Jahrbücher für Geschichte und Kultur Südosteuropas 5 (2003): 28-29.

21 John Beddoe, The Anthropological History of Europe: Being the Rhind Lectures for 1891, revised to date (Paisley, UK: Gardner, 1912), 86-87.

22 Tihomir R. Đorđević, "Contribution à l’étude anthropologique des Serbes du royaume de Serbie, par Eugène Pittard," (Revue de l’école d’anthropologie de Paris, septembre 1910, 307-311)," Srpski Književni Glasnik 25 (1910): 615-618.

23 Стефан Ватев [Stefan Vatev], Принос към антропологическо изучаване на Българите [Contribution to the anthropological study of the Bulgarians], n.p., n.d. [Sofia 1900] (= excerpt from the journal Български преглед [Bulgarian Survey] 6, no. 4 (1900): 1; on Luschan's role at the Colonial Exhibition, see Andrew Zimmerman, Anthropology and Antihumanism in Imperial Germany (Chicago, IL: University of Chicago Press, 2001), 30-35. 


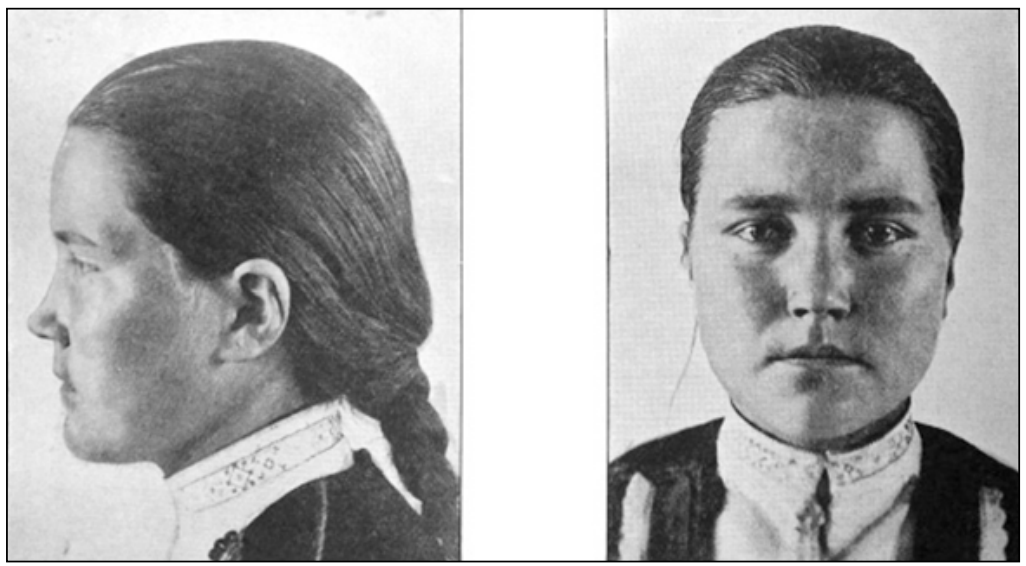

Figure 1. The original caption reads: "Bulgare. Race vistulienne ou Orientale Mélangée de Sang Turc." Source: J[oseph] Deniker, "Les Six Races Composant la Population Actuelle de l'Europe," The Journal of the Anthropological Institute of Great Britain and Ireland 34 (1904): plate xiii.

1925), was also a disciple of Luschan trained in Negeranthropologie, as he called it. Drončilov was entrusted with measuring the skulls of deceased railway construction workers in the German colony of Cameroon. ${ }^{24}$ In Bulgaria, the close relationship with German anthropology resulted in an uncritical attitude toward Western models generally. That tolerance is reflected in an affirmative review of foreign literature on the Bulgarians published by Vatev in $1910 .{ }^{25}$

Mentors, like the French anthropologist M. Joseph Deniker (1852-1918), allowed Stefan Vatev access to international anthropological journals-coups somewhat tarnished by Deniker's addition of condescending commentary. ${ }^{26}$ Vatev did, on one occasion, question Deniker's interpretation of a photograph of a Bulgarian woman he had sent him (Figure 1). In a widely noted lecture on the six races of contemporary Europe, Deniker had included the photograph as an example of the Eastern race mixed with Turkish blood. "We want to remark," Vatev wrote,

24 Krum Drontschilow, "Metrische Studien an 93 Schädeln aus Kamerun," Archiv für Anthropologie, n.s., 12 (1913): 161-183.

25 Стефан Ватев [Stefan Vatev], Чужда литература по антропологията на българите [Foreign literature on the anthropology of the Bulgarians] (Sofia: Държавна печатница [State Stationary Office], 1910).

26 S. Wateff, "Contribution a l'étude anthropologique des Bulgares," Bulletins et mémoires de la Société d'Anthropologie de Paris, 5th ser., 5 (1904): 437-458; M. Joseph Deniker, "Les Bulgares et les Macédoniens: Note complémentaire à la communication du Dr Wateff," Bulletins et mémoires de la Société d'Anthropologie de Paris, 5th ser., 5 (1904): 458-466. 
that Deniker wrongly considers this Bulgarian woman from a village near Sofia as being a mixture with Turkish blood. It is known that Turks never became Christians or Bulgarians - it was the other way around. In the region of Sofia, there were always only small numbers of Turks; and they lived solely in the towns; thus it is hard to accept that this type which is rather common in the region of Sofia contains an accidental mixture with Turkish blood. ${ }^{27}$

As Vatev's criticism was published only in Bulgarian, it had no international repercussions. The incident reveals the uncomfortable subaltern position of native scholars. They ran the risk of being reduced to humble collectors of anthropological material for Western colleagues, whose high-handed judgments on the makeup and origins of local populations upheld the image of the Balkans as heteronomous and impervious to outside influences. This attitude came to its full expression in the verdict pronounced by William Z. Ripley (1867-1941) in his book Races of Europe:

The Balkan Peninsula [...] has been unfortunate from the start. The reason is patent. It lies in its central or rather intermediate location. It is betwixt and between; neither one thing nor the other. Surely a part of Europe, its rivers all run to the east and south. "By physical relief it turns its back on Europe," continually inviting settlement from the direction of Asia. It is no anomaly that Asiatic religions, Asiatic institutions, and Asiatic races should have possessed and held it; nor that Europe, Christianity, and the Aryan-speaking races should have resisted this invasion of territory, which they regarded in a sense as their own. In this pull and haul between the social forces of the two continents we finally discover the dominant influence, perhaps, which throughout history has condemned this region to political disorder and ethnic heterogeneity. ${ }^{28}$

\section{In Search of the Nation: Bulgarian Anthropology up to the Balkan Wars}

Vatev's criticism of Deniker shows the power of interpretation in the field of physical anthropology. His rebuttal did not exhaust itself in a general complaint about casual assessments by Western researchers; it directly addressed a prejudice that merged Christian Bulgarians with Muslim Turks, a "contamination" already present in the "Tirk oder Griech" of the early eighteenth-cen-

27 Стефан Ватев [Stefan Vatev], "Les six races composant la population actuelle de l'Europe, par le Dr J. Deniker," Периодическо списание на Българското книжовно дружество в София [Periodical Journal of the Bulgarian Literary Society in Sofia] 18, nos. 7-8 (1907): 645.

28 William Z. Ripley, The Races of Europe: A Sociological Study (New York: Appleton, 1899), 402. 
tury Austrian Völkertafel. ${ }^{29}$ "Decontamination" for Vatev entailed distancing from the Ottoman legacy and the rejection of interbreeding with the Turks (while not excluding the possibility of racial mixtures with other populations). In Bulgarian nationalism, Turks and other Muslim minorities figured on the same subaltern level as the whole population of the Balkan Peninsula in the mind of Western anthropologists-a symbolic complex that Milica BakićHayden has called "nesting orientalisms." 30

How did such attitudes manifest themselves in Vatev's anthropological practice? In 1896, a committee for large-scale studies of the "Bulgarian Fatherland" was founded in Sofia. The committee planned a monograph on the anthropology and physiology of the Bulgarian population which would continue the examinations performed by the Lithuanian Ivan Juriev Basanovič (Jonas Yuro Bansaovichjus, 1851-1928) in northern Bulgaria in the 1880s. Basanovič had arrived as one of many foreign physicians helping to establish a public health system in the new state. During his time as district physician in the northwestern Bulgarian town and region of Lom, he had examined 185 women and nearly 2,500 men, coming to the conclusion that the Bulgarians were of Thracian origin. ${ }^{31}$

It would not be easy to surpass Basanovič's pioneering work. This could only be achieved by confronting the ultimate question, as Vatev explained:

The Bulgarians-history tells us - are a mixture of Slavs and Bulgarians of a Finnish tribe; Bulgaria, however, in the distant past was the road and guest house for many passing peoples. Out of the remnants of the former peoples who have moved and lived on our soil, out of the remnants of our forefathers and out of the study of the contemporary Bulgarian, the task of the anthropologist of the Bulgarian will be to determine by comparison which tribes they were, which tribe the Bulgarian one was, when and how it was mixed with the Slavic one, and whether the modern Bulgarian represents an independent Slavic type, a Bulgarian one, or a mixture of both of them, or of even more types. ${ }^{32}$

29 Zoran Konstantinović, "'Tirk oder Griech': Zur Kontamination ihrer Epitheta," in Europäischer Völkerspiegel: Imagologisch-ethnographische Studien zu den Völkertafeln des frühen 18. Jahrhunderts, ed. Franz K. Stanzel (Heidelberg: Winter, 1999), 299-314.

30 Milica Bakić-Hayden, "Nesting Orientalisms: The Case of Former Yugoslavia," Slavic Review 54, no. 4 (1995): 917-931.

31 Иван Бассанович [Ivan Basanovič], "Материали за санитарната етнография на България І. Ломският окръг (1880-1889)" [Materials for the sanitary ethnography of Bulgaria I. district of Lom (1880-1889)], Сборник за народни умотворения, наука и книжниа [Almanac of Folklore, Science, and Literature] 5 (1891): 26-32, 38-40; see Y[ordan]. A. Yordanov, "One Hundred Years of Anthropological Studies in Bulgaria," Annals of Anatomy 175 (1993): 385-387.

32 Стефан Ватев [Stefan Vatev], "Антропологическо изследване на България” [Anthropological research in Bulgaria], Български преглед [Bulgarian Survey] 5, no. 1 (1898): 148. 
With the cooperation of the War Ministry, Vatev supervised military physicians who took anthropological measurements of about six thousand soldiers stationed throughout the country. He informed Ranke in Munich of his preliminary results, and Ranke convinced him to expand the investigation to schoolchildren, following the example of Virchow and the German Society for Anthropology, Ethnology, and Prehistory. The Bulgarian Ministry of Education supported the plan, ordering Bulgarian teachers to follow Vatev's instructions, ${ }^{33}$ and, by 1901, Vatev had at his disposal the eye, hair, and skin color of 236,884 schoolchildren along with 31,469 soldiers. With the support of the Exarchate of the Bulgarian Orthodox Church, he also managed to acquire the data of almost thirty thousand pupils attending the schools run by the Exarchate in the Ottoman provinces of Thrace and Macedonia. ${ }^{34}$

Ranke had suggested retaining the hierarchy of Virchow's school statistics, and Vatev followed his advice. Virchow had differentiated between a favorable blond type, a less desirable brunette type, and a mixed type. Vatev kept the German hierarchy, even though the dark and mixed types (at 47 and 44 percent, respectively) were more common among the Bulgarian population than the blonds with only 9 percent. Fair-skinned subjects were more common in western Bulgaria than in the east. According to Vatev's figures, the distribution of the blond, dark, and mixed types among the Bulgarian population of Macedonia and Thrace was almost the same as among that of Bulgaria proper $^{35}$ - a result of potential utility for national policy. Vatev's results echoed those of Vasil Kănčov (1862-1902), who had presented ethnographic statistics on the population of Macedonia to show that Bulgarians were a single entity, whether inside or outside the principality. ${ }^{36}$ However, Vatev's anthropological findings did not gain similar popularity in Bulgaria.

33 Vatev, "Contribution to the Anthropological Study of the Bulgarians," 2-4; on the German school statistics, see Zimmerman, Anthropology and Antihumanism, 135-146.

34 Stefan Wateff, "Anthropologische Beobachtungen an den Schülern und Soldaten in Bulgarien," Correspondenz-Blatt der deutschen Gesellschaft für Anthropologie, Ethnologie und Urgeschichte 32, no. 4 (1901): 29-30; idem, "Anthropologische Beobachtungen der Farbe der Augen, der Haare und der Haut bei den bulgarischen Schulkindern in der europäischen Türkei," Correspondenz-Blatt der deutschen Gesellschaft für Anthropologie, Ethnologie und Urgeschichte 33, no. 3 (1902): 23-24.

Idem, "Anthropologische Beobachtungen an den Schülern und Soldaten"; idem, "Anthropologische Beobachtungen der Farbe der Augen." [Macedonia: Ethnography and statistics] (Sofia: Държавна печатница [State Stationary Office], 1900). 
Like Virchow, whose school study had tried to answer the question of whether there were differences between German and Jewish children, Vatev directed his attention to differences between Bulgarians and ethnic minorities, including Turks, Pomaks (Slavic-speaking Muslims), Armenians, Gagauz (Orthodox Christian Turks), and Jews. He gathered data on 54,734 pupils from ethnic minorities. To his embarrassment, the blond type, at 13 percent, was better represented among the Turks and the Pomaks than among the ethnic Bulgarians. Vatev published these unwelcome findings only in German, avoiding a direct comparison between ethnic Bulgarians and Muslim minorities. ${ }^{37}$ In any case, he evaded a final assessment of the racial origins of the Bulgarians, which had been the original motive for the tremendous administrative effort required to measure a quarter of a million people. Vatev published the results in Bulgarian only in 1939, when they were already outdated and marginalized by more recent research. ${ }^{38}$

\section{A Slovene in Serbia: Serbian Anthropology up to the Balkan Wars}

The basis for the establishment of physical anthropology in Serbia was different. The leading figure in the natural sciences was the geographer Jovan Cvijić (1865-1927). Anthropological measurements played a limited role; the group of young Serbian scholars who gathered around him were more interested in linking geography with ethnography, describing the somatic traits of

37 Stefan Wateff, "Anthropologische Beobachtungen der Farbe der Augen, der Haare und der Haut bei den bulgarischen Schulkindern von den Türken, Pomaken, Tataren, Armenier, Griechen und Juden in Bulgarien," Correspondenz-Blatt der deutschen Gesellschaft für Anthropologie, Ethnologie und Urgeschichte 34, nos. 7-8 (1903): 58-60.

38 Стефан Ватев [Stefan Vatev], Антропология на Българите [Anthropology of the Bulgarians] (Sofia: Книпеграф [Knipegraf], 1939). Apart from Vatev, the statistician Jakim Pomadov evaluated the body size of about one hundred thousand Bulgarian military recruits from 1897 until 1900 in order to assess the racial composition of the Bulgarian population, whereby he differed between a larger "Slavic" and a smaller "Thracian" type-see Помадов Яким [Pomadov Jakim], "Военна антропометрия: Резултати от измеранията височината и гърдите на младежите в България през 1897-1900" [Military anthropometrics: Results of the measurements of the body height and the chests of adolescents in Bulgaria in the years of 1897-1900], Трудове на българското природоизпитателно дружество [Papers of the Bulgarian Society of Natural History] 2 (1904): 173-199. 
local populations they studied only in vague terms. ${ }^{39}$ Although Cvijić was not persuaded of the potential of physical anthropology $y^{40}$, he was impressed by Deniker's concept of the Adriatic or Dinaric Race. Its members were tall, with round skulls, dark hair and eyes, and brownish skin. To these somatic traits, Cvijić attached psychological traits associated with mountain men: masculinity, honor, chivalry, and heroism. The highlanders' realm was the "patriarchal regime" of the Balkan Peninsula. ${ }^{41}$

Cvijić was at least partly responsible for the arrival of the Slovene Niko Županić (also written Zupanič or Županič) (1876-1961) in Serbia in 1907. Županić became Serbia’s first scholar of physical anthropology. He had studied history in Vienna, but had also pursued a specialization in anthropology in Ranke's department in Munich, and was a member of the Viennese Anthropological Society. As a staunch adherent of Yugoslavism, he had little chance of an academic career in Austria-Hungary, but in Serbia he became curator of the Belgrade History and Arts Museum. ${ }^{42}$

39 See the anthropological observations in Rista T. Nikolić, "Poljanica i Klisura: Antropogeografski proučavanja" [Poljanica and Klisura: Anthropogeographical studies], in Naselja srpskih zemalja [Settlements of the Serbian lands], ed. Jovan Cvijić, vol. 3 (Belgrade: Državna Štamparija [State Stationary Office], 1905), 124-131; Jovan Erdeljanović, "Kuči: Pleme u Crnoj Gori" [Kuči: A tribe in Montenegro], in Naselja srpskih zemalja [Settlements of the Serbian lands], ed. Jovan Cvijić, vol. 4 (Belgrade: Državna Štamparija [State Stationary Office], 1907), 172-190, 344-345; on the school of Cvijić, see Conrad Clewing and Edvin Pezo, "Jovan Cvijić als Historiker und Nationsbildner: Zu Ertrag und Grenzen seines anthropogeographischen Ansatzes zur Migrationsgeschichte," in Beruf und Berufung: Geschichtswissenschaft und Nationsbildung in Ostmittel- und Südosteuropa im 19. und 20. Jahrhundert, eds. Markus Krzoska and Hans-Christian Maner (Münster: LIT, 2005), 265-297.

40 Jovan Cvijić, Balkansko poluostrvo [The Balkan Peninsula] (Belgrade: Srpska akademija nauka i umetnosti [Serbian Academy of Sciences and Arts], 1987), 328-329 (first published in French in 1918).

41 Idem, "Kulturni pojasi Balkanskoga Poluostrva" [Cultural circles of the Balkan Peninsula], Srpski književni glasnik [Serbian Literary Review] 6 (1902): 914-916; idem, The Balkan Peninsula, 361-375; Karl Kaser, "Peoples of the Mountains, Peoples of the Plains: Space and Ethnographic Representation," in Creating the Other: Ethnic Conflict and Nationalism in Habsburg Central Europe, ed. Nancy M. Wingfield (New York: Berghahn Books, 2003), 219-224; Christian Töchterle, "Wir und die Dinarier: Der europäische Südosten in den rassentheoretischen Abhandlungen vor und im Dritten Reich," in Südostforschung im Schatten des Dritten Reiches: Institutionen —Inhalte_Personen, eds. Mathias Beer and Gerhard Seewann (Munich: Oldenbourg, 2004), 167-170.

42 Christian Promitzer, "Niko Županič in vprašanje jugoslovanstva: Med politiko in antropologijo (1901-1941)" [Niko Županič and the issue of Yugoslavism: Between politics and anthropology (1901-1941)], Prispevki za novejšo zgodovino 
In Bulgaria, the political uses of large anthropometric studies were limited, partly because the results were not in line with expectations. But it is also safe to say that immediate political application was not the chief aim of the inductive, liberal brand of German anthropology $y^{43}$ in which Vatev had been trained. Županić, on the other hand, had already joined German anthropology's turn toward "Nordic anthroposociological ideas." ${ }^{34} \mathrm{He}$ gave his work explicit ideological overtones from the beginning. Before commencing fieldwork, he analyzed descriptions of peoples in ancient and Byzantine texts to help preformulate a "racial history" of the Balkans.

The essence of Županić's thought is contained in a long article on the "System of the Historical Anthropology of the Balkan Peoples," published in the Serbian language as well as in a shorter article in German on the Illyrians. Županić believed he could justify the round heads and dark skin of the South Slavs by assuming the existence of a primordial population of brachycephalic brunettes. This population had mixed with xanthodolichocephalic (i.e., light-skinned, blond-haired, blue-eyed dolichocephalic) Aryan newcomers, Indo-Europeans who reached the Balkans in waves beginning in the second millennium B.C.E. They mixed repeatedly with the local population, but the domestic brachycephalic elements predominated over the more recent dolichocephalic one. Influenced by the rediscovery of Mendelian genetics, his hypothesis explained the gradual brachycephalization of newcomers to the Balkan Peninsula: Round heads were a dominant trait. Brachycephalization had progressed to the furthest extent among the Albanians, whose Illyrian ancestors had been the first Indo-European group to settle on the peninsula. The next group to fall victim to the process was the Greeks, who had migrated to the Balkans in the second millennium B.C.E.; after two thousand years of constant mixing, modern Greeks bore almost no resemblance to their ancient progenitors. The South Slavs, arriving in the sixth century, were only the most recent to undergo brachycephalization. ${ }^{45}$

[Contributions to Contemporary History] 41, no. 1 (2001): 14; “Vorstand und Mitglieder der Anthropologischen Gesellschaft in Wien nach dem Stande vom 20. März 1907," Mitteilungen der Anthropologischen Gesellschaft in Wien (MAGW) 37 (1907), Sitzungsberichte 1906-1907: 11.

43 Benoit Massin, "From Virchow to Fischer: Physical Anthropology and 'Modern Race Theories' in Wilhelmine Germany," in Volksgeist as Method and Ethic: Essays on Boasian Ethnography and the German Anthropological Tradition, ed. George W. Stocking (Madison, WI: University of Wisconsin Press, 1996), 79154.

44 Idem, "From Virchow to Fischer," 134.

45 Niko Županić, "Sistem istorijske antropologije balkanskih naroda" [System of the historical anthropology of the Balkan peoples], Starinar. Organ Srpskog arheološkog društva [Antiquary. Organ of the Serbian Archaeological 
Županić's narrative is an inventive extension of typical racial hierarchies to the Balkans and, at the same time, a defence of the racial superiority of the originally Nordic South Slavs. This becomes explicit when Županić references the historian Jakob Philipp Fallmerayer (1790-1861), who had become famous for his statement that "auch nicht ein Tropfen echten und ungemischten Hellenenblutes fließt in den Adern der christlichen Bevölkerung des heutigen Griechenland" [not one drop of genuine and unadulterated Hellenic blood flows in the veins of the Christian population of modern Greece]. Županić declares:

Fallmerayer is wrong when he thinks that the Slavs have contaminated the Greeks; the development goes the other way around. If xanthodolichocephaly is something noble, as many French and German anthropologists and historians argue ([Arthur de] Gobineau, [Georges] Vacher de Lapouge, L[udwig] Woltmann, H[ouston] S[tewart] Chamberlain, L[udwig] Wilser, K[arl] Penka, L[udwig] Reinhardt), then the Slavs could only invigorate, uplift and ennoble the Greeks and bring them closer to their ancient, fair-haired ancestors. ${ }^{46}$

By quoting such sources, Županić took sides with the most notorious racial theories and the German and French anthropologists who were their staunchest advocates. He did not question the right of the Nordic/Aryan (he used both terms) master race to the top position. He absolved the South Slavs of responsibility for the dominance of brachycephales on the Balkan Peninsula; their appearance had originally been Nordic, like that of the ancient Greeks. It was to their credit that they had arrived to delay the brachycephalization of the entire peninsula. However, in the long run, because of their noble sacrifice, the South Slavs had to bear the consequences: They became Dinaric.

With regard to the Serbs' immediate neighbors, Županić appeared to echo Serbian pretensions to Albanian-settled territories in western Macedonia and Bulgaria. He expressed doubt that the Albanians could be called a "nation"; they were few in number, lacked a common folk tradition, culture or literary language, and were divided among three confessions. ${ }^{47}$ Reinterpreting data gathered by Vatev, Županić concluded that the skull shapes and complexions of the population of western Bulgaria and western Macedonia resembled that of the Serbs of Bosnia and Herzegovina. ${ }^{48}$

Society], n.s., no. 2 (1907): 167-189; idem, "Sistem istorijske antropologije balkanskih naroda" [System of the historical anthropology of the Balkan peoples], Starinar. Organ Srpskog arheološkog društva [Antiquary. Organ of the Serbian Archaeological Society], n.s., no. 3 (1908): 1-70; Niko Županić, "Die Illyrier (Ein Profil aus der historischen Physioanthropologie der Balkanhalbinsel)," MAGW 37 (1907), Sitzungsberichte 1906-1907: 21-24.

47 Ibid., 2.

48 Ibid., 60-61. 
Interestingly, despite his Yugolavism, Županić rejected the idea of a SerboCroatian Volk, which was vehemently discussed at the time. Županić considered Serbs and Croats, language notwithstanding, to be two ethnic groups, like the Franconians and Bavarians who nonetheless belonged to a larger German nation. ${ }^{49}$ His conclusion may have something to do with his Slovene origins and the ongoing debate among Serbian intellectuals on whether Slovenes could be included in the Yugoslav program. By denying an anthropological commonality to Serbs and Croats, Županić was presumably led by a tacit wish to position the Slovenes, whose language was not as closely related to Serbian or Croatian, on the same level as Serbs and Croats. Together, they would form the larger nation of the Yugoslavs.

With his theses, Županić made a name for himself as an anthropologist in both Serbia and Slovenia. Shortly thereafter, he conducted his first anthropological examinations of three hundred inhabitants of Serbian villages on the border between Croatia and Carniola, which is a part of modern Slovenia. The study, published in 1912, ${ }^{50}$ was "the first anthropological work in Serbian science to rest on precise measurements," as the geographer Jevto Dedijer (18801918) stressed in a review. ${ }^{51}$

\section{POWs and Recruits: Bulgarian and Serbian Anthropology in the Balkan Wars}

Wartime provides unusual opportunities for anthropologists to make examinations of material living and dead, as the history of the anthropological sciences indicates. Wartime rallies large numbers of young men in the most enjoyable time of their lives and from different countries and regions, allowing easy comparison of physical traits. Anthropologists are spared the travails of long expeditions as well as the tempers and superstitions of peasants. ${ }^{52}$

49 Ibid., 51.

50 Idem, Žumberčani i Marindolci: Prilog antropologiji i etnografiji Srba u Kranjskoj [The people of Žumberak and Marindol: Contribution to the anthropology and ethnography of the Serbs in Carniola] (Belgrade: Državna štamparija [State Stationary Office], 1912); see Christian Promitzer, "'Gute Serben': Ethnologen und Politiker über die Identität der Serben in der Bela krajina," in Umstrittene Identitäten: Ethnizität und Nationalität in Südosteuropa, ed. Ulf Brunnbauer (Frankfurt a. M.: Lang, 2002), 173-199.

51 Jefto Dedijer, "D-r. Niko Županić, Žumberčani i Marindolci," Letopis Matice Srpske [Annual of Matica Srpska] 87, no. 286 (1912): 85.

52 Niko Županić, "Pontijski Bugari: Prilog fizičkoj antropologiji Balkanskog istoka" [The Pontic Bulgarians: Contribution to the physical anthropology of the Balkan island], Prosvetni glasnik: Službeni list Ministarstva prosvete i crkvenih 
These words were not written in World War I; they come from a 1913 article by Županić, who may have been the first European anthropologist to undertake systematic examination of prisoners-of-war (POWs). The first in Serbian custody were Ottomans captured during the First Balkan War. Županić was particularly interested in Turkish POWs from Anatolia: "The anthropologist is offered an exceptional possibility to study this tribe, who through five centuries has ruled the Balkan Peninsula, delaying the cultural and political development of the Serbs and Bulgarians and imposing Islam and Eastern ways of life." ${ }^{33}$

For the first six months of 1913, Županić was in Vienna under orders of the Serbian government to drum up support for Serbian aims. By the time he returned to Belgrade in early June, most of the Turkish POWs had been sent home. Only two or three hundred were still being held in the fortress in Belgrade, awaiting orders for repatriation. They were already free in legal terms and stood under the protection of the German embassy. Since the fortress also served as a quarantine for Serbian soldiers affected by epidemics-mainly cholera-Županić was advised to abandon his plans, but the commander of the fortress eventually allowed him access. ${ }^{54}$ He selected a Pomak, a Slavicspeaking Muslim, from the POWs and used him as an interpreter to ask the other prisoners about their age and birthplace ${ }^{55}$ before acquiring data including height, skull length, width and circumference, assorted distances, various facial indices, and skin, beard, hair, and eye color.

After an initial group had been examined, the rest refused their cooperation. ${ }^{56}$ Županić rose to the challenge:

But what cannot be reached by good words can be reached with force. I ordered the garrison [of the fortress], mainly peasants with sheepskin caps on their heads, long bayonets on their rifles, and otherwise dressed in peasant clothes, to take up

poslova [Educational Review: Official Paper of the Ministry of Education and Religious Affairs] 34, no. 7 (1913): 967.

53 Idem, "K antropologiji osmanskih Turaka angorskog i konijskog vilajeta" [On the anthropology of Ottoman Turks from the Vilayets of Angora and Konya], Etnolog: Glasnik kr. Etnografskega muzeja v Ljubljani [Ethnologist: Review of the Royal Ethnographic Museum in Ljubljana] 1 (1926-1927): 87.

54 Ibid., 87-88.

55 In a more sophisticated form, the same procedure was applied in the Austrian mass examinations of POWs during the First World War. See Margit Berner, "Forschungs-Material Kriegsgefangene: Die Massenuntersuchungen der Wiener Anthropologen an gefangenen Soldaten 1915-1918," in Vorreiter der Vernichtung? Eugenik, Rassenhygiene und Euthanasie in der österreichischen Diskussion vor 1938, eds. Heinz Eberhard Gabriel and Wolfgang Neugebauer (Vienna: Böhlau, 2005), 174.

56 Županić, "On the Anthropology of Ottoman Turks," 88. 


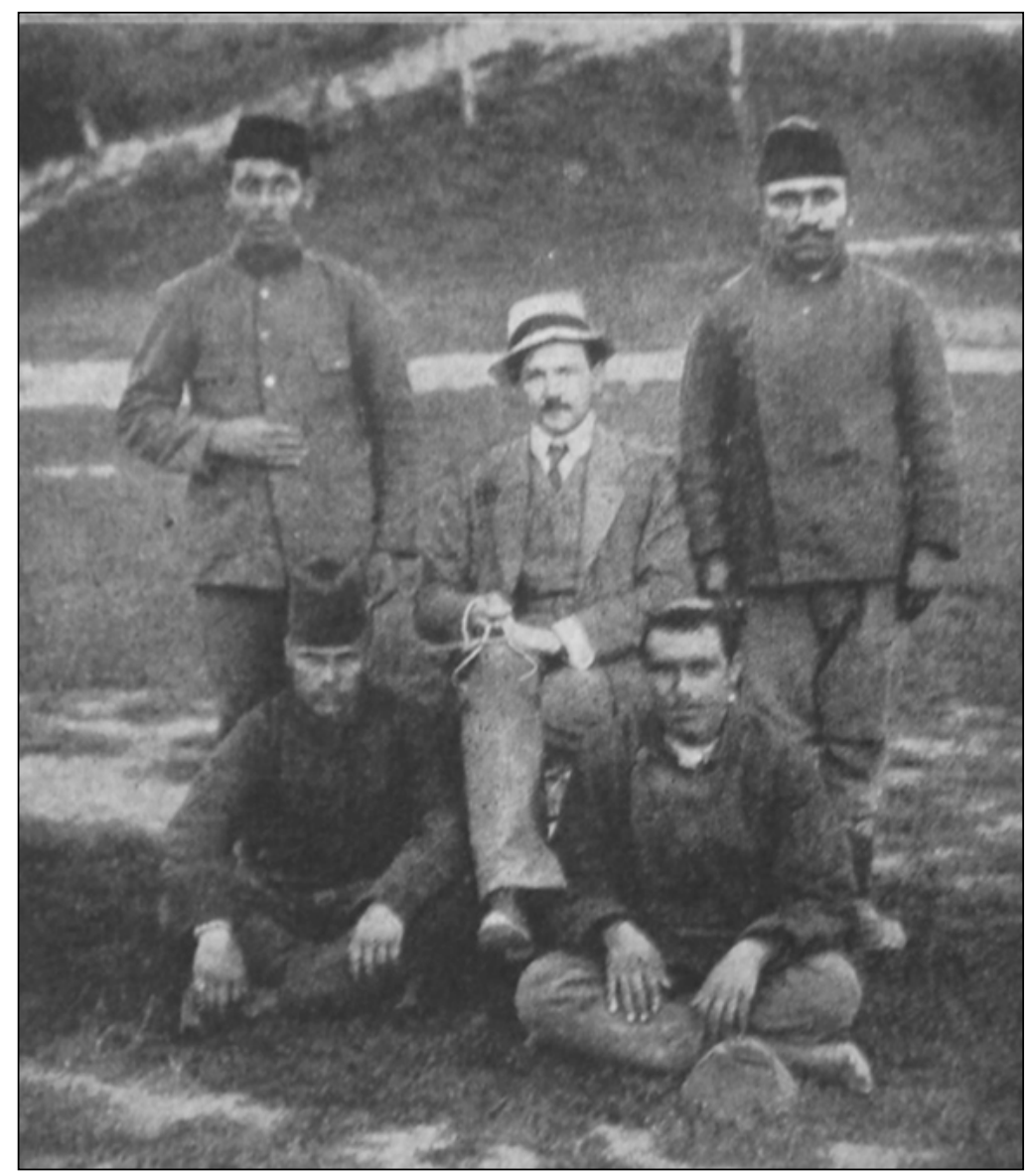

Figure 2. Niko Županić with a caliper surrounded by his Turkish interpreters and informants at the Fortress of Belgrade (1913). Source: Niko Županić, "Visina uzrasta Turaka Osmanlija," Vjesnik Etnografskog Muzeja u Zagrebu 2 (1936): 3-10, image from p. 5.

position in formation. And with some of them I went to the room of the Turks, and threatened that everybody who resisted examination would be shot. I gave them ten minutes to think about it, and went back to my office. And after some time, the translator appeared with five Turks who displayed compliance. For fear that the German embassy could at any time recall the Turkish POWs, I quickly examined 155 Turks, 24 from Europe and 131 from Asia Minor. ${ }^{57}$

The asymmetrical distribution of power between the anthropologist and his subjects is all too clear in the prisoners' humiliation. Županić's photographs

57 Ibid. 
(Figure 2) clearly visualize "the power of the scientist over the subject"58 and were harbingers of the photographs that German and Austrian anthropologists would take in the course of mass examinations of POWs two years later in the Great War. Županićs findings were not particularly noteworthy; he concluded that the Ottoman Turks were a subset of the central Asian Turks, though the epicanthal fold was less common among them, the reason being that the Ottoman Turks had assimilated the ancient ethnic substrate of Asia Minor. ${ }^{59}$ Županić went on to state that Ottoman Turks had no racial link to the Muslim South Slavs of Bosnia and Herzegovina, who, like other South Slavs, were taller than Turks. ${ }^{60}$ Cleansing the Bosnian Muslims of affinity to the Turks was in line with the Yugoslav program, which welcomed South Slavs from the western Balkans regardless of religious belief.

In an ironic twist, only a few years later, the Austrian anthropologist Josef Weninger (1886-1959) would examine Serbian POWs, find them to resemble Turks, and declare them Asians. The Ottoman Empire was allied with AustriaHungary at the time, but Turks were still regarded as "the quintessential racial and cultural 'other' in the history of the Austrian Empire."61

The Second Balkan War in the summer of 1913 offered Županić a renewed opportunity to measure POWs, in this case 179 Bulgarians from eastern districts of Bulgaria near the Black Sea. The examinations took place in the same Belgrade fortress, but under more congenial circumstances than with the Turkish POWs, perhaps because Bulgarians were viewed as closely related to Serbs. Although adversaries with respect to the Macedonian question, they had suffered similar fates under the "Ottoman yoke." Županić was supported in his work by two Bulgarian university students who were likewise POWs. ${ }^{62}$ His findings confirmed his a priori opinion, formulated in his "system," that the population of northeastern Bulgaria was shorter in height than other Bulgarians. He suggested that their small size might be a result of immigration

58 Andrew D. Evans, "Capturing Race: Anthropology and Photography in German and Austrian Prisoner-of-War Camps during World War I," in Colonialist Photography: Imagining Race and Place, eds. Eleanor M. Hight and Gary D. Sampson (London: Routledge, 2002), 236.

59 Županić, "On the Anthropology of Ottoman Turks," 128-129.

60 Idem, "Visina uzrasta Turaka Osmanlija" [The body size of the Ottoman Turks], Vjesnik Etnografskog muzeja u Zagrebu [Bulletin of the Ethnographic Museum in Zagreb] 2, nos. 3-4 (1936): 9.

61 Andrew D. Evans, "Anthropology at War: Racial Studies of POWs during World War I," in Worldly Provincialism: German Anthropology in the Age of Empire, eds. H. Glenn Penny and Matti Bunzl (Ann Arbor, MI: University of Michigan Press, 2003), 225.

62 Županić, "The Pontic Bulgarians," 967-969. 
by "Mongolian" elements from southern Russian and central Asia during the Middle Ages. ${ }^{63}$

Županić published the results of his Bulgarian POW study in late 1913 in the journal of the Serbian Ministry of Education. ${ }^{64}$ Due to its largely descriptive character and the distraction posed by the Great War, the article had no major impact in Serbia or on other anthropological studies of POWs elsewhere. The same was true of his examinations of Turkish POWs. Županić was supposed to give a paper, Zur physischen Anthropologie der Osmanischen Türken [On the Physical Anthropology of the Ottoman Turks] at the 45th General Meeting of the German Anthropological Society in August 1914, but the war intervened. ${ }^{65}$ Only after the war did the results of his examinations find an outlet, as two articles published in Serbian. ${ }^{66}$

Bulgarian anthropologists undertook no anthropological examinations of POWs. Vatev had withdrawn from extended fieldwork. In the autumn of 1912, shortly before the mobilization of recruits for the First Balkan War, the young Drončilov measured about 450 soldiers and policemen on leave in southwestern Bulgaria. When the war began, he was himself drafted, but with the help of military authorities succeeded in measuring 90 soldiers from the southern Bulgarian region of Plovdiv. The results of his examinations formed the backbone of his doctoral dissertation titled Contributions to the Anthropology of the Bulgarians, written under the supervision of Luschan and defended in 1914 in Berlin. Compared to the large-scale examinations of Stefan Vatev and Jakim Pomadov, the number of persons he screened was relatively small, but where Vatev and Pomadov had been assisted by draft boards and military physicians, Drončilov had to conduct all the measurements himself. Drončilov made measurements of various body parts, which he presented in his appendix for each individual in scrupulous detail. ${ }^{67}$

Unlike those of Županić in Serbia, Drončilov's conclusions were rather minimalistic, in line with the cautious assessments that had characterized the work of Vatev. Drončilov was notable in ranking scientific rigor above national interests. He agreed with Županić that the brachycephalic type was more common in west-

63 Ibid., 970.

64 Ibid.

65 Louis J. Pirc, "Iz življenja Dr. Nike Zupaniča” [From the life of Dr. Niko Zupanič], in Niko Zupanič, Slovenija vstani! Ameriškim Slovencem: Govor ki ga je imel pred Slovenci v Clevelandu 28. aprila 1916 [Slovenia, stand up! To the American Slovenes. Speech he gave before the Slovenes of Cleveland on 28 April 1916], (Cleveland, $\mathrm{OH}$ : Tiskarna "Clevelandske Amerike" [Printing House of the "Cleveland American"], 1916), xxviii.

66 Županić, "On the Anthropology of Ottoman Turks"; idem, "The Body Size of the Ottoman Turks."

67 Krum Drontschilow, Beiträge zur Anthropologie der Bulgaren (Braunschweig: Vieweg, 1914). 
ern Bulgaria, and that it displayed similarities with the Herzegovinian or Dinaric type ${ }^{68}$ With respect to the origin of the Bulgarians, he remarked laconically that "among the contemporary Bulgarians, apart from the Slavic one, there is also a quantitative significant representation of the Finnish element." ${ }^{69}$ His summary, however, was merely a modest reaffirmation of Vatev's claims of 1898.

\section{The Great War}

Given the research opportunities apparently provided by the Balkan Wars, it is surprising that anthropology in the Balkans was largely inactive during World War I.

In the case of Serbia, one explanation might be that, shortly after the Austro-Hungarian declaration of war, Belgrade was put under continuous heavy shelling. The king and the government as well as the intellectual elite, were evacuated to the city of Niš-among them Županić, who had recently become custodian of the anthropological section of the Serbian Ethnographic Museum. In early 1915, the Serbian government assigned Županić the task of advocating Yugoslav unification among the Entente. Consequently, he became a member of the Yugoslav Committee, a pressure group of South-Slavic émigrés from the Habsburg monarchy that commuted between London and Paris, lobbying for the creation of a Yugoslav state. ${ }^{70}$

The Bulgarian occupation of eastern and southern Serbia, parts of Kosovo, and what is now the Republic of Macedonia could have offered enviable opportunities to conduct anthropological examinations in situ. But without Vatev, neither the government nor the army developed an interest in supporting major anthropological studies as had been the case at the turn of the century. Drončilov, who served in the Bulgarian army, had to wait until early 1918 to obtain a permit from the First Bulgarian Army staff to conduct anthropological examinations in western Macedonia and Bulgarian-occupied Kosovo. With the support of local commanders, he measured around five hundred Slavic Macedonians and one hundred Albanians. ${ }^{71}$ Drončilov's research paralleled that of the Austrian

68 Ibid., 30-31.

69 Ibid., 32.

70 Ljubinka Trgovčević, Naučnici Srbije i stvaranje Jugoslavije 1914-1920 [The scientists of Serbia and the creation of Yugoslavia 1914-1920] (Belgrade: Narodna knjiga-Srpska književna zadruga [National Book-Serbian Book Cooperation], 1986), 26-27, 29-32, 93, 104, 108-110, 124, 157-158, 187-191, 272, 275, 278; Promitzer, "Niko Županič and the Issue of Yugoslavism," 15-18.

71 Крум Дрончилов [Krum Drončilov], "Материали за антропологията на българите. І. Македонските българи" [Materials for the anthropology of the Bulgarians: I. The Macedonian Bulgarians], Годишник на Софийският 


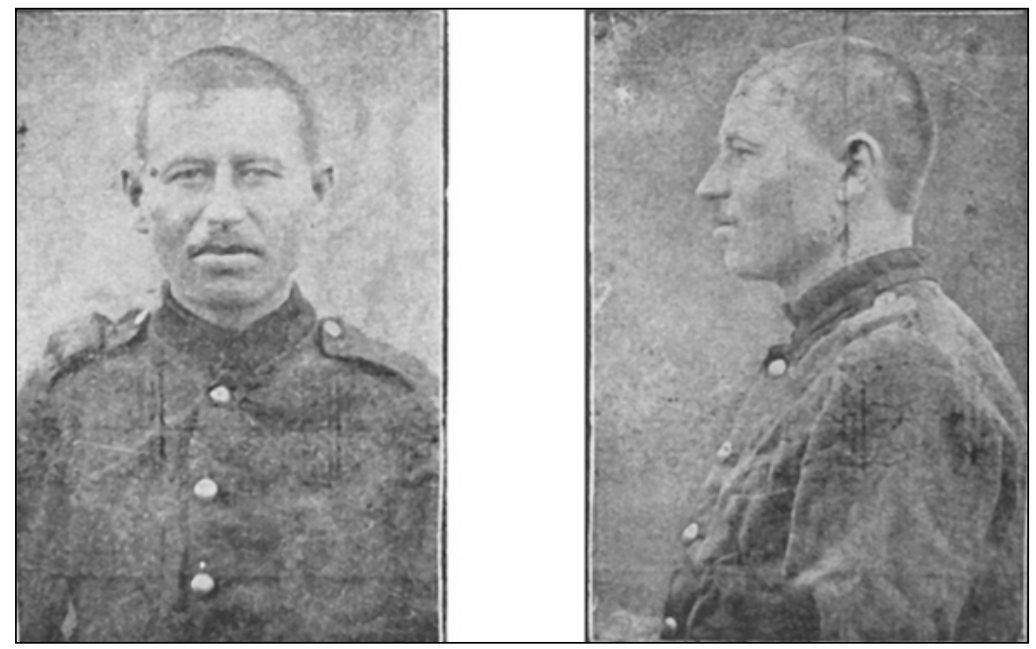

Figure 3. Albanian from the village Palčište/Pallçishti near Tetovo/Tetova in Macedonia. Source: Крум Дрончилов [Krum Drončilov], "Принос към антропологията на албанците" [Contribution to the anthropology of the Albanians], Списание на БАН [Journal of the Bulgarian Academy of Sciences] 21, клон-природо-математичен [Branch of Natural Science and Mathematics] 10 (1921): 111-134, section of photographs at the end of the article.

scholars Arthur Haberlandt (1889-1964) and Viktor Lebzelter (1889-1936), who, during the same period, examined over one hundred Albanians from the Austro-Hungarian occupation zones in Albania and Kosovo. ${ }^{72}$ But Drončilov failed to publish his results until the early 1920s, when their political uses had been mooted; both Macedonia and Kosovo were beyond postwar Bulgaria's reach. He no longer disavowed an alignment with long-term Bulgarian national policy, though making only sparing use of comments that could be construed as political. But his differing treatment of Slavic Macedonians and Albanians clearly expressed his bias. While conceding that there was no homogeneous anthropological type among the Slavic Macedonians, he did not question their

университет. І.Историко-филологически факултет [Yearbook of the University of Sofia. I. Faculty of History and Philology] 17 (1920-1921): 133-197; Idem, "Принос към антропологията на албанците" [Contribution to the anthropology of the Albanians], Списание на БАН [Journal of the Bulgarian Academy of Sciences] 21, клон природо-математичен [Branch of Natural Science and Mathematics] 10 (1921): 111-134.

72 Arthur Haberlandt and Viktor Lebzelter, "Zur physischen Anthropologie der Albanesen," Archiv für Anthropologie 17 (1919): 123-154. 
national affiliation as Bulgarians. ${ }^{73}$ With the Albanians, on the other hand, his way of proceeding recalls Županić:

The presented traits of the physical makeup of the Albanian population show in consequence that this population represents a colourful mixture of somatic elements. But it is still too early to answer the questions of how, when, and where these heterogeneous somatic elements gathered under a common culture, a common language, and a common ethnicity. ${ }^{74}$

Unlike the Macedonian Slavs, who were supposed to form part of the Bulgarian nation, the Albanians figured as an alien ethnic group, even when fighting in Bulgarian uniform, as the accompanying photographs show (Figure 3).

\section{Postwar Destinies}

In early 1919, Županić became a member of the "historical-ethnographic section," an advisory body to the official delegation of the recently founded Kingdom of Serbs, Croats, and Slovenes to the peace negotiations in Paris. Apart from coauthoring memoirs that supported Yugoslav territorial claims, ${ }^{75}$ he continued to utilize his racial theory for propaganda purposes.

In an article on "The First Inhabitants of the Yugoslav Lands," written in July 1918 and published in the first 1919 issue of the Revue Anthropologique, Županić reiterated his account of the Balkans as the "placenta" of brachycephalic populations. ${ }^{76}$ According to Županić, prehistoric "Mongolian" invaders brought brachycephaly to the Balkans, forever changing the long-headed, blond, blue-eyed South Slavs. ${ }^{77}$ In the American Journal for Physical Anthropology, the article was reviewed as a "useful anthropological sketch of the early inhabitants of the South-Slavic countries," but criticized for its "fanciful etymologies in trying to establish the Mongolian origin of the modern brachycephalic people."78

The article attacked "the gospel of pure Aryan origin" that Županić saw as dominating German science, ${ }^{79}$ but it was not a dismissal of Aryanism. While peace negotiations were still underway, Županić published Ave Illyria, a col-

73 Drončilov, "Materials for the Anthropology of the Bulgarians," 137, 166.

74 Idem, "Contribution to the Anthropology of the Albanians," 127.

75 Promitzer, "Niko Županič and the Issue of Yugoslavism," 18-19.

76 Niko Županić, Les premiers habitants des pays Yougoslaves: Ethnologie paléolithique et néolithique de I'Illyricum (Paris: Libraire Félix Alcan, 1919), 21.

77 Ibid., 21, 30.

78 Truman Michelson, "Les premiers habitants des pays Yougoslaves, by Županič," American Journal of Physical Anthropology 2 (1919): 343.

79 Županić, Les premiers habitants des pays Yougoslaves, 18-19. 
lection of essays in French financed by the government in Belgrade. One essay, "The Yugoslav Race and Blood," provided a racial explanation of South-Slavic unity, positing racial kinship between the South Slavs and the Albanians ${ }^{80}$ (to claim Albanian lands) and the South Slavs and the population of Veneto ${ }^{81}$ (to repudiate Italian claims to the eastern coast of the Adriatic). It included Županićs version of Aryan theory:

Although the Yugoslavs possess lots of Asian blood (melanobrachycephaly) and a little Hamitic blood (melanodolichocephaly), they are somatically and physically more Aryan than, for example, the Greeks, the Italians, the Spaniards, the southern French, the southern Germans, or the Rumanians. ${ }^{82}$

Consequently, the Yugoslavs were destined to play a major role in history.

Thus the South Slavs hope that, having poured out their blood in this war, they will continue the task for which they are chosen and prepared: regeneration in the east and the introduction of new elements into European civilisation. ${ }^{83}$

\section{Conclusion}

In both Serbia and Bulgaria, anthropology developed under German influence. In both countries, representatives of the discipline constituted a mere handful of researchers, and, for the most part, they conducted anthropology as a sideline heavily affected by their countries' subaltern positions in both the international arena and the academic world.

German anthropologists with direct influence in Bulgaria included Luschan at the University of Berlin and the Munich anthropologists Ranke and Birkner. Ranke also trained the Slovene racist Županić, Serbia's only committed anthropologist. Although he studied in Vienna, Županić showed scant influence of Austro-Hungarian anthropology, putting empirical data from Austro-Hungarian studies of Balkan populations (such as those of Weisbach, Leopold Glück, etc.) at the service his own theoretical speculations.

Bulgarian anthropology appears to have been committed to the earlier German anthropological tradition that Benoit Massin has called "racial liberalism," associated with inductive data-gathering and anthropometrics. In Bulgaria, this influence expressed itself in anthropologists' relatively high

80 Niko Zoupanitch, Ave Illyria (Paris: Société Générale d'Imprimerie et d'Édition Levé, 1919), 46.

81 Ibid.

82 Ibid., 46-47.

83 Ibid., 51. 
professional standing and their large-scale studies of recruits and schoolchildren. Lacking the resources of the Bulgarians, Županić concentrated instead on racial theories, which had already entered the German anthropological mainstream. His variations on Aryanism may also be traced to his interest in prehistory and linguistics, where speculative theories had traditionally played a larger role than in the narrower field of anthropology.

At least since the Enlightenment, the population of the Balkan Peninsula had been considered inferior, backward, and uncivilized. Such attitudes brought native anthropologists into a precarious position: Even in anthropology's "liberal" variant, they applied knowledge laced with intrinsic hierarchies that differentiated between a European "us" and a non-European "them." The Balkans were neither self nor Other; with their postcolonial setting following the end of Ottoman rule, they ranked somewhere "betwixt and between." Consequently, native anthropologists adopted epistemes from European anthropology as long as they were not in direct contradiction with their own national codes. Where contradictions occurred, they sought refuge in "nesting orientalisms," as Vatev's rebuttal of Deniker's amalgamation of Christian Bulgarians with Muslim Turks showed. Županić, on the other hand, gratefully appropriated Deniker's concept of the Adriatic/Dinaric race, hoping it would push the association of brachycephaly with racial inferiority into the background. He further tried to harmonize long heads with short by praising the advantages of racial mixture and diversity. But through the back door, he reaffirmed the hierarchy by pleading that the South Slavs had once had the appearance of the Nordic race and had lost it due to an unlucky combination of circumstances. Like Vatev, Županić was a "mimic man"-like a colonizer, but different ${ }^{84}$ - who could reproduce Western orientalisms on a smaller scale, to some degree vis-àvis Greeks and Bulgarians, but primarily vis-à-vis Albanians and Turks.

In both the Bulgarian and Serbian examples, we see attempts to formulate a canon of somatic traits typical for each nation, whose geographical distribution could be used to justify territorial pretensions. While Županić went to great lengths with his theory about the anthropological unity of the South Slavs, his Bulgarian colleagues, after initial optimism, refrained from such endeavors. In this context, it is intriguing that, although there were attempts to assess the affiliation of the Slavic population of Macedonia, the issue never played the preeminent role one might expect, given the pivotal place of the Macedonian question in the Balkan Wars and World War I.

While anthropological theories were enlisted to support military goals, the war years-in the Balkans from 1912 to 1918-offered the chance to study recruits and POWs. Županićs studies of POWs in the Balkan Wars may have

84 Maria do Mar Castro Varela and Nikita Dhawan, Postkoloniale Theorie: Eine kritische Einführung (Bielefeld: transcript, 2005), 90. 
been the first on European soil, but, due to the larger conflict that ensued, his dubious claim to fame did not gain international attention. The garrisons and POW camps of the Great War were not focal points for Balkan anthropologists; more often, they were focal points for typhus. One outbreak originating in a camp filled with Austrian POWs killed up to 150,000 people in Serbia in the spring of $1915 .{ }^{85}$ Despite Birkner's approving assessment of Bulgarian anthropology, the role of the Great War in its development should not be overestimated. After all, it took until 1918 for Drončilov to obtain permission to conduct his examinations of native populations in Kosovo and Macedonia.

For Županić, the peace negotiations after the war provided a forum for the dissemination of racial theories. But such anthropological argumentation was of use only to propagandists: Where scholars were invited to participate in drawing new maps, census data and ethnographic argumentation were considered more persuasive than the shapes of skulls. ${ }^{86}$

The end of the war ended an era in Balkan anthropology. The caesura was both biographical and methodological. Drončilov, who had a teaching position in geography and ethnography at the University of Sofia, died in an accident in 1925. ${ }^{87}$ Županić returned to Belgrade only briefly before moving to Ljubljana to become director of its newly founded ethnographic museum. Still in Ljubljana in 1940, he became a professor of ethnology at the age of sixty-one. ${ }^{88}$ A new generation of professionals-Božo Škerlj in Ljubljana, Boris Zarnik in Zagreb, and Branimir Maleš in Belgrade, to name the most important-became active in the second half of the 1920s in Yugoslavia. They were biological anthropologists and advocates of eugenics, and, from 1941 to 1945, with the exception of Škerlj who survived imprisonment in Dachau, they supported the quisling regimes. ${ }^{89}$ In Bulgaria, a school associated with the biologist Metodij Popov

85 Richard Pearson Strong et. al., Typhus Fever with Particular Reference to the Serbian Epidemic (Cambridge, MA: Harvard University Press, 1920); William Hunter, "The Serbian Epidemics of Typhus and Relapsing Fever in 1915: Their Origin, Course and Preventive Measures Employed for their Arrest," Proceedings of the Royal Society of Medicine 13, no. 2, Section of Epidemiology and State Medicine (1919): 29-158.

86 Andrej Mitrović, Jugoslavija na konferenciji mira 1919-1920 [Yugoslavia at the peace conference 1919-1920] (Belgrade: Zavod za izdavanje udžbenika SR Srbije [Institute for the Edition of Textbooks of the Socialist Republic of Serbia], 1969).

87 Анастас Иширков [Anastas Iširkov], "Д-р. Крум Дрончилов" [D-r. Krum Drončilov], Общ годишник за България (1926-1929) [General Yearbook for Bulgaria (1926-1929)] 3 (Sofia: Дружество на столичните журналисти [Society of the Capital's Journalists], 1928): 600-602.

88 Promitzer, "Niko Županič and the Issue of Yugoslavism," 19-20, 28.

89 Christian Promitzer, "Vermessene Körper: 'Rassenkundliche' Grenzziehungen im südöstlichen Europa," in Europa und die Grenzen im Kopf, eds. Karl Kaser, 
(1881-1954), which combined anthropometrics with blood-group analysis, came to power between the wars. Popov's magnum opus on the anthropology of the Bulgarians was published posthumously in 1959. ${ }^{90}$

One question remains to be answered: Why did Bulgarian anthropology before 1912 receive support from the state, the church, and the army, while Serbian anthropology in the same period remained virtually the private domain of a Slovene émigré historian? The one person who could have given Serbian anthropology a similar momentum was the geographer Cvijić, but his school of anthropogeography was more interested in ethnology than in taking anthropological measurements. The reason for his success, in turn, may have to be sought in the intrinsic logic of nationalism and nation-building: When the Serbian principality was founded in the early nineteenth century, nationalism played a secondary role. The self-image of Serbia as the nation-state of the Serbs only became important in the 1840 s. Since this period, national programs had been developed to address the issue of real and virtual, concentrated and scattered Serbian communities located in Hungary, Croatia, Dalmatia, BosniaHerzegovina, Montenegro, and the European provinces of the Ottoman Empire (Kosovo, Macedonia, and Albania). The diaspora was-as it still is-the central issue in Serbian nationalism. Anthropogeography fit that scheme perfectly, since it concentrated on ethnographic study and the historical reasons for migration. State resources were thus diverted away from physical anthropology.

Bulgaria, on the other hand, had established itself as a nation-state with its founding in 1878. But the move came late: Serbia, Romania, and Greece had already taken up positions in the neighborhood. Being latecomers, Bulgarian intellectuals felt uneasy about the rootedness of their nation; consequently, they were deeply committed to discussions about the origin of their nation, which was Slavic by language, but had a non-Slavic name. Oscillation between Slavism and its opposite became one of the leitmotifs of the modern Bulgarian self-image. They had to position their nation not only vis-à-vis the neighbors, but also vis-à-vis other Slavic nations-in particular the Serbs, but also Russia, with whom relations were volatile. Physical anthropology had an important role to play. How well it succeeded can be seen in Birkner's compliment that Bulgarian physical anthropology "has been hardly equalled, and never surpassed anywhere."91

Dagmar Gramshammer-Hohl, and Robert Pichler (Klagenfurt: Wieser, 2003), 384-387.

90 Методий Попов [Metodij Popov], Антропология на българския народ. 1. Физически облик на българите [Anthropology of the Bulgarian people: I. Physical shape of the Bulgarians] (Sofia: БAH [Bulgarian Academy of Sciences], 1959).

91 Birkner, "Die anthropologische Erforschung Bulgariens." 
Constructing a War Zone: Austrian Ethnography

in the Balkans 



\title{
Swords into Souvenirs: Bosnian Arts and Crafts under Habsburg Administration
}

\author{
Diana Reynolds Cordileone
}

\section{Colonialism, Orientalism, and the Exhibitionary Complex in Bosnia-Herzegovina}

Cultural politics was an integral part of the Austro-Hungarian civilizing mission in Bosnia as scholars, administrators, and ethnographers swarmed into the region after $1878 .{ }^{1}$ During the following two decades, their colonialist (and, at times, Orientalist) imaginations were incorporated into the exhibitionary complex of the Viennese metropole as new information about the region's geography, artefacts, people, and resources was regularly displayed in museums and international exhibitions until 1914.

One significant aspect of the culture of exhibition in Vienna was the taming of the Bosnian warrior. This involved a slow transformation from the image of a fierce enemy in 1878 into a picturesque and steadfast defender of the dual monarchy by the beginning of the Great War. This occurred in at least three ways. First, starting in 1885, the ethnographer Friedrich Salomo Krauss traveled throughout the territories at the behest of the Vienna Anthropological Society and began to document epic songs, the Guslarenlieder, as part of the legacy of Bosnia since the Middle Ages. ${ }^{2}$ Krauss's anthropological work

1 In this chapter, I use "Bosnian" and "Bosnia" in reference to the territory of Bosnia and Herzegovina as occupied and administered by the Habsburg monarchy from 1878-1908 and annexed in 1908. In addition, the term "Austrian" will be used to refer to the Austro-Hungarian monarchy and its agents in Bosnia.

2 Krauss traveled to the occupied territories in 1885 under the auspices of the Vienna Anthropological Society. See Christoph Daxelmüller, "Friedrich Salomo Krauss (Salomon Friedrich Kraus[s]) (1859-1938)," in Völkische 
validated the warrior traditions of the region while making them accessible to the scholarly gazes of the European anthropologist and folklorist. Second, the Bosnian warriors were physically transformed into an exotic and elite fighting unit in the Habsburg army. The Bosniak divisions of the kaiserliche und königliche Armee (k.u.k. army) created a stir wherever they were stationed and fueled widespread fantasies of former enemies now turned faithful sons of the Empire. ${ }^{3}$ Finally, the traditional weaponry of Bosnia was removed from the daily garb of the local population and transformed into quaint souvenirs for consumption by tourists and occupation soldiers. These artisanal crafts, along with their creators, were regularly displayed in Vienna and at international exhibitions, and their quality was meant to serve as proof of the civilizing effects of Austrian administration in the region. It is this last transformation of Bosnian artisanal traditions-swords into souvenirs-that is the subject of this chapter. After 1878, both colonialist and Orientalist rhetoric shaped the rehabilitation of Bosnian crafts, including weaponry and metalwork, in both Vienna and the occupied territories. The rapidly growing network of museums and international exhibitions helped to spread this message across western Europe.

The British historian Tony Bennett has coined the phrase the "exhibitionary complex" to describe the new institutions and disciplines of knowledge, such as art history and anthropology, that emerged in the second half of the nineteenth century. ${ }^{4}$ These scholarly disciplines worked hand in hand to exhibit their achievements at temporary events-such as World Fairs-and at the new public museums that proliferated in Europe after the London Crystal Palace Exhibition of 1851. For Bennett, the rise of the exhibitionary complex also represented a softer form of state power; its denizens organized knowledge for the purpose of "winning the hearts and minds" of citizens, educating the masses and communicating state ideologies.

Wissenschaft: Gestalten und Tendenzen der deutschen und österreichischen Volkskunde in der ersten Hälfte des 20. Jahrhunderts, ed. Wolfgang Jacobeit (Vienna: Böhlau, 1994), 461-476; Friedrich S. Krauss, Slavische Volksforschungen: Abhandlungen über Glauben, Gewohnheitsrechte, Sitten und Bräuche und die Guslarenlieder der Südslaven; Vorwiegend auf Grund eigener Erhebungen (Leipzig: Wilhelm Hiems, 1908); idem, "Thomas Dragicevic 'Guslarenlieder aus Bosnien und dem Herzogsland,'” Am Ur-Quell 1 (1890): 2-6.

3 Werner Schachinger, Die Bosniaken kommen! Elitetruppe in der k.u.k. Armee 1879-1918 (Graz: Leopold Stocker Verlag, 1989). See also Christoph Neumayer and Erwin A. Schmidl, eds., The Emperor's Bosniakes: The BosnianHerzegovinian Troops in the k.u.k. Army (Vienna: Verlag Militaria, 2008).

4 Tony Bennett, "The Exhibitionary Complex," in Grasping the World: The Idea of the Museum, eds. Donald Preziosi and Claire Farago (Aldershot, UK: Ashgate, 2004), 413-441. 
Colonialist and Orientalist approaches to the occupied territories shaped the exhibitionary complex in Vienna. Despite its lack of overseas colonies, the Habsburg monarchy behaved like a colonial power in Bosnia. In this, Austria was no different from the other European "Great Powers" that were busily dividing the world amongst themselves. The Berlin Congress of 1878, and the resulting Berlin Treaty, authorized Austria to occupy and administer the Ottoman territories, thereby bringing forth a new era of global imperialism. The same congress awarded the island of Cyprus to the British Empire, thus setting the stage for its occupation of Egypt. Meanwhile, it was generally understood that France would eventually occupy Tunisia in compensation for this gift to the British. Within a few years, England and France had acted on these opportunities and the scramble for Africa began in earnest. From a global perspective, therefore, with the Austrian occupation of Bosnia began the era of "new imperialism."

This seemed clear enough at the time, and many Europeans interpreted the occupation of Bosnia as a colonial move; Bosnia was the Austrian alternative to a colony in Africa. As a parliamentarian in the German Reich expressed it during a colonial debate, Austrians had the better deal: "That little slice of Herzegovina could well be worth more than the whole of East Africa." $\mathrm{A}$ habsburgtreu Czech used another colonial metaphor: "In terms of geographical science, Bosnia and Herzegovina have been very much like the great white spaces on the maps of central Africa." Bosnia was Austria's Africa, an unknown space on the map of southeastern Europe, waiting to be rescued from Ottoman tyranny, explored, mined for its wealth, and brought into the light of Western scholarship. This was the colonial fantasy about the occupied territories that inspired so many immigrants from the core of the monarchy.

Both the proximity of Bosnia to the dual monarchy's borders and its Ottoman past also fueled the Orientalist fantasies of its occupiers. Andre Gingrich has described the interaction between occupiers and the occupied as "frontier Orientalism," a process that, unlike Edward Said's definition of Orientalism, was shaped by relatively short distance between Austria's borders and the occupied territories. This resulted in a feeling of familiarity mixed with fear; a master narrative that had two components with regard to the inhabitants of the region:

On one hand he [the Bosnian] appears as a dangerous Turkish soldier, an armed representative of another high culture, an equal military foe whose defeat is neces-

5 "Das bisschen Hercegovina sei noch immer mehr werth, als ganz Ostafrika," Bosnische Post 6, [Sarajevo] January 30, 1889, 1. The Bosnische Post was the government-sponsored German-language newspaper in Sarajevo.

6 Abel Luksič, Bosnien und die Hercegovina Lexikon (Prague: Alois Hynek, 1878), 1. 
sary for one's own imperial ascent. On the other hand, he appears as a subjugated Bosnian colonial who remains loyal to the end, fighting against the enemies of the Empire. $^{7}$

Bosnia was administered and exhibited within a shifting perspective that was both colonialist and Orientalist.

In keeping with both perspectives, however, Austrians believed that it was incumbent upon them to introduce civilization to the former Ottoman regions. During a visit to Sarajevo in 1888, Crown Prince Rudolf declared: "Our mission [here] is to bring western culture to the Orient." ${ }^{8}$ For patriots, the enlightened administration of the territories was to serve as a model of colonial rule for other Great Powers. Those wishing to understand how to rule their overseas colonies wisely and well need only look at the Austrians in Bosnia. ${ }^{9}$ This became the central thesis of the Habsburg officials charged with administering Bosnia. To trace its course through the exhibitionary complex, we begin with a case study: The Bosnian peddler.

\section{The Bosnian Peddler}

Vienna was a multicultural and cosmopolitan city in the late nineteenth century. As the imperial capital of a multinational empire and a growing industrial center, it was home to a variety of ethnic groups ranging from Bohemian factory workers to Galician Jews. In the late 1880s, however, one more colorful figure could be seen on the streets of Vienna: the Bosnian peddler, selling his wares from door to door. An article in the Bosnian Post described him in the following way:

These peddlers from "new Austria" are clothed in the national costume, wearing narrowly pleated pants, colorful bordered jackets, the fez, and wide belts which hold a threatening array of small weapons. Carrying practically an entire arsenal, these peddlers are a walking warehouse of ivory-inlaid knives, match boxes, and cigar holders made of rosewood. [...] These peddlers are a type of pioneer, who seek to find a market for their admittedly modest goods in the great metropole of the Empire. They give an Oriental flair to Vienna's streets, but they are also a constant reminder of our mission in the East. ${ }^{10}$

7 Andre Gingrich, "Frontier Orientalism," 2006, http://campcatatonia.org/ article/1555/frontier-orientalism (accessed February 17, 2010).

8 Bosnische Post 5, [Sarajevo] June 17, 1888, 2.

9 Henri Moser, Bosnie-Herzegovine: Une œuvre de colonisation pacifique dans les Balkans (Paris: V. Goupy et G. Maurin, Successors, 1896).

10 "Bosnische Hausierer in Wien," Bosnische Post 6, [Sarajevo] February 13, 1889, 2-3. 


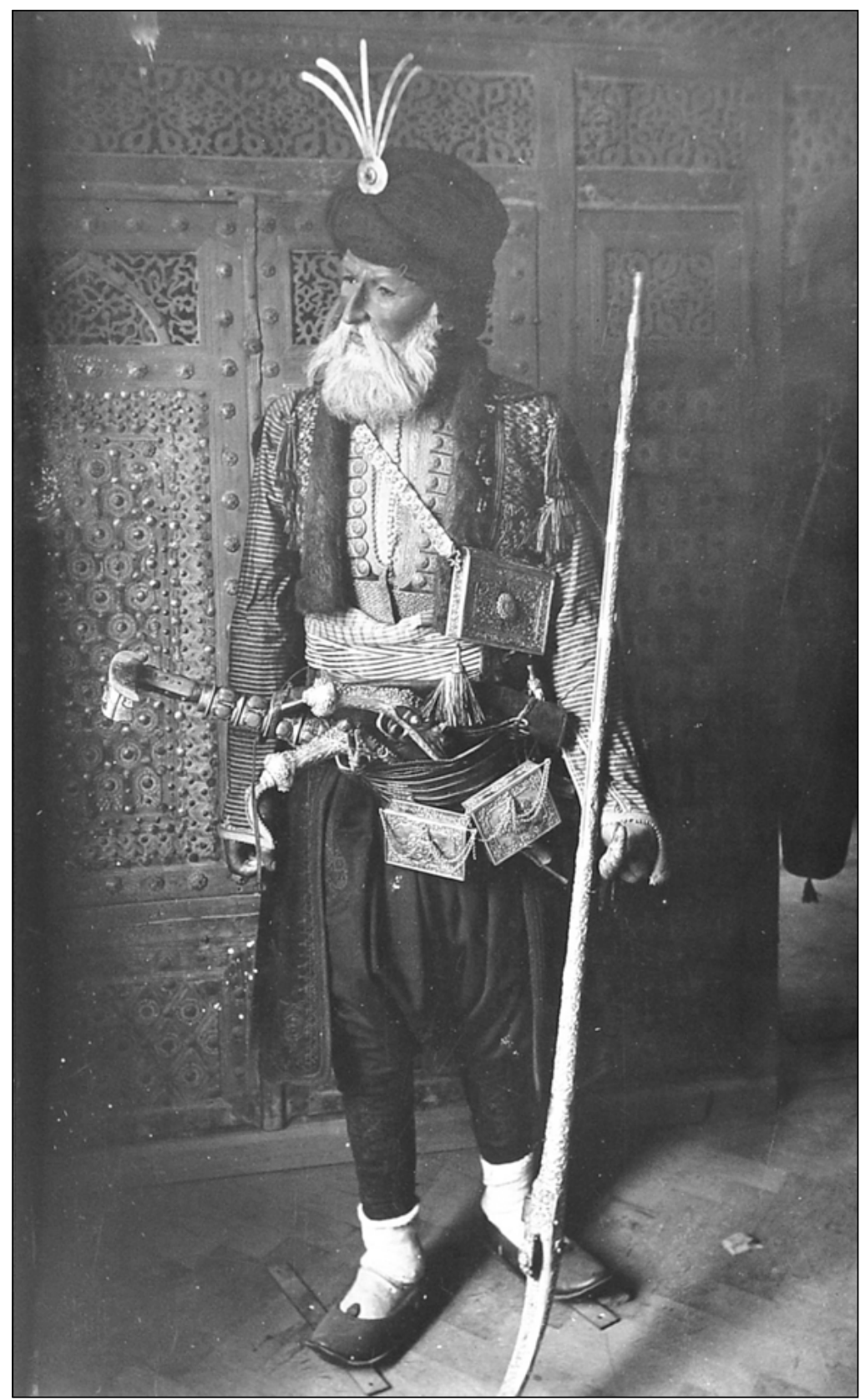

Figure 1. "Mohammedaner (Aga) aus Sarajevo im Waffenschmuck," as displayed in the Landesmuseum, Sarajevo, circa 1899. Source: Historical Archive of Sarajevo, Photograph Archive, Inv. No. 1276. 
The Bosnian peddler might have resembled a poorer version of a mannequin in Sarajevo's Regional Museum (Zemaljski muzej-Landesmuseum), which was created at about the same time (Figure 1). The figure presents a Muslim aristocrat, whose smiling eyes and gentle demeanor are in sharp contrast to the weapons he carries. His right hand holds a flintlock and his fabric belt is stuffed with daggers and pistols. This benign and tamed Muslim (who was later displayed in Vienna in 1891) ${ }^{11}$ was an ideological construction, but, for the moment, let us simply imagine a more shabbily clad version of this figure and we can picture our Bosnian peddler. The lively and humorous description of the peddler as bristling with weapons on the streets of Vienna is rich with the vocabulary of the Austrian colonial/Orientalist imagination; the occupied territories are christened "new Austria"; the fierce-looking Bosnian is merely a simple peddler who is a cultural pioneer; he is not a threat, but a reminder of the Austrian civilizing mission to the East.

The items in his arsenal-knives, pistols, and powder boxes-were part of one of the most important initiatives of Austria's administrators in Bosnia: the revival and rehabilitation of Bosnian crafts. The outcome of this process was intended not only to improve Bosnian products, thereby creating successful local businesses, but also to create loyal Bosnians, grateful to their new masters for the gifts of education and modernization. In Vienna, on the other hand, the process involved communicating a colonial and Orientalist ideology to the citizens of the metropole while recasting the populations of Bosnian as happy subjects of Austro-Hungarian rule. A postcard from Sarajevo published two decades after the occupation depicts this fantasy projection as docile metalworkers toiling diligently in an orderly government craft atelier (Figure 2).

Yet, the population of Bosnia was not so pacific in 1878. Despite the hopes of the Foreign Minister, Count Julius Andrássy, that the Austrian forces could occupy the territories with little effort ("a squadron of Hussars and a regimental band"), ${ }^{12}$ the Habsburg forces met with serious resistance from well-organized forces: the national militia from Sarajevo and organized bands of Muslim and Serbian fighters. This delayed the progress of Austrian troops, and the fight for Sarajevo was unexpectedly difficult. After a delayed entry into Sarajevo on 19 August 1878, the Austro-Hungarian commander Josef Freiherr Philippovich von Philippsberg requested reinforcements; eventually, over 250,000 men (roughly one-third of the total Austro-Hungarian

11 Karl Masner, Die Costümausstellung im k.k. österr. Museum 1891 (Vienna: J. Löwy, 1894); Wissenschaftliche Mittheilungen aus Bosnien 2 (1894): 504-508; Katalog der bosnisch-herzegowinischen Abtheilung, Costüme-Ausstellung im k.k. österreich. Museum (Vienna: Cárl [Carl] Gerold's Sohn, 1891).

12 Engelbert Deusch, "Andrassy und die Okkupation Bosniens und der Hercegovina," Oesterreichische Osthefte 12 (1970): 18-36. 


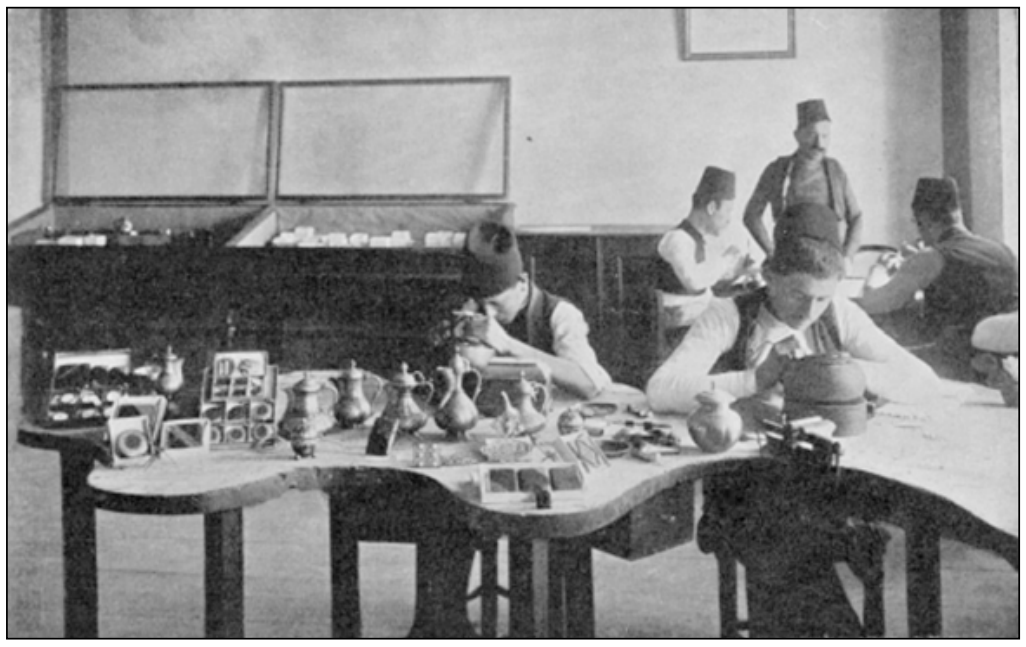

Figure 2. Metalworkers in the Kunstgewerbeschule in Sarajevo. Source: The Studio, special issue of Peasant Art in Austria and Hungary, ed. Charles Holme (London, 1911).

army) were required to put an end to the resistance. The ferocity of the fighting was legendary and made difficult by the locals' knowledge of the terrain. Like their Montenegrin neighbors, the mountain fighters in Bosnia had the ability to melt away before the Austrian forces only to reappear in guerilla operations elsewhere..$^{13}$ Accounts of decapitation and mutilations at the hands of Bosnian insurgents circulated in Vienna. ${ }^{14}$ This legend, although it had some basis in fact, was likely exaggerated after 1878, for the "warlike" populations of southeastern Europe were part of a standard topos of travel literature well before the military occupation. ${ }^{15}$ An English visitor to Sarajevo in 1875 (shortly before the uprising) described the proliferation of weapons and the restive population in the old city:

13 Ursula Reber, "Habsburgische Begegnungen mit nomadischen Kriegerstämmen Montenegro als strategischer Schauplatz," Kakanien Revisited, http:// www.kakanien.ac.at/beitr/fallstudie/UReber4 (accessed February 17, 2010).

14 For a discussion of the "imperialist myth" and other misconceptions that shaped Habsburg strategy in 1878, see Robert Donia, "The Battle for Bosnia: Austrian Military Strategy in 1878," in Posebna Izdanja 8 (Sarajevo: Akademija Nauka I Umjetnosti Bosne I Hercegovine, 1979), 109-129. For a broader discussion of the region, see Bela K. Kiraly and Gale Stokes, eds., Insurrections, Wars, and the Eastern Crisis in the 1870s (New York: Columbia University Press, 1985).

15 Cf. Clemens Ruthner, "Kakanien's Little Orient," Kakanien Revisited, http:// www.kakanien.ac.at/beitr/fallstudie/CRuthner5 (accessed February 17, 2010). 
Another street [in Sarajevo] resounded with the hammers of coppersmiths, moulding their metal into coffee-pots or platters; [...] or we came upon a group of armourers' shops-to-day ominously thronged-bristling with knives and swords of the famed Bosnian steel. ${ }^{16}$

These ominous throngs eventually became the resistance of 1878 , and Austrians contended with insurgents, who were often called brigands for political purposes, for four years after the military occupation. The Bosnian warrior was a fearsome opponent. After the military government had succeeded in establishing order, Bosnia was transferred to a civilian government in 1882. Now the mission of Austrian rulers was to subjugate, tame, and redirect this warrior spirit into patriotic channels.

In 1882, the Hungarian nobleman Benjamin von Kállay (1839-1903) was named the Reichsfinanzminister, thereby becoming the first civilian administrator of the region. ${ }^{17}$ Kállay firmly believed that institutions of good government would eventually create loyal subjects. In an interview with the English newspaper, The Daily Chronicle, he described his aims:

To make the people contented, to ensure justice, to develop agriculture, to render communication easy and cheap, to spread education, to retain the ancient traditions of the land vivified and purified by modern ideas-that is my administrative ideal. [...] Austria [...] is a great Occidental Empire, charged with the mission of carrying civilization to Oriental peoples $[\ldots]{ }^{18}$

Here, he characterized the local population in colonial terms, yet these were not the untamed barbarians of Africa. The region retained the cultural legacy of Ottoman civilization, yet its peoples were still in need of modernization and civilization according to Western standards. In the years that followed, Kállay attempted to introduce Western standards of industry, scholarship, and education. To revive and purify Bosnia's artisanal traditions, Kállay employed the exhibitionary complex of Vienna. One of several outcomes of this effort was the Vienna-directed transformation of traditional Bosnian weaponry into exotic trinkets for the tourist trade. Another outcome was the spread of his gospel of the civilizing mission about Bosnia into the metropole.

16 Arthur J. Evans, Through Bosnia and the Herzegovina on Foot during the Insurrection, August and September 1875, reprint ed. (New York: Arno Press, 1971), 274.

17 Tomislav Kraljačić, Kalajev Režim u Bosni I Hercegovini (1882-1903) (Sarajevo: Veselin Masleša, 1987).

18 "Round the Near East" [Interview with Benjamin von Kállay], The Daily Chronicle, October 3, 1895. 


\section{Vienna in Sarajevo}

By the late 1880s, the effects of Austrian administration in Sarajevo were visible in a variety of ways. Monumental construction projects, such as the new cathedral or the government palace, had begun to recreate the urban landscape of the provincial capital. ${ }^{19}$ The influx of soldiers, entrepreneurs, and administrators contributed to a significant rise in population and the ethnic and religious diversity of the city. ${ }^{20}$

Kállay's motives for reviving Bosnian crafts were more than colonial rhetoric, however. An important mandate of his government was to develop the economy along capitalist lines. When Kállay embarked on his program to rehabilitate Bosnian crafts, he had already noted the decline of local industries due to the influx of cheap industrial products from western Europe. ${ }^{21}$ Kállay envisioned creating viable local industries that could compete with Western products, thereby enhancing Austrian prestige as a faithful steward of the mandate of 1878. More importantly, however, Bosnian crafts were probably intended to serve as a source of revenue for the administration, as the Austrian and Hungarian delegations that approved the occupation declined to authorize funds to support civilian administration of the territories. Thus, Kállay had to find new and creative ways to finance his administration. This was one "colony" that had to pay for itself. ${ }^{22}$ No doubt he hoped that sales of Bosnian crafts would ultimately contribute to the administration's annual budget.

In addition, Kállay's efforts to revive and purify Bosnian crafts were undoubtedly one component of his larger effort to create a regional identity, Bosnianism (Bošnjaštvo), to promote loyalty to the territory of Bosnia. Amidst all the stylistic influences from the Byzantine, Venetian, and Ottoman Empires, whose trade routes had crisscrossed the region, in the 1880s many scholars began an intensive search for an indigenous "Bosnian" style derived from medieval Bogumil tombstones. A "national style" in ornament that predated the emergence of ethnonationalism might have been an effective weapon

19 See Robert J. Donia, Sarajevo: A Biography (Ann Arbor, MI: University of Michigan Press, 2006), 67-82.

20 Valeria Heuberger, "Politische Institutionen und Verwaltung in Bosnien und der Hercegovina 1878-1918," in Die Habsburger Monarchie 1848-1918, vol. 7 (Vienna: Verlag der österreichischen Akademie der Wissenschaften, 2000).

21 Archiv BiH, ZMF-prz., B.H. 91/1887; Kučna Radinost, Šifra 43/14/7; Benjamin von Kállay, "Zur Frage des kunstgewerblichen Reforms im OccupationsGebiet," Wien, 10 February 1887.

22 Robert J. Donia, Islam under the Double Eagle: The Muslims of Bosnia and Hercegovina 1871-1914 (New York: Eastern European Monographs, 1981), 11. 
against the surging Serb and Croat nationalist movements. (Muslim nationalism was still decades away.) This effort eventually failed. ${ }^{23}$

Whatever his many motives, to accomplish his aesthetic and commercial goals, Kállay relied on an extensive system of craft education that was already well-established in Cisleithanian Austria. Since 1863, the Austrian Museum for Art and Industry in Vienna had managed craft education through a welldeveloped network of local and regional craft schools. The focus of the $\mathrm{Mu}-$ seum had begun with industrialists, but, since the 1870s, the Museum and its educators had become more deeply involved in the improvement of the folk arts in the peripheral regions of the Empire where industrial processes had not yet completely displaced local handicrafts. ${ }^{24}$ In an effort to sustain the local populations and give them livelihoods beyond agricultural work, several schools for national "cottage industry" [Hausindustrie] were created in the 1870s. By the time Kállay began his intiative, the Museum in Vienna had already experienced some success in popularizing a variety of ethnic crafts (folk arts) through its nexus of education and display.

Kállay adopted the Viennese model for Bosnia by establishing government craft ateliers in Sarajevo, Livno, and Foča that brought local artisans into contact with craft educators from Vienna. ${ }^{25}$ The artisans' willingness to enter a government-sponsored atelier was probably an indicator of the degree to which craft production had indeed suffered through cheap foreign imports. Kállay's plan included a diverse set of schools for various crafts including carpets, embroideries, wood, and metalworking. One branch of Kállay's initiative involved the now-defunct weapons industry the English visitor had described in 1875. These were the ateliers dedicated to metal and mother-of-pearl inlay, ornaments from the Turkish traditions that were commonly found on pistols, sabers, and daggers; and these trades were practiced exclusively by Muslims. Kállay began his project just in time; according to government lore, in 1887 only one living practitioner of metal wire inlay could be found and brought to the atelier. ${ }^{26}$ Although he died within the year, the authorities prided themselves in having saved the craft from extinction.

23 For a discussion of Bosnianism and its relationship to the Bogumil traditions, see Donia, Sarajevo, 88-91.

24 For a detailed history of the origins of the Austrian Museum, see the exhibition catalog Kunst und Industrie, ed. Peter Noever (Ostfildern-Ruit: Hatje Cantz Verlag, 2000). For a discussion of the house-industry schools, see Diana Reynolds [Cordileone], "Die österreichische Synthese" in that volume, 209-218.

25 Bericht über die Verwaltung von Bosnien und der Hercegovina 1906 (Vienna: k.u.k. gemeinsamen Finanzministerium, 1906).

26 Anonymous, "Bericht über eine Reise nach Bosnien," Khartoum, 11 September 1905. Sarajevo Archiv BiH, ZVS 1905, K. 123, Šifra 115-29/05, p. 6. 
But rehabilitating Bosnian crafts meant refining them for urban markets. Kállay's plan would only succeed if the crafts attracted customers in the cities. The Bosnian peddler's "modest goods" and "crude wares" must be transformed into attractive consumer items. ${ }^{27}$ As a result, craft educators in Bosnia had the dual mandate to retain Bosnian traditions and inculcate the aesthetic principles of the West. This meant exposing local artisans to the aesthetic standards of the metropole. To this end, the Sarajevo silversmith, Mustafa Bektić, traveled to Vienna to study principles of classical drawing at the Museum for Art and Industry's Kunstgewerbeschule in $1889 .{ }^{28}$

In addition, the cadre of craft teachers from Austria (each an absolvent of the craft education system) arriving in Bosnia after 1887 brought their tastes and training with them. After being assigned to Sarajevo in the 1890s, the Czech born craft school teacher Alois Studnička wrote design handbooks in the local language that introduced the major historical styles for application in mosaics, inlaid wood, or drawing. ${ }^{29}$ In this sense, arts and crafts education in Sarajevo was a hegemonic discourse that emanated from Vienna. The taste for historical styles, from antiquity to the Renaissance, came with the new instructors.

At the same time, however, ethnographers were rediscovering another set of motifs for artisans. The Regional Museum in Sarajevo, established in 1884 , began to amass a large collection of weapons, textiles, and other objects that became the foundation of ethnographic research. ${ }^{30}$ The Museum's best examples of craft items were also shared with the craft schools, permitting students to observe and imitate well-made objects. In this way, an institution of the emerging exhibitionary complex interacted with education, artisanal traditions, and commerce in Sarajevo.

A rhetoric of redemption and paternalism accompanied these projects. The goal of craft education in Bosnia was not only to rescue and refine local tradi-

27 Bosnische Post 5, [Sarajevo] February 13, 1889, 2-3.

28 Bektić was given a contract to teach in a government atelier in 1888. Sarajevo, Archiv BiH Allgemeine Landesregierung, 1888 god. Kutija 8/ K 58 42-370, 137.

29 Alois Studnička, Zbirka Pregledalcia za prostoruko crtajne Il: Intarzije (Sarajevo: Zemaljska Vlada da Bosnu I Hercegovina, 1898). See also, Lada HubatováVacková, "Vulcan's Engagement to Venus: Alois Studnička's Venture into the Applied Arts," in Umění Art (Journal of the Institute of Art History of the Academy of Sciences of the Czech Republic) 5, LVIII, 2009: 453-468.

30 For an excellent description of the formation of the Regional Museum, see Donia, Sarajevo, 88-91; Constantin Hörmann, "Zur Geschichte des BosnischHercegovinischen Landesmuseums," Wissenschaftliche Mitteilungen aus Bosnien 1 (1893): 1-25, and Marian Wenzel, Bosanski stil na stećcima i metalu [Bosnian style on tombstones and metal] (Sarajevo: Sarajevo Publishing, 1999), 21-30, 171-180. 
tions, it was also intended to create a generation of grateful subjects. As Markus Nani, the Czech-born director of the Construction Woodworking School, told his graduating students in 1900, it was their task to remain grateful to the government. "Do not forget," he admonished, "the fatherly care that the government has dedicated to your education." ${ }^{31}$ Despite the generous investment of the administration, however, craft education in Bosnia was not intended to turn the "sons into the fathers." 32 The rehabilitation of Bosnian craft was a mixture of paternalist pedagogy and colonialist rhetoric conducted by Austrian administrators. Yet, the influence of the Austrians was not unilateral. Bosnia was becoming part of the colonial/oriental imagination of western Europe.

\section{Sarajevo in Vienna}

The institutions of the exhibitionary complex introduced the mystique of Bosnia-Austria's colonial orient-to the metropoles of western Europe. Starting with its own offices and expanding into local and international exhibitions, Kállay's administration [Landesregierung] disseminated the message of cultural redemption and the benefits of Austrian rule.

The office for craft education in Bosnia was located in Vienna's first district, not far from the Museum for Art and Industry. The "Bosnian Bureau" (as it was called) occupied three different sites between 1881 and 1905 and, with each move, the space became larger and more sumptuous. The most interesting aspect of the Bureau, however, was that it combined office and retail spaces. Administrators worked on the upper floors, but the ground floor was a shop for Bosnian crafts. Objects produced at government ateliers in Sarajevo made their way directly to the shop in Vienna. ${ }^{33}$ Both the office letterhead and advertisements in local journals depicted the arts and crafts of Bosnia (Figure 3).

To publicize its efforts, the administration also sponsored regular exhibitions of Bosnian crafts at other locations in Vienna. Starting in 1888, the Landesregierung participated in the annual Christmas exhibition at the $\mathrm{Mu}-$ seum for Art and Industry. Due do their exotic appeal, the Bosnian crafts attracted a great deal of public attention and sold out quickly. For the adminis-

31 Bosnische Post 17, [Sarajevo] January 3, 1900, 3.

32 Bosnische Post 6, [Sarajevo] December 10, 1889, 1.

33 Archiv BH, ZVS VI; Prz, B.H. 1892 4-41/92, Kunstgewerbe und Gewerbeförderungsamt (1892) 44-1/KG. Carpet design no. 2, weighing 24.5 kg., measuring $4.80 \mathrm{~m} \times 4.80 \mathrm{~m}$, was delivered to Vienna "for the office of Herr Ministerialrath Schmulmayer." Most of the other carpets in this shipment were intended for sale. The cost to produce each carpet is carefully noted in each shipment. 


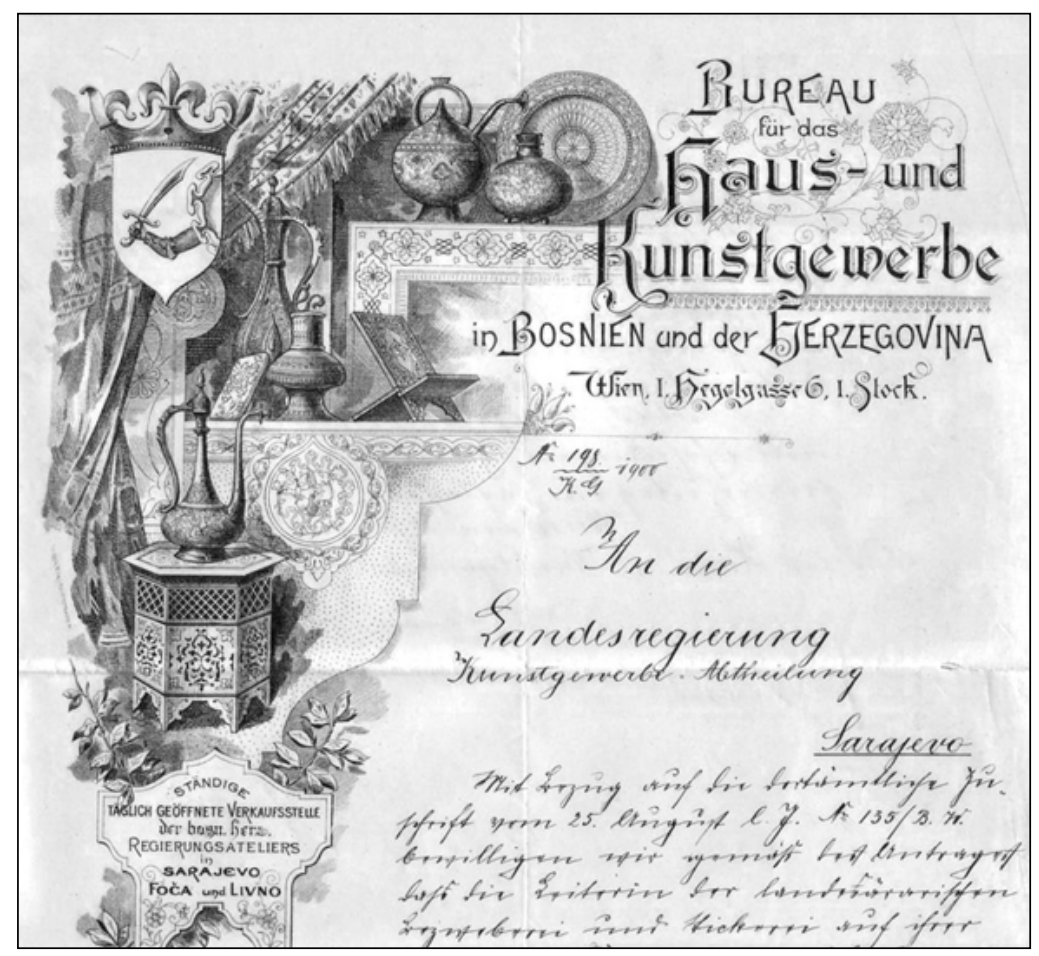

Figure 3. Letterhead for the Bureau für das Haus- und Kunstgewerbe in Bosnien und der Herzegovina, located in Vienna 1, Hegelgasse 6. Photograph by author.

tration, this was an unmitigated public success and Bosnian crafts were sold at every annual Christmas bazaar thereafter.

But the displays of Bosnian crafts in Vienna were not merely commercial. In 1889, the Bosnian carpet factory and school contributed Bosnian carpets to the Museum for Art and Industry's twenty-fifth anniversary exhibition. The Bosnian carpets, which had been "improved" by the Vienna Kunstgewerbeschule director, Josef von Storck, were hailed as the crowning decoration of the exhibition. ${ }^{34}$ They also unmasked the hybrid character of craft rehabilitation in Bosnia. As one observer blithely noted: "The wool is of Bosnian origin, [...]

34 Allgemeine Kunst-Chronik 13 (1889): 233-234. This article, entitled "NewAustria's Arts and Crafts" details the activities of the crafts schools and the Regional Museum in Sarajevo. Cf., Bosnische Post 6, [Sarajevo] December 11, 1889, 54-55. For Storck, the Museum's Kunstgewerbeschule, and Storck's involvement in Bosnian crafts, see Ulrike Scholda, "Theorie und Praxis im Wiener Kunstgewerbe des Historismus am Beispiel von Josef Ritter von Storck 1830-1902" (dissertation, Salzburg, 1991), 54-55. 
[but] it is brought to Vienna to be dyed and then sent back down there to be worked. Also the designs and motifs are old, but they have been happily updated and refined by Storck's artistic hands." ${ }^{35}$

No one seemed to notice the paradoxes inherent in taking wool from Bosnia, dyeing it in Vienna, and returning it to Bosnia to be woven into carpets according to improved designs. ${ }^{36}$ The revival of Bosnian carpets occurred under the supervision of Viennese educators utilizing the superior industrial techniques of the metropole. Both colonizers and colonized were deepening their reciprocal dependence, supinely and largely subconsciously accepting the roles assigned to them by the Austrian imperial mission.

The exotic appeal of Bosnia in Vienna created another public sensation in 1891 at the Museum for Art and Industry's Costume Exhibition. The Museum had planned an extensive historical exhibition, but, at the last minute, its administrators accepted Kállay's offer of a collection of ethnographic costumes from the Regional Museum in Sarajevo. The costume collection in Sarajevo had grown steadily and, inspired by the mannequins of Swedish folk costumes at the Paris Exhibition of 1889, administrators in Sarajevo had recently ordered a set of lifelike mannequins for its collection. These were no ordinary mannequins, however; each figurine was designed to correspond visually (skin color, facial features, and hair color) with the ethnic or regional origins of its costume. ${ }^{37}$ In addition, each figurine was furnished with the appropriate accessories to complete its look: pistols, pipes, looms, metal bowls, or carpets, as appropriate. When the two dozen figures from Sarajevo were arrayed in the Museum for Art and Industry's entrance hall, they quickly became a major attraction. Twenty more figures were stationed throughout the Museum. Insofar as the lifelike figures carried the attributes of their ethnicity, religion, and occupation they blended scholarly accuracy with the public spectacle of colonial exhibitions. For special effect, the genial Bosnian nobleman (Figure 1) was stationed in the center of the entrance hall, welcoming visitors to the display. This figure became a standard image of Austrian rule in Bosnia. His smile indicated that, despite his weapons, Austrians now had nothing to fear from this Bosnian. A wise and tolerant occupation government had won over the local population.

These mannequins became the administration's silent ambassadors, gracing every subsequent international exhibition of the Bosnian Landesregierung. Exhibition organizers used heraldic arrangements of weaponry, glass vitrines, and armor-clad mannequins to display both old traditions and new products from the craft schools. Most of the latter were for sale (Figure 4). The rehabili-

35 Allgemeine Kunst-Chronik 13 (1889): 235; see also Scholda, Theorie und Praxis im Wiener Kunstgewerbe, 55.

36 Allgemeine Kunst-Chronik 13 (1889): 233.

37 Archiv BiH ZVS, Zemaljski Museji, 1890, Šifra 41-77, p. 3-5. 


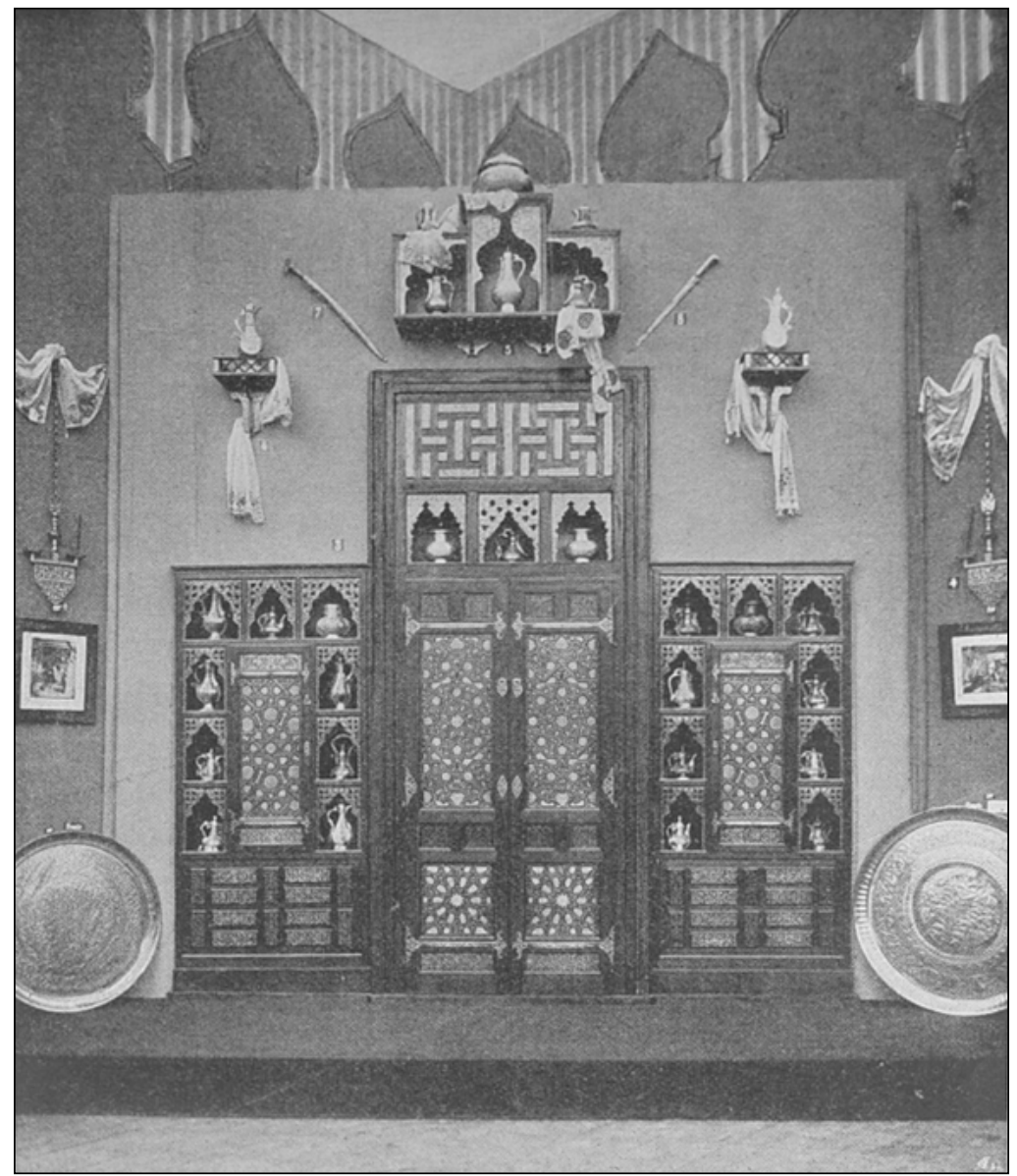

Figure 4. Bosnian arts and crafts, Brussels International Exhibition, 1897. Source: Nada 3 (1897): 225.

tation of Bosnian craft traditions blended the scholarship and spectacle of the exhibitionary complex and a colonial/Orientalist rhetoric of a civilizing mission, with an added commercial twist. ${ }^{38}$ The revival of Bosnian craft was taken as proof of Austria's benign administration of its proximate colony.

Meanwhile the aesthetic improvement of Bosnian/Turkish weaponry was accompanied by several changes in its use. Back in Sarajevo, the right of Muslims to carry weapons became severely restricted under Austrian administration. As one observer noted: Under the Ottomans, Bosnian men "armed

38 Das Kunstgewerbe in Bosnien und der Hercegovina auf der deutschen FächerAusstellung in Karlsruhe 1891 (Vienna: Reisser \& Wethner, 1891). 


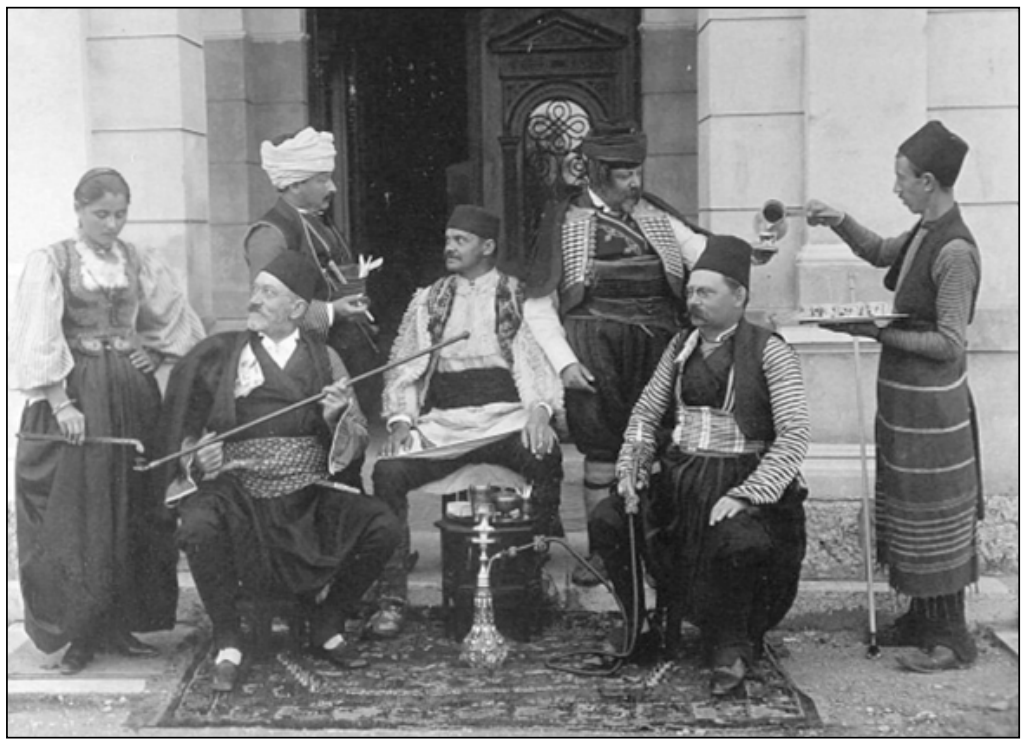

Figure 5. Dignitaries in Sarajevo, circa 1898. Note the weapons inserted in the sash of the standing nobelman (back row, on the right). Source: Historical Archive of Sarajevo, Photograph Archive, Inv. No. 1329.

themselves with damascene swords, daggers, pistols, and muskets. Hundreds of skilled craftsmen found work and were able to support themselves." ${ }^{39}$ In 1897, however, a visitor from Berlin noted a change: “These richly ornamented weapons can now be worn only by a few, privileged men. They may not actually use them however, so it is a natural outcome that soon no one will expend the effort to make them." 40 The weaponry had become ornamental, a decoration of the few elite (and loyal) Muslim noblemen (Figure 5). Sales of ornamental weapons diminished at the local level.

By 1900, however, the metal inlay and incrustation techniques were being applied to a new range of tourist items. In 1905, an observer remarked: "The products of these schools are [...] carefully made with the western market in mind. Instead of pistols and powder boxes, nowadays only inlaid cigarette holders, hatpins, picture frames, brushes, and letter openers are created." ${ }^{41}$

39 Sarajevo, Archiv BiH, ZVS 1905 Kut 123, Šifra 115 - 29/05. Anonymous, "Bericht über eine Reise nach Bosnien" Khartoum, 11 September 1905, p. 5.

40 M. Bartels, "Hausgewerbliche Gegenstände aus Bosnien," Verhandlung der Berliner Anthropologischen Gesellschaft [Sitzung vom 20 Februar] (1897): 98-99.

41 Sarajevo, Archiv BiH, ZVS 1905 Kut 123, Šifra 115 - 29/05. Anonymous, "Bericht über eine Reise nach Bosnien," 8. 


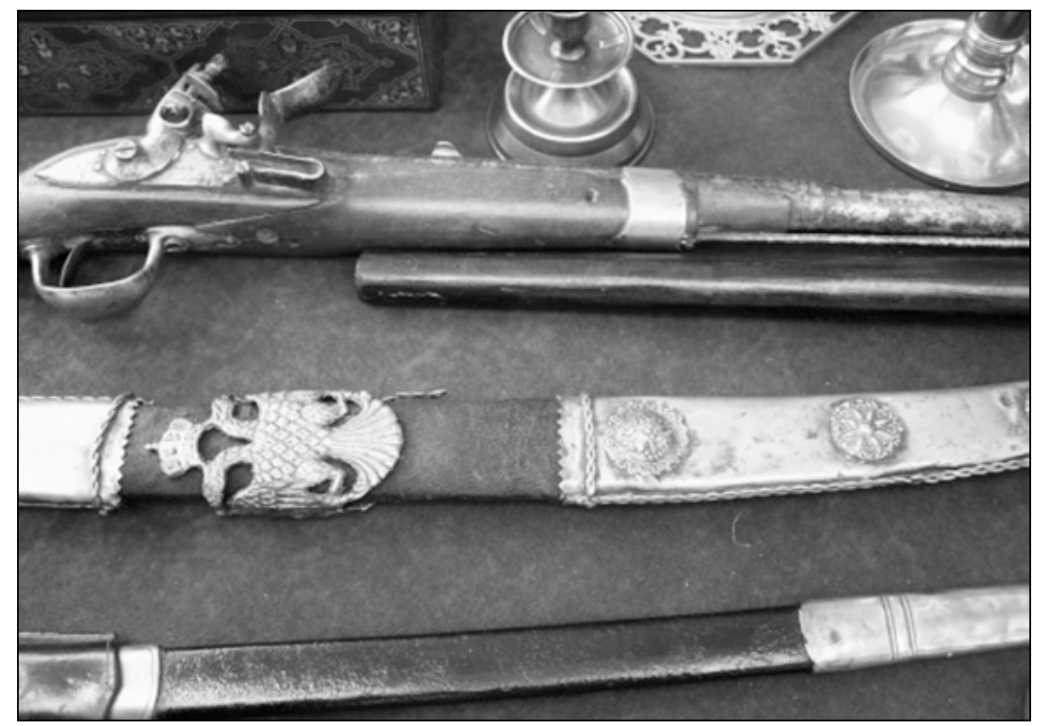

Figure 6. Ornamental weapons, Sarajevo ca. 1910 (private collection, Zagreb). Photograph by author.

Old, albeit improved, techniques had been adapted for new consumer demands. Furthermore, the weaponry craftsmen-having lost the local market due to Austrian restrictions-found a new market in souvenir shops frequented by a growing number of tourists and successive contingents of k.u.k. troops from all over the monarchy. The trade in these ornamental weapons had always been strong and the presence of a quarter of a million troops in the region over three decades increased the demand. In 1875, the English traveler noted: "In the small Turkish market there were many second-hand goods, and amongst them magnificent flint locks of antique form, with stocks richly inlaid with mother of pearl and golden arabesques." 42 These originals might no longer have been available after 1900, but thanks to the craft schools, copies were. These ornamental pistols, daggers, and small sabers were an obligatory purchase for the soldiers who rotated through Bosnia until $1918^{43}$ (Figure 6), while other, more precious inlay items were reserved for special occasions (Figure 7).

42 Evans, Through Bosnia and the Herzegovina on Foot during the Insurrection, 274-275.

43 Many of these artifacts circulated among Vienna's flea markets in the midtwentieth century as weapons left behind from the Turkish siege of Vienna in 1683. My thanks to Dr. M. Christian Ortner of the Heeresgeschichtliches Museum, Vienna, for this insight. 


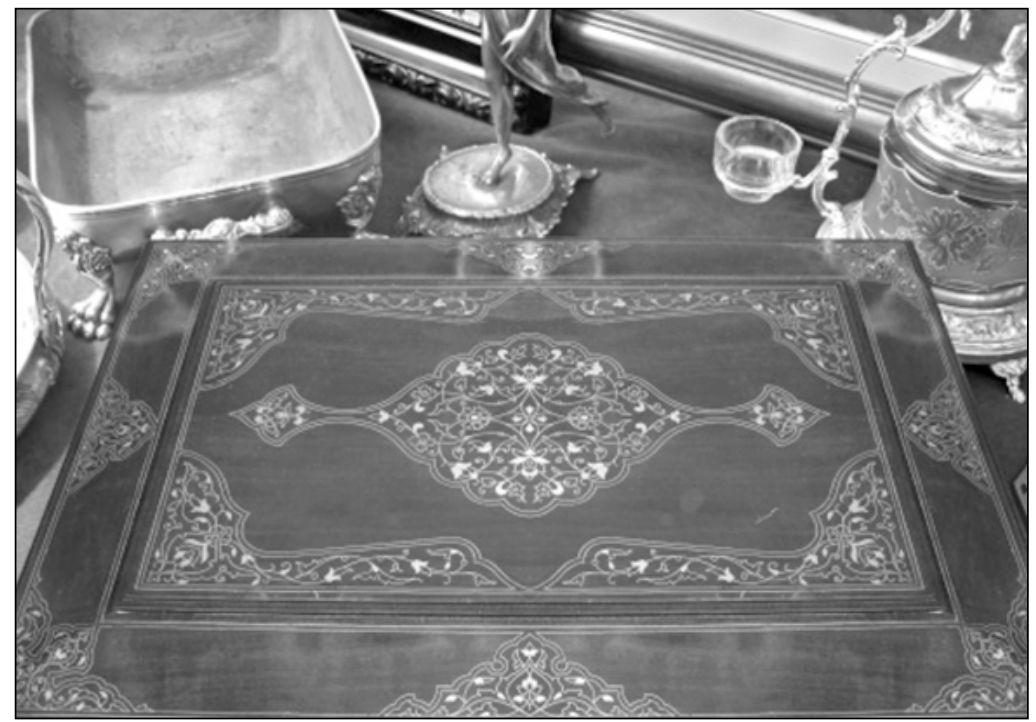

Figure 7. Silver-inlay ornamental box with inscription and dedication, Sarajevo, 1907 (private collection). Photograph by author.

The revival of Bosnian crafts testified to the success of the civilizing mission, and Austrian administrators preferred to emphasize that aesthetic education, not military might, had led to both pacification and redemption in the region. As Kállay's supporters described it, Austria had conquered Bosnia twice: once through weapons, but, finally, and more importantly, through wise administration and moral excellence. ${ }^{44}$ The dual conquest replaced Bosnian swordsmen with a "pacified" population of artisans who produced charming and exotic trinkets for city populations.

The rehabilitation of Bosnian weaponry was an aestheticized form of frontier Orientalism. The remnants of Ottoman designs in the region were not aboriginal, but the leftovers of a great civilization, a high culture. Ottoman designs could not be ignored or completely cast aside in favor of a Western aesthetic, so Austrian craft educators called for a revival. Yet, the outcome of this process, for those who submitted to the demands of the craft schools, was the creation of yet another subjugated and aestheticized Bosnian colonial. The Bosnian craftsman working in the government workshop had replaced the Bosnian peddler. The crude weapons the peddler carried in 1889 were

44 Bosnische Post 1, [Sarajevo] June 22, 1884, 1. "Österreich hat Bosnien und die Hercegowina zum zweitenmal erobert, nicht mehr durch die Gewalt der Waffen, sondern durch die Erfolge einer gerechten und weisen Verwaltung." 
transformed into exotic, albeit standardized, objects for Western consumers. Bosnia stood as a reminder to the Viennese of the significance of their colonial mission, not to Africa, but to the orient next door. The putative success of this mission was celebrated through exhibitions in Vienna and abroad.

\section{Education in Deracination}

The occupied territories were an important part of Viennese consciousness and the Austrian imperial imagination before 1900. Museum exhibitions, ethnographic research, and World Fairs illustrate the many ways in which scholarly disciplines and popular culture were complicit in a colonial/Orientalist discourse. The two-way exchange of designs indicates a hegemonic discourse that radiated out from Vienna, but it also illustrates several ways in which a widespread awareness of Bosnia and Bosnian designs entered Vienna and western Europe.

If, as Homi K. Bhabha has pointed out, the construction of national identities occurs through both pedagogic institutions and performative events (exhibitions and competitions), the Austrian civilizing mission in the Balkans was also part of this discursive field. ${ }^{45}$ For Austrians, however, the identity they sought to construct in a Europe of nation-states was not purely national, for that was impossible. Instead, the rhetoric of Austrian identity emphasized an aestheticized pluralism. To be Austrian meant to respect, revive, and consume the variety of crafts available from the many ethnic groups of the monarchy. The "colorful ethnic mosaic" of primitive crafts, all of which were continually exhibited in regional and international events, were constituent elements of an Austrian identity that, by 1900 , was striving to rise above nationalisms. ${ }^{46}$ In the case of Bosnia, it was as if a multinational Austria was uniquely qualified to administer and civilize a colony, perhaps better than any of the other European nations. As Kállay remarked, "We like Europe to know what we have done [in Bosnia] [...] and to say, "That is Austria!"'47 This was not only an Orientalist and colonialist rhetoric that was imposed upon Bosnia, but it was also a supranationalist strategy for a multinational Empire.

45 Dipesh Chakrabarty, Provincializing Europe: Postcolonial Thought and Historical Difference (Princeton, NJ: Princeton University Press, 2000), 10; Homi K. Bhabha, The Location of Culture (London: Routledge, 1994), 153.

"Volkskunde: Vergleichende europäisiche Ethnographie," in Ur-Ethnographie: Auf der Suche nach dem Elementaren in der Kultur; die Sammlung Eugenie Goldstern, ed. Franz Grieshofer (Vienna, Österreiches Museums für Volkskunde, 2004).

47 The Daily Chronicle, October 3, 1985. 
Yet, the aesthetic education of the Bosnian man was a program for failure. In 1910, an observer from Vienna suggested that the handicraft educational systems had created an "education in deracination." Everything-from the imposition of standardized building styles for school buildings to the preponderance of foreign bureaucrats and teachers-communicated only one thing to the inhabitants of Bosnia: "Everything here is bad! Everything here needs improvement!"49 This message could only produce an undesirable radicalism among the young people of the newly annexed territories. In addition, the changes imposed on Bosnian crafts by well-meaning improvers created products manufactured by a new proletariat. Worse, these products were neither appealing nor Bosnian. ${ }^{50}$ Describing the local kilims [carpets] he wrote:

To my astonishment I learned that in the Sarajevo weaving center they now only work according to established patterns, which was not the case years ago [before Austrian occupation]. When one restricts the weavers from the freedom to create their own patterns, which used to be determined by the local dyes and motifs, we are allowed to ask the question: what is specially "Bosnian" about these products?

This education in deracination was typical of colonial administrations, and its complicity with institutions of the exhibitionary complex was clear to the young generation of nationalists that coalesced after the annexation of the provinces in 1908..$^{52}$ Upon the completion of the new Regional Museum building in 1913, these deracinated youth recognized the hegemonic power of Austria that it represented. As Cvjetko Popović, a member of Young Bosnia, recalls: "Our anarchistic wishes were directed to the large new buildings of the Post Office and the imposing building of the Regional Museum (Zemaljski muzej). In our eyes this museum was only a bluff, a false sign of [the] cultural work of Austria in Bosnia." ${ }^{\text {53 }}$

48 A. Vetter, "Bericht über eine Studienreise nach Bosnien und der Herzegowina (September-October 1910)" (unpublished manuscript, Österreichisches Museum für Volkskunde, Vienna), 34. Vetter was director of the Imperial-Royal Office for the Promotion of Trades.

49 Ibid., 33-34.

50 lbid., 42-43.

51 Ibid., 43. The National Museum of Bosnia and Herzegovina recently staged an exhibition of Bosnian carpets: Carpets in Bosnia and Hercegovina: The Collection of the National Museum of B-H, Sarajevo: 2006.

52 Donia, Sarajevo, 93-120.

53 "... samo blef, lazni znak kulturnog rada Austrije u Bosne." [author's emphasis]. Svetko Dj. Popović, Sarajevski Vidovdan, 1914: Godina-dozivljaji i secanja (Belgrade: Prosveta, 1969), 31. Cited in Almaz Dautbegović, "Uz stogodišnjicu Zemaljskog muzej Bosne i Hercegovine u Sarajevu," in Spomenicaštogodisnjice 
These young men understood the power of the exhibitionary complex in Sarajevo and ultimately took up arms against it. Only a few months later, on 28 June 1914, one member of this group used a very real weapon to perform the most consequential assassination of the twentieth century-that of Franz Ferdinand, heir to the Habsburg throne. The swords of Bosnia were not beaten into plowshares, and some unintended consequences of Kállay's aesthetic orientalized vision were resistance and radicalism.

rada zemaljskog muzeja Bosne i Hercegovine 1888-1988 (Sarajevo: Zemaljski muzej Bosne i Hercegovine, 1988), 7-16. Popović goes on to remark on the irony of his 50-year career in the Regional Museum after World War I (p. 32); "... Cudnom igrom sudbine, ja sam posle podeset godina u tom istom muzeju zavrsio svoju sluzbenicku karijeru i otisao u penziju." 



\title{
The Experience of Borders: Montenegrin Tribesmen at War
}

\author{
URSULA REBER
}

In Austrian imaginings of the Balkans as a pastoral wilderness defended by cunning warlords loyal to their tribes alone, Montenegro figured as especially archetypal. Although the diminutive principality never posed a threat to Austria-Hungary's armed forces or the multinational Empire per se, it rose to prominence in its German-speaking press ${ }^{1}$ as well as through travelogues and military reports. ${ }^{2}$ While the military emphasized that Montenegrins were always battle-ready and cunning in their strategies, the image promoted by Austrian papers was ambiguous: The heroic chivalry of the otherwise untrustworthy Montenegrins culminated in blood feuds over stolen sheep. The notion that they were modern relics of ancient Sparta, supported in Britain by Prime

1 Especially the Neue Freie Presse (Vienna).

2 Josef Schön, Montenegrinische Kriegführung und Taktik, mit 1 Skizzentafel (Vienna: Seidel \& Sohn k.u.k. Hofbuchhändler, 1909), (essay originally appeared in Organ der militär-wissenschaftlichen Vereine, vol. 1, 1898, by Hauptmann Josef Schön des Generalstabskorps [later Kommandant des Infanterieregiments Erzherzog Carl Nr. 3]); Eduard Rüffler, Eine strategische Studie über Dalmatien, Montenegro, Bosnien und die Hercegovina mit einer Karte des Insurrections-Schauplatzes (Prague: H. Carl J. Satow, 1870); H. A., Die türkische Wehrmacht und die Armeen der Balkanstaaten: Bulgarien, Griechenland, Rumänien, Serbien und Montenegro (Vienna: Verlags-Anstalt "Reichswehr," 1892); Anon., Die serbische und montenegrinische Armee, mit Textskizzen u. Abb. (Vienna: Josef Roller \& Co., 1912); Spiridon Gopčević, Der Krieg Montenegro's gegen die Pforte im Jahr 1876, mit einer Kartenbeilage, Schlachtpläne enthaltend (Vienna: J. W. Seidel \& Sohn, 1877); J. J. Šestak and F. v. Scherb, Des Paschalik's Hercegovina und des Fürstenthums Crnagora sammt Karte (Vienna: self-published, 1862); for a more thorough analysis of the military treatises, see also Ursula Reber, Habsburgische Begegnungen mit nomadischen Kriegerstämmen: Montenegro als strategischer Schauplatz, http://www.kakanien. ac.at/beitr/fallstudie/UReber4.pdf (accessed January 13, 2010). 
Minister William Ewart Gladstone (1868-1874), was popular in Germany as well. ${ }^{3}$ Imported to Austria, high-flown praise for the "noble savage" merged with the image of the wild Montenegrin (or Albanian or Serbian) tribal warrior to create an, if not universal, at least enduring, interest in Montenegrin fighting techniques and their social and cultural bases.

This chapter will outline the construction of the prevailing discourse of the Montenegrin fighter, his partisan tactics, and his quasi-nomadic society as perceived by Austrian officers. Travelogues, ethnographic and geomorphologic treatises, and military studies of Austrian origin were all contributors, but his gestalt is not solely the product of Austro-Hungarian discourse, notable for its lack of continuity. Authors repeatedly emphasize their scientific intentions, but their imagery is of popular origin. As the occasion demanded, Austrian authorities, familiar with received notions of Montenegro's wild lands and men, took part in the discourse or exploited its suggestive power.

It can be difficult to place the protagonists of the popular and proto-ethnographic discourse under analysis here; most often, they are third-tier military men, adventurers, or amateur scholars, and it should be assumed that their part in the making of a discourse with claims to authority lies somewhere between shaping it and the transposition of extant opinions to the specific contexts of the pan-Balkan cultural-tribal threat and the resultant need for AustriaHungary's civilizing mission. This uncertainty regarding agency-whether it was the entire discourse or rather individual agents with their respective interests who created the situation of political instability-encouraged a paranoid atmosphere in which an entire set of "scientific" tools was wielded to reconnoiter a strange territory, people, and culture anew. This undertaking produced knowledge of the foreigners and allowed the development of strategies for successful interaction. At the same time, its central genre continued to be a combination of travelogue, diary, and geopolitical/-cultural treatise, ${ }^{4}$ structured along categorical lines to underline its scientific worth. ${ }^{5}$

The chapter addresses Austrian fantasies of war and territorial gain as well as the elusive frontier, sketching the geopolitical conflict that led to the Balkan

3 For Germany, see, for example, Gustav Hertzberg, Montenegro und sein Freiheitskampf:Vortragvon Dr. Gustav Hertzberg (Halle:Schrödel\&Simon, 1853). Generally, German travelogues lack the ambivalence toward Montenegro's culture found in most Austrian writings.

4 Zoran Konstantinović, Deutsche Reisebeschreibungen über Serbien und Montenegro (Munich: Oldenbourg, 1960), 111-137.

5 It is evident that this does not work out as intended. Texts on which those treatises relied were tendentious themselves. See, for example, Gopčevič as hypotext for many Austrian military treatises. See Reber, "Habsburgische Begegnungen"; on Gopčevič, see also Konstantinović, Deutsche Reisebeschreibungen, 119-123. 
military conflicts and diplomatic crises ${ }^{6}$ without focusing on particular events or military history. While it is not clear whether Austria actually had territorial interests in Montenegro, it reacted to Montenegro's claims to Albanian and Herzegovinian territory with at least the pretence of interest. With active economic and territorial interests elsewhere in the Balkans, Austria-Hungary had long been afraid that Montenegro and Serbia might join forces against its protectorate in Herzegovina to enforce territorial claims or simply to drive out the foreign religious and cultural influence. ${ }^{7}$ Austro-Hungarian distrust was primarily directed against Serbia, but tiny Montenegro, with its aspirations toward autonomy, played a considerable role in the construction of Serbia as an enemy. Since both peoples claimed common Serbian roots, Austro-Hungarian representatives had to reckon with the possibility of a united Serbia-Montenegro. I will discuss the imagined link between Montenegro's rugged geography and its political status, especially the instability of its borders and the tiresome process of redrawing them in the wake of the Congress of Berlin. The constant clash of "natural" borders with proposed political borders, and the impediments posed by war, offer the opportunity to explore differing conceptions of border constructs. Finally, I will look at the importance of popular "ethnographic" discourse for the military, especially the Austrian military government of Montenegro from 1916 onward and its justification of collective punishments.

\section{Montenegrin Warlords}

Praise for Montenegrins' historical bravery, their successful struggle against the Ottoman Empire, and their love of freedom is still in circulation, whether in Montenegrin self-representations or in scholarly publications, such as

6 John D. Treadway, The Falcon and the Eagle: Montenegro and Austria-Hungary, 1908-1914 (West Lafayette, IN: Purdue, 1983).

7 Cf. Feldmarschall Conrad, Aus meiner Dienstzeit 1906-1918, 3 vols. (Vienna: Rikola, 1921-1922).

8 Ethnography and ethnographic knowledge are used throughout this chapter in a nondisciplinary sense. The definitions of geography, society, and culture, as they have been drawn by travelers-military and nonmilitary-do not represent a scientific concept in this sense. They are not meant to establish an ethnographic discipline. Nevertheless, using geography as their main point of reference, they come close to an anthropogeography (Friedrich Ratzel) avant la lettre. In establishing a specific transcendence of the archaic mountaineous warrior tribal legacy based on the value of honor, one could also speak of the establishment of a Balkan/Montenegrin geo-aesthetics (this term is borrowed from the Marc Ries, Geoästhetik der Medien [unpubl.]) as practices of the perception of space as channeled and transformed by media and discourses. 
Elizabeth Roberts's recent historical study. ${ }^{9}$ It becomes difficult to disentangle the self-image conveyed by Montenegrin accounts from those ascribed to them, particularly in the many comparisons to ancient Spartans and the early Swiss.

In current usage, the loaded term "warlord" refers exclusively to self-appointed military leaders who consistently violate human rights. I employ it for its broad allusion to those who committed both legally sanctioned and prelegal, if not illegal-from the vantage point of modern states based on the separation of powers - acts of war which they "justified" by reference to social values, such as honor and vengeance as well as resistance and self-defense. In the Montenegrin case, the term implied an equal readiness to repel foreign invaders and to abduct neighbors' sheep. The myth-building efficacy of a nation of warrior heroes, prepared to confront any territorial threat, arises in response to desires both internal and external: to invoke a national history, to establish a lasting collective memory, to position both history and memory between ancient patriarchal and modern resistance-driven narratives, and to mark those narratives as worthy for inclusion in a shared history of Europe. These narrative features were already on the verge of acquiring the status of myth in the nineteenth and early twentieth centuries. ${ }^{10}$ But even then, a state ruled by warlords was not considered economically viable, and current Montenegrin independence, to a certain extent, reprises the "dependent independence" that followed the Congress of Berlin of 1878.

E. V. Zenker, a member of the Austrian State Council who reported on Montenegro's economy using material collected in 1908 and 1909, stated circa 1917 that "an independent Montenegro will hardly attain economic autonomy under its own power, and for that reason it has no natural claim to political independence." ${ }^{11}$ The reasoning behind the dismissal of Montenegro's politi-

9 Elizabeth Roberts, Realm of the Black Mountain: A History of Montenegro (Ithaca, NY: Cornell University Press, 2007).

10 Anthropologists claim that there is more to heroism than pure myth and selfrepresentation. Gerhard Gesemann, for example, critically discusses the sociological, group-related fact of the "heroic lifestyle" in Montenegro. Apart from his creating close relations between the landscape and a people's mentality [Volkscharakter], his argument that the "agon" society is reflected in many oral literary genres is convincing. See Gerhard Gesemann, Der montenegrinische Mensch: Zur Literaturgeschichte und Charakterologie der Patriarchalität (Prague: Kommissionsverlag der J. G. Calveschen Universitäts-Buchhandlung, 1934).

11 Montenegro: Eine Denkschrift über die wirtschaftliche Erschließung des Landes auf Grund einer im Auftrage des k.u.k. Kriegsarchivs unternommenen Studienreise verfasst vom Reichsrats-Abgeordneten E. V. Zenker k.u.k. Fähnrich (Vienna: 1919), 20: "Ein selbständiges Montenegro wird kaum jemals aus eigener Kraft sich zur wirtschaftlichen Unabhängigkeit erheben, und eben deshalb hat es keinen natürlichen Anspruch auf selbständige Staatlichkeit." 
cal autonomy is based less on its barren soil than on its inhabitants' lifestyle: With their disdain for industry and trade, patriarchal warriors were regarded as lazy. ${ }^{12}$ From the start, Zenker draws a connection between Montenegro's economic insufficiency and its social and cultural backwardness, which he pointedly calls "primitivism." ${ }^{13}$ In the discourse of enlightenment and progress, "primitivism" obstructed the development of a middle class and of commerce generally. The situation was exacerbated by Montenegro's social structure, restricted to bonds of family, clan, and comrades-in-arms. By inhibiting broader group loyalties, these ties prevented even the one honorable male profession-soldiering-from aspiring to professionalism. The country's "primitive" social structure extended to its army, where tactics and the arrangement of troops played only minor roles as opposed to the abilities of the individual fighter. In the critical view of Austrian strategists, the Montenegrin army lacked both discipline and strategy, ${ }^{14}$ and its tactics were the hit-and-run methods of partisans.

But the "primitive" was not always pejorative, even in the military context. Many ethnographers used the term in a rather positive way, accentuating the origins of culture and the authenticity of primitive societies. The positive usage of the primitive with regard to Montenegro reached its peak with anthropologist Gerhard Gesemann's Der montenegrinische Mensch, published in Prague in 1934. His study of patriarchy was a sophisticated melding of current vogues for reborn Sparta, the Darwinian vitality of "agon" cultures and the communion between a people's soul and the soil where it dwells that produces its respective anthropological race. ${ }^{15}$ A primitive race lives by heroic moral codes, safeguarding purity, continuity, and the genetic selection of the physically and morally strongest-notions familiar from Friedrich Nietzsche's Beyond Good and Evil.

12 Ibid., 19.

13 Ibid., 4: “[...], daß diese ungeheure wirtschaftliche Rückständigkeit im engsten Zusammenhang mit dem sozialen und kulturellen Primitivismus des Volkes steht." The use of the term "primitivism" is insofar surprising as the term was used in a positive sense within ethnology for a long time.

14 See Schön, Montenegrinische Kriegführung, 21.

15 Gesemann, Der montenegrinische Mensch, 63: "'Blut' ist hier eine zugleich naturhafte und moralische Kraft. Züchtung der Rasse in diesem Doppelsinne-Rasse ist aber nach gentiler Auffassung, nicht nur 'was man hat,' sondern auch 'was man ist'-ist dem Gentiliker keineswegs eine 'naturwissenschaftliche' Angelegenheit, die den Menschen in seiner geistigen Würde herabsetzt und dem Tiere gleichstellt, im Gegenteil: sich gehen zu lassen, den Instinkten des Wohllebens, des Sentiments, der Sinnlichkeit, der Liebe zu folgen, das ist animalisch, das ist 'Natur' im Sinne von Nicht-Kultur, denn Kultur heißt Ueberwindung der Natur mit ihren eigenen Waffen." 
Gesemann's theories took up a strain that recurred in National Socialist ideology, ${ }^{16}$ but his characterization of the Montenegrin has other precursors as well. In the Austrian officer Josef Schön's treatise, for example, one can observe a similar oscillation between revulsion and respect or even admiration for Montenegrin cruelty, irrationality, and disregard for material possessions, in particular real property. These shortcomings can also be read as discipline, courage, and the indomitable longing for freedom. Schön and his sources do not call their Montenegrin society "primitive," despite its characteristics' convergence with those outlined by Gesemann. The primitivism they have in mind can be defined by the blind spots of colonialism in dealing with native cultures that disregard its values and offer differing practices and techniques. Native habits that do not fit into to a colonizer's ideological system are not even grasped as following an unknown logic, but as being either the ideology's opposite, a deviant form of it, or entirely bereft of reason.

In an 1874 treatise, for example, the Austro-Hungarian officer August Terstyánszky calls the Montenegrin style of combat "inversion." Feigning retreat, they provoke pursuit to get the chance to break the enemy's train, effortlessly ambushing columns from behind rocks while blending seamlessly with the landscape. ${ }^{17}$ Schön avers that the Montenegrins "jump from cover to cover like swarms of locusts"18 in desert regions lacking even a bush to hide behind. For Schön, Montenegrin fighters were a natural phenomenon, more reminiscent of a plague than of the human cultural practice of making war. The partisan's renaturalization and the resulting difficulty of distinguishing him from the geological space he inhabits in the mind of the observer abnegates the realm of reason, treating the enemy unit as a natural disaster against which any military endeavor is bound to fail. On such a view, the Montenegrin warrior is neither accustomed, nor prone, to fight strategically. He seeks, instead, the manly duel between equally matched opponents, oblivious of the danger

16 Cf. Klaas-Hinrich Ehlers, "Prager Deutsche im Prager Zirkel: Ein Überblick," http://www.viadrian.euv-frankfurt-o.de/ sw1www/PublikationenEhlers/ PragerDeutsche.rtf (accessed in November 2007), and in Prager Strukturalismus: Methodologische Grundlagen, ed. Mared Nekula (Heidelberg: Winter, 2003), 70. See also Christian Töchterle, "Wir und die Dinarier-Der europäische Südosten in den rassentheoretischen Abhandlungen vor und im Dritten Reich," in Südostforschung im Schatten des Dritten Reichs, eds. Mathias Beer and Gerhard Seewann (Munich: Oldenbourg, 2004), 170-174, on Gesemann's combination of race, characterology, and physical anthropology.

17 August Terstyánszky, kgl. ung. Honved-Oberst, Das strategische Verhältniß des serbisch-bosnischen und bulgarischen Kriegsschauplatzes gegenüber dem Österreichisch-ungarischen Staate, nach den besten Quellen bearbeitet (Vienna: Verlag der Buchhandlung für Militär-Literatur Karl Prochaska, 1874).

18 Schön, Montenegrinische Kriegführung, 21. 
or even eagerly prepared to lay down his life for his motherland. At the same time, he attacks from ambush, from nowhere and everywhere, and any ostensible strategy-for example, the retreat mentioned above-is a ruse. That the heroic Montenegrin soldier could hardly be distinguished from a marauding bandit points up a latent gap between military and chivalric ideals. The affinity between his style of combat and his proverbial sheep rustling ${ }^{19}$ would not be denied by the "typical" Montenegrin, and his moral self-assessment would conflict with the Austrian's: In the right context, ambush and robbery are honorable acts. ${ }^{20}$

According to many reports, in Montenegro, "the soldier" or "the warrior" is everyman. Although there is a regular army, the task of warding off intruders is shared by all, even women. Following literary scholar Eva Horn, ${ }^{21}$ Montenegro's "soldiers" must be viewed as the equivalent of partisan guerrillas elsewhere-a scheme that subverts the political and social rules of war, whose laws, limits, and structures it constantly transgresses. War requires rules and explicit professionalization, that is, the potential to recognize combatants by their uniforms and weaponry as visible signs of military rule; in Montenegro, where, at the first sign of danger, shepherds leave their herds and businessmen close their shops, mustering brothers, sons, uncles, fathers, and grandfathers, the rules of war are abandoned, countering war's social order with disorder and the interpenetration of the civilian and military orders. In short, one finds in Montenegro the four criteria proposed in Carl Schmitt's Theory of Partisanship (1963): First, Montenegrin soldiers break the rules of war and are thus not legitimate soldiers, signifying their irregularity. Second, a tendency toward dispersed skirmishes and surprise attacks points to their increased mobility. Third, their disregard for danger and the loss of possessions indicates the intensity of the partisan ethos. Finally, the telluric character ${ }^{22}$ of the largely defensive fighting of Montenegrins is generally attested.

Horn $^{23}$ reads Carl Schmitt via Gilles Deleuze and Felix Guattari, whose "nomads"- defined as opposition to the apparatus of war-share qualities with Schmitt's partisans. This is no accident: Regardless of discipline, an alignment takes place between notions of primitive/native cultures and telluric character traits to random logic, warriordom, calculated mobility, the intensity of honor

19 See Gesemann, Der montenegrinische Mensch, 66-68.

20 Ibid.

21 Eva Horn, "Partisan, Siedler, Asylant: Zur politischen Anthropologie des Grenzgängers," Ästhetik und Kommunikation, September 1998, 39-46.

22 Telluric describes a people culturally and emotionally bound to its territory. The telluric character leads to a strong territorial community and its defense against invasions and foreign influence, since identity, culture, and territory are seen as interdependent.

23 Horn, "Partisan, Siedler, Asylant." 
and combat, and partisanship as an ethos and, thus, a culture in its own right. The vector that can be drawn is likewise transdisciplinary, since its movement, like nomadic movement itself, neglects the limits of disciplines and even of thought, combining ethnography, anthropology, mathematics, economics, cultural studies, the social sciences, and politics. Meditation on partisan warfare and nomadism contaminates ordered thought and reason with its own extravagant momentum. The topic of decentralization, for example, catapults Schön's reasoning to its own limits: The decentralized structure of the country will disqualify any attempt to conquer it. Thus, Schön repeatedly claims that Montenegro has no capital in the strict sense.

The occupation of Cetinje would do harm only to its inhabitants, yet would not considerably affect the country's defense. The whole situation is patriarchal in a simple way; organization, government, military support are not in the least dependent on a structured and complex bureaucracy as in larger states. It makes no difference whether Cetinje or some other town functions as the centre of command organising the resistance. ${ }^{24}$

\section{Ethno-/geo/graphy and Anthropogeography}

Schön and others explain the Montenegrins' constant state of alert, their many incursions into neighboring countries, such as Albania and Dalmatia (then part of Austria-Hungary), and their success in defending their territory against conventional armies by reference to ethnogeography. They argue that a country's geography forms its inhabitants; the development and adaptation of human culture takes place within a certain range of possibilities offered by the environment, while others are excluded. In the case of Montenegro, the idiosyncratic refusal to establish communications and the choice to perpetuate a premodern civilization is closely connected to the mountainous landscape as well as to Montenegro's being a "political island" 25 whose every border adjoins

24 Schön, Montenegrinische Kriegführung, 28: "Auch ein geographisches Operationsobjekt-wie es anderwärts etwa die Hauptstadt ist—fand sich für ein Invasionskorps nicht."

25 See Friedrich Ratzel, Politische Geographie, 3rd ed., revised by Eugen Oberhummer (Munich: Oldenbourg, 1923), 237: "Solche ganz umschlossene Gebiete könnte man als politische Inseln bezeichnen. Staaten von auch nur mäßiger Größe haben sich solcher Umarmungen mit aller Macht erwehrt oder sind darin untergegangen. [...] Es ist aber sehr interessant, zu sehen, daß selbst die kleinsten sich auf den Grenzen zweier großen entwickelten oder erhielten, wie Andorra zwischen Frankreich und Spanien, Liechtenstein zwischen Österreich und der Schweiz, Montenegro zwischen Österreich und der Türkei." 
an Empire (Austria-Hungary, the Ottoman Empire) or at least a larger country (the Kingdom of Serbia). An insular "dwarf state" must keep its weak borders inviolate while its own population crosses them at will, whether on business, conquest, or raiding forays.

Montenegrin society is analyzed by the military either as occupying a special ecological niche dictated by the environment or as a primitive society bearing traits of nomadism. The harsh geography at once provides "natural" borders and makes raids on neighboring countries inevitable, so that the seeming paradox of a nomadic-telluric culture can be traced to political geography: Geographic and political borders leave their impact simultaneously, and political borders are not arbitrary. Whenever they are drawn without regard for geography, turmoil arises. When we consider Deleuze and Guattari's conception of nomadism, the Montenegrin invasions of Albania-its repeated conquests of Scutari and subsequent retreats-represent not only the geography of crisis caused by unnatural borders, but also signify the special border-space of nomadism. Such attacks have a destabilizing effect upon coercive social systems, since uncertainty with regard to the duration of the occupation and its aims, if not territorial annexation, has a disorienting and disordering effect.

An equation of nomadic conquests with mere raids, a clear indicator for nomadic society's premodern status, was formulated by the influential German geographer Friedrich Ratzel in his Political Geography (1897), where nomads occupy the lowest rung of political culture. While Deleuze and Guattari share basically the same geographical parameters in their definition of nomadism, several important aspects differ from Ratzel's definition: They refuse to place nomads within a social hierarchy of status or value; nomadism is primarily a spatial paradigm; and, most importantly, the space that nomadism creates becomes a principle in and of itself. The noncapital Cetinje described by Schön and the country's shifting lines of communication are both symptomatic of the motile structure of a social geography in which strategic locations and property play negligible roles. It becomes a principle of human geography per se-the Other of a modern, highly structured machinery of war. Viewed in this way, nomadism is deessentialized, no longer bound to particular peoples or cultures, but may be observed in any society.

Austrian travelers and military did not use the term nomad, though they clearly-if with mixed feelings-outlined a seminomadic society that functioned as an Other for their own culture. One is struck by their admiration for the nomadic warriors of Montenegro as well as for the seamless space the partisans create by their peculiar way of fighting. In remarks on Montenegrins' habit of torching their homes when the enemy closes in ${ }^{26}$ it is evident that a disregard for material possessions occasions not only bafflement, but also respect.

26 See Schön, Montenegrinische Kriegführung, 27-28. 


\section{The Question of Borders in the Wake of the Congress of Berlin}

The 1878 Congress of Berlin granted Montenegro some measure of autonomy, and negotiations as to its territory could begin. As agreed at the Conference, a Delimitation Committee was established to redraw the borders. However, unexpected diplomatic impasses, as well as serious errors in the Austrian maps that were to serve as the basis for its work, doomed the Committee to delay and inactivity.

It was no surprise that the Ottoman Empire was less than delighted about ceding Albanian territory to Montenegro, and that it tried to hinder the proceedings. But the inaccuracy of the Austrian surveys came as a shock. Quite a few Austrian officials had traveled in the region and were proud of having provided details or corrected earlier mistakes. Given its strong imperial interest-which, as Ratzel remarked, came "naturally," since this "dark part" of Europe lay at its doorstep, while Germany's central location among civilized neighbors ${ }^{27}$ pushed its territorial ambitions overseas-Austria had been expected to work more conscientiously. But the maps' troubles did not originate with their representation of coastlines, rivers, and other natural phenomena, which were more or less correct, nor yet in the placement of cities and towns, but rather in the pitfalls of mapping itself.

Jacob Fischler discusses the example of the island of Gorica-Topal in Lake Scutari, which had been tentatively assigned to Montenegro. ${ }^{28}$ The island could not be found. An island roughly corresponding to the location on the map had a different name, while one bearing a similar name was situated at quite a distance and was thus of little use for drawing a straight border. The case of the stray island, though it seems ludicrous, raises three important points.

First, it is not the map itself, but rather the split process of signification that causes uncertainties and polysemy. A name is not merely a name, liable to willful change, despite the arbitrary nature of the sign. In a name, especially that of a significant location, entire stories are conveyed-narratives meaningful to the members of a community. Yet, the map does not consist of linguistic signs alone: There are also pictorial and diagrammatic signs, again connected in an arbitrary way. The misplacement of a single name in such a fragile system of interdependencies among pictorial, linguistic, and topological signs, which are hardly congruent in the first place, destroys its balance. While names embed narratives to which graphic elements alone are unable to refer, the pictorial or diagrammatic aspect of late nineteenth-century military maps, such as the Austrian map of the Balkans, is

27 Ratzel, Politische Geographie, 233.

28 Jacob Fischler, Die Grenzdeliminitierung Montenegros nach dem Berliner Kongresse vom Aug. 1878 bis Okt. 1887 (Vienna: self-published, 1925), 27. 
more an instrument of discipline than one of depiction. With elementary graphic symbols, the point and the line, it marks spaces of possession and belonging to be made accessible or inaccessible. Narratives, though they can be located, do not serve to mark possessions. Through their diachronic aspect, narratives partialize spaces, while a diagram totalizes them. The selection of a single name is already a distortion of those narratives, much as a diagram distorts the visual.

Second, the establishment of a border is a symbolic act that impacts not only the map's representative system, but, to a much greater degree, the people living in the border region-in a physical sense. They are expected to respect the border and its rules. To follow their usual ways of life, to walk their everyday routes to markets or houses of worship, or to pay visits to their families can become acts of trespassing.

Third, and closely connected to the second point, borders must be visible. In the nineteenth and early twentieth century, it was held that borders should follow so-called "natural" delimitations-ecological or geographic markers, such as rivers, coastlines, or the edges of mountain or desert regions. But ethnic, or in this case tribal, distribution was considered equally relevant. Ethnographic knowledge taken from diverse sources was applied to the creation of maps, with the aim of formalizing the existing dispersion of tribes. The Congress and the Delimitation Committee freely ascribed loyalties and values to the inhabitants of the newly established border regions. For instance, sections of Albanian tribal territory (Gusinje-Plava) in which most inhabitants were orthodox Christian Slavs were designated Montenegrin. ${ }^{29}$ But "ethnographic" knowledge of shared ethnic roots and faiths failed in its implementation; their supposed loyalties meant little to the population.

The attempt to satisfy Montenegro's territorial claims by ceding a northerly section of Albania to it led to even more serious problems. Albanian tribal chieftains (of the Hotti, Dinosch, Gruda, Touzi, Clementi, Selca, Vukel, Nikshi, and Lumba) pleaded with the Great Powers to prevent the loss of their status as Ottoman vassals. Their petition was sent to Kirby Green on May 2, 1880:

We have once before protested against the violation of the Treaty of Berlin, by which [...] a part of our territory had been awarded [to Montenegro]. [...] We declared to you that we would never accept the notoriously unjust, oppressive, and ill-constituted Government of Montenegro. [...] We repeat our former prayer that our incorporation with that unjust Government be prevented, and that, in conformity with the Treaty of Berlin, we be allowed to remain under the jurisdiction of our former and well-beloved Master the Sultan. ${ }^{30}$

29 See enclosure in No. 237, "Memorandum on the Montenegrin-Albanian Frontier Question (June 1880)," in Montenegro: Political and Ethnic Boundaries, 1840-1920, ed. Beitullah Destani (London: Archive Editions, 2001). 
The ongoing drawing and redrawing of the Montenegrin-Albanian frontier had unexpected side effects. The northern Albanian tribes shifted their loyalties from the Montenegrin tribes to the Great Powers and back again, according to momentary circumstances, in hopes of gaining additional autonomy. A few communities were indeed of mixed tribal/ethnic Albanian-Montenegrin identity, but even their representatives did not appreciate plans to surrender territory to Montenegro. Their resistance was encouraged by contemporary discourse that prompted them to discover their identity as Albanians. As they consolidated their sudden national integrity, it became impossible to approach Montenegro in any way, culturally or politically. Borders formerly permeable were made coercive. ${ }^{31}$

The ethnographic knowledge that Austrian travelers had collected during fifty years of study, with all their sensitivity to regional wants and loyalties, became useless and even counterproductive as the social space shifted from tribal bonds to national belonging and a history and culture shared with Turkey. Modernity's preference for nation-building and autonomous states had shattered the "darkness" of Albania long before Austria-Hungary came along. Its efforts to take local bonds and boundaries into consideration in the installation of political borders were quickly invalidated by fresh developments.

\section{Ethnographic Knowledge and Its Limits}

The ethnographic findings of Austrian, German, Czech, Hungarian, and other travelers were, in large part, based not on methodical collection, comparison, and evaluation of its subjects in any scientific or disciplinary sense, but on accounts by earlier travelers, extrapolation from common knowledge, secondhand oral narratives, the perusal of fiction, and short visits. Austria's "natural interest" in the Balkans, as Ratzel had called it, had always extended to ethnographic or rather anthropogeographical research. As had been the case with the redrawing of the Montenegrin-Albanian border at the Congress of Berlin, expectations were sometimes high: Ethnographic sophistication would enable Austria to extend its influence, preparing the region for diplomacy or for "civilizing" warfare.

Whatever the source, the ethnographic assessment of Montenegro's tribes, society, customs, national character, and mental or emotional disposition remained controversial. Its characterizations of the Balkan peoples ranged from "uncivilized" to "Homeric," from atavistic throwback to optimum raw

31 Allen Buchanan and Margaret Moore, "Introduction," in States, Nations, and Boundaries: The Ethics of Making Boundaries, eds. idem (New York: Cambridge University Press, 2003), 2. 
material for modernization. In analyses conducted from an imperialist vantage point and focused on developing strong centers, industrialized production and trade, Montenegro was accorded scant prospects of modernizing itself-geographically and culturally isolated from the neighboring countries as it is, as Ratzel puts it. ${ }^{32}$ Zenker, too, begins with geography: With regard to Montenegro's isolation, he, for once, does not compare it to Switzerland or Sparta, but to Tibet. Trapped by a culture that renders modernization impossible, the country's mineral resources and potential agriculture and industry are treated as subject to Austria's colonial whims. An Austro-Hungarian protectorate in Montenegro could solve its cultural and political problems simultaneously: Agriculture would replace the seminomadic lifestyle and discourage further raiding, ${ }^{33}$ with the hitherto fallow fertile soil around Podgorica gained in the Treaty of Berlin playing a pivotal role. ${ }^{34}$

Yet, neither ethnographic knowledge of its decentralized tribal structures, nor the superior "civilizing" techniques of the Austrian military proved helpful in the brief years of the Austrian occupation (1916-1918), despite the fact that the military government in Cetinje was led by officers who had both collected ethnographic data and fought against the Montenegrins. There are intimate connections between military and ethnographic knowledge, and civilization and war. The latter link is recapitulated by the German ethnographer Hugo Grothe, who traveled through Montenegro and Albania in 1912: "The war in the Balkans no doubt promotes civilization there and opens up great potentials for capital and investment, for technology, and for the individual pioneer who investigates the cultures and economic situation of these regions." 35 Nevertheless, all the optimism about "civilizing warfare," which, to a certain extent, relies on ethnographic knowledge - the civilizing mission of the military administration transforms the tribal into a "civil" society, implementing economic and civilizing techniques and administrative and executive institutions-was disappointed, as was the hope of quick transformation and progress after the victory. Arguing that sharecropping was "manly" did not turn herdsmen into farmers; instead, the supply of staple foods failed-let alone the transfer of agriculture as a technique of civilization. No sophistication about family ties could prepare the army for local subsystems of supply redistribution, which cut off the most needy Montenegrins. Swords were not turned into ploughshares, but instead were used in impromptu rebellions.

32 Ratzel, Politische Geographie, 227.

33 Ibid., 52-53.

34 For Austria-Hungary's mission in the Balkans, see Konstantinović, Deutsche Reisebeschreibungen, 119.

35 Hugo Grothe, Durch Albanien und Montenegro (Munich: Mörike, 1913), 8. 
Still, ethnographic knowledge was not dismissed as valueless. Military administrators were encouraged to keep journals ${ }^{36}$ preformatted into categories, including "social life," "habits and holidays," and "economic development." Especially interesting are the diaries kept by officers responsible for the judicial system. Their entries reliably mirror Austrian law, moral codes, and cultural values. Some entries evince the moral code's state of volatility: Complaints about parallel economies among members of families and tribes are frequent. Attempts to prove Montenegrins guilty of using neighbors' names to divert food supplies for their own families were, however, futile. The Austrian military's awareness of kinship-motivated fraud collided with their system of humanitarian aid. The impossibility of prosecuting the swindlers compounded the image of tribalism as socially primitive. Apart from such cases, the records cite violations of prohibitions on possessing firearms as the most common grounds for conviction, with pan-Serbian conspiracies also causing plentiful trouble. As one diary from Plevjle records in a summary dated February 10-28, 1917 , women played crucial roles in such conspiracies. In that particular case, prosecution was ineffective, because communication between the Montenegrin and Serbian conspirators was so much faster and more efficient than the official bureaucratic communications of the Austrian officials.

Where Austrian authority was met with violent resistance, the occupiers appropriated "tribal" law to make entire clans responsible for a single offence. For example, after Radomir Vešović escaped from arrest by killing an Austrian constable, half the inhabitants of his hometown of Kolašin were executed or jailed. Another case is documented in the K.u.K. Kundmachung Nr. 3061, An das k.u.k. Kreiskommando Nikšić, Feldpost 257 am 20.10.1918: The Austrian administration of Montenegro had ended. To guarantee a secure retreat from Nikšić, it was recommended that the troops take hostages-preferably immediate family; if they were unavailable, then other relatives or friends. ${ }^{37}$ In such cases, a cultural transfer took place from the tribal/primitive to the civilized. No satisfying attempt was made to justify the condemnation of half a village for one man's crime in legal terms; eager to demonstrate their mastery of the language of "blood," the Austrian administration simply adopted tribal norms of honor and kinship. Montenegro, it is suggested, with its brute men clinging to weapons, liberty, and interclan loyalties, offered them no latitude for negotiation. Austrian officers' "Balkanization" occurred through their co-optation or recuperation and re-"naturalizing" of tribal language, an effect familiar

36 These diaries (including also the aforementioned troubles with interclan supply) are to be found in documents from the Armeeoberkommando Cetinje 1917 and 1918 in the Viennese War Archive.

37 Roberts speaks of "considerable brutality" against civilian populations. Roberts, Realm of the Black Mountain, 318. 
from colonialism. Ethnographic knowledge played no further role in the occupation. If there ever had been widespread faith in its utility, Austrians quickly lost it.

The precise position of ethnographic knowledge between prejudice and phantasm can be difficult to specify, especially in its dealings with a group that embodied coherent and contradictory narratives-the warrior nomad's patriarchal purity, the living relic of ancient Sparta, the devious, emotionally unstable barbarian. The Austrians' civilizing mission, having subrogated that knowledge to a grand narrative of progress and reason, spoke two languages simultaneously: An abundance of official bulletins ${ }^{38}$ focused on positive aspects, trying in sundry ways to make industrious, pious, responsible masculinity more palatable to the Montenegrins. Failure was preprogramed, as ethnographic knowledge, prejudice, and personal experience inevitably reinforced one another. In the end, common knowledge simply reproduced itself, reifying Montenegro's image as a nation of petty warlords.

38 Published in Cetinjer Zeitung (1916-1918). 



\title{
Austro-Hungarian Volkskunde at War: Scientists on Ethnographic Mission in World War I
}

\author{
Christian Marchetti
}

Toward the middle of World War I, an Austro-Hungarian daily described the benefits of all-out war for scientific endeavor:

It is an old and well-known fact that war advances science; that it expands and deepens it. The greater the struggle for victory, the more demanding the requests made and the richer the resources given become. What in quiet times is only of value and interest to exclusive circles, prospering only barely in the confines of the study and the laboratory, is now seen as significant by a broad public and lavishly supported so that it may create for the one who destroys.

With the exception of utterly ivory-tower branches of knowledge, every discipline is now experiencing the fertilizing effects of the world war, and its exponents, even those under arms in the field, feel the duty to take full advantage of this blood-soaked opportunity. [...] Previously inaccessible areas and xenophobic peoples and tribes are explored and studied; their character is penetrated and interpreted. Antiquities are drawn, collected and listed, as are dialects, traditional costumes, mores and customs. Landscapes are surveyed, rivers sketched, and ores and geological data searched for. ${ }^{1}$

The "previously inaccessible areas" in question were the Balkans. AustroHungarian imperial forces had occupied the peninsula's western reaches in early 1916. War dismantled various obstacles that had hitherto "averted the scientific current and deflected it into the African colonies of the Great Powers and the owner-less Arctic and Antarctic." ${ }^{2}$ They included absent lines of com-

1 "Die Balkanforschung," Pester Lloyd, May 12, 1917, 6-7.

2 Ibid. The article quoted was one in a series intended to secure a piece of the action for the Balkans Institute in Sarajevo mentioned below. Its director Carl Patsch obviously felt neglected by the war-driven advancement of science. 
munication, frequent borders, and the distrust or outright malevolence of its inhabitants and authorities.

Among the disciplines benefiting from the scientific boom created by the Great War was the German-speaking Volkskunde of the Austro-Hungarian Empire. In the multiethnic dual monarchy, cultural branches of anthropology followed an idiosyncratic Sonderweg. While Germany cultivated a structural division between an inward-looking Volkskunde that investigated and invented the folk culture of its own nation and an outward-looking Völkerkunde that explored the "primitive" cultures of colonial Others, such dichotomies in Austria-Hungary were as blurred and contested as the disciplines themselves. World War I became a milestone on their path toward institutionalization and professionalization. Beyond its adverse effect on the multiethnic political realm, the war mobilized all sectors of society and the state, offering the young discipline a probationary field that it entered willingly.

This field was represented geographically by the occupied Balkan territories. From a western European perspective, the southeastern peninsula was perceived as a transitional zone between the European Self and the Oriental Other. Its in-between position, symbolized in the image of a bridge, construes the post-Ottoman Balkans as the West's "Other within," an inextricable part of Europe, but an incomplete Self. ${ }^{3}$ The perception extends to the Balkans' political (dis-)organization. While the classic oriental Other ${ }^{4}$ could be subjected to colonial discourse and ascriptions of oriental despotisms, the Balkans were the area where the putative ideal of European statehood, the homogeneous nation-state, was seen as perverted by hypertrophy. "Balkanization," a pejorative term for the fragmentation of former multiethnic imperial dominions into presumably nonviable and aggressive mini-nation-states, emerged in Western political discourse around the time of the Balkan Wars of 1912-1913. ${ }^{5}$

The Austro-Hungarian Empire was a special case. It bordered directly on the Balkans, even including parts of it. Ethnic heterogeneity and nationalist quarrels were features the two entities shared. The emergence of small nation-states in the area posed a direct threat to the Empire by providing some citizens with national affiliations beyond the dual monarchy. Hence, its attitude toward both the Balkans and the Orient differed from that of other European nation-states and imperial colonial powers: The Balkans were historically the space where the Empire's own mission became manifest. Turkish armies based there had threatened Christian Europe for hundreds of years, and their defeat at the walls of Vienna marked the advent of Austria's imperial mission and golden age.

3 Maria Todorova, Imagining the Balkans (New York: Oxford University Press, 1997), 15-17.

4 Edward W. Said, Orientalism (London: Penguin Books, 2003).

5 Todorova, Imagining the Balkans, 19. 
The cultural memory of military conflict with the Ottoman Empire in early modern times and the experiences gathered during political expansion into the regions of former Ottoman colonial rule in Europe nurtured an idiosyncratic "frontier Orientalism." This perceptual pattern extended from folklore to the high arts and science, addressing male violence in nearby "Oriental" cultures and symbolically separating "good" Balkan Muslims from "bad." As a political and cultural orientation, it offered a more diversified pattern of perspectives than the classic, colonialist model of Orientalism. ${ }^{6}$

Against this background, it is the purpose of this chapter to elaborate on the wartime experience of Austrian Volkskunde. While prewar research in the western Balkans was subject to a "heroic" paradigm, the war had the seemingly paradoxical effect of pacifying the scientific approach. Before the war, male heroism and violence were the dominant patterns both in representations of Balkan folk culture and the self-representations of maverick researchers. Cultural anthropologists in uniform were more interested in material and domestic aspects of daily life, presenting themselves as professional scientists. Thus they were able to contribute to colonial politics during the occupation and realign themselves to novel circumstances after the defeat.

\section{Multiethnic Volkskunde}

The Habsburg Empire gave rise to a variety of ethnological approaches. ${ }^{7}$ Austrian ethnology of non-European cultures had its inception in the Department of Anthropology and Ethnography at the Imperial and Royal Natural History Museum, founded in $1876 .{ }^{8}$ Habsburg anthropology's main objects of

6 Andre Gingrich, "Liberalism in Imperial Anthropology: Notes on an Implicit Paradigm in Continental European Anthropology before World War I," Ab Imperio 8, no. 1 (2007): 231; idem, "Kulturgeschichte, Wissenschaft und Orientalismus: Zur Diskussion des 'frontier orientalism' in der Spätzeit der k.u.k. Monarchie," in Schauplatz Kultur-Zentraleuropa, Transdisziplinäre Annäherungen, ed. Johannes Feichtinger (Innsbruck: Studien Verlag, 2006), 279-288; idem, Frontier Myths of Orientalism: The Muslim World in Public and Popular Cultures of Central Europe, vol. 2, Mediterranean Ethnological Summer School, Piran/Pirano Slovenia 1996, eds. Bojan Baskar and Irena Weber (Ljubljana: University of Ljubljana, 1998), 99-127.

7 Reinhard Johler, "Das ethnische als Forschungskonzept: Die österreichische Volkskunde im europäischen Vergleich," in Ethnologia Europaea: 5. Internationaler Kongreß der Societé International d'Ethnologie et de Folklore Wien, 12.-16. September 1994, eds. Klaus Beitl and Olaf Bockhorn (Vienna: University of Vienna, 1995), 80.

8 Christian F. Feest, "The Origins of Professional Anthropology in Vienna," in Kulturwissenschaft im Vielvölkerstaat: Zur Geschichte der Ethnologie und 
attention were not to be found overseas, but within the Empire's own borders. No country on earth could match Austria-Hungary's potential for ethnological research, the art historian Alois Riegl stated in 1894, for the Empire incorporated north and south, east and west, and the primitive and the modernized, boasting examples of every stage of economic development. ${ }^{9}$ The Empire was seen as a microcosm of Europe, encompassing within its borders numerous national, religious, cultural, and "civilizational" differences.

In 1895, two departmental assistants, the Semitist Dr. Wilhelm Hein and the Indologist Dr. Michael Haberlandt, founded a society for Austrian Volkskunde, claiming the Empire as their field of research. In contrast to the assorted national Volkskunde disciplines that had emerged in imperial subcenters at the end of the nineteenth century, the Viennese scholars positioned themselves as anti-, or at least nonnational. To legitimize itself, the discipline aspired to close the gap between urban high culture and primitive rural culture by integrating the latter into the former. The promoters and protagonists of the young discipline, both aristocratic and bourgeois, shared a form of Austrian patriotism that emphasized the Empire's unity in space and time, searching for the natural, organic basis of its Volk. A common foundation was thought to underlie the Empire's observable cultural variety, which was conceived as superficial: Discrete national cultures were assumed to have been constructed politically.

A central concern in Austrian Volkskunde was folk art. The discipline aimed to support the preservation and elaboration of traditional styles and techniques. Preindustrial handicrafts were to be protected from obliteration by modern industry and developed into competitive cottage industries that would include rural people on fair economic terms, halting migration to the cities and other undesirable consequences of modernization. The Empire's cultural diversity would become a competitive asset by providing a multiplicity of production styles. Metropolitan Weltkultur with its tendency to elide diversity and nationalist particularisms with their exaggerations of difference were to be countered by the elemental aesthetics of handicrafts. Conserving the traditional division of labor along gender and ethnic lines would help secure internal social peace. ${ }^{10}$ In this context, Austrian Volkskunde positioned itself as an "internal colonial science."11

verwandter Gebiete in Österreich ca. 1780 bis 1918, ed. Britta Rupp-Eisenreich (Vienna: Böhlau, 1995), 113-131.

9 Alois Riegl, Volkskunst, Hausfleiß und Hausindustrie (Berlin: Mäander-Kunstverlag, 1978 [1894]), 77.

10 Michael Haberlandt, "Ausstellung österreichischer Hausindustrie und Volkskunst," Kunst und Kunsthandwerk 9 (1906): 24-52.

11 For a Habsburg version of internal colonialism, see Katherine Verdery, "Internal Colonialism in Austria-Hungary," Ethnic and Racial Studies 2 (1979): 378-399. 


\section{Bosnia and Herzegovina}

The Habsburg Empire had no overseas colonies, ${ }^{12}$ confining its imperial ambitions to European soil. The occupation of Bosnia and Herzegovina in 1878 has often been, and still is, interpreted as the beginning of Austro-Hungarian colonialism in the Balkans. The special place occupied by Bosnia and Herzegovina in the dual legal-political body of the dual monarchy, its distinctive role and weight in the internal balance of the Empire, and its ethnic situation drew especial attention from the monarchies' centers.

Service in Bosnia and Herzegovina was an experience shared by many German-speaking anthropological scholars and explorers. Felix von Luschan served in the Medical Corps in Bosnia and Herzegovina in 1878/79. During his deployment, he took part in excavations, pursuing anthropometric studies and collecting anthropological and ethnographic objects. ${ }^{13}$ Another wellknown exponent of non-European ethnology, Richard Thurnwald, acquired foreign field experience as a member of the Bosnian Regional Administration in 1896/97..$^{14}$ The career paths of both led to Germany; Luschan became the first professor of anthropology in Berlin. Fieldwork in Bosnia seems to have been an advantageous jumping-off point for Austro-Hungarian careers as well. The archaeologist Moritz Hoernes, cofounder of the Viennese Association for Volkskunde, was a member of the occupation forces, like Luschan. When the occupation ended, he was engaged by the Ministry of Education to travel through Bosnia and Herzegovina cataloging Roman archaeological sites. He later became the cultural attaché to the joint administration of Bosnia and Herzegovina in Vienna. ${ }^{15}$

Beyond personal experiences and interests, the Austro-Hungarian colonial experience in Bosnia and Herzegovina was significant for the discipline's early institutional development. In 1884, the Viennese Anthropological Society established its Ethnographic Commission with the stated aim "to effectively stimulate

12 It refrained from such ambitions more out of lacking chances than out of higher insight, see Walter Sauer, ed., K.u.k. kolonial: Habsburgermonarchie und europäische Herrschaft in Afrika (Vienna: Böhlau, 2002).

13 Marion Melk-Koch, "Zwei Österreicher nehmen Einfluß auf die Ethnologie in Deutschland: Felix von Luschan und Richard Thurnwald," in Rupp-Eisenreich, Kulturwissenschaft im Vielvölkerstaat, 132.

14 Ibid., 136; Angela Riedmann, "Richard Thurnwald in Bosnien 1896-1897: Koloniale Wege zur Ethnologie," (master's thesis, University of Vienna, 2005). Thurnwald contributed to the volume on Bosnia of the series "Die österreichisch-ungarische Monarchie in Wort und Bild," often referred to as the "Kronprinzenwerk."

15 Moritz Hoernes, "Die Altertumsforschung in Bosnien-Herzegovina," Globus 61 (1892): 129-132, 150-154. 
and support the study of the ethnography of the Balkan countries along with the ethnography of Austria-Hungary." 16 One of the first individuals to explore the newly acquired territory on behalf of the Commission was the classical philologist Friedrich Salomon Krauss. ${ }^{17}$ Touring Bosnia in 1884/85, he collected vast quantities of material, mainly folk songs from Bosnia's three main religious communities. Krauss stressed the arduousness of his travels, claiming he dressed in rags to avoid being robbed. He held his materials in high esteem, especially the oral tradition of the Muslim "sect," as he called it, which for him had Homeric qualities. ${ }^{18}$ Other groups' songs were inferior, but equally belligerent. ${ }^{19}$

Viennese learned societies continued to dispatch scientists on expeditions to Bosnia and Herzegovina in the early years of the twentieth century. While the anthropologists' mandate was defined methodologically, the Imperial Academy of Sciences' Balkan Commission, constituted in 1897, had a geographical focus, promoting primarily philological-ethnographic and historical-archaeological research projects. ${ }^{20}$ In 1913, the Slavicist and folklorist

16 Mitteilungen der Anthropologischen Gesellschaft in Wien 14 (1884): 6.

17 Krauss (1859-1938) was born in Pozega, Slawonia, as the son of a Germanspeaking Jewish father and a Slavic mother.

18 Krauss was referring to the "Homeric thesis" of South-Slavic folklorists like the Franciscan collector Grgo Martić, but by constraining the label "classical" to the Muslim songs he thwarted their preference for Christian folklore. See Zlatan Čolaković, "Bosnian Epics: Problems of Collecting and Editing the Main Collections," Forum Bosnae 39 (2007): 323-361.

19 On Krauss's life and work, see Raymond L. Burt, Friedrich Salomon Krauss (18591938): Selbstzeugnisse und Materialien zur Biobibliographie des Volkskundlers, Literaten und Sexualforschers mit einem Nachlassverzeichnis (Vienna: Verlag der Österreichischen Akademie der Wissenschaften, 1990). On Krauss as part of a "Jewish moment" in the history of early folklore studies and Völkerkunde in the German-language zone before and after World War I, see Gingrich, "Liberalism in Imperial Anthropology, 231-233; Bernd Jürgen Warneken, "Völkisch nicht beschränkte Volkskundler: Eine Erinnerung an die Gründungsphase des Fachs vor 100 Jahren," Zeitschrift für Volkskunde 95, no. 2 (1999): 169-196; idem, "Negative Assimilation: Der Volkskundler und Ethnologe Friedrich Salomo Krauss," in ... das Flüstern eines leisen Wehens ...: Beiträge zu Kultur und Lebenswelt europäischer Juden, ed. Freddy Raphael (Constance: UVK-Verlagsgesellschaft, 2001), 149-170; Christoph Daxelmüller, "Friedrich Salomo Krauss (Salomon Friedrich Kraus[s]) (1859-1938)," in Völkische Wissenschaft: Gestalten und Tendenzen der deutschen und österreichischen Volkskunde in der ersten Hälfte des 20. Jahrhunderts, ed. Wolfgang Jacobeit (Cologne: Böhlau, 1994), 461-476; on his traveling practices: Christian Marchetti, "Scientists with Guns: On the Ethnographic Exploration of the Balkans by Austrian-Hungarian Scientists before and during World War I," Ab Imperio 8, no. 1 (2007): 170-173.

20 Archiv Österreichische Akademie der Wissenschaften. Balkankommission, K1B1, Protokollbuch 1897-1907. 
Matthias Murko traveled to Bosnia and Herzegovina at its behest to research the current state of Muslim folk song. Just as Krauss had done, Murko investigated a population which he divided along religious lines. Nevertheless, he highlighted the commonalities among epic folk songs, observing the exchange between Catholic, Orthodox, and Muslim singers and audiences. The most significant unifying effect, Murko noted, derived from the songs' gory nature: "The old songs have to have a bloody topic [...] because gusle [the traditional instrument], puška [gun] and oružje [weapon] are inseparable terms." ${ }^{21}$ Heroism was held in high esteem, regardless of denomination.

But violent folklore was in decline, Murko observed. As the Bosnian hero, the junak who derived his heroic status from hand-to-hand combat in the border regions between Herzegovina and Montenegro, was transformed into a disciplined soldier in the rank and file of the Austro-Hungarian army, ${ }^{22}$ the folk songs became relics of a heroic past.

Murko could rely on active support from local government, municipal authorities, and village teachers and priests. ${ }^{23}$ More important was the regionally based scientific community that had crystallized around the Bosnian National Museum founded in Sarajevo in 1888. The local scholars adhered to a rather pacifistic - or pacifying - agenda with regard to the representation of different folk cultures, stressing the harmonious aspects of multiethnic urban life. ${ }^{24}$ As the infrastructure for research improved, conceptualization of the ethnographic field stabilized. The Sarajevo museum aspired to become a local center for the study of the entire region. In 1908, the curator of its archaeological collection, Carl Patsch, founded a Balkan Institute, gathering a comprehensive collection of source material and launching an ambitious series of publications on the surrounding countries under the rubric Zur Kunde der Balkanhalbinsel. ${ }^{25}$

21 Ibid., 33.

22 The Bosnian Units formed an elite troop in the Imperial and Royal Army. A unit was stationed in Vienna and deployed against rioting civilians. During the World War the "Bosniaken" gained the nimbus of loyal and fearless fighters, especially in mountain warfare against Italy. A rich and nostalgic account is given by Werner Schachinger, Die Bosniaken kommen! 1879-1918 Elitetruppe in der k.u.k. Armee (Graz: Leopold Stocker Verlag, 1994).

23 Mathias Murko, "Bericht über eine Reise zum Studium der Volksepik in Bosnien und der Herzegowina im Jahre 1913," Sitzungsberichte der Kais. Akademie der Wissenschaften in Wien 176 (1915): 4.

24 Diana Reynolds, "Kavaliere, Kostüme, Kunstgewerbe: Die Vorstellung Bosniens in Wien 1878-1900," in Habsburg postkolonial. Machtstrukturen und kollektives Gedächtnis, ed. Johannes Feichtinger (Innsbruck: Studienverlag, 2003), 243257.

25 Carl Patsch, 12 March 1913, Gemeinsames Finanzminsterium, in Angelegenheiten Bosniens und der Herzegovina, Z3064, Hofarchiv, Ministerium des Äußeren, Fach 74 “Institute ÖU 3," 16/19287. 


\section{The Ethnologist Who Would Be King}

In the early twentieth century and up to the beginning of World War I, political and scholarly "conquest" moved southward to the young state of Albania. ${ }^{26}$ This most recent successor state to the Ottoman Empire had been haunted by violent conflicts stemming both from repeated Montenegrine and Serbian incursions and a number of insurgencies with subsequent Ottoman repression. Given its location on the Strait of Otranto-the narrow gateway to the Adriatic-the conflicting strategic interests of Austria-Hungary and Italy did not always have a soothing effect, but they did create a geopolitical opportunity to attain national independence. After the first Balkan War of 1912, both larger countries promoted Albania's independence from the Ottoman Empire. However, international involvement was unable to stabilize the hand-picked regime led by the German Wilhelm Prinz zu Wied, whose reign lasted less than one hundred days. ${ }^{27}$

Ethnographic information on Albania came to Austria-Hungary via three sources: diplomats stationed in the consulates in Skutari (Shkodra), Valona (Vlorë), and Durrazzo (Durrës); ${ }^{28}$ Catholic clergy under the tutelage of the Habsburg cultural protectorate of the northern Albanian Catholics; and maverick adventurers whose goals were more or less scientific. From the point of view of Volkskunde, information from any of the three groups was liable to distinct flaws. For example, when the consul Theodor von Ippen offered Carl Patsch a manuscript on the northern Albanian town of Skutari (Shkodra), he refrained from delivering a description of the social situation of the "Muslim, Catholic, and Serbian population" in the town, because it would necessarily imply political judgments. Discussing questions of religion and nationality as Patsch had requested would not be scientific in the sense of neutral and objective; in Ippen's view, they had become highly politicized issues in the Balkans. As he was expected to submit his manuscript for inspection by the Foreign Ministry before publication, he self-censored statements that might be considered incorrect or undesirable. ${ }^{29}$ Clerical sources were more loquacious. Ippen

26 Günther Ramhardter, "Propaganda und Außenpolitik," in Die Habsburgermonarchie im System der internationalen Beziehungen, ed. Adam Wandruszka (Vienna: Verlag der Österreichischen Akademie der Wissenschaften, 1989), 496-536.

27 Richard C. Hall, The Balkan Wars 1912-1913: Prelude to the First World War (New York: Taylor \& Francis Ltd., 2002).

28 Even during the military occupation and administration of Albanian territory, the k.u.k. officials never used the Albanian toponyms as was planned, but used the Italian versions and, at most, added the Albanian place names in brackets. This text does the same.

29 Theodor Ippen to Carl Patch wegen Veröffentlichung "Skutari," 12 July 1907, Bay HstA, Südost-Institut, Nachlass Carl Patsch, 287. 
himself drew heavily on the accounts of two Catholic missionaries for his contribution on Albanian common law to an anthology edited by his superior, Ludwig von Thalloczy. ${ }^{30}$ But while some clerical ethnography could capitalize on long and close contact between foreign-born authors and natives, others did not meet editors' requirements. When the Croatian missionary Fra Lovro Mihačević offered Carl Patsch an article on his journeys through Albania, he was turned down. The Hungarian nobleman Franz Baron Nopcsa, ${ }^{31}$ who had arranged the contact, himself admitted that the manuscript was only partially up to standard and that the author was neither willing nor able to revise it. ${ }^{32}$

During the Balkan wars of 1912-1913, public and scientific interest in Albania was especially strong. Albania was considered a living museum of European origins. It offered uncharted landscapes and untapped resources for scholarly exploration, including the archaeological heritage of the Roman Empire and the pre-Roman Illyrian civilization. Its people, especially those in the mountainous north, were regarded as inhabiting premodern tribal social structures, with an apparently primitive material culture and an authentic common law of blood revenge and honor codes. Armed violence and war were held to be endemic. Primitivism and belligerence were the two dominant topoi in representations of Albanian culture: No image of a tribesman was complete without his gun.

Nopcsa was the imperial and royal realm's most dazzling specimen of the ethnographic maverick to visit prewar and wartime Albania. Already a recognized palaeontologist and geographer, Nopcsa found his ethnological interests sparked by his Albanian travels. With Carl Steinmetz, a teacher at the technical school in Sarajevo, he filled a good part of Carl Patsch's series with accounts of northern Albania. ${ }^{33}$ In late 1912, he delivered a public lecture on

30 Theodor Ippen, "Das Gewohnheitsrecht der Hochländer in Albanien," in Illyrisch-Albanische Forschungen, ed. Ludwig von Thalloczy (Munich: Duncker \& Humblot, 1916), 389-435.

31 Ferenz Baron Nopcsa von Felsöszla (1877-1933), born in Deva, Transylvania, to a long line of Hungarian aristocrats. His uncle held high positions at the Emperor's court. See Gert Robel, Franz Baron Nopcsa und Albanien: Ein Beitrag zu Nopcsas Biografie (Wiesbaden: O. Harrassowitz, 1966). For an insight into Nopcsa's personality, see Franz Baron Nopcsa, Reisen in den Balkan:Die Lebenserinnerungen des Franz Baron Nopcsa, ed. Robert Elsie (Peja: Dukagjini, 2001).

32 Franz Nopcsa to Patsch, 21 February, 1909, Bay HstA, Südost-Institut Nachlass Carl Patsch, 390. This correspondence is particularly interesting, because the manuscript nevertheless reached a surprising level of distribution during the war.

33 See in the series subdivision "Travels and Observations": Karl Steinmetz, Eine Reise durch die Hochländergaue Oberalbaniens (Vienna: Hartleben's Verlag, 1904); idem, Ein Vorstoss in die Nordalbanischen Alpen (Vienna: Hartleben's Verlag, 1905); idem, Von der Adria zum schwarzen Drin (Sarajevo: Kajon, 1908); Franz Baron Nopcsa published his travel account Aus Sala und Klementi: Albanische 
the Albanians at the "Urania," a Viennese institute for popular scientific education, discussing their origins and "psyche" and depicting the country as an ideal new field for the anthropological sciences.

As with any other European people, Germans, Greeks, Slavs, and Italians, the origin of the Albanians stretches far back into prehistoric darkness. It can only be explored with the aid of ethnology, anthropology, archaeology, and comparative linguistics. From this point of view, the seclusion to which Albania was condemned under Turkish rule had advantages and drawbacks. Ethnology and anthropology have profited, comparative linguistics has suffered to a minor degree. Positive damage can be recorded for the "science of the spade." The author of these lines was one of the few who have tried in the last years to unearth parts of the so-called artificially preserved treasures for ethnology and other sciences. ${ }^{34}$

Nopcsa called Albanians "Europe's armed children" and advised those dealing with them that the "wild mountaineers" were to be "handled delicately, like chinaware. With rough brutal energy and brute violence, one can achieve short-term quasi-success, but the reaction can be expected sooner or later." 35 Demonstrations of decisiveness, a potential for violence, and intolerance of personal affront were, in his opinion, indispensable for acceptance in local culture and were best symbolized by the display of a sizeable firearm. His cover included a "going native" act based not only on fluency in Albanian dialects and knowledge of local dress, but also on his capacity and willingness to fight. His local partner Steinmetz also prized a Browning pistol as a means of ensuring respect. ${ }^{36}$ Nopcsa was not deterred by attempts on his life, apparently regarding them as a sign of his social acceptance. Traveling on the periphery of the Ottoman Empire had never been particularly safe or easy, and Ottoman officials were not fond of foreigners doing research in their border areas, in part because their own authority in the region was limited. Under the circumstances, weapons and disguises seemed advisable.

Nopcsa did not publish his material in monographic form until after the war. His interest in Albania was not restricted to science; he repeatedly offered his knowledge to political decision makers in Vienna. The "Urania" lecture, for example, especially the section on the Albanian psyche, was intended to educate the Foreign Minister, Leopold Graf Berchtold. But Nopcsa's enthusi-

Wanderungen (Sarajevo: Kajon, 1910), but also contributed to the official periodical of the Landesmuseum: Wissenschaftliche Mitteilungen aus Bosnien und Herzegovina; another contributor to Patsch's series was the Albanian nobleman Ekrem Bei Vlora, Aus Berat und vom Tomor: Tagebuchblätter (Sarajevo: Kajon, 1911); and during the world war the Albanologist Maximilian Lambertz, Die Volkspoesie der Albaner: Eine einführende Studie (Sarajevo: Studnicka, 1917).

Franz Baron Nopcsa, "Die Albaner," Urania 1/2 (1913): 2.

Marchetti, "Scientists with Guns," 165-190. 
asm for the Albanian cause met with strong resistance among diplomats and politicians in Vienna. His interest in the corridors of power waned in 1913, when his plan to become king of the newly independent country caused only stifled amusement in Viennese diplomatic circles. ${ }^{37}$

\section{Ethnographic Warfare}

The assassination of Franz Ferdinand by a separatist in Sarajevo-with a Browning pistol-became the spark that ignited the powder keg of Europe. But the Balkans, whose post-Ottoman ethnic heterogeneity and violent nationbuilding processes were already perceived as sources of political turbulence, played only a minor part in the war.

In 1916, World War I was at its peak. The multiethnic Austro-Hungarian Empire had struck down its archenemy Serbia, but only with substantial assistance from its German ally. To distract from their own weak performance, imperial forces chased the collapsing Serbian army down the Balkan Peninsula, conquering Montenegro and occupying northern parts of neutral Albania on the way. ${ }^{38}$ Bulgarian forces held the eastern part of Albanian-populated territory, while the southern part was occupied by French and Italian troops. The invading armies were slowed by flooding and the lack of roads and bridges and weakened by the subtropical climate's heavy winter rains and malarial summer swamps. The local population was not overtly hostile, but, in the eyes of the occupiers, the Albanians remained wild and unreliable, lacking a sense of national unity. The occupation was experienced as a "colonial campaign." ${ }^{9}$

Decisive fighting during the occupation, as well as the pursuit of the Serbian army down the peninsula, was led by a pro-Habsburg volunteer corps. Two of its leaders were Nopcsa and Steinmetz. Soon after the forces occupied Albania and installed a military administration, Nopcsa was expelled from the country; army officials suspected him of following his own agenda. ${ }^{40} \mathrm{He}$ shared this

37 Robel, Franz Baron Nopcsa und Albanien, 111-112.

38 Manfried Rauchensteiner, Der Tod des Doppeladlers: Österreich-Ungarn und der Erste Weltkrieg (Graz: Styria, 1993), 319-321.

39

Österreichisches Bundesministerium für Heerwesen und vom Kriegsarchiv, ed., Österreich-Ungarns letzter Krieg, vol. 4, Das Kriegsjahr 1916, Part 1: Die Ereignisse Jänner bis Ende Juli (Vienna: Verlag der Militärwissenschaftlichen Mitteilungen, 1933), 80. The authors of this officious war account put the term in quotation marks themselves.

40 Kriegsarchiv-Wien, AOK-OpAbt/B-Gruppe/1916/Nr. 24112, 22 April 1916. Nopcsa spent the rest of the war spying on Serbian infiltration in Rumania, where his family's estate was situated. As a result of the war, these possessions were lost. Nopcsa never returned to Albania and committed suicide in 1933. 
fate with other experts on Albania, all of them, vis-à-vis the military, victims of mutual antipathy. Military men disliked the experts' know-it-all manner, along with their insubordination and "Orientalized" appearance.

While the Empire's political and military leaders debated the goals of the war, their subordinates on the ground in Albania were at odds about the country's future. Diplomats wanting Albania to become a quasi-independent Austrian satellite encouraged Albanian nationalism, while the military saw Albania as the spoils of war and had clear colonial ambitions. The XIXth Army Corps installed a military administration and adopted various measures to pacify and govern the country. To stem the chronic violence, they proclaimed a general besa, a temporary moratorium on family feuds. ${ }^{41}$ Later, the administration tried to end blood revenge once and for all by installing commissions of reconciliation. ${ }^{42}$ The Habsburg High Command ordered the creation of a militia, with divisions based on different tribes. Given the country's peculiarities, conscription was shelved in favor of volunteer enlistment. ${ }^{43}$ Generally, Albanian volunteers were assigned to Bosnian units and sent to the front lines. The military saw its discipline as part of a civilizing mission. It would help to

put under surveillance the larger part of the population, which may be fit for military service but is actually always lazing around, and is therefore easily engaged in suspicious activities, and to get an overview of the military potential of the country and gain some positive influence on the population. ${ }^{44}$

41 In the ethnological literature on Albanian feuding, "besa" is translated as "holy promise" and defined as oath for reconciliation, the reconciliation itself, and the holy obligation of the ritual itself. See Stefanie SchwandnerSievers, "Humiliation and Reconciliation in Northern Albania: The Logics of Feuding in Symbolic and Diachronic Perspectives," in Dynamics of Violence: Processes of Escalation and De-escalation in Violent Group Conflicts, ed. Georg Elwert (Berlin: Duncker \& Humblot, 1999), 133-152. The k.u.k. authorities interpreted the word without its ritual "sacredness," ascribing to it a more general temporal public peace. Reconciliation was carried out with adequate bureaucratic formalism: Kriegsarchiv-Wien. XIX.Korps.1916/581/I-XXXVIII.

42 Mariano San Nicolo, Die Verwaltung Albaniens durch die k.u.k. österreichischungarischen Truppen in den ersten zwei Jahren der Besetzung des Landes an der Hand der ergangenen Befehle (Vienna: Druckerei des k.u.k. Kriegsministeriums, 1918).

43 Armeeoberkommando: Albanesen-Ausbildung, 13 April 1916, Kriegsarchiv, AOK-OpAbt/B-Gruppe/1916/Nr. 23366.

44 XIX Korpskmdo Op. Nr. 734/19, 26 March 1916, Albanesen Ausbildung Trollmann, in Armeeoberkommando: Albanesen-Ausbildung, 13 April 1916, Kriegsarchiv, AOK-OpAbt/B-Gruppe/1916/Nr. 23366. While k.u.k. diplomats advanced the creation of purely Albanian units and saw them as a precursor for a later national Albanian army, the military only reluctantly provided its heraldic competence to design adequate flags, showing the Albanian eagle 
To aid in organizing the tribal militia, the High Command put out a booklet entitled Tribal Structure, Norms, and Customs of the Albanians, ${ }^{45}$ extracted from a manuscript by the missionary Mihačević, who was now prior of the Sarajevo district's Franciscans. In large part, it had been translated and published in 1913 in Prague. ${ }^{46}$ It portrayed the rural Albanian population as separated into distinct clans, each of which could be traced back to a common ancestor, listing their territories in both Albania and Macedonia along with Catholic dioceses and parishes. The booklet portrayed the Albanian as a patriarchal tribesman, eternally armed and ready for a fight. His choleric temper and explosive violence is bound by a code of honor including blood revenge, besa, and hospitality. Mihačević described Albanians as heroic fighters, valued by the Ottomans and attaining to high ranks in their army, but called ambush and sniping their preferred tactics.

Turning these "tribal warriors" into disciplined soldiers was no easy task for Austrian officers, especially when they were also instructed to respect their costumes and psyches. Drill instructors were forbidden to use corporal punishment on Albanian volunteers; such an act would "force" the victim to take blood revenge. ${ }^{47}$ The dissonance between such representations and officers' actual experiences persisted throughout the occupation, causing lengthy disputes between liberal diplomats and military officers who urged a less sympathetic treatment of the volunteers, until the formations were dissolved in early $1918 .^{48}$

\section{Warlike Ethnography}

While the Sarajevo Institute could resort to a network of informants on site, and privileged mavericks were themselves capable of carrying their knowledge to the metropole, Viennese scholars needed a new arrangement to access the periphery.

on red ground, for it denied the Albanians sufficient patriotism. Kriegsarchiv Wien. AOK-OpAbt/B-Gruppe/1916/Nr. 25205, 20 May 1916.

45 Fra Lovro Mihačević, "Stammesgliederung, Sitten und Gebräuche der Albaner, Armeeoberkommando (Broschüre)," in KA, Zu K.-Nr. 23759.

46 Idem, Durch Albanien: Reiseeindrücke, trans. from the Croatian by Otto Slavik (Prague: Bonifatius-Buchdruckerei, 1913).

47 Allgemeine Direktiven für die Ausbildung der Albaner. Kriegsarchiv, AOKOpAbt/B-Gruppe/1916/Nr. 24336.

48 Stephan GrafBurian-Rajecz, "Auflösung der Albanerformationen," 17 September 1918, Hofarchiv, Diplomatie und Außenpolitik 1848-1918, GKA KsA Skutari, K 17 Verwaltung 1916-1918, 690. 
Accordingly, on May 11, 1916, Dr. Franz Kidrić bought himself a gun. A Slavicist in the employment of the Imperial Library, exempt from military service, he was preparing to take part in a scholarly venture officially entitled "Expedition [for the study of] Arts, History, Ethnography, Archaeology, and Linguistics in the Imperial-and-Royal Occupied Zones in Serbia, Montenegro, and Albania, Commissioned by the Ministry of Education and the Imperial Academy of Sciences." ${ }^{\prime 9}$

The impetus for the interdisciplinary expedition came from a meeting in the Ministry of Education that had been called to address the issue of collections and libraries in the occupied Serbian capital of Belgrade. The collections were scientific booty and had to be disposed of in a scientific way. Against a backdrop of struggles to pacify Albania, the plan for a historical-ethnographic Balkan expedition emerged as a tangent to this discussion. Its official mission was to demonstrate the strong scientific interest and the Kulturmission of Austria-Hungary in the Balkans and to counter enemy propaganda. ${ }^{50}$

One of the participants in the initial meeting was Michael Haberlandt, who attended as a representative of the Imperial and Royal Central Commission for the Protection of Historic Monuments. His son Arthur was a freshly qualified private lecturer in ethnography and heir apparent to his father's career. He had enlisted voluntarily, serving in the fortress of Trebinje in southern Herzegovina, and was wounded twice. He was one of the first to be named as a potential member of the expedition and one of the few to remain on the list throughout the planning process. It is conceivable that beyond the younger Haberlandt's scholarly qualifications and interests, the chance to serve with less risk to life and limb had its share in his and his father's motivations. ${ }^{51}$

Plans for the expedition took shape quickly. Six scholars, all in their late twenties or early thirties, were appointed to travel to Montenegro, northern Albania,

49 "Kunsthistorisch-Archäologisch-Ethnographisch-Linguistische Balkanexpedition in den k.u.k. besetzten Balkangebieten, im Auftrag des k.k. Unterrichtsministeriums und der kaiserlichen Akademie der Wissenschaften in Wien." With the label "expedition," the journey gained a heavy symbolic valorization. As the typical mode of traveling scientific exploration, expeditions were the products of intricate alliances between intellectual and commercial elites and stood in the focus of public interest. They served as powerful ideational and ideological apparatuses through which European citizenries related themselves to other parts of the world. See Mary Louise Pratt, Imperial Eyes: Travel Writing and Transculturation (London: Routledge, 1993), 23.

50 Allgemeines Verwaltungsarchiv Wien. 02 Unterricht "Kunstwesen Ausland in genere," K. 3118. Nr. 2709. 26 January 1916.

51 The numerous letters of petition sent by Haberlandt senior in the name of the Association for Austrian Volkskunde, pleading for the exemption of Haberlandt junior from military service for varying reasons, support this perception. 
and Serbia from May 22 to August 12, 1916. They were: Arthur Haberlandt, ethnographer; the Slavicist Franz Kidrić; two archaeologists, Arnold Schober and Camillo Praschniker; the linguist and expert on Albanian dialects Maximillian Lambertz; and the art historian Ernst Buschbeck. Haberlandt, Buschbeck, and Praschniker were army officers, while the rest were civilians. Kidrić and Schober had been exempted from military service in order to teach, respectively, Russian language at the Oriental Institute and archaeology at the university. Lambertz was considered unfit for service due to myopia.

As no one could travel to the Balkans unarmed, the civilians received permission to carry weapons. Kidrić also sought permission to wear a kind of uniform. He eventually received a grant to buy a sword and supplement a grey raincoat with some elements of a uniform so that he could travel under the guise of a military officer. ${ }^{52}$ While the civilians braced for their contribution to the war effort by dressing up as soldiers, the military men seemed to appreciate their new posting as a chance to avoid the lethal trenches of the front lines. At the head of the expedition was Buschbeck, the highest ranking officer.

The established academics, mentors to the young scientists, had apparently been candid about the enterprise's primarily scientific aims, but political and strategic goals were in evidence from the start. The expedition's participants were ordered to fulfill military requests "as far as possible to allow them to comply with their time budget and the aims of their scientific research." ${ }^{3}$ The military mainly sought expert assessment of the economic situation in the occupied regions. In an eleven-point list, it requested attention to aspects of the agrarian sector, infrastructure, natural resources and raw materials, social and cultural matters, and potential colonization and assimilation of the territory and its population. ${ }^{54}$

An official order permitted the group the use of military transportation and support and advised the occupation forces to assist the scholars in every way possible. From Vienna, the expedition traveled by train via Budapest to Sarajevo. Arthur Haberlandt began his ethnographic work on the way from the military harbor of Cattaro (Kotor) to Montenegro's capital at the time, Centinje. The expedition followed the military campaign's route over the Lovćen pass, where the decisive battle over Montenegro had been fought. From Podgorica, they crossed Lake Skutari and entered Albania. Skutari (Shkodra) became the expedition's base. ${ }^{55}$ From there, the journey continued via Kruja,

52 Hofarchiv-Wien, Oberstkämmerer-Amt, R.56,55/ No. 3092. 12 November 1916.

53 Rundschreiben an alle Teilnehmer wissenschaftlicher Expeditionen nach Serbien, Montenegro und Albanien. 1916/5, ÖAW, Balkankommission, K3 H10.

54 Ibid.

55 The k.u.k. administration tried to switch from the use of Italian spelling for town names to Albanian spelling. This attempt to eliminate Italian influence 
Tirana, and Elbasan southward as far as the Shkumbi River, which divides northern and southern Albania. Following the Shkumbi upstream, the expedition reached its headwaters, then turned northward back to Skutari. Travel was restricted to areas occupied by Austria-Hungary, in part due to Bulgaria's refusal to permit access to Bulgarian-occupied parts of western Albanian territory. From Skutari, Haberlandt and Buschbeck proceeded to cross the northern range into Kosovo on foot, reaching Belgrade by train. Schober returned to Vienna for the new academic semester, while Lambertz stayed on to study several local tribes' dialects. Kidrić and Praschniker were hospitalized for malaria and dysentery. ${ }^{56}$

The expedition's premature end surprised no one. The differences in scholarly objectives and methods that affect any collective scientific pursuit, conflicting opinions as to which sites were of interest, and divergent approaches to the population led the group to disband. While the linguist Lambertz, the most independent due to his fluent Albanian, hardly mentioned his colleagues in his report, Arthur Haberlandt praised the project's interdisciplinarity and was conscious of benefiting from military support. As he pointed out, many areas were accessible only because of the occupation. They included the interiors of Muslim homes; taking pictures there had previously been impossible. ${ }^{57}$ Albanian recruits were available for measurement and photography with methods advanced by Rudolf Pöch for use in prisoner-of-war (POW) camps. ${ }^{58}$

The material encountered by the expedition was sorted into various categories. Language, spoken or written, served as linguistic and historical evidence; Kidrić collected recent war-related publications for the war collection

was never fully implemented and, consequently, Italian names with Albanian names in brackets were used.

Arthur Haberlandt, "Bericht über die ethnographischen Arbeiten im Rahmen der historisch-ethnographischen Balkanexpedition," in Mitteilungen der Geographischen Gesellschaft in Wien 59 (1916): 736-742; Maximilian Lambertz, Bericht über meine linguistischen Studien in Albanien von Mitte Mai bis Ende August 1916 (Vienna: Verlag Kaiserl. Akademie der Wissenschaften, Philosophischhistorische Klasse, 1916); Camillo Praschniker and Arnold Schober, Archäologische Forschungen in Albanien und Montenegro (Vienna: Hölder, 1919); Ernst Buschbeck, "Vorläufiger Bericht über die Balkanexpedition im Sommer 1916," Mitteilungen der k.k. Zentral-Kommission für Denkmalpflege 16 (1918): 1-13; Hofarchiv Wien, Oberstkämmerer-Amt B/K 908/II/1916, R. 56 Nr. 2660, 1916/8/1.

57 Haberlandt, "Bericht über die ethnographischen Arbeiten."

58 Haberlandt published the results of these anthropological measurements together with Viktor Lebzelter, who added material of Albanians he measured in Austrian prisoner-of-war (POW) camps. Arthur Haberlandt and Viktor Lebzelter, "Zur physischen Anthropologie der Albanesen," Archiv für Anthropologie 17 (1919): 123-154. See also the articles by Margit Berner and Britta Lange in this volume. 
of the Royal Library and unearthed ancient Orthodox religious manuscripts from abandoned monasteries. The archaeologists discovered classical statuary and surveyed medieval towns and Roman fortresses. Beyond his ethnological data, Haberlandt also collected products of contemporary craftsmanship including pottery and elements of traditional costume.

But the expedition's mission was not to plunder in the name of science. The official instructions had stipulated that nothing may be carried away that the native population might regard as valuable, at least not for the moment. Not that all the researchers obeyed these instructions: Haberlandt carried home no fewer than 120 items, most of them bought at the bazaars of Skutari (Shkodra) and Üsküb (Skoplje). While Liebhaberei-collecting as a hobby or, better, for sentimental reasons-was an adequate excuse for officials back home, Haberlandt's reasoning was professional: His approach to ethnography was centered on things. Museum-based comparative scholarship needed objects and could not work with recorded evidence alone. Coming home emptyhanded would have made proper scientific inquiry impossible.

The expedition's primary mission was explicitly scientific, with no military purpose. But as its members interacted with the occupation, various paths eventually led them away from scientific neutrality. Some members became directly involved in the politics of occupation and the operations of military repression. Lambertz, having left his colleagues in order to roam the northern Albanian highlands, attached himself to an Austro-Hungarian battalion under the command of Oberstleutnant Gustav Broser, whom he had met in the village of Lurja Eper. As Broser was assigned to hold trials in Lurja and the neighboring Ksela tribal area, Lambertz was asked to assist with his knowledge of the native language. He submitted a report summarizing his duty:

What I experienced in my ten-day collaboration with the 19th battalion, in arduous cooperation with its pleasant officers in this uncomfortable corner of Albania, belongs more to the political history of Albania in these stormy times than in a scientific report of a learned society. Suffice it to say that we forcefully had to call it to the attention of the Mohammedan Lurjas, as well as to the in no way better Catholic Kselas, that the "good old" Albanian times were over, and that Central European civilization in the form of the Austro-Hungarian Army had permitted itself to knock on their doors, which were closed to cultural and ethical appeals. ${ }^{59}$

The visit from Central European civilization, as Lambertz failed to mention in his report, left around forty-four Albanian villagers dead. ${ }^{60}$ Lieutenant Colonel Broser had led a punitive military expedition in response to an assault

59 Lambertz, Bericht über meine linguistischen Studien in Albanien, 26.

60 August Ritter von Kral, 4 Oktober 1916, "Verstimmung der Albaner," in Anträge auf Änderung der Militärverwaltung in Albanien, Auszug aus einer 
on a mountain patrol that had killed two soldiers. Villages were searched for weapons, hostages were taken, and suspects executed. For the Counselor of the Foreign Ministry to the Military Administration in Albania, August Ritter von Kral, the "affaire Lurja" was proof that his military counterparts were acting without regard to the monarchy's relations to Albania. He charged the military not only with lacking understanding and goodwill, but being unwilling even to try to understand the character of the country's population. Kral alleged that Broser's repressions produced more than the officially stated forty-four dead, and that the imperial forces were accompanied by a band of Mirdite tribal warriors under the leadership of Kapetan Marka Dijon who allowed them to rob, loot, and murder. ${ }^{61}$ Kral's attack was aimed at the head of the general staff in Albania, Colonel Lustig, whose orders he called "demonic and dreadful." Lustig's conduct was based, he wrote, on the assumption that the Albanians were an inferior and despicable race to be tormented with impunity and crushed like worms. ${ }^{62}$

The disdain that civil and diplomatic personnel involved in the administration of occupied Albania felt for the military was mutual. While diplomacy followed a policy of nation-building, the military denied the Albanians the character of a nation, preferring to depict them as "partitioned into countless tribes, feuding with each other, situated on the lowest level of culture." Only a full integration of the occupied territory into the monarchy's realm and its civilizing dominion over the mountain tribes could secure the border region for Austria-Hungary. ${ }^{63}$ The various tribal policies can be seen as part of this strategy.

For the scientists, now considered experts on the region because they had toured it, the situation held various opportunities. Only three of them returned to their previous occupations while the war lasted: Schober kept his position at the Archaeological Institute in Vienna, and Kidrić rejoined the Imperial Library, while Buschbeck alone returned permanently to his military post. He advanced to become a staff officer in the Orientkorps and was involved in partisan fighting in eastern Albania up to the end of the war. Lambertz, having collaborated in the military's tribal strategy, changed sides to join the diplomatic project of nation-building. Kral had established a Literary Commission

Note des Außenministeriums, Kriegsarchiv, AOK-OpAbt/B-Gruppe/1916/K 510, Nr. 31667.

61 Ibid.

62 Idem, 3 August 1916, "Abberufung des Generalstabschefs Oberst Lustig," Hofarchiv, Diplomatie und Außenpolitik 1848-1918 GKA KsA Skutari, K 21 Nr. 804.

63 Franz Conrad von Hötzendorf, 20 April 1916, "Alleruntertänigster Vortrag über Kriegsziele der österreichisch-ungarischen Monarchie," Kriegsarchiv, AOK-OpAbt/B-Gruppe/1916/Nr. 24055. 
of Albanian intellectuals, including the priest and poet Gjergi Fishta, author of the epos of Albanian national struggle Lahuta e Malcis, and the linguist Gjergi Pekmezi, to elaborate on the question of an official Albanian alphabet and to develop textbooks for Albanian schools. Lambertz became secretary of the Commission and played a decisive role in its progress. ${ }^{64}$ Other expedition participants were assigned to the Orient Department of the War Ministry, installed in early 1917 to secure trade routes and supply lines with the Ottoman ally and other Near-Eastern countries. ${ }^{65}$ The Ministry returned the archaeologist Praschniker to Albania under orders to protect antique monuments and artefacts put at risk by warfare. ${ }^{66}$ The craving of imperial soldiers for souvenirs was among the more urgent dangers; Praschniker's mission included collecting and securing antiquities and making provisions for a museum. Kral had been thinking about the prospect of a national museum in Albania ever since he had toured the country with Patsch, starting from Sarajevo in November of $1917 .{ }^{67}$

The question of borders was another source of discord within the occupation regime, and redemption from the deadlock was to be provided by a scientific expert. After the occupation, imperial forces had turned the border between Montenegro and Albania into a demarcation line between two military governmental units. While Montenegro as conquered enemy territory was ruled by a Generalgouvernement, Albania was formally a neutral occupied country, administered by the XIXth Army Corps. Thus, the demarcation of the London Conference in 1912 was maintained, even though it contradicted the position that the Habsburg monarchy had taken during the proceedings. The ostensibly trivial administrative decision had severe local consequences. It cordoned off parts of the Gruda and Hoti tribes from their traditional markets, and Malsor shepherds farther east found trails to their pastures cut off. While diplomacy struggled to solve the problems, which were affecting Austria-Hungary's local prestige, the military insisted that the question of borders could only be solved in conjunction with that of the future status of the whole country. ${ }^{68}$ Arthur

64 August Ritter von Kral, 21 Oktober 1917, Albanische literarische Kommission, Hofarchiv, Diplomatie und Außenpolitik 1848-1918 GKA KsA Skutari, K 21, Konvolut 18, Nr. 753.

65 Orientabteilung, "Tätigkeitsbericht der Orientabteilung des k.u.k. Kriegsministeriums über das Jahr 1917," Kriegsarchiv, Kriegsministerium, Internakten, Karton 128, Nr. 4162.

66 Ibid.

67 Albanisches Nationalmuseum, 8 April 1918, Hofarchiv, Diplomatie und Außenpolitik 1848-1918 GKA KsA Skutari, K 21 Nr. 1815.

68 August Ritter von Kral, 6 May 1918, "Frage der Einverleibung von Gruda und Hoti in Albanien," Hofarchiv, Diplomatie und Außenpolitik 1848-1918 GKA KsA Skutari, K 20 Akt 5 Nr. 382. 
Haberlandt, who had returned to his artillery unit, was assigned to the Orient Department in early 1918 and charged with traveling as a scientific delegate into the "Slavic-Albanian borderlands." The plan was strongly supported by the Foreign Ministry. ${ }^{69}$

\section{Using the War}

Arthur Haberlandt's solo expedition never took place. Examining the interconnections of war and science, the historian Mitchell Ash points out that instrumentalization of scholarship by the military is a mutual effort. Research autonomy appears to be a matter of bargaining; to gain access to resources the military can offer, especially in times of war, the scientist must have something to exchange-not necessarily a product, more often a project or program.

The Orient Department, apart from promoting the Empire's war economy by organizing trade and supply from the southeast, was engaged in the economic and cultural development of the occupied Balkan territories. ${ }^{70}$ Part of its cultural mission was to support the collection of ethnographic objects for the Kaiser Karl Museum für österreichische Volkskunde. The Haberlandts were commissioned with staging a public exhibition, which opened under the title "On the Volkskunde of the Occupied Balkan Territories" in the ballroom of the University of Vienna in January, $1918 .^{71}$ They had already designed a display to present products of home industry from the occupied region in the Museum for Arts and Industry in October, 1916. While the first exhibition had displayed mostly objects collected before the war updated with photos from the expedition, the second show incorporated Arthur Haberlandts's Liebhaberstücke-his private collection-and other collections and portrayals made during the occupation, such as the work of the artist Leopold Forstner. ${ }^{72}$ Despite his duties at the Orient Department, Haberlandt found time to promote the relocation of the Volkskunde Museum from the stock exchange building to its new (and still

69 Kommandierung des Lt. d. Res Dr. Artur Haberlandt G.A.R.8 zur O.A. 1918/4/26, Kriegsarchiv, KM/Orientabteilung, Nr. 9366.

70 Orientabteilung, "Tätigkeitsbericht der Orientabteilung des k.u.k. Kriegsministeriums über das Jahr 1917," Kriegsarchiv, Kriegsministerium, Internakten, Karton 128, Nr. 4162.

71 See report in Zeitschrift für österreichische Volkskunde 21-22 (1915-1916): 201-202; "Die Balkanausstellung in der Universität," Neues Wiener Tagblatt, January 8, 1918.

72 Forstner traveled Albania in 1917 on behalf of the Imperial Military Museum; he collected and painted also for the Museum of Austrian Volkskunde. See Leopold Forstner, "Studien in Albanien und Mazedonien," Kunst und Kunsthandwerk 21 (1918): 8-10. 
current) home in the Palais Schönborn. The relocation was eventually carried out, with logistical support from the military, in 1918.

The Haberlandts also attempted to formalize a program of ethnographic contribution to the war effort. By the time the war ended, Arthur Haberlandt had written two monographs. The first, a detailed account of the expedition's findings, was published in 1917 as a special issue of the journal Volkskunde. After a lengthy passage on Balkan culture, he offered practical advice: The region possessed "in the modern sense inferior, but sufficiently developed economic and cultural bases that must be treated as autonomous and selfcentred economic entities, and not as virgin soil for colonial engagement by the West."73 Determination and a commitment of material support would be needed to overcome the natives' primitive, individualistic, and unproductive self-assertiveness. On a footing of self-confident power, imperial will might unite the fragmented people and lead them to higher stages of organization and culture, while education and literacy would accustom Montenegrins and Albanians to regular labor, integrating them into European civilization. ${ }^{74}$ In a memorandum to the War Ministry in 1917, the Haberlandts offered additional advice, proposing short essays for textbooks, pictures, and movies to help convey knowledge of the Balkan Peninsula to military personnel. ${ }^{75}$ The scientists even attempted to involve the military in collecting objects: The memo explained how to deal with the volkskundlicher Besitz [folkloric possessions] of occupied peoples, indicating that objects should not be misappropriated. Carpets and embroidery, even small wooden objects like spoons or forms for cheese, should be regarded as valuable both in the material sense as products of a domestic industry worthy of protection and as potential national symbols. ${ }^{76}$ If found abandoned, such objects should be collected and delivered to the museum in Vienna. An officer with appropriate expertise should be assigned to catalog the objects, most likely Arthur Haberlandt. Ethnographic research would have a positive local propagandistic effect by demonstrating the Habsburg rulers' concern for the cultures of their subjects.

73 Arthur Haberlandt, Kulturwissenschaftliche Beiträge zur Volkskunde von Montenegro, Albanien und Serbien: Ergebnisse einer Forschungsreise in den von den k.u.k. Truppen besetzten Gebieten Sommer 1916, trans. by Christian Marchetti (Vienna: Verein für österreichische Volkskunde, 1917), 167.

74 Ibid; The second monograph, a luxuriously printed folio volume with numerous pictures and single-spaced text, dealt with Balkan folk art and was published in 1919, immediately following the Austro-Hungarian defeat in the war.

75 "Zur wissenschaftlichen Erforschung der besetzten Balkangebiete," Zeitschrift für österreichische Volkskunde 23 (1917): 91-92.

76 "Obsorge für die Volksdenkmäler in den Kriegsgebieten," Zeitschrift für österreichische Volkskunde 23 (1917): 132-133. 
The museum would become the scholarly center of Balkan studies after the expected victory. ${ }^{77}$

Perhaps the Haberlandts were not merely selfish in preferring museum work to mediating border disputes in the Balkans. Ethnographic interests and activities were presented as having positive propagandistic and socially mobilizing effects. The elder Haberlandt insisted that Volkskunde could supply a scientifically ascertained canon of indisputable facts to counter any nationalistic argument. It could provide a clear picture of the ethnographic distribution of people and of their actual condition as well as the multiple cultural interrelations of the Volksstämme of the Empire. "Idiosyncrasy in all that is small and inward, commonality in all that is big, and united loyalty always and forever against the outside - this is the Austrian motto!"78

In January 1918, Woodrow Wilson declared his Fourteen Points for a postwar world, invoking the principle of national self-determination in proclaiming that "the peoples of Austria-Hungary, whose place among the nations we wish to see safeguarded and assured, should be accorded the freest opportunity of autonomous development." Arthur Haberlandt sketched Austrian Volkskunde's response to such claims:

What are peoples, how is their life, their existence made up, that they are now supposed to determine themselves, and what is the worth of the word "determine" against the unalterably given geographical conditions and the historically grown actual states? ${ }^{79}$

Arthur Haberlandt believed that neither constitutional law nor science could provide a consistent definition of a Volk [people]. ${ }^{80}$ Consequently, in his definitions, Volksstamm [tribe] and Volk were defined by "objective" common descent, language and culture. A Nation was a political entity, exemplified by the Swiss and American multiethnic nations. In the face of the highly differentiated and complex situation of the peoples of Europe and its multitude of contested

77 Archiv des österreichischen Vereins für Volkskunde Wien, Karton 3, Faszikel: Sitzungsprotokolle, "Protokoll der Sitzung des Unterausschusses für die Balkan-Abteilung des Kaiser Karl Museums, 7.3.1918."

Michael Haberlandt, "Nationalitätenstaat und Volkskunde," Österreichische Rundschau 53, no. 1 (1917).

79 Arthur Haberlandt, G. Freytags Völkerkarte von Europa (Vienna: G. Freytag \& Berndt Kartogr. Anstalt, 1918) (with a commentarial text).

80 Haberlandt expounded the problems of the use of language as an index of nationality as it was used by k.u.k. statistics. An interesting account of the role of the concepts of "Nation," "Volk," and "Volksstamm" in AustroHungarian constitutional law and judicial praxis is given by Emil Brix, Die Umgangssprachen in Altösterreich zwischen Agitation und Assimilation (Vienna: Böhlau, 1982), 36-66. 
borders, whether of language or culture, Haberlandt praised the Swiss paradigm as a state-organized community of "tribes." A multilingual state could free people from the narrow cage of language and further the development of "higher European culture." One can infer from these statements a distinct claim for German leadership, that is, a desire to install German as the lingua franca of the empire and its science. Such claims were never explicitly formulated. The hegemony of "higher" German culture, which would lead Slavic and Balkan "folk cultures" up the ladder of "European culture," was increasingly alluded to, but the claim was still tacitly based in a liberal paradigm.

From early 1918 on, leaders of the Empire's most influential political bodies engaged in controversial discussions of ethnographic questions, such as whether there is a South-Slavic nation. But soon a reality indifferent to such "facts" took over. ${ }^{81}$

\section{Losing the War}

Neither the Haberlandt nor the Habsburg dynasty could avert the dismemberment of the Empire after its defeat. For the scientists, the end of the war was more or less concomitant with the end of the liberal paradigm. As late as November of 1916, the Volkskunde Museum had been praised as "an outstanding monument to the Austrian Völkerschaften [peoples] and to the glorious unity of all Austrian Völkerstämme [tribes] in the war." ${ }^{22}$ Yet as early as March 1919, in a memorandum to the State Department of Education, the Haberlandts praised their museum's collection as being centered on German-speaking Austria and "depicting the autochthonous folk culture of the German Alps and Germans in the Sudetenland in all their expressions in an instructive display." In the eastern European collections, it was no longer underlying universal principles that surfaced, but instead "the broad cultural insemination and influence of German culture." ${ }^{83}$ The displays had not changed; the objects were simply as apt to construct nationally homogeneous imagined communities as to argue

81 Holm Sundhaussen, "Von der Multiethnizität zum Nationalstaat: Der Zerfall 'Kakaniens' und die staatliche Neuordnung im Donauraum am Ende des Ersten Weltkrieges," in 1917-1918 als Epochengrenze?, ed. idem (Wiesbaden: Harrassowitz, 2000), 79-100.

82 Präsidium des Vereines für Österreichische Volkskunde and das k.k. Ministerium für Kultus und Unterricht um Bewilligung von Subventionen, 10 November 1919, AVA 02 Unterricht, Museum für österreichische Volkskunde, Nr. 36016.

83 "Denkschrift über das Museum für Volkskunde Wien, AVA 02 Unterricht," 27 March 1919, Kaiser Karl Museum für Volkskunde, Nr. 12420. 
for the unity of the European peoples. ${ }^{84}$ The Haberlandts continued to publish on European folk culture through the late 1920s ${ }^{85}$ Arthur Haberlandt lectured Wehrmacht soldiers in occupied Belgrade on the folk art of the Balkans. ${ }^{86}$

Other experts executed a similar about-face. Patsch, who during the war had struggled to claim a piece of the war-induced scientific boom for his Balkan Institute (apparently, e.g., planting the article quoted at the beginning of this chapter), was forced to leave Sarajevo and set up a new Balkan Institute in Vienna in 1919. In 1924, he was invited by the Albanian government to design an Albanian national museum in Tirana. Drawing on his experience in Sarajevo, both positive and negative, he insisted it be not a Landesmuseum [country museum] but a national museum, displaying all of Albanian culture whether inside or outside the state's political borders. ${ }^{87}$

During World War I, Viennese Volkskunde basked in attention from state institutions as never before, helping to legitimize a multiethnic empire that would transfer its internal colonialism to new annexations. By the time ethnography toured Albania in an occupier's uniform, the country's culture was less a model for heroic posturing than an asset for appropriation by a German-Habsburg sense of cultural mission. As official policy, the international and subnational approach of Austro-Hungarian Volkskunde vanished with the Empire. But conserved for posterity in collections and accounts, multiethnic Volkskunde, continued-or continues-to underpin political aims even as circumstances change.

84 Johler, "Das ethnische als Forschungskonzept," 88. But also Albanian folklore scholarship under Communism could cite Franz Baron Nopcsa's and Arthur Haberlandt's works: Pirro Thomo, "Les habitations a kulle en albanie," Ethnographie Albanaise 12 (1982): 5-27; Spiro Shkurti, "Essai de classification des Araires Albanais," Ethnographie Albanaise 12 (1982): 93-131; Aleksander Dhima, "Variations du type physique chez les habitants du district de librazhd," Ethnographie Albanaise 12 (1982): 251-285.

85 Michael and Arthur Haberlandt, Die Völker Europas und ihre volkstümliche Kultur (Stuttgart: Strecker und Schröder, 1928).

86 Herbert Nikitsch, Auf der Bühne früher Wissenschaft: Aus der Geschichte des Vereins für Volkskunde (1894-1945) (Vienna: Selbstverlag des Vereins für Volkskunde, 2006), 400.

87 Carl Patsch, "Albanisches Nationalmuseum-Vorschläge-Konzepte," Bay HstA, Südost-Institut Nachlass Carl Patsch, K 276 Wiederbelebung der Erforschung Albaniens. 


\section{Studying the Enemy: Anthropological Research in Prisoner-of-War Camps}





\title{
Large-Scale Anthropological Surveys in Austria-Hungary, 1871-1918
}

\author{
Margit Berner
}

1889: At a joint meeting of the German and Viennese Anthropological Societies, Rudolf Virchow (1821-1902) announces that, in the next twenty years, more study should be devoted to the relations and differences between the inhabitants of Europe, which he regarded to be anthropologically less well studied than non-Europeans. ${ }^{2}$ Like the majority of his colleagues, he rejects the idea that "nationalities" past or present were identical with "races." Peoples of a "pure race" existed only in the distant past, and the nations of Europe are admixtures of those original groups. He professes particular interest in the German and Slavic populations of Germany, Austria-Hungary, and Russia. Russia and Germany intrigue him for their variety and regional differences in human morphology, while the dual monarchy is important, because here "the remnants of old nationalities were of greater purity than elsewhere in Europe." 3 Their persistence would facilitate discovery of the racial ancestry of European peoples generally.

1912: The keynote speech by Felix von Luschan $(1854-1924)^{4}$ at the fortythird meeting of the German Anthropological Society in Weimar makes refer-

1 I would like to thank Paul Weindling and the editors of this volume for useful comments and suggestions and for helping with the correction and editing the final version of the manuscript.

2 Rudolf Virchow, "Die Anthropologie in den letzten 20 Jahren," Mitteilungen der Anthropologischen Gesellschaft in Wien (MAGW) 19 (1889): (68). [numbers in parentheses indicate the pagination of the Sitzungsberichte, as opposed to the essay section of the journal].

3 Ibid., (59).

4 Luschan, since 1872 member of the Viennese Anthropological Society and curator of their collection, graduated in Medicine in Vienna in 1878. In the same year, he set up the ethnographic exhibition for the World's Fair in Paris. In 1882, he became a private lecturer [Privatdozent] in physical anthropology 
ence to Virchow's aspirations, only to regret that they have not been realized. ${ }^{5}$ Luschan stresses the need to improve insight into questions of "fitness" for military service and of "degeneration" through the nascent field of Sozialanthropologie or eugenics, with all its practical uses and theoretical appeal. ${ }^{7}$ Thus, he urges the collection of data on the physical condition of Germans on a large scale, which, if gathered for the army and navy, ${ }^{8}$ could be put to prophylactic use, while statistical profiles of racial "hybrids" would enhance the understanding of physical and mental traits. ${ }^{9}$

1915: The Viennese Anthropological Society initiates studies in prisonerof-war (POW) camps. Research led by Rudolf Pöch (1870-1921) initially aims at investigating the anthropologically less well-known peoples of the Russian Empire who, it is feared, may soon die out under Tsarist Russification. ${ }^{10}$ In the same year, similar research in Germany is initiated by Luschan. ${ }^{11}$ POWs from colonies around the world are seen as offering specialists an opportunity to

in Vienna. In 1885, he took a position as assistant at the Ethnological Museum in Berlin. In Berlin, Luschan acquired the venia legendi in physical anthropology in 1888, and, in 1900, an extraordinary professorship was established there for him. Luschan's chair became a full professorship in 1909. As early as 1891, he had applied for a professorship in anthropology in Vienna, but he never succeeded in founding an anthropological institute. Sergio Sergi, "Felix von Luschan," Rivista Anthropologia 26 (1924-1925): 521-524; Marion Melk-Koch, "Zwei Österreicher nehmen Einfluß auf die Ethnologie in Deutschland: Felix von Luschan und Richard Thurnwald," in Kulturwissenschaft im Vielvölkerstaat, eds. Britta Rupp-Eisenreich and Justin Stagl (Vienna: Böhlau, 1995), 132-140; Benoit Massin, "From Virchow to Fischer: Physical Anthropology and 'Modern Race Theories' in Wilhelmine Germany," in Volksgeist as Method and Ethic: Essais on Boasin Ethnography and the German Anthropological Tradition, ed. George W. Stocking (Madison, WI: University of Wisconsin Press, 1995), 84.

5 Felix von Luschan, "Anthropologie: Rückblicke und Ausblicke; Eröffnungsrede der 43. allgemeinen Versammlung der deutschen Anthropologischen Gesellschaft in Weimar," special issue, Aus der Natur 9 (1912): 1-11.

6 Ibid., 7.

7 Ibid., 6.

8 Ibid., 8.

9 Ibid., 10.

10 Rudolf Pöch, "1. Bericht über die von der Wiener Anthropologischen Gesellschaft in den k.u.k. Kriegsgefangenenlagern veranlaßten Studien," MAGW 45 (1915): 219-235.

11 See the contribution by Britta Lange in this volume. See also Andrew D. Evans, "Anthropology at War: Racial Studies of POWs during World War I," in Worldly Provincialism: German Anthropology in the Age of Empire, eds. H. Glenn Penny and Matti Bunzl (Ann Arbor, MI: University of Michigan Press, 2003), 208209; idem, "Capturing Race: Anthropology and Photography in German and Austrian Prisoner-of-War Camps during World War I," in Colonialist Photogra- 
resolve as yet open questions in anthropology, ${ }^{12}$ including the racial makeup of the peoples of India, the relationship of Berber and Arab peoples, and migrations to Europe from central Asia and the Near East. ${ }^{13}$

These three moments in the history of German-speaking anthropology serve to illustrate the field's main lines of development. From the perspective from within the field itself, it can be said that the interest in the origins of humankind, as well as in the emergence and hierarchical organization of what they called "races" of humanity, had been given additional impetus by the rise of evolutionary theory. Archaeological finds in the latter half of the nineteenth century steered it toward local research and appeared to support the notion that Germanic tribes descended primarily from a blond, long-skulled race, and Slavic tribes from brunette, short-skulled stock. Having mapped distribution of the "types" in Germany and neighboring countries, anthropologists now hoped to unravel their origins. Inquiry into the effects of "interbreeding" in colonial settlements outside Europe was transposed to the mixing of European "tribes." Multiethnic states, such as the Russian Empire and AustriaHungary, with their isolated backwaters as well as regions of intense "mixing," were regarded as invaluable storehouses of information on the racial makeup of European populations. From the perspective of influences outside the immediate realm of scientific inquiry, it can be said that intensifying nationalism and the emergence of eugenics suggested political connotations of notions of race and hybridization that went beyond mere categorization. Critiques of the effects of civilization gave way to politicized questions of the intrinsic constitution and "fitness" of the collective. Thus, the development of the discipline cannot be viewed as linear. It arose from the interplay between scientific inquiry and the search for practical applications, contact between non-European and European peoples, and the rush to study what were perceived as endangered communities in Europe and elsewhere.

Whereas fieldwork overseas was conducted primarily by individuals pursuing more or less their own personal research interests, large-scale domestic data-gathering was seen as potentially being in the national interest and was not only dependent on institutional support from scientific societies and their networks, but also sought government support. The Austro-Hungarian monarchy directly underwrote research into its subjects' varied ethnicity, in most cases by members of the Viennese Anthropological Society. This chapter

phy: Imag(in)ing Race and Place, eds. Eleanor M. Hight and Gary D. Sampson (London: Routledge, 2002), 226-256.

12 Felix von Luschan, “Ein Beitrag zur Völkerkunde im Weltkriege/Einführung in die Grundzüge der Anthropologie," in Hermann Struck, Kriegsgefangene: 100 Steinzeichnungen (Berlin: Reimer, 1917).

13 Ibid., 7, 84-89, 104-109. 
will focus on its attempts to investigate schoolchildren and, less successfully, military recruits. After describing the genesis and objectives of these surveys of race that began in the 1870s, the chapter will explore the nature and extent of nineteenth-century anthropology's influence on the POW studies as well as the differences between the large-scale domestic surveys and those of foreign POWs. While they built on the earlier studies, and the camps were considered a microcosm of Europe just as the Austro-Hungarian Empire had been, the conduct of physical anthropology in the camps was significantly and increasingly influenced by Pöch's field experience outside Europe.

\section{Surveys of the Empire}

Techniques of identification and classification by race changed in the late nineteenth century. Earlier paradigms like that of the highly influential Johann Friedrich Blumenbach (1752-1840) functioned by reference to "typical" individuals, but anthropologists now began measuring large cohorts and comparing data sets. In the place of visual assessments, averages and highest frequencies were used to establish "types."

A central criterion was the cephalic index, the ratio of a skull's length to its width. ${ }^{14}$ For example, the Austrian anatomist Augustin Weisbach (18371914) published measurements of individuals from different races in $1878,{ }^{15}$ incorporating head and body measurements of living people collected during a round-the-world expedition by the frigate Novara between 1857 and 1859 . He distinguished eighteen human varieties according to the cephalic index, the projection of the upper jaw, and the ratio of upper to lower limb length. His stated aim was to obtain a disinterested classification based on anatomy alone, but, perhaps predictably, Europeans occupied the top positions in his hierarchy, with Africans and Sinti and Roma at the bottom of the scale. ${ }^{16}$ Following Anders Retzius's classification of skulls as dolichocephalic (long), brachycephalic (short), or mesocephalic (in between), as well as the division of profiles into orthognathous and prognathous (straight vs. protruding upper jaw), ${ }^{17}$ for example, he reasoned based on his measurements of humans and apes that brachycephalic, prognathous people were closer to primates on

14 Stephen Jay Gould, The Mismeasure of Man, revised and expanded ed. (New York: Norton, 1996).

15 Augustin Weisbach, "Körpermessungen verschiedener Menschenrassen," supplement, Zeitschrift für Ethnologie 9 (1878).

16 Ibid., 7-9.

17 Idem, "Beiträge zur Kenntnis der Schädelformen österreichischer Völker," Wiener Medizinische Jahrbücher 20, no. 1 (1864): 52. 
the scale of human development ${ }^{18}$ (an interpretation which was later found, of course, to be utterly false). Weisbach's European data were collected among the various nationalities under Austro-Hungarian rule in which he came in contact in the course of his military service. During his deployment in Olmütz (Olomouc), he had collected data from soldiers, continuing when he became a senior physician in the military hospital in Istanbul. ${ }^{19} \mathrm{He}$ considered AustriaHungary an ideal venue for the study of national difference, categorizing its nationalities into racial groups, including Germanic, Slavic, and Romanic. ${ }^{20}$ He was convinced that the study of Stämme [tribes] (conceived in physical terms) would reveal typical internal structures of the brain case. Between 1864 and 1867, he published several articles on skull and pelvis measurements, addressing differences between the sexes and various nationalities. ${ }^{21}$

In 1882, Luschan submitted his own hypothesis for a systematic classification by race. ${ }^{22}$ Like Weisbach, he had studied medicine at the Military-Medical Academy Josephinum in Vienna. He had also collected data during his military service, ${ }^{23}$ but, where Weisbach's research conducted for the military had focused on the Empire, Luschan consistently took geographic distribution into account, utilizing and discussing findings in ethnology, archaeology, and linguistics, as well as anatomical data. ${ }^{24}$ To Luschan, races represented variet-

18 Idem, "Körpermessungen verschiedener Menschenrassen," 9.

19 Rudolf Pöch, "Dr. Augustin Weisbach 1837-1914," Wiener Prähistorische Zeitschrift 1 (1914): 143-149; Carl Toldt, "Augustin Weisbach,"MAGW 41 (1911): 9-11; see also Brigitte Fuchs, "Rasse," "Volk," "Geschlecht": Anthropologische Diskurse in Österreich 1850-1960 (Frankfurt a. M.: Campus, 2003), 139-144.

Weisbach, "Beiträge zur Kenntnis der Schädelformen österreichischer Völker," no. 1 (1864): 49-50.

21 Ibid., 49-127; idem, "Beiträge zur Kenntnis der Schädelformen österreichischer Völker," Wiener Medizinische Jahrbücher 20, no. 2 (1864): 33-86, 119-154; idem, "Die Becken österreichischer Völker," Wiener Medizinische Jahrbücher 22, no. 1 (1866): 27-96; idem, "Beiträge zur Kenntnis der Schädelformen österreichischer Völker," Wiener Medizinische Jahrbücher 23, no. 1 (1867): 123-152, 184-224; idem, "Beiträge zur Kenntnis der Schädelformen österreichischer Völker," Wiener Medizinische Jahrbücher 23, no. 2 (1867): 25-72.

22 Felix von Luschan, "Die physischen Eigenschaften der wichtigsten Menschenracen," special issue, Dr. Wittelhöfer's "Wiener Medizinische Wochenschrift" 39-42 (1882): 1-25.

23 During his period as a physician in the occupied area of Bosnia, Luschan arranged archaeological excavations, collected anthropological and ethnographic materials, and gathered anthropometric data on the people. MelkKoch, "Zwei Österreicher," 132-140.

24 Luschan undertook several journeys, amongst them, between 1882 and 1902 to Asia Minor, where he excavated in Sendschirli. Later in 1905, he traveled to South Africa and, in 1914, to the United States. On his journeys, he collected ethnographical "materials" and anthropometric data, as well as photographs 
ies of humans, ${ }^{25}$ and he postulated a correlation of height, brain weight, and intelligence with the capacity for civilization [Kulturfähigkeit]. ${ }^{26}$ While he underlined complexity and opposed broad generalizations, he nonetheless differentiated between civilized people [Kulturvölker] and "lower races." ${ }^{27}$ On the basis of geographical distribution, Luschan distinguished three races defined by typical external morphology as well as anthropometry.

In Luschan's view, a linking of language with physical appearance was unjustified. Peoples like the Basques or those of the Caucasus were the remnants of early immigration-thus their presence in remote regions, difficult to access. ${ }^{28}$ But the local uniqueness of their languages did not entail unique physical characteristics. Citing Johannes Ranke, Felix von Luschan considered the distribution of physical characteristics in Central Europe to be primarily determined by geography, rather than the product of a "specific mixture of peoples." ${ }^{29}$ Racial variation was seen as a function of environmental conditions. He suggested that maps of coloring distribution be made for countries bordering on Germany, eventually to include the entire "white race" and all humankind. ${ }^{30}$

The model for the mapping that Luschan proposed was a large-scale survey of German schoolchildren that had begun in 1871, a year after the founding of the German Society for Anthropology, Ethnology, and Prehistory, the results of which were published by Virchow in 1886 . The original plan had been to include German-speaking Austrians in the German organization, but the Viennese Anthropological Society was founded separately during the same year. It incorporated sections on Racenlehre, Ethnographie, and Urgeschichte [physical anthropology, ethnology, and prehistory]. ${ }^{31}$ At its inaugural meeting, Carl von Rokitansky (1804-1878) emphasized the importance of studying the national "materials" of Austria in light of race: "There is still much work to be done in der österreichischen Racenlehre [Austrian race studies]." 32 The new conception of racial classification demanded robust data from large samples, requiring standardized measurement and description by trained experts. In

and language recordings; Sergi, "Felix von Luschan," 521-524; Melk-Koch, "Zwei Österreicher," 132.

25 Luschan, "Die physischen Eigenschaften," 12.

26 Ibid., 4, 6 .

27 Ibid., 10.

28 Ibid., 23.

29 Ibid., 24.

30 Ibid., 25.

31 Virchow, "Anthropologie in den letzten 20 Jahren," (57).

32 Carl von Rokitansky, "Eröffnungsrede, gehalten in der constituierenden Versammlung der anthropologischen Gesellschaft in Wien am 13. Februar 1870," MAGW 1 (1971): 1-10, esp. 8. 
Austria, as in Germany, special committees were appointed to coordinate work and reconcile the methodology of the different fields. ${ }^{33}$

Virchow reported that, although there were times where their interests did not coincide, the two institutions exchanged information, and several joint meetings were held. ${ }^{34}$ In 1871, the German Society put Virchow in charge of a commission to carry out "a statistical study of skull form all over Germany," 35 but, within a year, it had become apparent that it would be difficult for anthropologists to find sufficient subjects for measurement, living or dead. The commission then put forward the idea that both public schools and the military constituted cross-sections of German society. Children were considered less desirable study objects, since the data they presented was not directly comparable to those obtained from adults. But German military authorities refused to allow data collection during recruitment, arguing that it would take up too much time, while the German states were willing to allow teachers to collect data from pupils. ${ }^{36}$ Criteria were reformulated to permit relatively reliable data-gathering by nonspecialists: ${ }^{37}$ Eye and hair color and height would provide a "picture of the ethnic type" [Völkertypus]..$^{38}$ Assuming the existence of two original "pure races" which in Germany had intermingled and produced a range of types varying from long-skulled, light-skinned, blond, and blueeyed to short-skulled, dark-skinned, brunette, and brown-eyed, the commission sought to determine their geographical distribution, obtaining data that would enable comparison with earlier and later measurements. ${ }^{39}$

Data-gathering took several years, and the Anthropological Society hired the Royal Statistical Bureau to compile the statistics. ${ }^{40}$ Virchow published the

33 MAGW 10 (1880): 67, 73-75; MAGW, 11 (1881): 59-60.

34 Virchow, "Anthropologie in den letzten 20 Jahren," (57).

35 Correspondenz-Blatt der deutschen Gesellschaft für Anthropologie, Ethnologie und Urgeschichte (1871): 53.

36 Correspondenz-Blatt der deutschen Gesellschaft für Anthropologie, Ethnologie und Urgeschichte (1874): 30-40.

37 Andrew Zimmerman, "Anti-Semitism as Skill: Rudolf Virchow's Schulstatistik and the Racial Composition of Germany, "Central European History 32 (1999): 413.

38 Archiv für Anthropologie 5 (1872): 509-512.

39 Correspondenz-Blatt der deutschen Gesellschaft für Anthropologie, Ethnologie und Urgeschichte (1873): 28-29; see also Zimmerman, "Anti-Semitism as Skill," 409-429.

40 Georg Mayr, "Die bayerische Jugend nach der Farbe der Augen, der Haare und der Haut," special issue, Zeitschrift des Kgl. Bayrischen Statistischen Bureau 4 (1875): 21-39; Rudolf Virchow, "Gesammtbericht über die Statistik der Farbe der Augen, der Haare und der Haut der Schulkinder in Deutschland," Correspondenz-Blatt der Deutschen Gesellschaft für Anthropologie, Ethnologie und Urgeschichte 16 (1885): 89-100. 
results, including comparisons with similar studies in Austria, Switzerland, and Belgium, in 1886. ${ }^{41}$ Types and traits were grouped and graphed and their frequencies inscribed on a map of Germany, presenting its geography in terms of the distribution of the two types. Jews were recorded separately, implying that they were a people apart-mostly of the brunette racial type, although 11 percent qualified as blond. Most children displayed ambiguous traits. The study's central finding was that, while the vast majority of the children displayed a mixture of traits, Germans could be viewed as "predominantly" of the blond type ["der herrschende Typus"], while the darker type was "secondary" [Nebentypus]. ${ }^{42}$

Following the German example, the Viennese Anthropological Society set up a commission to study the distribution of the blond and brunette types in Cisleithania (the Austrian part of Austria-Hungary). Initial attempts to collect data in military and educational institutions were unsuccessful. Eventually, in 1880 , the German questionnaire and a standard state questionnaire were used to tally the hair, eye, and skin color of 2.3 million pupils in Austrian elementary schools. Results were compiled by Gustav Adolf Schimmer (1828-1902), a member of the Central Statistical Commission, and published in $1884 .{ }^{43}$ In contrast to the German results, the brunette type predominated. Schimmer concluded that, for the blond type, there was a link between body type and nationality; the lower or higher incidence of blonds coincided with the language borders between Germans and Czechs, Poles and Ruthenians, and Germans and Italians given in Karl Freiherr von Czoernig's (1804-1889) ethnographic maps. ${ }^{44}$ Schimmer discussed the variances among German, German-Czech, and German-Polish school districts in Bohemia, Moravia, and Silesia, drawing special attention to the abundance of blonds in German, German-Czech, and German-Polish schools. Along the language boundary, he found a higher frequency of the brunette type in Czech school districts. ${ }^{45}$

The Austrians structured their study in much the same way as the Germans, with a significant difference: Data on Jewish children was not integrated, but

41 Rudolf Virchow, "Gesammtbericht über die Statistik der Farbe der Augen, der Haare und der Haut der Schulkinder in Deutschland," Archiv für Anthropologie 16 (1886): 275-475.

42 Ibid.; Zimmerman, "Anti-Semitism as Skill."

43 Gustav Adolf Schimmer, "Erhebungen über die Farbe der Augen, der Haare und der Haut bei den Schulkindern Österreichs," MAGW (1884), Supplement I: 8-9, 23.

44 For Czoernig, see also Regina Bendix, "Ethnology, Cultural Reification, and the Dynamics of Difference in the Kronprinzenwerk," in Creating the Other: Ethnic Conflict \& Nationalism in the Habsburg Central Europe, ed. Nancy M. Wingfield (New York: Berghahn, 2003), 149-166, 152-153; Fuchs, "Rasse," "Volk," "Geschlecht," 152-155.

45 Schimmer, "Erhebungen." 
appeared separately. Schimmer reasoned that in Bukovina and Galicia, where "this race still separates itself very strictly ritually and in its way of life and keeps itself pure," the differences between the Christian and Jewish schoolchildren would be considerably more than in countries where "a highly developed Culturleben [cultural life] has already removed these barriers for the most part." ${ }^{\prime 46}$ However, the numbers proved him wrong: The differences between Jewish and Christian children in Galicia and Bukovina were less significant than in Lower Austria, Moravia, and Bohemia, where he had expected more mixing. To resolve the conundrum created by his presumption of a "Jewish type," Schimmer divided Jews into sedentary and nomadic subtypes. In the latter group, the brunette type was then seen to be predominant.

Schimmer also attempted to connect cultural differences, such as language, with physical differences. For Virchow, geographical circumstances were more relevant-thus, his interest in the Austrian regions bordering Germany. He regarded Schimmer's finding of a link between physical "type" and nationality with scepticism, since there were discrepancies between maps of somatic types and those of ethnic groups ${ }^{47}$ But Virchow valued the information that the Austrian study provided on other ethnic groups, particularly on the Slavs. ${ }^{48}$ A study by Ludwig Schneider, a historic preservation officer in Bohemia, analyzed Gustav Adolf Schimmer's data for Bohemia in greater detail and found a more differentiated pattern, correlating the results with archaeological findings from prehistoric times. ${ }^{49}$ An 1878 study recorded hair, eye and skin color in Styria, with the aim of establishing a connection between language and somatic traits, but revealed only minor differences between German-speakers and Slovenes, suggesting to researchers that a considerable number of Germans were of Slavic descent. ${ }^{50}$

In 1881, the Viennese Anthropological Society set up another commission to collect anthropometric data on Austro-Hungarian "races and nations." The anatomist Carl Langer (1819-1887) wrote guidelines for ethnographic research on "Czechoslovak, Magyar, and German Stämme [tribes] (conceived of as ethnicities)" that included measurements of both living subjects and cranial remains. ${ }^{52}$ His recommendations were based on the assumption that

46 Ibid., 23-24.

47 Virchow, "Gesammtbericht," (1886), 374.

48 Ibid., 386.

49 Ludwig Schneider, "Verbreitung des blonden und des brünetten Typus in Böhmen," special issue, Verhandlungen der Berliner Anthropologischen Gesellschaft, Sitzung vom 18.7.1885, 339-353.

50 Christian Promitzer, "The South Slavs in the Austrian Imagination," in Wingfield, Creating the Other, 183-215, esp. 191.

51 MAGW 11 (1881): 59-60.

52 Carl Langer, "Programm für ethnographische Untersuchungen insbesondere auf dem Gebiete Oesterreichs," MAGW 13 (1883): 133-135. 
the territories of nations and those of races were not identical and that nations were not racial units. Modern populations were "racially mixed," meaning that the different European races had interpenetrated each other, but the extent of penetration varied from region to region. Thus, the computation of the arithmetical means of body measurements in an entire nation would not accurately reflect its racial makeup, regardless of sample size. Langer suggested that researchers begin data collection in well-defined regions of relative racial "purity," such as remote steppes and the inaccessible alpine valleys to prove the existence of earlier "racial elements." For populations failing to display a uniform character, he suggested that researchers subdivide it before beginning work at a given nationality's geographic center and continuing toward the periphery. Such studies would require expert knowledge, especially of anatomy, as well as practical competence. He also recommended employing illustrators and photographers. ${ }^{53}$

Austrian anatomists and military personnel carried out several regional studies. Augustin Weisbach and the anatomist Carl Toldt (1840-1920) were the main practitioners of craniometry as well as of measurements on living soldiers, largely in regions then considered Austrian. Heinrich Himmel (1843-1915), an army captain, collected data on recruits during his deployment in Herzegovina. With assistance from military personnel, he measured two hundred and thirty-three soldiers identified as Muslim, Catholic, and Eastern Orthodox, as well as sixty Moravian soldiers from another regiment. ${ }^{54}$ Himmel extended his research to Czernowitz in Bukovina, where he measured Romanians, Ruthenians, and Jews. ${ }^{55}$ A coworker also measured inhabitants of Bukovina. ${ }^{56}$

\section{The Encyclopedia of Empire}

The large-scale surveys of schoolchildren and regional studies of soldiers and local populations were included among the anthropological articles of the Kronprinzenwerk, an illustrated historical and ethnographic encyclopedia

53 Ibid.

54 Heinrich Himmel, "Das Rekrutenmaterial der Herzegowina, Vorlage der Arbeit von Josef Szombathy," MAGW 16 (1886): (67-68); idem, Das Rekrutenmaterial der Herzegowina (unpublished manuscript, Library of the Department of Anthropology, Inv. No. 303).

55 Idem, "Körpermessungen in der Bukowina, Vorlage der Arbeit von Augustin Weisbach,"MAGW 18(1888): (83-84); idem, Das Soldatenmaterial der Bukowina (unpublished manuscript, Library of the Department of Anthropology, Inv. No. 413).

56 MAGW 19 (1889), Jahresbericht: (6). 
formally known as Die österreichisch-ungarische Monarchie in Wort und Bild [The Austrian-Hungarian Monarchy in Words and Pictures]. Under the patronage of Crown Prince Rudolf, it was published in twenty-four volumes between 1886 and 1902. ${ }^{57}$ Members of the Viennese Anthropological Society were on the editorial committee: Ferdinand Andrian-Werburg (1835-1914) for ethnography, Gundacker von Wurmbrand for prehistory, and Franz von Hauer (1822-1899), superintendent of the new Natural History Museum in Vienna, for the natural sciences. ${ }^{58}$ A separate editorial committee was appointed for Hungary. Each Crown land was accorded a separate volume with its own contributors, each himself a representative of that country. Earlier ethnographic schemes, such as that of Archduke Johann Salvator, had been based on analyses of people and nationalities without being structured according to the political units of the Crown lands. ${ }^{59}$

An ethnographic orientation dominated the entire opus. Reinhard Johler has described how the encyclopedia's contents contributed to the implementation and understanding of Austrian ethnography as a discipline: Ethnography emerged as a central political science. One of its objectives was to provide representations of diversity that would help consolidate the Empire. ${ }^{60}$ Earlier assessments that dismissed the Kronprinzenwerk as an apolitical popular journalistic work have been subject to reevaluation. Katherina Weigand, for

57 See Justin Stagl, "The Kronprinzenwerk-Representing the Multi-National State," in Ethnicity, Nation, Culture: Central and East European Perspectives, eds. Bálint Balla and Anton Sterbling (Hamburg: Krämer, 1998), 17-30; idem, "Das 'Kronprinzenwerk': Zur Einführung," in Ethnographie in Serie: Zu Produktion und Rezeption der "Österreichisch-ungarischen Monarchie in Wort und Bild," vol. 28, eds. Jurij Fikfak and Reinhard Johler (Vienna: Veröffentlichungen des Instituts für Europäische Ethnologie), 28-41; Bendix, "Ethnology."

58 Christiane Zintzen, ed., Die österreichisch-ungarische Monarchie in Wort und Bild: Aus dem Kronprinzenwerk des Erzherzog Rudolf (Vienna: Böhlau, 1999), 279.

59 Katharina Weigand, "'Die österreichisch-ungarische Monarchie in Wort und Bild': Ein kulturpolitisches Instrument am Ende des 19. Jahrhunderts," in Fikfak and Johler Ethnographie in Serie, 62-80.

60 Reinhard Johler, "[...] die Lesewelt auffordernd zu einer Wanderung durch weite, weite Lande, zwischen vielsprachigen Nationen, inmitten stets wechselnder Bilder. Zur Geschichte des Monumentalwerkes ‘Die österreichischungarische Monarchie in Wort und Bild,' dargestellt am Beispiel des 1898 erschienen Bandes 'Galizien,'" in Galizien: Ethnographische Erkundung bei den Bojken und Huzulen in den Karpaten; Begleitbuch zur Jahresausstellung '98 im Ethnographischen Museum Schloß Kittsee vom 6. Juni bis 2. November 1998. Kittseer Schriften zur Volkskunde 9, ed. Klaus Beitl (Vienna: 1998), 43-55. 
instance, regards it as an instrument in a policy to create and strengthen patriotism by constructing the monarchy as "total." ${ }^{1}$

With the exceptions of Croatia, Slovenia, and Hungary, one chapter of each volume was dedicated to physical anthropology. Although aimed at a general readership, they were authored by physicians, anatomists, or both, jointly, and reflect the prevailing level of scientific knowledge in the various countries. Compared to other articles, their style and vocabulary can be characterized as more scientific, documenting research results, descriptions of frequencies of observations, measurements, and statistics. Generally, for each Crown land, the physical appearance of its various "ethnic tribes" [Volksstämme] was described in anthropometric terms, such as the cephalic index. Most articles referenced the school study's examination of children's coloring, deploring the lack of measurements of adults and historic and prehistoric skulls. Up to this point, data on prehistoric skulls had been associated with archaeological and historical tribes, and a link between skull shape and coloring could not be verified. Nevertheless, skull forms were assumed to represent racial groups: Blond types were regarded as the offspring of dolichocephalic Germanic tribes and brunettes as stemming from Slavic or other eastern or Mediterranean groups. The large number of hyperbrachycephalic heads-very short and round-was mentioned in each article and ascribed either to an older "race type" or to "mixing." Military statistics on height and fitness were likewise included. Nearly all articles incorporate descriptions of physical appearance, but some also turned to government data on mortality, birth rates, migration, and the frequency of certain diseases and developmental disorders. On occasion, articles added mental characteristics. Drawings illustrated typical inhabitants of each land, but without accompanying maps. Rural life was regarded as beautiful, harmonious, and healthy, while industrialization was associated with deleterious effects on physical appearance and "degeneration."

The Kronprinzenwerk makes plain that anthropologists aspired to map anthropological traits onto current and past populations of the Empire. With the help of history and ethnology, it would be possible to trace racial types in nationalities past and present. The authors hoped to resolve questions about racial constancy and mixing as well as the influences of migration and environment. As conceived, the project would require huge numbers of measurements, and the military was the preferred source. But despite making several attempts, the Anthropological Society did not succeed in collecting sufficient data on the physical appearance of the inhabitants of Austria-Hungary to answer such questions during the nineteenth century.

61 Weigand, "Die österreichisch-ungarische Monarchie." 


\section{National Surveys with "Colonial" Input: Promoting Anthropology at the University}

With the Kronprinzenwerk, it became obvious that no comprehensive survey of the physical makeup of Austria-Hungary's subjects had yet been achieved. The school study remained an interim solution, as it was believed that racial features develop fully only in adulthood. Since it was also believed that racial studies could be best pursued on males, the army was considered the superior site for research. It incorporated all the monarchy's nationalities, and its disciplined ethos ought to permit anthropometry on a large scale. But scientific access to conscripted bodies was not as easy as it seemed. The German Society had also not been successful in gaining access to the military: In his 1886 publication on the school study, Virchow regretted that it had not been possible to overcome objections to systematic research, be it on active-duty soldiers or recruits. He did not detail the reasons for the military's lack of enthusiasm, except to say that the studies would have entailed extraordinary time and effort. ${ }^{62}$ Only in Baden and Bavaria had it been possible to collect data on soldiers. ${ }^{63}$ In 1888 , the Viennese Society established a commission for body measurements of the army, ${ }^{64}$ and, a year later, in cooperation with the German Society, developed a data sheet for measurement of recruits that would allow rigorous comparisons.$^{65}$ But its efforts met with familiar difficulties. Anthropological studies in Bosnia were hindered, and the data collected in Salzburg by Karl Rabl (1853-1917) could not be compiled. The Society hoped for the intervention of the Medical Corps. ${ }^{66}$

With the new century, the two anthropological societies tried again. ${ }^{67}$ Rudolf Martin (1864-1925) developed a new data sheet that was accepted, with some modifications, by the committees of both countries. ${ }^{68}$ But within a few years, the Viennese Society again complained that it had not been possible to

62 Virchow, "Gesammtbericht," (1886), 290.

63 Otto Ammon, Die natürliche Auslese beim Menschen: Auf Grund der anthropologischen Untersuchungen an Wehrpflichtigen in Baden und anderer Materialien (Jena: Fischer, 1893); idem, Zur Anthropologie der Badener: Bericht über die von der anthropologischen Kommission des Karlsruher Altertumsvereins an Wehrpflichtigen und Mittelschülern vorgenommenen Untersuchungen (Jena: Fischer, 1899); Johannes Ranke, Beiträge zur physischen Anthropologie der Bayern (Munich: Theodor Riedel, 1883).

64 MAGW 18 (1888), Ausschusssitzung 13.3.1888: (49).

65 "Resultate der Kommissionsberatthungen," MAGW 19 (1889): (185-187).

66 MAGW 18 (1888), Jahresbericht 14.2.1888: (25).

67 MAGW 33 (1903), Monatsversammlung 10.11.1903: (110-111); MAGW 34 (1904), Jahresversammlung 22.3.1904: (22).

68 MAGW 36 (1906), Monatsversammlung 14.11.1905: (85). 
complete the studies. Explanations ranged from organizational difficulties to the deaths of committee members, but a recurring theme was the lack of an institute of anthropology and ethnology at the university in Vienna. The Society members at work in military surroundings were independent researchers or physicians who only pursued anthropology as a sideline interest. A university institute would centralize and focus their efforts. The Viennese Society had already been promoting the establishment of a chair in anthropology and ethnography at the university for some time. One of their central arguments had been that the dual monarchy, despite its lack of exotic colonies, promised exceptional opportunities for ethnographic and anthropological study of its own diverse nationalities. ${ }^{69}$ But now, complaints surfaced that there was a complete lack of incentives for researchers to undertake anthropological-ethnographic studies, whereas the colonial policies of the Great Powers were regarded as providing their scientists with such incentives. ${ }^{70}$ Although the Society had tried to legitimize the institutionalization of physical anthropology at the university on the basis of racial studies within the monarchy, research outside Europe seems to have been considered more attractive and prestigious.

The turn of the century also saw the publication of novel theories on the racial makeup of Europeans: German and Austrian anthropologists flocked to the classification of the French naturalist Joseph Deniker (1852-1918), who posited six European races. ${ }^{71}$ A 1906 conference in Monaco charged a commission with reconciling craniometry and cephalometry, ${ }^{72}$ and Martin, anthropometry's main spokesman in Germany, published the first comprehensive German anthropological textbook in $1914 .^{73}$ Eugen Fischer (1874-1967) published his book on race mixing in South Africa in 1913, seeing his findings as evidence for Mendelian heredity in humans. ${ }^{74}$ With the emergence of genetics, racial science, and racial or social hygiene as mainstream scientific endeavors, increasing importance was given to the challenge of distinguishing nature from nurture with regard to both physical and mental traits. Alfred Ploetz (1860-1940) founded the Society for Racial Hygiene in 1905, and Eugen Fischer and Felix von Luschan were among its earliest members, later joined by Rudolf Pöch. All subsequently became involved in POW stud-

69 MAGW 39 (1909): (15-18).

70 MAGW 40 (1910), Jahresversammlung 9.3.1910: (19).

71 Joseph Deniker, The Races of Man (London: Walter Scott, 1900).

72 Josef Szombathy, "Die internationale Konferenz über Schädel- und Kopfmessung, Monaco 1906," MAGW 44 (1914): (9-26).

73 Rudolf Martin, Lehrbuch für Anthropologie in systematischer Darstellung mit besonderer Berücksichtigung der anthropologischen Methoden (Jena: Fischer, 1914).

74 Eugen Fischer, Die Rehoboter Bastards und das Bastardisierungsproblem beim Menschen (Jena: Fischer, 1913). 
ies. ${ }^{75}$ The notion that Kulturvölker had deteriorated, for whatever reasons, lent questions of fitness for combat a new significance, encouraging anthropology to see itself no longer as just an inductive or descriptive science, but as an applied technology with political implications. Though nowhere explicitly stated, it appears against this backdrop that the POW studies could also be understood as a possibility to compare the constitution of Germans with their enemies, however, in the final analysis, it was intended to support wider ranging interpretations in the context of racial science.

In 1913, the University of Vienna acquired in Pöch its first associate professor of anthropology and ethnography. He had trained as a physician, taking part in an 1897 expedition to study the plague in Bombay, an experience that seems to have catalyzed his interest in physical anthropology. He began his studies in Berlin with Luschan in 1900. From 1904 to 1906, he undertook an anthropological-ethnographic expedition to Australia and New Guinea. After the Herero and Nama War (1904-1907), Pöch went on an expedition to Southwest Africa from 1907 to $1909 .^{76}$ By 1913, when he became associate professor in Vienna, Pöch was completing a doctoral thesis in physical anthropology with Ranke in Munich, studying natives of New South Wales and crania from Australian aborigines.

Pöch preferred to focus on peoples he regarded as racially pure. His definitions of pure races came from information provided by colonial authorities, but he measured and photographed large numbers of individuals, selecting for further study those about whose purity he had no doubt. ${ }^{77} \mathrm{He}$ did not collect samples solely on the basis of looks, but the final selection was certainly made according to his idea of what looked right. Pöch was also interested in the effects of colonization, suggesting that a way of life to which a people were not "evolutionarily adapted" might cause "degeneration." Aborigines, for example, were not adapted to agricultural labor, and it was causing their decline as a people. Like Fischer, Pöch was intrigued by questions of racial mixing, and his approach similarly makes clear that he regarded mixed-race individuals as superior to indigenous peoples. Fischer had lectured on his research at the Viennese Society in 1910, emphasizing its potential value for race studies and genetics ${ }^{78}$ and suggesting that research on "hybridization" would bring an

75 Paul Weindling, Health, Race and German Politics between National Unification and Nazism, 1870-1945 (Cambridge, UK: Cambridge University Press, 1989).

76 Eugen Oberhummer, "Rudolf Pöch (gestorben am 4. März 1921)," MAGW 51 (1921): 95-104; Fuchs, "Rasse," "Volk," "Geschlecht," 190-211.

77 Rudolf Pöch, Studien an Eingeborenen von Neu-Südwales und an australischen Schädeln (Dissertation, Ludwigs-Maximilians-Universität München, 1913) (Munich: Hamburger, 1915).

78 "Zur Anthropologie und Ethnologie des 'Bastardvolkes' in Deutsch-Südwestafrika," MAGW 40 (1910): (22). 
understanding of ethnology in light of the "struggle of cultures." In his comments on the lecture, Pöch echoed Fischer's view that segregated mixed-race populations in Africa, although they retained numerous aspects of European culture, did not work as hard or as effectively as Europeans. ${ }^{79}$

Although the Viennese Society had a great interest in studying AustriaHungary, the decision to hire Pöch reflected the need to consider interdisciplinary concerns and to favor experience outside Europe. For Toldt, the Society's president, research on hybrid "bastards" was of "great scientific significance," not only for Pöch's current area of interest ("Bushmen"), but for the monarchy itself: "We in Austria live in the midst of Volksstämme who are constantly mixing with each other." ${ }^{80}$ The transposition of the methods and findings of "bastard" studies to the Habsburg monarchy encouraged a hierarchical classification of Europeans by physical criteria which was increasingly linked to cultural differences. Pöch's 1914 obituary for Weisbach, whom he had not known personally, criticized his methodology as inadequate, but saluted his commitment to intensive study of Austro-Hungarian nationalities. Pöch expressed the hope that those studies could be continued with modern methods. ${ }^{81}$

\section{New Research Potential: Studying Captured Soldiers in POW Camps}

A visit to a POW camp in Upper Austria convinced Rudolf Pöch and his fellow Anthropological Society member, the geographer Eugen Oberhummer (1859-1944), of the camps' potential value for anthropological research. ${ }^{82}$ Pöch argued that he could study "material evenly culled from an entire country" in the camps, which was otherwise possible only where conscripts were concentrated in garrisons. ${ }^{83}$ Toldt duly initiated racial studies of the POWs, ${ }^{84}$ with the Viennese Society providing financial support and appointing a committee to organize and prepare them. Additional support came from the Imperial Academy of Sciences and the Imperial War Ministry. The committee included

79 Ibid., (22-23).

80 MAGW 40 (1910), Jahresversammlung 9.3.1910: (18).

81 Pöch, "Dr. Augustin Weisbach"; Rudolf Pöch to Luschan, 6 August 1915, Nachlass Felix von Luschan, Dr. Augustin Weisbach, Staatsbibliothek zu Berlin-Preußischer Kulturbesitz.

82 Oberhummer, "Rudolf Pöch (gestorben am 4. März 1921)."

83 Rudolf Pöch, "3. Bericht über die von der Wiener Anthropologischen Gesellschaft in den k.u.k. Kriegsgefangenenlagern veranlaßten Studien," MAGW 47 (1917): 77-100, quote on p. 80.

84 Carl Toldt, Carl Toldt: Autobiographie (Berlin: Urban \& Schwarzenberg, 1922), 34-35. 
members of previous commissions for racial and national surveys in AustriaHungary, including Carl Toldt and Josef Szombathy (1853-1943), curator of the anthropological-prehistoric collection at the Natural History Museum in Vienna. ${ }^{85}$ From 1915 to 1918, anthropometric measurements of thousands of POWs interned in Austria-Hungary and Germany were carried out by a team led by Rudolf Pöch and his chief assistant Josef Weninger (1886-1959) that eventually included several students. Briefly, Pöch also made ethnographic recordings of songs, even filming dances, but he soon ceded those aspects to the Phonographic Commission of the Academy, preferring to concentrate on his racial researches. ${ }^{86}$

Pöch's example inspired a wave of wartime anthropometric studies in the Austro-Hungarian Empire. The anthropologist Viktor Lebzelter (1889-1936) measured Serbs, Roma, and Sinti while stationed in Krakow. The ethnologist Arthur Haberlandt (1889-1964) measured Albanians in Montenegro and Albania. Georg Kyrle (1887-1937), a geologist and pharmacist who had worked with Rudolf Pöch during 1915, undertook family studies of Wolhynians as commander of an epidemiological laboratory. Pöch extended his own research to women and children by initiating study of Wolhynian families in a refugee camp in Austria. The work performed by his student and later wife Helene Schürer von Waldheim (Hella Pöch, 1893-1976) ${ }^{87}$ can be seen as the first inheritance study in which somatic traits included palm lines. Although she assumed that nutrition, health, and lifestyle also played a role in racial hygiene, they were not analyzed. ${ }^{88}$

85 Pöch, "1. Bericht," 219.

86 Ibid.; idem, "2. Bericht über die von der Wiener Anthropologischen Gesellschaft in den k.u.k. Kriegsgefangenenlagern veranlaßten Studien," MAGW 46 (1916): 107-131; idem, "3. Bericht"; idem, "4. Bericht über die von der Wiener Anthropologischen Gesellschaft in den k.u.k. Kriegsgefangenenlagern veranlaßten Studien," MAGW 48/49 (1918/1919): 146-161; Margit Berner, "From 'Prisoners of War Studies' to Proof of Paternity: Racial Anthropologists and the Measuring of 'Others' in Austria," in "Blood and Homeland": Eugenics and Racial Nationalism in Central and Southeast Europe 1900-1940, eds. Marius Turda and Paul Weindling (Budapest: Central European University Press, 2006), 41-54; idem, "Forschungs-'Material' Kriegsgefangene: Die Massenuntersuchungen der Wiener Anthropologen an gefangenen Soldaten 1915-1918," in Vorreiter der Vernichtung: Eugenik, Rassenhygiene und Euthanasie in der österreichischen Diskussion vor 1938; Zur Geschichte der NS-Euthanasie in Wien Teil III, eds. Heinz Eberhard Gabriel and Wolfgang Neugebauer (Vienna: Böhlau, 2005), 167-198; idem, "Die 'rassenkundlichen' Untersuchungen der Wiener Anthropologen in Kriegsgefangenenlagern 1915-1918," Zeitgeschichte 30 (2003): 124-136.

87 Ibid.

88 AÖAW, Subventionen, math.-nat., K.7, Konv. '1918' No. 250/1918, Bericht; Berner, "Forschungs-'Material' Kriegsgefangene, 184. 
Pöch differentiated between Volk and race. In his view, a multitude of "recent ethnic groups" had been formed from a few originally widespread races; the degree of mixing was visible as racial difference. ${ }^{89} \mathrm{Up}$ to this point, he followed Langer's guidelines for ethnographic research. ${ }^{90}$ What was new was his understanding of race in the light of Mendelian genetics. Recessive genes could explain why racial traits assumed to be static did not correspond to field observations. Fischer's studies had shown that race per se was not inherited; instead, individual traits were passed down, so that mixing created "hybrids" rather than new races. ${ }^{11}$ Thus, within a given population, inadvertent backcrossing might produce individuals who represented pure types. Researchers strove to locate accidental specimens of long-vanished pure races in an approach that reprised nineteenth-century research on nationalities in Austria-Hungary. Many considered pure races to possess an aesthetic advantage. Pöch found Bashkir and Tatar individuals to be "disharmonious and ugly" in comparison with the "uniform, pure" Mongolian or Finnish types who he postulated had provided their constituent "racial elements." 92

In line with Langer, Pöch created sample groups in the camps by selecting a quorum of individuals he found to be representative of some particular type, ${ }^{93}$ then recording personal data for each prisoner, including his parents, tribal affiliation, and places of birth and residence with region and district, to allow the creation of maps. Increasingly, physical and mental features overlapped. Pöch insisted that the character of a Volk was determined by psychological traits and talents which were just as hereditary as physical traits. ${ }^{94}$ Physical anthropology in Austria, especially craniometry, was no longer content to remain inductive, but aspired to offer wide-ranging interpretations and evaluations of "races" and peoples, which were nonetheless heavily influenced by common stereotypes and prejudices.

The camps were Pöch's first foray into racial surveys which included European subjects. His earlier studies had concentrated on non-Europeans. The POW studies betray continuity in organization and research design, as well as protagonists, with earlier anthropology. Sponsorship by the Viennese Anthropological Society, endeavors to obtain support from official authorities, appointments, and committee work were traditions of long standing. The standard form resembled the military's own assessments of physical fitness as well

89 Rudolf Pöch, "Neue anthropologische Fragestellungen," Mitteilungen der Geographischen Gesellschaft in Wien 62 (1919): 193-209.

90 Langer, "Programm," 133-134.

91 Pöch, "Neue anthropologische Fragestellungen."

92 Ibid., 197-198.

93 Idem, "3. Bericht," 78-79.

94 Idem, "Neue anthropologische Fragestellungen," 197-198. 
as procedures originally designed for large-scale investigations on recruits that had never been carried out. The Viennese Anthropological Society stressed with pride that the founding of the university department was the main factor behind the success of the POW studies in Austria. ${ }^{95}$ Pöch's position, his commitment to the project, and his intermittent exemptions from military service allowed him to concentrate on research, and he managed to examine POWs on a vast scale.

Pöch's initial design for the POW research was similar to that of his earlier ethnographic and racial field studies, but his interest shifted, and he came to concentrate on racial studies alone. He began the project under the influence of his own past expeditions, with the idea of investigating prisoners from the multiethnic Russian Empire. Race and subrace were terms integral to his taxonomy, entailing discussions of origin and demarcation. Constructed or "ideal" racial types provided the framework for investigations aimed at defining racial features and types ${ }^{96}$ - with Mendelian heredity allowing "pure" traits to survive crossbreeding, so that even "mixed" peoples could take their places in racial hierarchies. The fact that he extended his research to include Africans suggests that the project had taken on a life of its own: With so much emphasis on the once-in-a-lifetime opportunity to collect "material," data-gathering came to overshadow the evaluation and publication of results. Among other things, Pöch apparently hoped to supply the teaching collection of his new institute with many plaster heads. It is doubtful that participation was entirely voluntary; his own hesitations regarding the casting of facial features and complaints from Egon von Eickstedt (1892-1965) about the reluctance of prisoners in German camps to submit to measurements are well documented. ${ }^{97}$

Although information on the POW studies was exchanged between Germany and Austria, the Viennese Society began the project without a mutual cooperative arrangement. ${ }^{98}$ Only after Pöch expanded the studies to include Africans did he work together with Luschan..$^{99}$ Luschan's interest stemmed from his desire to answer open questions with a geographically oriented catalog of the world's races. ${ }^{100} \mathrm{He}$ assigned his student Egon von Eickstedt and the

95 MAGW 46 (1916): (3).

96 Peter Weingart, Jürgen Kroll, and Kurt Bayertz, Rasse, Blut und Gene: Geschichte der Eugenik und Rassenhygiene in Deutschland (Frankfurt a. M: Suhrkamp, 1996), 355-360.

97 Evans, "Anthropology at War," 209, 217-222.

98 Anthropologische Gesellschaft archive, Protokoll der Ausschuß-Sitzung am 11. Juni 1915.

99 Letters from Pöch to Luschan on 6 March 1917, 24 May 1917, and 27 February 1918, Nachlass Felix von Luschan, Staatsbibliothek zu Berlin-Preußischer Kulturbesitz.

100 See also Luschan, "Ein Beitrag zur Völkerkunde im Weltkriege." 
anthropologist Otto Reche (1879-1966) to a parallel German POW project. Reche began his study with ethnic groups from central Asia, and Eickstedt with Indians, Turks, and Asians. Each developed his own interests, Reche shifting his attention to western Europeans while Eickstedt went on to measure Scots, Irish, English, Ukrainians, Poles, ethnic Russians, and others. ${ }^{101}$

\section{Conclusion: Three Phases in Viennese Anthropology}

After Pöch's death in 1921, Weninger led the evaluation and publication of the data, mostly based on student theses, ${ }^{102}$ and was appointed to a professorship in 1927.

In 1938, as head of the Institute of Anthropology in Vienna, Weninger sketched three stages of development that had characterized the Institute's first twenty-five years, ${ }^{103}$ based on the central themes of Pöch's career. The initial phase had been the collection of skeletal remains from non-European indigenous populations on expeditions to Australia, New Guinea, and Africa; the second phase turned to materials acquired in the POW camps during World War I, regarded as high-quality source data for general and systematic anthropology. Family and inheritance research-the "erbbiologische Richtung"constituted the third phase with its serial studies of children and families from Austrian populations and a research project on ethnically German families in Romania as well as various persons examined in the context of paternity assessments for some courts in Vienna. ${ }^{104}$ Weninger considered the three stages not merely in terms of current research: Their accumulated data and materials would serve as important resources to establish an institutional archive for

101 Evans, "Anthropology at War," 209, 217-222.

102 Berner, "Die 'rassenkundlichen' Untersuchungen"; idem, "Forschungs'Material' Kriegsgefangene."

103 Josef Weninger, "25 Jahre Anthropologisches Institut an der Universität Wien," MAGW 68 (1938): 191-205.

104 Idem, "25 Jahre Anthropologisches Institut"; Maria Teschler-Nicola, "Volksdeutsche and Racial Anthropology in Interwar Vienna: The 'Marienfeld Project,'" in "Blood and Homeland": Eugenics and Racial Nationalism in Central and Southeast Europe 1900-1940, eds. Marius Turda and Paul Weindling (Budapest: Central European University Press, 2006), 55-82; Margit Berner, "Die Bedeutung der biometrischen Erfassungsmethode in der österreichischen Anthropologie in der ersten Hälfte des 20. Jahrhunderts," in Eugenik: Biopolitische Methoden und Strukturen von 1900-1945, eds. Gerhard Baader, Veronika Hofer, and Thomas Mayer (Vienna: Czernin, 2007), 239-256; Fuchs, "Rasse," "Volk," "Geschlecht." 
purposes of continued research and teaching. ${ }^{105}$ Weninger noted a trajectory through the three stages from non-Europeans to Europeans as subjects. Via the study of eastern Europeans and Asian Russians, the ultimate focus had shifted, he argued, to Austrians and other German-speakers. But his argument is false. Pöch's studies outside Europe were completed before he acquired a university position, and the activities of the Viennese Anthropological Society are disregarded entirely. It had pursued studies of local populations since its inception.

Shifts in the focus of anthropological inquiry have been addressed in numerous recent historical studies that illuminate continuities and ruptures with the aim of improving our understanding of the role of anthropology in National Socialist Germany. ${ }^{106}$ The studies posit a break with a fin-de-siècle liberal-humanist tradition in reaction to various sociopolitical forces and shifts in scientific paradigms, culminating in an illiberal paradigm conducive to National Socialist cooptation. This narrative is often assumed to be true for Austria as well, as German physical anthropology played a leading role in the discipline and anthropology of the Reich, the dual monarchy, and Germanspeaking Switzerland, which were seen as forming, in effect, one "scientific nation." ${ }^{107}$ But while this may be true for certain aspects of research, methodology especially, to assume that it is also true for the sociopolitical context underestimates Austria-Hungary's and later Austria's cultural, historical, and geopolitical particularities, as well as the not insignificant role played by the interests of individual researchers.

105 Weninger, "25 Jahre Anthropologisches Institut," 196, 199.

106 Robert Proctor, "From Anthropology to Rassenkunde in the German Anthropological Tradition," in Bones, Bodies, Behavior: Essays on Biological Anthropology, History of Anthropology 5, ed. George W. Stocking (Madison, WI: University of Wisconsin Press, 1988), 138-179.

107 Massin, "From Virchow to Fischer," 83. 



\title{
Jews among the Peoples: Visual Archives in German Prison Camps during the Great War
}

\author{
Margaret Olin
}

\section{Drawing on the Borders}

Minorities were a menace to modern nationalism, and none more so than Jews in Germany in the nineteenth and early twentieth centuries. Among other issues, their seeming cosmopolitanism made them a threat to the cultural categories on which nationalism based its claims. Richard Wagner inveighed against "Judaism in music," because, as outsiders, Jews could not express the soul of a nation, rooted only in the blood of its natives. ${ }^{2}$ The field of art history warded off similar threats to national ethnic ideals and its own nationalistic structure in a more straightforward fashion, with recourse to the anti-Semitic notion that Jews were forbidden to make art. ${ }^{3}$ The present chapter concerns the situation of the Jew along the borders between ethnicities as they were constructed in the early years of the twentieth century. In doing so, the chapter operates on other seams and boundaries as well: the blurred boundaries around visual phenomena we call art, the boundaries between Self and Other in the visual communities constructed by photographs and other depictions, and the boundaries between anthropology and art. These boundaries demarcate spaces, determining who may, or must, enter them, and who is pushed, or allowed, out. This chapter takes place in a location that was itself a blurred

1 This chapter is a draft of ongoing research. I am grateful to all participants in the conference on Anthropology in Wartime for their suggestions, and particularly to Andrew Evans, Britta Lange, and Monique Scheer, for sharing their forthcoming publications and research with me.

2 Richard Wagner, "Das Judentum in der Musik" (1850), in Gesammelte Schriften und Dichtungen, vol. 5 (Leipzig: G. W. Fritzsch, 1888), 66-85.

3 Margaret Olin, The Nation without Art: Examining Modern Discourses in Jewish Art (Lincoln, NE: University of Nebraska, 2001), esp. 5-31. 
boundary: German prisoner-of-war (POW) camps during the Great War. Cohabited by prisoners from many parts of the world, visited by German scholars and artists, the POW camps were the source of eclectic collections of visual images of prisoners, their captors, and the scholars who studied them.

The questions addressed here derive ultimately from a few sentences in Wilhelm Doegen's 1925 book Unter Fremden Völkern. Doegen had conducted phonographic recordings of prisoners in the camps as part of a large, government-sponsored interdisciplinary undertaking, involving a distinguished group of anthropologists and linguists, "to use prisoners of war undergoing an involuntary residence in Germany for phonetic speech recordings." In the preface, Doegen discussed the genesis of the project. Along with recordings, he wrote, skull measurements and X-rays were sometimes taken, and a dentist, Doegen's brother, took an image of the upper surface of the vocal tract (a palatogramm) of some prisoners in order "to study the unusual sounds of exotic tribes at their place of origin." ${ }^{\prime}$ A member of an exotic tribe, that of Lutheran bookkeepers, was actually recorded and photographed in the dental office of a prison camp. ${ }^{6}$ While the recordings became the basis of an acoustical archive, initially housed in the Preußische Staatsbibliothek, the essays by the scholars were collected in Doegen's book. ${ }^{7}$

The book also contained photographs of prisoners representative of each ethnic or linguistic group. Doegen distinguished the photographs of the prisoners taken to accompany the text, however, from the rest of the project.

My illustrations are based on photographs that I personally arranged, completely autonomously, and independently from the sound recordings in the prisoner of

4 Wilhelm Doegen, ed., Unter fremden Völkern: Eine neue Völkerkunde (Berlin: Verlag für Politik und Wirtschaft, 1925), 9. For more on this project, see Britta Lange, "Ein Archiv von Stimmen: Kriegsgefangene unter ethnografischer Beobachtung," in Original/Ton: Zur Mediengeschichte des O-Tons, vol. 34, Kommunikation audiovisuell, eds. Harun Maye, Cornelius Reiber, and Nikolaus Wegmann (Constance: Universitätsverlag Konstanz, 2007), 317-342.

5 Doegen, Unter fremden Völkern, 16; see Lange, "Ein Archiv von Stimmen."

6 The identification card of one such prisoner, Josef Klemmer, of Estonia, is illustrated in Horst Bredekamp, Jochen Brüning, and Cornelia Weber, eds., Theater der Natur und Kunst, vol. 2, Katalog: Wunderkammern des Wissens (Berlin: Henschel, 2000), 124, fig. 8/37b.

7 The archive is now in Humboldt University. For its history, see Susanne Ziegler, "Die akustischen Sammlungen: Historische Tondokumenta im Phonogramm-Archiv und im Lautarchiv," in Theater der Natur und Kunst, vol. 1, Essays, eds. Horst Bredekamp, Jochen Brüning, and Cornelia Weber (Berlin: Henschel, 2000), 197-208. See also the website of the Berliner Lautarchiv, http://publicus.culture.hu-berlin.de/lautarchiv/geschichte.htm (accessed February 23, 2010). 
war camps, and without any government funds. For providing stimulation and the guidance for these photographs, which were made to my specifications by the photographer at the Art Historical Institute of the University of Berlin, Herr Gerdes, I hereby thank Professor Goldschmidt. ${ }^{8}$

Adolph Goldschmidt (1863-1944) was himself a distinguished scholar, founder of the Institute for Art History in Halle in 1904, and Ordinarius for Art History in Berlin from 1912. A major force in the field of medieval art studies, Goldschmidt came into contact with, and mentored, most significant art historians and curators of his day and later, in many different fields, in Germany and the United States. ${ }^{9}$ These few words, in which Doegen acknowledges that he included photographs on the urging of a renowned art historian, suggest a unique interdisciplinary collaboration between anthropology and art history.

The role of anthropologists who studied prisoners in camps has attracted the interest of scholars. ${ }^{10}$ The role of the Art Historical Institute of Berlin, and of Goldschmidt as its head, is perhaps less well studied. Goldschmidt's participation did not end with his suggestion to Doegen that photographs be taken. According to his memoirs, the Art Historical Institute housed a card catalog of the languages of the prisoners, intended for philologists. ${ }^{11}$ These cards are presumably the ones now located in the acoustical archive. Even more signifi-

8 Doegen, Unter fremden Völkern, 6.

9 On Goldschmidt's life and works, see especially Kathryn Brush, The Shaping of Art History: Wilhelm Vöge, Adolph Goldschmidt, and the Study of Medieval Art (Cambridge, UK: Cambridge University Press, 1996); Kurt Weitzmann, Adolph Goldschmidt und die Berliner Kunstgeschichte (Berlin: Kunsthistorisches Institut, Fachbereich Geschichtswissenschaften der Freien Universität Berlin, 1985); Carl Georg Heise, ed., Adolph Goldschmidt zum Gedächtnis: 1863-1944 (Hamburg: Ernst Hauswedell, 1963); Adolph Goldschmidt, Adolph Goldschmidt, 1863-1944: Lebenserinnerungen, ed. Marie Roosen-RungeMollwo (Berlin: Deutscher Verlag für Kunstwissenschaft, 1989); Heinrich Dilly and Gunnar Brands, eds., Adolph Goldschmidt 1863-1944: Normal Art History im 20. Jahrhundert (Weimar: VDG, 2007).

10 See Andrew D. Evans, "Anthropology at War: Racial Studies of POWs during World War I," in Worldly Provincialism: German Anthropology in the Age of Empire, eds. H. Glenn Penny and Matti Bunzl (Ann Arbor, MI: University of Michigan Press, 2003), 198-229; Monique Scheer, "'Völkerschau' im Gefangenenlager: Anthropologische 'Feind'-Bilder zwischen popularisierter Wissenschaft und Kriegspropaganda 1914-1918," in Zwischen Krieg und Frieden: Die Konstruktion des Feindes, ed. Reinhard Johler et al. (Tübingen: Tübinger Vereinigung für Volkskunde, 2009), 69-109.

11 Goldschmidt, Adolph Goldschmidt, Lebenserinnerungen, 186-187. Most of the following information about Goldschmidt's activities in the camps comes from these memoirs, where the camps are discussed on pp. 185-192. 
cantly, Goldschmidt participated in the photographs themselves. Herr Gerdes was a fine photographer, Adolf Goldschmidt wrote, but his intelligence did not extend to the task at hand, and someone with a greater understanding had to accompany him. Consequently, Goldschmidt himself spent a great deal of time during the war years in German POW camps. There, besides photographing the prisoners, the photographer also took pictures of the camps themselves and the activities held in them. Goldschmidt owned a copy of at least one of the books in which Doegen used his photographs, perhaps given him by Doegen in recognition of his role. ${ }^{12}$

His motivations for taking on this assignment may have been varied. Goldschmidt was an enthusiastic traveler. In 1916/17, when he could not leave Germany, the prison camps allowed him to enjoy the illusion of worldwide travel. There, he celebrated his birthday, saw French plays, took a dislike to an Indian festival, and was afraid to be left on his own in a room full of Africans, but he asked to be introduced to Nigerians from Benin, the origin of wonderful bronze heads that he had seen in Berlin, as though he wondered whether Nigerian artistic sensibilities had changed in the four centuries since the sculptures were created. A curiosity about the relation between ethnicity and art may have led him to the camps. His memoirs express his lively interest in the prisoners whom he met there during the Great War. Indeed, the different ethnicities he encountered in his travels, including African Americans he met in the United States during various sojourns there, invariably attracted his interest.

This explanation, however, leaves several questions open. The first few involve the photographs themselves. As an art historian, did Goldschmidt have a scholarly reason to urge that these photographs be taken, and, having done so, why was it necessary for him to direct the photographer who took them? It is hard to imagine a photographer so intellectually challenged as not to grasp the only guidelines that Goldschmidt mentions, namely, that the photographs necessitated sharp profile and frontal views, taken, where possible, without any headgear. ${ }^{13}$ Most portraits in the book follow these guidelines straightforwardly (Figure 1).

12 Goldschmidt, Adolph Goldschmidt, Lebenserinnerungen, 192. Since the book Goldschmidt mentions discusses the conditions of the camps themselves, it is probably Wilhelm Doegen, Kriegsgefangene Völker, vol. 1, Der Kriegsgefangenen Haltung und Schicksal in Deutschland (Berlin: Verlag für Politik und Wirtschaft, 1921), which is illustrated mainly with views of the camp and photographs of prisoners engaged in activities. In its preface (p. v), Doegen thanks Goldschmidt and Gerdes.

13 Goldschmidt mentioned the difficulties involved in persuading the Sikh prisoners to remove their turbans. Goldschmidt, Adolph Goldschmidt, Lebenserinnerungen, 190. 


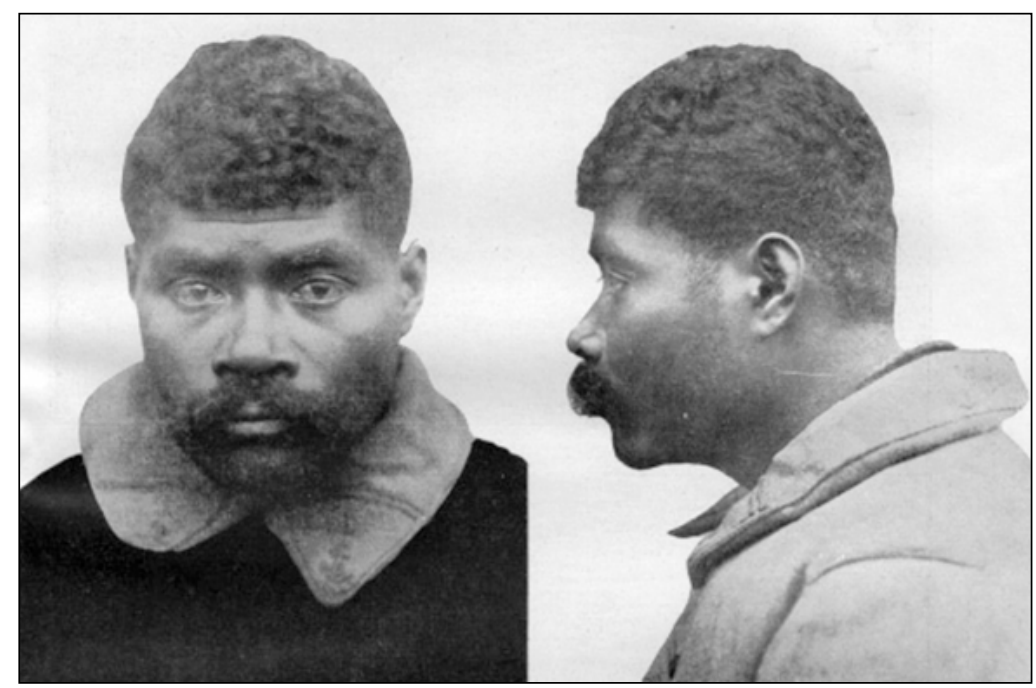

Figure 1. "Ein Neukaledonier im Messbild." Source: Doegen, Unter fremden Völkern.

A second set of questions touches on another aspect of Goldschmidt's fame. In 1904, an imperial dispensation made him the first Jew to hold a chair in art history without converting to Christianity. No direct evidence explains why Goldschmidt, a secular Jew, refused to convert to Christianity, but his identification with his own ethnicity is unmistakable. ${ }^{14}$ The question of Goldschmidt's Jewish identity makes his participation in Doegen's project even more puzzling. Andrew D. Evans has already pointed out that among the exotic sounds of the foreigners were the sounds of fellow Europeans. He has suggested that the consequences of these studies were to racialize the difference between Germans and other Europeans. This use of prisoners, he argues, helped German anthropology move from a universal standpoint in the nineteenth century to racism in the twentieth, introduced the idea of experimenting on prisoners, and, hence, led to many of the abuses of the Third Reich. ${ }^{15}$

At the end of that "hence" were Jews, the Europeans perhaps most threatened by a racial interpretation of their differences. Interestingly, Jews were among the groups that Gerdes photographed, apparently under Goldschmidt's direction (Figure 2). Some are photographed to accentuate stereotypes, with ears that protrude, small eyes, a prominent nose, or frizzy hair. Their captions, as Evans points out, subtly suggest stereotypical Jewish professions, such as

14 See Margaret Olin, "Adolph Goldschmidt: Another Jewish Art History for the Education of Mankind?" in Dilly and Brands, Adolph Goldschmidt 1863-1944, 397-411.

15 Evans, "Anthropology at War," 226-229. 


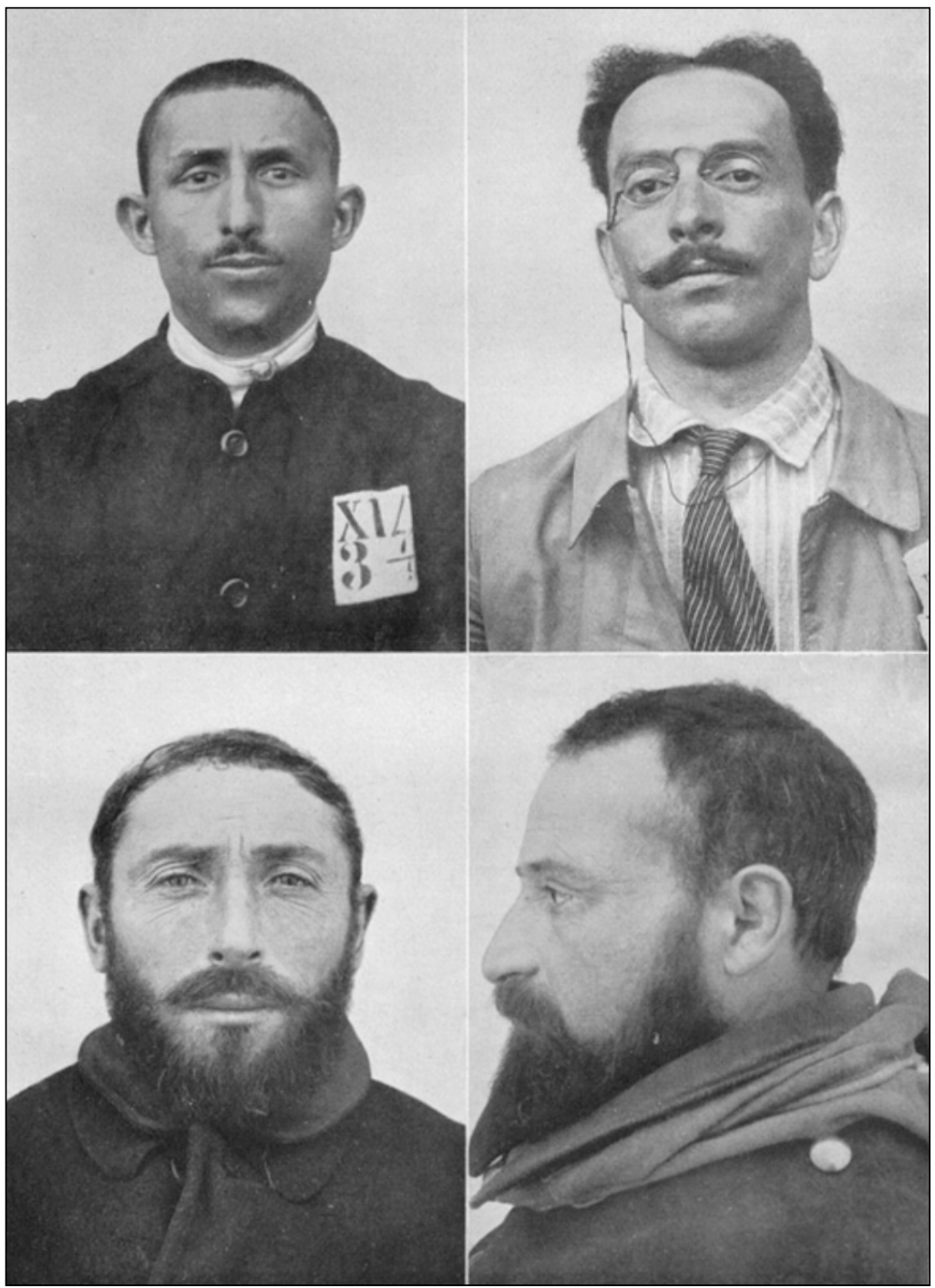

Figure 2. "Jüdische Volkstypen," Source:Doegen, Unter fremden Völkern.

"lawyer," while the other prisoners in Doegen's books, if their jobs are mentioned at all, are usually farmers. ${ }^{16}$ Did the Jewish professor arrange for the

16 Andrew D. Evans, "Capturing Race: Anthropology and Photography in German and Austrian Prisoner-of-War Camps during World War I," in Colonialist Photography: Imag(in)ing Race and Place, eds. Eleanor M. Hight and Gary D. Sampson (London: Routledge, 2002), 250. 
photographs of fellow Jews as exotic Others? Although as eastern Jews, some German Jews would have thought them culturally inferior, few would have thought of them as racially distinct. His own sensitivity to anti-Semitism should have influenced his actions, unless, as I shall suggest below, there could have been another explanation. ${ }^{17}$ In his memoirs, Goldschmidt spoke only of the other ethnicities in the camps, however, never his own.

The participation of other Jews in the studies of the prison camps raises similar issues. Apart from the authors of scholarly essays included in Doegen's book, one of whom will be discussed below, these also include at least one artist. Hermann Struck, a well-known artist and Zionist, was an important contributor to the visual archives of prisoners in the camps. Struck had joined the German army, which employed him as a Yiddish interpreter. ${ }^{18}$ Like other artists in uniform, he had ample opportunity to pursue his artistic activities, under the auspices of General Erich von Ludendorff himself, and make them part of the war effort. ${ }^{19}$ An important fruit of this artistic campaign was a book of lithographs of POWs, introduced by the anthropologist Felix von Luschan. ${ }^{20}$ According to Luschan, the drawings were primarily "art," but had scientific value as well. Like the photographs, most of the drawings utilize frontal or profile views, perhaps in response to a request by the anthropologist. ${ }^{21}$ Letters from Struck to Luschan indicate that he reworked some of his drawings to conform to Luschan's racial stereotypes. He told Luschan, for example, that he had revised a drawing to give an African "pretty, frizzy" hair. ${ }^{22}$ One might conclude that anthropologists followed preconceived notions of the races and made sure that illustrations corresponded to them. The illustrations, however,

17 See Olin, "Adolph Goldschmidt." A discussion of changing attitudes toward Jewish identities and the "Ostjude" can be found in Steven E. Aschheim, Brothers and Strangers: The East European Jew in German and German Jewish Consciousness, 1800-1923 (Madison, WI: University of Wisconsin Press, 1982); Michael Brenner, Marketing Identities: The Invention of Jewish Ethnicity in Ost und West (Detroit, MI: Wayne State University, 1998).

18 Jane Rusel, Hermann Struck (1876-1944): Das Leben und das graphische Werk eines jüdischen Künstlers (Frankfurt a. M.: Lang, 1997), 165.

19 Ibid., 165. Among Struck's war-related publications were In Russisch Polen: Ein Kriegstagebuch (Berlin: J. Bard, 1915); Hermann Struck and Herbert Eulenberg, Skizzen aus Litauen, Weissrussland und Kurland (Berlin: George Stilke, 1916). Other artists also worked on the front, whether or not in uniform themselves, producing such books as, Theodor Rocholl et al., Kriegsfahrten deutscher Maler: Selbsterlebtes im Weltkrieg 1914-1915 (Bielefeld: Velhagen and Klasing, [1916]).

20 Hermann Struck, Kriegsgefangene: Hundert Steinzeichnungen (Berlin: Reimer, 1916).

21 Felix von Luschan, "Einführung in die Grundfragen der Anthropologie," in Struck, Kriegsgefangene, 3.

22 Evans, "Capturing Race," 235. 


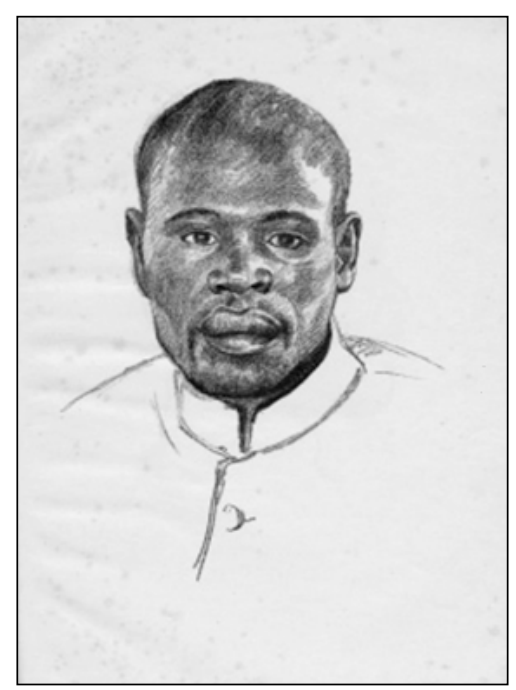

Figure 3. "Media Diouf," lithograph. Source: Struck, Kriegsgefangene.

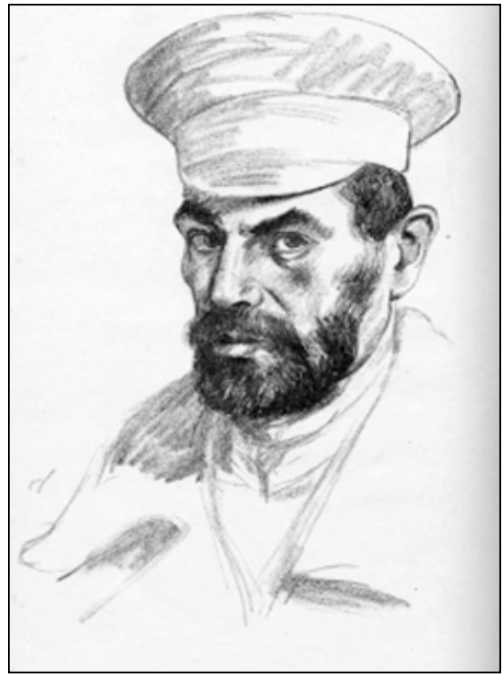

Figure 4. "Isaac Chotoran," lithograph. Source: Struck, Kriegsgefangene.

may sometimes have been more subtle than the anthropologists intended. A glance at Struck's lithographs, for example, indicates that he showed some restraint in the area of frizzy hair even in the final images ${ }^{23}$ (Figure 3).

In other ways, also, Struck may have destabilized the borders between ethnic groups. Not surprisingly, Struck's images of fellow Jews stray the farthest from common stereotypes. Certainly, their features are less stereotypically "Jewish" than the images that Goldschmidt's photographer took for Doegen. Isaac Chotoran, for example (Figure 4), has a nose as straight as any proud Nordic type and no other noticeably ethnic "Jewish" features, such as the popout eyes and hook noses, thick lips, and weak chests attributed to Ashkenazi Jews by Ferdinand Freiherr von Reitzenstein in a similar volume of anthropological texts paired with illustrations, Leo Frobenius's lavish 1920 publication of essays, watercolors, and drawings, Deutschlands Gegner im Weltkriege. ${ }^{24}$ Had Luschan demanded from Struck ethnic representations true to type in all respects, the results would have disappointed.

In fact, Struck's images, although Luschan rarely refers to them in his text, surely did not disappoint the anthropologist. To the contrary, Chotoran's depic-

23 Rusel discusses the work along similar lines. Rusel, Hermann Struck (18761944), 169-173.

24 Ferdinand Freiherr von Reitzenstein, "Kaukasischer Bergjude," in Deutschlands Gegner im Weltkriege, ed. Leo Frobenius (Berlin: Verlagsanstalt Hermann Klemm, [1920]), 48. 


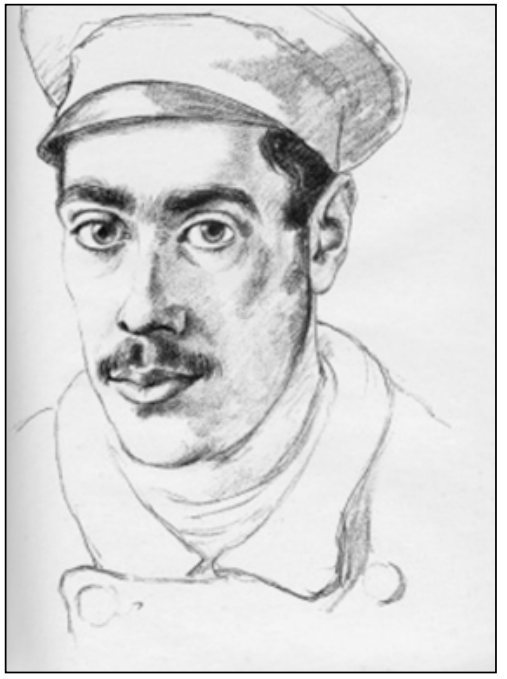

Figure 5. "Chajus Krasikow," lithograph. Source: Struck, Kriegsgefangene.

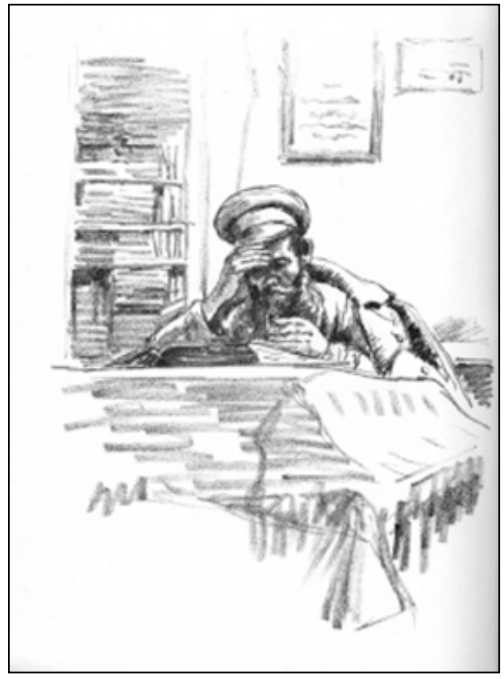

Figure 6. "David Bomblatt," lithograph. Source: Struck, Kriegsgefangene.

tion, and those of other subjects, suggest that Struck, probably with Luschan's tacit consent, may have intended his drawings specifically to attack stereotypes of Jews and perhaps of other peoples as well. Differences between his depiction and those in Doegen's book abound. Gerdes has taken his photographs of Jews from slightly below; the subjects lean back from the camera and avoid gazing directly into the lens, giving them a possibly devious appearance. Struck depicts his subjects, such as the bookkeeper Chajus Krasikow, straight on or from slightly above, and the viewer must meet their gaze (Figure 5). Krasikow's eyes even turn from his slightly off-center view to meet the beholder. Unlike the Jews in Doegen's book, Struck's subjects are in military uniform, rather than civilian or prison garb. These explicitly military images of Jews in themselves disrupt Jewish stereotypes. If anything, Jews were characteristically considered military shirkers, more loyal to their fellow Jews than to their so-called "host" countries, and physically unfit for military service. ${ }^{25}$ Struck depicted one officer, David Bomblatt, a temple official like one of Doegen's subjects, not only in uniform, but also in his religious pursuits (Figure 6). If Struck strived to depict types, he also sought to make his subjects individuals. Perhaps this combination is what Luschan meant when he called them "art."

25 Omer Bartov, "Defining Enemies, Making Victims: Germans, Jews, and the Holocaust," The American Historical Review 103 (1998): 771-816; Sander Gilman, The Jew's Body (New York: Routledge, 1991), 38-59. 


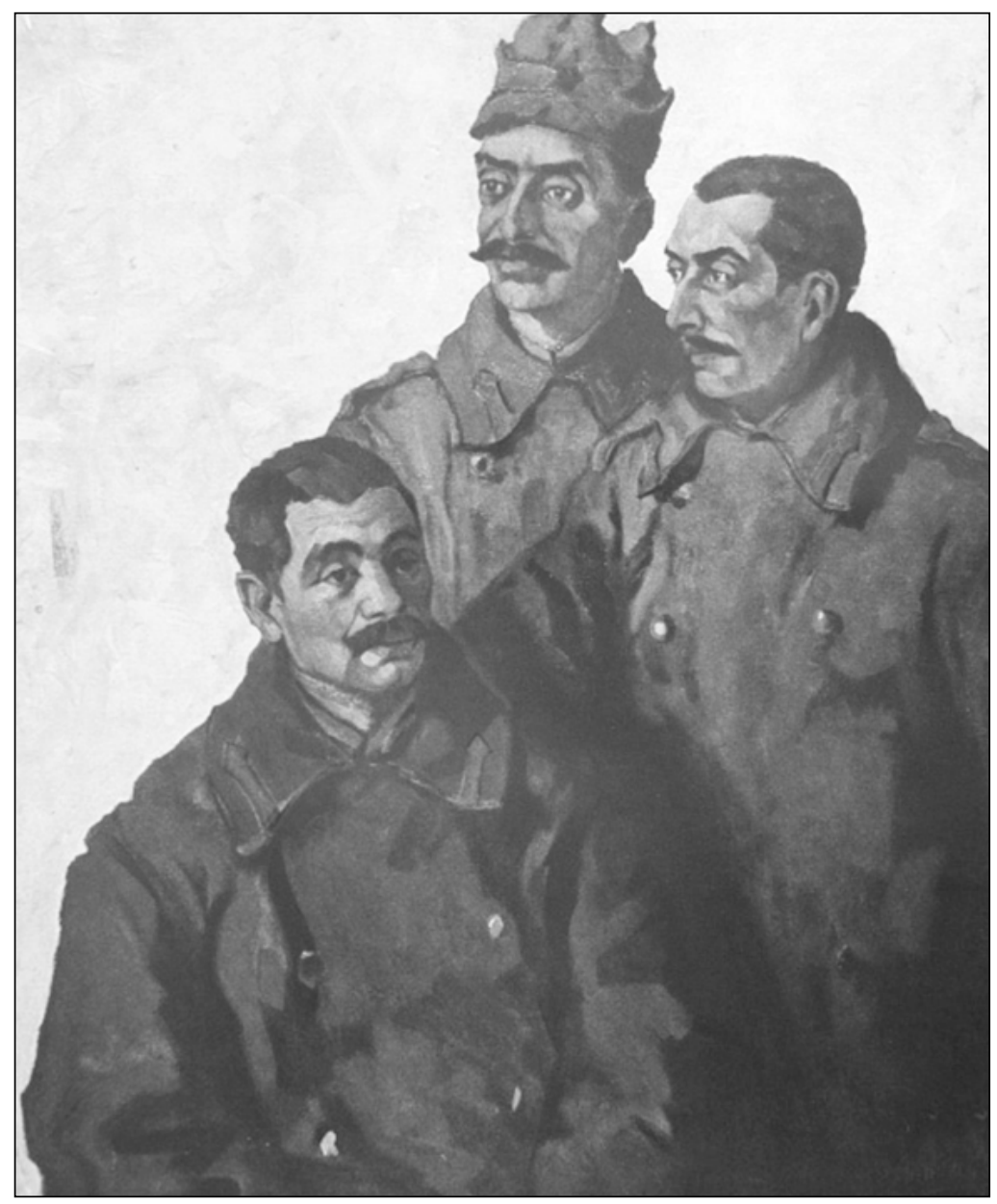

Figure 7. Erwin Emmerich, "Rumänen (Lipovean u. rumän. Juden)." Source: Frobenius, Deutschlands Gegner im Weltkriege.

Other such illustrated works also raise issues involving the visual interpretation of Jews. In the above-mentioned work by Frobenius, for example, the portrayals echoed the standard format, often grouping prisoners to exhibit frontal, three-quarter, and side views of the same ethnic type within the same frame. These groupings could be compared with one another. Erwin Emmerich's Rumanian Jews, for example, seem to be a gloss on Wilhelm Thöny's Rumanians (Figures 7 and 8). The poses mirror one another, as though commenting on one another. The facial features form part of the contrast. The Jews have pop-out eyes and curving noses; the Rumanians all wear hats, yet their faces appear less round than the Jewish faces; even the Jews' moustaches 


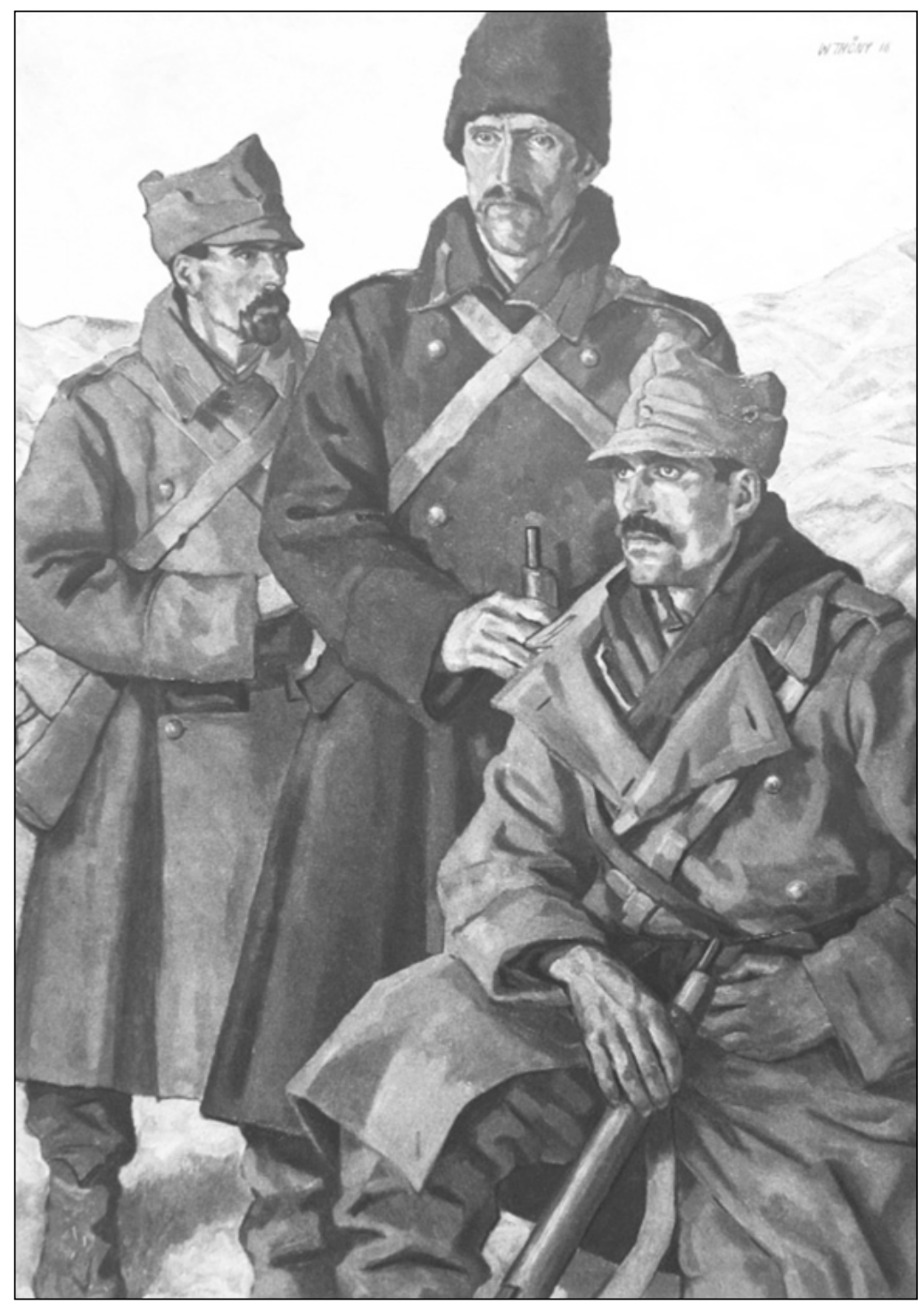

Figure 8. Wilhelm Thöny, "Rumänen (Oltean/Lipovean und Moldovean)." Source: Frobenius, Deutschlands Gegner im Weltkriege.

protrude in a way that ties them together and distinguishes them from the Rumanians. The one hat worn by a Jew has a crinkled look, and the jagged outline of his uniform contrasts with the smooth outline of the Rumanian's garb. The Jews seem an unkempt group of soldiers, compared to the straightarrow Rumanians. 


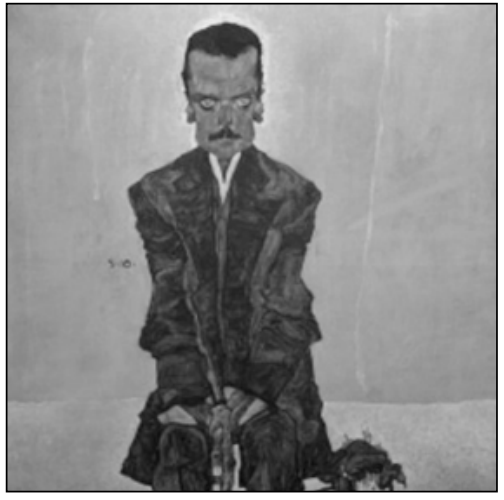

Figure 9. Egon Schiele, "Portrait of Eduard Kosmack," 1910, oil on canvas. Reprinted with permission, Österreichische Galerie Belvedere.

These observations might appear to emanate from stylistic differences alone. Indeed, the jagged outline Emmerich lends his Jews recalls portraits by Egon Schiele (Figure 9). This avant-garde style, however, was sometimes itself associated with Jews, because so many of the patrons, though not the artists, were Jewish. ${ }^{26}$ It was not Emmerich's only style, however, and he may have intended it to suit his subject. His Georgians, in the same volume, wear smooth coats (Figure 10). Oddly, the description in the texts does not always match the illustration. The ethnic stereotype of Ashkenazi Jews mentioned above, for example, is found in an essay on "Mountain Jews of the Caucasus," where it is accompanied incongruously by

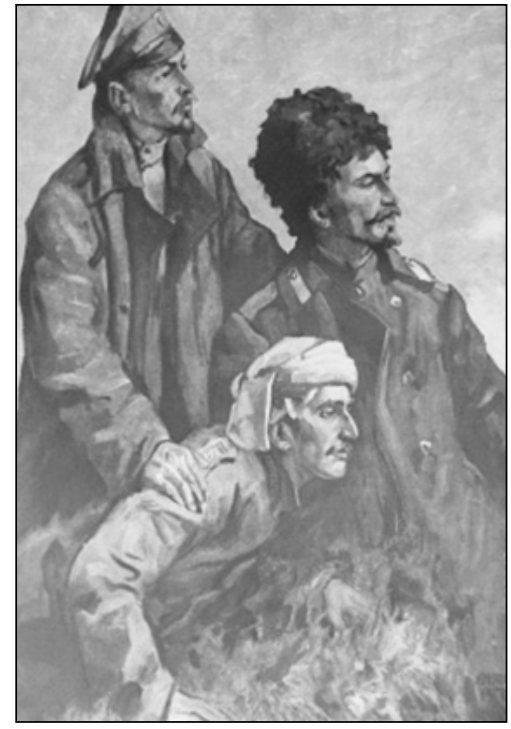

Figure 10. Erwin Emmerich, "Georgier (Grusiner)." Source: Frobenius, Deutschlands Gegner im Weltkriege.

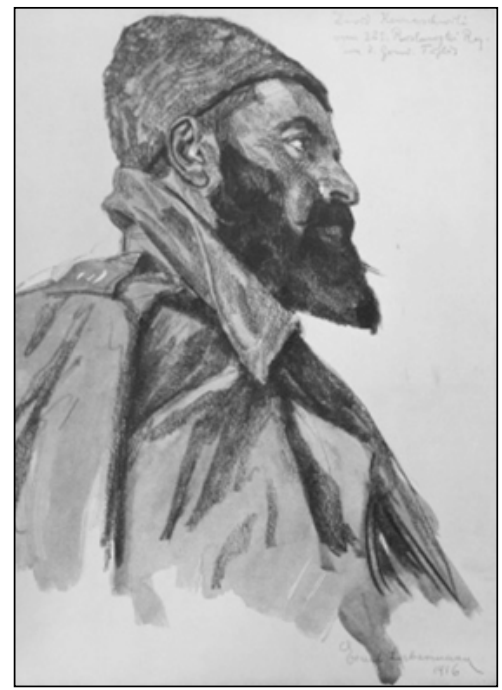

Figure 11. Ernst Liebermann, "Kaukasischer Bergjude," dated 1916. Source: Frobenius, Deutschlands Gegner im Weltkriege.

26 See James Shedel, Art and Society: The New Art Movement in Vienna, 1897-1914 (Palo Alto, CA: Society for the Promotion of Science and Scholarship, 1981). 
Ernst Liebermann's illustration of a seemingly stalwart mountain man with a steady gaze (Figure 11). Perhaps Reitzenstein never saw the picture. Or perhaps Liebermann, like Struck, wished to avoid corroborating visual stereotypes.

If artists like Struck tried to avoid including Jews among exotic others, however, why did they include images of them, singled out as Jews? Struck's job was visual-if Jews did not look distinctive, what was their purpose in being there? Perhaps the archives were a visual project after all, including the ostensibly aural project by Doegen. While Doegen's project appears based on aural signs of race, languages rather than facial forms, the divisions in his books do not always correspond to language. Jewish, after all, is not a language, even though some Jews speak languages limited to Jews, such as Yiddish or Ladino. Since language groups are not really the (only) criteria, then the possibility arises that the aural project was partially organized along visual lines. The next section returns to Goldschmidt, approaching this visual project through the relation between art history and anthropology.

\section{A Connoisseur of People}

The two disciplines shared a great deal. They were new disciplines. Both of them were constantly in danger of being mistaken for dilettantism. ${ }^{27}$ But beyond that, they had similar tools and techniques, similar methods of analysis, and similar aims.

Their tools and techniques involved travel and observation and the compilation of visual archives and notes. Officially, neither discipline trusted photographs. Scale is difficult to ascertain in photographs, as anyone knows who has looked at a projected slide of a small cameo or studied a large fresco in a book. Anthropologists, too, had reservations about scale, because they depended on accurate measurements that were difficult to take even from subjects in the flesh. ${ }^{28}$ Furthermore, photographic representations were difficult to control. As Goldschmidt put it, the photograph can show "naturally not everything, and to be sure not the most essential thing, which can only be grasped through study of the original." ${ }^{29}$ In Goldschmidt's day, art historians continued to make extensive use of drawings. As a student, Goldschmidt had worked

27 Adolph Goldschmidt, "Kunstgeschichte," in Aus Fünzig Jahren deutscher Wissenschaft: Die Entwicklung ihrer Fachgebiete in Einzeldarstellungen, ed. Gustav Abb (Berlin: de Gruyter, 1930), 192-193; Andrew Zimmerman, Anthropology and Antihumanism in Imperial Germany (Chicago, IL: University of Chicago Press, 2002), 118-119.

28 Zimmerman, Anthropology and Antihumanism in Imperial Germany, 164-165.

29 Goldschmidt, "Kunstgeschichte," 195. 
as a draughtsman on art historical expeditions. ${ }^{30}$ The anthropologist Gustav Fritsch wrote that drawings represent "in a clear manner many of the parts that in the photograph, are more difficult to see." ${ }^{31}$ Nevertheless, photography was increasingly important to both fields, and compilation of a photographic archive was not optional. With an archive, scholars could study works in their absence and compare them with one another.

Examination and comparison was important to both disciplines, because they shared an investigative method: close visual analysis, pursued with a "sharp, discriminating [unterscheidendes] eye," trained through exercises in connoisseurship that continued to be a dominant practice in art history departments into the late twentieth century. ${ }^{32}$ A skill honed on assigning dates and provenances to paintings or sculptures, without questioning the social circumstances of their making, in which words like "volumetric" or "abstract" could be applied indiscriminately to Buddhavistas and madonnas, figures of hunters or marginal ornamentation, could it not apply just as well and just as significantly, to people on the bus one took to class? Once the types are established, the scholar can find them anywhere that seems convenient.

By the late twentieth century, the ability to assign dates in the third or sixteenth centuries, not only to sculptures of those periods, but to actual people living in the twentieth century, made connoisseurship, as practiced in many art historical seminars, appear to be a meaningless parlor game. At least it seemed harmless. On further reflection, however, maybe it was not. For such connoisseurship was exactly Goldschmidt's expertise. His ability to spot "types" must have been what enabled him to show the photographer what to do. Just as, in the field, he knew which sculptural plinths or miniatures to photograph or draw (one would never send a photographer on his own to photograph a Romanesque church), so he could walk into a room of people and spot the "typical" ones. Apparently, Goldschmidt drew the comparison between connoisseurship of art and of people. But for him it was no parlor game. When he asked to meet Africans from Benin, he was surely trying to combine the practice of anthropology and art history by seeking formal relationships between present-day people and the sculptures made by their ancestors. If this practice led to racism, then Goldschmidt had a hand in it.

If the methods of the two disciplines seem the same, it is no accident; for their goals were the same. Both art historians and anthropologists wished to explain

30 Goldschmidt, Adolph Goldschmidt, Lebenserinnerungen, illustrates several examples of Goldschmidt's drawings. Franz Wickhoff, Meyer Schapiro, and many other art historians have been known to draw as part of their scholarship.

31 Quoted in Zimmerman, Anthropology and Antihumanism in Imperial Germany, 99.

32 The quotation is from Goldschmidt, "Kunstgeschichte," 193. 


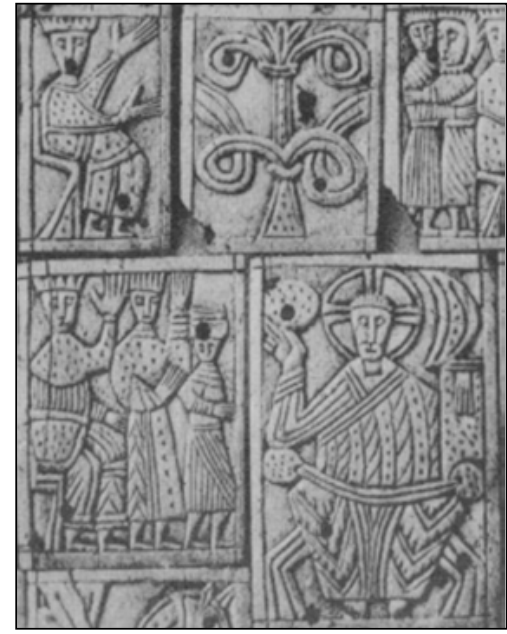

Figure 12. Ivory carving, Musée Cluny, Paris. Source: Goldschmidt, Die Elfenbeinskulpturen (detail of plate 78).

origins and, having done so, to explain change. The point of Goldschmidt's exercises in connoisseurship was to understand "whether a work originates in a unitary conception or whether it is imitative or jumbled together." 33 In his scholarship, for example in his corpus of Romanesque ivories, he put these exercises into practice:

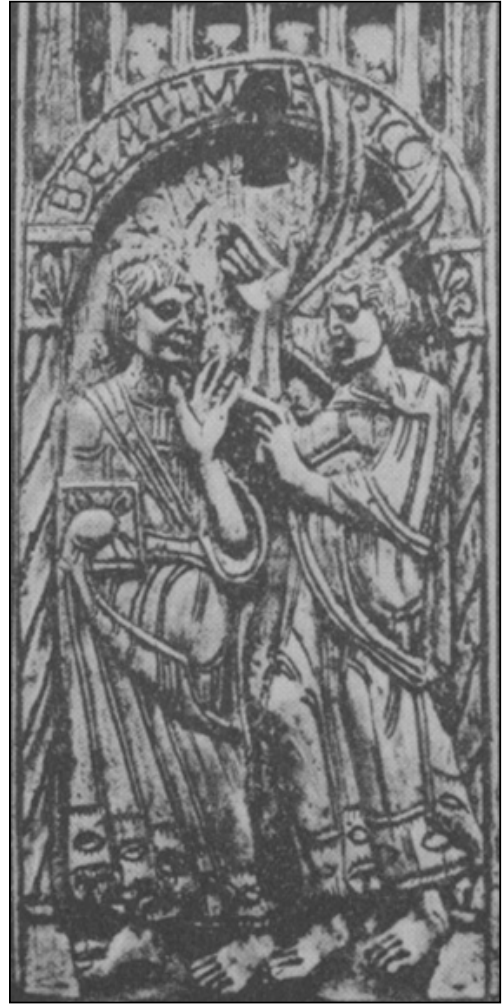

Figure 13. Ivory carving, Museo Arqueologico, Madrid. Source: Goldschmidt, Die Elfenbeinskulpturen (detail of plate 94).

We will call the whole northern Spanish production provisionally Castilian, since the individual provenances cannot be determined [...].

The first group corresponds to Mozarabic manuscripts [...] from the end of the 10 th century [...]. The figures are very flat in relief and very crudely drawn. The heads are egg formed, pointed below, with a flat cranium mostly seen frontally, sometimes in sharp profile, seldom slightly turned. The nose is made of two parallel lines. [Figure 12]

[...] We encounter a style in the middle of the 11th c., which is much more developed in its individual forms, and which is represented by the gifts of Ferdinand I to his newly built church S. Isidoro in Leon. [...] The heads have completely changed. The hair no longer sits like a flat cap on the cranium, but frames the face, which in contrast to earlier appears more in halfprofile. The nose is aquiline, the mouth has strongly plastic lips, the groove between cheek and mouth is strongly hollowed out,

33 Ibid. 
the eyes are deeply drilled out, the hair often has a corrugated look or is sharply subdivided diagonally.

A completely new character has come in, which is obviously derived from the cloisters of Catalonia, especially from Ripoll, where the richly illustrated bibles of Farfa and Rosas were made in the first half of the 11th century. ${ }^{34}$ [Figure 13]

If carried to an extreme, this method, based on close visual analysis, could result in a highly speculative conclusion, as it did in the work of one of Goldschmidt's students, who concluded similar analyses by postulating the existence of an original ideal type, often from classical antiquity, sometimes from Jewish sources, although provisionally these works existed only in his imagination. ${ }^{35}$

Anthropologists similarly derived origins from descriptions. Frobenius describes a drawing by Walter Georgi as follows:

The head is large for an African of his stature; the face broad, the forehead over the eyes springs forward, not arched like young negroes. The nose is clear cut and not swelling. The eyes are relatively close together and smaller than negro eyes usually are. The skin color is brown, but not very dark [...]. The hands are light, [...]. One must conclude that [the hair] is rather more wavy than frizzy.

What we have here is probably one of those oasis mixtures, as from Arab, Fulbe und Negroes from the interior. ${ }^{36}$ [Figure 14]

Luschan explains a contrast through origins as well:

Such types, however, have been mixing along the whole northern rim of Africa for millenia, in that continual lighter blood has seeped through to the darker tribes, and not seldom also Negro blood into the lighter Berbers and Arabs. The many different mixtures are self explanatory. Wonderful, and only comprehensible in Mendel's sense is the fact that any pure forms still exist. ${ }^{37}$ [Figure 15]

The concentration on origins, shared by both disciplines, made such arguments seem worthwhile. But the people themselves are not the basis of Luschan's argument. The types he describes are depictions, not people, just as are the ivories and illuminations described by Goldschmidt. Luschan's man of "lighter blood" is depicted in three-quarter view and a steady gaze, in the style of Victorian portraiture, while the African with more "negro blood" is treated in the style of a so-called "Meßbild." Furthermore, the whiter man is treated to

34 Adolph Goldschmidt, Die Elfenbeinskulpturen aus der Romanischen Zeit, XI-XIII. Jahrhundert, vol. 4 (Berlin: Bruno Cassirer, 1926; reprint ed. Berlin: Deutscher Verlag für Kunstwissenschaft, 1975), 1-2.

35 For a discussion of one such scholar, see Olin, The Nation without Art, 139148.

36 Frobenius, Deutschlands Gegner im Weltkriege, 198.

37 Luschan, "Einführung in die Grundfragen der Anthropologie," 60. 


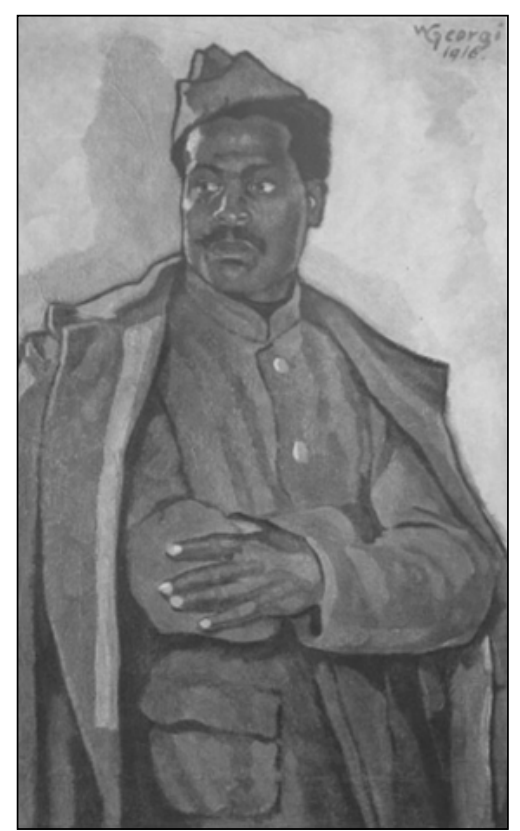

Figure 14. Walter Georgi, "Höriger Mischling aus Igli (Gusfanatal)." Source: Frobenius, Deutschlands Gegner im Weltkriege.
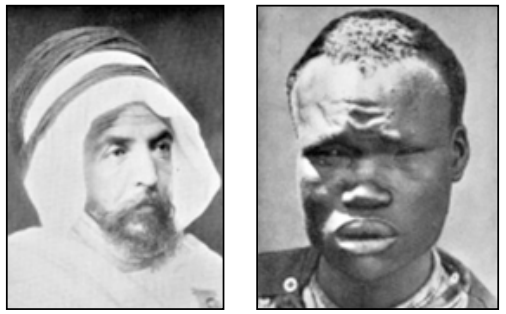

Figure 15. "Berber aus Marokko, and Sudanese aus dem Quellgebiet des weißen Nil," illustrations in Luschan, "Einführung in die Grundzüge der Anthropologie." Source: Struck, Kriegsgefangene.

soft and even lighting, while the black man, like many of the photographs Luschan uses (he took this one himself), is lit harshly. His eyes appear sunken, his nose and lips stand out, like an animal in headlights. In contrast, Goldschmidt's photographer did not avail himself of either style. Rather, he lit his subjects like statues, trying to illuminate them evenly, making all the detail clearly visible. In other words, apart from the subjects themselves, the representations of prisoners in the camps created by Luschan and Goldschmidt would themselves be good candidates for the kind of visual analysis that Goldschmidt practiced on manuscript illuminations.

\section{Jewish Space}

The concentration on origins, which united art history and anthropology, also helps explain why Jews like Goldschmidt would place themselves willingly within the discourse of racial imagery. While their motives may differ, examining Jews among other ethnic identities, including those of other Europeans, allowed Jews to establish their identity as a people among peoples, rather than as a people apart. In his art historical scholarship, Goldschmidt aimed primarily at understanding German artistic origins. He saw these origins, however, not as purely Germanic, but as hybrid. His dissertation on Lübeck painting and sculpture understood its local forms in terms of the adaptation and assimilation of styles from outside, due to Lübeck's participation 
in the Hansa league. In his book on the Evangeliary in the Goslar Rathaus, ${ }^{38}$ he speculated that it would have been better for German art if French Gothic had not hindered it from its ongoing assimilation of Byzantine art. He regarded Jewish art as not having a particular style of its own. Rather than being a shortcoming, however, this lack of style meant that Jews could participate universally in all arts.

Luschan may have shared such views. At the end of his introductory essay to Struck's portfolio, he celebrated the unity of mankind along with its protean nature ${ }^{39}$ Luschan looked at hybrid races similarly to the way that Goldschmidt looked at hybrid styles; he endeavored, for example, to defend the notion of a single origin of mankind. Consequently, he needed to discuss the myriad hybrid forms of mankind: If the origin of humanity can be traced to a single source, then nearly everyone is a mixture. Everyone is related to everyone else, and the original source is not as important as the variety of forms taken by all the family members. These remarks, even if they do not intentionally allude to the issue of Struck's Jews, suggest that, if Struck's depictions of Jews had a double motive, Luschan may have participated knowingly.

In Doegen's book, the text on Jews, along with the section on Tatars, was written by a Jewish scholar, Gotthold Weil. Weil identified the Ostjuden as linguistically German. These German Jews had been true to their homeland, but the homeland had rewarded the immense contributions they had made to it by cruelly driving them away. ${ }^{40}$ If we fail to recognize the German character of these émigrés, we have only our ignorance of Mittelhochdeutsch, from which Yiddish descends, to blame. Weil's discussion of these Jewish “enemies" in fact argues that they were really relatives (Germans) who had been driven away. He was to know all too well what he was talking about. Weil had to wait until 1932 to be named Ordinarius in Frankfurt (for Semitic philology). He had a year to enjoy his success before he himself was cruelly driven away, as Goldschmidt would also be a few years later. ${ }^{41}$

Weil's argument that the Jews he studied were really Germans makes a point similar to that of other contributors to the volume and transcends the relation between Jews and Germans. The contribution of the Anglicist, for example, begins by characterizing the English prisoners as "cousins" [ein Vetternvolk]. The English (like Weil's Jews) are really Germans. Furthermore, as a

38 Adolph Goldschmidt, Das Evangeliar im Rathaus zu Goslar (Berlin: Bard, 1910), 18.

39 Luschan, "Einführung in die Grundfragen der Anthropologie," 27.

40 Gotthold Weil, "Die Juden," in Doegen, Unter fremden Völkern, 258.

41 Jacob M. Landau, "Gotthold Eljakim Weil (Berlin, 1882-Jerusalem, 1960)," in Die Welt des Islams, vol. 38, no. 3, The Early Twentieth Century and Its Impact on Oriental and Turkish Studies (November, 1998), 280-285. 
sign of their relationship, they invited their captors to tea. ${ }^{42}$ Since, as we have seen, anthropologists like Luschan had already pointed to the common origin of all mankind, it is easy to draw from these books, collectively, the conclusion that the world lined up against the Germans (the books make this point almost against themselves) was, for better or worse, actually full of relatives and friends.

A perusal of these camp studies suggests that the myth of the happy cosmopolitan camaraderie of prison camps during the Great War developed even before the war was over. Film director Jean Renoir, speaking after World War II of his prewar film La Grande Illusion (1938), expressed this myth and even a kind of nostalgia for the Great War. "In 1914", said Renoir, "the Nazis hadn't spoiled yet the spirit of the world. May I say that to a certain extent, the war of 1914 was almost a war of gentlemen." ${ }^{33}$ His film depicts the camaraderie that the war fostered among soldiers from different backgrounds and the communities that sprang up in prison camps, where captors and captives, peoples of different origins, all got along together. The scholars and artists who came to the camps to measure, record, photograph, and draw the prisoners fostered this myth long before Renoir. To them, the prison camps were wonderful, multiethnic places with opportunities to see and record peoples from all over the world, which made even an urban metropolis like Berlin seem homogeneous. Furthermore, the visitors regarded the camps as humane and civilized. The Austrian artist Egon Schiele, who also drew in the camps, could not understand why the well-treated Russian prisoners in the camp tried to escape. ${ }^{44}$

The POW camp in Renoir's film was a place to put on plays and to break down the barriers of class and ethnicity, a place where a Jew named Rosenthal (played by Marcel Dalio), with his multiple origins and defiance of categories, could fit in. As Rosenthal explains, he was born "in Vienna, capital of Austria, to a Danish mother and a Polish father, naturalized French." ${ }^{45}$ At the end of the film, the Breton Lieutenant Maréchal, played by Jean Gabin, successfully escapes with Rosenthal. When finally they walk off together across the border to Switzerland, ready to fight again for La France, Gabin says to Rosenthal,

42 Alois Brandl, "Der Anglist bei den Engländern," in Doegen, Unter fremden Völkern, 362-375.

43 Jean Renoir, in the theatrical trailer for rerelease of La Grande Illusion, DVD, directed by Jean Renoir (1937, rerelease 1960, Criterion Collection, 1999).

44 "Das Gefangenenlager ist mit allem Komfort ausgestattet, und doch versuchen immer wieder welche auzubrechen." Egon Schiele to Marie and Melanie Schiele, 6. May, 1916, quoted in Christian M. Nebehay, Egon Schiele, 1890-1918: Leben Briefe Gedichte (Salzburg: Residenz Verlag, 1979), 376. His drawings of prisoners can be found in the collection of the Albertina, Vienna, and in the Leopold-Museum, Vienna.

45 Soundtrack, La Grande Illusion. 
affectionately, "Goodbye, Dirty Jew," thus sealing their camaraderie with a reference to the ethnic obstacles that their shared experience in the prison camp has helped them to overcome.

The German camps were probably less congenial than Renoir depicted them, and the Jews less welcome in their microcosm of society. Even Renoir suggests some inequality when he portrays the condescension of his French officers to an African prisoner who rooms with them. The depiction in memoirs, if not of POW camps, then of the camp for displaced persons at Ruhleben, is less than rosy as it concerns Jewish inmates. According to the memoirs of one Jewish prisoner, the Jews were at first housed with their national groups. But soon, when a nearby synagogue offered to send kosher food to the camp, the guards lined up the prisoners. Those who wanted kosher food were to step out of line and move to a barrack together, so that their food could be distributed to them efficiently. Either they did not keep kosher or they were wary about being singled out. In any case, few volunteered. So the Germans added to their number everyone with a Jewish name and finally hauled off more people who simply looked Jewish. People in other barracks assumed that the Jews were getting exclusive privileges. "Barrack 6 " became a standing joke and a target of anti-Semitic caricature in camp newspapers. Hastily scrambled together from an old stable, "Barrack 6" was not a nice place to live; the German congregation found it harder to supply food to the prisoners than it had anticipated; food arrived late, in insufficient amounts, and half-spoiled. Eventually, the barrack was dissolved, and the Jews, to their relief, were redistributed about the camp. ${ }^{46}$ The memoirist was probably not paranoid or exaggerating. Another memoir of the camps, this one by a Christian, mentions the privileges acquired by "Barrack 6." ${ }^{\text {"7 }}$

The German scholars and artists we have discussed walked a delicate line. On the one hand, they wished to use their writings about Jews, or their support of Jewish artists like Struck, to combat anti-Semitism. Jews, similarly, put themselves on the genealogical map by allowing themselves to be identified as people among other peoples. On the other hand, by identifying Jews as a category, they participated in their own racialization. When Jews eagerly portrayed Jews, and cooperated in the anthropological studies in the camps, did they realize that they risked facilitating a visual identity not among the nations, but outside and against them? Certainly, this had come about by World War II. Luschan did not live long enough to experience the consequences, but Doegen

46 Israel Cohen, The Ruhleben Prison Camp: A Record of Nineteen Months' Internment (New York: Dodd, Mead, 1917), 40-50, 196-209.

47 Henry Charles Mahony with Frederick A. Talbot, Sixteen Months in Four German Prisons: Wesel, Sennelager, Klingelputz, Ruhleben (London: S. Low, Marston, 1917), 278. 


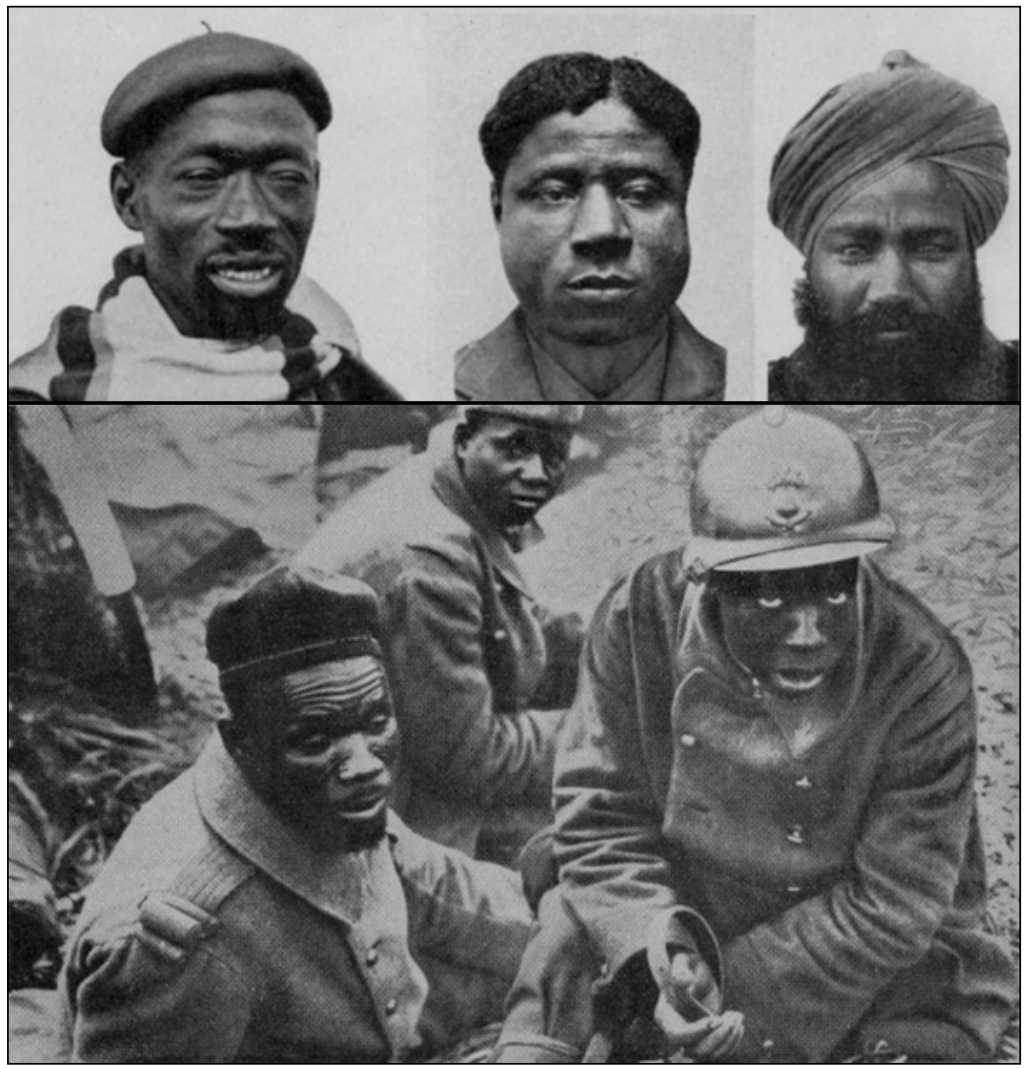

Figure 16. "Französischer Kolonialsoldat 1940." Source: Doegen, Unsere Gegner damals und heute (detail plate II).

did. His last book illustrated with Goldschmidt's pictures, Unsere Gegner, damals und heute, appeared in $1941 .{ }^{48}$ In it, the recent portraits differ sharply from the pictures in the same volume that stem from the earlier war and from the camera, most likely, of Gerdes. The portrait of a French colonial soldier, with his open mouth and squinty eyes, characterizes him as belonging to a lower order of humanity, compared to the portraits of prisoners from World War I, who are ranged to his right (Figure 16). The prisoners who did not want to belong to "Barrack 6," or presumably have their portraits taken as Jews, had sound instincts.

48 Wilhelm Doegen, Unsere Gegner damals und heute: Engländer und Franzosen mit ihren europäischen und fremdrassigen Hilfsvölkern in deren Heimat, an der Front und in deutscher Gefangenschaft im Weltkriege und im jetzigen Kriege; Großdeutschlands koloniale Sendung (Berlin: Oskar Franz Hübner, 1941). 
Yet the Jews who participated in the archival effort may have been prescient after all. In the preface to Unsere Gegner damals und heute, Doegen did not thank the recently emigrated Goldschmidt. Weil's essay on Jews did not appear in the book. His essay on the Tatars appeared anonymously. ${ }^{49}$ If one is included in the community of enemies, one is at least in the community of mankind. By World War II, the Jews were no longer accorded the dignity of being an enemy.

\section{Epilogue}

In a still later work of 2002, another German artist looked for a similar melting pot to make a record of the speech of peoples from all over the world. The project involved sound recordings, photographs, essays, and speculations on the relationships between peoples. This collaboration between art and anthropology, similar to the one held in the POW camps of the Great War, took place in New York City in 2002.

Karin Sander's work Wordsearch, sponsored by Deutsche Bank, ran in the stock pages of the New York Times on October 4, 2002..$^{50}$ A member of each of 250 linguistic groups in New York City contributed a word, which was then translated into all the other languages. The words ran in long columns in the New York Times. At first glance, the tables looked like the stock pages into which they were interpolated. Like the audio archive, "cards" were made for the contributors, giving their provenance and their location when the research team found them and samples of their handwriting. One could access the cards on the internet. By clicking on a speaker icon, one could hear the person pictured on the card pronounce his or her word. The project was more consistent than that of the anthropologists and linguists in the camps. Since only language was used as a classification, there were no classifications for ethnic groups, such as "Sikh" or "Jewish." Instead, one could find Hebrew, Yiddish, and several Indian languages.

In spite of this level of sophistication, Wordsearch nevertheless resembles Doegen's research in several ways. It still conveys the enthusiasm of finding many different languages in a small place. The participants seem to cooperate

49 "Tartaren aus Ufa und Orenburg und der Krim singen exotische Chöre," in Doegen, Unsere Gegner damals und heute, 82-83. This essay is excerpted, slightly rewritten, with some additions, from Gotthold Weil, "Die Tartaren," in Doegen, Unter fremden Völkern, 177-190.

50 Additional information on Wordsearch can be found in the catalog, "Wordsearch: A Translinguistic Sculpture by Karin Sander," advertising supplement, The New York Times Magazine, September 29, 2002, and on the website, http://www.moment-art.com/e/sander/ (accessed February 23, 2010). 
out of ethnic pride, a desire to see themselves in the community of languages. Yet, with each distinct culture boiled down into a word, is their trust rewarded better than that of the prisoners in German camps during World War I?

Interdisciplinarity is a virtue fostered by globalism, but also, it seems, by war. War turned a connoisseur of images into a connoisseur of people, enabling him to unite with anthropologists and artists, who with light, camera angles, and line, subtly competed to produce a complex discourse of visuality and race. In another moment of warfare, the two disciplines of the same age, with a shared history that intersected during World War I, intersect once again in the pages of this chapter, revisiting their history and questioning the significance of their shared moment in their past. 



\title{
Captive Voices: Phonographic Recordings in the German and Austrian Prisoner-of-War Camps of World War I
}

\author{
Monique SCHEeR
}

On the territory of the Central Powers, World War I provided the cultural sciences with new venues in which to launch large-scale research projects: the prisoner-of-war (POW) camps, in which the relatively new technologies of photography, film, and phonographic recording could be implemented on a mass scale. The subject of this chapter is this intersection of wartime space and data-producing devices and their impact on the scientific approach and fieldwork methods among researchers gathering audio data: anthropologists, comparative musicologists, and linguists. When researchers entered German and Austrian POW camps, they made sense of this new venue by fitting it into a pattern familiar to them. The camps were seen as a living museum of the "world of peoples" united in battle against the Central Powers. ${ }^{1}$ Anthropologists likened the camps to the ethnographic spectacles of the metropole where they were accustomed to taking measurements on "natives" and perhaps interviewing them on their home culture. For researchers primarily interested in audio data, the camp was an enormous archive of sounds waiting to be transferred onto media where they could be preserved and reproduced at will, for study, teaching, or entertainment. Furthermore, they construed the camp as a space providing optimum conditions for recording the voices of the prisoners. This encouraged them to bring in the best possible technology, and to focus

1 On the characterization of the Allied forces as a "world of peoples" surrounding the Central Powers, see Aribert Reimann, Der Große Krieg der Sprachen: Untersuchungen zur historischen Semantik in Deutschland und England zur Zeit des Ersten Weltkriegs (Essen: Klartext, 2000), 214-215. This phrase is often found in the publications of the scientists discussed in this chapter. 
their attention on the quality of the reproduction. In the space created by the camp, the archive mentality could flourish. In this sense, the war did not cause innovation as much as it facilitated a familiar paradigm, delivering it more quickly and definitively to its own limits.

In the following, this argument will be fleshed out in an account of the recordings made in POW camps by German and Austrian scientists. First, the significance of recording technology before the war for the emergence of comparative musicology as a scientific pursuit as well as for comparative-historical linguistics and phonetics will be sketched out in order to make clear why the camps could be viewed as the perfect setting for collecting sound recordings, the subject of the second section. Then, the specific characteristics of recording technologies used in the camps and their relevance to fieldwork methods will be discussed. The details of each of the two large-scale data-gathering projects in the camps, one led from Vienna, one from Berlin, will then point to the role of technology and research setting in the execution of each.

\section{Archives Waiting to Be Filled: Phonography in Cultural Sciences Prior to World War I}

Histories of the introduction of the phonograph into the ethnographic disciplines have noted that the response to the potential of Thomas Edison's 1877 invention was generally quick and positive. ${ }^{2}$ It was not until 1888 that an affordable device, practical for use in the field, was available, and American ethnologists were the first to try it out. Whereas some saw the phonograph simply as a mechanical supplement or replacement for the notebook, using the wax cylinders to derive written transcriptions and subsequently discarding them, ${ }^{3}$

2 On German-speaking ethnographers' use of the phonograph, especially in Vienna, see Burkhard Stangl, Ethnologie im Ohr: Die Wirkungsgeschichte des Phonographen (Vienna: WUV Universitätsverlag, 2000), esp.68. On early American ethnography, see Erika Brady, A Spiral Way: How the Phonograph Changed Ethnography (Jackson, MS: University Press of Mississippi, 1999). On the use of the phonograph in the POW-camp studies, see Britta Lange, "Ein Archiv von Stimmen: Kriegsgefangene unter ethnografischer Beobachtung," in Original/Ton: Zur Mediengeschichte des O-Tons, vol. 34, Kommunikation audiovisuell, eds. Harun Maye, Cornelius Reiber, and Nikolaus Wegmann (Constance: Universitätsverlag Konstanz, 2007), 317-342; see also Britta Lange, Playback: Wiederholung und Wiederholbarkeit in der frühen vergleichenden Musikwissenschaft (preprint 321, Max Planck Institute for the History of Science, 2006).

3 See Brady, A Spiral Way, 62. The Bureau of American Ethnology made thousands of recordings which were eventually stored at the Library of Congress, Archive of Folk Culture. The Federal Cylinder Project subsidized by the 
this was decidedly not the case among ethnographers on the European continent. From the beginning, the idea of recording music and languages for ethnographic purposes was connected with the intent to collect and preserve. A report on recordings of Zuni music in 1890 immediately inspired Carl Stumpf, professor of experimental psychology at the university in Berlin with an interest in cross-cultural comparisons of aural perception, ${ }^{4}$ to collect such recordings himself, and he obtained copies of the American material. By 1900, he and Otto Abraham, a medical doctor with an interest in musical psychology, were able to make recordings of their own and established the Berlin Phonographic Archive, marking what is considered to be the birth of comparative musicology in Germany. ${ }^{5}$ At the same time, scientists in Paris and Vienna were also keen to be the first to found phonographic archives, ${ }^{6}$ and, like in Berlin, these efforts made resources available to European anthropologists, musicologists, and linguists to collect sound recordings in the field, beginning in the first decade of the twentieth century.

An archive is generally thought to house documents which have already existed for many years and are to be deposited elsewhere for safekeeping, but the phonographic archives were founded before there was any material to put in them; the technology of the phonograph alone seemed to dictate the necessity of their formation. ${ }^{7}$ The very use of the term "archive" for these collections

Smithsonian Institution began in 1979 to catalog, preserve, and disseminate these recordings.

4 Carl Stumpf (1848-1936) began studying tone psychology and acoustics in 1875 as a young professor in Würzburg, publishing the first volume of his main work, Carl Stumpf, Tonpsychologie, vols. 1-2 (Leipzig: S. Hirschel, 18831890 ), in 1883 and the second in 1890 . He was working on a planned third volume, which never materialized, at about the time of the founding of the phonographic archive. For an autobiographical sketch by Carl Stumpf, see Carl Murchison, ed., A History of Psychology in Autobiography, vol. 1 (New York: Russell \& Russell, 1961).

5 Artur Simon, "History of the Berlin Phonogramm-Archiv (1900-2000)," in Das Berliner Phonogramm-Archiv 1900-2000: Sammlungen der traditionellen Musik der Welt, ed. idem (Berlin: Verlag für Wissenschaft und Bildung, 2000), 25-46.

6 See Stangl, Ethnologie im Ohr, 134-136. Plans for the Vienna Archive became official in 1899; the first recordings, however, were not made until 1901. The archive in Paris was initiated by the anthropologist Leon Azoulay, who made some four hundred cylinder recordings of native performers at the World's Fair in Paris in 1900. See also Leon Azoulay, "L'ère nouvelle des sons et des bruits: Musées et archives phonographiques," Bulletins et Memoires de la Société d'Anthropologie de Paris 1 (1900): 172-178.

7 This point is well made by Christoph Hoffmann, "Vor dem Apparat: Das Wiener Phonogramm-Archiv," in Bürokratische Leidenschaften: Kultur- und 
belies the salvage mentality motivating their creation, the assumption being that they were storing away documents of cultures destined for extinction. For Stumpf's assistant professor, Erich M. von Hornbostel, given the job of running the Berlin Archive in $1905,{ }^{8}$ time was of the essence. Unlike polar research, archaeology, or literary studies, "studies whose object are the so-called primitive peoples do not [...] tolerate being put off for decades or even for a matter of years," he wrote in 1911. For even as one must hurry to collect objects of near-extinct cultures in ethnological museums, the sounds of language and music are lost even more quickly:

The lingua franca of the South Seas, Pidgin English, threatens the languages of the native dwellers [...] Christianity spreads church hymns everywhere; the introduction of schooling, our folk songs; the colonial troops, our military marches; and the gramophones of the colonials, our worst popular hits. ${ }^{9}$

Stumpf and Hornbostel began cooperating closely with the director of the Ethnological Museum in Berlin and later professor of anthropology, Felix von Luschan, making sure that nearly every German anthropologist who went into the field took an Edison phonograph along to make recordings for the archive. By 1914, the Berlin Archive housed approximately nine thousand phonographic recordings, most of which came from the German colonies in Africa and the South Pacific. ${ }^{10}$ Funding for this project, however, was a constant problem. Some financial resources came from the archive's location in the university's Department of Psychology, but additional money had to be supplied by scientific research foundations, by the Academy of Sciences (of which Stumpf was a member) and even directly out of Stumpf's own pocket. ${ }^{11}$

By contrast, the Viennese Archive, located in the university's Institute for Physiology, where a similar interest for questions of aural perception was be-

Mediengeschichte im Archiv, ed. Sven Spieker (Berlin: Kulturverlag Kadmos, 2004), 281-294.

8 Erich M. von Hornbostel (1877-1935) was born in Vienna, where he acquired a doctorate in chemistry before moving to Berlin in 1900 where he became involved in Stumpf's institute and was appointed head of the phonographic archive in 1905. He remained in Berlin until forced into exile in 1933. Already ailing, he spent the last two years of his life in New York and Cambridge, UK. See Sebastian Klotz, ed., Vom tönenden Wirbel menschlichen Tuns: Erich M. von Hornbostel als Gestaltpsychologe, Archivar und Musikwissenschaftler; Studien und Dokumente (Berlin: Schibri-Verlag, 1998).

9 Erich M. von Hornbostel, "The Preservation of Unwritten Music," in Simon, Das Berliner Phonogramm-Archiv 1900-2000, 90-95, esp. 90-91. Originally published in Berliner Tagblatt, October 22, 1911, Beiblatt 2 (in German).

10 Susanne Ziegler, "Erich M. von Hornbostel und das Berliner PhonogrammArchiv," in Klotz, Vom tönenden Wirbel menschlichen Tuns, 146-168, esp. 156.

11 Ibid., 155-156. 
ing pursued by Professor Sigmund Exner, was relatively generously supported by the Imperial Academy of Sciences, of which Exner was a member. Its scope was considerably broader than in Berlin, including European as well as nonEuropean sound material, music as well as spoken language. ${ }^{12}$ Far from being coterminous with the founding of this archive, as in Berlin, the beginnings of comparative musicology in Vienna lay further back in time and were not connected with the experimental sciences, but with the philosophy of musical aesthetics. Guido Adler, later to become the highly influential chairman of the Music Department at the University of Vienna, had determined as early as 1885 that "systematic musicology" was to be an integral part of the discipline of music history and include comparative musicology, the study of nonWestern music. ${ }^{13}$ The first scholar to teach this subject in Vienna was Richard Wallaschek, beginning in 1897. ${ }^{14}$ Neither Wallaschek nor the Music Department participated in the establishment of the Academy's phonographic archives, ${ }^{15}$ nor did they appear to have any interest in doing so. Like the British school in which he studied anthropology, ${ }^{16}$ Wallaschek was sceptical of the uses of phonography in musical ethnography. According to Hornbostel's report on his contribution to an anthropological conference in Vienna in 1908, Wallaschek criticized the notion that effective musical study could be aided by recordings, believing that only a long stay in the field could provide the basis for a reliable judgment by the scholar on what was "typical" for the people under study.

12 Cf. Stangl, Ethnologie im Ohr, 137-141. The petition to the Academy for the founding of the archive of April 1899 states a threefold objective: (1) the "acoustic documentation" of European languages and dialects, and all other languages in the world, by sending a phonograph along on future research expeditions launched by the Academy; (2) the "fixation" of significant performances of European classical music as well as the music of "savage peoples" for the purposes of comparative musicology; and (3) the recording of the voices of famous individuals, beginning, of course, with Kaiser Franz Joseph.

13 Guido Adler, "Umfang, Methode und Ziel der Musikwissenschaft," Vierteljahrschrift für Musikwissenschaft 1 (1885): 5-20.

14 Richard Wallaschek (1860-1917) was named associate professor [außerordentlicher Professor] in the Musicology Department in 1908, where he stayed until his death in 1917.

15 This is also noted by Gerda Lechleitner, "Much More Than Sound and Fury! Early Relations between the Phonogram Archives of Berlin and Vienna," in Music Archiving in the World: Papers Presented at the Conference on the Occasion of the 100th Anniversary of the Berlin Phonogramm-Archiv, eds. Gabriele Berlin and Artur Simon (Berlin: Verlag für Wissenschaft und Bildung, 2002), 173-180, esp. 175.

16 For observations on British folklorists' lack of enthusiasm for the phonograph, see Brady, A Spiral Way, 84. 
Researchers who visited a village for just a day or a week, recording a few random musical offerings by the locals, risked archiving completely "untypical" material, in his view. ${ }^{17}$ Wallaschek also criticized the Berlin school's method of precise measurements of sound waves and frequencies in non-European music, "filling long tables which no one reads." Such precision was superfluous, Wallaschek felt, as a performer's own imprecision in intonation created an enormous source of potential misinterpretation. ${ }^{18}$ Wallaschek's views echo those expressed by American ethnologists, such as Ralph Vaughan Williams, who considered meticulous transcriptions of individual performances "mad" and "a waste of time," since every performer made minor alterations and it was therefore necessary for the ethnologist to determine what they "meant" to sing. ${ }^{19}$ Hornbostel, on the other hand, advocated phonographic recording precisely to eliminate the subjectivity of the ethnographer from the fieldwork equation, especially his or her sense of musical aesthetics:

He who leaves his European prejudices at home-which is usually easier for those without much talent for music than the musically inclined-and wins the trust of the natives - a precondition for any successful fieldwork - can collect [...] excellent phonographic recordings. ${ }^{20}$

Phonography could allow for the collection of large amounts of data, and the determination of what was "typical" would then not be left to the individual judgment of the "expert," but rather become a function of calculations that other scientists could follow. ${ }^{21}$

17 Erich M. von Hornbostel, "Musikalisches vom XVI. Internationalen Amerikanisten-Kongreß in Wien," Zeitschrift der Internationalen Musikgesellschaft 10 (1908/09): 4-7.

18 Ibid. Wallaschek illustrated his point by recounting the story of an Indian musicologist he had met in London: This scholar had difficulty understanding the European musical system, because he took each individual variation in the intonation of his informants-that is, when they were singing "offkey" - to be intentional.

19 Brady, A Spiral Way, 63-64. Perhaps this congruence is due to Wallaschek's own Anglo-Saxon training: After studying philosophy and musical aesthetics in Vienna, he studied ethnology in London, where he spent five years at the British Museum before publishing his groundbreaking Primitive Music: An Inquiry into the Origin and Development of Music, Songs, Instruments, Dances, and Pantomimes of Savage Races (London: Longmans, Green, and Co., 1893), and then returning to teach in Vienna.

20 Hornbostel, "Musikalisches vom Amerikanisten-Kongreß," 7.

21 In these remarks, Hornbostel reiterated the view he and Abraham had expressed in a programmatic article on the work of the archive: Otto Abraham and Erich M. von Hornbostel, "Über die Bedeutung des Phonographen für die Vergleichende Musikwissenschaft," Zeitschrift für Ethnologie 36 (1904): 
Hornbostel's arguments echoes the nineteenth-century "antihumanist" critique described by Andrew Zimmerman: The study of humanity, purportedly the domain of the humanities, was too Eurocentric to meet the demands of a world which colonialism was making increasingly smaller. The objective methods of the natural sciences were thought to bring a greater understanding of what it meant to be human, and anthropology saw itself as optimally positioned to deliver this knowledge. ${ }^{22}$ The marriage of scientific positivism to a kind of cross-cultural historicism, or an appreciation of the necessity to understand cultural phenomena within their own context, is a legacy of nineteenth-century German anthropology which has been characterized as more "liberal" than its French, British, and American counterparts of the same era. ${ }^{23}$ Stumpf followed in its tradition of inductive methodology, striving to collect enough evidence to account for what he and his students saw as a development from simple to complex forms of music. ${ }^{24}$ Only the centralized collection of as many musical "documents" as possible through the collaboration of many ethnographers delivering material to the archive would give comparative musicologists access to enough non-European material to address the questions that interested them most: those of the origins of music in what was understood to be a universal psychic foundation of all humanity. Their method was comparative, comparison being, as Hornbostel explained in 1905, the "noblest means of acquiring scientific knowledge." However,

[...] comparison on a scale that would allow us to approach the solution of the most general questions will not be possible until we have available at the very least some

222-231. The anthropologist Luschan, in his instructions to fieldworkers on using the phonograph, also explicitly points out that they should fully disregard their own Eurocentric judgments of the music they encounter, but "aesthetic judgements by the natives on their own music as well as on European music (sung to them or played on a phonograph) should be collected." Felix von Luschan, Anleitung für ethnographische Beobachtungen und Sammlungen in Afrika und Oceanien, Abschnitt L, Musik (Berlin: Königliches Museum für Völkerkunde, 1908), 14.

22 Andrew Zimmerman, Anthropology and Antihumanism in Imperial Germany (Chicago, IL: University of Chicago Press, 2001).

23 See the introduction by the editors to H. Glenn Penny and Matti Bunzl, Worldly Provincialism: German Anthropology in the Age of Empire (Ann Arbor, MI: University of Michigan Press, 2003), 1-30. Whereas the latter became more and more liberal in the course of the twentieth century, however, German anthropology turned ever more illiberal, culminating in the collaboration with the racist politics of Nationalist Socialism.

24 For the most part, this development was assumed to correlate with the development of societies from "primitive" to "civilized." See Eric Ames, "The Sound of Evolution," Modernism/Modernity 10, no. 2 (2003): 297-325. 
samples of musical expression from all four corners of the earth. Until then, we must be satisfied with writing up the material monographically in the haphazard order in which it comes to us. ${ }^{25}$

Musical ethnologists of the Berlin school were "collectors and observers," who were to document ephemeral material "whose final evaluation might well be left to future generations of researchers." 26

Missing from the Berlin Archive, compared to the Viennese Phonographic Archive, were collections of spoken languages from inside Europe as well as outside. These areas were covered by a second archive, whose realization was made possible by World War I. Wilhelm Doegen, an English teacher in Berlin who had helped pioneer the use of audio recordings in language instruction in Germany, was the driving force behind the commission founded to collect primarily spoken language in the POW camps and, secondarily, examples of the music and folk songs of all peoples. ${ }^{27}$ Doegen had no apparent affinity for studies on non-Europeans per se, having no connections to anthropology or the study of non-European languages. His interest in the global scope of the recording project stemmed from his background in areas of applied linguistics, language instruction, and phonetics. ${ }^{28} \mathrm{He}$ was interested in the "material basis" of language, the sounds, inflections, and intonations of speech. In this way, he shared with the founders of the other archives an orientation toward positivism and natural sciences, adding palatograms and X-rays to his archive which would capture the physical basis of the articulation of certain-especially "exotic"-phonemes. ${ }^{29}$ Unlike in comparative musicology, where the

25 Erich M. von Hornbostel, "Die Probleme der vergleichenden Musikwissenschaft," Zeitschrift der internationalen Musikgesellschaft 7, no. 3 (1905): 85-97, esp. 85 and 87.

26 Hornbostel, "Musikalisches vom Amerikanisten-Kongreß," 7.

27 Wilhelm Doegen, ed., Unter fremden Völkern: Eine neue Völkerkunde (Berlin: Otto Stollberg Verlag, 1925), 9-16. In the footnote on page 9, Doegen cites a memo dated February 27, 1914, to the Prussian Ministry of Culture proposing the idea of establishing a Royal Prussian Phonetic Institut which would include a "Phonographisches Lautarchiv" [phonographic "phonetic" or "sound" archive] that could contribute to understanding the "culture and intellectual life" of different peoples ["zum Zwecke des mittelbaren Verständnisses des völkischen Kultur- und Geisteslebens"].

28 Doegen's teacher was the English professor Alois Brandl, who studied under the legendary British phonetician Henry Sweet, after whom the fictional character of Henry Higgins (of Shaw's Pygmalion and Broadway's My Fair Lady) was-at least loosely-modeled.

29 Doegen, Unter fremden Völkern, 16. Very few of these images still exist in the Lautarchiv, now located at the Humboldt University in Berlin, and it is not quite clear how many were made to begin with. 
invention of the phonograph is seen as having made the discipline possible, this technology does not appear to have been seen as revolutionary for the discipline. Linguistics seems to have integrated recording technologies alongside others more or less as a matter of course, primarily for the study of unwritten languages, including European dialects. ${ }^{30}$ The field of comparative linguistics was hardly distinguishable from historical linguistics at this time, both being primarily concerned with reconstructing the "family trees" of languages, first and foremost the Indo-European; the study of non-European languages was primarily the domain of Africanists, Orientalists, and anthropologists. ${ }^{31}$ The opportunity that World War I represented brought these diverse groups together.

\section{PoW Camps as Ethnicized Societies}

As Hornbostel repeatedly noted during the first decade of the twentieth century, comparative musicologists and linguists urgently required access to large numbers of non-European peoples in the shortest time possible. World War I was to create such access in the form of POW camps. Two and a half million soldiers were imprisoned in Germany, another 1.3 million in camps on the territory of the Austro-Hungarian Empire. Fully 70 percent of these prisoners were from the Russian army alone, another 25 percent were from French divisions, some 185,000 from the British forces, and tens of thousands more from each of the smaller countries fighting the Central Powers. ${ }^{32}$ Since the French and British employed large contingents of troops from their colonies on the European frontlines, and since the Russian army recruited soldiers from almost all parts of the Eurasian continent, German and Austrian POW camps

30 There is, to my knowledge, no systematic study of the impact of the phonograph in the field of linguistics comparable to the studies in ethnomusicology. Histories of the discipline focus on the development of theory and the influences of ideology, but little on technologies and practices used by the discipline's practictioners. For an overview, see E. F. K. Koerner and R. E. Asher, eds., Concise History of the Language Sciences from the Sumerians to the Cognitivists (Oxford: Pergamon, 1995), 195-232. See also more specifically the German context: Clemens Knobloch, Volkhafte Sprachforschung: Studien zum Umbau der Sprachwissenschaft in Deutschland zwischen 1918 und 1945 (Tübingen: Max Niemeyer Verlag, 2005).

31 Cf. N. E. Collinge, "History of Comparative Linguistics," in Concise History of the Language Sciences from the Sumerians to the Cognitivists, eds. E. F. K. Koerner and R. E. Asher (Oxford: Pergamon, 1995), 195-202.

32 These estimates are taken from Uta Hinz, Gefangen im Großen Krieg: Kriegsgefangenschaft in Deutschland 1914-1921 (Essen: Klartext Verlag, 2006), 10. 
began filling up with hundreds of thousands of soldiers of non-European origin beginning in late 1914. By the spring of 1915, the Viennese Anthropological Society was determined to take advantage of this opportunity to study peoples otherwise very difficult to reach by travel and sought financial support from the Imperial Academy of Sciences. Rudolf Pöch, who had just been named the first professor for anthropology at the university in Vienna in 1913, was chosen to conduct the camp studies, and members of the Phonographic Archive Commission in the Academy requested Pöch's funding be made contingent upon his agreement to make phonographic recordings in the camps. ${ }^{33}$ Pöch readily agreed, viewing this excursion into the camps as essentially equivalent to an expedition to a foreign country. This meant that he planned, in addition to his main occupation of measuring and photographing the bodies of soldiers to determine the racial composition of a given population, to collect ethnographic data by filming prisoners performing their native folk dances and prayer rituals, as well as demonstrating their skill at various crafts, and by making phonographic recordings of languages rarely heard in the metropole, as well as folk songs. ${ }^{34}$

The POW camps not only brought together a large variety of non-European ethnic groups, but also prisoners from neighboring European countries. Their military identities were closely linked with their ethnic identities, as military units were often created along ethnic lines (Scottish, Polish, or Algerian battalions within the larger Allied armies). When the prisoners retained their uniforms, their affiliations and ranks were immediately visible. In the multicultural society into which the prisoners were suddenly forced, the significance of ethnicity as a source of identity was magnified, especially since, as they were utterly displaced and decontextualized, they were stripped of sources of identity other than those the military and their own origins offered: officer or enlisted man; European, Asian, African. The camp societies were thus strongly "ethnicized" communities, and the cultural hierarchy of the prisoners that existed in the minds of their German and Austrian captors appears to have been intensified and reified in combination with the situation of everyday life in the camps. On top were the British, "who in their confident behavior always showed they were the Herrenvolk [ruling nation] of the camps," as Doegen phrased it, ${ }^{35}$ and with whom the Germans had long considered themselves racially related, ${ }^{36}$

33 Archives of the Austrian Academy of Sciences, Subventionen, mathematischnaturwissenschaftliche Klasse, No. 411/1915.

34 Rudolf Pöch, "1. Bericht über die von der Wiener Anthropologischen Gesellschaft in den k.u.k. Kriegsgefangenenlagern veranlaßten Studien," Mitteilungen der Anthropologischen Gesellschaft in Wien (MAGW) 45 (1915): 219-235.

36 As Alois Brandl put it, they were a "cousin people" [Vetternvolk]; in Doegen, Unter fremden Völkern, 362. 
and the French, whom the Germans saw as their closest neighbors. ${ }^{37}$ At the bottom were Black Africans or, where they were present, the small numbers of Australian and Melanesian Aboriginals. ${ }^{38}$ In between were Russians and the eastern European and central Asian subjects of the Czarist Empire, North Africans, and Indians. This imagined hierarchy-largely constructed by the evolutionary paradigm of the anthropological sciences-was materialized in representations of the ethnic variety in the camps in anthropologist-supported publications, such as Unsere Feinde [Our Enemies] and Deutschlands Gegner im Weltkriege [Germany's Opponents in the World War], ${ }^{39}$ as well as in internal military reports. ${ }^{40}$ Particularly the introduction to Unsere Feinde, a book of photographs taken of prisoners by Otto Stiehl, reveals the extent to which his daily observations of prisoners had been conditioned by ethnic categorizations and flat-out racism. ${ }^{41}$ Presenting himself as an authority by virtue of his service as the commander of a POW camp in which Muslim prisoners were incarcerated, ${ }^{42}$ Stiehl presents an overview of the many ethnic groups

37 Otto Stiehl, Unsere Feinde: 96 Charakterköpfe aus deutschen Kriegsgefangenenlagern (Stuttgart: Verlag Julius Hoffmann, 1916), 7.

38 Doegen, Unter fremden Völkern, 15.

39 On the interconnections between these publications and the anthropological sciences in Berlin and Vienna, see Monique Scheer, "'Völkerschau' im Gefangenenlager: Anthropologische 'Feind'-Bilder zwischen popularisierter Wissenschaft und Kriegspropaganda 1914-1918," in Zwischen Krieg und Frieden: Konstruktionen des Feindes, ed. Reinhard Johler (Tübingen: Tübinger Vereinigung für Volkskunde, 2009), 69-109.

40 See, for example, "Bericht über die Kriegsgefangenen in den sächsischen Kriegsgefangenenlagern in Form einer Darstellung nach Staatsform, Volkstum und Rasse" [Report on the POWs in the camps in Saxony in the form of a presentation according to the form of government, ethnicity, and race], submitted by a camp physician in August of 1918 as part of a larger report on the use of prisoners for hard labor in the Inspektion der Kriegsgefangenenlager XII u. XIX A-K Br.-B-Nr. 6600 III (Stuttgart: Bibliothek für Zeitgeschichte).

41 To cite an example: "For a lack of an inner connection and probably also due to their basic sense of tribality from the wild, [the Black Africans] usually separated themselves strictly from the other prisoners, and it was a strange thing to observe how through the strict dignity of their authentic, proud nature, the better among them, in spite of all their savagery, were able to lift themselves to their advantage above the backdrop of the Frenchmen swirling about them, constantly opportunistic and changeable." (Stiehl, Unsere Feinde, 14)

42 Stiehl was the commander of the camp in Zossen, near Berlin, one of two camps set up specifically to hold Muslim POWs separately from the rest of the Allied prisoners and to supply them with pro-Turkish propaganda. For background on these camps and this publication, see Gerhard Höpp, Muslime in der Mark: Als Kriegsgefangene und Internierte in Wünsdorf und 
at war against the German Reich, whose representatives he has had opportunity to observe in the camps. Generalized descriptions of Frenchmen, Arabs, Afghans, Serbs, and Russians, to name a few, are placed in a text next to each other-just as the photographs of the prisoners representing each group in the main section are juxtaposed-for the purpose of highlighting differences, "unique" traits, and national "characters." Doegen takes the same approach in his introduction to Unter fremden Völkern [Among Foreign Peoples] a collection of essays written by the linguists who had participated in the camp studies. ${ }^{43}$ "From the Belgian people the hot-blooded, easily inflamed Walloons of the French tongue and down-to-earth Flemish [...] fiery, sentimental Serbs [...] dull but good-natured Russians [...] magnificent Estonians [...] honorable Finns [...] conscientious Mordvins [...]." ${ }^{\prime 4}$ The list goes on for several pages, creating, for the reader, the impression that each and every ethnic group can be distinguished from the other by fairly obvious physical and character traits.

Comparison, which Hornbostel had lauded as the "noblest means of acquiring scientific knowledge," was an everyday practice in the "laboratory" of the POW camp. But whereas the liberal anthropological enterprise ultimately conceived of comparison as bringing out similarities between peoples, revealing the universal structures underlying all humanity, the comparisons between ethnicities in the camp setting served to identify what was specific about each and to essentialize their differences. Stiehl asserts his authority as a person knowledgable about "foreign peoples" in the closing of his introduction:

Even if I have made an effort to also do justice to the good sides of the savages and semi-savages which the hatred of our enemies has set upon us, I must not forget to emphasize that in my impression of these exotic masses as a whole, roughness and barbarity outweigh the rest by far. Anyone who has had the opportunity to get to know these assorted crowds [diese bunten Scharen] would agree with all his soul $[\ldots]{ }^{45}$

Life in a POW camp seemed to make a person knowledgable about the vast variety of "national characters," just as if one had taken a trip around the world.

Since their inception, the phonographic archives in both Berlin and Vienna had taken the opportunity of recording the songs and languages of

Zossen, 1914-1924 (Berlin: Verlag Das Arabische Buch, 1997); Margot Kahleyss, Muslime in Brandenburg: Kriegsgefangene im Ersten Weltkrieg; Ansichten und Absichten, Veröffentlichungen des Museums für Völkerkunde Berlin N. F. 66 (Berlin: Staatliche Museen zu Berlin-Preußischer Kulturbesitz, 1998).

44 Ibid., 13.

45 Stiehl, Unsere Feinde, 31. 
non-Europeans traveling through the capital, ${ }^{46}$ very often performers in ethnographic "shows" (Völkerschau). Pöch was referring to such practices when he exclaimed with obvious delight in a 1916 article that the POW camps were, in fact, a "Völkerschau beyond compare!"47 They were "beyond compare" not only because of the unprecedented number of different ethnicities incarcerated in the camps, but also because, while there was often doubt about the "authenticity" of the performers in professional ethnographic shows, ${ }^{48}$ he assumed there could be none whatsoever about the soldiers brought to Europe by the war. ${ }^{49}$ They were not professionals accustomed to the European metropole, but more or less "fresh off the farm," making their folkloristic performances, in his view, examples of a truly authentic folk culture. The camps could thus be construed as "living museums" of folk culture, with all the breadth an ethnologist could wish for, examples of humanity from all four corners of the planet. ${ }^{50}$ Again, the prisoners were viewed less in terms of what they had in common with the researchers or their fellow combatants on both sides of the front, and more decidedly from the point of view of what made them interesting for research: as carriers of ethnic and racial traits, waiting to be recorded by German and Austrian scientists.

\section{Two Types of Technology}

By 1915, two types of recording technology were available. The phonograph developed by Thomas Edison recorded onto cylinders by transferring the sound waves into a vertical, "hill-and-dale" pattern in the groove in the wax. The device itself was relatively easy to transport and to operate, which seems to be one of the reasons that Hornbostel and the Berlin Archive preferred it. It was crank-driven, requiring no electric current or batteries, and was about the size and weight of a typewriter, therefore, easy enough to carry with one hand in its wooden case by the handle. Hornbostel could instruct anthropologists

46 The first recording Stumpf made for the Berlin archive was of a Thai orchestra giving a concert in the city; soon afterwards, Hornbostel and Abraham recorded Japanese and Indian musicians making guest appearances in Berlin.

47 Rudolf Pöch, "Anthropologische Studien an Kriegsgefangenen," Die Umschau 20 (1916): 988-991, quote from p. 989, emphasis in the original.

48 Cf. Zimmerman, Anthropology and Antihumanism, 30.

49 Researchers in the camps in fact did often have difficulty determining the "true" ethnic identities of the prisoners they examined, as Britta Lange discusses in her contribution to this volume.

50 On the philosophy behind Berlin's Ethnological Museum, see H. Glenn Penny, "Bastian's Museum: On the Limits of Empiricism and the Transformation of German Ethnology," in Penny and Bunzl, Worldly Provincialism, 86-126. 
preparing for fieldwork on how to use the device within just a few hours and then send them on their way. When in the field, the phonograph had another quality that made it very useful: It was possible to listen to the recording, immediately after having made it, simply by exchanging the cutting stylus for a playback needle, allowing the sound just previously projected into the horn to reemerge from it, or be listened to via ear tubes connected to the device. Luschan recommends in his guidelines for recording in the field that every recording be played back immediately in full. "This usually pleases the natives and encourages them to make more recordings." ${ }^{11}$ Pöch had had this very experience in Papua New Guinea in 1904. He writes in his report,

[...] as soon as someone had decided to sing into the horn and then I had played back the singing before the astounded listeners, one after the other volunteered to sing into the device. I was then happy to put on a "performance" with the Edison phonograph every evening for several days, and to make trial recordings; I was then able to select the best ones [to keep for the archive]. I consider this procedure-playing back for the people themselves what had been sung and spoken into the device-to be very advantageous. They lose their shyness, become interested in the thing themselves, and most of all, learn to distinguish between a good and a poor-quality recording and then know after that which mistakes to avoid. ${ }^{52}$

Equally important for the anthropologist, therefore, was that immediate playback gave him or her the opportunity to check the quality of the recording. Furthermore, it allowed for transcription of the recorded text and/or music into European notation while still in the field, enabling the informants to take part in this process as well. There was, however, one serious drawback to playing back the wax cylinders: Each playback reduced the quality of the recording. Pöch was only able to so generously put on "performance evenings" in the field because he had indeed taken two phonographs with him, the other one being reserved for the archive recordings, which were carefully preserved and not played back. Otherwise, archivists interested in the quality of the recording itself warned the anthropologists not to unnecessarily diminish it by playing back too freely. The requirements of the archive thus intruded into the fieldwork interaction.

The other recording technology available, and rapidly overtaking the Edison cylinder during the first decade of the twentieth century, was the gramophone developed by Emile Berliner in 1895. It recorded onto wax discs

51 Luschan, Anleitung für ethnographische Beobachtungen, 2.

52 Rudolf Pöch, "Bericht über die Aufnahmen mit einem Archivphonographen der kais. Akademie der Wissenschaften in Wien, unter den Monumbo auf Neu-Guinea vom 28. Juli bis 24. November 1904," Mitteilungen der Phonogrammarchivkommission 5 (1905): 897-904, here 900-901, quoted in Stangl, Ethnologie im Ohr, 158. 
by reproducing the sound waves in a horizontal direction, creating a wavy groove which spiraled from the edge into the center of the disc. A metal negative was then made from the wax disc. From this negative, multiple copies could be made in shellac and later vinyl. The devices mass-marketed to the public were designed only for playback, as the record producers began to realize that they could protect and expand their market by offering prerecorded discs, which consumers also found easier to handle and store than the cylinder. By 1913, even Edison gave in to the market pressure and discontinued production of the cylinder recording devices for home use, manufacturing them only for offices as dictaphones. Cylinder blanks continued to be produced into the 1930s, and anthropological fieldworkers were among the few remaining customers who required them. ${ }^{53}$ Whether or not the gramophone technology produced recordings which were inferior to the Edison cylinders in terms of sound quality, they were superior in terms of conservation and duplicability, which were soon deemed the more important criteria for a mass market. For fieldwork, however, the gramophone recorder's size and expense were prohibitive: Even as late as the mid-1930s, so-called "portable" devices required batteries weighing half a ton. ${ }^{54}$ As a result, gramophone technology was hardly used in the field. The relatively small number of shellac records collected by the Berlin Archive (371 by 1933) were, for the most part, prerecorded discs that had been purchased. ${ }^{55}$

The archivists shared commercial manufacturers' concerns regarding conservation and duplicability of recordings. Upon founding the archive in Vienna, the Academy commission immediately concerned itself with these questions and determined that, though their inscription was superior, the wax cylinder technology was lacking, since, at that time, copies could not be made from them. ${ }^{56}$ Wanting the best of both worlds, the Viennese Archive invented

53 See Brady, A Spiral Way, 24-26.

54 Ibid., 26.

55 There are thirty-one discs referred to in the inventory as "originals," but this appears to refer to the fact that they were gramophone duplicates of recordings originally made on cylinders. See Susanne Ziegler, "The Wax Cylinder Project in Rescue of the Largest Collection of Old Sound Documents of Traditional Music from Around the World: Wax Cylinders and Shellac Records of the Berlin Phonogramm-Archiv," in Simon, Das Berliner Phonogramm-Archiv 1900-2000, 200.

56 The Berlin Archive did not develop a method for making durable copies of their wax cylinders until 1907. Copper negatives of the recording were made (during which process the wax original was destroyed), from which multiple copies in hard plastic could be produced. Both negatives and copies make up the majority of cylinder holdings in the archive today. See Ziegler, "Das Walzenprojekt," 196. 
its own special "archive phonograph" using the Edison-type "hill-and-dale" inscription, but on disks rather than cylinders. It was initially somewhat heavier than the Edison, but this problem was greatly improved by 1915, and like the Edison, the archive phonograph could be made to play back right away, a feature not available with the gramophone. ${ }^{57}$

These issues do not appear to have been serious concerns for linguists in the field at this time, who still preferred paper and pencil in the field. However, a dialectologist mostly concerned with accurately grasping the phonetic nuances of the spoken word could view recording technology as a chance to shortcut this process. Alois Brandl, English professor at the university in Berlin and, as Doegen's former teacher, a major supporter of his projects, recalls in his memoirs that when he began to study English dialects in 1903, visiting farmers in southwestern Scotland, he was hampered by their lack of stamina.

I would pick out one of them and have him repeat a few sentences until I could say them myself and write them down in precise phonetic notation. But he would always repeat them in a different way and was exhausted after an hour anyway, calling out "Oi feel oncommon droy," that is, asking for liquor, and soon he had no time for me at all anymore. ${ }^{58}$

In the face of such difficulties in the field, he viewed the advent of recording technology as a great help, because it could immediately preserve the first version of the spoken material-not solving the issue of which particular utterance should be viewed as "typical," but at least maximizing the amount of material one could acquire before an informant lost interest. Apparently, he did not use an Edison phonograph, noting that speakers of dialect were recruited to come to London, where they would speak into a gramophone. This suggests that the gramophone was the technology of choice in linguistics from the beginning, ${ }^{59}$ making it clear why it would be chosen for the work in the camps.

Researchers working too far from the metropole to bring their informants to a recording studio had to make do in the field, but nevertheless strove to achieve the highest possible recording quality. Concerns about the placement of the phonograph affecting it seem to have plagued them, the more philologically oriented Viennese perhaps more intensely than the ethnomusicological Germans. Luschan only mentions in his guidelines that the phonograph should be placed somewhere where it could not be moved during the recording session. ${ }^{60}$ The special Viennese archive phonograph, being considerably

57 See Stangl, Ethnologie im Ohr, 158-159.

58 Alois Brandl, Zwischen Inn und Themse: Lebensbeobachtungen eines Anglisten (Berlin: Grote'sche Verlagsbuchhandlung, 1936), 326.

59 Ibid.

60 Luschan, Anleitung für ethnographische Beobachtungen, 2. 
heavier, had led its first users in the field to leave it in their hotel room and attempt to coax informants to join them there to make recordings, often with little success. ${ }^{61}$ Even after the device was made lighter, it was still believed that recordings should always be made indoors, in order to protect the discs from attracting dust or moisture. Pöch recommended this himself, though, in practice, he made all of his Papua New Guinea recordings outdoors to avoid another problem: that of the echo in the recording created by the sound bouncing off interior walls. ${ }^{62}$ In the summer of 1915 , however, Pöch was in a situation to dictate the terms of the field in a way he hadn't been able to before, raising his expectations of what fieldworkers could achieve.

\section{The Viennese Project}

For the camp studies, the Viennese Phonographic Archive provided Pöch with one of their phonographs and a set of wax discs, on which, by the end of the summer of 1915, he delivered sixty-five recordings made in three POW camps, twenty-five of which were of spoken text, thirty-seven of song, and three of instrumental music. ${ }^{63}$ In the first camp, Pöch came upon two Hungarian linguists from the Academy of Sciences in Budapest who were also conducting research among the prisoners and were willing to offer their help for the first sixteen recordings. Based on their previous experience with the informants, the Hungarian scholars chose the individuals, texts, and songs they deemed worthy of recording, providing written transcriptions and translations. ${ }^{64}$ In the next two camps he visited in 1915, Pöch did not have such assistance and relied instead on Russian prisoners who could transcribe the Georgian or Finno-Ugric texts more or less phonetically into Latin letters and translate them into Russian and sometimes even German. Here, however, the informants themselves seem to have chosen what to speak or sing into the device,

61 Stangl, Ethnologie im Ohr, 154, relates this telling anecdote from the linguist Paul Kretschmer, who took an archive phonograph to Greece: He wrote to Sigmund Exner in 1901 that the informants' "hesitancy was greater than their curiosity [...]. A young boy who had been brought all the way to my house ran away at the last minute, and when people tried to stop him, he began to cry."

62 Ibid., 154-156.

63 Rudolf Pöch, "Phonographische Aufnahmen in den k.u.k. Kriegsgefangenenlagern," Mitteilungen der Phonogrammarchivs-Kommission der Kaiserl. Akademie der Wissenschaften in Wien 41 (1916): 21-26, esp. 25. Pöch was first and foremost concerned with measuring the bodies of prisoners, as the number of recordings shows, which averages to little more than one per working day. Ibid., 23-24. See also Pöch, "1. Bericht," 228-229. 
often choosing the themes of nostalgia for home and family. ${ }^{65}$ One Armenian prisoner used the opportunity to dictate a message to his parents in verse form. ${ }^{66}$

These recordings represent some of the last that Pöch was to supervise, and, in an article written for the Viennese Phonographic Archive a year and a half later, he summarizes what he had learned from his experiences recording "on expeditions," to which he also counts his stays in the POW camps but a few hours from home. To Pöch's mind, fieldwork represented a less than desirable setting for gathering acoustic data. He notes at the beginning that the gold standard is the studio recording, and, while such conditions can never be reached in the field, they must be approached in order to acquire recordings of scientific value.$^{67}$ His views seem to have been influenced by his most recent experience in the POW camps, since only there was he himself able to fulfill the standard he now recommends: setting up the recording device indoors while avoiding poor acoustics, and acquiring a perfect transcription of the recorded text in phonetic notation on site. Pöch assumes that the fieldworker does not speak the language of his informants and goes into great detail on how to ensure that the transcription nevertheless perfectly matches the recording, without which, he claims, it is scientifically useless. In the end, it comes down to the choice of the informant, which Pöch considers the single most decisive factor in the quality of the recordings, "and this choice is that much more difficult, since the individual in question must have a combination of quite a number of certain characteristics," ${ }^{68}$ such as clear articulation and the ability to repeat a spoken text verbatim a second time, so that it will correspond with the notation of the text as spoken in the dry run. Due to problems with the latter, Pöch remarks that the most efficient method of acquiring a recording with a perfect transcription is for informants to write down what they wish to say and then read it into the phonograph. Where this is not possible (because the informants cannot read and write), they should speak only single words and short expressions as examples of their mother tongue. ${ }^{69}$ Pöch is aware, however, that, due to these restrictions imposed by

65 Idem, "Phonographische Aufnahmen," table to p. 24: For example, disc no. 19, two Russian tenors sing a Ukranian folk song called "When Two People Part"; disc no. 22, a Wotjak tenor sings a military song, taking leave from the homeland; discs nos. 24/25, Armenian folk song about a prisoner asking a swallow to tell him about the hills and flowers of his homeland.

66 See ibid., disc no. 27.

67 Idem, "Technik und Wert des Sammelns phonographischer Sprachproben auf Expeditionen," Mitteilungen der Phonogrammarchivs-Kommission der Kaiserl. Akademie der Wissenschaften in Wien 45 (1917): 3-15, esp. 3. Ibid., 14.

69 lbid., 8. 
the technology, the "living language" in its natural "melody" is not captured in the recordings and thus recommends a final recording of untranscribed, completely spontaneous speech which more accurately represents the natural cadences of the language. ${ }^{70}$

After the first summer of research in the camps had gone well and the funding for the next summer had been secured, Pöch sought to delegate the work of audio recordings to other scientists. In a letter to the Academy written in July 1916, he indicated that the potential for collecting myths and legends as well as folk music was so extraordinary that he recommended the Academy dispatch experts for these tasks, naming specifically the "mythographer" Wolfgang Schultz and the comparative musicologist Robert Lach. Schultz was unable to accept the commission offered by the Academy, as he himself had become a POW in Italy. ${ }^{71}$ Lach, however, already exempted from military service due to a health condition, could quickly organize the necessary leave of absence from his position at the Royal Library's Music Collection and obtain the War Ministry's permission for entry into the camps. In August of 1916, he took over the musicological data-gathering from Pöch, following the anthropologist's lead in focusing on ethnicities located at the periphery of the Russian Empire which had not yet been the object of intense anthropological investigation. There is a striking correlation between the application for further funding submitted by Pöch to the Academy in May of $1916^{72}$ and the structure of the multivolume work Lach would eventually produce from his data. Both name three main ethnic categories of interest to them: (1) the "eastern Finnish" peoples whose homelands are located just west of the Ural mountain chain and along the Volga, among others, the Komi, Udmurts, Mari, Chuvashes, and Mordvins. ${ }^{73}$ Pöch emphasizes that these groups in particular must be studied now, as they have been "violently denationalized" by the Russians and will soon become "extinct"; ${ }^{74}$ (2) ethnic groups from some of the same areas who speak Turkic

70 Ibid., 11. It does not appear that he made any untranscribed recordings in the POW camps, however.

71 Archive of the Austrian Academy of Sciences, file "Gesänge russischer Kriegsgefangener (Robert Lach)," Akt.-No. 496/1916, esp. letter from the Academy to the War Ministry on August 1, 1916, in which Schultz's imprisonment is noted.

72 Archive of the Austrian Academy of Sciences, Subventionen, mathematischnaturwissenschaftliche Klasse, Akt.-No. 367/1916. Pöch application of May 18, 1916, attachment 2.

73 Pöch and Lach refer to them by their German names: Syränen, Wotjaken, Permiäken, Tschuwaschen, Mordwinen.

74 Archive of the Austrian Academy of Sciences, Subventionen, mathematischnaturwissenschaftliche Klasse, Akt.-No. 367/1916. Pöch application of May 18, 1916, attachment 2, p. 3. 
languages, including Bashkirs and Volga and Crimean Tatars; and (3) peoples of the Caucasus region, particularly Georgians and Armenians.

Lach was not a natural scientist by training, but a musicologist and musician who composed operas in his free time..$^{75}$ What seemed to qualify him for the research in the camps was his study of musical development, Studien zur Entwicklungsgeschichte der ornamentalen Melopöie, ${ }^{76}$ a cross-cultural and historical study of ornamentation in melodies and tour d'horizon of all known musical cultures past and present, ordered in a strict hierarchy of lower to higher development. Wallaschek had also postulated developmental hierarchies, but he was an opponent of Charles Darwin's theory of the origins of music in the courtship behavior of animals, denying that animals even had music, thus drawing a clear distinction between human culture and the animal world. ${ }^{77}$ Lach, on the other hand, defended Darwin's theory and, with the aid of Freudian psychology, expounded upon on the link between animal and human musical behavior. ${ }^{78}$ Lach argued that musical development followed natural laws and therefore should be studied with the same comparative methods as the natural sciences.

Thus, in Vienna, it was the war which brought the comparative musicologist and the phonographic archive together for the first time. Lach had had little to no experience with ethnographic fieldwork or phonographs and required the assistance of a technician from the phonographic archive in order to operate the device. ${ }^{79}$ Based on what he had read, Lach judged the music of many of the people he was going to come face to face with in the camps to be "approximately at the same level" as the music of native Americans, which, following Stumpf's assessment, he considered "belonging not at all to an archaic or even primitive state of music," but in fact closer to the highest point

75 Robert Lach (1874-1958) came to musicology somewhat late, having first studied law. After acquiring his PhD in 1902, he left Vienna for health reasons for several years. In 1911 he took a position at the Royal Library [Hofbibliothek], where he was employed until being appointed Wallaschek's successor at the university in 1920.

76 "Studies on the Developmental History of Ornamental Melopoeia" was an expanded version of Lach's dissertation, submitted in Prague to Heinrich Rietsch in 1902. It was published in Leipzig with the assistance of Guido Adler and the Viennese Music Department in 1913, but Lach makes no mention in the preface of any personal debt to Richard Wallaschek.

77 Wallaschek, Primitive Music, 237-250.

78 Robert Lach, Studien zur Entwicklungsgeschichte der ornamentalen Melopöie: Beiträge zur Geschichte der Melodie; mit zahlreichen Notenbeilagen (Leipzig: Kahnt, 1913), 524-640.

79 Lach's assistant was Hans Pollak, later Leo Hajek, see Archive of the Austrian Academy of Sciences, "Gesänge russischer Kriegsgefangener (Robert Lach)," Akt-No. 496/1916. 
on the scale of development (i.e., Western music) than to its lowest. ${ }^{80}$ The scientists spent eight weeks together in the camps, alongside the prison camp guards and administrative officers, in whose barracks they were housed. The cooperation that ensued was deemed fruitful and positive by both sides. Lach was aided by Pöch and his assistant, who integrated the choice of prisoners to perform for the musicologist into their selection process for somatic measurements and photography. ${ }^{81}$ That is to say, Lach was presented with "material," as informants were routinely referred to, who had been selected based on racial criteria by the physical anthropologists. They had determined that the person in question was "typical" enough of his ethnic group to provide reliable musical data. ${ }^{82}$ Lach saw this collaboration as providing a great deal of support, relieving him of the need to determine the "true" ethnic identity of his informant based on the music he produced-which he might have picked up somewhere outside his "homeland." Furthermore, the musicologist could correlate racial and ethnic statistics with physical characteristics pertaining to musicality, for example, the ability to hear and discern different tones and intervals. ${ }^{83}$ Lach did not construct ethnicity from the music produced by the informants, but rather took it-and its place in the imagined hierarchy of cultures he, as an evolutionist, worked with-as a given. Pöch wrote in his report to the Academy in November of 1916 that working together with a music historian meant exchanging findings in their respective areas about connections between peoples and, in particular, informing the musicologist "to what

80 Lach, Studien Melopöie, 102-103.

81 Idem, Vorläufiger Bericht über die im Auftrag der kaiserlichen Akademie der Wissenschaften erfolgte Aufnahme der Gesänge russischer Kriegsgefangener im August und September 1916, Mitteilungen der Phonogramm-Archiv-Kommission 46 (Vienna: Alfred Hölder, 1917), 5.

82 See Walter Graf, "Österreichs Beitrag zur Musikethnologie," in Beiträge Österreichs zur Erforschung der Vergangenheit und Kulturgeschichte der Menschheit mit besonderer Berücksichtigung Mitteleuropas: Bericht über das erste Österreichische Symposion auf Burg Wartenstein bei Gloggnitz 8.-12. September 1958, ed. Wenner-Gren Foundation, Emil Breitinger, Josef Haekel, and Richard Pittioni (Horn: Berger, 1959), 148-161. In the minutes of the discussion following Graf's presentation, Josef Weninger is quoted as remarking: "I would like to add that R. Lach always conducted his recordings in the prisoner-of-war camps together with R. Pöch and myself, so that for his work he was always provided with individuals who had been precisely categorized according to race and ethnicity. In this way, his ethnomusicological studies were greatly facilitated."

83 Cf. Robert Lach, Die vergleichende Musikwissenschaft, ihre Methoden und Probleme, Akademie der Wissenschaften in Wien, Sitzungsberichte 200, 5 (Vienna: Hölder-Pichler-Tempsky, 1924), 112-113. 
extent connections in the purely somatic area or in cultural achievements have already been uncovered." ${ }^{4}$

Lach and his technician made about fifty recordings that summer-no more than Pöch had produced "on the side" the summer before-but Lach could capitalize on his musical training by transcribing some seven hundred song performances directly onto paper in Western musical notation. ${ }^{85}$ The following summer he collected another 837 written transcriptions and thirtythree recordings for the archive. ${ }^{86} \mathrm{He}$ had so much material, in fact, that it took him thirty years to finally complete the writing up of the data, ${ }^{87}$ which was published by the Academy of Sciences in bits and pieces over the years: first, two preliminary reports directly from the camps, published in 1917 and 1918, and then, between 1926 and 1952, three volumes, each with several parts, of the full analyses of the music of the Finno-Ugric ethnic groups, the Turkish-speaking Tatars, and peoples of the Caucasus. ${ }^{88}$ Having been drawn into an unusual fieldwork setting by the anthropologist Pöch proved advantageous to Lach's career, ${ }^{89}$ a debt he acknowledged in his dedicated inclusion of the issue of race in his work. Ethnomusicology under Lach hardly cooperated with the Viennese cultural anthropology school under Pater Wilhelm Schmidt,${ }^{90}$ which was to become synonymous with the "theory of cultural circles" [Kulturkreislehre], of which, in fact, the Berlin school later made extensive

84 Rudolf Pöch, "3. Bericht über die von der Wiener Anthropologischen Gesellschaft in den k.u.k. Kriegsgefangenenlagern veranlaßten Studien," MAGW 47 (1917): 77-100, esp. 96.

85 Lach, Vorläufiger Bericht 1916.

86 Idem, Vorläufiger Bericht über die im Auftrag der kaiserlichen Akademie der Wissenschaften erfolgte Aufnahme der Gesänge russischer Kriegsgefangener im August bis Oktober 1917, Mitteilungen der Phonogramm-Archiv-Kommission 47 (Vienna: Alfred Hölder, 1918).

87 Archive of the Austrian Academy of Sciences, Personalakte Robert Lach, Autobiographical sketch submitted on Februar 22, 1941.

88 These three volumes were published in several parts each, in varying order, in the series Mitteilungen der Phonogramm-Archivs-Kommission of the Austrian Academy of Sciences, vols. 54, 55, 58, 61, 65, 66, 68, 74, and 78, between 1926 and 1952: Robert Lach, Gesänge russischer Kriegsgefangener, vol. 1: FinnischUgrische Völker (in four parts), vol. 2: Turktatarische Völker (in three parts) and vol.3: Kaukasische Völker (in two parts) (Vienna: Hölder-Pichler-Tempsky, 1926-1952).

89 Not only did Lach succeed Wallaschek as associate professor for systematic musicology in Vienna in 1920, but one year before, largely due to his work in the POW camps, Lach was appointed a corresponding member of the Academy of Sciences. In 1927, he was made full professor and Guido Adler's successor as department chair.

90 See also Stangl, Ethnologie im Ohr, 81-83. 
use. ${ }^{11}$ Rather, Lach remained close to the physical anthropologists, his reports to the Academy and the Anthropological Society displaying a clear interest in collaborating with the natural sciences and in exploring what he called "The Race Problem in Comparative Musicology." In a lecture with this title which Lach gave after the war, ${ }^{92}$ however, he laments that the musicologist still does not have the necessary methods to determine exact reliable criteria and characteristics of musical styles that would correspond with races, nations, or tribes. His desire to find them shines through his texts quite clearly, yet he repeatedly states his conviction that musical style does not correspond to the racial composition of a people, but rather adheres to the laws of evolution. Put plainly, it meant that when similarities are found between the music of the Bashkirs and that of the Chinese, then it is not due to a common "Asian/racial" heritage, but instead to the fact that these peoples' musical systems were at equivalent levels of development. Building on his findings in his dissertation, Lach asserts that the lower the level of development, the more monotonous and repetitive the music is, but that these characteristics are found in all cultures in different times in history-in medieval Christian chants as well as the music of various "primitive" cultures-so that it cannot be linked to physical evolution. ${ }^{93}$ Although Lach's interest in race and the biological basis of music seems to suggest an affinity for essentializing musical cultures and styles, reifying their differences, in his writings, it seems as if he continued to find commonalities between them which undermined clear racially connoted hierarchies. Considering his own anti-Semitic convictions, which he publicly displayed on several occasions, one could say that, in his own work, Lach supported liberal notions in spite of himself. ${ }^{94}$

91 See Albrecht Schneider, Musikwissenschaft und Kulturkreislehre: Zur Methodik und Geschichte der vergleichenden Musikwissenschaft (Bonn: Verlag für systematische Musikwissenschaft, 1976).

92 Robert Lach, "Das Rassenproblem in der vergleichenden Musikwissenschaft," Berichte des Forschungsinstitutes für Osten und Orient 3 (1923): 107-122.

93 Ibid.

94 There is a great deal of evidence pointing toward Robert Lach's open antiSemitism, not least his opposition to the granting of an honorary doctorate by his department to Richard Strauss, as the composer had collaborated with Jewish librettists. Lach joined the National Socialist party in Austria in 1933, when it was still illegal to do so, and when the Anschluss corresponded with the year he was to retire from his post, he petitioned the Ministry of Culture in Berlin, asking for an extension of his appointment and citing his loyalty to the party (Nationalbibliothek Wien, Musiksammlung, F 17 Lach 329 "Kaukasische und ural-altaische Gesänge," letter dated May 13, 1939). See also "Warum Richard Strauss nicht Ehrendoktor werden durfte," Neues Wiener Journal, September 30, 1927, 5; Pamela M. Potter, Most German of the Arts: 


\section{The Berlin Project}

The presence of so many different ethnicities in the POW camps in Germany seemed to Wilhelm Doegen a golden opportunity to stock up the Lautarchiv ["phonetic" or "sound" archive] he had been dreaming of creating, and, in the summer of 1915, he convinced key members of the Ministry of War of the necessity of the venture. By October, the Royal Prussian Phonographic Commission was created, funded in large part by the Kaiser's personal budget, with Doegen as its technical and logistical director. ${ }^{95}$ His academic credentials were not sufficient to be named chairman of such a commission; this office went to the head of the already existing phonographic archive, the highly respected Professor Carl Stumpf. The rest of the commission was composed of a group of scholars from Berlin and Hamburg, some of which were members of the Prussian Academy of Sciences, which also provided some of the funding for the POW-camp project. They were mostly philologists: Orientalists, Africanists, as well as scholars of English, Celtic, and the Romance languages. ${ }^{96}$ The anthropologist Luschan was also a member of the commission, and through it, he received funding for physical anthropological studies in the camps. ${ }^{97}$ Stumpf was the only musicologist included. It is not clear how many, if any, recordings the archive director Hornbostel himself made in the POW camps. ${ }^{98}$ While the members of the commission viewed wartime as an opportunity for their own studies, Hornbostel actually interrupted his musicological research and put his knowledge of the psychology of hearing directly in the service of the military: Together with Max Wertheimer, he developed a method for determining precisely the direction from which enemy artillery fire was coming and apparently also did military duty on submarines. ${ }^{99}$

Musicology and Society from the Weimar Republic to the End of Hitler's Reich (New Haven, CT: Yale University Press, 1998), 242.

On the history of the Lautarchiv, see Kirsten Bayer and Jürgen Mahrenholz, "'Stimmen der Völker'-Das Berliner Lautarchiv," in Theater der Natur und Kunst, exhibition catalog, ed. Horst Bredekamp, Jochen Brüning, and Cornelia Weber (Berlin: Henschel, 2000), 117-128.

96 The members of the commission are listed in Doegen, Unter fremden Völkern, 10-11. Some of these scholars came from Hamburg, where they were affiliated with the "Phonetic Laboratory" founded in 1910 at the Colonial Institute.

97 These were conducted in large part by Egon von Eickstedt; see the article by Britta Lange in this volume.

98 Doegen mentions that he was briefly involved (Unter fremden Völkern, 10), but he is not named in any of the reports or minutes of meetings of the Phonographic Commission preserved in the Phonogrammarchiv at the Ethnological Museum in Berlin. See Ziegler, "Erich M. von Hornbostel und das Berliner Phonogramm-Archiv," 146-168, esp. 156-157. lbid. 
In the spring of 1916, Stumpf sent an archive assistant, Georg Schünemann, into the camps to make musical recordings with an Edison phonograph. Schünemann had a background in Western music history and had until then showed no particular interest in comparative musicology. However, he had become ill during his military service on the frontlines and, through various connections, was able to obtain a release which allowed him to work for the commission for the duration of the war. ${ }^{100}$ The list of the over one thousand recordings that Schünemann made of POWs' performances corresponds exactly to the itinerary of Doegen's visits, ${ }^{101}$ suggesting that Schünemann must have traveled with Doegen's team between the end of April 1916 and early September 1918, visiting a total of twenty-five different camps in visits never lasting more than a few days at a time. In a total of less than one hundred days, Schünemann collected as many recordings as the archive had previously acquired in a whole year. The recordings were mostly of songs sung by the prisoners and were by no means limited to non-Europeans, though this was the general focus of the phonographic archive in Berlin. Like Doegen, Schünemann recorded whoever was available in the camp and thus gathered recordings of folk songs from some African and Asian soldiers, but just as many, if not more, from eastern and southeastern Europeans, as well as a few French and Basque samples. Shortly after the war, Schünemann wrote his Habilitation on one set of these recordings-those of the Volga Germans, analyzing how German folk music had fared after a few hundred years in the diaspora. ${ }^{102}$ Other than one article on the music of the Tatars, ${ }^{103}$ Schünemann did not shift his focus from European music, nor was he interested in using the comparative method to find similar "levels" of development among peoples. Similarities between "uncivilized"

100 See Heike Elftmann, Georg Schünemann (1884-1945): Musiker, Pädagoge, Wissenschaftler und Organisator: Eine Situationsbeschreibung des Berliner Musiklebens, Berliner Musik-Studien 19 (Sinzig: Studio Verlag, 2001), 26-29. Stumpf was contacted by Max Friedländer to help Schünemann escape frontline duty. Paul Bekker wrote Schünemann a year later that "perhaps coincidence has led you to an area in which you can make a very special contribution."

101 Thanks are due to Dr. Susanne Ziegler of the Phonogrammarchiv at the Ethnological Museum in Berlin for providing a list of Schünemann's recordings as well as access to the notes he made on each of the camp visits. Doegen's itinerary is preserved in the Lautabteilung Aufnahme-Journal (3 vols.) in the Lautarchiv at the Humboldt University in Berlin. Thanks to archivist Jürgen Mahrenholz for his assistance.

102 Georg Schünemann, Das Lied der deutschen Kolonisten in Russland: Mit 434 in deutschen Kriegsgefangenenlagern gesammelten Liedern, Sammelbände für vergleichende Musikwissenschaft 3 (Munich: Drei Masken Verlag, 1923).

103 Georg Schünemann, "Kasantatarische Lieder," Archiv für Musikwissenschaft 1, no. 4 (1919): 499-515. 
peoples and earlier stages of Western music were not necessarily, in his view, proof of a universal line of development. Similar musical figures might have developed out of completely different preceding types, for different reasons, so that it was necessary to understand each music in its own right and not as a step on an evolutionary ladder. ${ }^{104}$ After this interlude working for the commission, Schünemann returned to his emphasis on Western music and became the acting director of the conservatory (Hochschule für Musik) in Berlin.

Doegen himself, who traveled in his capacity as technical director to every recording site, accompanied by the scholar whose "peoples" were being recorded as well as a technician who operated the gramophone, visited thirty-two different camps from December 1915 to December 1918, some of them several times. ${ }^{105}$ A total of about 1,650 recordings were made for the Phonographic Commission, which had its offices in a spare room in the university's Art History Department chaired by Adolph Goldschmidt. ${ }^{106}$ The Art History Department also provided the services of their photographer, who traveled with the commission to the POW camps to take pictures of the prisoners participating in the recording sessions as well as other scenes in the camps. ${ }^{107}$ The photographs were not attached to the files documenting each recording, and it appears that, after

104 See Schünemann's response to Lach's evolutionary thinking on music in Das Lied der deutschen Kolonisten, 29. See also Georg Schünemann, "Über die Beziehungen der vergleichenden Musikwissenschaft zur Musikgeschichte," Archiv für Musikwissenschaft 2, no. 2 (1919/20): 175-194.

105 As a result of his many visits to many different camps, the Reichswehr Ministry later asked Doegen to write a book reporting on the treatment of POWs in German camps during the war. Doegen jumped at the opportunity to perform this patriotic duty, finishing his Kriegsgefangene Völker: Der Kriegsgefangenen Haltung und Schicksal in Deutschland (Berlin: Verlag für Politik und Wirtschaft, 1921) before completing work on Unter fremden Völkern.

106 This is mentioned by Adolph Goldschmidt in his memoirs. Idem, Lebenserinnerungen, ed. Marie Roosen-Runge-Mollwo (Berlin: Deutscher Verlag für Kunstwissenschaft, 1989), 186. On Goldschmidt's own experiences visiting the POW camps, see also the article by Margaret Olin in this volume.

107 It is not clear whether photos were actually made of every single prisoner who was audio-recorded. Doegen does not mention this in Unter fremden Völkern, and in Kriegsgefangene Völker he notes only that photographs were made in the camps with the aid of Goldschmidt's photographer. As Goldschmidt recounts it, photographs were apparently only to be made of the more "exotic" ethnicities; when he visited the camp in Dürotz, he remarks that it was mostly filled with French, English, and Russian soldiers, so "there were relatively few photographs made of races (Basques and Cheremis [Mari]), and thus relatively many made instead of all kinds of other scenes and also interiors" (Goldschmidt, Lebenserinnerungen, 187), whereas the visit to the Muslim camp in Zossen provided "more opportunities to make photographs of [racial] types" (ibid., 188-189). 


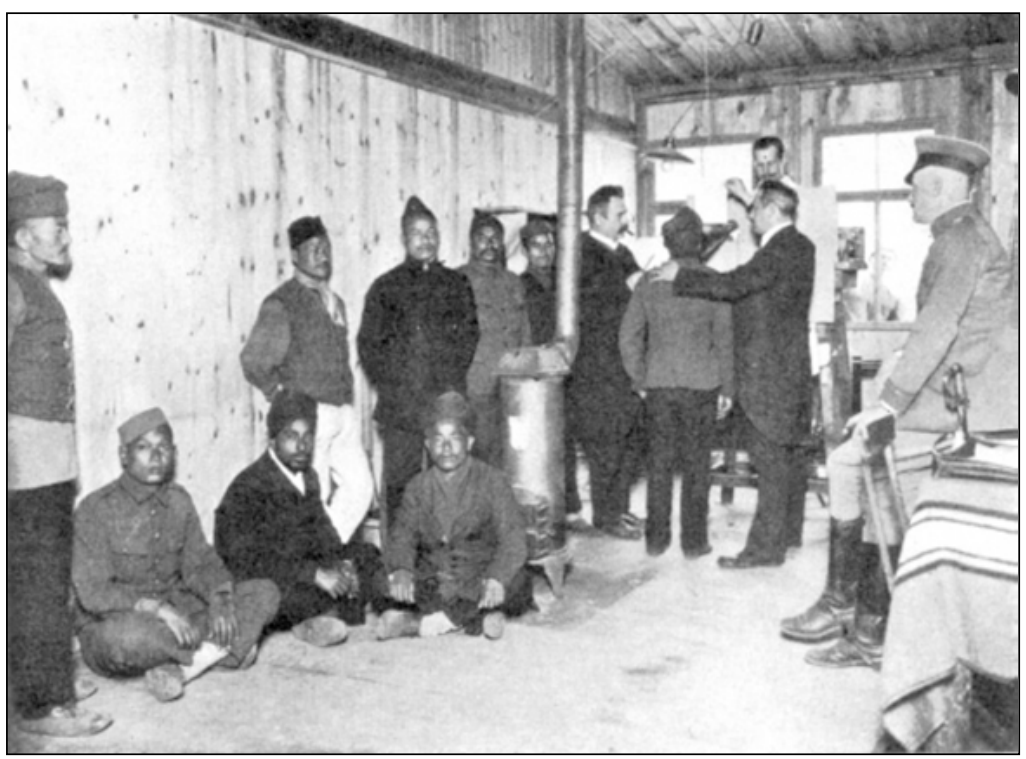

Figure 1. Wilhelm Doegen stands to the right of a Gurkha prisoner speaking into the horn of the gramophone. Behind the partition, the technician operates the recording device. To the left of the prisoner is Heinrich Lüders, professor of ancient Indian languages and literature, member of the Academy of Sciences in Berlin. Source: Wilhelm Doegen, Jahrbuch des Lautwesens 1931 (Berlin: Lehner, 1930), 33.

the war, they were more or less scattered among the former members of the commission, kept as Doegen's personal possessions, or simply lost. Very few are left in the Lautarchiv, but they, like the ones printed in Doegen's book, show that they were taken in the anthropological style, with a frontal and a profile view, underlining the commission's understanding of its task as a broad comparative ethnological study which encompassed language and race.

Though Doegen did record some instrumental music and, more often, folk songs, the majority of the recordings were of spoken language. To ensure the highest recording quality possible, a studio environment had to be created in each camp. A room was chosen-often one connected with the cultural program offered the prisoners in the camp, a reading room, theater barracks, or chapel; sometimes the common room for the officers running the camp was the site chosen to set up the equipment and bring in the prisoners selected to speak or sing for the German scientists. ${ }^{108}$ The performer stood before the gramophone's horn, which was mounted into a partitioning board, behind which the techni-

108 The rooms in which the recordings were made in each camp are noted in the Lautabteilung Aufnahme-Journal. 
cian operated the recording device itself, thus isolating the speaker from the recording equipment (Figure 1). For each of the recordings, a file was created containing a data sheet on the prisoner whose voice was recorded, the text of what each prisoner was asked to read out in his own dialect or language, followed by a phonetic rendition of the text based on the recording, and often a German translation of the text. A common method of linguists in the field was to have different language or dialect groups read out the same text, so that a direct comparison could be made. In the camps, the Christian parable of the prodigal son was used for many of the recordings from the European prisoners.

The recordings and their transcriptions served as the basis for publications which some of the linguists of the commission produced during the interwar years. ${ }^{109}$ As Pöch had already noted, a written transcript of exactly what was on the recording was considered indispensible for the scientific usage of the recordings. With the Edison technology, it was no problem to create this transcript after the fact, allowing the informants to improvise during their performance. Later, as we saw, Pöch had informants write down and read out their own texts. With Doegen's gramophone recording, however, any divergence from the text the informants had been instructed to read was seen as a disturbance and cause for considerable irritation. Brandl's account suggests that, in order to avoid this problem, the texts were practiced by the informants several times in advance, making the recording even more a staged performance and far less the fixation of "natural speech" which the technology was supposed to provide. ${ }^{110}$

The scholarly commission had authority over Doegen, whom they considered to be in charge only of the logistics of the enterprise. The truly scientific work, in their view, was their own, the working up of the data gathered in the camps. This was also somewhat hindered by the gramophone technology. Because the researchers could not listen to the recordings directly after they were made in the camps, they were required to wait until the shellac records had been manufactured. In practice, it appears that they relied as much on their own notebooks as on the recordings, if not more so. ${ }^{111}$ Furthermore, the working relationship between Doegen and the university scholars, in particular the chairman Carl Stumpf, can only be described as tense. Doegen apparently felt

109 See the series Lautbibliothek: Phonetische Platten und Umschriften published by the Lautabteilung of the Preußische Staatsbibliothek, the interwar successor institution to the Prussian Phonographic Commission and the Lautarchiv. The pamphlets in the series appeared at irregular intervals from 1926 to 1952. Many publications based on research done in the camps were most likely published elsewhere, possibly without specific reference to the origin of the material presented.

110 Alois Brandl, "Der Anglist bei den Engländern," in Doegen, Unter fremden Völkern, 362-383, esp. 366-367.

111 See the remarks in the essays in Doegen, Unter fremden Völkern. 
himself to be the real initiator and genius behind the POW-camp enterprise and resented the condescending attitude of some of the university professors. On the other hand, many of the letters from the scholars involved reveal that they were annoyed by Doegen's overweening attitude, leading Luschan to recommend to his researchers to plan their stays in the various camps such that they would avoid running into Doegen and his team. ${ }^{112}$

Thus, neither the musicologist Schünemann nor the linguists worked under the auspices of an anthropologist, as in the Vienna case. Whereas Pöch and, under his influence, to a certain extent Lach, attempted to recreate a sort of fieldwork environment by actually living in the camps for several weeks in a row, focusing on the non-European informants, and recording and transcribing with their help, Doegen's commission recreated a recording studio environment. Their data-gathering plan was not an extension of a preexisting fieldwork paradigm, but entirely dependent on the camp environment and the fact of the proximity of the informants from the outset. Doegen and his team descended upon a camp only for the day or two necessary to make the recordings. While attempting to create an aura of scientific and anthropological rigor, including the filling out of data sheets and taking frontal and profile photographs of each informant, their style of work was so anathema to the anthropologist's methodology that Luschan collaborated with the rest of the commission as little as possible. Doegen's choice of title for his postwar publication showcasing the commission's work, "Among Foreign Peoples," claimed to be "A New Ethnology" in the subtitle, but this was not a result of intense interdisciplinary cooperation with anthropologists.

It might have had more to do with a shift in the focus of linguistic studies. As in musicology, the methods of the natural sciences had been gaining prestige in linguistics for some time prior to World War I. The dominant school, known as the Junggrammatik [Neogrammarians], had reformed linguistic study along more empirical lines since the mid-nineteenth century and oriented comparative linguistics toward the search for universal laws of language. Since the late nineteenth century, an "antipositivist" and "idealist" opposition to this school had been forming which sought to associate the study of language more closely with the study of national character. ${ }^{113}$ The ethnicized society of the POW camp lent itself to this latter option, leading Doegen to appropriate

112 See the correspondence between Luschan and his doctoral student, Egon von Eickstedt, in Staatsbibliothek zu Berlin, Handschriftenabteilung, Nachlaß Felix von Luschan, Korrespondenzmappe Eickstedt, in particular the letters and postcards from the camp in Ohrdruf in March of 1916, in which Doegen's behavior toward the camp commanders is described.

113 On this development in particular and how it developed over the course of the Third Reich in Germany, see Knobloch, Volkhafte Sprachforschung. 
anthropological terminology ("race," "ethnology") and symbols (frontal and profile photographs of informants) without so much as lip service to the liberal paradigm to which anthropologists were still, for the most part, obliged and which made clear distinctions between race and language, between physical and cultural attributes. The "understanding among peoples" [Völkerverständigung] which Doegen claimed his project would promote, ${ }^{114}$ consisted for him, it seems, in essentializing their differences rather than seeking their commonalities, a confrontational model that reflected the conflict surrounding them.

\section{Conclusion}

The introduction of the phonograph into the study of music made possible the establishment of ethnomusicology as a field in which music was examined as an object of scientific analysis rather than aesthetic appreciation. The comparative method associated with this kind of musical science-as it was practiced, by and large an inductive method-required large amounts of data from diverse areas of the world. The POW camps seemed to provide the ideal source for this kind of data right at the beginning of the endeavor to build up archival collections, not only because of the diversity of individuals incarcerated there, but also because of the controlled and controllable setting, which the scientists compared to a "laboratory," further underscoring the natural-science approach. This setting was also attractive to linguists interested in building up archives of spoken language which, like music, could then be transcribed and used for study, comparison, performance, or teaching, or simply preserved for future generations interested in observing changes in language over time. This combination of scientific interest and "salvage mentality," like the evolutionary theory which underpinned it, were legacies of the late nineteenth century. The POW-camp setting appeared at first glance to facilitate and optimize the conditions this kind of science required. The universalist option of the evolutionary paradigm, however, was severely undermined in the camp setting, leading scientists away from a comparative method which sought similarities and toward one which desired to explicate and reify differences.

The recording technology promised-like photography and film-to capture performances "as they actually were" without any shaping or rendering by the data-gatherer. This conformed to an ideal of the inductive method from natural sciences which promised a high level of objectivity. However, in the camps, the sheer amount of potential data that scientists could have gathered forced them to select their informants, not only based on preconceived ideal types, but also based on the imperatives of recording quality. As the need for

114 Doegen, Unter fremden Völkern, 9. 
archivable material gained more weight than the desire for participation by informants in the creation of the data, the device placed itself more and more firmly between the scientist and the informant, culminating in the partition set up in front of the gramophone. Not only the space of the POW camp itself, but also the archive indirectly impinged upon the data-gathering process, as did the technology which framed every recording as a performance.

It is striking how much and yet how little came from the POW-camp projects in the scholarly fields involved in them. On the one hand, many doctoral theses, scientific articles, and a few books emerged from the masses of data gathered in the camps. Several careers were made because of the POWcamp studies. But they do not appear to have brought, in any field, the kind of breakthrough that the scientists had assumed in the beginning that such an opportunity would provide. The comparative method, so highly lauded by many scientists of culture as the royal path to forming general laws about all of humanity, did not rise to this task in the setting of the POW camps, but rather succumbed to the pressures of its ethnicizing milieu, generating knowledge about human diversity, about essential differences. In the end, much of the data gathered there languished in the Viennese and Berlin Phonographic Archives for decades, unused by anyone for scholarly purposes. Whether this was because the personnel necessary to work up the vast amounts of material could not feasibly be mobilized, or because research questions and methods had shifted over time, making the data less useful or interesting, the point remains that the POW-camp project was, in the final analysis, a project of collection and preservation, an archival project. As such, it may yet have purposes to serve in the present and future. 



\title{
AfterMath: Anthropological Data from Prisoner-of-War Camps
}

\author{
BRITTA LANGE
}

Anthropology was a largely philosophical enterprise in the eighteenth century, but, by the mid-nineteenth century, examinations of the human body began to disentangle themselves from the humanities. This branch, known then as "physical anthropology" in the German Empire, belonged to the natural sciences and was closely associated with Rudolf Virchow. Its exponents focused on describing and measuring physical characteristics, constructing complex patterns in order to distinguish themselves from investigators in anatomy, ethnology (defined as analyzing the culture of human "types"), and the emerging field of genetics. Physical anthropologists tried to identify human "racial characteristics" and "racial types" using the methods of anthropometrics or biometrics and of comparative morphology. These promised to provide a systematics of human "types" modeled on zoological systematics, which were to allow clear-cut "racial diagnoses."

This chapter presents two ways in which anthropology attempted to achieve a "racial diagnosis." Both attempts took their data from a comparable infrastructure: German and Austrian prisoner-of-war (POW) camps during World War I, which promised unimpeded access to their research objects under ideal working conditions ("Project Planning"). But in fact, the researchers, gathering their data following nearly identical criteria, faced an unexpectedly high number of problems ("Realization"). With regard to data interpretation, German scientists focused on measurements, conducting their analysis via statistics, whereas Austrian scientists relied on "anthropological seeing" and descriptions of physical characteristics. Operating by measuring/calculating as well as by seeing/describing, each group sought the same ends: the identification of "racial elements." For all the differences in their legitimating arguments and use of media, they were eventually confronted with the same problem: They found discrepancies between the ideal "racial types" they thought they could pick out visually, the concrete prisoners they examined, and the 
calculated "types" they identified using mathematics ("Interpretation"). This discrepancy sheds light on the history of the methodology of physical anthropology in the prewar and wartime period. Even though these methods were fundamentally challenged by the experiences of "fieldwork" in the camps, they did not prevent the protagonists from exploiting their time there to launch careers and enhance prestige ("Conclusions").

\section{Project Planning}

German and Austrian POW camps during World War I offered scientists of the Central Powers (the German, Austro-Hungarian, and Ottoman Empires, and, after 1915, Bulgaria) attractive conditions for their research. The opposing political block consisted of a variety of nations and ethnic groups: Belgium; the nations of the Triple Entente: the UK, France, and Russia; peoples from the Asian part of the Russian Empire; and the African and Asian colonial troops of Britain and France. As Rudolf Martin (1864-1925), professor of anthropology in Munich, put it: "Because of our enemies' practice of gathering auxiliary troops from everywhere, representatives of the most diverse peoples have indeed come to Germany who would never have touched German soil under normal conditions." The camps allowed scientists to examine normally distant peoples as they might at a Völkerschau, ${ }^{2}$ with all the comforts of home. For the researchers, traveling through the POW camps seemed like inverted travel around the world; the camps served as a kind of exhibition of ethnic "types." The simultaneous presence of various different nationalities in the camps attracted above all researchers who did comparative studies: linguists, musicologists, sociologists, anthropologists, and ethnologists.

The structure of the camps seemed to preclude many of the problems which usually accompanied studies in the ethnographic field. Rudolf Pöch (1870-1921), associate professor of anthropology and ethnology in Vienna since 1913, remarked that:

The conditions artificially caused by the war are much more convenient for anthropological examinations than all other natural ones. All the preparations to find

1 Rudolf Martin, "Anthropologische Untersuchungen an Kriegsgefangenen," Die Umschau 19 (1915): 1017. The term "colored auxiliary troops" [farbige Hilfstruppen] was rather derogatory, clearly privileging the European soldiers' value, compared to the value of the colonial troops.

2 Völkerschauen, "ethnic shows," took place in Europe from the middle of the nineteenth century onward and consisted of groups of "foreign" (nonEuropean) people who had to represent their "culture" via songs, dances, rituals, and so forth. 
and assemble the persons to be measured are left out. The people are there, at our disposal. We do not need to sift through the material, since thanks to the military selection process the useless elements for the study of racial characteristics have already been eliminated. The examination can take place under the best possible circumstances; it is laboratory work, compared to that of a travelling researcher outside. $^{3}$

In the scientific laboratory exported to the camp and the imported ethnographic field, the test persons as well as the technical apparatus and scientific methods seemed utterly unproblematic, at least at first glance. But as the studies were carried out, the very definition of racial "types" proved to be troubled on many levels. These problems resulted, on the one hand, precisely from the specific conditions of the camp laboratories and, on the other hand, from the anthropological method itself.

In Austria, studies in POW camps were initiated by Pöch and the Viennese Anthropological Society. Body measurements, along with photographic, sound, and film recordings, were financed in large part by the Imperial Academy of Sciences in Vienna and carried out between the summer of 1915 and November 1918.

In contrast, much of the research in Germany was not launched so much by an academic discipline as by a medium - the phonograph or gramophone. During 1915, Professor Carl Stumpf (1848-1936, musicologist, psychologist, and founder of the Berlin Phonogram Archive) and the grammar school teacher Wilhelm Doegen (1877-1967, popularizer of gramophone records in language instruction) requested permission for a group of scientists to conduct linguistic and musicological research in German POW camps for a comparative archive. ${ }^{4}$ That November, the Königlich Preußisch-Phonographische Kommission [Royal Prussian Phonographic Commission] was established by the Prussian Ministry of Culture and completed more than 2,500 recordings by the end of $1918 .{ }^{5}$ Felix von Luschan (1854-1924, Royal Ethno-

3 Rudolf Pöch, "Anthropologische Studien an Kriegsgefangenen," Die Umschau 20 (1916): 989.

4 See also the article by Monique Scheer in this volume as well as Britta Lange, "Ein Archiv von Stimmen: Kriegsgefangene unter ethnografischer Beobachtung," in Original/Ton: Zur Mediengeschichte des O-Tons, vol. 34, Kommunikation audiovisuell, eds. Harun Maye, Cornelius Reiber, and Nikolaus Wegmann (Constance: Universitätsverlag Konstanz, 2007), 317-342.

5 See, for example, Kirsten Bayer and Jürgen Mahrenholz, "Stimmen der Völker'-Das Berliner Lautarchiv," in Theater der Natur und Kunst, eds. Horst Bredekamp, Jochen Brüning, and Cornelia Weber, vol. 2, Katalog: Wunderkammern des Wissens (Berlin: Henschel, 2000), 117-128; Susanne Ziegler, "Die akustischen Sammlungen: Historische Tondokumente im Phonogramm-Archiv und im Lautarchiv," in Theater der Natur und Kunst, 
logical Museum in Berlin, professor of anthropology and ethnology at the University of Berlin since 1911) was the Commission's ethnological consultant. He advised several young scientists-in particular his doctoral student Egon von Eickstedt (1892-1965) - on taking biometric measurements in the camps, but the German project remained much smaller in scope than that of Austria.

Pöch had also studied under Luschan, and the two maintained close contact, exchanging their experiences with the camp studies. With regard to methods, both invoked Martin's standard work Lehrbuch für Anthropologie in systematischer Darstellung [Systematic Manual of Anthropology], published in $1914 .^{6}$ To achieve reliable "racial diagnoses," Martin recommended "somatoscopic" observations of nonquantifiable characteristics, such as eye and nose shape and hair and eye color-qualities describable only qualitatively and in relative terms. Therefore, Martin and other anthropologists devised a fixed system of adjectives and number codes for such characteristics. Most of the book, however, was dedicated to the presentation of "somatometric" methods, making it a "real guide for techniques of physical measurements" 7 as late as the 1960s. The data gathered were interpreted using statistical analyses.

Martin's standardized catalogue of data-gathering methods and his techniques of measurement and calculation were all predicated on one fundamental assumption. In the 1830s, the Belgian astronomer Adolphe Quételet had discovered that the measured values of human physical characteristics were distributed at random around an average value as were his astronomical observations. This led him to conclude that the average represented an "average man" [homme moyen] from which real, existing people deviated in minor, but predictable, ways. As a consequence, this "average man" would conform to the (ideal) "type" of a human collective which could be defined statistically within anthropometrics and be visualized by the bell shape of the Gauss error distribution curve. ${ }^{8}$ Like many other anthropologists, Martin subscribed to Quételet's vision. He worked not only with measured values, but with indices (ratios of two values), referring mainly to the work of the French brain

vol. 1, Essays (Berlin: Henschel, 2000), 197-206. See also http://www.huberlin.de/lautarchiv (accessed February 15, 2010).

6 Rudolf Martin, Lehrbuch für Anthropologie in systematischer Darstellung: Mit besonderer Berücksichtigung der anthropologischen Methoden für Studierende, Ärzte und Forschungsreisende (Jena: Fischer, 1914), 7.

7 See Wilhelm E. Mühlmann, Geschichte der Anthropologie (Frankfurt a.M.: Athenäum, 1968), 100.

8 Adolphe Quételet, Anthropométrie, ou mesure des différentes facultés de I'homme (Brussels: Muquardt: 1870). 
researcher Paul Broca. ${ }^{9}$ To relate different characteristics and define their interdependency, he applied the British correlation analysis developed by Francis Galton and Karl Pearson. ${ }^{10}$

This mathematical approach suggested that human "racial elements" or "biological types" could be defined by interpreting the measured data. During the nineteenth century, "races" had been regarded as stable entities which could be definitively classified, ${ }^{11}$ but the emergence of genetics at the turn of the century had provoked a rethinking of existing "racial types." Eugen Fischer's research on the "Rehoboth bastards"-offspring of European colonists and local populations in South Africa-appeared to prove that inheritance of human morphological complexes conformed to Mendel's hypotheses about peas. ${ }^{12}$ It was not the "racial type" as a whole which was passed on, but only isolated traits, thus, the combination of two "races" would create not a new "race," but a "racial mixture." Physical anthropologists thus reasoned that it should be possible to deduce the postulated "original" races or "racial types," which no longer existed in their "pure" form in the present, from the existing "mixed" populations. They made it their task to disassemble the "racial elements" of the heterogeneous peoples of the present through measurements and a mathematical approach. The POW camps seemed ideal for this purpose, as they contained members of different ethnic groups that might be related.

\section{Realization}

For the camp studies, Pöch basically followed Martin's recommendations, adopting thirty-two required measurements from his manual ${ }^{13}$ (Figures 1 and 2). He preferred Luschan's Nasenschema [nose scheme], however, as “much

9 Paul Broca, Mémoires d'anthropologie, in 5 parts (Paris: Muquardt, 1871-1888). See Martin, Lehrbuch für Anthropologie, 63-66. Martin also referred explicitly to the work of Stanislaw von Poniatowski.

10 Ibid.

11 See, for example, the system of six "main races" and thirty "subraces" proclaimed by Joseph Deniker in Les races et les peuples de la terre (Paris: C. Reimer, 1900).

12 See Eugen Fischer, Die Rehoboter Bastards und das Bastardisierungsproblem beim Menschen (Jena: Fischer, 1913).

13 Pöch published four reports on his ongoing research in the POW camps in the Mitteilungen der Anthropologischen Gesellschaft in Wien [journal of the Anthropological Society of Vienna] (MAGW): Vol. 45 (1915): 219-235; Vol. 46 (1916): 108-131; Vol. 47 (1917): 77-100; Vol. 48 (1918): 146-161. He remarks in the first report (1915) on adopting Martin's recommendations on page 232. The form used to record the measurements is reproduced on pages 125 and 126 of the second report (1916). 


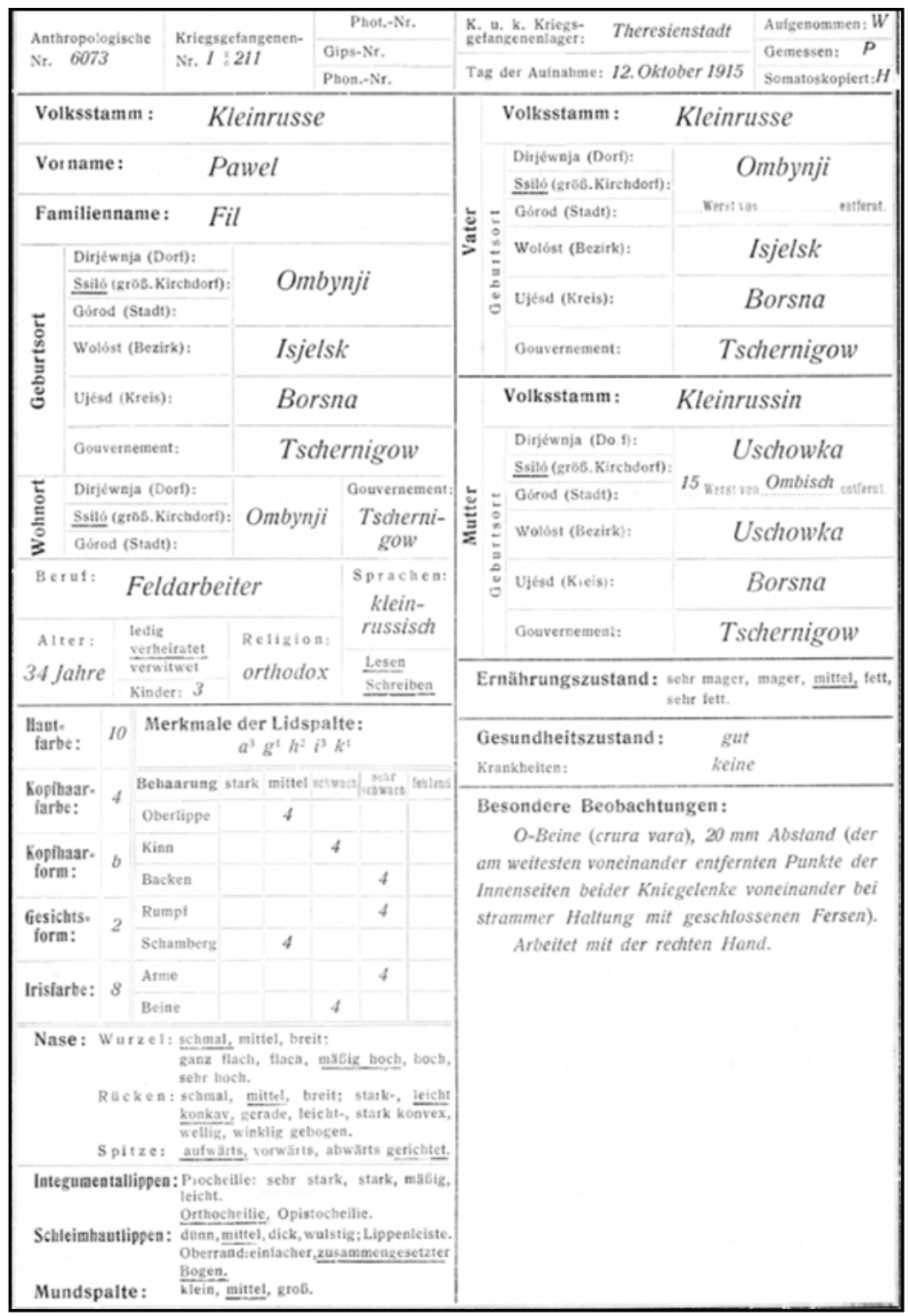

Figure 1. Form used by R. Pöch and his assistants for recording measurements taken on the POWs. Source: Pöch, "2. Bericht," 108-131. 


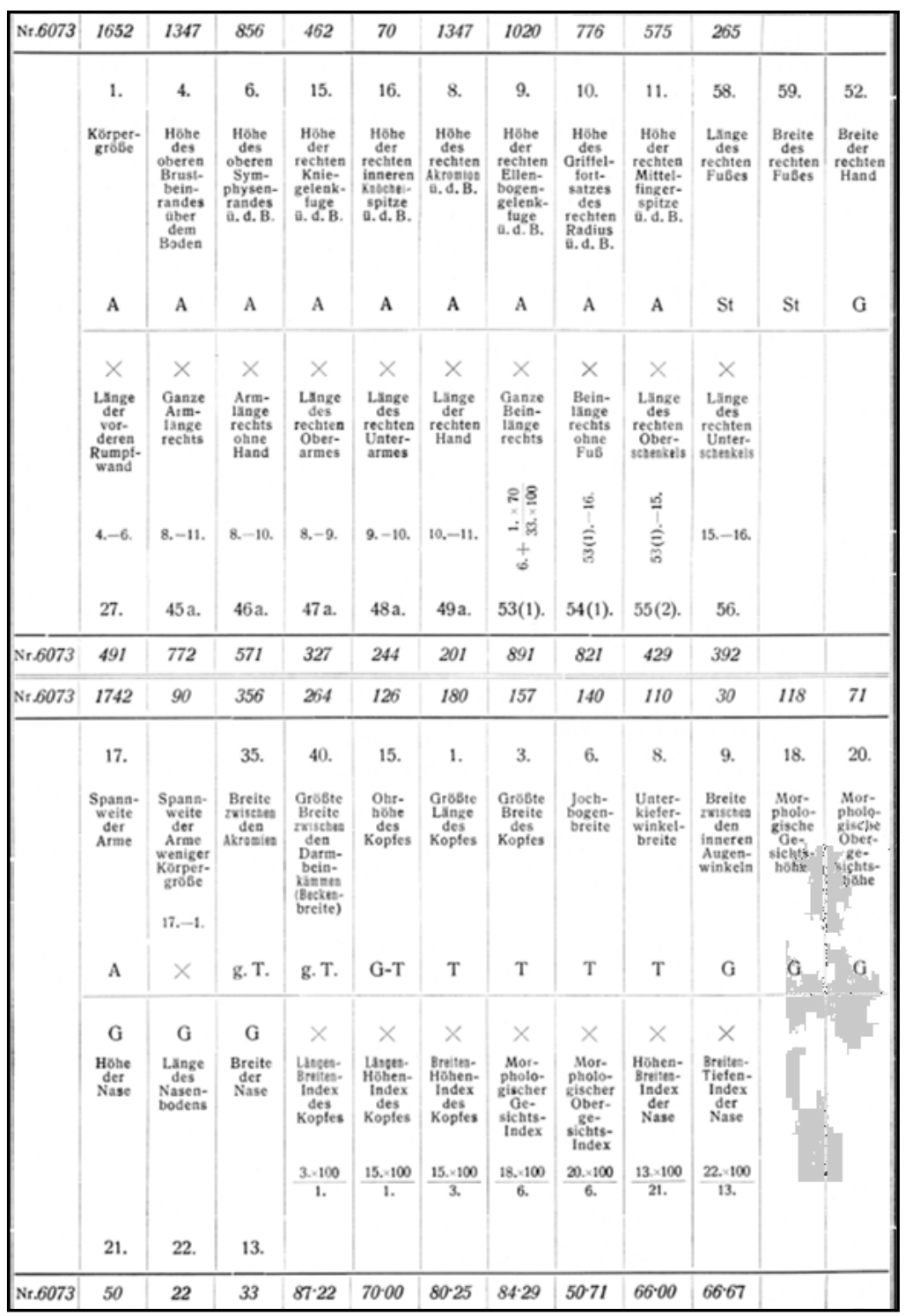

Figure 2. Form used by R. Pöch and his assistants for recording measurements taken on the POWs. Source: Pöch, "2. Bericht," 108-131. 
more convenient" than Martin's, ${ }^{14}$ along with the Haarfarbentafel [hair color chart] devised by Fischer. Pöch developed his own schemes for classifying the eyes and facial shape, which he also used in his lectures at the university. ${ }^{15}$ Because he was accountable to his financial backers, he published progress reports every year. The first report showed that, only a short time after beginning work in 1915, the Vienna-based anthropologists had already examined hundreds of prisoners. ${ }^{16}$

German anthropologists felt forced to react. Martin wrote to Luschan that it would be "truly sad" if the Germans could not afford "what Pöch accomplished in Austria." ${ }^{17}$ Luschan promoted a German project and asked, in the summer of 1915, for a sample of Pöch's data sheet. The Austrian professor confirmed that he would like "the analyses in Austria-Hungary and Germany to be realised in a standardised and complementary way." 18 The idea was for Luschan and Pöch to plan the simultaneous research conjointly, making their research results comparable and offering a standardized basis for statistical calculations to be performed after the war. ${ }^{19}$

Luschan obtained permission for his student Eickstedt to examine POWs in various German camps. Armed with the classic instruments of physical anthropology, the student numbered his subjects, noting prescribed measurements on the standardized forms. From January 1916 until February 1917, he traveled through sixteen German camps, applying his calipers to a total of 1,784 individuals whom he assigned to sixty-six "peoples." His identification of "racial types" came close to those Luschan had already identified by telediagnosis, based on descriptions provided in Eickstedt's letters.

Where Pöch's published reports in the Proceedings of the Academy of Sciences in Vienna and in the Journal of the Viennese Anthropological Society were objective in tone and even optimistic, Eickstedt's letters to Luschan seem fraught with doubt. One reason for the contrast is surely that Pöch's articles aimed to justify the support given him by both institutions and to secure

14 Postcard from Rudolf Pöch from the POW camp in Theresienstadt (Bohemia) to Felix von Luschan, 1 October 1915, Staatsbibliothek Berlin, Handschriftenabteilung [manuscripts], Nachlass [private papers] Felix von Luschan (quoted below as STBBNLL), correspondences with Pöch, p. 214.

15 Letter from R. Pöch to Luschan, 3 July 1916, STBBNLL, p. 228-229.

16 See Rudolf Pöch, "1. Bericht über die von der Wiener Anthropologischen Gesellschaft in den k.u.k. Kriegsgefangenenlagern veranlaßten Studien," MAGW 45 (1915): 45.

17 Letter from Rudolf Martin to Luschan, 16 April 1917, STBBNLL.

18 Postcard from R. Pöch in the POW camp in Reichenberg (Bohemia) to Luschan, 29 August 1915, STBBNLL, p. 210.

19 See letter from R. Pöch from the POW camp in Reichenberg to Luschan, 13 September 1915, STBBNLL, p. 212-213. 
future financing. Another was that his studies were arguably quite successful. He felt he was examining "racial groups" that could be delineated without serious inconsistencies. Eickstedt's diary-like correspondence with his adviser Luschan, on the other hand, was not meant for publication. Confronted with a much wider range of "peoples" than in the Austrian camps and, unlike Pöch, working alone, he reported not only difficulties in defining "racial types," but also in the most basic processes of data gathering.

Eickstedt's letters provide a rare close-up view of the manifold problems that scholars encountered when doing "fieldwork" in the POW camps. The camp-laboratory's supposed logistical advantage-access to diverse groups gathered conveniently on German soil-turned out to be the chief impediment to research. In contrast to the situation of scientists traveling to the home countries of their informants, the lack of the ethnographic field, of geographical, social, and cultural context, threw the prisoners' nationalities into question. Their ethnic identity, however, was the very basis for constructing groups for the purposes of comparative analysis. The camp scientists had to rely on affirmations of affiliation provided by subjects themselves, and they were apparently not always reliable, as Eickstedt's letters show: "Tomorrow at 9 a.m., we will check the validity of the nationality of 50 Tatars." ${ }^{20}$ In many cases, he was simply unable to verify ethnische Echtheit ${ }^{21}$ [ethnic authenticity] and had to content himself with affirmations instead of the hard facts provided by devices: "No. 728, a 29-year-old Kabyl from Tiziouzou (French communal state, Sardún Ghusín near Mukhamed, comes from the nearby village Beni Meádgar) has again reaffirmed that he is a very true Kabyl." 22 The questioning by the scientist thus allowed the more savvy prisoners to escape the measuring procedure ("many tried to chicken out by giving imprecise or obviously wrong information"). ${ }^{23}$

Anthropologists with field experience were well acquainted with such unruliness. Test persons would only rarely agree to undress and be touched by scientists or their instruments. In January 1916, for example, Eickstedt attempted to measure "Russian Jews" who "had little inclination for anthropology," as he reported to Luschan: They "try to get around my nice measurements in many

20 Letter from Egon von Eickstedt from the POW camp in Ohrdruf to Luschan, 28 February 1916, STBBNLL.

21 Expression used by Werner Michael Schwarz, Anthropologische Spektakel:Zur Schaustellung "exotischer" Menschen; Wien 1870-1910 (Vienna: Turia und Kant, 2001), 40-41.

22 Letter from Eickstedt from the POW camp in Darmstadt to Luschan, 20 May 1916, STBBNLL.

23 Postcard from Eickstedt from the POW camp in Ohrdruf to Luschan, 18 March 1916, STBBNLL. 
ways. I always have to corner them with tricks and cigarettes." ${ }^{24}$ When prisoners learned why they had been brought to the office, they "simply ran away."

Additional problems arising from the POW-camp setting included insufficient instruments, inadequate supplies, inappropriate spaces, poor lighting, and language barriers that forced anthropologists to work with interpreters. But some problems were immanent to the anthropological method itself. In January 1916, Eickstedt wrote to Luschan: "Why don't we measure the amplitude of the zygomatic bone?" ${ }^{26}$ He immediately received the order to proceed. ${ }^{27}$ His letters reveal many doubts:

I am measuring 14 men on an average day and have reached no. 315 today. There are around 12 Estonians and Latvians. I think I will be done next Thursday. However, I would really like to measure Moroccan, French, and English Jews. To compare the results should be most interesting. [...] Until now I have measured the amplitude of the hand while forming a fist. But it seems to me that the extended hand would provide reliable values. How should I proceed? The new measurements would be a little smaller and not comparable to the old ones. [...] There seems to be a relation between the size of the body and the ankle, but there are many exceptions. ${ }^{28}$

The methods were unsophisticated, especially when it came to their practical implementation. But they could not be modified in course of the investigations without reducing the comparability of the results.

At the same time, Eickstedt's reflections showed that it might have been necessary and reasonable to reconsider the methods. Pöch also thought so: He wrote to Luschan in April 1916 that, apart from gathering data, the point of the camp studies was to make "permanent changes and improvements in method and technique." ${ }^{29} \mathrm{He}$ and his assistant Josef Weninger took steps to optimize wartime data collection on an ongoing basis. Their innovations were aimed less at measurement procedures than at strategies of description and medial reproduction. Pöch improved the technique for making plaster head casts, publishing detailed instructions. ${ }^{30} \mathrm{He}$ added a third "norm" to anthro-

24 Letter from Eickstedt from the POW camp in Groß-Breesen near Guben to Luschan, 11/12 January 1916, STBBNLL.

25 Postcard from Eickstedt to Luschan, 13/14 January 1916, STBBNLL.

26 Letter from Eickstedt from the POW camp in Groß-Breesen to Luschan, 3 January 1916, STBBNLL.

27 See letter from Eickstedt from the POW camp in Groß-Breesen to Luschan, 6 January 1916, STBBNLL.

28 Letter from Eickstedt from the POW camp in Erfurt to Luschan, 4/5 February 1916, STBBNLL.

29 Postcard from R. Pöch from the POW camp in Hart near Amstetten to Luschan, 16 April 1916, STBBNLL, p. 246.

30 Rudolf Pöch, "3. Bericht über die in den k.u.k. Kriegsgefangenenlagern veranlaßten Studien," MAGW 47 (1917): 88-90. 


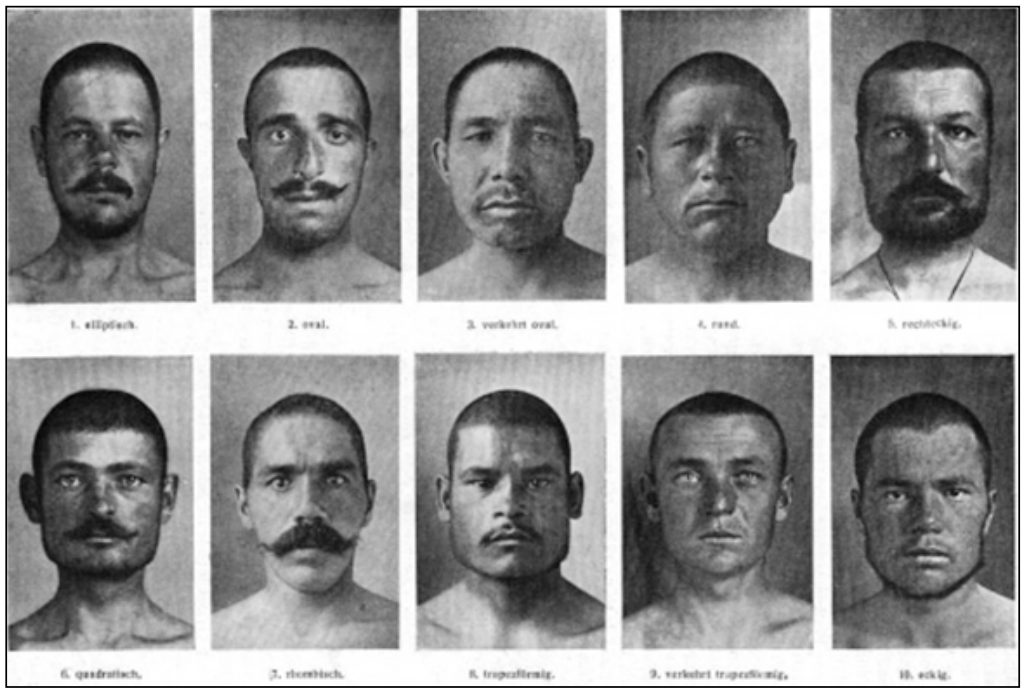

Figure 3. R. Pöch's table of "facial forms." Source: Pöch, "2. Bericht."

pological photography's usual two poses as per Alphonse Bertillon (en face and en profil), an Eindrittelseitenaufnahme [one-third side photo] in which the head was turned 30 degrees away from the frontal position to replace the frequently used "three-quarter profile photo." ${ }^{31}$ For photographs "in the three norms," the anthropologists at first used a modified Bertillon camera and later a new model constructed by the Viennese firm Moll. ${ }^{32}$ Pöch and Weninger also expanded criteria for describing the body, particularly the face, with "somatologic forms" that went beyond Martin, focusing particularly on the eye and the epicanthal fold (which was thought to reveal "Mongolian" ancestry) ${ }^{33}$ and developing a partitioned scheme for the nose. ${ }^{34}$ Still, the modifications did not violate Martin's framework, but merely improved techniques that went fundamentally unchallenged (Figures 3 and 4).

A prerequisite for the statistical analysis according to Martin was the existence of a collective, permitting a random sample capable of rendering meaningful results. To Pöch's and Martin's mind, the prison camp was such an ideal research site precisely because it offered these conditions. But the construction

31 Ibid. 85-88.

32 Idem, "4. Bericht über die in den k.u.k. Kriegsgefangenenlagern veranlaßten Studien," MAGW 48 (1918): 150-157.

33 Idem, "2. Bericht über die in den k.u.k. Kriegsgefangenenlagern veranlaßten Studien," MAGW 46 (1916): 115-127. For further modifications of the somatologic form, see idem, "4. Bericht," 157-161.

34 Idem, "3. Bericht," 83. 


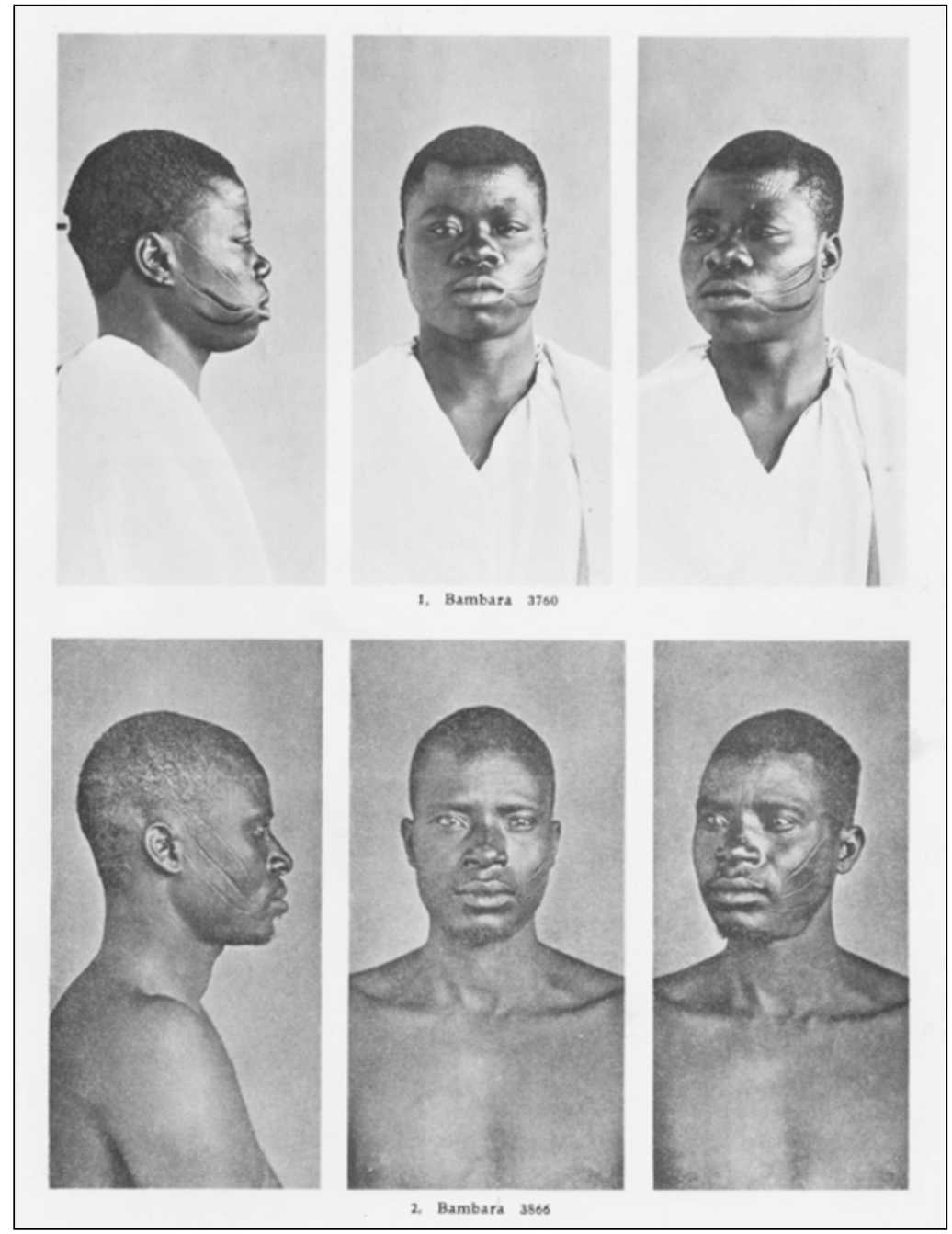

Figure 4. Photographs of West Africans "in the three norms" developed by R. Pöch. Source: Weninger, Eine morphologisch-anthropologische Studie.

of the collectives necessary for statistical studies turned out to be the most daunting problem facing the camp scientist. As they themselves had to admit, the prisoners were all men who had been judged large and strong enough for military service. Without women, children, and invalids, obviously no group present in the camps was actually representative of the population of any nation or region. The so-called "material" for study was not randomly selected at all, but selected according to the criteria of the military and then again according to the interests of the scientists. 
Once the ethnic collectives had been defined, the next task was ostensibly to "uncover" their "racial elements." Where these were already known beforehand, researchers had merely to identify them in particular prisoners, Pöch explained. But even where "elements" remained to be defined, researchers should "already have in mind an idea of the different racial types within a certain group while gathering material; then one would be able to take those types into account while selecting and describing the subjects." Pöch suggested that researchers select subjects for group assignment according to the frequency and similarity of their "characteristics."

Apart from giving a feeling of the togetherness of a self-contained type, the repetition of a certain image will allow for the definitive fixation of a type. The concluding judgement about the composition of a population has to be made only at the end of the examinations, but I recommend beginning with at least a provisional classification of types, because the observer will better recognise the main types at the beginning of his research. The longer one deals with a group of people, the better the recognition of single characteristics will get; but at the same time the unprejudiced registration of the important will suffer! I thus recommend that researchers classify the main types right on the first day of examining a new group. Of course, the indices have to be calculated at the same time, as one needs the measured values as well as the described characteristics to define a type. The ceaseless control and critique during the following examinations will often invalidate the types initially proposed. We have followed the method to note the belonging to a certain type as it seemed at first glance on the measuring sheet. This note has to be checked later on, and the classification of types is only definitive when all the material has been examined. ${ }^{35}$

Pöch recommended identifying "types" with an initial impartial scan, then calculating their indices and comparing the results with what had been seena dialectical procedure in which "anthropological seeing" or even "feeling" comes before, and ranks above, measurement. It is obvious that Pöch's results, despite his protestations of positivism, would be strongly influenced by preconceptions. For him, calculation acquired an objectifying function dependent on the visual focus, the role of mathematics being, above all, to confirm what had been seen. Eickstedt, in contrast, strove to retain his focus on each ethnic group as a whole, working primarily with the measurements he had taken. The two approaches to the practice of physical anthropology both employed mathematics and vision, but in reverse order and with varying emphasis. The problem they faced remained the same: a (more or less pronounced) discrepancy between the concrete individuals in the camps, the ideal "racial types" often visualized by selected photographs, and the calculated "types" that resulted from applying statistics.

35 Idem, "2. Bericht," 79. 


\section{Interpretation}

The first work emerging from the Viennese researches in the POW camps to appear in book form was Eine morphologisch-anthropologische Studie: Durchgeführt an 100 westafrikanischen Negern [A Morphological-Anthropological Study Conducted on 100 West African Negroes], published by Weninger in $1927^{36}$ (Figures 5 and 6). Pöch's former assistant grouped his one hundred subjects according to their "tribes." For each group and each physical characteristic, he provided a table with the average, standard deviation, and variation coefficient, as well as the probable error of all three, along with the range of variation, that is, the minimum, maximum, and the span between the two. ${ }^{37}$ His operations reduced the procedures suggested by Martin to a more generally comprehensible minimum. Weninger's graphs were confined to frequency distributions: They showed the curve resulting from measured values or indices and the number of people they corresponded to. All display clear-cut peaks near the average, slightly resembling the curve of a normal distribution and therefore seeming to indicate homogeneous groups (Figures 7 and 8).

Weninger considered measurements merely a framework, giving much more attention to the "observation" of "somatologic" characteristics. In 1924, he and Hella Pöch had published their Leitlinien zur Beobachtung der somatischen Merkmale des Kopfes und Gesichtes am Menschen [Guidelines for the Observation of Somatic Characteristics of the Human Head and Face], based on the reports published by Rudolf Pöch during the war. ${ }^{38}$ They legitimated the approach by reference to the insights of experimental genetics: "If a form is not inherited completely, if the characteristics composing this form are inherited separately, we have to begin to decompose the forms we see into their discrete characteristics." ${ }^{39}$ Features, such as the folds of the eyelid, were

36 Josef Weninger, Eine morphologisch-anthropologische Studie: Durchgeführt an 100 westafrikanischen Negern, als Beitrag zur Anthropologie von Afrika, (= Rudolf Pöchs Nachlass, Serie A: Physische Anthropologie, Band 1) (Vienna: Verlag der Anthropologischen Gesellschaft in Wien, 1927). As Austrian POW camps contained almost exclusively citizens of the Russian Empire, Pöch and Weninger traveled to Berlin in 1917, invited by Luschan, to do research on Africans and Asians in the camps of Wünsdorf and Zossen. Pöch died in 1921 and did not publish anything about the camp studies beyond his progress reports. But he willed half of his legal estate to the Viennese Academy of Science to finance publications by his students based on his scientific legacy.

37 Weninger, Eine morphologisch-anthropologische Studie, 15.

38 Hella Pöch and Joseph Weninger, "Leitlinien zur Beobachtung der somatischen Merkmale des Kopfes und Gesichtes am Menschen," MAGW 54, no. 6 (1924): 232-270.

39 Ibid. 232. 


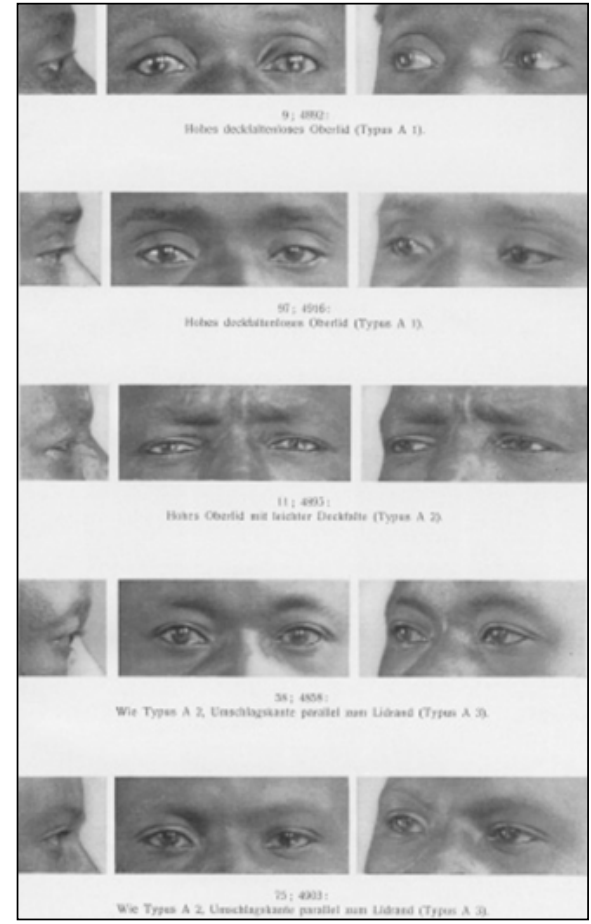

Figure 5. Types of eyes according to Weninger. Source:Weninger, Eine morphologisch-anthropologische Studie.

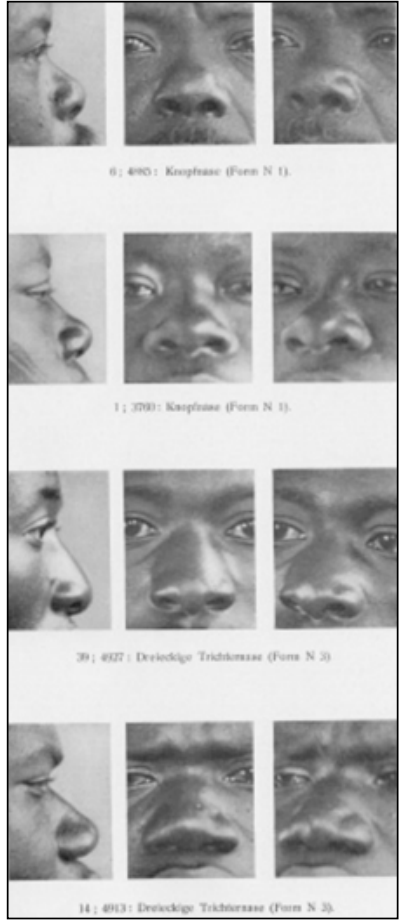

Figure 6. Types of noses according to Weninger. Source: Weninger, Eine morphologischanthropologische Studie.

\begin{tabular}{|c|c|c|c|c|c|c|}
\hline \multicolumn{7}{|c|}{ f) Der morphologische Obergesiditsindex. } \\
\hline Stamm & n & Variationsbreite & Spannung & $M \pm E(M)$ & $a \pm \mathrm{E}(v)$ & $v \pm E(v)$ \\
\hline Bambara & 27 & $4245(4286)-(54 \cdot 62) 5938$ & 1693 & $4885 \pm 052$ & $403 \pm 037$ & $825 \pm 0.75$ \\
\hline Tukulor & 16 & $43-17(45-95)-(54-23) 5462$ & $11 \cdot 45$ & $4912 \pm 050$ & $300 \pm 036$ & $611 \pm 072$ \\
\hline Malinke & 11 & $37 \cdot 59(44 \cdot 85)-(52-59) 57 \cdot 67$ & 2008 & $4900 \pm 097$ & $4 \cdot 78 \pm 068$ & $975 \pm 1 \cdot 40$ \\
\hline Wolof & 10 & $4621(47 \cdot 33)-(5074) 54 \cdot 48$ & 827 & $4930 \pm 045$ & $2 \cdot 08 \pm 031$ & $4 \cdot 22 \pm 0 \cdot 63$ \\
\hline Susu & 6 & $44.85(46 \cdot 10)-(53 \cdot 4) 56.82$ & $11 \cdot 97$ & $5008 \pm 1 \cdot 12$ & $4 \cdot 09 \pm 080$ & $8 \cdot 17 \pm 1.59$ \\
\hline Sammelgruppe & 30 & $3759(39-04)-(54 \cdot 48) 5565$ & 1806 & $4787 \pm 0-53$ & $4 \cdot 28 \pm 037$ & $894 \pm 078$ \\
\hline Gesamtmaterial & 100 & $37.59(3759)-(5767) 59 \cdot 38$ & 2179 & $4870 \pm 0.27$ & $396 \pm 019$ & $813 \pm 0.39$ \\
\hline
\end{tabular}

Figure 7. The morphological index of the upper face. Source: Weninger, Eine morphologisch-anthropologische Studie. 


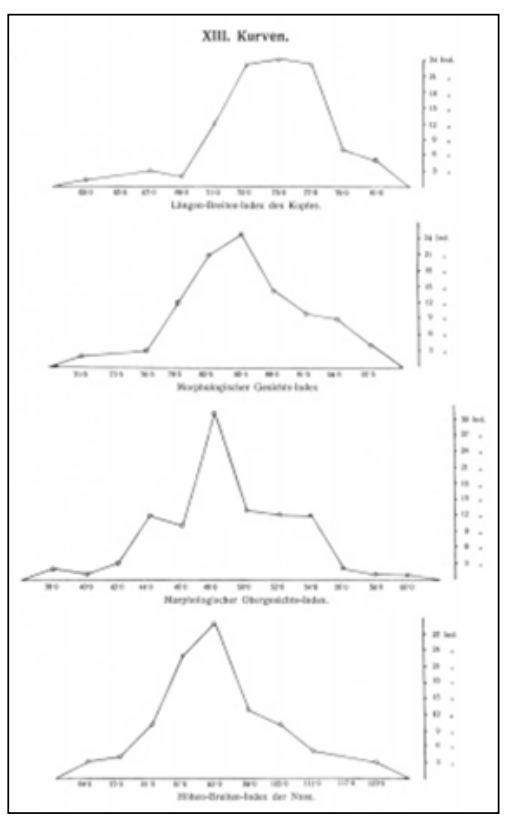

Figure 8. Curves on various indices. Source: Weninger, Eine morphologischanthropologische Studie. categorized with standardized qualifying attributes. Weninger grouped people who displayed the same attributes into Sammelgruppen [collective groups] consisting of several ethnic groups. Only then, within the "collective group," did Weninger apply mathematical methods to obtain average height, for instance. The results were related back to the ethnic groups through percentages.

For such a procedure based on "anthropological" or "morphological seeing"-in contrast to measurement-photographic material turned out to be of key importance: "We were able to check every single morphological appearance against the carefully produced photographs; the well-made photos even drew our attention to many important details." According to Weninger, the photographs permitted "retroactive corrections and even some new observations." ${ }^{40}$ Pictures were deemed a genuine part of "anthropological seeing" and thus preceded mathematical operations.

Eickstedt limited his description of morphological characteristics (so-called "observations") to eye, hair, and skin color, beard shape, and the grip strength of the hand. He began his analysis of the camp data in the summer of 1919, submitting his dissertation in February 1920. His thesis supervisor, Luschan, arranged for publication of the work in the Anthropological Society's journal, Zeitschrift für Ethnologie, in 1921. ${ }^{41}$

In the printed version, Eickstedt explained that he had examined seventy-six Sikhs from the eastern Punjab in the POW camp of Wünsdorf, near Berlin. He took forty-five measurements per subject and calculated twenty-two bodily and nine head indices for each, deviating from Martin's recommendations only trivially. For example, he was constantly bothered by the height of the

40 Weninger, Eine morphologisch-anthropologische Studie, 17. As the photographs were black and white, they could not serve to identify colors.

41 Egon von Eickstedt, "Rassenelemente der Sikh," Zeitschrift für Ethnologie 52 (1920/21): 317-394. 
ear in relation to the head, ${ }^{42}$ eventually deciding to abandon this "difficult and unreliable measurement completely." ${ }^{43}$ His work aimed at understanding Biotypen or "racial elements" as well as Typengruppen and Phänotypen. ${ }^{44} \mathrm{He}$ incorporated statistics to make his data tell a story. While continuing to use Martin's models, he confidentially told Luschan that his

respect for M[artin]'s mathematics has diminished more and more. At least at some points, he himself did not understand what he was writing. Only in this way can one explain his contradictions and errors and, above all, the fact that he provides dead formulas but nothing to make them understandable. In this way, it is totally impossible to achieve results.

According to Eickstedt, the real problem lay not in the methods, but in Martin's far too voluminous explanation. ${ }^{45}$ The calculations, reported Eickstedt, were "all time-consuming and time-killing," ${ }^{\prime 6}$ and the corresponding graphs merely sowed confusion.

Eickstedt had initially assumed a single "racial type" for his Sikh subjects. A few weeks later, after some punishing mathematics, he confessed: "I dropped my initial idea that the Sikhs could be a homogeneous group. The curves seemed to show two groups. But having provisionally worked on them, I consider three groups most probable." ${ }^{47}$

The source of his uncertainty was the "recurrent peaks very close to each other" in his graphs. Presuming he would find a bell curve, Eickstedt guessed that the "occasional (slight) lopsidedness and the amplitudes of the peaks of simplified curves" indicated "heterogeneous material," that is, more than one "racial element." But, as he admitted himself, his difficulties also arose from the graphic visualization-for example, from the question "of whether the intervals had been chosen correctly." ${ }^{48}$ His doubts referred to a graph that he called the Variationspolygon (Figure 9). Because he used so few points per interval, the probable error

42 Letter from Eickstedt to Luschan, 3 January 1916, STBBNLL.

43 Eickstedt, "Rassenelemente der Sikh," 328.

44 Ibid., 340. Somatic groups: "racial elements" for Eickstedt were synonyms for "biotypes" [Biotypen], "genotypic entities" [genotypische Einheiten], and the "stable complex of dispositions" [stabiler Anlagenkomplex]; "groups of types" [Typengruppen] were synonyms to "phenotypes" [Phänotypen], "genotypic multiplicities" [genotypische Vielheiten] and the "unstable complex of dispositions" [labiler Anlagenkomplex]. In addition, he considered the possible existence of "external single types" [fremde Einzeltypen]. See ibid., 340-341.

45 Letter from Eickstedt to Luschan, 26 August 1919, STBBNLL.

46 Postcard from Eickstedt to Luschan, 6 August 1919, STBBNLL.

47 Letter from Eickstedt to Luscan, 26 August 1919, STBBNLL.

48 Letter from Eickstedt to Luschan, 29 June 1919, STBBNLL. 


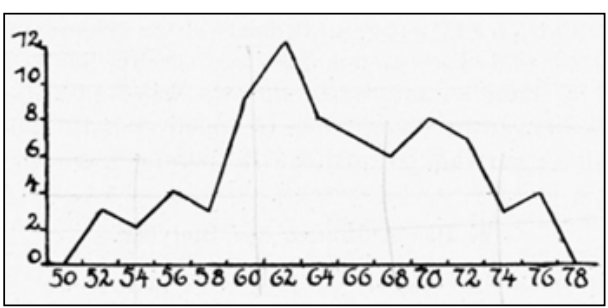

Figure 9. Variational polygon of he nasal index. Source: Eickstedt, "Rassenelemente der Sikh." of his curve rose to more than 50 percent. $^{49} \mathrm{He}$ was well aware that his strategy could produce "a false multi-peakedness" [eine falsche Mehrgipfligkeit]. ${ }^{50}$ To obtain meaningful results, he would have to have measured at least one hundred individuals, which he claimed was impossible under the circumstances.

The ambiguous compromise that the anthropologist had made by applying sensitive statistical analysis to a small sample size accommodated the practical and administrative potential of the measurements, but produced only limited results. The aim was an anthropology typology, but the mathematical approach selected did not seem to fit. Consequently, all his graphs occasioned similar troubles: "They all show a similar (not identical) curve with two very close peaks, comparable to the nose index and the head index of my people." ${ }^{1}$ Eickstedt nevertheless supposed that his results did not show a false, but a genuine, multipeakedness-an expression of the complex situation of the Sikh population. He asserted that other strategies, such as geographical analyses, would be necessary to clarify whether they were a heterogeneous population. ${ }^{52}$

He therefore began to correlate selected measurements according to British techniques of correlation analysis. Korrelationstabellen registered, for example, height and the nose index by listing the number of relevant subjects in a coordinate system (Figure 10). In the graph that resulted, he tried to find clusters (i.e., "types"), which he marked by circling. To confirm their accuracy, he would have been obligated to construct and compare multiple correlation charts. Instead, he queried the influence of geographical criteria ${ }^{53}$ and, as proof, correlated bodily indices with regions. He claimed that the geographische Kombinationstafeln [geographical combination boards], which permitted the "analysis of a mixed population based on their geographic distribution" constituted "his" method $^{54}$ (Figure 11). They served to explain the "genuine multipeakedness" of his graphs and the lack of a bell-shaped curve. In the end, his observations and

49 He divided the nose index of the Sikhs into twenty-five intervals to distribute seventy-six measuring points. The probable error was $1: \sqrt{76}$.

50 See Eickstedt, "Rassenelemente der Sikh," 375.

51 Letter from Eickstedt to Luschan, 22 July 1919, STBBNLL.

52 See Eickstedt, "Rassenelemente der Sikh," 376.

53 Ibid., 348.

54 lbid., 367. 


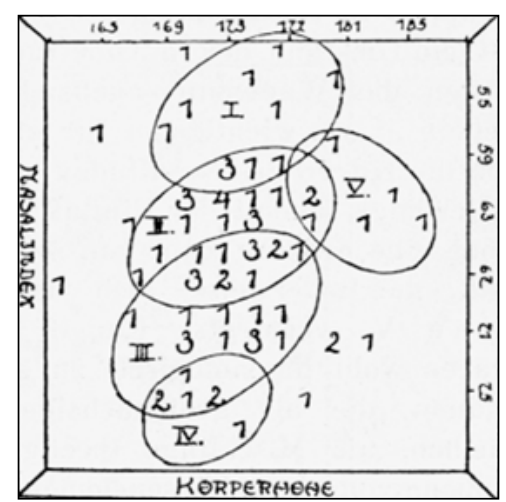

Figure 10. Correlation table for the nasal index with the body height. Source: Eickstedt, "Rassenelemente der Sikh."

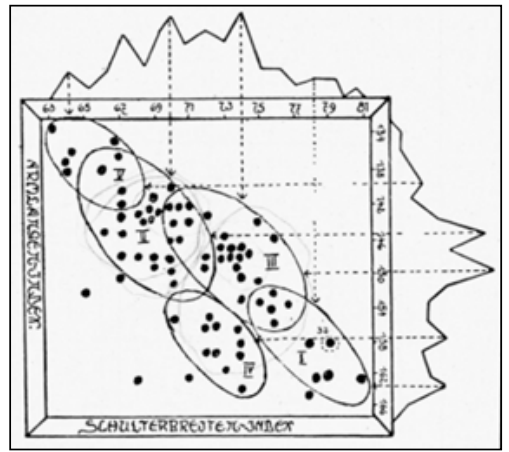

Figure 11. Combination table for the index of shoulder width and of arm length. Source: Eickstedt, "Rassenelemente der Sikh."

graphs suggested to him that the Sikhs were a heterogeneous population with two "racial elements" or Biotypen and three smaller "type groups" or Phänotypen, two of them closely associated with the "racial elements."

Statistical analysis had therefore compelled Eickstedt to revise his initial idea of a homogenous Sikh population. Mathematics had put forward what had not or could not have been seen before. That is to say, the "types" identified by mathematical means failed to match the "types" Eickstedt had seen. Had they coincided, his approach to the camps would have been tautological. ${ }^{56}$ But patently circular reasoning would have precluded the possibility of finding "racial elements" previously unknown to science-an aim he consciously pursued. Eickstedt did establish provisional "racial elements" by visual means, taking photographs of what he thought to be typical Sikhs of the eastern Punjab. But he was unable to match these "types" that were identified before the application of mathematics to the "types" which he later calculated for his dissertation, at least to some extent. The discrepancy derived from systematic errors using statistics on material that was not random, much too small, and clumsily handled. Furthermore, given the assumption of the ubiquity of racial "mixing," "racial elements" in their pure form could not have existed as phenotypes in reality in any case.

55 Ibid., 366.

56 Margit Berner has noted this tautology. See, for example, idem, "Forschungs'Material' Kriegsgefangene: Die Massenuntersuchungen der Wiener Anthropologen an gefangenen Soldaten 1915-1918," in Vorreiter der Vernichtung? Eugenik, Rassenhygiene und Euthanansie in der österreichischen Diskussion vor 1938 (= Geschichte der NS-Euthanasie in Wien, Teil III), eds. Heinz Eberhard Gabriel and Wolfgang Neugebauer (Vienna: Böhlau, 2005), 174. 
After the war, Eickstedt could not check his results on the prisoners he had measured. Because of the high cost of the procedure, he had not even photographed all his subjects. Where Pöch had aimed for a comprehensive visual archive of "foreign peoples," Eickstedt used the camera only to document selected individuals and to keep Luschan informed about his research. In 1919, he reported retrospectively: "I photographed around fifteen Sikhs. I tried to determine the average type." He added with delight that the "average type" hardly differed from drawings of Sikhs done by the Jewish artist Hermann Struck (1876-1944) that had been published in 1916.57

Beginning in 1915, Struck had planned "to craft a collection of lithographs and etchings which represents different types of our prisoners," wishing to make anthropological concerns relevant to its realization. ${ }^{58}$ When Luschan agreed to write an introduction, ${ }^{59}$ Struck assured him that he would remove drawings that Luschan did not deem appropriate. ${ }^{60}$ Luschan's authority grew as the project progressed. He not only intervened in the selection of lithographs, but in the drawings themselves, requesting specific changes. The artist responded to one of his letters:

Your remarks concerning the Negroid type were completely correct, and I immediately changed his hairdo. Now he has very nice curly Negro hair, and I think you will like him. I also enlarged the skull and the ear of a Russian that you rejected some time ago. ${ }^{61}$

Luschan was not content with the realities or interpretations of realities offered by Struck. He was determined to produce clear-cut "types." Unlike photography, the medium of drawing was highly amenable to such a project. About the pictures that were finally published, even Martin had to admit that "the overall impression emerges more clearly than with most photography." 62

Eickstedt thought the "type groups" of the Sikhs were better represented in Struck's drawings than in his own photographs, which he had taken "years before identifying the racial elements." His photographs "indicated only the direction in which we have to look for the characteristics and the outer appear-

57 Letter from Eickstedt to Luschan, 1/3 August 1919, STBBNLL.

58 Letter from Hermann Struck to Luschan, 25 May 1915, STBBNLL. See also the article by Margaret Olin in this volume.

59 Hermann Struck, Kriegsgefangene: Ein Beitrag zur Völkerkunde im Weltkriege; Hundert Steinzeichnungen, with a foreword by Prof. Dr. F. von Luschan (Berlin: Reimer, 1916). Luschan's text was illustrated by sixty photographs labeled "racial images" that were to supplement the drawings by Struck.

60 Letter from Struck to Luschan, 25 January 1916, STBBNLL.

61 Letter from Struck to Luschan, 14 March 1916, STBBNLL.

62 Letter from Rudolf Martin to Luschan, 16 April 1917, STBBNLL. 


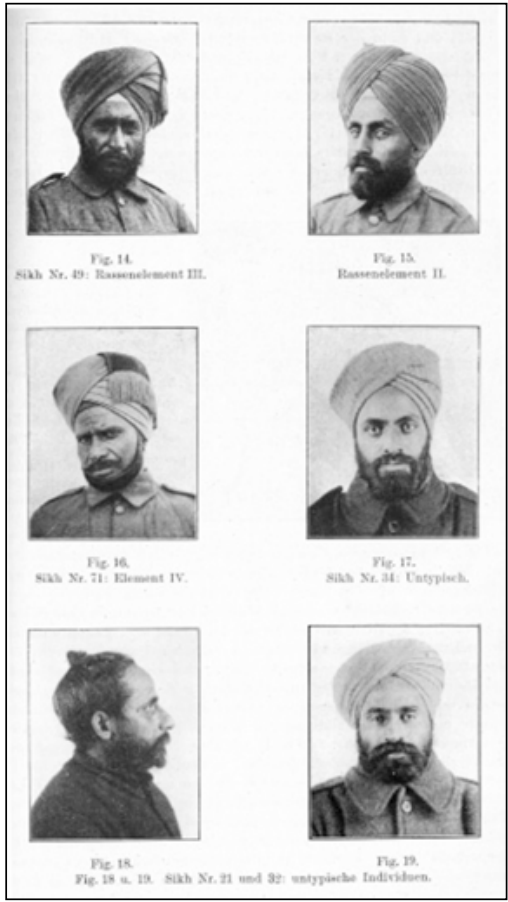

Figure 12. Six Sikh POWs; photographs by Egon von Eickstedt. Source: Eickstedt, "Rassenelemente der Sikh."

ance of the discrete elements." ${ }^{3}$ In 1919, he wrote to Luschan that his three main "types" of Sikhs had been "rendered perfectly" by Struck, "who as an artist appreciates the extreme." He also noted that:

He must have liked the broad-nosed Sikhs. [...] I have just noticed that Struck's pictures show the broad noses above all for Thakurn-which is correct. Couldn't I use one of his beautiful heads for my work $?^{65}$

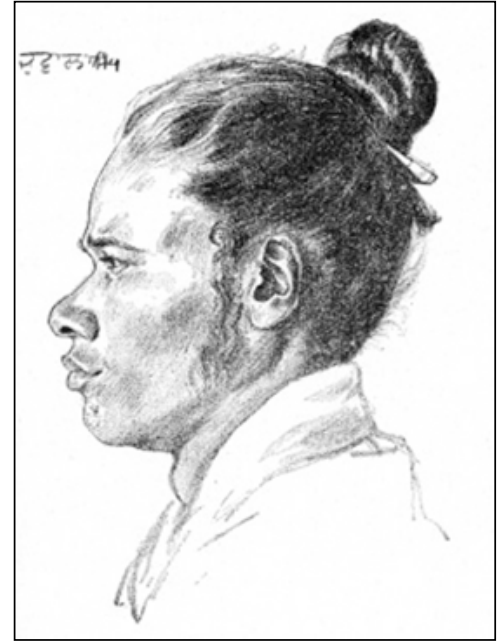

Figure 13. Sikh No. 73: [Racial] element IV. Source: Eickstedt, "Rassenelemente der Sikh."

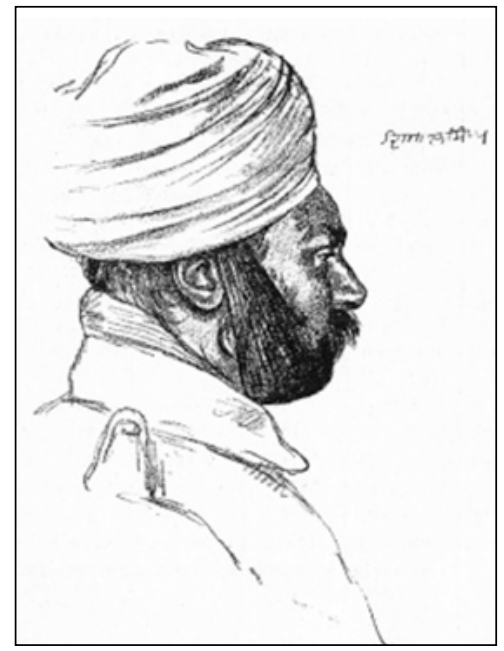

Figure 14. Sikh No. 46: [Racial] element III. Source: Eickstedt, "Rassenelemente der Sikh."

63 Eickstedt, "Rassenelemente der Sikh," 355.

64 Letter from Eickstedt to Luschan, 26 August 1919, STBBNLL.

65 Letter from Eickstedt to Luschan, 1/3 August 1919, STBBNLL. 


\section{Abhandlungen und Vorträge.}

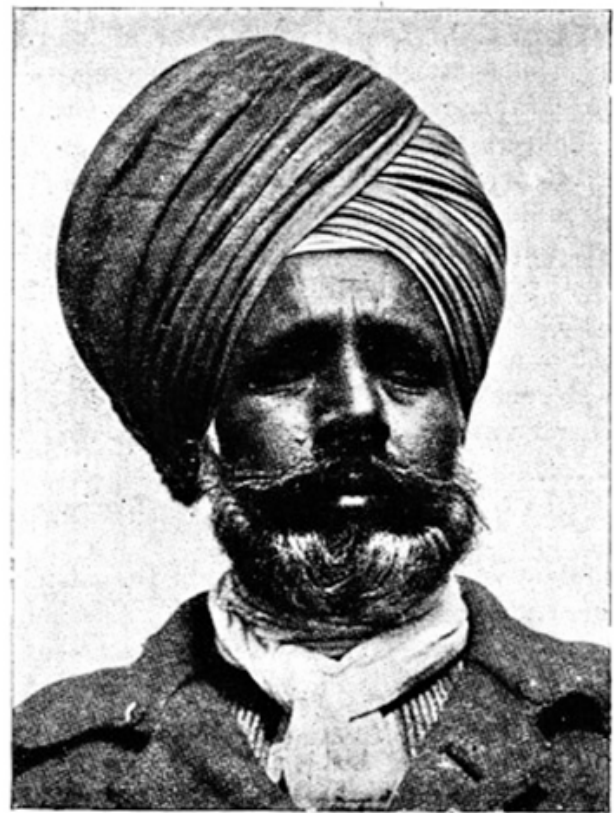

Fig. ${ }^{1}$ ). Sikh Nr. 25: Rassenelement II.

\section{Rassenelemente der Sikh.}

Mit einem Anhang über biometrische Methoden.

$$
\text { Von }
$$

Dr. Egon v. Eickstedt,

Assistent am geographischen Insti ut Freiburg i. B.

\section{I $\mathrm{n}$ h a $1 \mathrm{t}$ :}

1. Das Punjab in anthropogeographischer Beziehung . . . . . . . . . . 815

2. Vókerbewegungen in Nordwest-ndien und die Stellung der Jat Sikh * *. . . . 320

3 Die Aufarbeitung des Materials . . . . . . . . . . . . . . . . 3

4. Das Auffinden der Biotypen:

a) somatische Kombinationstafeln . . . . . . . . . . . . . . . . 39

b) geographische Kombinationstafeln $\ldots . .347$

c) Beschreibung der Elemente. . . . . . . . . . . . . . . . . . 355

5. Die Herkunft der Rassenelemente und Typengruppen. . . . . . . . . . . . . . 359

6. Zusammenfassung der Ergebnisse. . . . . . . . . . 366 A $\mathrm{n}$ h a $\mathrm{ng}$ :

1. Bemerkungen zu biometrischen und graphischen Methoden . . . . . . . 368

2. Literaturverzeichnis. .377

3. Personalien, Individualmaíse und Indices

3) Mit freundlicher Erlaubnis von Verfasser und Verleger reproduziert aus: O. Stiehl, Unsere Feinde, Verlag Holfmann, Stuttgart.

Zeitschrift für Etbnologie. Jabrgang 1920/21. Heft 4/5

22

Figure 15. Sikh No. 25: [Racial] element Il; photograph by Otto Stiehl, titel page of Eickstedt's thesis. Source: Eickstedt, "Rassenelemente der Sikh." 
In the end, Eickstedt's publication on Sikhs included six of his own photographs (Figure 12). Only three of them were identified with the "racial types," while the other three were labeled "untypical." Two drawings by Struck illustrated one "typical" Sikh and one who was "not totally typical," but represented two "racial elements" (Figures 13 and 14).

A third "racial element" was represented by a Sikh whom Eickstedt had measured in the camp, but who was illustrated by a photograph from the 1916 publication Unsere Feinde [Our Enemies] by the camp Commandant, Otto Stiehl ${ }^{66}$ (Figure 15). Stiehl's booklet included photographs of ninety-six "striking heads from German POW camps." His work enjoyed a positive reception by anthropologists. Although they found that he had not followed the norms of anthropological photography, "he had chosen his types with a very good eye." ${ }^{67}$ Reviewers granted the nonanthropologist, with his naïve gaze, as "good" an eye for types as a professional.

The success of Stiehl's photographs and Struck's drawings indicate both the imprecision of "anthropological seeing" and the ability of drawings to heighten "typical" traits. An anachronistic medium in the era of photography, drawings permitted easy simulation of "types." Photographs showed people, not hypotheses, therefore, photographs fulfilling anthropological ideals were scarce. ${ }^{68}$ In 1922, even the self-styled racial authority H. F. K. Günther (who later acquired the notorious nickname of "Rassengünther") asked readers of his third edition of Rassenkunde des deutschen Volkes [Racial Studies of the German People] "to send appropriate pictures to the publisher, pictures that provide good illustrations of racially pure or almost racially pure people."69

\section{Conclusions}

The differences between the findings of German and Austrian physical anthropologists looking for "racial types" or "racial elements" in POW camps did not stem from differing scholarly backgrounds, differences in "national schools," or because they worked with different "material"-Russian peoples in the Austro-Hungarian camps as opposed to peoples from the "rest of the world" in German camps. Rather, I have argued here that problems emerged

66 Otto Stiehl, Unsere Feinde: 96 Charakterköpfe aus deutschen Kriegsgefangenenlagern (Stuttgart: Hoffman, 1916).

67 See Rudolf Pöch, review of "Unsere Feinde" by Otto Stiehl, MAGW 47 (1917): 122.

68 See, for example, a copy of a letter from von Luschan to von Eickstedt, 19 November 1919, STBBNLL.

69 Hans Friedrich Karl Günther, Rassenkunde des deutschen Volkes, 3rd ed. (Munich: Lehmann, 1923), 3 (emphasis in original). 
from the methods of physical anthropology itself-the inherent disagreement between statistical and visual "data." Pöch solved the problem through visual preselection of individuals for measurement, fixing the data so that the math would support the visual evidence. Eickstedt tried to surmount the problem by using drawings to simulate "types" whose idealized visions existed only in the interplay between his statistical methods and his imagination.

As the snags in execution and interpretation show, the POW-camp studies were not the well-oiled anthropological machine that investigators had hoped for. They occasioned numerous problems, caused, on the one hand, by historical conditions and, on the other, by their own methods, with each complex of problems exacerbating the other. This could have led the researchers to conclude that it was necessary to abandon preconceptions, from the meaning of the material to the methods of physical anthropology. They had assumed from the outset that the original "racial elements" could not be found in their "pure" form and that the "original racial type" could only be taken as an ideal. So why did physical anthropologists not revise their methods? Possibly, because they could convince themselves that the methods were not the problem.

One ready excuse was a simple practical issue: Despite initial assertions, the camps did not provide access to large numbers of test persons within clearly defined collectives. Eickstedt resorted to studying a small group defined by religious and geographic criteria. But even Pöch and his assistants, looking at the peoples of Russia, could not find sufficient candidates from any single ethnic group: Meaningful results would have required at least one thousand test persons.

Another way of getting around their failure was in the integration of the problems into the anthropological method through the construction of "approximations." As Eickstedt stated, his results were only "approximations" of the original "racial elements." In his words, they should "only indicate the direction in which we have to look for the characteristics and the outer appearance of the discrete elements." The notion of approximation-elaborated philosophically and mathematically in the Kollektivmaßlehre [theory of collective measurements] of Gustav Theodor Fechner as a tool for physical anthropologists ${ }^{70}$ - did not define the distance from the ideal or original "type" precisely. It left an indeterminate space between concrete results and perfection. The gap could only be bridged by a similarly arbitrary step: a simulation, such as a drawing, for example.

Other, and perhaps the most effective, arguments favoring the further pursuit of physical anthropological methods concerned not content, but strat-

70 Concerning the "Kollektivmaßlehre" see, for example, Michael Heidelberger, Die innere Seite der Natur: Gustav Theodor Fechners wissenschaftlich-philosophische Weltauffassung (Frankfurt a. M.: Klostermann, 1993), 323-385. 
egy - the conquest and defense of academic redoubts. Eickstedt, a clear antagonist of the biogenetics of Fischer, never distanced himself from Martin's methods of applied statistics in physical anthropology, despite his bitter lamentations from the camps. In the 1930s, he even broadened the concept, insisting that physical types were linked to spiritual traits. He continued to employ the methods of physical anthropology, along with geographical criteria, while holding the chair for anthropology at the University of Breslau from 1933 onward, founding what became known as the "Breslau School" of physical anthropology.

The usefulness of the camp studies in fine-tuning prewar methods for postwar use was even more obvious in Vienna. Diligence during the war led to professional success: Pöch was named full professor in 1919. After his death in 1921, his assistant Weninger, author of the study of 100 West African POWs, went on to take credit for founding the "Vienna School" of physical anthropology, which continued to publish books, based on the work in the camps, into the 1950s. 



\title{
Ethnographic Films from Prisoner-of-War Camps and the Aesthetics of Early Cinema
}

\author{
Wolfgang Fuhrmann
}

In the summer of 1915, the Austrian Ministry of War gave permission for a group of Austrian anthropologists to perform fieldwork in prisoner-of-war (POW) camps located in Eger, Reichenberg, and Theresienstadt. ${ }^{1}$ The programme had been initiated by the Viennese Anthropological Society several weeks earlier at its June meeting, after its president argued that scientists should not miss the chance to examine soldiers from all over Europe. The camps gathered ethnic groups normally scattered across vast regions, ${ }^{2}$ providing research opportunities unlikely to be repeated in the foreseeable future. ${ }^{3}$ Under the direction of Rudolf Pöch, a central figure in Austrian anthropology and ethnography at the time, anthropologists began work in the POW camp in Eger in July 1915. The group collected personal and anthropometric data, took photographs, and recorded songs and stories with a phonograph. In addition, Pöch soon began shooting films of the prisoners as they demonstrated traditional customs and craft-making.

Using a movie camera in anthropological fieldwork was neither a novelty in the discipline, nor was it a new technology for Pöch. Ethnographic film had been established in German-speaking anthropology for nearly ten years. Films like Völkerkundliche Aufnahmen aus der Südsee aus den Jahren 1908-1910

1 Rudolf Pöch, "1. Bericht über die von der Wiener Anthropologischen Gesellschaft in den k.u.k. Kriegsgefangenenlagern veranlaßten Studien," Mitteilungen der Anthropologischen Gesellschaft in Wien 45 (1915): 219-235.

2 The Society's President Carl Toldt quoted in Andrea Gschwendtner, "Als Anthropologe im Kriegsgefangenlager-Rudolf Pöchs Filmaufnahmen im Jahre 1915," Wissenschaftlicher Film 42 (1991): 107.

3 Pöch, "1. Bericht," 219. 
[Ethnological Film Documents from the Pacific in the Years 1908-1910] from the Hamburg South Seas Expedition or Aus dem Leben der Kate auf Deutsch Neuguinea: Aufnahmen aus dem Jahre 1909 [From the Life of the Kate in German New Guinea-Pictures from the Year 1909] by Richard Neuhauss document the discipline's interest in the new medium. ${ }^{4}$ Pöch himself had been among the first ethnographers to exploit film. He purchased a movie camera during his New Guinea expedition of 1904-1906, having realized that photographs were inadequate to record dance choreographies. ${ }^{5}$ During his next expedition, 1907-1909, Pöch filmed in the Kalahari. ${ }^{6}$ His film Bushman Speaks into a Phonograph has become one of the most cited early documents in ethnographic film history.

Pöch's POW-camp films leave today's viewers uneasy. In principle, they were part of an anthropological research project and, thus, no more or less problematic than many other ethnological films of the time. But the POW camp setting itself conveys a strange blend of scientific interest, humiliation, and voyeurism. Visibly staged performances appear to contravene Pöch's statements regarding the objectivity of the cinematographic apparatus and the authenticity of the events he filmed.

This chapter approaches Pöch's POW-camp film recordings from the perspective of film history. Focusing on the aesthetics of early nonfiction films on colonial themes, the chapter seeks to situate Pöch's wartime films, which were not the first of their kind, in a broader filmmaking context. General audiences had seen similar films, made ten years before Pöch arrived in Eger, shot in the concentration camps set up by the colonial government of German Southwest Africa during the Herero and Nama War (1904-1907). Furthermore, film was just one element in a whole industry of representing colonial subjects that extended from picture postcards to popular illustrated journals. All of these media employed an aesthetic quality and sequential logic that aimed at making even a concentration camp seem picturesque and exciting. ${ }^{7}$

The intention here is not to argue that Pöch's scientific films are indistinguishable from, or equivalent to, commercial film for popular entertainment. But viewing Pöch's short-lived POW-camp film project in the context of early film aesthetics can help make them more legible to us today. Conventions of

4 The unique collection of early German ethnographic films including Rudolf Pöch's films are archived at the IWF Wissen und Medien gGmbh in Göttingen, Germany. http://www.iwf.de/IWF (accessed February 9, 2010).

5 Rudolf Pöch, "Reisen in Neu-Guinea in den Jahren 1904-1906," Zeitschrift für Ethnologie 39 (1907): 382-400.

6 "Photographie und Kinematographie bei den Buschmännern," Photographische Korrespondenz 581 (1909): 94.

7 Tom Gunning, "The Cinema of Attractions: Early Film, its Spectator and the Avant-Garde," in Early Film: Space-Frame-Narrative, eds. Thomas Elsaesser and Adam Barker (London: British Film Institute, 1990), 56-62. 
representation dominant in early cinema exercised considerable pressure even on anthropological filmmaking. The abrupt end of Pöch's endeavors may also comment on film's contested role as an ethnographic tool in the scientific community.

\section{Representations of the POW Camp: German Southwest Africa, 1904-1909}

When the Herero and Nama War broke out in January 1904, the distance between the European metropole and the African colony did not allow for immediate media coverage. However, the war became one of the first proving grounds for modern mass media in Germany, with panoramas, picture postcards, photography, and film contributing to visual representation of the war at home. As early as February 1904, painted panoramas two square meters in size were advertised as "fast and cheap" in a trade journal for fairground operators, Der Komet. ${ }^{8}$ They sold well, so that fairs and amusement parks provided some of the earliest opportunities for the German public to view images of the military campaign in the colony.

That December, Chancellor Bülow ordered the establishment of "concentration camps" for the "temporary accommodation and lodging of the remainder of the Herero people." In the following months, numerous official and semiprivate camps were set up throughout the colony, confining Africans under inhuman conditions. Access was not restricted to military or government officials, but was open to both amateur and professional photographers and cameramen. It was only a matter of time until a new genre of war representations entered the public market-photographs of captive Herero and Nama.

One amateur who exploited the chance to shoot photographs and films in the camps was the Altenburg merchant and brewery owner Julius Friedrich Carl Müller (1868-1935). To promote his business at home and obtain material for colonial propaganda, Müller visited the German colonies twice, first in 1904-1905 and again in 1906. Screenings of his films at local chapters of the Deutsche Kolonialgesellschaft [German Colonial Society] made him a wellknown figure in the colonial movement. ${ }^{10}$ Staying in close contact with his

8 Der Komet, no. 986, February 13, 1904, 32.

9 Joachim Zeller, "'Ombepera i koza-Die Kälte tötet mich': Zur Geschichte des Konzentrationslagers in Swakopmund 1904-1908," in Völkermord in Deutsch Südwestafrika, eds. Jürgen Zimmerer and Joachim Zeller (Berlin: Ch. Links Verlag, 2003), 64-85, quotes from p. 65.

10 Wolfgang Fuhrmann, "Bilder aus den deutschen Kolonien: Lichtbilder und kinematographische Aufnahmen," in KINtop. Jahrbuch zur Erforschung des frühen Films 8 (1999): 101-116. 


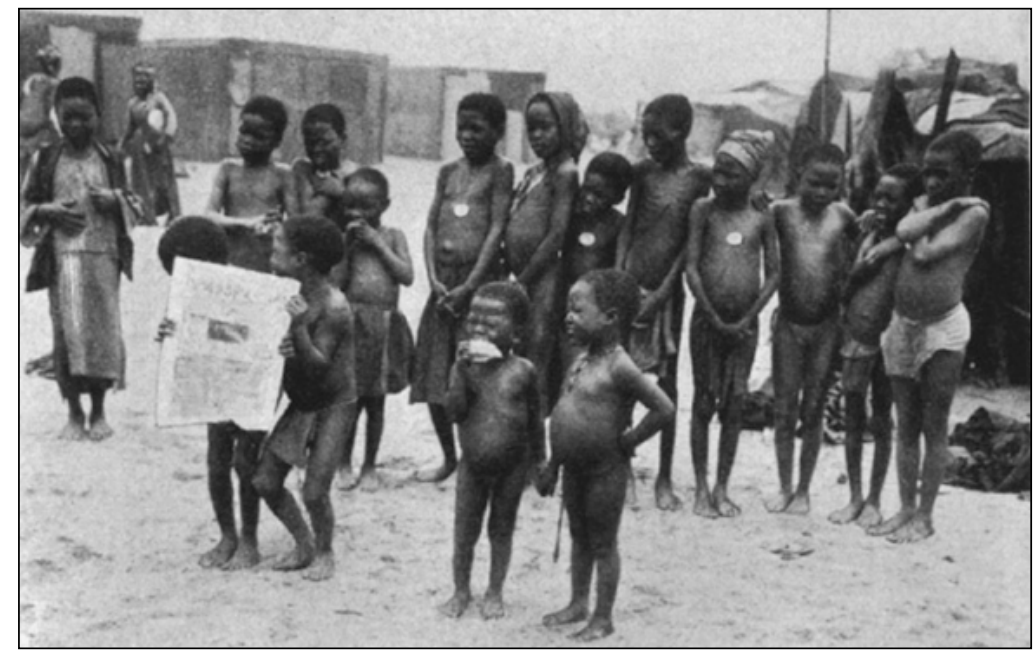

Figure 1. Herero children in a camp in German Southwest Africa, 1906. Photograph by Julius Friedrich Carl Müller. Source: Ottomar Bettziech, Das Buch von unsern Kolonien, 4th rev. ed. (Leipzig: Ferdinand Hirt \& Sohn, 1908), 59.

family and his hometown, Müller regularly sent notes and photographs. One camp scene showed sixteen African children wearing tags that identify them as prisoners. The photograph was first displayed in the window of a bookshop in Altenburg. Commentary in local newspapers over the next few days emphasized the picture's "entertaining character" (Figure 1).

The photograph shows [...] 16 Negro babies of varying size, of whom two little boys have concealed themselves behind an issue of the Altenburg newspaper to read it. The photograph of the little black compatriots is technically impeccable. The card will surely brighten many people's day. ${ }^{11}$

The photograph is a striking example of colonialism's reception and exploitation in imperial Germany. The image stood in sharp contrast to reality. The missionary Heinrich Vedder remarked that the Roheit, geile Sinnlichkeit, and Herrentum [brutality, lecherous sensuality, and arrogance] that had spread among troops and civilians was such that it would be impossible to exaggerate the horror of the camps. ${ }^{12}$ None of that is evident in the light-hearted caption ("little black compatriots") attached to the visibly malnourished children and toddlers.

11 "Altenburger Zeitung für Stadt und Land, April 10, 1906.

12 For a discussion of the photographs from POW camps during the Herero War, see Joachim Zeller, "Wie Vieh wurden hunderte zu Tode getrieben und wie Vieh begraben': Fotodokumente aus dem deutschen Konzentrationslager in 


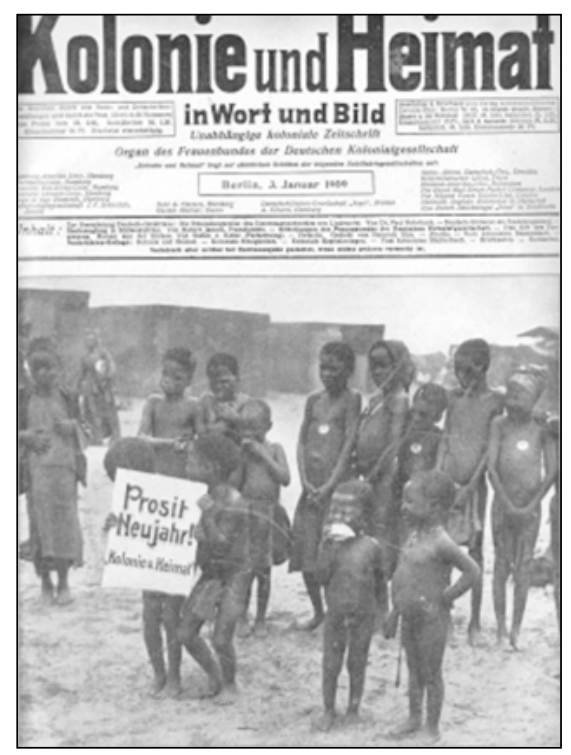

Figure 2. "Idyll in a Herero Village (werft)." Photograph taken in a concentration camp by Müller. Source: Kolonie und Heimat, January 3, 1909, 1 .

In the following weeks and months, the image circulated in Germany as a picture postcard. More than a consumer product to be purchased, sent, sold, and traded, it became a media palimpsest. Whether as window dressing, postcard, or illustration, the image produced new meanings again and again. One example is its reprinting in a popular colonial journal in 1909 (Figure 2).

The image is the same as that displayed in the Altenburg shop window three years earlier, but cropped and retouched. In the context of a concentration camp, the children holding a sign that reads "Cheers! Happy New Year!" might appear rather cynical, but the new caption "Idyll in a Herero Village" suggests that the picture was taken in front of typical Herero dwellings outside a colonial city. It is unclear whether readers were aware of the photograph's actual origin and were amused by the caption or whether they sincerely believed the caption that transformed the memory of a murderous war into a happy idyll. Whatever contemporaries would have answered, pictures of Herero and Nama prisoners formed part of a racist media practice with new distribution and exhibition contexts producing their own colonial reality. Film was also a part of this practice.

No comprehensive tally of films shot in the camps exists. However, films, such as Bilder aus dem Kriegs- und Friedensleben [Images of War- and Peacetime] from Robert Schumann, 1907; Land und Leute in Deutsch-Südwest-Afrika [Land and People in German Southwest Africa], from Deutsche Mutoskope und Biograph, 1907; Südwest-Afrika from Deutsche Bioscope, 1907; and the films made by Müller were among those depicting the war and its aftermath. ${ }^{13}$

Swakopmund/Namibia 1904-1908," Zeitschrift für Geschichtswissenschaft 3 (2001): 226-243.

13 At least in one case we know about a film that was shot in a prison camp in German East Africa. The Pathé catalogue lists the film "Un bagne en Afrique orientale allemande" [A penitentiary in German East Africa], April 1910. According to a brief summary, the film showed "the rude and miserable life 
To understand the films in a film-historical context requires more than just labeling them "colonialist"-which is tantamount to formulating a tautology, as media historian Klaus Kreimeier remarks. ${ }^{14}$ More productive is to address how film in colonial times organized "views" and visual regimes.

\section{The Colonial Travelogue Film in Wartime}

Examination of surviving films as well as the titles, reviews, advertisements, and summaries of films that have been lost reveals that the form considered most appropriate for representing the colonies to the national film audience was the travelogue. Generally composed of a montage of emblematic scenes, travelogues were one of the most popular genres in early cinema for illustrating foreign places or regions. As Jennifer Peterson remarks, they served "as vicarious travel, as a substitute for actual travel that could be experienced by those without the financial means to tour around the globe."15

The travelogue relies on the aesthetic of the "view," which film historian Tom Gunning calls the Urform of early documentary film. ${ }^{16}$ The term highlights "the way early actuality films were structured around presenting something visually, capturing and preserving a look or a vantage point." ${ }^{17}$ The "view" is a constituent element in a "cinema of attractions" that focused on showing, rather than telling, stories and was the dominant form before $1906{ }^{18}$ The cinema of attractions "directly solicits spectator attention, inciting visual curiosity, and surprisingly pleasure through an exciting spectacle-a unique

of a prisoner in Africa: putting chains on the prisoners' neck, visit of the director, the labor duties (les corveés) with wood, water, and stones, the meals, and the punishments." Even though we cannot rule out that the film was shown in Germany, no evidence exists in the German trade journals that the film was officially distributed or sold in Germany. Henri Bousquet, ed., Catalogue Pathé des Années 1896 á 1914, 1910-1911 (Buressur-Yvette: Bousquet, 1994), 282.

14 Klaus Kreimeier, "Mechanische Waffen und Haudegen überall: Expeditionsfilme; Das bewaffnete Auge des Ethnografen," in Triviale Tropen: Exotische Reise- und Abenteuerfilme aus Deutschland 1919-1939, ed. Jörg Schöning (Munich: edition text + kritik, 1997), 47.

15 Jennifer Peterson, "'Truth is Stranger than Fiction': Travelogues from the 1910s in the Nederlands Filmmuseum," in Uncharted Territory: Essays on Nonfiction Film, eds. Daan Hertogs and Nico de Klerk (Stichting: Nederlands Filmmuseum, 1997), 78.

16 Tom Gunning, "Before Documentary: Early Nonfiction Films and the 'View' Aesthetic," in Hertogs and de Klerk, Uncharted Territory, 14.

17 Ibid.

18 Gunning, "The Cinema of Attractions," 56. 
event, whether fictional or documentary, that is of interest in itself." ${ }^{19}$ However, in contrast to an attraction, like a filmed comedic gag or vaudeville act, Gunning considers the view as possessing a "greater claim to recording an event of natural or social history." ${ }^{20}$

"Views" tend to carry the claim that the subject filmed either pre-existed the act of filming (a landscape, a social custom, a method of work) or would have taken place even if the camera had not been there (a sporting event, a funeral, a coronation), thus claiming to capture a view of something that maintains a large degree of independence from the act of filming it. ${ }^{21}$

In film, the view does not simply unfold a landscape in front of the viewers' eyes, but emulates the act of looking, so that the camera "literally acts as tourist, spectator or investigator." 22 The audience's pleasure in the "view-film" thus lay in the "surrogate of looking." 23

The "views" of the travelogue explore what Peterson calls a "central obsession of Western visual culture from the nineteenth century through the First World War: images of the other and of other places and images of the changing modern world." ${ }^{4}$ As viewers explored the exotic world of the Other, the conventions of the travelogue genre demanded "fascinating yet potentially threatening moving images." 25 In other words, while the travelogue's formulaic structure presented a wide range of exotic views, its explorations were secured by "the familiar confines of the travelogue genre."26

It is this tension between the "different" and the "normal" that fuels the travelogue. It is a delicately-balanced polarity: crudely put, the place presented must merit the curious filmgoers' gaze, therefore the place must be (constructed as) exotic, yet in this presentation there is at the same time a certain disavowal of that exoticism, a desire to mark what is Other and then contain it, to keep it at arm's length. ${ }^{27}$

This tension has been highly efficacious and adaptable, as Peterson points out, characterizing the colonial and exotic landscapes of film as European locales. ${ }^{28}$ Travelogues refer to places that exist in the real world, but, as representations,

19 Ibid.

20 Gunning, "Before Documentary," 14.

21 Ibid.

22 Ibid., 15.

23 Ibid.

24 Peterson, "Truth is Stranger than Fiction," 76.

25 Ibid.

26 Ibid.

27 Ibid., 81.

28 Ibid., 76. 
they present an entirely new "idealised cinematographic geography" that exists geographically only on the screen. ${ }^{29}$

When analyzing representations of colonies, the travelogue's ambivalence - its confining the exotic to a strict set of conventions-must be further differentiated. While colonial travelogues certainly addressed their audiences through exotic locations and visual novelties, it was not merely genre convention that defined the experience of the exotic Other. Colonial travelogues explicitly tried to subdue the exotic by emphasizing colonies' most familiar aspects; colonial ideology did not want to unnerve people, but to attract them. The "view" aesthetic in colonial travelogues thus has an important secondary connotation. John Noyes points out that the appropriation of space is a key issue in German colonial discourse, closely related to the way of looking: "When the colonizer arrives in a new territory, the gaze with which he surveys it is an initial appropriation of space. It defines spaces of objectivity and establishes relations between these spaces." 30 The organization of colonial space into structures was therefore "conducive to the functioning of the colony." ${ }^{11}$ To watch colonial films with the colonial "view" means, for instance, to be aware of the particular power relation between scenes of colonizers and colonized or of how the sequential logic of a travelogue was organized.

One of the first travelogues from the German colonies to reach German cinemas was Südwest-Afrika in 1907. The film has not survived, but, since early films were not rented but sold, a production company handbill provides information about the film's content. The film was made in 1907 by a German, Georg Furkel, for Deutsche Bioscope. ${ }^{32}$ Other clients included a railroad construction company, Lenz \& Co., that ran its own work camps, impressing Africans into forced labor. ${ }^{33}$ The various "views" listed in the advertisement (Figure 3) evidence the influence of political events: While the shot order in travelogues often appears scattered and loose, a closer look at Südwest-Afrika shows that the composition of the individual shots seems to follow a visual dramaturgy in which recent events in German Southwest Africa are integrated

29 Jennifer Peterson, "World Pictures: Travelogue Films and the Lure of the Exotic 1890-1920" (PhD thesis, University of Chicago, 1999), 32. John Noyes, Colonial Space: Spatiality in the Discourse of German South West Africa 1884-1915 (Chur: Harwood Academic Publishers, 1992), 163.

31 Ibid., 18.

32 Parallel to this, the Deutsche Mutoskope- und Biograph $\mathrm{GmbH}$ released "Leute in Südwest Afrika" [People in Southwest Africa] with "original scenes from the theatre of war [Kriegsschauplätze]," Der Komet, no. 1162, June 20, 1907,2 . No information about the content of this film could be found.

33 Georg Furkel, "Film vor 30 Jahren," Der Kinematograph, November 7, 1926, 15-16; ibid., November 14, 1926, 11-12; ibid., November 21, 1927, 11-12. 


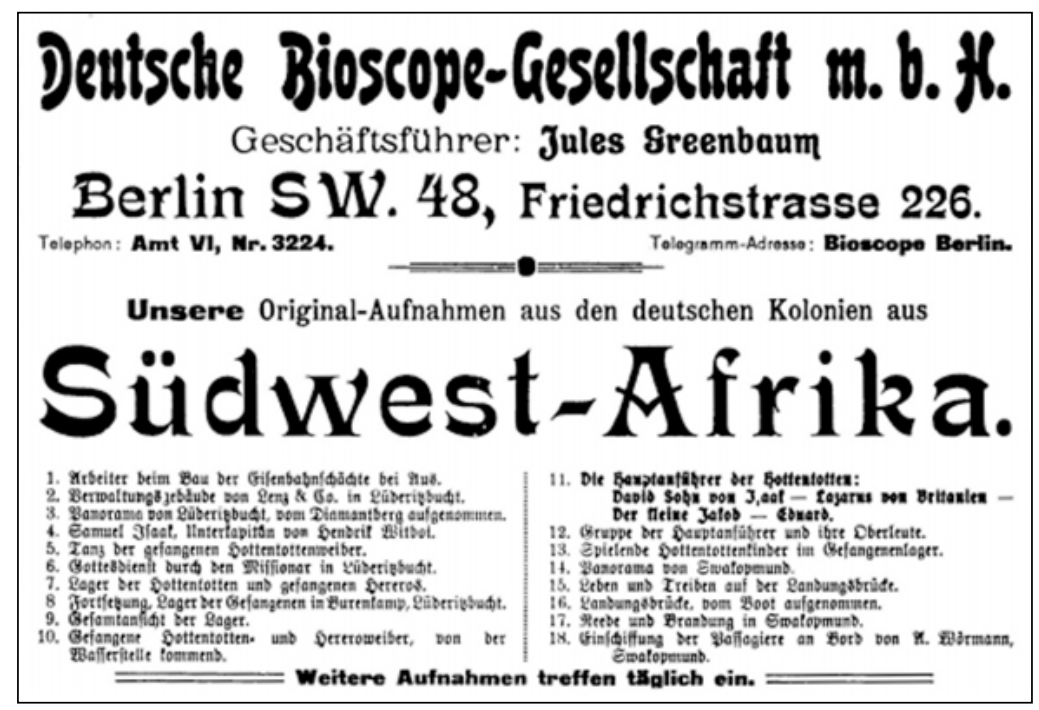

Figure 3. Advertisement for the Deutsche Bioscope film Südwest-Afrika by Georg Furkel, 1907. Source: Der Komet, no. 1158, June 1, 1907, 16.

into processes of colonization and progress. ${ }^{34} \mathrm{~A}$ violent past is softened by the film's sequential logic.

The film starts with shots of workers, company property, and the bay:

(1) Workers at the construction sites of railway shafts near Aus.

(2) Administration buildings of Lenz \& Co. in Lüderitzbucht.

(3) Panorama of Lüderitzbucht from Diamond Mountain.

The next nine scenes are dedicated to the Herero and Nama ("Hottentot") prisoners:

(4) Samuel Isaak, subcaptain of Hendrik Witboi.

(5) Dance of imprisoned Hottentot women.

(6) Religious service by the missionary in Lüderitzbucht.

(7) Camp of the Hottentot and imprisoned Herero.

(8) Continuation, POW camp in Burenkamp, Lüderitzbucht.

(9) Overall view of the camp.

(10) Captive Hottentot and Herero women returning from fetching water.

(11) The main leaders of the Hottentot: David, son of Isaak-Lazarus of Britain -The small Jakob-Eduard.

(12) Group of the main leaders and their subordinates.

(13) Hottentot children playing in the POW camp.

34 Peterson, "World Pictures," 126. 
In this second series of scenes, number eleven, printed in boldface, was apparently intended to be the film's highlight: the leaders of the Nama warriors. After this climax, the next seven shots show Nama children playing in the concentration camp, a panorama of Swakopmund, life on the jetty, roads and shore, and, finally, passengers boarding a steamer:

(14) Panorama of Swakopmund.

(15) Hustle and bustle on the jetty.

(16) Jetty, taken from a boat.

(17) Harbor and surf in Swakopmund.

(18) Passengers boarding the A. Wörmann, Swakopmund.

The three groups of shots-Lüderitzbucht, POW camp, Swakopmund-establish rather different spaces in the same locality.

The high point of Südwest-Afrika is plainly meant to be the depiction of the rebel leaders in scene eleven, while its contextual integration reassures viewers that the colony is a safe place to live and travel. ${ }^{35}$ In contrast to the POW camp, the opening and concluding scenes, panoramas of colonial cities and progress, emphasize more picturesque aspects. Framed by the construction of infrastructure and the boarding of an ocean liner, the film touts the colonies as a place worth visiting. Likewise, the opening and closing panoramas bracket reminiscences of the colonial war, so that the most violent period in German colonial history becomes integrated into a discourse of progress and peaceful everyday life. ${ }^{36}$ Südwest-Afrika can be considered an example of colonization's creation of discrete spatial units facilitating control and administration of the geographic territory. With Africans fenced into POW camps, traces of the Other have been effaced from colonial territory which is now ready to be filled with colonizers' presence.

Attention to the sequence shows that the film was carefully composed: The three groups of scenes provide a narrative flashback into the history of German Southwest Africa. The transition to the POW camp reminds viewers that the war has only recently ended. The sequence could be seen as an illustration of Michel de Certeau's conception of the division of space as a panoptic practice, ${ }^{37}$ with its views functioning like a surveillance camera to monitor the prisoners. But the prison sequence is not merely a document of punishment:

35 Der Komet, no. 1158, June 1, 1907, 16.

36 One could also argue that the monitoring look of the camera in the POW camp sequence makes possible the integration into the filmic discourse of peace in the colony.

37 Michel de Certeau, The Practice of Everyday Life, trans. Steven Randall (Berkeley, CA: University of California Press, 1984), 36, quoted in Noyes, Colonial Space, 129. 
It also presents the work of missionaries. The POW camp becomes the place where African warriors come to Christ-a beneficent reformatory. ${ }^{38}$

The transition from the POW camp to more pleasant views, such as the panorama of Swakopmund, is mediated by a depiction of children playing, just as the missionary is introduced by the dancing of scene five. Was the transition from Herero fighters to children intended to denigrate the enemy or merely to show that the Herero no longer threatened German life in the colony? Since the film has been lost, we cannot know for sure whether the montage meant to evoke colonialist arguments of the colonized as children or whether the children reprised the dancing women. The film was not intended as a shocker, as its use of landscapes, women, and children indicates. They lend the film an alternating rhythm of threat and amusement, following genre conventions that Peterson describes as a continuous "acting-out of tensions between attraction and repulsion." ${ }^{39}$ Gunning contends that early films make us uncomfortable, because they make the ambivalent power relation of the "view" aesthetic so explicit: The voyeurism of the tourist, the colonialist, the filmmaker, or the spectator reveals itself in the films without the overvoiced narrator or the exculpatory political rhetoric familiar from later documentaries. ${ }^{40}$ The film shows that images rife with implicit racism, violence, and degradation easily found their place within a discourse of spectacle and tourism.

\section{Rudolf Pöch's POW-Camp Films of 1915}

The aesthetic of early cinema, in the form of the "cinema of attractions" and the "view," guaranteed the long-lasting popularity of the travelogue genre and also left its traces on early anthropological filmmaking. "As an Anthropologist in a POW Camp-Rudolf Pöch's Films of 1915" is an archival compilation of Pöch's original film material, published by the Austrian Federal Institute for Scientific Film and includes all fifteen of his surviving ethnographic films. ${ }^{41}$

38 The same reformatory impulse also characterizes Müller's picture postcard of the Herero children that was first presented in the Altenburg shop window. As a postcard, it circulated with the title "Wissbegierige Hereokinder mit Gefangenenabzeichen" [Inquisitive Herero children with prison-camp tags]. The new title does not hide the location of the POW camp, but implies, at the same time, that the presence in the camp serves colonial educational purposes.

39 Peterson, "Truth is Stranger than Fiction," 76.

40 Gunning, "Before Documentary," 24.

41 Andrea Gschwendtner, Als Anthropologe im Kriegsgefangenenlager-Rudolf Pöchs Filmaufnahmen aus dem Jahre 1915, Film P 2208 des ÖWF, Wien. 
(1) The first film shows a theatrical performance, "Wedding Ceremony." The wedding party stands in the foreground, with a male prisoner playing the bride. In the background, we see other prisoners in a semicircle, watching. At the left are two musicians. Various actors enter the frame, including some playing a dancing bear and his tamer, performing (possibly) traditional wedding dances for the bridal couple.

(2) Pan from right to left over the ceremony's audience.

(3) Wrestling match. Three men take turns, with the third acting as referee.

(4) A Russian dance with musicians in the background.

(5) A second Russian dance with musicians in front of a shack.

(6) A third Russian dance. Two men clap the rhythm for the dancing colleague.

(7) Group dance performed by eight men.

(8) Muslim prayer ritual.

Seven scenes of craft manufacturing follow the outdoor scenes above:

(9) Weaving straw shoes. The scene is composed of two shots illustrating different stages in the manufacturing process.

(10) Making a balalaika.

(11) Whittling bone. From a medium objective, a second shot moves the camera closer to allow viewers to follow the craft in more detail.

(12) Turning a coin into a ring.

(13) Making a wooden pigeon (interior?).

(14) Making a toy snake (interior?).

(15) Making a plaster cast of a prisoner's face. This process is shown in two additional shots.

Not knowing the exact sequence in which Pöch projected the films or the context in which they were shown, an analysis can only be tentative. However, the surviving films do invite questions about the influence of contemporary film aesthetics on early anthropological filmmaking.

In his initial report on his work in the POW camps, Pöch remarks that his possibilities were limited from the outset. ${ }^{42}$ The artificial setting and the lack of traditional costumes, he claimed, made "real" ethnographic film impossible. In contrast to his overseas expeditions, where, as Andrea Gschwendtner points out, Rudolf Pöch claimed not to intervene in the profilmic event in the camps he felt that anthropological "authenticity" had to be carefully staged. ${ }^{43}$

Österreichisches Bundesinstitut für den wissenschaftlichen Film 1991. See the supplementary information to the film in Gschwendtner, "Als Anthropologe im Kriegsgefangenenlager," 105-118.

42 Pöch, "1. Bericht," 230.

43 Gschwendtner, "Als Anthropologe im Kriegsgefangenenlager," 116. 
The compilation does not presume to follow any original order in which the films were spliced for presentation. However, the two groups correspond to the aesthetic conventions of the "attraction" and the "view." ${ }^{4}$ The first group focuses on kinetic events, like dances, leisure, and entertainment, corresponding to Gunning's notion of the "cinema of attractions." The panorama shot (2) over the crowd of prisoners has no anthropological value other than to emphasise that wedding dances are visual spectacles-for guests as well as the camera. The prisoners are obviously performing for the camera, acknowledging its presence either by looking directly at the lens or communicating with the operator or his assistants. The staged character of their performances receives additional emphasis from the visible presence of the camp: In almost all the outdoor scenes in the first group, except the "group dance," fences and guards are clearly visible. They form the rear edge of the "stage" and become part of the performance by continually marching in and out of the frame. The similar number of "attractions" and "views" raises the question of how the films were screened: Were the two genres projected alternately or in sequence, as in the compilation?

A close look at (3) and (6) shows that Pöch had a cast. Not only is the location the same, but also the actors. Pöch apparently chose his performers according to their skill with the camera. His reports describe how scenes were staged and rehearsed. ${ }^{45}$ The same goes for (4) and (5), but with a striking change of backdrop: The cast appears to be the same, but (4) is shot in front of the camp fence, while the next dance takes place in front of a shack. Why did Pöch change the scenery? Did he worry that a backdrop of fences and guards might distract viewers from the performance or detract from the film's anthropological quality?

In contrast to the theatricality of the first group, the craft scenes of the second group of films reflect Gunning's aesthetic of the view. However, in contrast to a travelogue that explores various aspects of a city, region, or country, viewers here do not explore space. Instead, the film's "dominant organization principle is temporal, detailing the stages of a process in a logical order." ${ }^{\prime 66}$ The overall principle of (9), (11), and (15) is the two-shot film in which the second shot either offers the viewer a better perspective on the manufactured item as in (11) or shows a further stage in production as with (9) and (15).

44 In his reports, Pöch does not mention the exhibition context of his films. Unfortunately, it was impossible to have access to Pöch's personal files and records due to an ongoing research project on Pöch by the Austrian Research Foundation titled "Rudolf Pöch-Anthropologe, Forschungsreisender, Medienpionier," FWF-Forschungsprojekt P17761-G6, 2005. See also http://poech.fox.co.at (accessed May 21, 2010).

Gunning, "Before Documentary," 17. 
The most striking sequence in the film is certainly the plaster casting of a prisoner's head, the final scene in the compilation. It is composed of two shots. The first outdoor shot shows two scientists, masked with white hoods, applying plaster to a prisoner's head. Straws in his nostrils prevent asphyxiation. Another prisoner assists by mixing plaster in a bowl. The second shot shows final steps in reproduction. Two men, presumably the same as in the previous shot, display their skill in turning the plaster mold into a replica of the prisoner's head. In contrast to the previous shot, the scholars are now casually dressed with turned-up sleeves and caps more reminiscent of Bohemian sculptors than academics. The staging of the second shot recalls a magic trick or a presentation of the latest technical wonder. Vaudeville acts were often included in early film programs that combined entertainment with science and education.

What makes the sequence unsettling is not only the scientists' white hoods, but their callous treatment of the prisoner. The "original" is obviously of less value to them than the reproduction. While the filmic documentation of anthropological method stands in remarkable juxtaposition to the documentation of the craft techniques of the prisoners, the didactic purpose of the concluding film comments on anthropology's aim to "record for posterity" in its own particular way.

Pöch was not a commercial film operator by trade. However, a handbook of ethnographic filmmaking that he wrote in the 1910s shows that he was familiar with early film aesthetics. ${ }^{47}$ His technical recommendations incorporate an aesthetic dimension. He recommends that anthropological filmmakers, beyond thinking about how to shoot wirksame [effective or striking] images, take time to study successful programming in local cinemas. Models available there followed Gunning's "view" aesthetic: tinted or hand-colored nonfiction films, with the formulaic structure of the travelogue. Pöch's recommendations suggest that popular commercial films serve as models for scientific work. He seems to have been interested in reaching a broader audience. This interest is evidenced by his allowing his anthropological photographs and casts of prisoner's heads to be displayed at the Viennese War Exhibitions of 1916 and $1917^{48}$

Pöch seems to have quit filming in the camps by September 1915. We do not know his reasons. It is possible that the footage obtained was already suf-

47 I would like to thank Dr. Susanne Ziegler from the Phonogram Archive at the Museum of Ethnology in Berlin for drawing my attention to this document, which could be identified as having been written by Pöch. Untitled File, Berliner Phonogramm-Archiv, Staatliche Museen zu Berlin-Preußischer Kulturbesitz, Ethnologisches Museum. berichte, 36-37. 
ficient for his aims. Perhaps he was dissatisfied with the need for intervention in film shots that made them appear less authentic to him. This perception seems to be behind his statements to the effect that staged events could never substitute for fieldwork on site. Moreover, a comparison of his films with the travelogues he appears to have imitated shows that aesthetic considerations moved his films toward the realm of popular "attractions" and "views." This may have been a deeper source of his dissatisfaction with filming in the camps. After September, 1915, Pöch concentrated almost exclusively on physical anthropology, which would remain his specialty as well as that of his students.

Pöch may have realized that images from POW camps inevitably entail a kind of voyeurism that anthropological filmmaking simultaneously feared and had never been without. His motives to stop filming in the camps-whatever they may have been-seem to point to an epistemological problem for the genre as a whole. He and his films both suffered under their limited scientific value. As evidenced in his films' apparent similarity to the commercial offering Südwest-Afrika, what distinguishes Pöch's films from popular cinema cannot be located in the images themselves, but only in the scientific context. Stripped of their scientific aura, his films exploit the same Schaulust and unleash the same pleasures, powers, and dangers of looking.

Pöch's POW-camp films mark the end of ethnographic film's initial phase. Even before he began work, discussion of the value of film for ethnography was in full swing. The medium was rapidly losing its credibility as a purely documentary technology, as the private correspondence between two German ethnographic filmmakers shows: In letters dating from 1914, Theodor KochGrünberg and Fritz Krause agree that ethnographic film can only illustrate the spoken word. ${ }^{49}$ Only with forceful contextualization by the lecturerthe ethnographer-could ethnographic film images produce ethnographic meaning. ${ }^{50}$

A turn to the narrative aesthetic that came to dominate popular entertainment solved ethnographers' dilemma of producing films that did not require accompanying lectures which guided the viewers' attention and understanding. "Attractions" and "views" did not disappear, but they became integrated into producer-driven narratives, establishing a new rhetoric in nonfiction film-the documentary.

49 VKMr A 14. Nachlass Theodor Koch-Grünberg at the Institut für Vergleichende Kulturforschung, Phillips-Universität Marburg.

50 Ibid. 

Afterword 



\title{
After the Great War: National Reconfigurations of Anthropology in Late Colonial Times
}

\author{
ANDRE GINGRICH
}

The ways in which we formulate our research questions always inform the results we obtain. "Anthropology in times of war" is a good example of a field in which to examine the formulation of research questions. A comparative perspective including present-day examples of, say, anthropologists "embedded" in US combat units during the Iraq war since 2003, or German anthropological counseling for NATO operations in northern Afghanistan in 2007, together with historical examples from World Wars I and II perhaps would yield results with a much stronger emphasis upon the more general fields of ethical dilemmas and of the constraints and risks that are involved in any anthropological engagement during times of war. By contrast, a discussion of "anthropology in times of war" through an exclusive focus on World War I is bound to emphasize the very specific historical circumstances and contingencies of that particular era and their impact upon academic developments. Such a focus is established throughout this book, and quite appropriately so in view of how little we still know about that crucial phase of the early twentieth century, about the anthropological disciplines' role in it, and how those years of armed conflict shaped the divergent courses of anthropological research.

The focus chosen for this volume therefore privileges the historical specificities of the World War I era. In many ways, World War I and its outcome put an end to a "long nineteenth century" and to some of its main imperial antagonists in Europe. The significance of colonial troops and of colonial interests, however, was substantial, and the role of the United States in the last year of the war outright decisive. Both factors-the colonial dimension and the USA's part in the war's outcome-make the term "World War" more than merely technical. From the outset, the global element in the term in fact indicates an earlier phase of globalizing tendencies that do connect that distant past with 
the present era. Those tendencies were shaped by late colonial and imperial rivalries which constituted the core of the Great War.

If our research questions to an extent always inform our results, then these questions are also inspired by the times and circumstances in which we live. Addressing in the early twenty-first century the interface between World War I and anthropology almost unavoidably introduces global and postcolonial perspectives. These perspectives are immediately and obviously relevant in the context of the colonial and transatlantic dimensions of this book's focus on World War I. In the context of anthropology's own history of that era, however, these perspectives are not so self-understood.

During the early years of the twentieth century, anthropology was increasingly elaborated in very diverse national directions, thereby leaving behind many of the global dimensions the anthropological fields had shared during their previous formative phases. In this sense, anthropology became part of the "end of scientific internationalism," as some ${ }^{1}$ have called what World War I accelerated, as well as brought about, across a whole range of academic fields. My present contribution ${ }^{2}$ argues that, as an outcome of World War I, an entirely new global academic landscape became established in the anthropological fields along national or quasi-national lines. These differing national directions soon gained momentum of their own and established themselves as new research traditions. The first part of this chapter presents a short overview of the major clusters of these new national anthropological traditions. Then, the second part addresses the German-speaking anthropological record in its World War I and post-World War I dimensions, as one core element in that new setting of nationalization in global anthropology. Institutional and disciplinary dimensions, methodological and theoretical orientations, as well as key actors and their political agendas will be assessed to identify some of the major contrasts and intersections among the national and quasi-national anthropological records.

1 Elisabeth Crawford, Nationalism and Internationalism in Science, 1880-1939: Four Studies of the Nobel Population (Cambridge, UK: Cambridge University Press, 1992); for the nineteenth century's last quarter, see also the excellent analysis by Chris Manias, "The Race prussienne Controversy: Scientific Internationalism and the Nation," Isis 100 (2009): 733-757.

2 For their very helpful comments and suggestions about an earlier version of this chapter, I am particularly grateful to Matti Bunzl (Urbana-Champaign), Henrika Kuklick (Philadelphia), Britta Lange (Berlin-Vienna), Peter Schweitzer (Fairbanks), and Maria Six-Hohenbalken (Vienna). I also thank Monique Scheer (Berlin) and Reinhard Johler (Tübingen) as coeditors of this volume and as hosts of the preceding conference for their substantial input. Finally, I wish to thankfully acknowledge the editorial assistance of Julene Knox (London). 


\section{Anthropology's Emerging National Traditions during World War I}

The rationale of the present argument claims that national and quasinational traditions constituted the core of anthropology's history throughout the "short twentieth century" (1914-1989), spanning what we today may call anthropology's first modernity. These hegemonic, competing national traditions emerged before, during, and after World War I and became fully established as a by-product of World War I. The global and postcolonial perspectives of anthropology today in its second modernity will thus also allow us to raise new questions about the eve of that first modernity, when the late colonial world had already become increasingly global in commercial, political, and military ways, while anthropology embarked upon its diverse national trajectories.

\section{Two Traditions Apart: the SOVIET Union (RUSSia) AND the USA}

The two countries that were to emerge from World War II as the superpowers of the Cold War both played very different, but equally discontinuous, roles during World War I. Imperial Russia was the major eastern ally of the western powers until the Czar's Empire collapsed in 1917. After Lenin's Bolshevik party came to power with some German assistance, the new leaders signed a separate peace accord in Brest-Litovsk with the Central Powers, which signaled a possible change of developments for the western front as well. The United States, on the other hand, had refrained from entering World War I until that point, but their eventual participation effected the decisive turning point for the war's outcome. Toward the end of the war, the leaders of both countries thus were able to present themselves as rival messengers of a new era, and as representing political forces with programs that were entirely distinct from those of other main antagonists in World War I. In particular, this messenger role related to national and colonial questions. On behalf of the United States, Woodrow Wilson presented the "fourteen points" program with its emphasis on sovereignty and self-determination. Again, in a different, but parallel, emphasis, Lenin's party declared that self-determination of oppressed nations and colonies was part of its political agenda. Beyond their widespread propaganda effects upon public opinion in Europe and elsewhere, these declarations also had a limited and partial practical impact upon the treaties of Brest-Litovsk, St. Germain, and Versailles.

The courses that anthropology took during the war years in both countries were quite different from each other and, in fact, also from what went on in 
western and Central Europe. For the Russian Empire, Marina Mogilner ${ }^{3}$ shows how deeply physical anthropology was institutionalized within the army, where it contributed to the Czar's war effort. This kind of physical anthropology largely followed a descriptive and pragmatic orientation, which only reluctantly accepted the inclusion of ethnic and national criteria and displayed little inclination toward any explicit racism. Taken together, the three main schools of physical anthropology before 1917 did play a more central role in imperial academic life than the various larger and smaller centers of ethnography, which mostly led a relatively separate existence only at museums. So far, little evidence has come to light of any substantial involvement of Russian ethnography in the World War I effort.

The institutional beginnings of Soviet ethnography had emerged out of the Petrograd Institute of Geography, and Soviet ethnography would always maintain a specific disciplinary affinity to geography. After the 1917 revolutions, the relationship between physical anthropology and ethnography in Russia became almost inversed. Physical anthropology under Soviet rule was downgraded to a position of minimal significance. By contrast, ethnography received growing attention and public support under the Marxist premise of what was now becoming the Soviet Union. The underlying reasons were political, in an ideological as much as in a pragmatic sense: In ideological terms, it was believed that ethnography-in the evolutionist tradition of Karl Marx's and Friedrich Engels's interpretations of L. H. Morgan's works-could provide additional substantiation for Marxist theory. In pragmatic political terms, ethnography was regarded as a key tool for ruling the non-Russian peoples of Siberia, central Asia, and the Caucasus regions. In spite of these dramatic shifts of political and institutional contexts, and notwithstanding the formal insertion of Marxist dogma, Peter Schweitzer ${ }^{4}$ has shown that some continuity with pre-1917 Russian ethnography was maintained well into the early 1930s, which was primarily based on the work of Lev Sternberg and Vladimir G. Bogoras. ${ }^{5}$ Both were evolutionists, but while Sternberg was close

3 See Marina Moligner in this volume; see also idem, "Russian Physical Anthropology in Search of 'Imperial Race': Liberalism and Modern Scientific Imagination in the Imperial Situation," Ab Imperio 8, no. 1 (2007): 191-223.

4 Peter Schweitzer, "Siberia and Anthropology: National Traditions and Transnational Moments in the History of Research" (habilitation thesis, University of Vienna, 2001).

5 Igor Krupnik, "The 'Bogoras Enigma': Bounds of Culture and Formats of Anthropologists," in Grasping the Changing World:Anthropological Concepts in the Postmodern Era, ed. Vaclav Hubinger (London: Routledge, 1996), 35-52; idem, "Jesup Genealogy: Intellectual Partnership and Russian-American Cooperation in Arctic/North Pacific Anthropology, Part I, From the Jesup Expedition to the Cold War, 1897-1948," Arctic Anthropology 35, no. 2 (1998): 199-226. 
to Marxism and had been quoted by Engels, Bogoras displayed some affinity to German geographic diffusionism, including the work of anthropogeographer Friedrich Ratzel. In a way, therefore, evolutionist Marxism combined with some less visible Ratzelian influences ${ }^{6}$ was forging the new Soviet ethnography, with its primary focus on non-Russians in the USSR, a strong historical and a weaker social science component, and a rigid territorial emphasis on typological distinctions.

This first strand of Soviet ethnographic tradition continued until the late 1930s, when it was destroyed by Stalin's terror. After 1945, a second strand of ethnographic tradition had emerged, which partially built on the first through key concepts, such as "historical-ethnographic provinces." The second tradition was exported, and was imposed upon many other countries of the communist world in east Central Europe and elsewhere.

In the United States, Franz Boas had established what became known as the four-field approach in anthropology already some time before 1914. Including physical, archaeological, linguistic, and cultural anthropology, this approach could steadily consolidate and expand while the United States refrained from entering the war. During these first war years, Boas's reputation suffered a public and institutional setback after he criticized anti-German spy activities among some of his American colleagues. It took him and his supporters several years to overcome this setback after the war. The influence of nineteenthcentury German liberal academic traditions upon Boas's four-field approach has often been outlined, and quite rightly so. ${ }^{7}$ It is also necessary to emphasize that, while Boas had left some of the less liberal German traditions behind him, he also modified and reshaped those elements that he did take with him, giving them new directions for their new US contexts. Within the four-field approach, for instance, the four subfields basically enjoyed an equal standing that had not been understood in the German context from which Boas had taken inspiration and where physical anthropology continued to dominate. It is also noteworthy that, in the United States, the four-field approach never explicitly included folklore studies. ${ }^{8}$ Boas had initiated the foundation of an

6 The most prominent Ratzelian in Soviet ethnography was Petr Fedorovich Preobrazhenskiy, who, in the course of Stalin's terror, was arrested in 1937 and shot in 1941 (Schweitzer, "Siberia and Anthropology").

7 Matti Bunzl, "Franz Boas and the Humboldtian Tradition: From Volksgeist and Nationalcharakter to an Anthropological Concept of Culture," in Volksgeist as Method and Ethic: Essays on Boasian Ethnography and the German Anthropological Tradition, ed. George W. Stocking Jr. (Madison, WI: University of Wisconsin Press, 1996), 17-78; Douglas Cole, Franz Boas: The Early Years, 1858-1906 (Vancouver: University of Washington Press, 1999).

8 In this chapter, I apply the term "folklore (studies)" in the sense in which it was used at the beginning of the twentieth century in the English-speaking 
academic folklore association and a corresponding journal, ${ }^{9}$ but he envisioned an institutional and academic development for these folklore studies apart from, and outside of, anthropology proper. This was an evident continuation of J. G. Herder's distinction between Naturvölker and Kulturvölker. With its focus on the respective domestic majority population, this kind of folklore approach paralleled similar developments in the Germany of Boas's times.

In theoretical and methodological terms, the four-field approach promoted close interdisciplinary cooperation between the natural sciences and humanities on an explicitly nonracist basis, which avoided the establishment of any quick correlation between physical and cultural diversities. With its focus on local histories and empirically corroborated diffusion processes, Boas's program accentuated the basic equality of human biological and cultural diversity. Academically and intellectually, this program was already fairly well established within the United States toward the end of the war. In physical anthropology, some schools competed with the Boasians, and several among them pursued explicitly racist orientations until well into the late 1920s. To some extent, Boas's program received a certain public boost from Wilson's Fourteen Points, when they became part of general discourse and public opinion. The political call for national self-determination and an academic program focusing on humans' biological and cultural equality corresponded with each other. US-American interwar isolationism, however, did not create too friendly an environment for the Boasian enterprise at first. Still, the intellectual influence of Boasian anthropology slowly but gradually continued to grow within and also beyond the United States after World War I. In an institutional sense, however, the four-field approach was not going to be successful anywhere outside of North America.

\section{Two Related Traditions: the UK and France}

Henrika Kuklick ${ }^{10}$ clearly demonstrates the very limited intellectual and research impact which World War I had on anthropology in the British realm. The main academic journals of those years testify to only a modest increase in concern on the part of physical anthropology for war-related themes, and to a refined distinction between topics that were dealing with human biology

academic world and as an equivalent of what emerged at the same time as Volkskunde in German.

9 Regina Bendix, In Search of Authenticity: The Formation of Folklore Studies (Madison, WI: University of Wisconsin Press, 1997).

10 See Henrika Kuklick in this volume; see also idem, "The British Tradition," in A New History of Anthropology, ed. idem (Oxford: Blackwell, 2008), 52-78. 
and race and those that related to society and culture. In anthropology, the war years coincided with the peak of A. C. Haddon's and W. H. R. Rivers's academic influence at home, while the young Polish immigrant Bronislaw Malinowski embarked upon his ethnographic enterprise in the Pacific. By and large, the war accelerated developments that were already under way. The outbreak of the war, and his own status as an alien citizen, certainly promoted the kind of fieldwork by Malinowski that would become paradigmatic-but even that had its conspicuous precursors, which ranged from the Torres Straits Expedition ${ }^{11}$ to Heinrich Barth, Alois Musil, ${ }^{12}$ and Franz Boas. ${ }^{13}$ Other research developments that were accelerated by the war included the ongoing separation between physical anthropology and social anthropology, with continuing relevance for evolutionism in the former and its demise in the latter. Although linguistic, physical, and social anthropology remained combined in some major departments (Oxford, Cambridge, University College London), the discrete establishment of social anthropology as a social science emerged to an extent that would make it prevail in the UK, at first, and in the British Empire during the decades that followed.

Some further research may still be necessary to clarify whether British anthropologists contributed to the recruitment and training of any colonial forces. The evidence that has been presented so far, however, indicates that British anthropologists' involvement remained quite limited in most of these more applied and practical fields during World War I. ${ }^{14}$ In an intellectual sense, the Great War therefore promoted British physical anthropology's coherent integration into the natural and life sciences. By contrast, social anthropology in the UK and the British realm went through its shorter diffusionist phase only to become, under Malinowski first and then A. R. Radcliffe-Brown, part of the social sciences.

On the other side of the Channel, developments in French anthropology were not as different from the UK as one perhaps might intuitively expect. Long before World War I, Émile Durkheim had already established his sociological school, which included ethnography and social anthropology as

11 Fredrik Barth, "Britain and the Commonwealth," in One Discipline, Four Ways: British, German, French, and American Anthropology; The Halle Lectures, by Fredrik Barth, Andre Gingrich, Robert Parkin, and Sydel Silverman (Chicago, IL: University of Chicago Press, 2005), 3-60.

12 Andre Gingrich, "Ruptures, Schools and Nontraditions: Re-Assessing the History of Sociocultural Anthropology in German," in One Discipline, Four Ways, 61-153.

13 Michael W. Young, Malinowski: Odyssey of an Anthropologist, 1884-1920 (New Haven, CT: Yale University Press, 2004).

14 Henrika Kuklick, The Savage Within: The Social History of British Anthropology (1885-1945) (Cambridge, UK: Cambridge University Press, 1991). 
distinct and different parts. ${ }^{15}$ The social anthropology of Durkheim's school thus clearly belonged to the emerging social sciences, and it displayed little institutional and intellectual affinity at all to physical anthropology. One could argue that, in this sense, French anthropology at the outbreak of World War I had advanced even further than its British counterpart. This is also confirmed by the formative influence of Durkheim's reasoning upon the intellectual profile of Radcliffe-Brown. ${ }^{16}$ The war itself and its devastations, however, did not so much accelerate, but rather postpone and impede, further developments of anthropology in France. This was related not least to the fact that some of the war's most important battlefields were located on French soil. In addition, the war took its toll among some of Durkheim's most brilliant students, such as Robert Hertz. ${ }^{17}$

Both Durkheim and his immediate disciples were essentially armchair anthropologists, who appreciated the results of fieldwork by others, but did not promote it themselves. Consequently, their kind of anthropology was regarded as fairly useless in any practical sense by the French Republic in its colonial and World War I efforts. Much of the early ethnographic fact-finding by the French was carried out by missionaries, colonial administrators, or individual scholars outside the Durkheim school. The available evidence suggests a correspondingly minimal role for French anthropologists in the recruitment and training of colonial troops, although this might also require additional research. In view of the war losses and of anthropology's institutional weakness, it took Durkheim's nephew and foremost disciple Marcel Mauss some time after the war to put social anthropology back on track again. ${ }^{18}$ The Durkheim school was not the only one in France during the two decades following World War $\mathrm{I},{ }^{19}$ but its growing importance contributed to the enduring separation between ethnography and social anthropology as a social science, and physical anthropology as belonging to the natural and life sciences.

France and Britain were the two major European powers which fought and won World War I. In turn, this enabled them to reorganize the late colonial world in the war's aftermath according to their own interests. The available evidence suggests that anthropologists' academic involvement in the French and British World War I efforts was minimal. In both cases, post-World War I

15 Gérald Gaillard, The RoutledgeDictionaryofAnthropologists(London:Routledge, 2004).

16 Adam Kuper, Anthropology and Anthropologists: The Modern British School, 3rd ed. (London: Routledge, 1996).

17 Robert Parkin, "The French-Speaking Countries," in One Discipline, Four Ways, 157-256.

18 Wendy James and Nick J. Allen, eds., Marcel Mauss: A Centenary Tribute (Oxford: Berghahn, 1998).

19 Gaillard, The Routledge Dictionary of Anthropologists. 
developments in anthropology featured a wide-ranging integration of physical anthropology in the natural sciences, the ongoing academic establishment of social anthropology as a distinct social science, and thus a far-reaching separation between the two. Equally significant was the fact that neither in the British nor in the French academic landscapes did any specialized research discipline emerge that would exclusively focus on folklore studies or on any similar field. Such studies were of course carried out in Britain as well as in France. ${ }^{20}$ Scholars in this field often had their own museums and sometimes also their own journals and associations. Yet, on the level of academic teaching, degrees, and university institutions, folklore studies in the French and British national and colonial realms would always remain an integral, nonspecialized subfield of social anthropology. This inclusion into social anthropology more broadly, and its simultaneous separation from physical (or biological) anthropology, demarcates a distinct, northwest European trajectory in anthropology's first modernity. If World War I had any effect on this tradition, then it was in a double sense: The war helped to further consolidate this orientation, and its implementation after 1918 promised to make sense of a newly arranged colonial world.

\section{A Cluster of New Beginnings: Anthropology in Europe's Newly Independent Countries}

An originally very small group of old, independent, and noncolonial European countries (among them Switzerland and the special case of Sweden's union with Norway) had gradually become enlarged during the nineteenth century as a result of the Ottoman Empire's continuing demise, leading to the establishment of the independent states of Greece, Romania, Serbia, and Bulgaria. In a sense, however, this had only been the first wave of what became a virtual flood of new declarations of independence before, during, and, most importantly, after World War I. This flood swept through northern, Central, and southeastern Europe and included Ireland (1922), Norway (1905), Finland (1917), the Baltic countries (1918), Poland (1918), Czechoslovakia (1918), Yugoslavia (1918), and Albania (1912). On an evidently less voluntary basis, this list of newly established, noncolonial countries with new borders also included, after the war, the core remainder states of two former empires, that is, Austria, Hungary, and Turkey.

Any attempt to understand anthropology's European trajectories following World War I would be quite futile without a basic acknowledgment of the fact that more than half of Europe's political landscape was redrawn and

20 Isaac Chiva and Utz Jeggle, eds., Deutsche Volkskunde_Französische Ethnologie: Zwei Standortbestimmungen (Frankfurt a. M.: Campus, 1987). 
rewritten immediately before, during, or after the Great War. None of these new countries had any colonies elsewhere. From today's perspective, some of those new states (e.g., Czechoslovakia or Yugoslavia) resembled federal rather than nation states. In their time, however, most of them certainly promised to fulfill national aspirations and longings in one way or another, and, in that sense, they did represent widespread local sentiments. Identifying, praising, and popularizing their respective national cultural traditions therefore became a pressing public agenda in the new institutional contexts of each of these countries. Where this had previously been at all possible, it was now important to redefine and reassess. Everywhere, it became necessary to collect, to document, to invent, to interpret, and to display. These were the great times of folklore studies, or of disciplines with different names but similar topics. As a cluster of specialized academic disciplines with distinct teaching programs, degrees, university departments, and, equally important, with corresponding museum collections and museums they quickly gained academic respectability and public support in most parts of northern, Central, and southeastern Europe. Studying and teaching "local cultures at home" was a political priority and thus an educational necessity which brought a number of earlier developments from the late eighteenth and nineteenth centuries to an unprecedented peak. These studies usually put a certain emphasis on historical origins, and they maintained a relatively stable focus on preindustrial rural material culture as well as on oral and musical traditions. Because of national political and ideological priorities, the methodological focus in these studies was usually not comparative, but particularist. Their historicist and particularist focus, plus their strong relationship to national language traditions, clearly placed these research records within the wider fields of the humanities. By and large, the influence of historicism and of geographical determinism was thus relatively strong in these fields. In some cases, this cross-fertilized with creative new sources of inspiration from other fields, as most notably in Polish and Czech linguistic studies. ${ }^{21}$

In most contexts in these newly independent states, ethnographic research on any cultures other than one's own was impossible for lack of funding or had little relevance because of national priorities. Some exotic ethnographic collections continued to exist as the decontextualized remains of a now bygone imperial past; the post-1918 Helsinki and Prague museum departments are two well-known cases in point. In a few other cases, the search for one's own ethnic origins had developed into very specific expertise about distant, but allegedly ethnically related cultures, as is testified by early Hungarian and Finnish exper-

21 Roy F. Ellen, Ernest Gellner, Grazyna Kubica, and Janusz Much, eds., Malinowski between Two Worlds: The Polish Roots of an Anthropological Tradition (Cambridge, UK: Cambridge University Press, 1988). 
tise in Finno-Ugric cultures. ${ }^{22}$ Both of these exotic exceptions-the by-products of an imperial past as much as the results of researching one's distant originswere easily subsumed under the typical priority given to ethnographic folklore studies. These studies represented a top political agenda in the cultural and educational fields of Europe's newly independent states after 1918. If considered at all, then certain elements of sociocultural anthropology were integrated into this priority. By necessity and by definition, the early institutionalized research activities of folklore studies in these newly independent countries could not possibly be free from nationalist ideologies, which defined and demanded their installation. Sometimes, the impact of these nationalist ideologies in academia represented one combination or another of revitalized older forms of Central European romanticism with more recent local political ideologies. The quality and the extent of these nationalist ideologies, however, differed widely. In addition, it should be emphasized that nationalist ideological elements in folklore studies per se excluded neither some degree of empirical accuracy nor liberal elements: On the contrary, some versions of nationalism may combine very well with liberal orientations within uncontested national boundaries. ${ }^{23}$

As for physical anthropology, Marius Turda ${ }^{24}$ and Christian Promitzer ${ }^{25}$ have provided exemplary historical case studies for Hungary, Bulgaria, and Serbia, while similar studies for physical anthropology in the newly independent countries of northern Europe still need to be carried out. It might still be somewhat early to draw wider conclusions from these three countries for others in Central and southeastern Europe - after all, with Bulgaria and Hungary, two of these three cases represent successor states to the Central Powers in World War I. At least for these cases, however, Turda's argument for Hungary about an inherent racism in physical anthropology under a nationalist premise deserves careful consideration. The existing evidence for Central and southeastern Europe's physical anthropology during those decades at any rate indicates very diverse profiles. Intellectually, it ranged from explicit racism as in the Serbian version of physical anthropology to less ideologically charged empiricism. Institutionally, physical anthropology remained loosely linked to ethnographic and folklore studies at home in some cases, which promoted

22 Schweitzer, "Siberia and Anthropology."

23 Ernest Gellner, Nations and Nationalism (New York: Cornell University Press, 1983).

24 Marius Turda, The Idea of National Superiority in Central Europe, 1880-1918 (New York: Edwin Mellen Press, 2005); idem, "Race, Politics and Nationalist Darwinism in Hungary, 1880-1918," Ab Imperio 8, no. 1 (2007): 139-164.

25 See Christian Promitzer in this volume; idem, "Vermessene Körper: 'Rassenkundliche' Grenzziehungen im südöstlichen Europa," in Europa und die Grenzen im Kopf, eds. Karl Kaser, Dagmar Gramshammer-Hohl, and Robert Pichler (Klagenfurt: Wieser, 2003), 384-387. 
their ideological juxtaposition. In other cases, such as the Bulgarian example discussed by Promitzer, ${ }^{26}$ physical anthropology developed along lines that were largely independent from those in ethnography and folklore studies. As a provisional summary, we may thus refer to a partial intertwinement between physical anthropology and folklore studies during the early years of Europe's newly independent states. The context of new national priorities indicates that, by and large, ethnography and folklore studies in most cases took priority over physical anthropology, during those early years at least. In anthropology's post-1918 European contexts, this internally heterogeneous context of a strong emphasis on folklore studies at home, a weak and partially interconnected physical anthropology, and very few elements of cross-cultural anthropology represented a specific configuration that differed markedly from those discussed so far. It never gained wider international recognition, but in one or the other version, until World War II, it often prevailed locally in this newly independent half of Europe.

\section{Reassessing the Impact of World War I on Anthropology's Fields in the German-Language Zone}

The preceding overview sketches some of the major ways in which different national and quasi-national traditions in anthropology developed during and after World War I, and it allows us to present some conclusions for the anthropological fields in the German-speaking context. In an intellectual and institutional sense, three main features can be emphasized. These are (a) the collapse of previous global interactions and accelerated national reinvention after the outbreak of the war, (b) the uniquely intense military engagement of German and Austrian anthropologists during the war, and (c) the elaboration of a new and distinct national setting for post-1918 anthropology in German.

\section{Outbreak of World War I: Collapse of Global Communication and Accelerated National Reorientation}

Since the late eighteenth and throughout the nineteenth century, the Germanspeaking countries had had far-reaching and very diverse influences on the international formative phases of these anthropological fields. These earlier influences of course had never been one-sided, that is, simply emanating from

26 Idem in this volume. 
German-speaking countries: They took many directions and were accompanied by the absorption into the German-language zone of even more influences from elsewhere. In most cases, this had involved a more active participation by the centers of imperial and colonial powers and a less active role on the part of academic networks in the younger and newly independent academic institutions.

Still, within these evolving, hierarchically structured imperial and colonial relations before 1914, a competitive global academic landscape had thrived, to which a German-speaking anthropology in the making had rendered many substantial, albeit quite heterogeneous, contributions. We have seen that this was most explicit in the establishment of Boas's four-field approach in the United States after the turn of the nineteenth century, whereas much older German influences had taken on quite different forms since the late eighteenth century in the formation of Russian physical anthropology and ethnography. Less well-known and more dispersed elements of German contributions to the formation of global anthropology before 1914 could be added. They would include the recognition of works by Georg and Johann Reinhold Forster, contributions by Gustav Klemm and by Theodor Waitz to the early formation of British anthropology, ${ }^{27}$ perhaps even the contested role of Carl Strehlow's and his son's work in the formation of anthropology in Australia, ${ }^{28}$ and several others. While most of these intellectual influences had been creative and productive, some others certainly had the opposite effect. Promitzer's study ${ }^{29}$ of the formative phase of a racist physical anthropology in Serbia, initiated by a Slovene disciple of Johannnes Ranke, is a telling example. Similar cases could also be made of some of the Herderian influences upon several among the more chauvinist versions of the new folklore studies in parts of northern, east Central, and southeastern Europe. After the establishment of the "second" German Empire in 1871, German and Austrian sociocultural and physical anthropologists certainly played their increasing part in aggressive colonial expeditions and in the construction of European colonial, missionary, and orientalist supremacy over the rest of the world. At the same time, the intellectual contributions and influences from the German-speaking countries to anthropological reasoning before 1914 continued to comprise a liberal element, an amount of respect for linguistic diversity, and a productive component of interdisciplinarity between the natural sciences and the humanities. ${ }^{30}$

27 Gingrich, "Ruptures, Schools and Nontraditions," 61-153.

28 Anna B. Kenny, "From Missionary to Frontier Scholar: An Introduction to Carl Strehlow's Masterpiece 'Die Aranda- und Loritja- Stämme in ZentralAustralien' (1901-1909)" (PhD thesis, University of Sydney, 2008).

29 See Christian Promitzer in this volume.

30 H. Glenn Penny and Matti Bunzl, eds., Worldly Provincialism: German Anthropology in the Age of Empire (Ann Arbor, MI: University of Michigan Press, 2003). 
In the last years before the war, liberalism in many parts of German-speaking academia came under increasing pressure. This was so not only because of the growing rivalries between the big powers, and of the minor armed conflicts in Europe that preceded the Great War, but also in view of armed persecution of indigenous revolts in the colonies. For example, the Herero revolt in today's Namibia, the ensuing massacres and detentions, and their media representation in Germany and Austria ${ }^{31}$ provoked some lukewarm regret, but did not elicit any serious protests from liberal German-speaking anthropologists that we know of today. In itself, this is another indicator for the erosion of liberalism in German-speaking anthropology. It suggests that the voices of those in German anthropology like Eugen Fischer-who had an explicit racist agenda and who supported brutal repression in what was called German Southwest Africa $^{32}$ - grew stronger.

The outbreak of World War I therefore not only accelerated the further erosion of the few remaining liberal elements of anthropology in the Germanspeaking countries, but also cut off these decaying liberal elements from their counterparts on what was now the enemies' side. The war also upgraded and promoted the militant and chauvinist voices in German-speaking academia in general as much as in anthropology in particular, and it made many among those who had formerly been more liberal change their minds. ${ }^{33}$ In addition, World War I also changed the contexts of what previously had been established as lively, liberal German intellectual influences in those non-German-speaking countries where they had been absorbed. There, the outbreak of the war, by necessity, had to accelerate the integration of those older German influences into the new national contexts of an ongoing war against German-speaking powers.

What had been a late colonial and imperial form of global anthropology thereby became more rapidly and more rigidly compartmentalized and cut up into national and quasi-national anthropologies through the outbreak

31 See Wolfgang Fuhrmann in this volume.

32 Bernhard Gessler, Eugen Fischer (1874-1927): Leben und Werk des Freiburger Anatomen, Anthropologen und Rassenhygienikers bis 1927 (Frankfurt a. M.: Lang, 2000); Niels C. Lösch, Rasse als Konstrukt: Leben und Werk Eugen Fischers (Frankfurt a. M.: Lang, 1997).

33 Anja Laukötter, Von der "Kultur" zur "Rasse"-Vom Objekt zum Körper? Völkerkundemuseen und ihre Wissenschaften zu Beginn des 20. Jahrhunderts (Bielefeld: Transcript Science Studies, 2007); Maria Six-Hohenbalken, "Felix von Luschans Beiträge zur Ethnologie-Zwischen imperialem Liberalismus und den Anfängen des Sozialdarwinismus," in Felix von Luschan-Arzt, Anthropologe, Forschungsreisender und Ausgräber: Akten des Symposions zu seinem Leben und Wirken, eds. Peter Ruggendorfer and Hubert Szemethy (Vienna: Böhlen, 2009), 165-193. 
of, and during, the war. Inside the German-speaking countries and their anthropology, this had the additional effect of strengthening international isolation and of accelerating the erosion of the liberal legacy.

\section{A Uniquely Intense InVolvement in World War I}

The chapters in this volume clarify the uniquely intense engagement of German-speaking anthropologists in World War I-related activities. This is not to say that there was no involvement at all by anthropologists elsewhere. But in those other cases, it was either a fairly routine continuation of preWorld War I activities, as in the Russian army's physical anthropology before 1917 , or a minor additional aspect as in the UK or in Bulgaria, or even an individual initiative as in the Serbian case. Some cases still require more research to determine the actual nature and possible extent of any involvement by anthropologists. The evidence and analyses that are available so far, however, very clearly suggest that anthropologists' involvement in World War Irelated activities was nowhere as intense as it was on all levels in Germany and in Austria. In addition to their contributions to propaganda and intelligence, folklore studies, physical, and sociocultural anthropology actively pursued large-scale programs of measurement among POWs as well as military research expeditions, and they carried out ethnographic, visual, and acoustic documentation in camps as well as during those expeditions. ${ }^{34}$

A fair percentage-perhaps almost a quarter-of professional anthropologists in Germany and Austria, in addition to other professionals and students, participated for varying periods in these activities. ${ }^{35}$ Some of the field's key officeholders were the driving force (Felix von Luschan, Rudolf Pöch, Arthur Haberlandt), for some it was a peak of their career (Alois Musil ${ }^{36}$ ), while quite a few others who would go on to become relatively prominent either based their subsequent careers on, or promoted them by means of, these war-related ac-

34 See contributions to this volume by Margit Berner, Andrew D. Evans, Britta Lange, Christian Marchetti, Ursula Reber, Margaret Olin, and Monique Scheer; see also Britta Lange, "Ein Archiv von Stimmen: Kriegsgefangene unter ethnografischer Beobachtung," in Original/Ton: Zur Mediengeschichte des O-Tons, vol. 34, Kommunikation audiovisuell, eds. Harun Maye, Cornelius Reiber, and Nikolaus Wegmann (Constance: Universitätsverlag Konstanz, 2007), 317-342.

35 This first and very rough quantitative estimate relates to the total of museum and university professionals who were primarily engaged in anthropological activities, that is, in the narrower sense of the three subfields discussed here. Theologian and ethnographer Alois Musil's Middle Eastern activities during World War I have been described best by Karl Johannes Bauer, Alois Musil: Wahrheitssucher in der Wüste (Vienna: Böhlau, 1989). 
tivities (Leo Frobenius, Michael Haberlandt, Erich M. von Hornbostel, Robert Lach, Viktor Lebzelter, Otto Reche, Egon von Eickstedt, and Josef Weninger). Indeed, nothing of a comparable scale and intensity went on in anthropology in any other of the main countries involved in the war.

A consideration of the main reasons and motives behind this unique engagement by German-speaking anthropologists has to start with their countries' position in the war. Germany was a very young and thus relatively aggressive newcomer in the late imperial and colonial global competition. As its main war ally, the old Austro-Hungarian Empire by contrast was increasingly lagging behind in this global rivalry in many key areas. For these different sets of reasons, a sense of the urgent need for extra effort was certainly widespread in leading academic circles in both countries.

In 1914, anthropologists in Germany and Austria could already look back at a fairly continuous record of cooperation between some of their own major projects and expeditions and their countries' armies and civil authorities. ${ }^{37}$ This record had ranged from Rudolf Virchow's first Schulstatistik project to the military's logistic support since 1900 for German and Austrian research expeditions in several parts of the world, including Oceania and South Arabia. After the outbreak of World War I, the thought of continuing and reinvigorating this earlier cooperation became an easy scenario to envision. International academic relations largely being cut off, any thought of increasing academic research almost unavoidably had to involve domestic state and army support and, at the very least, such extra activities had to be made to appear useful.

From the scholars' point of view, state loyalty and war enthusiasm played their part. In Germany and Austria, the war's outbreak was accompanied by a public enthusiasm for war that had few parallels in history. ${ }^{38}$ This mass enthusiasm, of course, was instigated and orchestrated by those in power, and it gradually became less joyful as the war dragged on. Still, it would be quite unrealistic to assume that a state-sponsored academic establishment in Germany and Austria was left untouched by such public enthusiasm. In view of the liberal paradigm's ongoing erosion before the war within anthropology, and in view of the fact that the large majority of political forces-including Liberals and Social Democrats-backed the declarations of war, it is far more realistic to work with the hypothesis that the large majority of German and Austrian anthropologists actively supported their countries' war from the outset. These are some of the main political, institutional, and ideological factors that I can

37 Andre Gingrich, "Liberalism in Imperial Anthropology: Notes on an Implicit Paradigm in Continental European Anthropology before World War I," Ab Imperio 8, no. 1 (2007): 224-239.

38 Manfried Rauchensteiner, Der Tod des Doppeladlers: Österreich-Ungarn und der Erste Weltkrieg, 2nd ed. (Graz: Steirische Verlagsgesellschaft, 1998). 
identify as key contexts for the fact that, during World War I, German and Austrian anthropologists launched war-related engagements which, by their scope as well as by their unique intensity, were definitely quite different from what went on in anthropology during World War I in most other countries.

These contexts also provide a better understanding of the main motives. Most of these major anthropological war-related projects were initiated by the scientists themselves. As far as we know, they did not originate as requests by the military or political authorities "from above," but as scholarly proposals and project applications "from below" to these authorities, whose representatives then took some time to consider them before they were convinced and agreed. The German and Austrian imperial authorities thus had to be persuaded that these anthropological projects were acceptable and potentially useful for them.

In their written proposals and reports, the scholars engaging with POWcamp studies and expeditions explicitly mentioned two main motives. These projects would be useful anthropological contributions to the Central Powers' war effort, and, simultaneously, the war would represent unprecedented opportunities for scholarly research. It may very well be that the anthropologists actually believed in the first of these two motives, that is, providing improved knowledge about enemies in order to further optimize the Central Powers' chances for victory. The results and research reports delivered during the war indicate, however, that any such claims, promises, and expectations were far too optimistic. If not as a realistic plan, then at least as a rhetorical pretext, the claims to be able to deliver serious academic contributions were nevertheless a diplomatic necessity in convincing the authorities. Sooner or later, this would combine with a minor and implicit reason that could never be openly talked about. Creating war-related research opportunities made applicants look good in the eyes of the military and political authorities. Thus, these projects might also provide enough reasons for the authorities not to draft the actors themselves into active military service. In specific cases, this implicit motive shines through between the lines, as shown for the examples of Wolfgang Schultz ${ }^{39}$ and Michael Haberlandt. ${ }^{40}$

In short, the first among the two explicit motives discussed here represented a diplomatic and rhetorical necessity and, perhaps, also a sign of loyalty and enthusiasm, but it hardly represented any realistic goal. In fact, if we assess Germany's and Austria's anthropological war projects according to their actual utility for their countries' war efforts, then the results were largely irrelevant in any substantial military sense. Monique Scheer ${ }^{41}$ makes this very clear. If anything, these projects sometimes served as the opposite of a contribution to the war, namely, as a good pretext for evading military service.

39 See Britta Lange in this volume.

40 See Christian Marchetti in this volume.

41 See Monique Scheeer in this volume. 
In practical terms, German and Austrian World War I anthropological projects therefore reinvented major areas of their own fields along more chauvinist and less liberal lines by benefiting from the war, while they largely failed as contributions to the war. The second explicit "research opportunity" motive thus turned out to be the most enduring. Academic expeditions in an army context promised new fieldwork and documentation activities in situ; POWcamp inquiries were seen as condensed fieldwork opportunities ex situ, which might work faster, cheaper, and on a larger scale.

It was pointed out in the first part of this chapter that before, during, and after the war, anthropologists in North America and most countries of Europe reinvented their field along very diverse national and quasi-national lines. The German and Austrian POW-camp and military expedition projects during World War I thus can now be identified as the crucial vehicles by which the new national traditions in Germany and Austria came into being. Among the POWs who were subjected to the camp projects, and among the colonial subjects in the Balkan peninsula, in Africa and western Asia where the expeditions were carried out ${ }^{42}$, these anthropological activities in times of war took a painful toll in terms of human dignity and also human lives. Among the German and Austrian anthropologists involved, these projects standardized and routinized the supremacist, orientalist, ${ }^{43}$ and chauvinist normality of their research procedures. The human individuals with and among whom this kind of research was carried out were construed as "colonial/oriental" inferior objects with little will of their own. Machines and tools of measurement and documentation shaped the reified relation between superior "white" researchers and their inferiorized and dehumanized alien objects of research. Physical anthropology now set the tone of the inquiry, while the humanities assisted them as mere auxiliary forces.

\section{A New Triangular Setting for Anthropology in Germany AFTER 1918}

For a sober assessment of anthropology's development in Germany and Austria after World War I, it does not suffice to merely examine what happened during the first few years after 1918. At first, the turmoil and revolutionary crises accompanying the collapse of both monarchies left little room for any

42 Good overviews on these specific topics are provided by Peter Jung, Der k.u.k. Wüstenkrieg: Österreich-Ungarn im Vorderen Orient, 1915-1918 (Graz: Styria-Militärhistorischen Dienst, 1992), 128; and by Thomas Zitelmann, “Des Teufels Lustgarten: Themen und Tabus der politischen Anthropologie Nordostafrikas" (habilitation thesis, Freie Universität Berlin, 1999).

See Diana Reynolds Cordileone in this volume. 
substantial academic developments. Germany had lost all its former colonies overseas, and the Austro-Hungarian Empire had literally been dismantled. Severe restrictions and several obligations were imposed upon the German and Austrian remainder states, among them the prohibition of any unity between both of them. In addition to the political crises, public budgets were so depleted that the mere maintenance of anthropological positions and institutions was a permanent problem. Assessing the emerging new institutional setting after World War I in anthropology in these two countries also requires the consideration of medium-term developments. It is therefore more useful to examine where that new setting was leading to and to take the late 1920s as a timeline for such an examination. In spite of the peace treaties' ban on any political Anschluss, many central institutional, academic, and civil society developments in Austria at first followed those in Germany to such an extent that my account of anthropology in those years will continue to treat this as a single process.

In the decade following 1918, the new institutional setting very gradually emerged in Germany and Austria. This new setting was the result of developments before and during the war; its emergence had definitely been promoted by anthropological engagements with war-related activities, and it became determined by the war's outcome: Colonies and empire were gone, and, instead, new and relatively weak nation-states were installed. It took a decade after the war for Germany's Weimar Republic and what would be called Austria's First Republic to become as stabilized as they would ever get-before being hit by the next world economic crisis and before the decisive rise to power of National Socialism and fascism. The year 1928, therefore, provides a fairly good timeline for assessing the kind of institutional setting which finally prevailed in anthropology's new postwar (and interwar) republican contexts in the German-speaking countries.

By the late 1920s, a new "triangular" setting for the anthropological disciplines had become the dominant pattern at universities and museums in the German-language zone. This triangular pattern comprised:

- A significant rise in the weight and importance of physical anthropology: This included the strengthening of existing, and the addition of some new, university chairs, the establishment in 1927 of a specialized section of the Kaiser-Wilhelm-Gesellschaft (today's Max Planck Society), and enlarged sections for physical anthropology either at the museums for Völkerkunde or at the natural history museums. ${ }^{44}$

- The early establishment of specialized folklore studies [Volkskunde] chairs and departments at the universities. As a plethora of specialized museums, journals, and academic associations, folklore studies had

44 Gessler, Eugen Fischer (1874-1927); Lösch, Rasse als Konstrukt. 
emerged in the nineteenth century. As a distinct field of university degrees, chairs, and departments, it was institutionalized after 1918 and remained loosely intertwined with physical anthropology: Research in German cultures often claimed a possible correspondence with notions of a German race. ${ }^{45}$

- The slower establishment of sociocultural anthropology [Völkerkunde] as a field with merely partial independence from physical anthropology, in so far as both fields continued to be jointly represented by some major museums (must notably in Berlin), in some anthropological societies (esp. those in Berlin and Vienna), and through some university chairs (e.g., Vienna until 1927 and Leipzig after 1927). By 1928, I count four university chairs or departments for sociocultural anthropology that had been established (in addition to the oldest, Leipzig, there were Hamburg, Frankfurt, and Vienna ${ }^{46}$ ).

Both the fields of folklore studies and sociocultural anthropology therefore succeeded during the postwar decade in gradually shifting some of their academic centers away from the museums that were their main prewar base and installing themselves with some weak independence from physical anthropology within the universities. Folklore studies succeeded in this regard more quickly and to a greater extent, while sociocultural anthropology took longer and had a lesser impact in this endeavor.

What was said in the first part of this chapter now demonstrates that this priority for folklore studies was clearly part of wider developments in parts of northern, Central, and southeastern Europe at the time, with some very weak parallels in the United States. ${ }^{47}$ By contrast, the belated and weaker installation of sociocultural anthropology was related to the loss of all colonial realms, on the one hand. On the other hand, the Western examples of the US, the UK, and France, as well as the domestic expertise and the collections, which

45 Wolfgang Jacobeit, Hannjost Lixfeld, and Olaf Bockhorn, eds., Völkische Wissenschaft: Gestalten und Tendenzen der deutschen und österreichischen Volkskunde in der 1. Hälfte des 20. Jahrhunderts (Vienna: Böhlau, 1994). In 1938, the official documents related to potential candidates for the vacancy in Vienna referred to five other chairs in the "Reich"—where the Völkerkunde chairs in Cologne and Göttingen had, however, been fully established after 1930 (Julia Gohm and Andre Gingrich, "Rochaden der Völkerkunde: Hauptakteure und Verlauf eines Berufungsverfahrens nach dem 'Anschluss,"' in Geisteswissenschaften im Nationalsozialismus: Die Universität Wien 1938-1945, eds. Mitchel G. Ash, Wolfram Nieß, and Ramon Pils (Göttingen:V \& R unipress, in press).

47 In Austria, the paradigmatic change from multicultural, imperial folklore studies before 1918 to a national and, at times, pan-German orientation after 1918 was even more drastic (see Christian Marchetti in this volume). 
both remained, nevertheless led to the installation of weaker, distinct forms of sociocultural anthropology at the university levels in Germany and Austria. The priority for folklore studies therefore reflected Germany's and Austria's enforced transformation into new nation-states and, in that sense, was part of a wider eastern and northern European development. The distinct establishment of Völkerkunde at the university level, by contrast, reflected developments in Britain and France and confirmed the continuity of colonial and imperial interests.

The physical anthropology that emerged in Germany and Austria after the war had only very little in common with its counterparts in the West. In the United States, Boasian physical anthropology was an independent and equal, nonracist partner subfield in the four-field approach. In the UK and France, physical anthropology was part of the natural sciences, with very little, if any, interaction with social anthropology as part of the social sciences. By contrast, in Germany and Austria, physical anthropology emerged after 1918 as an upgraded biological field that felt it had-and claimed to have-high relevance for a weakly institutionalized and largely historical sociocultural anthropology [Völkerkunde] and for the stronger, new academic discipline of folklore studies [Volkskunde].

The triangular pattern, which we have identified here as the main institutional outcome of the decade following World War I, therefore provided a relatively unusual new quasi-national context for the anthropological fields in Germany and Austria. Few other major national or quasi-national fragments of the global, late imperial academic landscape that had collapsed in 1914 developed similar institutional articulations for the fields of anthropology after the war. ${ }^{48}$

The German-Austrian triangle of a dominant physical anthropology, a not fully independent sociocultural anthropology, and a separate field of folklore studies had drifted far away from the US trajectory with which it previously had shared some common origins; and, by comparison, it differed from the French

48 If the German-Austrian triangular setting in the anthropology of the postWorld War I era had any close parallels elsewhere, then they cropped up during the same years in parts of Scandinavia and southern Europe (Italy, Spain, and Portugal) - in short, among some minor colonial powers. In these cases, however, folklore studies usually took the exclusive lead at the university level, whereas variants of ethnology or sociocultural anthropology had their main place in the museums. The possible correlation between variants of a triangular institutional pattern in anthropology and fascist political developments in several of these countries during the 1920s and 1930s is interesting and deserves further exploration. See Christian Lindberg, "Anthropology on the Periphery: The Early Schools of Nordic Anthropology," in Kuklick, A New History of Anthropology, 161-172. 
and British settings even more strongly than from its Soviet counterparts. The triangular institutional constellation for post-World War I anthropology in Germany and Austria thus was a relatively specific, postimperial setting for the main losers in the Great War. By its inherent priorities, it signaled claims toward nationalist reinvigoration and the desire to win back lost colonies.

\section{Epilogue}

The triangular institutional pattern that dominated in the German-speaking anthropological fields by the late 1920s must not be confused with the changing networks of academic actors contesting for, and competing within, these institutions. The triangular pattern from the late 1920s does indicate which forces won the upper hand in these internal academic contests, and it also demonstrates that this was supported or accepted by the deciding forces in academic and political hierarchies. Yet, the pattern itself certainly does not tell us about the diversity of interests, alliances, and actors that were involved in German and Austrian physical anthropology, Völkerkunde, and Volkskunde during those years.

For German physical anthropology's theories and methods, Andrew Evans ${ }^{49}$ argues that these followed more nationalist and racist orientations after the war than before, when a liberal paradigm was still relatively influential. During the Weimar Republic, the field increasingly became dominated by figures like Eugen Fischer, Hans Günther, and Egon von Eickstedt. In addition, Margit Berner ${ }^{50}$ has demonstrated that, in the Vienna university version of this field, much less liberal orientations had prevailed from the outset, which was continued by Pöch's disciple Weninger even more rigidly.

For Volkskunde in Germany and Austria, Reinhard Johler's analysis ${ }^{51}$ indicates a somewhat stronger element of liberal continuity after 1918, in spite of the now explicitly national agenda for this field in its postimperial contexts. German-speaking academia in the 1920 s tended to be more conservative than the societies at large at the time, and several main actors in German-speaking anthropology belonged politically to the far right within this largely conservative spectrum. Still, some segments of the rank and file of Volkskunde continued to deliver useful and interesting results during the 1920 s.

49 See this volume; Andrew D. Evans, "A Liberal Paradigm? Race and Ideology in Late Nineteenth Century German Physical Anthropology," Ab Imperio 8, no. 1 (2007): 113-138.

50 See this volume.

51 See Reinhard Johler in this volume. 
In fact, it is worth noting that, for historical ethnographies of Central Europe, or of southeastern Europe for that matter, a critical reading and careful interpretative usage of many research results by German and Austrian Volkskunde from before 1933/34 remains indispensable to this day. The same can hardly be claimed for physical anthropology from these years, for example, of Weninger's volume about West Africa, ${ }^{52}$ which had resulted from his own and Pöch's POW-camp investigations. Apart from studies in the history of science, I know of no current physical anthropologists who would use these data for any reasonable present-day or historical research purpose. ${ }^{53}$

In retrospect, it has thus become much clearer than it already was that German-speaking physical anthropology was increasingly developing into a highly speculative, noncumulative dead end, with little potential other than serving as a legitimizing tool for reactionary and racist political goals. Folklore studies, by contrast, did continue to document ethnographic evidence. Some of it was highly biased by national and historical-diffusionist priorities, and much of what would have been important was not even considered for research. Still, this biased and partial ethnographic evidence from the past cannot be totally discarded today.

Although Völkerkunde was the weakest among the three disciplines in the triangle, the record looks even more diverse and potentially interesting for sociocultural anthropology in its German interwar dimensions before 1933. Elsewhere, I have outlined the rich theoretical and methodological plurality of those years, which included incipient German-speaking versions of most major international research orientations, in addition to a few specifically German-speaking approaches. ${ }^{54}$ To an extent, the loss of the colonies in fact reinvigorated an older German and Austrian anthropological tradition in which some of the best ethnographic research had been carried out outside any colo-

52 Britta Lange and Andre Gingrich, "Gefangene Stimmen, Internierte Körper: Rudolf Pöch, die Wünsdorf-Reise 1917 und die Frage der Geschichte der Völkerkunde," in Archivhorizonte: Wissenslandschaften und Perspektivgrenzen im multimedialen Nachlass des Anthropologen und Forschungsreisenden Rudolf Pöch, eds. Thomas Ballhausen, Katarina Matiasek, and Maria Teschler-Nicola (Vienna: Löcker, in press).

53 This retrospective contrast between the proud claims for research budgets by some fields of the natural sciences, and their results, which produced no useful cumulative effect in any sense whatsoever, is not only interesting in itself, but also if compared against the much more enduring cumulative quality of some of the ethnographic research referred to here. Both would also provide interesting material for present-day debates about the unequal distribution of research funding in Europe.

54 Gingrich, "Ruptures, Schools and Nontraditions." 
nial or missionary realm of those countries. ${ }^{55}$ Still, within Völkerkunde the triangular institutional pattern also favored the more conservative, missionary, and procolonial forces, who could claim to represent truly national interests. They were explicitly compatible with parallel orientations in physical anthropology and folklore studies and often reinforced each other. By 1928, the four university chairs or departments were all held by representatives of one or the other school of historical diffusionism. They were thus inspired by theories that were highly speculative and, with few exceptions, far removed from any liberal orientations. Most of the more productive and innovative research was carried out by researchers other than the holders of those positions.

To sum up, the German-speaking anthropological institutional triangle of the post-1918 decade favored the further rise of a dominating physical anthropology and kept Volkskunde and Völkerkunde closely within the former's range. Within these two latter subfields, the triangle did allow for some remarkable pluralism of research — but for the key academic positions, this institutional development favored the installation of historical diffusionism mostly in its nonliberal and speculative versions.

In contrast with Boas's four-field approach in the USA, not to mention social anthropology's sociological orientation in the UK and France, anthropology's institutional triangle in the German-language zone therefore turned out to be more of an obstacle than a useful vehicle for pluralistic and fruitful academic research.

This was decisively aggravated by the biographical background of some of the key actors in the triangle's central positions. They had been missionaries since the pre-World War I era (Diedrich Westermann and Pater Wilhelm Schmidt); they had gained some of their empirical academic experience before and during World War I in the colonies (Eugen Fischer, Leo Frobenius, Arthur and Michael Haberlandt, and Richard Thurnwald); and, in addition, some of them had established the empirical basis of their careers in the POW-camp projects (Otto Reche, Egon von Eickstedt, and Josef Weninger).

The decade after 1918, therefore, was a contested period in German-speaking anthropology, in which not everything was yet decided. But as a result, the triangular institutional setting emerged as a dominant pattern and favored illiberal, racist, orientalist, and nationalist orientations more than others. In this triangular pattern, key players rose to dominant influence whose professional biographies had been shaped by ideologies and experiences of religious, colonial, or national supremacy.

Inside the German Weimar Republic and the Austrian First Republic, this introduced deep hierarchies into these particular segments of academic life. At the same time, these internal constellations gave German-speaking anthropol-

55 Penny and Bunzl, Worldly Provincialism. 
ogy a new and distinct quasi-national profile set apart from others. Sometimes, this profile included interesting potential for international exchange and communication. More frequently, however, some of its leading representatives and their works were understood internationally as representing a new nationalist orientation that was heading toward confrontation, again. 



\section{List of Contributors}

Margit Berner received her PhD in Human Biology and Zoology at the University of Vienna. She has been employed at the Museum of Natural History in Vienna since 1986 and became the curator of its collection of plaster casts in the anthropology section in 1995 when she also began teaching at the Institute for Anthropology at the University of Vienna. Her research interests are osteology, functional morphology, the history of anthropology, and paleopathology. Margit Berner has published several articles on the research activities of Viennese physical anthropologists during the First World War and the National Socialist period, including: “Die 'rassenkundlichen' Untersuchungen der Wiener Anthropologen in Kriegsgefangenenlagern 1915-1918," Zeitgeschichte 30, no. 3 (2003): 124-136; "Forschungs-'Material' Kriegsgefangene: Die Massenuntersuchungen der Wiener Anthropologen an gefangenen Soldaten 1915-1918," in Vorreiter der Vernichtung? Eugenik, Rassenhygiene und Euthanasie in der österreichischen Diskussion vor 1938, eds. Heinz Eberhard Gabriel and Wolfgang Neugebauer (Vienna: Böhlau, 2005), 167-198.

Diana Reynolds Cordileone is professor of History at Point Loma Nazarene University in San Diego, California. She studied European studies, art history, and classical and early Christian archeology in San Diego and at the Friedrich Alexander University of Erlangen-Nürnberg. Diana Reynolds Cordileone was the recipient of a Fulbright Grant for a year of study in Vienna and received her $\mathrm{PhD}$ in 1997 from the University of California at San Diego. She is currently working on a research project called "Manufacturing Mother Austria: Arts and Crafts Reform and Austrian Identity in the Age of Empire (1871-1914)."

Fabio Dei is associate professor of Cultural Anthropology at the University of Pisa. He received his $\mathrm{PhD}$ in 1994 from the University of Siena, and was then researcher at the University of Rome "La Sapienza." His research subjects include medical anthropology, anthropology of violence, and folk and popular culture in Italy. Among his works are: Antropologia della violenza (Rome: Meltemi, 2005); Fabio Dei and Pietro Clemente, eds., Poetiche e politiche del 
ricordo (Rome: Carocci, 2005); Beethoven e le mondine: Ripensare la cultura popolare (Rome: Meltemi, 2002); La discesa agli inferi: J. G. Frazer e la cultura del '900 (Lecce: Argo, 1998); Fabio Dei and A. Simonicca, eds., Ragione e forme di vita: Razionalità e relativismo in antropologia (Milan: Angeli, 1990); $G$ Simbolo e teoria nell'antropologia religiosa (Lecce: Argo, 1998). Fabio Dei is currently interested in the role of the gift in popular culture, doing research on different topics like blood donation, file-sharing on the internet, and material objects in domestic cultures: M. Aria and F. Dei, eds., Culture del dono (Roma: Meltemi, 2008); M. Aria, F. Dei, and G. L. Mancini, La donazione del sangue: Per un'antropologia dell'altruismo (Pisa: Pacini, 2008).

Andrew D. Evans received his PhD in History in 2002 from Indiana University and is currently assistant professor in the History Department of the State University of New York (SUNY) in New Paltz. He is the author of Anthropology at War: World War I and the Science of Race in Germany (Chicago, IL: University of Chicago Press, 2010), and has also published: "Capturing Race: Anthropology and Photography in German and Austrian Prisoner-of-War Camps during World War I," in Colonialist Photography: Imag(in)ing Race and Place, eds. Eleanor M. Hight and Gary D. Sampson (London: Routledge, 2002), 226-256; "Anthropology at War: Racial Studies of POWs during World War I," in Worldly Provincialism: German Anthropology in the Age of Empire, eds. H. Glenn Penny and Matti Bunzl (Ann Arbor, MI: University of Michigan Press, 2003), 198-229.

Wolfgang Fuhrmann teaches Film Studies at the University of Zurich. He studied in Bochum and Amsterdam and completed his PhD thesis on German colonial cinematography at Utrecht University. Wolfgang Fuhrmann is currently working on a research project: "Film and Ethnography in Germany 1900-1930.” In addition to many publications in German, he has recently published in English: "Local Entertainment and National Patriotism: The Distribution of Colonial Films in Germany," in Networks of Entertainment: Early Film Distribution 1895-1915, eds. Frank Kessler and Nanna Verhoff (London: John Libbey \& Company Ltd., 2007), 246-254; "First Contact: The Beginning of Ethnographic Filmmaking in Germany, 1900-1930," History of Anthropology Newsletter 34, no. 1 (2007): 3-9; "Locating Early Film Audiences: Voluntary Associations and Colonial Film," Historical Journal of Film, Radio and Television 22 (2002): 291-304.

Andre Gingrich is full professor of Cultural and Social Anthropology at the University of Vienna, where he received his $\mathrm{PhD}$ in 1978. He also was visiting professor and guest researcher in Paris, Chicago, Boston, Santa Fe, Birzeit, and London. In 2000, he received the Ludwig Wittgenstein Prize, Austria's highest 
award for outstanding scientific achievement. Since 2002, he is a full member of the Austrian Academy of Sciences and director of its Institute for Social Anthropology, and, since 2007, he also is a member of the Royal Swedish Academy of Sciences. Since 2008, Gingrich serves as Panel Chair for the European Research Council. His recent books include: Andre Gingrich and Richard G. Fox, eds., Anthropology, by Comparison (London: Routledge, 2002); Fredrik Barth, Andre Gingrich, Robert Parkin, and Sydel Silverman, One Discipline, Four Ways: British, German, French, and American Anthropology; The Halle Lectures (Chicago, IL: University of Chicago Press, 2005); Andre Gingrich and Marcus Banks, eds., Neo-nationalism in Europe and Beyond: Perspectives from Social Anthropology (Oxford, NY: Berghahn, 2006).

Reinhard Johler is professor of European Ethnology [Empirische Kulturwissenschaft] at the Ludwig Uhland Institute, University of Tübingen. He received his PhD in 1994 from the University of Vienna, with stops in Cambridge (UK) and Milan (Italy) during his graduate studies. Reinhard Johler was then assistant professor at Vienna University from 1997 to 2001 and an invited visiting professor at the Départment des Sciences Sociales, École Normale Superieure Paris in 2004. Among other volumes, he has published: Everyday Culture in Europe: Approaches and Methodologies, edited with Máiréad Nic Craith and Ullrich Kockel (Aldershot, UK: Ashgate, 2006); Europa und seine Fremden: Die Gestaltung kultureller Vielfalt als Herausforderung, edited with Ansgar Thiel, Josef Schmid, and Rainer Treptow (Bielefeld: transcript, 2007). $\mathrm{He}$ is co-organizer of the annual conferences with the Laboratoire "Cultures et sociétés en Europe," Université Marc Bloch Strasbourg, and of the International Summer Schools (Tempus-Network for Contemporary European Ethnology) in Berlin in 1997, Lund in 1998, and Warsaw in 1999. Reinhard Johler is on the editorial board of Folklore (London: Taylor \& Francis) and was former editor of the Zeitschrift für Volkskunde.

Henrika Kuklick is professor at the University of Pennsylvania's Department of History and Sociology of Science. She received her PhD in Sociology from Yale in 1974. Among her publications are: The Imperial Bureaucrat: The Colonial Administrative Service in the Gold Coast, 1920-1939 (Stanford, CA: Hoover Institution Press, 1979); Henrika Kuklick and Robert Alun Jones, Current Perspectives on the History of the Social Sciences (Greenwich, CT: JAI Press, 1983); The Savage Within: The Social History of British Anthropology, 1885-1945 (Cambridge, UK: Cambridge University Press, 1991, 1992); a special issue of Osiris, vol. 11, Science in the Field, edited with Robert Kohler (Chicago, IL, University of Chicago Press, 1996); "Islands in the Pacific: Darwinian Biogeography and British Anthropology," American Ethnologist 23, no. 3 (1996): 611-638; "'Humanity in the Chrysalis Stage': Indigenous Australians in the 
Anthropological Imagination, 1899-1926," British Journal for the History of Science 39, no. 4 (2006): 535-568; A New History of Anthropology (Oxford: Blackwell, 2008), an edited collection to which she has also contributed.

Britta Lange is a research fellow at the Austrian Academy of Sciences in Vienna, where she is continuing the research begun during her time at the Max Planck Institute for the History of Science in Berlin, a study of the history of the "typical," based on the research done on POWs in World War I. She studied art history, theater, cultural communication, and cultural studies in Berlin, writing a master's thesis on the war exhibitions of the First World War, published in 2003 as "Einen Krieg ausstellen: Die 'Deutsche Kriegsausstellung' 1916 in Berlin.” Britta Lange then went on to receive her PhD in Kulturwissenschaft in 2005 from the Humboldt University in Berlin, with a dissertation published as Echt, Unecht, Lebensecht: Menschenbilder im Umlauf (Berlin: Kadmos, 2006).

Christian Marchetti is a doctoral candidate in European Ethnology [Empirische Kulturwissenschaft] at the Ludwig Uhland Institute, University of Tübingen, and was a researcher at the Collaborative Research Centre on War Experience at the University of Tübingen from 2005 to 2009. Currently, he is completing his dissertation on the "Balkan expeditions" and Austrian folklore studies at the Ludwig Uhland Institute. See also his article "Scientists with Guns: On the Ethnographic Exploration of the Balkans by AustrianHungarian Scientists before and during World War I," Ab Imperio 8, no. 1 (2007): 165-190.

Marina Mogilner is a historian trained in Russia (BA, 1993; Candidate of Sciences, 1999), Europe (MA, 1995), and the USA (PhD, Rutgers University, 2000). Currently, she is a research fellow at the nongovernmental Center for the Studies of Nationalism and Empire (Kazan, Russia). She is cofounder (in 2000) and editor of the bilingual international quarterly Ab Imperio, dedicated to studies of new imperial history and nationalism in the post-Soviet space. Among the recent publications: "Russian Physical Anthropology of the Nineteenth-Early Twentieth Centuries: Imperial Race, Colonial Other, Degenerate Types, and the Russian Racial Body," in Empire Speaks Out: Languages of Rationalization and Self-Description in the Russian Empire, eds. Ilya Gerasimov et al. (Leiden: Brill, 2009). In 2008, she published the first history of Russian physical anthropology: Homo imperii: Istoriia fizicheskoi antropologii v Rossii [Homo Imperii: A History of Physical Anthropology in Russia] (Moscow: New Literary Review, 2008). Currently, she is working on a book on the history of Jewish physical anthropology and discourses of the Jewish race in the Russian Empire. 
Margaret Olin is a senior research scholar at the Yale Divinity School with additional appointments in the Department of Religious Studies, the Program in Judaic Studies, and the Department of the History of Art. From 1986 to 2009, she was professor in the Departments of Art History, Theory and Criticism, and Visual and Critical Studies at the School of the Art Institute of Chicago. Margaret Olin received her PhD in 1982 from the University of Chicago. Among her recent publications are: The Nation without Art: Examining Modern Discourses on Jewish Art (Lincoln, NE: University of Nebraska Press, 2001) and Monuments and Memory Made and Unmade (Chicago, IL: University of Chicago Press, 2003), edited with Robert S. Nelson. She is coeditor, with Steven Fine and Vivian B. Mann, of Images: A Journal of Jewish Art and Visual Culture. Her book Touching Photographs is forthcoming.

Christian Promitzer is assistant professor at the Institute for History, Center for Southeast European History at the University of Graz. He wrote his doctoral dissertation on a small region in the process of national differentiation at the Austrian-Slovene border. He is co-editor of (Hidden) Minorities: Language and Ethnic Identity between Central Europe and the Balkans (Münster: LIT, 2009). Christian Promitzer has written various articles on ethnicity, imagology, as well as on the history of anthropology and medicine in southeastern Europe. He is preparing a major work on epidemics and public health in the eastern Balkans up to 1912.

Ursula Reber studied classics, German studies, philosophy, religious studies and Indology at the Philipps University of Marburg, receiving her PhD in 2006 with a dissertation entitled "Bildverschleifungen: $\mathrm{Zu}$ einer Theorie der Metamorphose" at the University of Vienna. Since 2000, she has been a member of the Editorial Committee of the internet platform "Kakanien Revisited," dedicated to the study of Central, eastern, and southeastern Europe. In 2003, she was a fellow at the Wirth Institute at the University of Alberta at Edmonton and, since 2004, has been a member of the research project "Center and Peripheries in Austria-Hungary, 1867-1918," where her research interests include literary theory, romanticism, postcolonial studies, and the philosophy of space.

Monique Scheer is a research scholar at the Max Planck Institute for Human Development in Berlin. From 2002 to 2007, she was a research fellow at the Collaborative Research Centre on War Experience at the University of Tübingen. Monique Scheer is a graduate of Stanford University (BA, History) and received her PhD in European Ethnology [Empirische Kulturwissenschaft] from the University of Tübingen in 2005. She is the author of Rosenkranz und Kriegsvisionen: Marienerscheinungskulte im 20. Jahrhundert (Tübingen: 
Tübinger Vereinigung für Volkskunde, 2006) and has also published in several places on the subject of Black Madonnas, see especially "From Majesty to Mystery: Change in the Meanings of Black Madonnas from the Sixteenth to Nineteenth Centuries," American Historical Review 107, no. 5 (2002): 1412-1440.

Paolo De Simonis teaches Cultural Anthropology at the University of Florence. He has also held teaching appointments of Italian Dialectology at the University of Scutari (Albania). His research subjects, especially carried out in the Tuscany area, include popular songs and writings, autobiography and life stories, and museology and cultural heritage. Among his recent works are: "Congiuntivi futuri: Aufgabe del traduttore; narrazioni, identità e poteri tra le due sponde," in Traduzione, tradizione: La traduzione dalle varianti linguistiche alle varianti culturali, ed. A. Brettoni (Rome: Bulzoni, 2009), 279-308; "Luoghi comuni e singolari: Fratture antropologiche nel paesaggio," Annali (Università degli Studi di Firenze, Dipartimento di Storia delle Arti e dello Spettacolo) 10 (2009): 9-44; "Fissazioni: Tempi e metodi nell'accogliere e conservare voci e immagini di Toscana," in I custodi delle voci: Archivi orali in Toscana; primo censimento, eds. A. Andreini and P. Clemente (Florence: Regione Toscana, 2007), 315-340; Passi nella memoria: Guida ai luoghi delle stragi nazifasciste in Toscana (Roma: Carocci, 2004); Atlante delle tradizioni popolari nel Pistoiese, with C. Rosati (Siena: Maschietto \& Musolino, 2000); "Raccogliere e rappresentare per gli studi demoetnoantropologici," in Istituzioni culturali in Toscana: Dalle loro origini alla fine del Novecento, eds. F. Adorno, M. Bossi, and A. Volpi (Florence: Edizioni Polistampa, 2000), 301-311. 


\section{Name Index}

A

Abraham, Otto 281

Adams, Mark 74

Adler, Guido 283

Andrássy, Count Julius 174

Andrian-Werburg, Ferdinand 243

Anuchin, Dmitrii Nikolaevitch 50, 67

Ardigò, Roberto 80

Ash, Mitchell 226

\section{B}

Bächtold, Hanns 131

Bacon, Sir Francis 105

Bakić-Hayden, Milica 149

Balfour, Arthur 39

Bansaovichjus, Jonas Yuro 149

Barbi, Michele 83

Barth, Heinrich 361

Bartok, Béla 134

Basanovič, Ivan Juriev 149

Bastian, Adolf 17-19, 101, 103, 105, 119

Bateson, Gregory 12

Bausinger, Hermann 129

Bava Beccaris, Fiorenzo 80

Beddoe, John 37, 146

Beil, Christine 137

Bektić, Mustafa 179

Bellucci, Giuseppe 91-94

Benedict, Ruth 12
Bennett, Tony 170

Berchtold, Leopold Graf 216

Bergson, Henri 89

Berliner, Emile 292

Berner, Margit 25, 376

Bertillon, Alphonse 321

Beyrau, Dietrich 70

Bhabha, Homi K. 187

Birkner, Ferdinand 114, 142-44, $163,165-66$

Bismarck, Otto von 18

Bloch, Marc 88

Blumenbach, Johann Friedrich 236

Boas, Franz 19, 39-40, 116-17, $359-61,367,375,378$

Bogoras, Vladimir G. 358-59

Bomblatt, David 263

Bona, Emma 79

Brandl, Alois 294, 306

Brauer, August 110

Broca, Paul 16, 106, 315

Broser, Gustav 223-24

Bülow, Bernhard Heinrich Karl Martin von 339

Bunzl, Matti 102

Buschan, Georg 143-44

Buschbeck, Ernst 221-22, 224

C

Caravaglios, Cesare 85, 91, 93-95

Certeau, Michel de 346 
Chotoran, Isaac 262

Clemente, Pietro 78

Cocchiara, Giuseppe 79, 84, 87

Cordileone, Diana Reynolds 24

Corso, Raffaele 76, 78-79, 87, 89-91, 93-95

Croce, Benedetto 75, 78, 83, 96-97

Cunningham, D. J. 31-32

Cvijić, Jovan 151-52, 166

Czoernig, Karl Freiherr von 240

D

Dalio, Marcel 273

D'Ancona, Alessandro 77

Darwin, Charles 17-18, 31, 33, 41, $105-7,195,298$

Dauzat, Albert 89, 133

Dedijer, Jevto 155

De Gubernatis, Angelo 77

Dei, Fabio 21, 26

Deleuze, Gilles 197, 199

De Maistre, Joseph 94

De Martino, Ernesto 76, 94, 96-98

Deniker, M. Joseph 147-48, 152, 164,246

De Simonis, Paolo 21, 26

Dijon, Marka 224

Djordjević (Đorđević),

Tihomir R. 146

Doegen, Wilhelm 256-63, 267, 272, $274,286,288,290,294,302-8$, 313

Drončilov, Krum 146-47, 159-61, 165

Durkheim, Émile $13,16,96,361-62$

E

Edison, Thomas 280, 282, 291-94, 303, 306

Eickstedt, Egon von 115-16, 118, $120,251-52,314,318-20,323$, $326-30,333-34,370,376,378$
Eliot, T. S. $94-95$

Elliot Smith, Grafton 32, 38, 44

Emmerich, Erwin 264, 266

Engels, Friedrich 358-59

Evans, Andrew D. 19, 35, 259, 376

Exner, Sigmund 283

\section{$\mathbf{F}$}

Fallmerayer, Jakob Philipp 154

Fechner, Gustav Theodor 334

Ferdinand, Franz 189, 217

Fischer, Eugen $106,111,118-19,121$, 246-48, 250, 315, 318, 335, 368, 376,378

Fischler, Jacob 200

Fishta, Gjergi 225

Fleure, H. J. 40

Forster, Georg 367

Forster, Johann Reinhold 367

Forstner, Leopold 226

Foucault, Michel 94, 123

Frazer, James G. 43, 77, 88, 90-91, 95

Fritsch, Gustav 268

Frobenius, Leo 113-14, 262, 264, $270,370,378$

Fuhrmann, Wolfgang 26

Furkel, Georg 344

\section{G}

Gabin, Jean 273

Galton, Francis 33, 315

Gemelli, Agostino 133, 135

Gemelli, Fr. Agostino 76, 79-85, $87-89,91,93,95,97$

Georgi, Walter 270

Geramb, Viktor von 137

Gerdes, Herr 257-59, 263, 275

Gesemann, Gerhard 195-96

Gil'chenko, Nikolai Vasil'evitch 59-61

Gingrich, Andre 20, 26, 171 
Gladstone. William Ewart 192

Glück, Leopold 163

Goldschmidt, Adolph 25, 257-59, 261-62, 267-68, 270-72, 275-76, 304

Gräbner, Fritz 100

Gramsci, Antonio 81

Green, Kirby 201

Griffini, Mario 83, 85-86

Grothe, Hugo 203

Gschwendtner, Andrea 348

Guattari, Felix 197, 199

Gumbrecht, Hans Ulrich 123

Gunning, Tom 342-43, 347, 349-50

Günther, Hans F. K. 333, 376

Gusev, Mikhail Ivanovitch 70-71

\section{H}

Haberlandt, Arthur 161, 220-23, 226-30, 249, 369, 378

Haberlandt, Michael 210, 220, 226-30, 370-71, 378

Haddon, A. C. 31, 39-41, 361

Hartland, Edwin S. 77

Hauer, Franz von 243

Hein, Wilhelm 210

Herder, Johann Gottfried 17, 360, 367

Hertz, Friedrich 131

Hertz, Robert 362

Himmel, Heinrich 242

Hoernes, Moritz 211

Holquist, Peter 55, 64

Hornbostel, Erich M. von 282-85, 287, 290-91, 302, 370

Horn, Eva 197

Hovelacque, Alexandre Abel 145

Hurch, Bernhard 123

Huxley, Julian 40

Huxley, Thomas 33-34, 40

\section{I}

Ippen, Theodor von 214
J

Jahier, Piero 84-85

Janet, Pierre 89, 91, 97

Johler, Reinhard 20, 243, 376

K

Kállay, Benjamin von $176-80,182$, 186-87, 189

Kammerer, Paul 125, 127

Kănčov, Vasil 150

Kan, Mary Noel 34

Keith, Arthur 30, 32

Kidrić, Franz 220-22, 224

Klemm, Gustav 367

Koch-Grünberg, Theodor 351

Kodály, Zoltán 134

Kollman, Julius 103, 119

Kopernicki, Isydor 145

Korff, Gottfried 128, 137

Koselleck, Reinhart 129, 138

Kozlov, Nikolay 55

Kral, August Ritter von 224-25

Krasikow, Chajus 263

Krause, Fritz 351

Krauss, Friedrich Salomo 169, 212-13

Kreimeier, Klaus 342

Kudrin, Vladimir 55

Kuklick, Henrika 24, 360

Kyrle, Georg 249

$\mathbf{L}$

Lach, Robert 297-301, 307, 370

Lamarck, Jean-Baptiste de 31

Lambertz, Maximillian 221-25

Lange, Britta 25

Langer, Carl 241-42, 250

Larsen, Karl 20

Lavagna, Francesco 82

Lebzelter, Viktor 161, 249, 370

Le Gros Clark, W. E. 35-36

Lenger, Friedrich 138 
Lenin, Wladimir Iljitsch 357

Lévy-Bruhl, Lucien 91, 96

Liebermann, Ernst 267

Linton, Ralph 13

Lloyd George, David 39

Lombroso, Cesare 58, 60

Loria, Lamberto $77-78$

Loritz, Johann Baptist 141-43

Ludendorff, Erich von 261

Luschan, Felix von 99-101, 103, $106-8,110-12,115,117,119$, $146-47,159,163,211,233-34$, 237-38, 246-47, 251, 261-63, 270-74, 282, 292, 294, 302, 307, $313-15,318-20,326-27,330,369$

Lustig, Colonel 224

\section{M}

Maleš, Branimir 165

Malinowski, Bronislaw 9, 14, 44-45, 361

Mantegazza, Paolo 76

Marchetti, Christian 24

Marett, Robert R. 77

Marpicati, Arturo 84, 86

Martin, Rudolf 103-4, 106-8, 112, 114, 116-20, 245-46, 312, 314, 318, $321,324,326-27,330,335$

Marx, Karl 20, 83, 358-59

Massin, Benoit $17-18,101,163$

Mausser, Otto 130-31, 136

Mauss, Marcel 16, 362

Mead, Margaret 11

Meier, John 132

Mele, Giulio 85,87

Mendel, Gregor 18, 40, 106, 153, 246, 250-51, 270, 315

Meyer-Lübke, Wilhelm 123

Mihačević, Fra Lovro 215, 219

Mikhnevich, Ivan 63, 66-70

Miliutin, Dmitrii 54, 64,71

Mochi, Aldobrandino 77
Mogilner, Marina 20,358

Mollison, Theodor 119

Morgan, L. H. 358

Müller, Julius Friedrich Carl 339-41

Murko, Matthias 213

Musil, Alois 361, 369

Myers, Charles S. 31, 35, 41

\section{$\mathbf{N}$}

Nani, Markus 180

Naumann, Hans 137

Neuhauss, Richard 338

Nietzsche, Friedrich 195

Nigra, Constantino 77, 83

Nikol'skii, Dmitrii Petrovitch

57-58, 63-64

Nopcsa, Franz Baron 215-17

Novati, Francesco 78

Noyes, John 344

O

Oberhummer, Eugen 248

Ol'denburg, Sergey F. 73

Olin, Margaret 25

Otto, Rudolf 78

\section{P}

Parsons, F. G. 35-36

Pashutin, Viktor 55

Patsch, Carl 213-15, 225, 230

Peake, Harold 38

Pearson, Karl 30, 32-35, 315

Pear, T. H. 44

Pekmezi, Gjergi 225

Penck, Albrecht 100

Penny, H. Glenn 102

Peterson, Jennifer $342-43,347$

Pettazzoni,Raffaele 78

Philippovich, Josef Freiherr 174

Pitré, Giuseppe 77-78

Pittard, Eugène 146

Ploetz, Alfred 246 
Pöch, Hella 249, 324

Pöch, Rudolf 120, 222, 234, 236, 246-53, 288, 291-92, 295-97, 299-300, 306-7, 312-15, 318-21, 323-24, 330, 334-36, 337-39, 347-51, 369, 376-77

Pomadov, Jakim 159

Popović, Cvjetko 188

Popov, Metodij 165-66

Praschniker, Camillo 221-22, 225

Price, David H. 11

Prinz zu Wied, Wilhelm 214

Proctor, Robert 17, 101

Promitzer, Christian 365-67

Q

Quételet, Adolphe 314

\section{$\mathbf{R}$}

Rabl, Karl 245

Radcliffe-Brown, A. R. 9, 44, 361-62

Ranke, Johannes 49, 103-5, 107, $114,119,142,150,152,163,238$, 247, 367

Ratzel, Friedrich 199-200, 202-3, 359

Reber, Ursula 24

Reche, Otto $107,115-16,120,252$, 370, 378

Reitzenstein, Ferdinand

Freiherr von 262, 267

Remmert, Adolf 55

Renoir, Jean 273-74

Retzius, Anders 236

Reuschel, Karl 137

Ribot, Théodule 89, 91

Riegl, Alois 210

Ripley, William Z. 148

Rivers, W. H. R. 41-45, 99, 361

Roberts, Elizabeth 194

Rokitansky, Carl von 238

Rubieri, Ermolao 83
Rudolf, Crown Prince 172, 243

Ruscalla, Giovenale Vegezzi 76

\section{S}

Said, Edward 171

Salvator, Johann 243

Sander, Karin 276

Santoli, Vittorio $78,83,85$

Scheer, Monique 25, 135, 371

Scheiber, Sámuel Henriket 145

Scheidt, Walter 120

Schiele, Egon 266, 273

Schimmer, Gustav Adolf 240-41

Schmidt, Leopold 137

Schmidt, Pater Wilhelm 77, 97, 300, 378

Schmitt, Carl 197

Schneider, Ludwig 241

Schober, Arnold 221-22, 224

Schön, Josef 196, 198-99

Schuchardt, Hugo 78

Schultz, Wolfgang 297, 371

Schumann, Robert 341

Schünemann, Georg 303-4, 307

Schürer von Waldheim, Helene 249

Schwalbe, Gustav 107, 110

Schweitzer, Peter 358

Seler, Eduard 107, 110

Seligman, C. G. 30,45

Sibeud, Emmanuelle 16

Sikorskii, Ivan Alekseevich 52

Škerlj, Božo 165

Smith, Steven A. 72

Spamer, Adolf 140

Spitzer, Leo 123-25, 127

Spranger, Eduard 130

Stalin, Josef 359

Steinmetz, Carl 215-17

Sternberg, Lev 358

Stiehl, Otto 289-90, 333

Storck, Josef von 181-82

Strehlow, Carl 367 
Struck, Hermann 25, 261-63, 267, 272, 274, 330-31, 333

Studnička, Alois 179

Stumpf, Carl 281-82, 285, 298, 302-3, 306, 313

Szombathy, Josef 249

\section{$\mathbf{T}$}

\section{Tarenetskii, Alexander} Ivanovitch 56-57, 60

Tarnovskaia, Praskov'ia 55

Terstyánszky, August 196

Thalloczy, Ludwig von 215

Thöny, Wilhelm 264

Thurnwald, Richard 109, 211, 378

Toldt, Carl 242, 248-49

Traverso, Enzo 98

Turda, Marius 365

Tylor, Edward B. 43, 77, 88

\section{V}

Van Gennep, Arnold 78, 89

Vatev, Stefan 146-51, 153-54, 159-60, 164

Vaughan Williams, Ralph 284

Vedder, Heinrich 340

Vešović, Radomir 204

Vidossi, Giuseppe 79, 96

Virchow, Rudolf $17-18,50,101-8$, $112,114,116,119,145,150-51$, 233-34, 238-39, 241, 245, 311, 370

\section{W}

Wagner, Richard 255

Waitz, Theodor 367

Waldeyer, Wilhelm von 106, 109, $112-13$

Wallaschek, Richard 283-84, 298

Webb, Beatrice 38

Webb, Sidney 38

Weigand, Katherina 243

Weil, Gotthold 272, 276
Weisbach, Augustin 146, 163, 236-37, 242, 248

Weninger, Josef $158,249,252-53$, 320-21, 324-26, 335, 370, 376-78

Wertheimer, Max 302

Westermann, Diedrich 378

Wolf, Eric 15

Woodrow Wilson, Thomas 39, 72, $228,357,360$

Woodruff Smith 101

Wurmbrand, Gundacker von 243

$\mathbf{Y}$

Yatsuta, K. 59

\section{$\mathbf{Z}$}

Zarnik, Boris 165

Zenker, E. V. 194-95, 203

Zimmerman, Andrew 19, 101, 285

Zolotariev, A. M. 64

Županić, Niko 152-60, 162-65 